\title{
A INFLUÊNCIA DA VARIAÇÃO DA UMIDADE PÓS-COMPACTAÇÃO NO COMPORTAMENTO MECÂNICO DE SOLOS DE RODOVIAS DO INTERIOR PAULISTA
}

\author{
Marcelo de Castro Takeda
}

Tese apresentada à Escola de Engenharia de São Carlos da Universidade de São Paulo, como parte dos requisitos para a obtenção do título de Doutor em Engenharia Civil - Área de Transportes

ORIENTADOR: Prof. Tit. Alexandre Benetti Parreira 
FOLHA DE JULGAMENTO

Candidato: Engenheiro MARCELO DE CASTRO TAKEDA

Tese defendida e julgada em 22-05-2006 perante a Comissão Julgadora:

Cas AluxBParriza

APROVADO

Prof. Associado ALEXANDRE BENETTI PARREIRA (Orientador)

(Escola de Engenharia de São Carlos/USP)

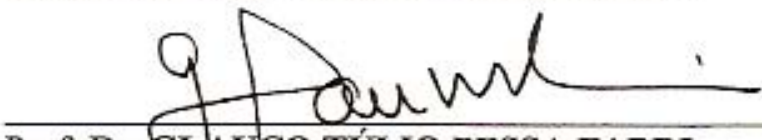

Al LOS HDO

Prof. Dr. GLAUCO TÚlIO PESSA FABRI

(Escola de Ehgepharia de São Carlos/USP)

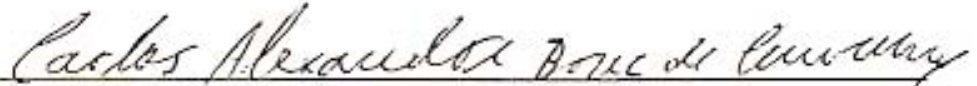

Prof. Dr. CARLOS ALEXANDRE BRAZ DE CARVALHO

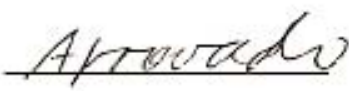

(Universidade Federal de Viçosa/UFV)

\section{Rinioluetrus}

Prof. Dr. MÁRGIO MUNIZ DE FARIAS

(Universidade de Brasília/UnB)

Loaura Maria Goretti da hotta

(Universidade Federal do Rio de Janeiro/UFRJ)

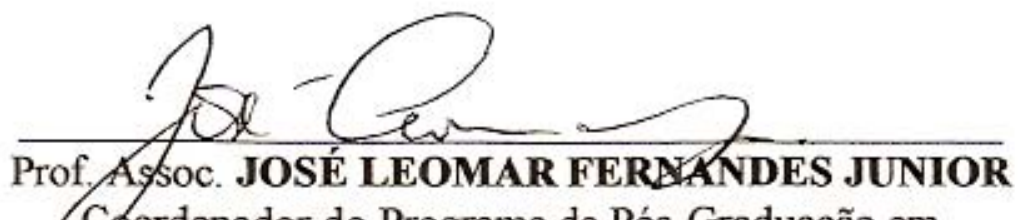

Coordenador do Programa de Pós-Graduação em

Engenharia de Transportes

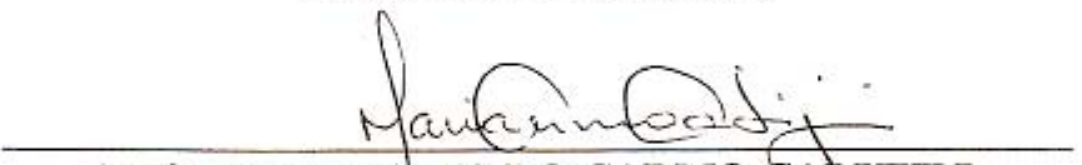

Profa. Titular MAIRIA DO CARMO CAYIJURI

Presidente da Comissão de Pós-Graduação da EESC 
Não se preocupe em entender.

Viver ultrapassa todo entendimento...

(Clarice Lispector) 
À minha esposa Renata e ao meu filho Gabriel. Aos meus pais, Luiz e Shirley. Aos meus sogros que me acolheram como filho, Adurse e Humberto (in memoriam).

Valeu a pena? Tudo vale a pena, quando a alma não é pequena.

(Fernando Pessoa) 
A Deus, em primeiro lugar.

Ao Prof. Tit. Alexandre Benetti Parreira, pelos ensinamentos, orientação e confiança depositados, pessoa a quem aprendi a respeitar e admirar.

À Profa. Dra. Laura Maria Goretti da Motta, pelo apoio e ensinamentos transmitidos durante o período em que estive na COPPE/UFRJ.

À FAPESP, pela bolsa de estudos concedida.

A todos os professores do Departamento de Transportes da Escola de Engenharia de São Carlos - USP, pelos ensinamentos transmitidos.

A todos os funcionários do Departamento de Transportes, em especial aos grandes amigos Gigante, Paulo e João, pelos ensinamentos e ajuda imprescindível na realização dos ensaios.

A todos os amigos e colegas do Departamento de Transportes.

Ao Departamento de Geotecnia, por me permitirem usar o equipamento para realização dos ensaios triaxiais cíclicos, e em especial ao Benedito, técnico do Laboratório de Mecânica das Rochas, pela confiança depositada.

Finalmente, alguns agradecimentos muito especiais...

... à Renata, por toda a colaboração na elaboração do trabalho, mas especialmente por sua paciência, compreensão, carinho e pelo amor demonstrado em todos os momentos

... ao meu pequeno Gabriel, um presente de Deus para a minha vida

... aos meus pais, por todo o incentivo e amor dedicados ao longo destes anos

... aos meus sogros, que receberam como um filho, e sempre me incentivaram na busca de um ideal. 


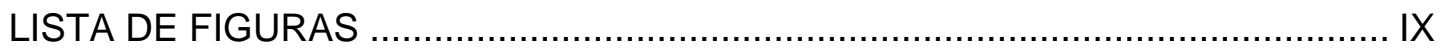

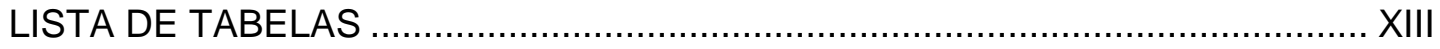

LISTA DE ABREVIATURAS E SIGLAS .....................................................

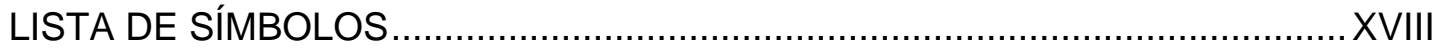

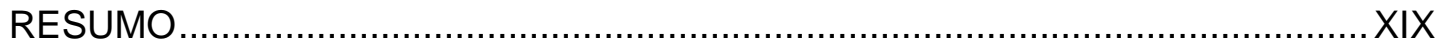

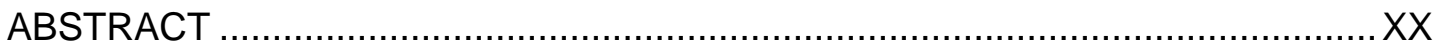

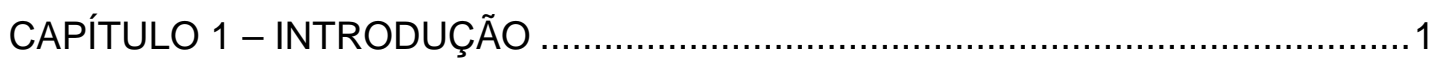

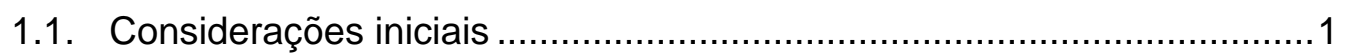

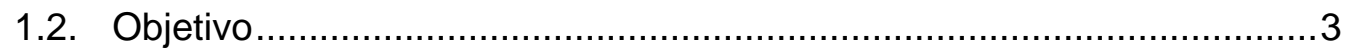

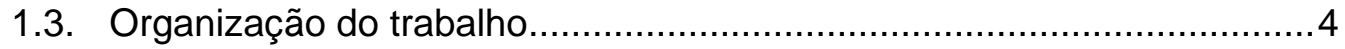

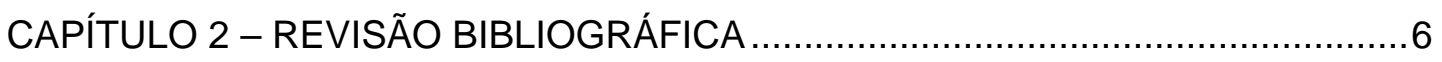

2.1. O pavimento sob ação do clima...................................................... 6

2.1.1 A umidade de equilíbrio em regiões não tropicais.......................8

2.1.2 A umidade de equilíbrio em regiões tropicais...........................13

2.2. A gênese dos solos em regiões tropicais .............................................15

2.3. Relação entre umidade e sucção ........................................................24

2.4. O módulo de resiliência no projeto de pavimentos ...............................30

2.5. A influência da variação de umidade no valor do módulo de resiliência36

2.6. A influência da sucção no módulo de resiliência ...................................46

2.7. Modelagem do módulo de resiliência ...............................................48

2.7.1 Relações com o estado de tensão .........................................49 
2.7.2 Relações com índices vinculados à natureza e estado do solo ...58

2.7.3 Relações do $M_{R}$ com resultados de ensaios triaxiais convencionais 60

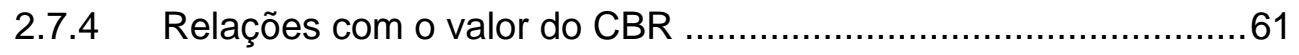

2.7.5 Relações com resultados de ensaios de compressão simples ....61

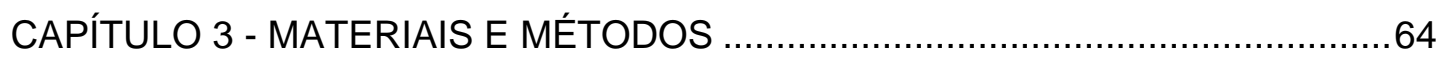

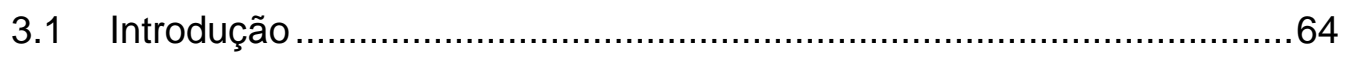

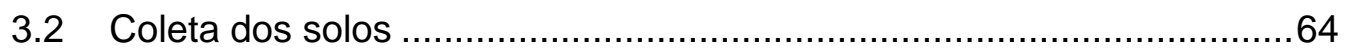

3.3 Armazenagem e preparação dos materiais .........................................67

3.4 Caracterização e classificação dos solos ...........................................67

3.5 Identificação do caráter laterítico dos solos ..........................................67

3.5.1 Classificação MCT .............................................................67

3.5.2 Microscopia eletrônica de varredura (MEV) …..........................68

3.5.3 Difração de raios-x (DRX) ..................................................69

3.5.4 Adsorção de azul de metileno pelo método da mancha...............72

3.6 Ensaios de compactação............................................................ 74

3.7 Comportamento mecânico frente à variação da umidade ......................75

3.7.1 Seleção dos solos para o estudo do comportamento mecânico ..75

3.7.2 Ensaios triaxiais cíclicos, compressão simples e de medida de

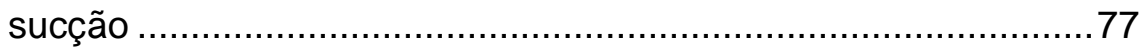

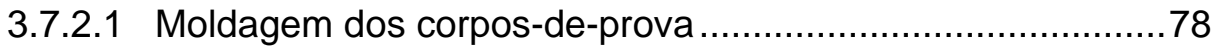

3.7.2.2 Condições de umidade dos corpos-de-prova.......................79

3.7.2.3 Ensaios Triaxiais Cíclicos .................................................. 81

3.7.2.3.1 Equipamento .................................................... 81

3.7.2.3.2 Procedimentos de ensaio ........................................... 83

3.7.2.4 Ensaios de Compressão Simples ........................................86

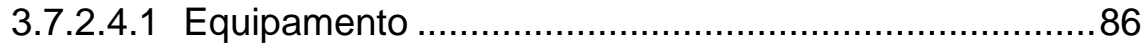

3.7.2.5 Determinação da sucção no solo ...................................... 89

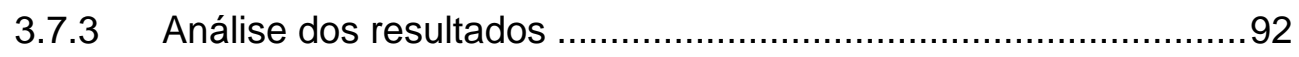

3.7.3.1 Identificação do caráter laterítico dos solos..........................92

3.7.3.2 Modelagem dos resultados dos ensaios triaxiais cíclicos em função do estado de tensão .................................................92

3.7.3.3 Análise da influência da granulometria e da gênese da

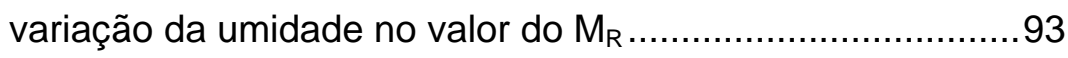


3.7.3.4 Relação do módulo de resiliência com os resultados dos ensaios de compressão simples e propriedades físicas dos solos

CAPÍTULO 4 - ESTUDO DA GÊNESE DOS MATERIAIS - IDENTIFICAÇÃO DO CARÁTER LATERÍTICO DOS SOLOS....................................................95

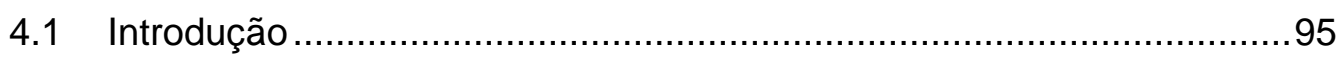

4.2 Resultados da classificação MCT ................................................96

4.2.1 Relação entre as classes MCT e a pedologia ...........................102

4.3 Ensaio de microscopia eletrônica de varredura (MEV)......................106

4.4 Ensaio de difração de raios-x (DRX) ….........................................111

4.5 Ensaio de adsorção de azul de metileno .........................................115

4.6 Análise conjunta dos ensaios MCT, MEV, DRX e adsorção de azul de metileno para as amostra selecionadas ...........................................118

CAPÍTULO 5 - APRESENTAÇÃO E DISCUSSÃO DOS RESULTADOS ..............120

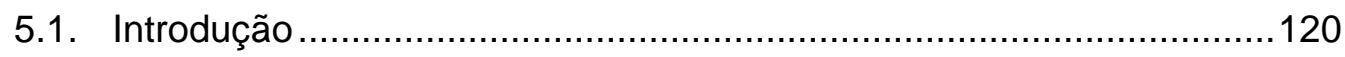

5.2. Ensaios de compactação...................................................... 120

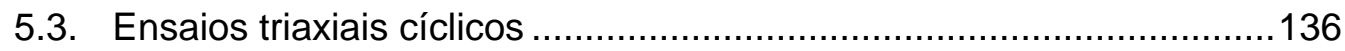

5.3.1 Variação do módulo de resiliência com o estado de tensão ......136

5.3.1.1 Calibração e desempenho dos modelos na representação do módulo de resiliência com o estado de tensão.....................136

5.3.1.2 Análise da influência do estado de tensão no módulo de resiliência.

5.3.2 Análise da influência da granulometria e da gênese no valor do módulo de resiliência

5.3.2.3 O módulo de resiliência típico............................................147

5.3.2.4 O módulo de resiliência médio ........................................152

5.3.3 A influência da variação da umidade pós-compactação no valor do módulo de resiliência

5.3.3.5 O módulo de resiliência como função da umidade dos solos 165

5.4. Ensaios de compressão simples 171

5.4.1 Resultados de módulo tangente inicial na condição ótima do Proctor Normal 
5.4.2 Resultados de módulo tangente inicial com variação da umidade pós-compactação 173

5.5. Relações do Módulo de resiliência com as propriedades físicas dos solos e os resultados dos ensaios de compressão simples 176

CAPÍTULO 6 - CONCLUSÕES E RECOMENDAÇÕES ...................................183

6.1. Introdução ............................................................................. 183

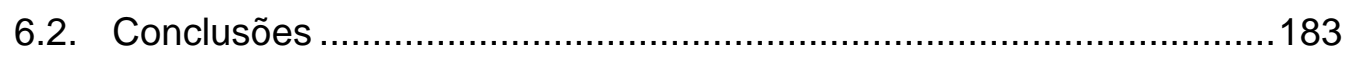

6.3. Recomendações e sugestões para trabalhos futuros..........................190

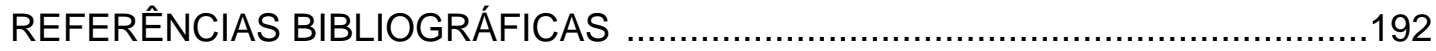

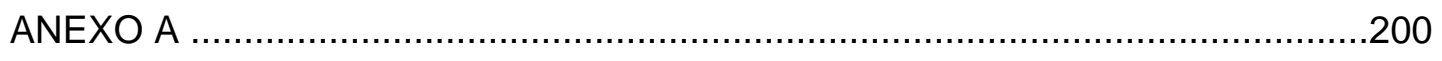

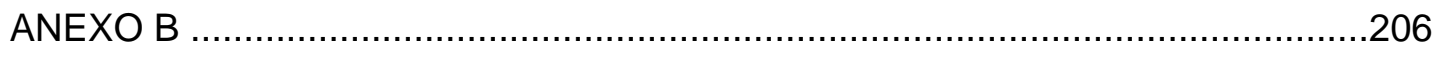

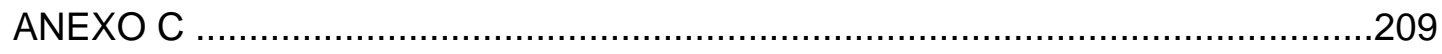

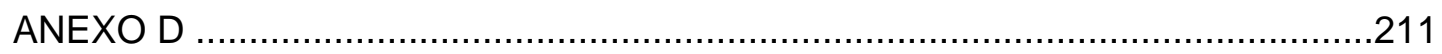

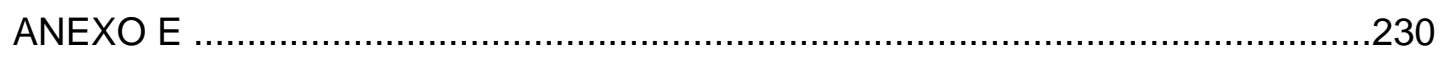

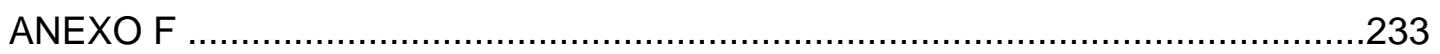

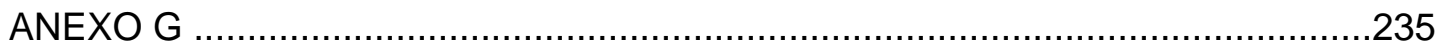

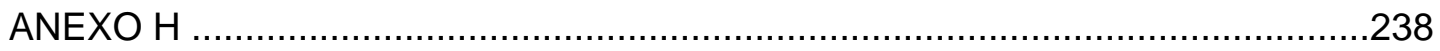

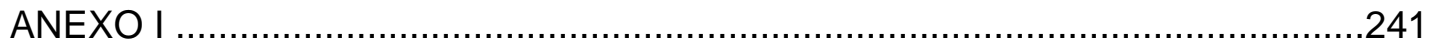

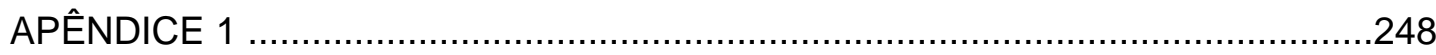


Figura 2.1: Tipos de fluxos de água do solo para o papel filtro 26

Figura 3.1: Mapa do Estado de São Paulo com indicação aproximada dos locais de coleta .66

Figura 3.2: Difração de raios-x por um reticulado cristalino (lei de Bragg)...............70

Figura 3.3: Gráfico para identificação da atividade dos argilominerais presentes na fração fina de um solo tropical.....

Figura 3.4: Prensa Versatester para compactação estática de corpos-de-prova e cilindro de compactação 78

Figura 3.5: Câmara para secagem dos corpos-de-prova .80

Figura 3.6: Conjunto de pedras porosas utilizadas no processo de umedecimento dos corpos-de-prova .80

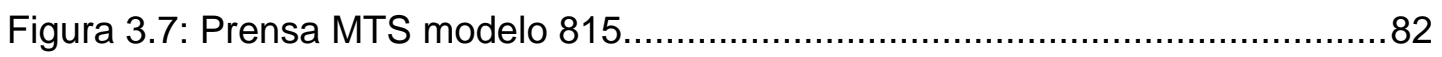

Figura 3.8: LVDT's instalados nos terços médios do corpo de prova ......................82

Figura 3.9: Tela principal do programa de aquisição de dados do ensaio triaxial cíclico. .85

Figura 3.10: Prensa instrumentada para a realização do ensaio de compressão simples 87

Figura 3.11: Tela principal do programa de aquisição de dados do ensaio de compressão simples 88

Figura 3.12: Exemplo de determinação do módulo tangente inicial. .89

Figura 3.13: Balança com capacidade de leitura de 0,0001 g usada na determinação da umidade do papel filtro. .91 
Figura 4.1: Gráfico de classificação MCT com a indicação dos setenta e dois solos coletados. 96

Figura 4.2: Mapa do Estado de São Paulo com indicação dos locais de coleta e a identificação do comportamento laterítico ou não-lateríticos dos solos.

Figura 4.3: Mapa do Estado de São Paulo com indicação dos locais de coleta de solos separados em função das faixas granulométricas adotadas nesta pesquisa

Figura 4.4: Mapa do Estado de São Paulo com os locais de coleta associados aos grupos da classificação MCT. 100

Figura 4.5: Gráfico de classificação MCT-M com a indicação dos setenta e dois solos classificados. 101

Figura 4.6: Padrões de imagens indicativos de solos de lateríticos (aumento 3000x). 108

Figura 4.7: Padrões de imagens indicativos de solos não-lateríticos (aumento 3000x). 109

Figura 4.8: Gráfico de classificação MCT-M e MCT com a indicação dos solos em que foram observadas divergências entre as indicações da MEV e da classificação MCT.

Figura 4.9: Gráfico da classificação MCT com a indicação da posição de cada um dos solos selecionados para a para o estudo do comportamento mecânico dos materiais com a variação da umidade.

Figura 4.10: Mapa do Estado de São Paulo com a indicação dos locais de coleta associado à granulometria

Figura 4.11: Mapa do Estado de São Paulo com a indicação dos locais de coleta associada à classificação MCT.

Figura 4.12: Ábaco para caracterização da atividade da fração argila dos solos com a indicação da posição dos solos selecionados. 116

Figura 5.1: Umidade ótima versus massa específica seca máxima para os solos coletados e separados segundo o comportamento laterítico ou nãolaterítico previsto pela classificação $\mathrm{MCT}$. 121

Figura 5.2: Umidade ótima versus massa específica seca máxima para os solos coletados e separados segundo a granulometria .

Figura 5.3: Relações entre a umidade ótima $\left(w_{0}\right)$ e características físicas dos solos 
Figura 5.4: Relação entre a massa específica seca máxima ( $\left.\rho_{\mathrm{dmax}}\right)$ e características físicas dos solos. 123

Figura 5.5: Limite de liquidez versus umidade ótima 124

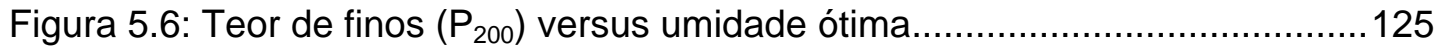

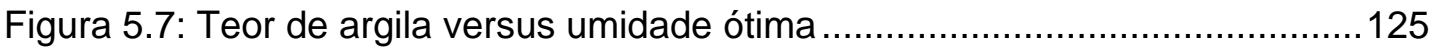

Figura 5.8: Limite de liquidez versus massa específica seca máxima ....................126

Figura 5.9: Teor de finos $\left(P_{200}\right)$ versus massa específica seca máxima ................126

Figura 5.10: Teor de argila versus massa específica seca máxima. 127

Figura 5.11: Valores observados de $w_{0}$ versus valores de wo previstos pelo modelo da AASHTO (equação (5.2) e (5.3)) - solos separados segundo o comportamento laterítico ou não-laterítico 129

Figura 5.12: Valores observados de $\rho$ dmax versus valores de $\rho$ dmax previstos pelo modelo da AASHTO (equação (5.4)) - solos separados segundo o comportamento laterítico ou não-laterítico 129

Figura 5.13: Valores observados de $S_{0}$ versus valores de $S_{0}$ previstos pelo modelo da AASHTO (equação (5.1)) - solos separados segundo o comportamento laterítico ou não-laterítico. 130

Figura 5.14: Valores observados de $w_{0}$ versus valores de $w_{0}$ previstos pelo modelo da AASHTO (equações (5.2) e (5.3)) - solos separados segundo a granulometria 130

Figura 5.15: Valores observados de $\rho_{\text {dmax }}$ versus valores de $\rho_{\text {dmax }}$ previstos pelo modelo da AASHTO (equação (5.4)) - solos separados segundo a granulometria. 131

Figura 5.16: Gráficos com a relação entre o grau de saturação (S) e parâmetros físicos dos solos

Figura 5.17: Valores observados de wo versus valores previstos pelas equações (5.6) e (5.7)

Figura 5.18: Valores observados de pdmax versus valores previstos pelas equações (5.8) e (5.9). 135

Figura 5.19: Valores observados de $M_{R}$ versus valores previstos de $M_{R}$ pelo modelo composto para corpos-de-prova ensaiados na umidade ótima 140

Figura 5.20: Box plots para os valores de módulo de resiliência típico dos solos grossos, intermediários e finos 150

Figura 5.21: Box plots para os valores de módulo de resiliência médios dos solos grossos, intermediários e finos 
Figura 5.22: Taxa de variação da umidade $\left(\Delta \mathrm{w} / \mathrm{w}_{0}\right)$ versus tempo de umedecimento segundo a trajetória $\mathrm{w}_{0} \rightarrow \mathrm{w}_{0}+1 \%$

Figura 5.23: Taxa de variação da umidade $\left(\Delta \mathrm{w} / \mathrm{w}_{0}\right)$ versus tempo de secagem segundo a trajetória $w_{0}-1 \% \leftarrow$ wo 161

Figura 5.24: Taxa de variação da umidade $\left(\Delta \mathrm{w} / \mathrm{w}_{\mathrm{o}}\right)$ versus tempo de secagem segundo a trajetória $w_{0}-2 \% \leftarrow w_{0}$

Figura 5.25: Sucção versus umidade ótima de ensaio 165

Figura 5.26: Variação do módulo de resiliência versus variação da umidade de ensaio 166

Figura 5.27: Variação do módulo de resiliência versus variação da umidade para diferentes estados de tensão 168

Figura 5.28: Variação do módulo de resiliência versus variação da umidade para todos os solos e todas as umidades

Figura 5.29: Valores médios de módulo tangente inicial versus teor de argila 173

Figura 5.30: Variação do módulo tangente inicial versus variação da umidade de ensaio 174

Figura 5.31: Variação do módulo de resiliência e do módulo tangente inicial versus variação da umidade de ensaio 175

Figura 5.32: Relações entre os parâmetros $k_{1}, k_{2}$ e $k_{3}$ do modelo composto com propriedades físicas dos solos 177

Figura 5.33: Valores previstos de $k_{1}$ versus valores observados de $k_{1}$ 179

Figura 5.34: Valores previstos de $k_{3}$ versus valores observados de $k_{3}$ 180

Figura 5.35: Valores previstos de $k_{1}$ pelas equações (5.20) e (5.22) versus valores observados de $\mathrm{k}_{1}$ 
Tabela 2.1: Técnicas de medição de sucção

Tabela 2.2: Parâmetros de compactação do solo estudado segundo o ensaio miniProctor. 29

Tabela 2.3: Resumo dos valores das medianas e médias para cada coeficiente do modelo $k_{1}-k_{3}$, assumindo $k_{6}=0$, e para cada um dos materiais de base e sub-base e solos de subleito 57

Tabela 2.4: Resumo das propriedades físicas consideradas importantes na previsão do MR para cada tipo de solo.

Tabela 3.1: Valores pré-determinados do coeficiente de atividade (CA) da fração fina do solo para caracterização do grau de atividade dos argilominerais 74

Tabela 3.2: Valores limites adotados nas faixas granulométricas..........................75

Tabela 3.3: Distribuição das amostras selecionadas por faixas granulométricas....76

Tabela 3.4: Indicação da nomenclatura dos trinta solos selecionados ....................76

Tabela 3.5: Seqüência de ensaio para subleito segundo a AASHTO T 307-99 ......83

Tabela 3.6: Seqüência de ensaio para base/sub-base segundo a AASHTO T 307-99

Tabela 3.7: Equações de calibração entre sucção e umidade para o papel filtro Whatman 42 90

Tabela 3.8 - Modelos avaliados na representação do $M_{R}$ em função do estado de tensão 92

Tabela 4.1: Distribuição dos solos nas classes MCT. 97 
Tabela 4.2: Distribuição dos solos em função da faixa granulométrica e classe MCT.

Tabela 4.3: Distribuição de solos em função do comportamento e da classe MCT-M 102

Tabela 4.4: Classificação pedológica dos solos classificados como de comportamento laterítico pela MCT. 103

Tabela 4.5: Classificação pedológica dos solos classificados como de comportamento não-laterítico pela MCT. 104

Tabela 4.6: Número de solos por classe pedológica em função do comportamento laterítico ou não-laterítico 105

Tabela 4.7: Número de concordâncias e discordâncias observadas na comparação ente os resultados dos ensaios de MEV e classificação MCT. 107

Tabela 4.8: Minerais encontrados nas amostras de solo selecionadas e a característica determinada pela constituição dos solos.

Tabela 4.9: Resultados dos ensaios de azul de metileno com a indicação da atividade dos argilominerais em comparação com a classificação MCT.

Tabela 4.10: Comparação entre os resultados dos ensaios de MEV, DRX, azul de metileno e classificação MCT.

Tabela 5.1: Relações matemáticas para determinação de parâmetros físicos dos solos no nível 2 do novo guia da AASHTO 128

Tabela 5.2: Modelos genéricos de regressão para a umidade ótima 133

Tabela 5.3: Resultados da regressão para modelagem da umidade ótima em função dos parâmetros físicos dos solos

Tabela 5.4: Modelos genéricos de regressão para a massa específica seca máxima 135

Tabela 5.5: Resultados da regressão para modelagem da massa específica seca máxima em função dos parâmetros físicos dos solos 135

Tabela 5.6 - Modelos avaliados na representação do $M_{R}$ em função do estado de tensão.

Tabela 5.7: Coeficientes de determinação $\left(R^{2}\right)$ dos modelos (5.10), (5.11), (5.12), (5.13) e (5.14) para os solos ensaiados na umidade ótima 138

Tabela 5.8: Parâmetros de regressão $k_{1}, k_{2}$ e $k_{3}$ do modelo (5.13), e coeficientes de determinação $\left(R^{2}\right)$ para os solos ensaiados na umidade ótima 141 
Tabela 5.9: Resumo dos valores da média, mediana e desvio-padrão para cada um dos coeficientes do modelo composto e solos separados segundo o comportamento laterítico e não-laterítico 143

Tabela 5.10: Parâmetros de regressão $k_{1}, k_{2}$ e $k_{3}$ do modelo composto e coeficiente de determinação $\mathrm{R}^{2}$ para os solos grossos. 145

Tabela 5.11: Parâmetros de regressão $k_{1}, k_{2}$ e $k_{3}$ do modelo composto e coeficiente de determinação $\mathrm{R}^{2}$ para os solos intermediários

Tabela 5.12: Parâmetros de regressão $k_{1}, k_{2}$ e $k_{3}$ do modelo composto e coeficiente de determinação $R^{2}$ para os solos finos 146

Tabela 5.13: Valores típicos de módulo de resiliência determinados a partir do modelo composto para valores de $\sigma 3=13,8 \mathrm{kPa}$ e $\sigma \mathrm{d}=68,9 \mathrm{kPa}-$ solos separados em função da granulometria e da gênese 148

Tabela 5.14: Valores médios de módulo de resiliência - solos separados em função da granulometria e da gênese. 152

Tabela 5.15: Valores de módulo de resiliência típicos em diferentes teores de umidade e taxa de variação do $M_{R}$.

Tabela 5.16: Valores de umidade de ensaio e razão entre a taxa de variação do módulo de resiliência e a taxa de variação da umidade.

Tabela 5.17: Tempos de secagem e umedecimento dos corpos-de-prova submetidos ao ensaio triaxial cíclico 159

Tabela 5.18: Taxa de variação do módulo de resiliência com relação ao tempo de umedecimento dos corpos-de-prova 163

Tabela 5.19: Valores de sucção determinados a partir de corpos-de-prova compactados na umidade ótima

Tabela 5.20: Parâmetros de regressão e coeficiente de determinação para o ajuste entre a taxa de variação do módulo de resiliência e a variação da umidade para diferentes estados de tensão 168

Tabela 5.21: Valores médios de $E_{0}$ e RCS para os solos submetidos ao ensaio de compressão simples na condição ótima do Proctor Normal. 172

Tabela 5.22: Valores médios de módulo tangente inicial $\left(E_{0}\right)$ para os solos submetidos ao ensaio de compressão simples com variação da umidade pós-compactação

Tabela A.1 - Informações sobre a localização do ponto de coleta de cada uma das amostras.

Tabela B.1: Resultados dos ensaios de caracterização e classificação dos solos 207 
Tabela C.1: Resultados dos ensaios de compactação na energia normal 210

Tabela E.1: Espaçamento interplanar (d) e $2 \theta$ dos minerais considerados na identificação das amostras estudadas. 231

Tabela F.1: Resultados de umidade ótima $\left(\mathrm{W}_{0}\right)$, massa específica seca máxima ( $\rho d m a x)$ e grau de saturação $\left(S_{r}\right)$ para os solos coletados. 234

Tabela H.1: Determinação da gênese dos solos lateríticos (LA e LA'), segundo a MCT, a partir dos ensaios de MEV. 238

Tabela H.2: Determinação da gênese dos solos lateríticos (LG'), segundo a MCT, a partir dos ensaios de MEV. 239

Tabela H.3: Determinação da gênese dos solos não-lateríticos (NS'), segundo a MCT, a partir dos ensaios de MEV. 239

Tabela H.4: Determinação da gênese dos solos não-lateríticos (NA e NA'), segundo a MCT, a partir dos ensaios de MEV. 239

Tabela H.5: Determinação da gênese dos solos NG' a partir dos ensaios de MEV. 240

Tabela I.1: Parâmetros de regressão $k_{1}, k_{2}$ e $k_{3}$ dos modelos analisados na representação do módulo de resiliência com o estado de tensão para os diferentes teores de umidade estudados. 
AASHTO - American Association of State Highway and Transportation Officials; ABNT - Associação Brasileira de Normas Técnicas;

ASTM- American Society for Testing and Materials;

c.p. - Corpo de prova;

DER-SP - Departamento de Estradas de Estradas de Rodagem de São Paulo; DRX - Difração de raios-X;

EESC - Escola de Engenharia de São Carlos;

EUA - Estados Unidos da América;

FWD - Falling Weight Deflectometer;

GC - Grau de compactação;

HRB - Highway Research Board;

IP - Índice de Plasticidade;

LL - Limite de Liquidez;

LP - Limite de Plasticidade;

LVDT - Linear Variable Differential Transducers;

MCT - Miniatura, Compactado, Tropical;

MEV - Microscopia eletrônica de varredura;

MTS - Material Testing System;

NP - Não Plástico;

PN - Proctor normal;

USCS - Unified Soil Classification System;

USP - Universidade de São Paulo; 
a e b - Parâmetros da reta regressão;

$\mathrm{E}_{0}$ - Módulo Tangente Inicial;

H - Altura inicial do trecho onde estão instalados os LVDT's;

$\mathrm{Hz}$ - Hertz;

$k_{1}, k_{2}, k_{3}, k_{4}, k_{5}, k_{6}$ - Parâmetros de regressão dos modelos de módulo de resiliência;

$M_{R}$ - Módulo de resiliência;

pF - Sucção $\left(\mathrm{cm} \mathrm{H}_{2} \mathrm{O}\right)$;

$\mathrm{R}^{2}$ - Coeficiente de determinação;

S - Grau de saturação;

$\mathrm{W}_{\mathrm{o}}$ - Umidade ótima;

$\rho_{d}$ - Massa específica aparente seca do corpo de prova;

$\phi$ - Diâmetro;

$\%$ - Porcentagem;

$\Delta \mathrm{H}$ - Deslocamento medido pelos LVDT's;

$\sigma_{a}$ - tensão axial;

$\varepsilon_{a}-$ Deformação axial;

$\varepsilon_{R}$ - Deformação resiliente;

$\sigma_{1}-$ Tensão principal maior;

$\sigma_{3}-$ Tensão confinante;

$\sigma_{\mathrm{c}}-$ Tensão confinante;

$\sigma_{\mathrm{d}}-$ Tensão desvio;

$\theta$ - Primeiro invariante de tensão $\left(\sigma_{1}+\sigma_{2}+\sigma_{3}\right)$. 
Takeda, M. C. A influência da variação da umidade pós-compactação no comportamento mecânico de solos de rodovias do interior paulista. São Carlos, 2006. Tese (Doutorado) - Escola de Engenharia de São Carlos, Universidade de São Paulo.

$\mathrm{Na}$ construção de rodovias, as condições de umidade e densidade observadas na compactação são, geralmente, próximas daquelas correspondentes ao pico da curva de compactação obtida no ensaio Proctor. É sabido que variações ambientais no decorrer da vida do pavimento podem alterar, de maneira significativa, a umidade do subleito e dos seus componentes e assim, as suas propriedades resilientes. O objetivo principal desta pesquisa é avaliar a influência da variação da umidade pós-compactação no módulo de resiliência de solos de rodovias do interior paulista a partir de resultados de ensaios de laboratório. Foram coletados e caracterizados setenta e três solos, e, dentre estes, selecionados trinta para a etapa de estudo da variação da umidade pós-compactação, após a realização de ensaios MCT, difração de raios-x, microscopia eletrônica de varredura e azul de metileno para determinação da gênese. Os solos selecionados apresentam características distintas quanto à gênese, sendo metade laterítico e metade não-laterítico. Os corpos-de-prova foram compactados na umidade ótima e submetidos a processos de secagem e umedecimento e, posteriormente, realizados ensaios triaxiais cíclicos. Os resultados permitiram a modelagem do $M_{R}$ em função do estado de tensão para diferentes umidades e a avaliação da competência de alguns modelos matemáticos nesta representação. Estudouse a influência da gênese e da granulometria sobre o valor do $M_{R}$ e avaliou-se a conseqüência da variação da umidade sobre este para solos lateríticos e não-lateríticos. Determinou-se uma expressão para estimar a variação do $M_{R}$ com a variação da umidade a partir do parâmetro $k_{1}$, independentemente do estado de tensão. Pesquisou-se a existência de relações entre os parâmetros de regressão do modelo composto e os resultados dos ensaios de compressão simples e as propriedades físicas dos solos, de forma a permitir a estimativa do módulo de resiliência a partir do resultado de ensaios mais simples. Investigou-se a possibilidade de se utilizar as relações entre a variação do módulo tangente inicial com a variação da umidade para estimar os efeitos sobre o $M_{R}$.

Palavras-chave: Módulo de resiliência; Resiliência; Ensaio triaxial cíclico; Subleito; Teor de umidade; Sucção; Compressão simples; pavimentação. 


\section{Abstract}

Takeda, M. C. (2005). The influence of post-compaction moisture content variation on the mechanical behavior of soils from São Paulo state pavements. São Carlos, 2006. Tese (Doutorado) - Escola de Engenharia de São Carlos, Universidade de São Paulo.

On road construction, the field compaction conditions are usually close to those determined from Proctor tests. Environmental variations may lead to changes in the pavement moisture and also changing its resilient properties. The main objective of this research is to study the influence of post-compaction moisture content variation on the resilient modulus of soils from São Paulo state pavements, using laboratory tests. To accomplish this objective, seventy three soils samples were collected and characterized. Among them, thirty samples were selected, after four different tests were carried out to determine the soils genesis, to study the post-compaction moisture content variation. Half of these selected soils are lateritic ones, and the other half are non-lateritic soils. The specimens were compacted at optimum moisture content and submitted to drying and moistening processes prior cyclic triaxial test to be carried out. The results allowed the resilient modulus modeling as a function at the stress state and the performance evaluation of five different models. The genesis and grain size distribution influence on the resilient modulus values were studied. The effects of moisture content variations on lateritic and nonlateritic soils were investigated. An expression to estimate the resilient modulus variations with the moisture variations was determined, independently of the stress state. The existence of relations of the compound model regression parameters with the results of unconfined compressive strength and soil properties were studied. The possibility of using the initial tangent modulus variations with the moisture variations to estimate the effects on the resilient modulus were also investigated.

key-words: Resilient Modulus; Resilience; Cyclic triaxial tests; Subgrade; Moisture content; Suction; Compressive strength test; Pavement. 


\section{Capítulo 1 - Introdução}

\subsection{Considerações iniciais}

A análise mecanística e o projeto de pavimentos flexíveis dependem do conhecimento do carregamento imposto pelo tráfego, dos materiais, e dos fatores climáticos. As variações sazonais de fatores climáticos, tais como temperatura e precipitação, afetam as condições das camadas do pavimento, incluindo a temperatura e o teor de umidade in situ. Por sua vez, estas condições têm uma relação direta com a resistência e rigidez do pavimento, causando variações da resistência e dos módulos das camadas.

Historicamente, o dimensionamento da espessura de um pavimento é baseado em princípios empíricos, como por exemplo, o método do CBR e as equações de projeto do guia de dimensionamento da AASHTO de 1993 que foram baseados nos resultados do AASHO Road Test e são, desta forma, limitadas às condições encontradas no local dos testes. Apesar dos métodos empíricos serem usados com sucesso, surge um grande problema quando devem ser analisadas condições diferentes das originais. Existe, portanto, uma tendência de migração de métodos empíricos de dimensionamento para métodos chamados semi-empíricos, ou mecanístico-empírico.

Este tipo de procedimento usa, como entrada de dados para modelos numéricos ou analíticos, a espessura inicial das camadas, as propriedades dos 
materiais, e as condições de carregamento, sendo possível, assim, o cálculo das tensões, deformações e deflexões em qualquer ponto da estrutura. A porção empírica deste método está em relacionar as tensões e deformações calculadas ao desempenho do pavimento.

Desde 1986, o guia de dimensionamento da AASHTO recomenda o uso do módulo de resiliência para a caracterização dos materiais usados em pavimentos flexíveis. Este módulo, determinado a partir de ensaios triaxiais de carga cíclica, é definido como a razão entre a tensão desvio e a deformação elástica recuperável, ou resiliente. É uma propriedade básica do solo de acordo com a teoria da elasticidade.

Como as propriedades dos materiais empregados na pavimentação, tal como o módulo de resiliência das camadas, sofrem influência das condições climáticas, é necessário quantificar esses efeitos para uma determinada região.

Dentre os fatores que influenciam no valor do módulo de resiliência, que se sabe é muito variável, pode ser citada a condição de carregamento e estado de tensão; a natureza do solo, relacionada à origem, composição e estrutura; e o estado físico do solo, definido pelo teor de umidade e massa específica seca.

No que diz respeito às condições ambientais, diversas pesquisas mostraram que alterações na umidade pós-compactação do solo promovem variações significativas no módulo de resiliência. Dentre estas pesquisas podem ser citadas: Elliott \& Thornton (1988), Motta et al. (1990), Li \& Selig (1994), Mohammad et al. (1995), Thadkamalla \& George (1995), Drumm et al. (1997), Bernucci (1997), Rodrigues (1997) e Gonçalves (1999).

Segundo Drumm et al. (1997), a compreensão do mecanismo de variação das propriedades resilientes do subleito com as alterações no teor de umidade póscompactação, em conjunto com o conhecimento das variações sazonais da umidade do subleito, podem ser usadas para a obtenção do módulo de resiliência efetivo do subleito necessário ao projeto de pavimentos. 
O clima influencia o comportamento do subleito quando a água da chuva atinge esta camada, seja pelos acostamentos, principalmente se estes não são revestidos, ou por infiltração por poros, trincas e juntas existentes na superfície do pavimento. Também pode promover variações da umidade do subleito a oscilação do lençol freático e gradientes de temperatura, que causam o movimento de água na forma de vapor.

Como é comum no Brasil a adaptação de métodos empíricos desenvolvidos para países de clima temperado, é importante se destacar as diferenças climáticas com relação a países de clima tropical, principalmente o tropical úmido que é o caso brasileiro.

\subsection{Objetivo}

O objetivo principal desta pesquisa é avaliar a influência da variação da umidade pós-compactação no módulo de resiliência de solos tropicais de subleito de rodovias do interior paulista, a partir de ensaios de laboratório, considerando-se materiais de comportamento laterítico e não laterítico segundo a classificação MCT (Nogami \& Villibor, 1995).

Para se alcançar este objetivo, os materiais coletados foram caracterizados e classificados, conforme se apresenta no Capítulo 3. Posteriormente, determinaramse as curvas de compactação dos materiais previamente selecionados para o estudo e compactados corpos-de-prova (c.p) em condições de umidade préestabelecidas. Os c.p. assim produzidos foram submetidos a ensaios triaxiais cíclicos após a variação da umidade pós-compactação, buscando refletir condições observadas em campo. Pôde-se, dessa forma, a partir dos resultados de ensaios obtidos, modelar o módulo de resiliência em função do estado de tensão e avaliar a influência da variação da umidade sobre o módulo de resiliência. A utilização de solos de diferentes classes no estudo (laterítico e não-laterítico) permitiu que se estabelecesse uma comparação entre o comportamento dos materiais quanto à umidade. 
Para as mesmas condições descritas nos ensaios triaxiais cíclicos, foram compactados corpos-de-prova para ensaios de compressão simples, com a finalidade de se avaliar a existência de relações entre o módulo tangente inicial $\left(E_{0}\right)$ e o módulo de resiliência, o que permitiria a estimativa deste último a partir de um ensaio mais simples.

\subsection{Organização do trabalho}

O Capítulo 2 apresenta a revisão bibliográfica desenvolvida. Destacam-se aspectos relevantes para o desenvolvimento do projeto, que subsidiam a pesquisa. Neste capítulo abordam-se alguns aspectos relacionados à interação do pavimento com o meio ambiente, tratando, principalmente, da umidade de equilíbrio do subleito e sua ocorrência em regiões de clima tropical e não tropical. Aborda-se também a consideração do módulo de resiliência no projeto de pavimentos, e a influência sobre este parâmetro da variação da umidade. Ainda quanto ao módulo de resiliência, apresentam-se trabalhos que discutem a influência da sucção sobre o mesmo. O capítulo também apresenta uma discussão sobre a relação entre umidade e sucção e sobre a modelagem do módulo de resiliência a partir do estado de tensões, bem como relações com índices vinculados à natureza e ao estado do solo e propriedades físicas.

O Capítulo 3 apresenta os procedimentos utilizados de caracterização e classificação dos solos, aspectos relacionados à escolha das amostras para a pesquisa e a descrição dos materiais selecionados, com indicação de sua origem, classificação geotécnica e caracterização física. Também são apresentados tópicos sobre os procedimentos experimentais para realização dos ensaios triaxiais cíclicos e compressão simples.

O Capítulo 4 apresenta um estudo da gênese dos materiais selecionados para a pesquisa, que permitiu, através dos ensaios de difração de raios- $\mathbf{x}$, microscopia eletrônica de varredura e azul de metileno, a identificação do caráter laterítico das amostras, confirmando a classificação MCT obtida para as mostras selecionadas. 
O Capítulo 5 apresenta os resultados dos ensaios triaxiais cíclicos e de compressão simples. Discute-se sobre a modelagem do módulo de resiliência em função do estado de tensão, a influência da granulometria e gênese sobre o valor do $M_{R}$ e a influência da variação da umidade também sobre $\circ M_{R}$, bem como as relações dos parâmetros de regressão obtidos da modelagem do $M_{R}$ com os resultados dos ensaios de compressão simples e as propriedades físicas dos solos.

O Capítulo 6 apresenta as conclusões do presente trabalho e as recomendações para trabalhos futuros. 


\section{Capítulo 2 - Revisão bibliográfica}

\subsection{O pavimento sob ação do clima}

O pavimento enquanto estrutura está sujeito às intempéries, e sofre com a sua ação. A precipitação atmosférica e a radiação solar são dois elementos do clima que podem influir no desempenho do pavimento (Medina, 1997).

Estes elementos podem atuar no subleito e na estrutura do pavimento. Neste trabalho serão discutidos seus efeitos sobre o subleito, objeto do estudo.

Segundo Abo-Hashema et al. (2002), o desempenho do pavimento é afetado por sua condição estrutural, que pode ser representada pelo módulo de elasticidade das camadas do pavimento. Por outro lado, o módulo de elasticidade de uma camada flexível é uma propriedade importante que depende do tipo e condição do material. Por exemplo, as camadas com tratamento asfáltico são sensíveis a variações de temperatura, enquanto as camadas não tratadas, como base e subleito, são mais sensíveis à variação de umidade. Assim, é de extrema importância para o projeto de pavimentos e processos de avaliação de desempenho o conhecimento da variação das propriedades dos materiais com a variação das condições ambientais.

Em campo, os materiais não-tratados usados em pavimentação são normalmente compactados próximos à condição ótima de umidade e massa 
específica seca. Com o tempo, o teor de umidade alcançará uma condição de equilíbrio que depende das propriedades de drenagem e condições ambientais. De forma a simular esta variação em laboratório, recomenda-se compactar os corposde-prova na umidade ótima e massa específica seca máxima, e então variar o teor de umidade (por secagem ou umedecimento) até se atingir o valor desejado, quando o ensaio de módulo de resiliência deve ser realizado. Especialmente no caso de solos de granulometria fina (coesivos), a compactação diretamente no teor de umidade desejado pode resultar em corpos-de-prova com uma estrutura diferente e que não representa as condições de campo (NCHRP 1-37A, 2004).

Ainda segundo Medina (1997), o clima pode influenciar o comportamento do subleito quando: a água da chuva atinge o subleito pelos acostamentos, principalmente se não são revestidos, por infiltração não interceptada por drenos e através de trincas e juntas não vedadas e de poros na superfície envelhecida; ocorre a oscilação do lençol freático, podendo promover variações da umidade do subleito; há movimento de água na forma de vapor, devido a gradientes de temperatura diários e sazonais.

Em países de clima temperado, a ocorrência de períodos de congelamento também influencia sobremaneira o comportamento do subleito. Segundo Medina (1997), a ocorrência de temperaturas inferiores a $0^{\circ} \mathrm{C}$ por um período de tempo prolongado promove o congelamento da água do solo provocando o "inchamento" das camadas do pavimento, principalmente sub-base e subleito.

Como é comum no Brasil a adaptação de métodos empíricos desenvolvidos para países de clima temperado, é importante se destacar as diferenças climáticas com relação a países de clima tropical, principalmente o tropical úmido que é o caso Brasileiro. Segundo Nogami \& Villibor (1995), o solo tropical apresenta peculiaridades de propriedades e de comportamento, relativamente aos solos não tropicais, em decorrência da atuação no mesmo de processos geológicos e/ou pedológicos, típicos das regiões tropicais úmidas.

Observando-se essas diferenças, ou peculiaridades, serão apresentados separadamente na seqüência, alguns estudos realizados em regiões de solos tropicais e estudos realizados em regiões de solos não tropicais no que diz respeito 
à umidade de equilíbrio, principalmente, do subleito. Medina (1997) define a umidade de equilíbrio como o valor médio da gama de variação do teor de umidade do solo do subleito ao longo do ano, após a fase de acomodação dos primeiros meses de serviço.

\subsubsection{A umidade de equilíbrio em regiões não tropicais}

No estado Americano de Oklahoma, realizou-se, durante seis anos, um estudo sobre as condições de umidade do subleito sob rodovias existentes, em 52 locais diferentes. Os resultados do estudo são apresentados por Haliburton (1972). Os solos de subleito dos locais onde ocorreram os estudos foram classificados como A-6 e A-7 pela HRB, e CL e CH pela USCS. As informações sobre umidade e densidade do subleito foram coletadas periodicamente com uma sonda nuclear de profundidade, sendo esta calibrada para as condições particulares dos solos do local. Adicionalmente, foram compiladas informações relativas a: precipitação, temperatura do ar, tipo de solo, projeto da rodovia e histórico da construção, desempenho do pavimento e acostamentos, tráfego e temperatura do subleito, e deformações do pavimento. A análise destas informações indicou dois tipos básicos de comportamento da umidade: acúmulo de umidade no subleito e variação de umidade do subleito.

No primeiro caso, o teor de umidade sob pavimentos novos e relativamente novos, e sob pavimentos antigos, mas com boas condições de acostamento e excelente desempenho, tendiam, após um período inicial curto no teor de umidade de construção (geralmente abaixo da umidade ótima de compactação), a aumentar sem uma variação significativa durante um período de 18 a 24 meses até se atingir um teor de umidade de equilíbrio da ordem de 1,1 a 1,3 vezes o limite de plasticidade do solo de subleito. Esta condição era válida para pavimentos considerados impermeáveis. Neste caso, o acúmulo é creditado, principalmente, a fontes de capilaridade, mas em alguns locais isso se deveu à infiltração ocorrida além dos acostamentos pavimentados. Verificou-se, também, que gradientes de temperatura no subleito causaram apenas pequenas mudanças na umidade. Em locais em que o pavimento apresentava condições inferiores ao considerado excelente (usualmente indicativo de pavimentos permeáveis ou com juntas abertas), com acostamentos sem revestimento e sistema de drenagem deficiente, 
as variações de umidade ocorreram sobrepostas pela tendência de acúmulo. A maior parte dessa variação foi causada por infiltração da água da chuva e evaporação, usualmente ocorrida além dos acostamentos ou através da superfície do pavimento, mas que não interromperam a taxa de acúmulo de umidade, que, na maior parte dos casos, continuou até que o teor de umidade do subleito alcançasse valores acima do limite de plasticidade.

No segundo caso, a tendência de variação de umidade observada no estudo de Haliburton (1972), na maior parte dos locais pesquisados, onde o acúmulo de umidade não estava em progresso, as variações ocorriam sazonalmente em ciclos anuais, com teores máximos de umidade ocorrendo durante os meses de inverno, ou eram dependentes da precipitação. Na maior parte dos locais onde ocorriam apenas variações sazonais de umidade, os pavimentos eram considerados excelentes e impermeáveis, e as variações de umidade tiveram pouca relação com a precipitação medida. Imaginou-se, inicialmente, que estas variações fossem induzidas pela temperatura; entretanto, apesar da ocorrência desse fenômeno nos solos de subleito do estado, são de pequena magnitude, causando variações anuais de umidade de apenas $1 \%$ a $2 \%$. Na maioria dos locais onde as variações sazonais não puderam ser relacionadas com a precipitação, o evento foi creditado à variação do nível do lençol freático, ou por infiltração retardada proveniente de áreas adjacentes ao pavimento, causados por condições particulares de drenagem. A maior parte das variações sazonais sob sistemas impermeáveis não excedeu a $5 \%$ do teor de umidade de projeto, e em muitos casos foram metade deste valor. Como regra geral, as variações máximas de umidade ocorriam, geralmente, de 6 a 8 semanas após a chuva, sendo necessário períodos ainda mais longos para a ocorrência de variações a maiores profundidades. A magnitude das variações é dependente das condições gerais do pavimento, presença de acostamentos revestidos ou não, e do tipo de material de base e sub-base usado no pavimento. As grandezas das variações causadas pela precipitação e evaporação foram quase sempre maiores do que as variações produzidas pelas tendências sazonais. Em alguns locais as variações de umidade excederam de $10 \%$ a $15 \%$, em valores relativos, o teor de umidade de projeto durante períodos de 6 meses, e produziram alterações, facilmente identificáveis, nas condições dos pavimentos e acostamentos. Em outros locais, a infiltração da água da chuva levou os teores de 
umidade do subleito a valores próximos ao limite de liquidez, resultando em perda de suporte e rápida deterioração do pavimento.

A resistência dos pavimentos é fortemente influenciada pelo teor de umidade do subleito. Portanto, torna-se preponderante determinar as alterações ocorridas neste teor, bem como os fatores que contribuem para este fenômeno. Neste sentido, Vaswani (1975) desenvolveu um estudo, no estado americano da Virginia, onde foram realizadas comparações entre os resultados de temperatura e umidade de trechos de solos descobertos e solos de subleito de pavimentos. Selecionaram-se 17 locais para estudo, que variavam em idade de construção, de novos até 12 anos. A determinação da umidade do subleito foi realizada com uma sonda nuclear e a sua temperatura com o auxílio de termistores. Adicionalmente, foram obtidas informações sobre precipitação e temperatura do ar nos locais próximos aos trechos em análise. As medidas de umidade e temperatura foram realizadas sob o solo descoberto, sob o acostamento e sob o pavimento, em diversas profundidades. Também foi considerada a situação de implantação da rodovia, sendo avaliados trechos construídos em corte e aterro.

No estudo em questão, o autor descreve algumas conclusões obtidas com a análise das informações, relacionadas à umidade e temperatura. Segundo o mesmo, a temperatura do subleito era maior do que a temperatura média do ar dos cinco dias anteriores, e que mudanças na temperatura do subleito seguiram alterações na temperatura do ar. Assim, durante a primavera e o verão, as temperaturas na porção superior do subleito eram maiores do que aquelas na parte inferior. Essa tendência se alterava durante o outono e o inverno. Em função do gradiente de temperatura no subleito, ocorria um fluxo de umidade, por exemplo: a umidade se moveria da parte inferior para a porção superior do subleito no outono e inverno, e inverteria o movimento durante a primavera e o verão. Observou-se também que a temperatura do subleito em aterros era menor do que em cortes. Verificou-se que em pavimentos novos, havia um aumento rápido da umidade do subleito até um certo nível, provocado pela precipitação, e que dependia da massa específica, da compactação e da granulometria do solo. Atingido este nível, a razão de acessão do teor de umidade diminui, tornando-se notáveis as variações de umidade devidas ao gradiente de temperatura. Observou-se que em pavimentos de 10 anos ou mais quase não havia alterações na umidade do subleito, e não se 
verificaram os efeitos do gradiente de temperatura. Como conclusão final do trabalho, o autor coloca que o teor de umidade do subsolo em terreno descoberto e do subleito de pavimentos sob o acostamento foi muito afetado pelas condições climáticas, tais como, chuva, neve e temperatura. As variações observadas foram máximas no terreno descoberto, menores sob acostamentos cobertos com uma camada de $10 \mathrm{~cm}$ de agregados, e muito menores sob acostamentos cobertos com uma camada de agregados de $15 \mathrm{~cm}$.

A vida em serviço de um pavimento depende do desempenho e condição de seus componentes. Durante este período, o subleito experimenta variações de umidade e conseqüentemente, grandes flutuações na resistência (Thadkamalla \& George, 1995). Os autores citam que, geralmente, o subleito é preparado com um grau de compactação de $95 \%$ a $100 \%$ da massa específica e na umidade ótima, determinados na energia do Proctor Normal. Entretanto, para as condições encontradas nos Estados Unidos, logo após o pavimento ser selado, o subleito exibe um aumento no teor médio de água na sua porção mais superficial e uma redução nas flutuações do teor de água com o tempo. Esta umidade, alcançada após a construção, está em equilíbrio com o meio ambiente e é chamada de teor de umidade de equilíbrio. Segundo os autores, o movimento de umidade e a umidade de equilíbrio sob áreas cobertas têm sido objeto de estudo de vários pesquisadores. Descrevem que, historicamente, pesquisas envolvendo o efeito da umidade nos solos têm coincidido com o crescimento da necessidade de se avaliar a dependência climática dos parâmetros dos solos no projeto de rodovias.

Entre os trabalhos citados pelos autores, relacionados ao estudo da umidade de equilíbrio, podem ser destacados: Low \& Lovell Jr. (1959) ${ }^{1}$, concluíram que o teor de umidade do subleito apresenta variações sazonais pequenas e contínuas; Chu \& Humphries ${ }^{2}$ (1972) conduziram uma investigação para correlacionar a umidade do subleito com fatores locais, tais como, o tipo de solo, fatores ambientais, e assim por diante. Os resultados, que envolviam 32

\footnotetext{
${ }^{1}$ Low, P. F., \& Lovell Jr., C. W. (1959). The factor of moistures in frost action. In Highway Research Bulletin 225. HRB. National Research Council. Washington. D.C., 1959.

${ }^{2}$ Chu, T. Y. \& Humphries, W. K. (1972). Investigation of subgrade moisture conditions in connection with the design of flexible pavement structures. Final Report. College of Engineering, University of South Carolina, Columbia, 1972.
} 
localidades, mostraram que quanto mais fino o solo, maior é a diferença entre a umidade de equilíbrio e a umidade ótima. A maior diferença observada foi de aproximadamente $8 \%$ para um solo com teor de finos (\% que passa \#200) igual a $55 \%$. Para alguns solos estudados, particularmente com teores de finos menores do que $25 \%$, a tendência observada foi contrária, ou seja, a umidade de equilíbrio do subleito foi menor do que a umidade ótima. Nesta época, segundo Thadkamalla \& George (1994), ganhava aceitação para a estimativa empírica da condição de umidade dos solos de subleito o índice de umidade de Thornthwaite, que relaciona a condição de umidade do subleito a índices climáticos, tais como precipitação, evapotranspiração e temperatura média do ar.

Segundo Medina (1997), o Índice de umidade de Thornthwaite (Thornthwaite Moisture Index - T.M.I), ou simplesmente Índice de umidade ( $\mathrm{Im})$, é definido por:

$$
\operatorname{Im}=\frac{100 \cdot e x c-60 \cdot d e f}{E P}
$$

ou

$$
T M I=\frac{S-0,6 \cdot D}{P E}
$$

onde: exc (S): excedente anual de água (surplus);

def (D): déficit anual de água;

EP (PE): evapotranspiração anual, definida como a quantidade de água que seria perdida através de uma superfície completamente coberta de vegetação.

O déficit é determinado pela diferença entre a evapotranspiração potencial anual e a evapotranspiração real, sendo definido como a parte da demanda total de água pela vegetação que não é satisfeita num determinado período. O excedente é determinado pela diferença entre a precipitação e a evapotranspiração potencial num determinado período, já estando satisfeita a capacidade de retenção de água no solo. Portanto, o Índice de umidade indica o balanço hídrico anual num solo natural.

Em uma pesquisa desenvolvida por Abo-Hashema et al. (2002) em cinco trechos de rodovias do estado americano de Idaho para estudar os impactos das 
mudanças ambientais sobre o desempenho do pavimento, o teor de umidade do subleito apresentou uma flutuação nos primeiros dois anos seguintes à construção, após os quais se observou um equilíbrio da umidade. Na média, os dados coletados mostraram que a umidade de equilíbrio variou de 1,2 a 2,3 vezes o limite de plasticidade dos solos de subleito estudados, quando estes eram considerados plásticos.

\subsubsection{A umidade de equilíbrio em regiões tropicais}

Atchison \& Richards $(1965)^{3}$ apud Thadkamalla \& George (1995) reportaram, num estudo realizado na Austrália, que a estabilidade da umidade sob grande parte das áreas pavimentadas é semelhante em todos os trechos analisados, independentemente das condições climáticas.

Num estudo desenvolvido por Souza et al. (1977), e descrito por Medina (1997), para avaliar o método de dimensionamento de pavimentos flexíveis do DNER, foram realizadas sondagens em trechos homogêneos de $500 \mathrm{~m}$ a $1000 \mathrm{~m}$ de extensão, sendo constatado que a umidade natural era, quase sempre, inferior à ótima.

Em pesquisa desenvolvida pelo Instituto de Pesquisas Rodoviárias de 1979 a 1984, P.A.E.P. - Pesquisa de Avaliação Estrutural de Pavimentos, estudou-se a sazonalidade das deflexões medidas em provas-de-carga com rodas pneumáticas de caminhão, em 53 trechos experimentais de estradas brasileiras. Foram abertos quatro poços por trecho, sendo dois na estação chuvosa e dois na estação seca. Em cerca de onze trechos a umidade do subleito permaneceu invariável; para os demais, se procurou a correlação da deflexão com a umidade. O efeito da sazonalidade foi verificado insignificante quanto a variações de umidade refletidas na deflexão. Numa das regiões, verificou-se que a umidade média de cada trecho era tanto maior quanto maior a deflexão. Entretanto, em cada trecho considerado individualmente, não se verificou o efeito sazonal, seja aumento da deflexão ou da

\footnotetext{
${ }^{3}$ Atchison, G. D. \& Richards, B. G. (1965). A broad scale study of moisture condition in pavement systems throughout Australia. Moisture equilibria and moisture changes in soils beneath covered areas. Butterworth, Australia, 1965.
} 
umidade in situ na estação chuvosa em relação à estação seca. Este trabalho foi descrito por Medina (1997).

O mesmo autor relata outros dois trabalhos desenvolvidos no mundo tropical. No primeiro, Morin \& Todor $(1975)^{4}$, na pesquisa sobre lateritas como material de pavimentação empreendida pela U.S.A.I.D. em três regiões do mundo tropical, entre elas o Brasil, ficou patente que as umidades in situ das camadas de base e subbase de laterita são quase sempre inferiores aos teores ótimos de compactação. No segundo trabalho, conhecido como Road Note $31^{5}$, é descrita a experiência inglesa nos trópicos. Citam os autores que, "na maioria dos países tropicais, se a drenagem for adequada do ponto de vista da engenharia, raramente o teor de umidade do subleito é superior ao teor ótimo de compactação. $\mathrm{Na}$ verdade, os subleitos são, em geral, mais secos e mais resistentes dos que os de países temperados".

Num estudo desenvolvido em São Paulo por Villibor (1981), foram realizados ensaios in situ com o objetivo de analisar as variações do teor de umidade em camadas de base de pavimentos, constituídas de solos arenosos finos lateríticos. As medidas de umidade aconteceram em vários trechos, na fase de construção e após a abertura ao tráfego, e em diversos meses do ano, durante períodos de chuva e estiagem. Segundo o autor, os teores de umidade da camada de base estavam compreendidos no intervalo de $55 \%$ a $110 \%$ da umidade ótima. Em $90 \%$ dos trechos avaliados, na porção superior da base $(0$ a $5 \mathrm{~cm})$, os teores de umidade apresentam-se inferiores a $80 \%$ da umidade ótima, enquanto que na porção inferior (5 a $15 \mathrm{~cm}$ ), estes teores variam entre $80 \%$ e $100 \%$ da umidade ótima. De modo geral, os teores de umidade de trabalho encontram-se abaixo da umidade ótima de laboratório, mesmo em períodos de chuva.

Em um trabalho realizado por Bernucci et al. (2000) em que se estudou os efeitos da sucção e da temperatura na movimentação d'água em pavimentos

\footnotetext{
${ }^{4}$ Morin, W. J. \& Todor, P. C. (1975). Laterite and lateritic soils and other problem soils in the tropics. (Lyon Associates Inc.), Rio de Janeiro, 1975. 377p.

${ }^{5}$ TRANSPORTATION AND ROAD RESEARCH LABORATORY. A guide to the structural design of bitumen-surfaced roads in tropical and sub-tropical countries. Road Note 31. Londres: HMSO, 1977, 3 ed., 26p.
} 
construídos com solos lateríticos, os efeitos do clima quente e úmido, combinados com as condições hidrológicas e de relevo do interior paulista, provocam umidades de equilíbrio de bases de solos abaixo daquelas utilizadas na compactação.

\subsection{A gênese dos solos em regiões tropicais}

Processos geológicos e/ou pedológicos, característicos de zonas tropicais, atuando sobre os solos conferem a estes peculiaridades de propriedades e de comportamento, quando comparados aos solos de regiões não tropicais. Para que um solo possa ser considerado como tropical, não é suficiente que a sua formação tenha ocorrido na faixa tropical ou em regiões de clima tropical úmido, mas é necessário que estes apresentem peculiaridades de interesse geotécnico. Duas grandes classes podem ser destacadas dentre os solos tropicais: os solos lateríticos e os solos saprolíticos (Nogami \& Villibor, 1995). Os autores destacam que os primeiros são caracterizados por possuírem uma série de propriedades que levam a classificá-lo como solo de comportamento laterítico, segundo a classificação MCT, enquanto os últimos resultam da decomposição e/ou desagregação da rocha, mantendo a estrutura da rocha de origem.

A constituição mineralógica é importante para as propriedades e comportamento dos solos. Provavelmente, as variações mineralógicas existentes nos solos tropicais são muito maiores que os solos de outras regiões. Além disso, muitos dos comportamentos peculiares dos solos tropicais podem ser explicados por sua constituição mineralógica, justificando a importância de se considerar essa característica no estudo geotécnico dos solos tropicais (Nogami \& Villibor, 1995).

Com o intuito de listar os minerais passíveis de serem encontrados nos diversos solos estudados nesta pesquisa, realizou-se um levantamento bibliográfico onde foram consultados, principalmente, os trabalhos de Nogami \& Vilibor (1995), Brinatti (2001) e Alves (2002).

Inicialmente, apresenta-se uma discussão sobre o tema extraído de Nogami \& Villibor (1995). 
Estes autores destacam que os solos superficiais lateríticos apresentam uma mineralogia relativamente simples, sendo o quartzo um mineral encontrado com muita freqüência e, quase sempre, de maneira predominante nas frações areia e pedregulho desses solos, como acontece também nos solos não tropicais. Outros minerais, resistentes à ação das intempéries, podem ocorrer nesses solos, dentre eles: magnetita, ilmenita, rutílio, turmalina, zircão, etc. Outro mineral, na verdade uma associação de minerais, que freqüentemente ocorre na fração pedregulho dos solos superficiais lateríticos é a laterita ou concreção laterítica, constituída essencialmente de óxidos hidratados de ferro e de alumínio. Ainda segundo estes autores, em contraste com os solos superficiais lateríticos, os solos saprolíticos possuem a sua fração areia e pedregulho constituída por uma grande variedade de minerais distintos do quartzo, como os feldspatos, as micas e fragmentos de rocha. Entretanto, isso não exclui que em muitos solos saprolíticos haja também a possibilidade de o quartzo ser o mineral predominante ou mesmo exclusivo. Observam que muitos siltes de solos lateríticos são constituídos essencialmente dos mesmos minerais da fração areia, como os mencionados anteriormente (magnetita, ilmenita e micas). De forma similar ao caso da fração areia, a constituição mineralógica da fração silte dos solos superficiais lateríticos é quase sempre muito simples, sendo nítida a predominância do quartzo. Nos solos desenvolvidos com a contribuição importante de rochas básicas, sobretudo basaltos, podem ocorrer siltes nos quais os constituintes predominantes são a magnetita e a ilmenita. No caso dos solos saprolíticos, a fração silte, de forma semelhante à fração areia, apresenta constituição mineralógica muito variada, podendo, entretanto, ser constituída por apenas um mineral predominante, tal como a caulinita e as micas. O quartzo é um mineral muito comum na fração silte desses solos e a sua presença pode ser considerada normal.

Os mesmos autores destacam que os principais constituintes da fração argila (grãos de diâmetro inferior a 0,002 mm) podem ser classificados da seguinte maneira: i) constituintes minerais (argilominerais, óxidos e hidróxidos de ferro e/ou alumínio), e; ii) constituintes orgânicos. A identificação destes elementos apresenta sérias dificuldades, exigindo equipamentos e pessoal altamente especializados. Para este fim, são utilizados métodos tais como: difração de raios-x, microscopia eletrônica de varredura, análise térmica diferencial, análise química quantitativa, etc. Estes métodos, geralmente, estão fora do alcance dos laboratórios geotécnicos 
rotineiros para finalidades viárias. Os autores ressaltam que a constituição da fração argila dos solos tropicais, principalmente dos lateríticos, desempenha um papel decisivo no comportamento peculiar desses solos, quando comparados com aqueles similares granulometricamente aos de países situados em climas não tropicais. Daí a necessidade de se conhecer as peculiaridades de constituição dos solos tropicais, mesmo que a sua determinação só possa ser feita excepcionalmente.

Os argilominerais são silicatos de alumínio hidratados, podendo conter pequena quantidade de elementos alcalinos $(\mathrm{K}, \mathrm{Na}, \mathrm{Li})$ e alcalinos terrosos ( $\mathrm{Ca}$ e $\mathrm{Mg}$, principalmente), Além disso, o alumínio de sua estrutura cristalina pode ser total ou parcialmente substituído por $\mathrm{Fe}^{+++}, \mathrm{Fe}^{++}$ou $\mathrm{Mg}^{++}$. A maioria dos argilominerais possui arranjo atômico lamelar, tabular ou alongado. Os argilominerais são classificados, geralmente, com base na sua estrutura atômica, sendo:

1. Estrutura atômica tipo $1: 1$, isto é, uma repetição sucessiva de pacotes constituídos de uma camada de tetraedros de sílica e de uma camada de octaedros de alumina, sendo que esses pacotes estão ligados por força atômica do tipo hidrogênio, que é um tipo de ligação considerada forte.

- Grupo da caulinita - cristais tabulares

- Grupo da Haloisita - cristais alongados (tubulares)

2. Estrutura atômica tipo 2:1, isto é, repetição sucessiva de pacotes constituídos de 2 camadas de tetraedros de sílica e uma de octaedros de alumina (ou de magnésia). Esses pacotes são ligados por cátions trocáveis (caso das ilitas) ou, apenas, por forças de Van der Waals, de pequena intensidade.

- Grupo da Montmorilonita (ou esmectita) - expansivo, com unidades estruturais ligadas apenas por forças de Van der Waals, permitindo a penetração de moléculas de água na sua estrutura

$$
\begin{aligned}
& \Rightarrow \text { Montmorilonita } \\
& \Rightarrow \text { Nontronita }
\end{aligned}
$$

- Grupo da llita - não expansivo, na realidade são micas com graus variados de hidratação e algumas substituições atômicas, por isso também conhecidas por hidromicas ou hidromuscovitas

3. Estrutura atômica em camadas alongadas 
- Atapulgita

- Sepiolita

- Paligorskita

4. Estrutura atômica de camadas de tipo 2:2 (clorita), mistas de tipos 2:2 e 2:1 e tipos gradacionais.

Os argilominerais caracterizam-se por possuir uma série de propriedades peculiares, das quais se destacam:

i. Enorme superfície específica, decorrente sobretudo de suas dimensões diminutas (da ordem de micrômetros a nanômetros) e de sua forma lamelar e/ou alongada;

ii. Cargas elétricas predominantemente negativas, que the proporcionam capacidade de troca catiônica, quando em suspensão aquosa e, também, condicionam o grau de acidez ou pH do solo;

iii. Tornam-se plásticos quando apropriadamente umedecidos e, nessa condição, se submetidos à secagem, adquirem considerável resistência;

iv. Apresentam grandes variações volumétricas, tanto por perda de umidade por secagem ou por aplicação de pressão, quando saturados (adensamento), como por aumento de umidade (expansão);

v. Quando em suspensão aquosa, exibem o fenômeno da floculação (agregação de grãos) e dispersão, cujo grau depende bastante da concentração e natureza das substâncias químicas em solução.

De maneira geral, as propriedades acima caracterizadas se acentuam na seguinte ordem: grupo da caulinita, grupo da ilita e grupo da montmorilonita. Como a maior intensidade de muitas das propriedades acima consideradas são prejudiciais às obras civis, a presença de solos que contêm elevada porcentagem de minerais do grupo da montmorilonita é freqüentemente temida.

As partículas de argila, devido à natureza dos argilominerais, apresentam forma lamelar e têm carga elétrica negativa, o que provoca a atração de cátions $\left(\mathrm{Na}^{+}, \mathrm{K}^{+}, \mathrm{Ca}^{++}\right)$e moléculas de água. A água que é atraída pela partícula juntamente com os cátions é chamada água adsorvida e a que escoa livremente nos vazios do solo é denominada de água livre. Quanto maior a carga elétrica 
negativa do argilomineral, maior a quantidade de íons atraídos pela partícula e maior a espessura da camada de água adsorvida. Tem-se, portanto, maior capacidade de retenção de água pelo solo (Holtz \& Kovacs, 1981).

Ainda segundo Nogami \& Villibor (1995), os óxidos e hidróxidos de ferro e de alumínio mais freqüentes na fração argila dos solos tropicais e as suas propriedades de maior interesse geotécnico são os seguintes:

1. Hidróxidos e óxidos hidratados de ferro $\left(\mathrm{Fe}_{2} \mathrm{O}_{3} \cdot \mathrm{nH}_{2} \mathrm{O}\right)$

- Goetita - óxido de ferro e hidrogênio ortorrômbico, de brilho adamantino ou metálico, dimorfo da lepidocrocita. Ocorre sob a forma de agulhas e ripas

- Lepidocrocita - óxido de ferro ortorrômbico, dimorfo da goetita e mais raro que esta, de cor vermelha ou acastanhada. Ocorre sob a forma de placas alongadas, muitas vezes mal cristalizadas.

- Limonita - óxido de ferro hidratado de cor amarelo-ocre ou marrom, formado por oxidação de minérios de ferro, constituído principalmente de goetita. Na realidade é uma mistura de vários óxidos de ferro com alguma água adsorvida, conhecida também como hidrogoetita. As suas propriedades dependem sobretudo das dimensões e estado de agregação de seus componentes.

- Ferrihidrita - mal cristalizado, partículas esféricas extremamente pequenas, da ordem de nanômetros

2. Hidróxidos de alumínio $\left(\mathrm{Al}_{2} \mathrm{O}_{3} \cdot \mathrm{nH}_{2} \mathrm{O}\right)$

- Diásporo - óxido de alumínio de hábito lamelar, encontrado em bauxitas

- Boehmita - forma ortorrômbica de óxido e hidróxido de alumínio $\mathrm{AlO}(\mathrm{OH})$, encontrado na bauxita

- Gibbsita - hidróxido de alumínio monoclínico, principal constituinte de muitas bauxitas, branco, incolor ou cores claras, freqüentemente mal cristalizado, aparentemente amorfo.

- Bauxita - rocha com a aparência de argila, mas sem plasticidade, constituída de hidróxidos de alumínio e óxidos de alumínio hidratados, e contendo impurezas, como sílica em estado livre, lodo, hidróxido de ferro e minerais argilosos. Formada em climas tropicais 
e subtropicais por intemperismo sobre rochas aluminosas através da lixiviação da sílica. Na realidade é uma mistura de vários hidróxidos de alumínio, com alguma água adsorvida. As suas propriedades dependem, portanto, do tamanho de seus componentes e do estado de agregação dos mesmos

3. Hidróxidos de ferro e de alumínio amorfos que ocorrem sob a forma de gel

4. Óxidos anidros de ferro - ocorrem em pequena porcentagem na fração argila e sua influência nas propriedades da fração argila é pouco conhecida, a não ser como responsável pelo matiz preto e vermelho

- Hematita - sesquióxido de ferro trigonal, é o principal mineral-minério de ferro, de cor cinza ou preta, forte brilho metálico e traço vermelho.

- Magnetita - óxido de ferro cúbico, de cor preta, fortemente magnético, opaco, um dos três principais minerais-minério de ferro

Os óxidos e hidróxidos de ferro e de alumínio hidratados possuem propriedades cimentantes, desempenhando papel importante na formação de agregados e concreções lateríticas dos solos lateríticos. Importante é a contribuição dos óxidos de ferro na cor dos solos e eventuais propriedades pozolânicas dos óxidos de alumínio hidratados.

Portanto, no que diz respeito à fração argila, os solos superficiais lateríticos caracterizam-se por conter elevada porcentagem de óxidos e hidróxidos de ferro e de alumínio, citados anteriormente. Geralmente, o argilomineral presente na fração argila dos solos lateríticos é a caulinita, pertencente à família dos argilominerais menos ativos coloidalmente. A atividade é ainda mais reduzida com a associação aos óxidos e hidróxidos de $\mathrm{Fe}$ ou de $\mathrm{Al}$, que recobrem a caulinita conferindo ao conjunto um aspecto "cimentado". No caso dos solos saprolíticos, a fração argila caracteriza-se, de maneira geral, pelo seguinte: i) possibilidade de ocorrerem argilominerais mais ativos do que aqueles da família da caulinita, tais como os da família da esmectita e da ilita. Entretanto, isso não impede que, em muitos solos saprolíticos, os argilominerais da família da caulinita sejam os exclusivos ou predominantes; ii) os argilominerais e, eventualmente, outros minerais presentes não se apresentam recobertos por óxidos e hidróxidos de $\mathrm{Fe}$ e $\mathrm{Al}$, como no caso dos solos lateríticos. Os contornos dos cristais que o constituem podem ser 
distinguidos com nitidez nas microfotografias obtidas na microscopia eletrônica por varredura.

Nogami \& Villibor (1995) foram os únicos, entre a bibliografia pesquisada, a indicar os constituintes da fração argila individualizados para solos lateríticos e solos saprolíticos (não-lateríticos). Os demais estudos abordam a questão separando os solos, e indicando seus constituintes principais, em função da classe pedológica. Por exemplo, Brinatti (2001) estuda a composição mineralógica de três solos brasileiros com a utilização da técnica de difração de raios- $X$, entre outras. Os solos estudados são: Terra Roxa Estruturada Eutrófica, Cambissolo e Latossolo vermelho-Escuro, segundo a nomenclatura antiga de classificação de solos. Conforme a notação atual, baseada no Sistema Brasileiro de Classificação de Solos (EMBRAPA, 1999), os materiais estudados são, respectivamente: NITOSSOLO VERMELHO Eutrófico latossólico, CAMBISSOLO HÁPLICO Tb Distrófico típico e LATOSSOLO VERMELHO Eutroférrico típico. As amostras de solo foram coletadas em diversos horizontes e, posteriormente, separadas segundo intervalos de diâmetro de partículas. Foram obtidas as frações argila $(\phi \leq 2 \mu \mathrm{m})$, silte $(2 \mu \mathrm{m}<\phi \leq$ $20 \mu \mathrm{m})$, areia fina $(20 \mu \mathrm{m}<\phi \leq 53 \mu \mathrm{m})$ e areia grossa $(53 \mu \mathrm{m}<\phi \leq 1 \mathrm{~mm})$. No total, foram analisadas 44 amostras. Ainda segundo o autor, de forma geral, a comparação entre os solos estudados permite afirmar que a grande diferença da Terra Roxa Estruturada Eutrófica é a maior presença dos argilominerais (caulinita, nacrita e haloisita), presença de ilmenita, com pouca quantidade de anatásio, rutílio e gibbsita. O Cambissolo mostra pequenas quantidades de hematita e goetita, e o grande diferencial do Latossolo Vermelho-Escuro é a presença marcante de gibbsita.

Segundo Alves (2002), os latossolos são os que melhor representam as tendências pedogenéticas dos solos tropicais, sendo definidos como aqueles que apresentam um horizonte subsuperficial mineral B latossólico, que evidencia seu estágio avançado de intemperismo, como mostrado pela completa ou quase total alteração e decomposição de minerais facilmente intemperizáveis, pela elevada profundidade e pela baixa capacidade de troca catiônica. Além dos latossolos, há destacada presença de argissolos, os quais se apresentam com diferentes graus de intemperismo. O autor destaca ainda que, os latossolos apresentam mineralogia da fração argila basicamente dominada por caulinita, gibbsita, goetita e hematita, além 
de óxidos de ferro e alumínio mal cristalizados, tais como a lepidocrocita e a maghemita. Sobre a gibbsita o pesquisador a descreve como sendo o único óxido de alumínio cristalino presente em solos das regiões tropicais, e que micas, rutílio e anatásio são outros minerais geralmente identificados nos latossolos; os argissolos, por sua vez, tendem a apresentar, além dos referidos minerais e óxidos mal cristalizados, argilominerais do tipo 2:1, como a vermiculita e a ilita.

Conforme já discutido anteriormente, sendo os argilominerais (minerais constituintes mais importantes da fração argilosa dos solos) tão pequenos (da ordem de nanômetros), sua identificação pelas técnicas convencionais não é possível. Portanto, outros meios devem ser empregados para esta finalidade, tais como a difração de raios-x.

Sabe-se que materiais com padrões regulares, ou repetitivos, de estrutura cristalina provocam a difração de raios-x. Minerais diferentes, com estrutura cristalina diferente, apresentarão padrões diferentes de difração dos raios- $x$, conferindo-lhes uma identidade. Os padrões para os minerais mais comuns são identificados e divulgados, sendo relativamente simples a comparação entre um espectro de difração desconhecido com padrões conhecidos de minerais. Entretanto, essa aparente "facilidade" se extingue ao se trabalhar com solos, que são uma mistura de argilominerais e podem conter matéria orgânica além de outros constituintes que não os argilominerais. Usualmente, uma análise quantitativa detalhada é impossível a partir de um ensaio de difração de raios- $x$, o máximo que se pode dizer é que minerais estão presentes e grosseiramente o quanto de cada (Holtz \& Kovacs, 1981). Na verdade, para um espectro de raios-x de um solo seria possível dizer que minerais estão presentes em maiores quantidades na amostra pela comparação entre as intensidades dos picos característicos indicados no padrão de difração, já que a quantidade de material, além do grau de cristalinidade, é uma das variáveis que influenciam na intensidade destes picos.

É possível empregar a difração de raios-x na caracterização de materiais porque na maior parte dos sólidos (cristais) os átomos se ordenam em planos cristalinos separados entre si por distâncias da mesma ordem de grandeza dos comprimentos de onda dos raios-x. Algumas das razões para se preferir utilizar a difração de raios-x na identificação mineralógica de argilas são: a possibilidade de 
estudo de apenas uma reflexão dos argilominerais, que pode ser obtida entre 2 a 3 minutos percorrendo apenas a região de $2 \theta$ que corresponde a essa reflexão do argilomineral em estudo, sendo que $\theta$ representa o ângulo de difração dos raios-x. Percorrendo a região de $2 \theta=2^{\circ}$ e $2 \theta=15^{\circ}$, é possível detectar em 15 minutos as reflexões basais dos principais argilominerais; percorrendo a região de $2 \theta=2^{\circ}$ a $2 \theta$ $=30^{\circ}$, detectam-se também as reflexões de segunda ordem dos argilominerais, as reflexões mais intensas dos óxidos de silício e de hidróxido de alumínio; percorrendo a região de $2 \theta=2^{\circ}$ até $2 \theta=65^{\circ}$, detecta-se a maior parte das reflexões, inclusive a reflexão que permite a diferenciação entre argilominerais di e trioctaédricos (Santos, 1992).

Segundo Albers et al. (2001), ao se caracterizar argilominerais, a utilização da técnica de difração de raios-x torna-se ainda mais indicada, pois uma análise química reportaria os elementos químicos presentes no material, mas não a forma como eles estão ligados. A análise química poderia então ser associada à análise racional, porém os resultados obtidos não apresentam elevada confiabilidade, além deste procedimento não ser indicado para identificar fases polimórficas. A semelhança do comportamento térmico dos argilominerais também descarta a utilização isolada das técnicas termo-diferenciais, que também são mais dispendiosas e demoradas.

Segundo Santos (1992), o método de difração de raios-x em relação a outros métodos físicos, como a análise térmica diferencial, ou químicos, como a análise química ou capacidade de troca de cátions, oferece a vantagem de o difratograma apresentar um número grande de picos, o que facilita a identificação, principalmente no caso de misturas, onde pode haver superposição de alguns picos, mas nunca de todos (exceto em caso de estruturas cristalinas muito próximas, como a caulinita e haloisita- $2 \mathrm{H}_{2} \mathrm{O}$ ); por outro lado, em uma mistura, não há alteração da posição dos picos devido à mistura, em oposição ao que ocorre, por exemplo, em análise térmica diferencial de misturas de caulinita com ilita ou montmorilonita, cujos picos são resultantes combinadas das posições dos picos dos argilominerais componentes. Naturalmente, o método de difração de raios-x falha na identificação de substâncias amorfas, como o alofano, cliaquita ou matéria orgânica, sendo necessários outros métodos para essas substâncias. 
Segundo Albers et al, (2001), na caracterização dos minerais, o elevado teor de quartzo de uma amostra e sua facilidade de orientar-se resultam em picos bem definidos e de grande intensidade, prejudicando muitas vezes a identificação e caracterização dos demais minerais. Outros problemas ou dificuldades encontrados na aplicação do método podem ser devidos à presença de teores elevados de compostos de ferro (Santos, 1992).

\subsection{Relação entre umidade e sucção}

Sucção é a força com que um elemento poroso absorve água quando esta está livre para se mover. Esta avidez por água é função basicamente da mineralogia, massa específica e umidade do solo (Fredlund \& Rahardjo, 1993).

A sucção total $(\psi)$ pode ser considerada como sendo a soma de duas parcelas: a sucção matricial ou mátrica $\left(u_{a}-u_{w}\right)$ e a sucção osmótica $(\pi)$, onde a primeira está relacionada com a matriz do solo, ou seja, com as forças capilares e de adsorção e a segunda ao fenômeno da osmose. A sucção matricial é definida quantitativamente como a diferença entre a pressão na fase ar $\left(u_{a}\right)$ e a pressão na fase água $\left(u_{w}\right)$, atuantes nos poros do solo. Já a sucção osmótica deve-se à concentração de sais dissolvidos presentes na água encontrada nos solos (Botelho et al., 2000).

Segundo Aguilar (1990), a medida direta da sucção em solos é difícil de se realizar, sendo usualmente possível para valores baixos de sucção (menores do que uma atmosfera). Foram desenvolvidos métodos indiretos que permitem a determinação da sucção do solo através de correlações ou curvas de calibração. Uma destas técnicas envolve a obtenção da curva característica umidade-sucção, que relaciona a sucção com o teor de umidade volumétrico $(\theta)$. A construção da curva característica em função do parâmetro $\theta$ apresenta o problema de que, na realidade, variações de sucção produzem deformações no solo, não sendo, portanto, constante o volume total da amostra durante o ensaio. Assim, a definição correta da curva característica em função do parâmetro $\theta$ exige a determinação da variação volumétrica do solo em cada estágio de sucção, o que complica notavelmente o ensaio, pois a medida de variação de volume de uma amostra não- 
saturada requer técnicas mais complexas. Segundo o autor, acredita-se que nos problemas de engenharia geotécnica relacionados com resistência, um índice mais recomendável para definir a curva característica é a umidade em peso do solo (w), definida como a relação entre o peso da água e o peso seco do solo, pois ela não depende da variação volumétrica da amostra durante o ensaio. Já em problemas de deformações em solos não-saturados a umidade volumétrica é mais conveniente, pois ela está relacionada ao volume total da amostra, que para cada intervalo de tempo seria a solução do problema.

Existem vários métodos para a medição de sucção em solos, no campo e em laboratório. A Tabela 2.1 apresenta as técnicas mais usadas para medir a sucção e os intervalos de aplicação de cada técnica.

Segundo Camacho \& Bernucci (2000), é comum a ocorrência de tensões de sucção de algumas centenas de kPa em solos argilosos compactados mais secos, sendo necessário meios de determinações de sucções mais altas. Dentre eles, o método do papel filtro tem sido utilizado por sua simplicidade e baixo custo, e por permitir a determinação de valores extremamente altos de tensões.

Tabela 2.1: Técnicas de medição de sucção

\begin{tabular}{|c|c|c|c|c|}
\hline \multirow{2}{*}{ Técnica } & \multicolumn{3}{|c|}{ Sucção } & \multirow{2}{*}{$\begin{array}{c}\text { Intervalo } \\
(\mathrm{kPa})\end{array}$} \\
\hline & Matricial & Osmótica & Total & \\
\hline Psycrômetro & & $\uparrow$ & $\uparrow$ & $100-8000$ \\
\hline Papel filtro & $\uparrow$ & & $\uparrow$ & $0-29000$ \\
\hline Tensiômetro & $\uparrow$ & & $\uparrow$ & $0-100$ \\
\hline Translação de eixos & $\uparrow$ & & & $0-1500$ \\
\hline Condutividade térmica & 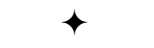 & & & $0-400$ \\
\hline Condutividade elétrica & 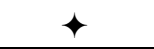 & 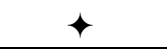 & & $20-1500$ \\
\hline
\end{tabular}

Segundo Marinho (1994), o método do papel filtro baseia-se no princípio de que quando um solo é colocado em contato com um material poroso que possua capacidade de absorver água, a mesma irá passar do solo para o material poroso até que o equilíbrio seja alcançado. Tendo-se a relação entre sucção e umidade do material poroso, chamada de calibração, a sucção do solo pode ser obtida referindo-se à curva de calibração. O estado de equilíbrio fornece a mesma sucção no solo e no material poroso, porém umidades diferentes. A sucção obtida depende do tipo de transferência de água do solo para o papel, que pode se dar por capilaridade ou através de vapor, e é determinada pela interação entre o papel 
filtro/solo. No caso de fluxo de vapor, as moléculas de água têm que escapar da água de poro vencendo as forças capilares no solo e eventualmente forças osmóticas que agem devido à presença de sais. $\mathrm{O}$ espaço de ar deixado entre o solo e o papel filtro fornece uma barreira para os sais, permitindo apenas o fluxo de vapor de água. Neste caso, mede-se a sucção total $(\Psi)$, uma vez que estará incorporando forças osmóticas e capilares que retêm as moléculas de água. O fluxo capilar ocorre através das partículas do solo e das fibras do papel filtro, sem que a água perca continuidade. O fluxo capilar implica numa interação entre o papel filtro e a água de poro. Quando o fluxo ocorre apenas por capilaridade a sucção matricial $\left(u_{a}-u_{w}\right)$ é medida. Neste caso, o componente osmótico não age como força adicional que impede o fluxo de água para o papel filtro. A Figura 2.1 indica os tipos de fluxos de água do solo para o papel filtro.

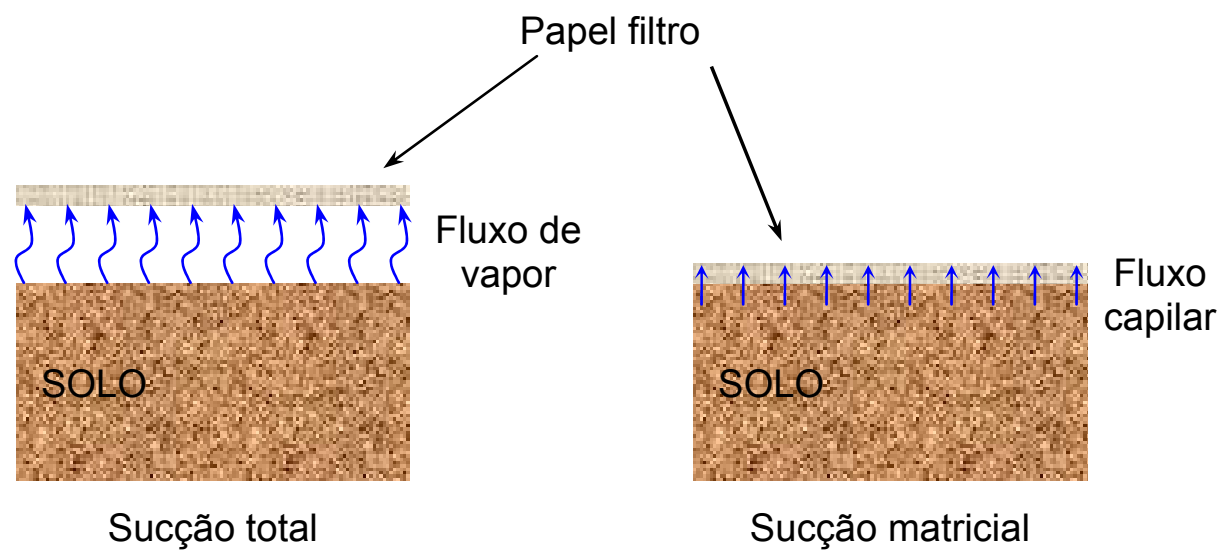

Figura 2.1: Tipos de fluxos de água do solo para o papel filtro

Discutem-se no, Capítulo 3, item 3.4.1.3, alguns aspectos práticos sobre a determinação da sucção e obtenção da curva característica.

$\mathrm{Na}$ seqüência, apresentam-se alguns estudos realizados no Brasil relacionados à determinação da sucção e obtenção da curva característica de solos pelo método do papel filtro.

Gonçalves (1998) determinou a relação entre o teor de umidade e sucção para um solo fino, classificado como LG'/A-7-6/CL segundo as classificações MCT, HRB e USCS, respectivamente, em diversas condições de umidade, através do método do papel filtro. A curva característica foi determinada para corpos-de-prova compactados na $w_{0}\left(19,5 \%\right.$ para o Proctor normal), compactados na $w_{o} e$ 
umedecidos até $w_{0}+1 \%$, compactados na $w_{0}$ e secos até $w_{0}-2 \%, w_{0}-4 \%, w_{0}-6 \%, w_{0}-$ $8 \%$ e $w_{0}-15 \%$, compactados na $w_{o}$ e secos por $48 h$, seguido de umedecimento até $w_{0}$. O autor observou que a sucção diminui com o aumento da umidade, sendo válido o inverso, a sucção aumenta quando a umidade diminui. Os corpos-de-prova submetidos a ciclos de secagem e umedecimento $\left(w_{0} \rightarrow\right.$ seco por $48 \mathrm{~h} \rightarrow \mathrm{w}_{\mathrm{o}}$ ) apresentaram uma redução de $87 \%$ no valor de sucção quando comparados com aqueles c.p. moldados na $w_{0}$ e que não tiveram a umidade variada. Verificou-se também que os ensaios triaxiais cíclicos não alteraram o nível de sucção dos corpos-de-prova ensaiados, sendo semelhantes as curvas características obtidas antes e após a execução dos ensaios.

Camacho \& Bernucci (2000) estudaram a variação das sucções matriciais ao longo da curva de compactação mini-Proctor, na energia equivalente ao Proctor normal, de um solo arenoso fino laterítico, classificado como LA'/A-4 segundo as classificações MCT e HRB, respectivamente, e com 52\% das partículas passando na peneira \#200. Utilizou-se no trabalho o método do papel filtro para a determinação das sucções matriciais. Segundo os autores, os resultados obtidos mostram que, para determinações sem imersão dos corpos-de-prova, a diminuição da umidade de moldagem implica em sucções crescentes. Para sucções determinadas após a imersão dos corpos-de-prova, as curvas características se assemelham à curva de compactação, ou seja, apresentam um valor máximo de sucção para umidades de moldagem próximas da $w_{0}$. Observou-se que, para corpos-de-prova compactados no ramo úmido, as tensões de sucção já são bem mais baixas em função do alto grau de saturação, e conseqüentemente, as diminuições das sucções matriciais, após a imersão, não são significativas quando comparadas àquelas verificadas no ramo seco. No ramo seco, os graus de saturação são baixos, diminuindo à medida que se afasta da $w_{0}$. Nestas condições, a imersão em água ocasiona uma queda significativa da sucção, sendo tanto maior quanto mais secos, ou mais distantes da $\mathrm{w}_{\mathrm{o}}$.

Botelho et al. (2000) estudaram a influência da variação da umidade de compactação na curva característica de um solo fino laterítico, a partir de determinações em laboratório, pelo método do papel filtro, das curvas características de um solo argiloso (classificado como LG' e A-7-5 segundo as classificações MCT e HRB, respectivamente) compactado dinamicamente, segundo 
o Proctor intermediário, em três níveis de umidade $\left(w_{0}=23,7 \%, w_{0} \pm 3 \%\right)$. Os autores concluíram que ao se observarem os resultados das curvas características em sua representação convencional, dir-se-ia que a umidade de compactação não as influenciariam. Entretanto, ao se analisar os resultados pela ótica do modelo de normalização proposto por Camapum de Carvalho \& Leroueil (2000), seria possível verificar que as curvas características do solo estudado são afetadas pela umidade de compactação.

É importante destacar que Camapum de Carvalho \& Leroueil (2000) apresentam um modelo de normalização da curva característica em função do índice de vazios, tornando-a uma função única quando se trata da mesma distribuição de poros. Segundo Delgado (2002), para um dado solo têm-se curvas características ( $\mathrm{pF}$ x Sr) variando com o índice de vazios, pois quanto menor este índice, maior será a sucção para um mesmo grau de saturação. Portanto, ao solicitar-se um solo ocorre redução do índice de vazios e, conseqüentemente mudança de curva característica. Sendo assim, a transformação da curva característica por este modelo é realizada multiplicando-se a sucção $(\mathrm{pF})$ pelo índice de vazios (e). Dessa forma, a partir da equação (2.3) obtêm-se uma curva característica única, definida pela equação (2.4), representativa de diferentes índices de vazios para a mesma distribuição de poros.

$$
\begin{gathered}
p F_{i}=a_{i} \cdot S r_{i}+b_{i} \\
e \cdot p F=a_{n} \cdot S r+b_{k}
\end{gathered}
$$

onde: $\mathrm{pF}_{\mathrm{i}}$ : logaritmo da sucção em centímetros de coluna de água;

$a_{i}:$ estabelece a alteração de pFi em função das variações do grau de saturação;

$\mathrm{Sr}_{\mathrm{i}}$ : grau de saturação;

$b_{\mathrm{i}}$ : corresponde à pressão de entrada de ar para um dado índice de vazios;

$a_{n}$ : produto do índice de vazios por $a_{i}$;

$b_{k}$ : produto do índice de vazios por $b_{i}$;

Camacho et al. (2001) usaram o método do papel filtro para determinar as sucções matriciais de corpos-de-prova compactados com um solo LA'/A-4, segundo 
as classificações MCT e HRB, respectivamente, em conformidade com o procedimento mini-Proctor da metodologia MCT, para energias de compactação equivalentes ao Proctor normal e intermediário. A Tabela 2.2 apresenta os parâmetros de compactação dos corpos-de-prova em função da energia usada.

Os c.p. foram submetidos a processos de secagem, partindo-se da $w_{0}$, e a processos de umedecimento, de modo que, cada ponto das curvas características corresponde a um corpo-de-prova.

Tabela 2.2: Parâmetros de compactação do solo estudado segundo o ensaio miniProctor (adaptado de Camacho et al., 2001).

\begin{tabular}{ccc}
\hline \multirow{2}{*}{ Energia } & $\begin{array}{c}\text { Peso específico aparente } \\
\text { seco máximo }\left(\mathrm{kN} / \mathrm{m}^{3}\right)\end{array}$ & Umidade ótima (\%) \\
\hline Normal & 19,8 & 10,4 \\
Intermediária & 20,6 & 9,7 \\
\hline
\end{tabular}

Os pesquisadores observaram que as umidades alcançadas no final das curvas de umedecimento foram de 10,8\% na energia normal, e de 9,7\% na intermediária, ou seja, as umidades atingidas por reabsorção retornam praticamente aos valores de partida $\left(w_{\mathrm{ot}}\right)$. Verificou-se a ocorrência do fenômeno da histerese, quando as sucções não retornam ao ponto de partida.

Delgado (2002) desenvolveu um trabalho em que se estudou a influência da sucção no comportamento mecânico de um perfil de solo laterítico compactado. As amostras para pesquisa foram coletadas em profundidades variando de 0,0 a 9,0 m no Campo Experimental do Programa de Pós-Graduação em Geotecnia da Universidade de Brasília. Utilizou-se o método do papel filtro para determinação das curvas características dos materiais nas diversas profundidades. Ao estudar a influência da umidade na sucção em corpos-de-prova com densidades variáveis, a pesquisadora verificou a ocorrência de uma nítida redução da sucção com o aumento da umidade de compactação, para todas as profundidades trabalhadas. Observou também que mesmo com diferentes índices de vazios, não se verificou para a mesma umidade, alterações significativas na sucção, o que coloca a umidade como principal fator definidor da sucção. A autora estudou ainda a variação da sucção com o aumento da energia de compactação, tendo verificado que a sucção não sofre grandes variações com o aumento da energia aplicada para uma determinada umidade de compactação. 


\subsection{O módulo de resiliência no projeto de pavimentos}

A aplicação de métodos racionais, também conhecidos como métodos mecanísticos, para o projeto de pavimentos requerem o conhecimento de propriedades mecânicas dos materiais, tais como o módulo de resiliência dos solos.

Desde 1986 o guia de dimensionamento da AASHTO passou a recomendar o uso do módulo de resiliência como a propriedade para a caracterização dos materiais empregados em pavimentos flexíveis.

Como já discutido anteriormente, o subleito está sujeito a variações sazonais do teor de umidade, que podem refletir em variações sazonais do módulo de resiliência.

O procedimento de dimensionamento de pavimentos da AASHTO é um método empírico, baseado nos resultados do AASHO road tests, conduzido próximo a Ottawa, Illinois, entre 1958 e 1960. Foram avaliadas um total de 10 faixas, sob cargas controladas (de eixos simples de $9 \mathrm{kN}$ até eixos tandem de 215 $\mathrm{kN}$ ). Aplicou-se um total 1.114.000 passagens de carga de roda durante os testes.

O projeto é baseado em propriedades funcionais da estrutura do pavimento, tais como trincas e deformações permanentes. As variações nas propriedades funcionais são indicadas pelo PSI (present serviceability index), que varia de 0 a 5 , sendo o valor 5 atribuído para condições excelentes. Em rodovias, quando o PSI atinge 2,5 é necessário que se realize a reabilitação do pavimento. A equação original de projeto (2.5), apresentada a seguir, é uma relação entre uma carga de eixo de $80 \mathrm{kN}$ com a espessura das camadas de pavimento e o subleito do AASHO road tests.

$$
\log \left(W_{t 18}\right)=9,36 \cdot \log (S N+1)-0,20+\frac{\log \left[\frac{\left(4,2-p_{t}\right)}{(4,2-1,5)}\right]}{0,40+\left[\frac{1094}{(S N+1)^{5,19}}\right]}
$$

onde: $W_{t 18}$ : número total de aplicações da carga de $80 \mathrm{kN}$ ao final do período de tempo t; 
$S N$ : número estrutural do pavimento;

$P_{t}$ : índice serventia final do pavimento.

Posteriormente, esta equação foi modificada para a consideração de outros tipos de solo de subleito, além do tipo A-6 (segundo a classificação HRB) encontrado no $A A S H O$ road test. Foi então adicionado o termo de valor de suporte do solo $\left(S_{i}\right)$. Incorporou-se também à equação um outro fator, chamado de fator regional $(R)$, para a consideração de outros tipos de clima, além do encontrado no local dos testes. A equação resultante é mostrada em (2.6).

$$
\log \left(W_{t 18}\right)=9,36 \cdot \log (S N+1)-0,20+\frac{\log \left[\frac{\left(4,2-p_{t}\right)}{(4,2-1,5)}\right]}{0,40+\left[\frac{1094}{(S N+1)^{5,19}}\right]}+\log \left(\frac{1}{R}\right)+0,372 \cdot\left(S_{i}-3,0\right)
$$

onde: $W_{t 18}$ : número total de aplicações da carga de $80 \mathrm{kN}$ ao final do período de tempo t;

$S N$ : número estrutural do pavimento;

$R$ : fator climático regional;

$S_{i}$ : valor de suporte do solo.

Com a introdução do guia de dimensionamento da AASHTO de 1996, o valor de suporte do solo foi substituído pelo módulo de resiliência efetivo, $M_{R}$, do solo de subleito, resultando na equação (2.7):

$$
\log \left(W_{t 18}\right)=9,36 \cdot \log (S N+1)-0,20+\frac{\log \left[\frac{\left(4,2-p_{t}\right)}{(4,2-1,5)}\right]}{0,40+\left[\frac{1094}{(S N+1)^{5,19}}\right]}+2,32 \cdot \log \left(M_{r}\right)-8,07(2.7)
$$

onde: $W_{t 18}$ : número total de aplicações da carga de $80 \mathrm{kN}$ ao final do período de tempo $\mathrm{t}$;

$S N$ : número estrutural do pavimento;

$P_{t}$ : índice serventia final do pavimento;

$M_{r}$ : módulo de resiliência efetivo do subleito. 
O módulo de resiliência a ser usado nesta expressão (equação (2.7)) é um valor único que produz a mesma quantidade de danos anual à estrutura do pavimento quando comparado com o dano obtido com o uso dos diferentes módulos do subleito determinados ao longo do ano. $O$ dano relativo $\left(u_{\mathrm{f}}\right)$ é calculado, segundo o guia da AASHTO de 1996, por meio da equação (2.8):

$$
u_{f}=1,18 \cdot 10^{8} \cdot M_{r}^{-2,32}
$$

onde: $u_{f}$ : dano relativo;

$M_{r}$ : módulo de resiliência.

O valor médio dos danos, determinado para cada um dos valores de módulo de resiliência, é usado para se obter o valor único de $M_{R}$ para uso na equação de dimensionamento da AASHTO. Este valor é chamado de módulo de resiliência efetivo, e pode ser estimado a partir de ábacos, ou pela equação (2.9), a seguir:

$$
M_{r}=3005 \cdot \bar{u}_{f}^{-0,431}
$$

onde: $\bar{u}_{f}$ : dano relativo médio;

$M_{r}:$ módulo de resiliência efetivo.

Segundo Drumm et al. (1997), a compreensão do mecanismo de variação das propriedades resilientes do subleito com as alterações no teor de umidade póscompactação, em conjunto com o conhecimento das variações sazonais da umidade do subleito, podem ser usadas para a obtenção do módulo de resiliência efetivo do subleito necessário ao projeto de pavimentos.

Neste sentido, diversas pesquisas vêm sendo realizadas para o estudo da variação sazonal do módulo de resiliência, ou seja, a influência sobre o módulo de resiliência da variação da umidade.

Desde a adoção do Guia de dimensionamento da AASHTO de 1986, reconheceu-se a necessidade e os benefícios de um procedimento mecanísticos para projeto de pavimentos. De 1960 até 1986, todas as versões do guia foram baseadas em equações de desempenho empíricas limitadas às condições 
desenvolvidas no AASHO Road Test, em 1950. Desde então, verificaram-se alterações significantes nos veículos, materiais, processos construtivos e de reabilitação, e projeto. Tornou-se então aparente nesta época a necessidade de um procedimento que levasse em conta mudanças nas cargas, nos materiais e nas características de projeto, bem como a consideração direta dos efeitos climáticos no desempenho do pavimento (NCHRP 1-37A, 2004).

Desenvolve-se desde 1996 o projeto NCHRP 1-37A Guide for MechanisticEmpirical Design of New and Rehabilitated Pavement Structures, que apresentou seu relatório final em março de 2004 com o novo guia de dimensionamento da AASHTO para pavimentos novos e reabilitados, sejam flexíveis ou rígidos. Este guia é baseado em procedimentos de projetos de pavimentos que usam tecnologias mecanísticas-empíricas existentes, incluindo metodologias para calibração, validação e adaptação às condições locais. O guia emprega parâmetros de projeto comuns para tráfego, meio ambiente, e segurança para todos os tipos de pavimento. São fornecidas recomendações para a estrutura (espessura e materiais das camadas) de pavimentos novos e reabilitados, incluindo procedimentos para seleção de espessura das camadas do pavimento, tratamentos de reabilitação, drenagem sub-superficial, estratégias de melhoria de fundação. $E$ de forma opcional, inclui-se uma análise de ciclo de vida. Alguns dos motivos para a implementação deste novo guia estão relacionados às limitações das versões anteriores, que incluem: a não consideração de procedimentos para projeto de reabilitação no $A A S H O$ Road Test; a realização destes testes em uma localidade específica, o que dificulta a consideração dos efeitos das diferenças climáticas no desempenho do pavimento; apenas um tipo de subleito foi usado em todas as seções; apenas bases granulares não estabilizadas foram incluídas nas seções principais do pavimento (incluiu-se o uso limitado de bases estabilizadas quimicamente para pavimentos flexíveis); as suspensões dos veículos, configuração de eixos, e tipos de pneus eram representativos dos anos 50, e muitos não são mais utilizados atualmente; o projeto do pavimento, materiais, e métodos construtivos são representativos do período do $A A S H O$ Road Test; não foi incluída drenagem sub-superficial nas seções de teste; um problema menos óbvio é a diferença entre a magnitude das cargas aplicadas durante o AASHO Road Test e as cargas a que estão submetidos os pavimentos atuais; outra grande extrapolação é a vida de projeto do pavimento, considerando-se que os efeitos a longo prazo do 
clima e envelhecimento dos materiais não foram considerados pela curta duração dos testes (2 anos).

Os procedimentos de projeto mecanístico-empírico incluídos neste novo guia permitem aos projetistas avaliar os efeitos das variações nos materiais, inerentes e devidas a procedimentos construtivos, no desempenho do pavimento. Variações de desempenho durante a vida útil do pavimento devem ser reduzidas já que os procedimentos mecanísticos consideram de forma melhor os efeitos do clima, envelhecimento, materiais modernos, e as cargas atuais dos veículos. $O$ projetista inicialmente considera as condições locais (tráfego, clima, subleito, a condição do pavimento existente para reabilitação) e as condições de construção, propondo um dimensionamento inicial para o pavimento novo ou reabilitado. A adequação desta tentativa é avaliada, e se esta não atende aos critérios de desempenho adotados deve ser revisado e o processo de avaliação é repetido enquanto necessário. Assim o projetista está envolvido no processo de dimensionamento e tem a flexibilidade para considerar diferentes características de projeto e materiais para as condições prevalentes do local. Esta aproximação torna possível a otimização do projeto e confere maior confiança de que tipos específicos de defeitos não se desenvolverão.

No que diz respeito à caracterização dos materiais de pavimentação, o novo guia requer o conhecimento de suas propriedades de resposta para previsão dos estados de tensão, deformação e deslocamento quando a estrutura do pavimento está sujeita a uma carga de roda externa. No sistema mecanístico-empírico do guia as propriedades adotadas são o módulo de elasticidade $(E)$ e o coeficiente de Poisson $(\mu)$. Estas propriedades são informações necessárias para cada camada do pavimento. Requer também o conhecimento dos critérios de aceitação, normalmente associados a alguma medida de resistência (resistência ao cisalhamento, resistência à compressão, módulo de ruptura) ou à manifestação de algum efeito de um defeito (deformação permanente, ruptura por fadiga de materiais cimentados).

O novo guia estabelece uma hierarquia, em três níveis, para a seleção dos parâmetros de projeto relacionados ao tráfego, materiais e meio ambiente. No Nível 1 , que fornece o maior nível de acurácia, os parâmetros de entrada devem ter o 
menor nível de incerteza ou erro, e se aplica a pavimentos com alto volume de tráfego ou a pavimentos em que a falha prematura possa causar danos econômicos e à segurança. Neste nível as propriedades de todos os materiais devem ser obtidas a partir de ensaios em laboratório ou em campo, necessitando assim mais recursos do que os outros níveis. No Nível 2, que fornece um nível intermediário de projeto e seria o mais próximo dos procedimentos usados atualmente no projeto de pavimentos, as propriedades dos materiais podem ser selecionadas pelo projetista, geralmente em um banco de dados, podem ser obtidas a partir de um programa de ensaios limitado, ou estimadas a partir de correlações. O Nível 3, que fornece o menor nível de acurácia, só deve ser utilizado onde as conseqüências de uma falha prematura sejam mínimas. Neste nível, as propriedades dos materiais seriam selecionadas pelo projetista a partir de valores padrão ou médias típicas de uma região. Para este nível, o guia sugere valores padrões para vários itens, tais como o coeficiente de Poisson.

No caso de materiais de bases não-tratadas, sub-bases e subleitos o módulo de elasticidade é caracterizado em termos do módulo de resiliência, descrito a partir de um modelo universal não-linear (vide item 2.7.1.9), aplicável a todos os tipos de materiais de pavimentação não-tratados, variando desde uma argila muito plástica até bases granulares.

No novo guia da AASHTO a consideração dos efeitos climáticos no projeto do pavimento é feito através de uma sofisticada ferramenta de modelagem climática chamada de Enhanced Integrated Climatic Model - EICM, constituindo-se de um programa que simula alterações no comportamento e características do pavimento e materiais de subleito em conjunto com as condições climáticas ao longo de vários anos de operação. O EICM tem a capacidade de calcular e prever as seguintes informações ao longo de todo o perfil pavimento/subleito: temperatura, fatores de ajuste do módulo de resiliência, sucção, teor de água, profundidades de congelamento e descongelamento, inchamento provocado pelo congelamento, e desempenho da drenagem. O modelo pode ser aplicado tanto para pavimentos de concreto asfáltico (flexíveis) quanto para pavimentos de concreto de cimento Portland (rígidos) (NCHRP 1-37A, 2004). 


\subsection{A influência da variação de umidade no valor do módulo de resiliência}

Diversos autores vêm pesquisando ao longo do tempo o efeito da variação da umidade sobre o valor do módulo de resiliência, tanto em estudos realizados em campo quanto em laboratório. Estas pesquisas mostram a forte dependência do módulo de resiliência da condição de umidade do solo. São descritos a seguir alguns destes trabalhos.

Desde a definição do conceito de módulo de resiliência da forma triaxial, proposto por Seed et al. (1962), diversos estudos de laboratório vêm sendo desenvolvidos para se determinar a variação deste parâmetro com mudanças nas propriedades dos solos, teor de umidade, e compactação.

Thompsom \& Robnett (1976) ${ }^{6}$, apud Drumm et al (1997), conduziram uma extensa série de ensaios de módulo de resiliência em uma grande variedade de solos de subleito do estado americano de Illinois. Foram desenvolvidas correlações para a previsão do módulo de resiliência a partir da classificação, granulometria e condições de compactação. Determinou-se que o grau de saturação influencia significativamente o módulo de resiliência, para graus de compactação de $95 \%$ e $100 \%$.

Jones \& Witczak (1977), ao trabalharem com solos de subleito (argila siltosa) provenientes de várias seções de uma rodovia experimental construída em San Diego, nos anos 60, mostraram que ao se aumentar o teor de umidade de compactação deste material de $11 \%$ para aproximadamente $20 \%$ verificou-se uma redução significativa no módulo de resiliência, variando de $275 \mathrm{MPa}$ para próximo de $52 \mathrm{MPa}$.

Elliott \& Thornton (1988) analisaram a influência da variação do módulo de resiliência nos parâmetros de projeto e espessuras de pavimento obtidos pelo guia de dimensionamento da AASHTO de 1986. Apresentam um estudo das deflexões medidas numa pista experimental pelo Departamento de Transportes de Illinois ao

${ }^{6}$ Thompson, M. R. \& Robnett, Q. L. (1976). "Final report, resilient properties of subgrade soils". Rep. Civ. Engrg. Studies Transp. Engrg. Ser. No. 14, Illinois Cooperative Hwy and Transp. Ser. No 160, Univ. of Illinois, Urbana-Champaign, III. 
longo de um ano e justificam que a variação observada deve-se, principalmente, à variação sazonal do $M_{R}$ do subleito. $O$ estudo propõe uma abordagem alternativa sobre a definição do valor do módulo de resiliência mais representativo a ser assumido no dimensionamento, que pelo guia de 1986, supõe um valor único para - $\mathrm{M}_{\mathrm{R}}$. Na abordagem proposta pelos autores, um solo deve ser testado em um "período do ano" representativo das condições de umidade, usado para representar as condições médias de todo o ano.

Li \& Selig (1994) desenvolveram um procedimento para estimar os efeitos do tipo de solo, do estado físico do solo representado pelo teor de umidade e massa específica, e estado de tensão. Este procedimento foi usado para prever valores de $M_{R}$ para altos teores de umidade a partir de valores conhecidos de $M_{R}$ obtidos de corpos-de-prova compactados na umidade ótima. No estudo, os autores destacam que o estado físico do solo é fator determinante no valor do módulo de resiliência e que suas variações podem ser expressas através da associação de duas trajetórias: a) amostras que apresentam mudanças no teor de umidade, mas com massa específica seca constante e, b) amostras que apresentam mudanças no teor de umidade, mas que conservam uma energia de compactação única, ou seja, existe variação na massa específica seca. A diferença entre estas duas trajetórias deve-se ao fato de que a variação da massa específica seca máxima pode conduzir a uma alteração significativa do módulo de resiliência e, portanto, a consideração do efeito de variações da umidade no $M_{R}$ devem ser acompanhadas pelas informações sobre variação na massa específica seca máxima. Neste sentido, a influencia de variações de umidade com e sem variação da massa específica seca máxima podem ser significativamente diferentes. Para reduzir o efeito de outros fatores nas relações entre o módulo de resiliência e as variações de umidade nas duas trajetórias, a variação do $M_{R}$ para qualquer solo individualmente em qualquer estado físico é normalizada pelo $M_{R}$ obtido na umidade ótima e massa específica

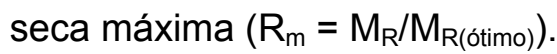

Estes autores recorreram à literatura para realizarem o estudo. Para a condição a), foram analisados 27 resultados de ensaios dinâmicos executados com variação de umidade em onze solos finos. Verificou-se que a função polinomial que melhor se ajustava aos resultados experimentais era dado pela equação (2.10), que apresentou um coeficiente de determinação $\left(R^{2}\right)$ igual a 0,76 . 


$$
R_{m 1}=0,98-0,28 \cdot\left(w-w_{o}\right)+0,029 \cdot\left(w-w_{o}\right)^{2}
$$

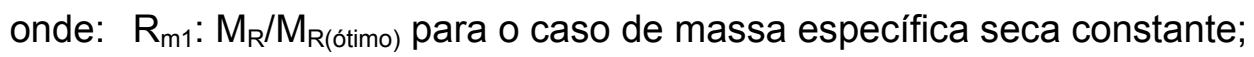

$M_{R}$ : módulo de resiliência numa dada umidade w (\%) e mesma massa específica do $\mathrm{M}_{\mathrm{R}(\text { ótimo); }}$

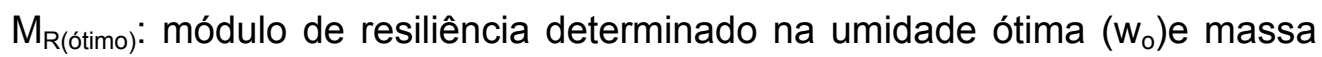
específica seca máxima para uma energia de compactação qualquer.

Para a condição b), foram analisados 26 resultados de ensaios dinâmicos executados com variação de umidade em dez solos finos de subleito. Verificou-se que a função polinomial que melhor se ajustava aos resultados experimentais era dado pela equação (2.11), que apresentou um coeficiente de determinação $\left(R^{2}\right)$ igual a 0,83 .

$$
R_{m 1}=0,96-0,18 \cdot\left(w-w_{o}\right)+0,0067 \cdot\left(w-w_{o}\right)^{2}
$$

onde: $R_{m 1}: M_{R} / M_{R(\text { totimo) }}$ para o caso de energia de compactação constante;

$M_{R}$ : módulo de resiliência numa dada umidade w (\%) e mesma energia de compactação do $\mathrm{M}_{\mathrm{R}(\text { ótimo); }}$;

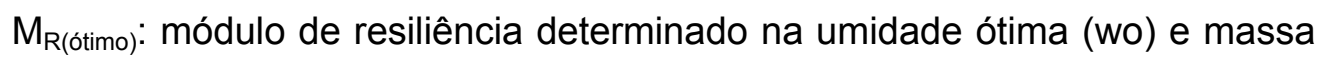
específica seca máxima para uma energia de compactação qualquer.

Assim, as equações (2.10) e (2.11), que correlacionam o módulo de resiliência e o estado físico do solo para os dois casos, compõem a base para previsão de variações do módulo de resiliência com as variações no estado físico do solo. Li \& Selig (1994) verificaram que, para as duas condições, um aumento do teor de umidade conduz a uma redução significativa da rigidez do solo. Destacam que, ao se comparar as duas condições, o caso a), em que a massa específica seca é constante, causa maiores variações no módulo de resiliência do que o caso b), em que a energia de compactação é constante, para teores de umidade abaixo da ótima. A diferença entre os dois casos se torna menor para teores de umidade acima da ótima. Explicam que esta tendência pode ser justificada pelo efeito da massa específica seca sobre o $M_{R}$. Se o módulo de resiliência aumenta, diminui, ou ambos com o aumento da massa específica depende do teor de umidade. Geralmente, para teores mais baixos de umidade $\circ M_{R}$ tende a aumentar com $o$ 
aumento da massa específica seca, enquanto para teores mais altos de umidade o $M_{R}$ tende a diminuir com o aumento massa específica seca.

Mohammad et al. (1995) realizaram ensaios dinâmicos utilizando uma prensa MTS com medidores de deslocamento instalados externamente e internamente à câmara, sendo esta última a melhor montagem, segundo os autores. Foram ensaiadas uma areia e uma argila siltosa, classificados respectivamente como A-3 e A-7-6, segundo a HRB. Os corpos-de-prova foram compactados na umidade ótima e nos ramos seco e úmido da curva de compactação do Proctor Normal. O estudo não abrangeu aspectos relacionados com a massa específica seca, sendo que o grau de compactação variou de $98 \%$ a $100 \%$. Os autores concluíram que os valores do $M_{R}$ do solo argiloso diminuem com o aumento da umidade, fato este creditado ao aumento da pressão neutra positiva desenvolvida com um aumento na umidade ou grau de saturação. Maiores valores de poro pressão acabam por reduzir a tensão efetiva e a resistência ao cisalhamento dos corpos-de-prova de argila, resultando menores valores de módulo de resiliência. As areias apresentaram maiores valores de $M_{R}$ para umidades acima e abaixo da ótima. Entretanto, a variação estatística entre os resultados obtidos, para os três níveis de teores de umidade, foi considerada insignificante, provavelmente devido à pequena variação da compactação relativa usada e à menor influência do teor de umidade nas areias.

Thadkamalla \& George (1995) desenvolveram um estudo para investigar o efeito do grau de saturação sobre o módulo de resiliência do subleito. Foram avaliados 2 materiais granulares e 2 materiais finos, classificados segundo a HRB como A-2, A-2-4, A-4 e A-7-5. A variação da umidade do corpo-de-prova, ou saturação, foi realizada por três meios: capilaridade, contrapressão e compactação na umidade desejada. Segundo os autores, como esperado, o módulo de resiliência diminuiu com a saturação, resultando nas seguintes observações:

i) em solos granulares, o $M_{R}$ não é afetado significativamente pela quantidade e maneira de saturação, tendo sido a redução de aproximadamente $20 \%$; 
ii) em solos finos, o $M_{R}$ é drasticamente reduzido pela saturação, levando a uma queda de $50 \%$ a $75 \%$ dependendo do grau de saturação e do método usado na saturação;

iii) para os solos finos, o método de saturação usado apresentou uma variedade de efeitos sobre o $M_{R}$ dos corpos-de-prova ensaiados. Quando da saturação por contra-pressão, o valor do $M_{R}$ diminui exponencialmente com o aumento do grau de saturação, e diminui linearmente com a saturação por capilaridade, assim como, para corpos prova compactados com teor de umidade acima do ótimo;

iv) para os solos finos, a diminuição do $M_{R}$, tanto para a saturação por capilaridade quanto para a compactação acima da umidade ótima, é praticamente idêntica.

Um programa de ensaio foi estabelecido por Drumm et al (1997) para investigar a resposta resiliente de um conjunto de solos de subleito, do estado americano do Tennessee. O propósito do estudo era a coleta de informações sobre o módulo de resiliência de solos de subleito típicos do local, e a investigação de como varia $\circ \mathrm{M}_{\mathrm{R}}$ com o aumento do teor de umidade pós-compactação (e dessa forma com o grau de saturação). Na coleta dos materiais, os pesquisadores procuraram identificar solos que fossem representativos dos materiais encontrados no subleito de pavimentos da região. Dessa forma, restringiu-se o universo de amostragem a materiais com mais de $50 \%$ das partículas passando na peneira \#200, já que esta é a característica da maioria dos solos de subleito encontrados no Tennessee. Foram estudados 11 solos classificados como A-4 (3 solos), A-6 (3 solos), A-7-5 (2 solos) e A-7-6 (3 solos). Procedeu-se a compactação dos corposde-prova, na respectiva umidade ótima e massa específica seca máxima, por amassamento. Segundo os autores, foram compactados três corpos-de-prova para cada solo, sendo que um deles foi ensaiado na condição original de compactação e os outros dois após umedecimento. Os corpos-de-prova designados para variação da umidade pós-compactação foram "saturados" em uma câmara triaxial, no dia seguinte à compactação, por meio da aplicação de uma pressão de água na sua parte inferior e a manutenção da pressão atmosférica no seu topo. Essa condição gerou um diferencial de pressão que permitiu à água fluir através do corpo-deprova. O umedecimento dos corpos-de-prova foi realizado para dois níveis de grau 
de saturação. Todos os corpos-de-prova permaneceram por sete dias em câmara úmida antes da realização dos ensaios triaxiais cíclicos.

No estudo em questão, os pesquisadores concluíram que todos os solos exibiam uma diminuição no módulo de resiliência com o aumento do grau de saturação, mas a magnitude dessa redução estava vinculada ao tipo de solo estudado. Para solos do tipo A-7-5 e A-7-6 verificaram-se os maiores valores de módulo de resiliência para as condições originais de compactação, ou seja, umidade ótima e massa específica seca máxima. Entretanto, estes materiais exibiram uma maior redução nos valores de $M_{R}$ com o umedecimento póscompactação, em comparação com solos classificados como A-4 e A-6.

Bernucci (1997) verificou, para diferentes solos lateríticos brasileiros, o efeito da variação da umidade pós-compactação sobre o valor do módulo de resiliência. Segundo a autora, foram ensaiados materiais desde os mais arenosos não coesivos até os mais argilosos, classificados segundo o sistema MCT como: LA, LA' e LG'. Procurou-se, nos ensaios, simular as condições reais de estado dos solos em campo variando-se a energia de compactação e a umidade. Foram ensaiados corpos-de-prova: compactados na umidade ótima; compactados na umidade ótima e submetidos a quatro dias de imersão em água, simulando uma condição de "saturação", e; compactados na umidade ótima e secos até $80 \%$ da umidade original de compactação. Verificou-se que a imersão em água tem pequena influência no valor do $M_{R}$ e que a perda de umidade produz um acréscimo significativo no seu valor.

A influência da variação da umidade no valor do $M_{R}$ de solos de subleito foi pesquisada no Rio Grande do Sul por Rodrigues (1997). Neste estudo, foram utilizados quatro solos, classificados pelo sistema MCT como LG', NA', LG' e LA', para a compactação de corpos-de-prova na umidade ótima $\left(w_{0}\right)$ e massa específica seca máxima $\left(\rho_{\mathrm{dmax}}\right)$ do Proctor normal. Submeteram-se, então, os c.p. assim preparados a trajetórias de secagem, de umedecimento e de secagem seguida de umedecimento. Posteriormente, foram realizados os ensaios triaxiais cíclicos. Comparando-se os resultados obtidos para corpos-de-prova compactados na $\mathrm{w}_{\mathrm{o}}$, na $w_{0}-2 \%$ (após secagem) e na $w_{0}+2 \%$ (após umedecimento), verificou-se que para o menor teor de umidade os valores de $M_{R}$ são maiores, e diminuem com o 
aumento da umidade e da tensão desvio. Em outra avaliação realizada no estudo, procurou-se identificar o efeito de um ciclo de secagem e umedecimento sobre o valor módulo. Compararam-se os valores de $M_{R}$ de corpos-de-prova submetidos à secagem apenas, com umidade de $w_{0}-2 \%$, com os valores de $M_{R}$ de corpos-deprova submetidos à secagem até atingir um valor de umidade igual a $w_{0}-5 \%$ e posteriormente umedecidos até $\mathrm{w}_{\mathrm{o}}-2 \%$. Observou-se que para o último caso, os valores de $M_{R}$ são menores do que os determinados para o primeiro caso. Em um estudo semelhante, compararam-se os valores de $M_{R}$ de corpos-de-prova compactados na $w_{o}$ com os valores de módulo de corpos-de-prova compactados na $w_{0}$ e submetidos a uma secagem até $w_{0}-5 \%$, sendo novamente conduzidos a $w_{0}$ através de umedecimento. Verificou-se, que neste caso, o ciclo de secagem e umedecimento resultou em valores de $M_{R} 68 \%$ menores do que o $M_{R}$ dos corposde-prova compactados e ensaiados na umidade ótima.

Gonçalves (1998) avaliou a influência da variação do teor de umidade no valor do módulo de resiliência de um solo argiloso de subleito do interior de São Paulo. O material estudado foi classificado como LG'/ A-7-6/CL, respectivamente, pelas classificações MCT, HRB e USCS, e a análise granulométrica do material indicou que $52 \%$ das partículas passam na peneira \#200. Foram realizados ensaios triaxiais cíclicos para se estimar o módulo de resiliência de corpos-de-prova ensaiados em diversas condições de umidade, a saber:

i) Simularam-se trajetórias de secagem $\left(w_{0}-2 \%\right)$ e umedecimento $\left(w_{0}+1 \%\right)$ a partir de corpos-de-prova compactados na umidade ótima $\left(w_{0}=19,5 \%\right)$ e massa específica seca máxima;

ii) Corpos-de-prova compactados na $w_{o}$ e $\rho_{\text {dmax }}$ ficaram exposto ao ar por $48 \mathrm{~h}$ para secagem (verificou-se ser a umidade atingida função das condições atmosféricas), sendo, em seguida, parte dos corpos-de-prova umedecidos até a umidade ótima;

iii) Corpos-de-prova foram compactados com $\rho_{\mathrm{dmax}}$ e teores de umidade de $w_{0}-2 \%, w_{0}$ e $w_{0}+1 \%$.

Constatou-se que os corpos-de-prova moldados na $w_{0}$ e submetidos a trajetórias de secagem e umedecimento (caso i) alcançaram valores de $M_{R}$ superiores e inferiores, respectivamente, ao se comparar com o $M_{R}$ de corpos-de- 
prova ensaiados na $w_{0}$. Este fato foi também observado para os corpos-de-prova moldados com massa específica seca máxima, em teores de umidade abaixo e acima do teor ótimo (caso iii). No caso ii, o umedecimento até $\mathrm{w}_{\mathrm{o}}$ de corpos-deprova moldados na $w_{o}$ e em seguida secos por 48 conduziu a valores de $M_{R}$ menores do que os observados para corpos-de-prova compactados e ensaiados na $\mathrm{w}_{\mathrm{o}}$.

Andrew et al. (1998) também estudaram em campo a influência da variação da umidade sobre o módulo de resiliência $\left(M_{R}\right)$, tendo desenvolvido um método para determinação do $M_{R}$ que incorpora mudanças no grau de saturação de solos de subleito. Neste estudo, foram instrumentadas 4 seções de pavimentos flexíveis em diferentes regiões climáticas do estado americano do Tennessee para monitorar as variações sazonais do teor de umidade e temperatura das várias camadas dos pavimentos. O objetivo final do estudo é estabelecer um método para se avaliar a variação sazonal do módulo de resiliência do subleito e selecionar um valor único que melhor represente os danos acumulados durante todas as estações do ano, conforme preconiza o guia de dimensionamento da AASHTO de 1993. Utilizaramse ensaios com FWD (Falling Weight Deflectometer), realizando medidas mensais nas seções de estudo para avaliar a variação sazonal no $M_{R}$. Os resultados permitiram ainda estabelecer um procedimento para identificar a estação mais apropriada para os ensaios, de maneira a obter-se um valor único de módulo para o subleito, representativo daqueles observados durante todas as estações do ano.

Muhanna et al. (1999) estudaram o efeito de diversos fatores sobre o módulo de resiliência de corpos-de-prova compactados com dois solos diferentes, classificados como A-6/SC (42\% de finos) e A-5/SM-ML (48\% de finos), respectivamente, pelas classificações HRB e USCS. Foram considerados três teores de umidade $\left(w_{\circ}\right.$ e $\left.w_{0} \pm 2,5 \%\right)$, sendo, dessa forma, avaliado o efeito da variação da umidade sobre o $M_{R}$. Os corpos-de-prova foram submetidos a um processo de umedecimento por contrapressão, por um período de duas semanas, para aumentar seus teores de umidade. Para o solo A-6, os corpos-de-prova umedecidos apresentaram um $M_{R} 25 \%$ menor do que os corpos-de-prova compactados na umidade ótima. Para os solos A-5, o umedecimento dos corposde-prova compactados na umidade ótimos reduziu o módulo de resiliência em 15\% 
a $25 \%$, mas um processo de secagem após o umedecimento elevou os $M_{R}$ aos valores antigos.

Ksaibati et al. (2000) desenvolveram um estudo em rodovias estaduais da Florida para avaliar a redução na resistência das camadas de base e subleito devido à proximidade do lençol freático. Foram realizados, durante 5 anos, ensaios com os equipamentos Dynaflect e FWD em diferentes trechos das rodovias para determinação da resistência das camadas, e em diferentes períodos do ano, com a determinação da respectiva posição do nível d'água. Os autores puderam observar que à medida que diminui a profundidade da superfície do pavimento até o nível do lençol freático verifica-se um aumento significativo nos teores de umidade das camadas de base e sub-base. Nos ensaios realizados com o Dynaflect, os módulos da base e sub-base experimentaram reduções de $5 \%$ a $35 \%$ devido ao aumento da umidade nestas camadas. Os resultados com o FWD ampliaram o efeito da umidade sobre os valores de módulo das camadas, apresentando em alguns casos redução da ordem de $96 \%$. Verificaram também que para aumentos da umidade da ordem de $1 \%$, na camada de base, as reduções mais significativas nos valores de módulo foram $8,54 \%$ e 29,41\%, para ensaios com Dynaflect e FWD, respectivamente. Para os valores de módulo do subleito, as reduções mais significativas para Dynaflect e FWD foram 4,56\% e 7,77\%, respectivamente. Os autores creditam as diferenças observadas à aplicação da carga para medida dos deslocamentos, que é diferente entre os equipamentos.

Abo-Hashema et al. (2002) desenvolveram uma pesquisa cujo objetivo era quantificar os impactos ambientais sobre o desempenho do pavimento para inclusão no processo de projeto de pavimentos novos e reabilitados. O parâmetro chave selecionado na pesquisa para refletir os impactos ambientais foi o módulo de elasticidade das camadas do pavimento, visto que o mesmo se altera com o ambiente circundante. Para atingir este objetivo, foram instrumentados cinco trechos de rodovias do estado americano de ldaho para medir variações de temperatura e umidade no pavimento. Realizou-se o monitoramento periódico (4 períodos: inverno, primavera, verão e outono) da variação do teor de umidade do subleito em conjunto com a variação do módulo do subleito, este último obtido através de ensaio com FWD (Falling Weight Deflectometer). A análise dos dados coletados, adicionalmente aos dados do LTPP-SMP (Long-Term Pavement 
Performance Program - Seasonal Monitoring Program) para a região em questão, levou ao desenvolvimento de equações de regressão que relacionam o teor de umidade e o módulo de resiliência do subleito para vários tipos de solo e regiões climáticas. Tais equações podem ser usadas para ajustar $\circ M_{R}$ do subleito de uma estação para outra, conhecido o teor de umidade médio no período. Ainda segundo os autores, a relação entre a $M_{R}$ e o tempo se parece com uma função senoidal com um ângulo de inclinação negativo, sendo que os parâmetros dessa função são dependentes do tipo de solo e condições ambientais. As alterações do $M_{R}$ do subleito com o tempo, segundo os autores, são devidas a alterações no teor de umidade com o tempo, sendo assim possível estabelecer uma relação entre o módulo de resiliência do subleito e o teor de umidade.

Heydinger (2003) apresenta uma análise dos dados coletados durante o programa SMP (Seasonal Monitoring Program) desenvolvido em 18 trechos de uma rodovia no estado americano de Ohio. O solo de subleito nestes trechos foi classificado como A-6 e CL segundo os sistemas de classificação da AASHTO e Unificada, respectivamente. Durante o programa foram coletadas informações sobre o clima (temperatura do ar e precipitação), temperatura do pavimento em três profundidades (inclusive do subleito) e umidade do solo. Verificou-se nesta pesquisa que o módulo de resiliência varia sazonalmente devido a alterações no teor de umidade dos solos, diminuindo o valor do $M_{R}$ com o aumento da umidade. O pesquisador relata que é difícil determinar relações entre estes fatores por serem dependentes do tipo de material e sua história, mas destaca que o $\mathrm{M}_{\mathrm{R}}$ pode variar de fator de dois ou mais para alterações na saturação da ordem de 10\% a 15\%.

Salem et al. (2003) utilizaram os dados disponibilizados em janeiro de 2002 pelo LTPP para avaliar a variação da umidade e do módulo de resiliência com o tempo (análise de séries temporais). O estudo foi desenvolvido nos Estados Unidos com 7 solos de regiões consideradas livres de congelamento, divididos, para efeito de análise, em dois grupos - solos plásticos e não-plásticos. Os dados indicaram que $\circ M_{R}$ retrocalculado poderia ser relacionado com o teor de umidade com uma função inversa, ou seja, o módulo de resiliência aumenta quando a umidade diminui, e vice versa. Os autores verificaram ainda que os valores máximos de módulo e mínimos de umidade foram medidos durante o verão (entre julho e 
agosto), enquanto os valores mínimos de módulo e máximos de umidade foram obtidos durante o inverno (entre janeiro e fevereiro).

O NCHRP 1-37A (2004) destaca que, se todas as outras condições são iguais, quanto maior o teor de umidade menor é o módulo dos materiais nãotratados. Entretanto, a umidade pode atuar de duas formas, sendo elas: a) pode afetar o estado de tensão através da sucção, sendo possível que materiais grossos e finos apresentem um aumento de mais de cinco vezes no módulo devido à secagem dos solos; b) pode afetar a estrutura do solo através da destruição da cimentação entre as partículas do solo.

\subsection{A influência da sucção no módulo de resiliência}

Edil \& Motan (1979) apresentam resultados experimentais de um estudo relacionado às propriedades resilientes de um solo fino de subleito, classificado com A-6, realizado para identificar e quantificar o efeito da água no solo, em termos de sucção e outros parâmetros pertinentes, sobre as características resilientes e de resistência, sob condições típicas de carregamento de um pavimento. Para simular o carregamento em campo, foram realizados ensaios de compressão simples e ensaios uniaxiais cíclicos em corpos-de-prova compactados com uma mistura de um solo típico de subleito, do estado americano de Wisconsin, e $25 \%$ de areia. Procedeu-se a compactação em três níveis de umidade, a saber: umidade ótima $\left(w_{o}\right)$ e $w_{o} \pm 2 \%$. A fase experimental da investigação envolveu três estágios: a) preparação dos corpos-de-prova; b) equilíbrio de umidade das amostras em vários valores de sucção; e c) ensaio de carga repetida e subseqüente ensaio de compressão simples nos corpos-de-prova. Concluiu-se que o módulo de resiliência tem uma forte dependência da umidade de compactação no ramo seco da curva de compactação, dependência esta, insignificante para o ramo úmido, isto dentro do intervalo de umidade considerado no estudo ( $\left.w_{0} \pm 2 \%\right)$. Os autores concluíram também que o módulo de resiliência aumenta monotonicamente para valores de sucção entre $100 \mathrm{kPa}$ e um valor crítico, além do qual ele diminui. Para o solo testado, este valor parece ser aproximadamente $800 \mathrm{kPa}$, equivalente a um teor de umidade de $w_{0}-2 \%$. Esta faixa de variação de sucção do solo estudado corresponde a uma faixa de variação de -15 a +15 do Índice de umidade de Thornthwaite. 
Phillip \& Cameron (1995) conduziram um estudo para explorar a relação entre a sucção e o módulo de resiliência. Os autores realizaram uma série de ensaios triaxiais cíclicos em corpos-de-prova, de sucção conhecida, compactados com solos expansivos de subleito. Foram selecionadas quatro amostras diferentes do subleito de um estacionamento, àquela época, em serviço por mais de 10 anos. Observou-se neste estudo a existência de uma relação linear entre o $M_{R}$ e a sucção para solos estudados quando a massa específica é constante, ou seja, o módulo aumenta linearmente com o aumento da sucção. Esta relação foi considerada nãolinear quando se avaliaram em conjunto os resultados obtidos para corpos-de-prova com massa específica variável.

Rodrigues (1997) estudou, para 4 tipos de solo (2 LG', 1 LA' e 1 NA'), a influência da sucção sobre o módulo de resiliência. Neste trabalho, a sucção foi determinada a partir da aplicação do método do papel filtro. O autor verificou que para os quatro tipos de solo existe uma relação direta entre $\circ M_{R}$ e a sucção, na medida em que aumenta a sucção há um aumento correspondente do módulo de resiliência. O crescimento é tanto maior quanto menor for a tensão desvio de ensaio. Observou-se que os solos estudados classificados como LG' e NA', segundo o sistema MCT, apresentaram um valor máximo de módulo de resiliência para um determinado nível de sucção, a partir do qual tende a diminuir. O mesmo padrão não foi observado para o solo LA'.

Gonçalves (1998) também avaliou a influência da sucção sobre o módulo de resiliência. Neste trabalho, a sucção foi determinada pela técnica do papel filtro, que segundo o autor, apresentou um bom desempenho mesmo para altos valores de sucção. Os resultados obtidos indicaram que o módulo de resiliência varia com a variação da sucção. O aumento desta última conduz a um aumento do primeiro. Este crescimento é diretamente proporcional à tensão desvio, ou seja, quanto maior a tensão desvio, maior é o crescimento.

Khoury et al. (2003) realizaram um estudo para avaliar o efeito da sucção no módulo de resiliência de solos de subleito coletados no estado americano de Oklahoma. Foram ensaiados no total de 18 amostras indeformadas de solos para determinação dos valores de $M_{R}$ e de sucção, determinados pelo método do papel 
filtro. Os solos considerados neste estudo foram classificados de A-4 a A-7, segundo o sistema de classificação da AASHTO, e o índice de plasticidade e limite de liquidez destes materiais variaram de 10 a 32 e 28 a 51, respectivamente. Os autores verificaram que o módulo de resiliência aumenta com o aumento da sucção total e matricial, revelando a mesma tendência de variação para ambas as sucções determinadas. Como resultado, concluiu-se que a sucção osmótica não apresenta efeito significativo sobre o $M_{R}$. Os pesquisadores também investigaram o efeito do teor de umidade sobre o módulo de resiliência, entretanto, não observaram nenhuma tendência específica entre estes fatores. Explicam os autores que isto pode ser devido ao fato de que diferentes teores de umidade podem produzir a mesma sucção matricial, dependendo da curva característica do solo, e dessa forma o mesmo estado de tensão que controla $\circ M_{R}$. Conseqüentemente, concluíram aqueles, que o módulo de resiliência se correlaciona melhor com a sucção do solo do que com o teor de umidade, e que a sucção tem um papel vital no comportamento mecânico de solos coesivos de subleito.

\subsection{Modelagem do módulo de resiliência}

O valor do módulo de resiliência é muito variável, sendo que os fatores que interferem em sua magnitude podem ser agrupados em três categorias, a saber: [a] condição de carregamento e estado de tensão; [b] natureza do solo: origem, composição e estrutura; e [c] estado físico do solo, definido pelo teor de umidade e massa específica seca.

Os fatores [a] e [b] são considerados quando são propostos modelos que permitem representar o módulo de resiliência a partir do estado de tensão e da natureza do solo. O estado físico do solo [c] pode ser alterado pela variação das condições ambientais e pelo efeito da compactação causada pelo tráfego, e a sua influência é tão importante quanto a das duas primeiras categorias.

O módulo de resiliência é, geralmente, representado na forma de modelos de caracterização, ou constitutivos, tais como, o modelo potencial em função da tensão desvio, para solos coesivos, e o modelo potencial em função do primeiro invariante de tensão, para solos granulares. Podem ainda ser representados a partir 
de relações com índices vinculados à natureza e estado do solo, e ainda com os resultados de outros ensaios considerados de execução mais simples. Dessa forma, poder-se-ia estimar o módulo de resiliência de projeto a partir de outros materiais ou propriedades do solo.

Segundo Yau \& Von Quintus (2002), uma vantagem potencial de se estimar o $M_{R}$ a partir de propriedades físicas dos materiais é que as variações sazonais no módulo de resiliência poderiam ser estimadas a partir das mudanças sazonais ocorridas nas propriedades físicas dos materiais. O conceito que foi utilizado no desenvolvimento do novo guia de dimensionamento da AASHTO 2002 é a aplicação do Modelo Climático Integrado Melhorado (Enhanced Integrated Climatic Model - EICM) para prever alterações nas propriedades físicas dos solos e materiais não-tratados e estimar os efeitos dessas mudanças sobre $0 M_{R}$. Entretanto, a determinação do módulo de resiliência a partir de propriedades físicas pode considerar os efeitos da variação sazonal do $M_{R}$ como resultado de alterações sazonais nas propriedades físicas dos materiais, mas não considera o efeito da sensibilidade à tensão.

Estudos anteriores já desenvolveram relações entre o módulo de resiliência e as propriedades dos solos. Estas relações, quando apresentam boa correlação, estão condicionados a um grupo específico de solos. Outros estudos em que foram utilizados uma grande variedade de solos e condições, geralmente, resultaram em correlações fracas.

São apresentados na seqüência alguns modelos utilizados na representação da variação do módulo de resiliência com a variação do estado de tensão, bem como relações com índices vinculados à natureza e estado do solo e propriedades físicas.

\subsubsection{Relações com o estado de tensão}

\subsubsection{Modelo bi-linear}

Este modelo foi usado por diversos autores para representar o módulo de resiliência de solos coesivos e a sua variação com a tensão atuante nas camadas 
do pavimento (Motta et al., 1985; Motta \& Ceratti, 1986; Pezo et al., 1994; entre outros). Foi proposto inicialmente por Hicks (1970), e é representado pelas equações (2.12) e (2.13) apresentadas a seguir.

$$
\begin{aligned}
& M_{R}=k_{2}+k_{3} \cdot\left(k_{1}-\sigma_{d}\right) \stackrel{\text { para }}{\longrightarrow} k_{1}>\sigma_{d} \\
& M_{R}=k_{2}+k_{4} \cdot\left(\sigma_{d}-k_{1}\right) \stackrel{\text { para }}{\longrightarrow} k_{1}<\sigma_{d}
\end{aligned}
$$

onde: $M_{R}$ : Módulo de resiliência;

$\sigma_{\mathrm{d}}$ : Tensão desvio;

$\mathrm{k}_{1}, \mathrm{k}_{2}, \mathrm{k}_{3}$ e $\mathrm{k}_{4}$ : Parâmetros de regressão.

\subsubsection{Modelos potenciais}

\subsection{Modelo $\left(k-\sigma_{d}\right)$}

Geralmente, usado para solos coesivos na representação da variação do módulo de resiliência com a tensão desvio. Entretanto, Motta et al. (1990) observaram um bom desempenho do modelo na representação do comportamento resiliente de solos pedregulhosos lateríticos. A equação (2.14) descreve o comportamento do modelo.

$$
M_{R}=k_{1} \cdot \sigma_{d}^{k_{2}}
$$

onde: $M_{R}$ : Módulo de resiliência;

$\sigma_{\mathrm{d}}$ : Tensão desvio;

$\mathrm{k}_{1}$ e $\mathrm{k}_{2}$ : Parâmetros de regressão.

É um modelo mais simples que o bi-linear, possuindo apenas dois parâmetros de regressão. O uso deste modelo evita o problema na definição do ponto de inflexão como no bi-linear.

\subsection{Modelo $\left(k-\sigma_{3}\right)$}

Este modelo descreve a relação entre o módulo de resiliência e a tensão confinante, sendo mais utilizado para solos granulares. Surgiu basicamente através de Hicks \& Monismith (1971), e é representado pela equação (2.15).

$$
M_{R}=k_{1} \cdot \sigma_{3}^{k_{2}}
$$


onde: $M_{R}$ : Módulo de resiliência;

$\sigma_{3}$ : Tensão confinante;

$\mathrm{k}_{1}$ e $\mathrm{k}_{2}$ : Parâmetros de regressão.

\subsection{Modelo $(k-\theta)$}

Nos solos arenosos, ou granulares, o módulo de resiliência depende principalmente da tensão confinante, $\sigma_{3}$, ou da soma das tensões principais, na figura do primeiro invariante de tensão $\left(\theta=\sigma_{1}+2 \sigma_{3}\right)$. Diversas pesquisas mostram essa dependência do $M_{R}$ quanto ao $\theta$ (Nataatmadja \& Parkin, 1989; Bernucci, 1995; entre outros). A equação (2.16) identifica o modelo citado.

$$
M_{R}=k_{1} \cdot \theta^{k_{2}}
$$

onde: $M_{R}$ : Módulo de resiliência;

$\theta$ : Primeiro invariante de tensão;

$\mathrm{k}_{1}$ e $\mathrm{k}_{2}$ : Parâmetros de regressão.

\subsubsection{Modelo composto $\left(k-\sigma_{d}-\sigma_{3}\right)$}

Este modelo representa $\circ \mathrm{M}_{\mathrm{R}}$ em função de todas as tensões aplicadas, indicando um comportamento resiliente único para qualquer tipo de solo ou material não tratado quimicamente (Ferreira \& Motta, 2002). Este modelo foi proposto por Macêdo (1996), sendo representado pela equação (2.17):

$$
M_{R}=K_{1} \sigma_{d}^{K_{2}} \sigma_{3}^{K_{3}}
$$

O modelo composto pode ser obtido a partir do modelo de deformabilidade definido pela equação (2.18):

$$
\varepsilon_{a}=a \sigma_{d}{ }^{b} \sigma_{3}{ }^{c}
$$

onde: $\varepsilon_{a}$ : deformação axial específica;

$\sigma_{\mathrm{d}}$ : Tensão desvio aplicada $\left(\mathrm{kgf} / \mathrm{cm}^{2}\right)$;

$\sigma_{3}:$ Tensão confinante aplicada $\left(\mathrm{kgf} / \mathrm{cm}^{2}\right)$;

$a, b$ e $c$ : Parâmetros de regressão obtidos dos dados experimentais. 
Por definição, o módulo de resiliência é: $M_{R}=\frac{\sigma_{d}}{\varepsilon_{a}}$.

Portanto, o modelo de deformabilidade pode ser expresso pela equação (2.19):

$$
M_{R}=\frac{\sigma_{d}}{\left(a \sigma_{d}^{b} \sigma_{3}^{c}\right)}=\frac{\left(\sigma_{d}^{(1-b)} \sigma_{3}^{-c}\right)}{a}
$$

Fazendo $\left\{\begin{array}{l}\frac{1}{a}=K_{1} \\ 1-b=K_{2}, \text { o } M_{R} \text { pode ser definido conforme a equação (2.20): } \\ c=-K_{3}\end{array}\right.$

$$
M_{R}=K_{1} \sigma_{d}^{K_{2}} \sigma_{3}^{K_{3}}
$$

As constantes $\mathrm{K}_{1}, \mathrm{~K}_{2}$ e $\mathrm{K}_{3}$ são determinadas a partir do modelo de deformabilidade, aplicando-se o logaritmo natural à expressão. O modelo resultante é expresso pela equação (2.21):

$$
\operatorname{Ln} \varepsilon_{a}=a+b \operatorname{Ln} \sigma_{d}+c \operatorname{Ln} \sigma_{3}
$$

Com a técnica de regressão linear múltipla podem ser determinados os parâmetros de regressão $a, b$ e $c$ do modelo, permitindo o cálculo das constantes $\mathrm{K}_{1}, \mathrm{~K}_{2}$ e $\mathrm{K}_{3}$ do modelo composto.

Em estudo desenvolvido por Ferreira \& Motta (2002) constatou-se ser este o modelo mais adequado para o cálculo do módulo de resiliência de solos e materiais não tratados quimicamente mais utilizados no Brasil, quando comparado aos modelos potenciais $\left(k-\sigma_{d}\right),\left(k-\sigma_{3}\right)$ e $(k-\theta)$. Os autores destacam que este modelo, além de poder ser aplicado para qualquer tipo de material, demonstrou ser capaz de avaliar com precisão superior aos demais o valor do módulo de resiliência, e sugerem que os esforços de pesquisa devem se concentrar no aprimoramento deste ou na elaboração de modelos que apresentem desempenho superior ao deste, abandonando definitivamente os modelos potenciais citados. Esta pesquisa foi desenvolvida a partir da análise dos resultados de ensaios triaxiais dinâmicos de 535 amostras, realizados no Laboratório de Geotecnia da COPPE/UFRJ, entre 1985 e 2000. 


\subsubsection{Modelo hiperbólico}

Utilizado por Drumm et al. (1990) na representação do $M_{R}$ em função da tensão desvio de 11 solos coesivos do estado americano do Tennessee. A equação (2.22) representa o modelo.

$$
M_{R}=\frac{k_{1}+k_{2} \cdot \sigma_{d}}{\sigma_{d}}
$$

onde: $M_{R}$ : Módulo de resiliência;

$\sigma_{\mathrm{d}}$ : Tensão desvio;

$\mathrm{k}_{1}$ e $\mathrm{k}_{2}$ : Parâmetros de regressão.

\subsubsection{Modelo semilogarítmico}

Fredlund et al. (1977), após a realização de ensaios triaxiais cíclicos em solos Canadenses propôs o modelo para solos coesivos de subleito a partir da equação (2.23) dada a seguir.

$$
M_{R}=10^{\left(k_{1}-k_{2} \cdot \sigma_{d}\right)}
$$

onde: $M_{R}$ : Módulo de resiliência;

$\sigma_{\mathrm{d}}$ : Tensão desvio;

$\mathrm{k}_{1}$ e $\mathrm{k}_{2}$ : Parâmetros de regressão.

\subsubsection{Modelo combinado}

Aranovich (1985) ${ }^{7}$ apud Medina (1997), propôs este modelo quando de uma pesquisa inter-regional de pavimentos não-convencionais de estradas vicinais brasileiras. As equações (2.24) e (2.25) descrevem o modelo com cinco parâmetros de regressão.

$$
\begin{aligned}
& M_{R}=\left[k_{2}+k_{3} \cdot\left(k_{1}-\sigma_{d}\right)\right] \cdot \sigma_{3}{ }^{k_{5}} \stackrel{\text { para }}{\longrightarrow} \sigma_{d}<k_{1} \\
& M_{R}=\left[k_{2}+k_{4} \cdot\left(\sigma_{d}-k_{1}\right)\right] \cdot \sigma_{3}{ }^{k_{5}} \stackrel{\text { para }}{\longrightarrow} \sigma_{d}>k_{1}
\end{aligned}
$$

\footnotetext{
${ }^{7}$ Aranovich, L. A. S. (1985). Desempenho de pavimentos de baixo custo no estado do Paraná. Rio de Janeiro. Dissertação (Mestrado). COPPE/UFRJ.
} 
onde: $M_{R}$ : Módulo de resiliência;

$\sigma_{\mathrm{d}}$ : Tensão desvio;

$\sigma_{3}:$ Tensão confinante;

$\mathrm{k}_{1}, \mathrm{k}_{2}, \mathrm{k}_{3}, \mathrm{k}_{4}$, e $\mathrm{k}_{5}$ : Parâmetros de regressão.

\subsubsection{Modelo octaédrico}

Mohammad et al. (1999) desenvolveram um estudo com oito solos diferentes do estado americano da Louisiana. Foram conduzidos ensaios de módulo de resiliência em corpos-de-prova com diferentes valores de massa específica e teores de umidade, em vários estados de tensão. Desenvolveu-se um modelo não-linear universal para representar o comportamento de solos de subleito, chamado de octaédrico. A equação (2.26) representa o modelo.

$$
\frac{M_{R}}{\sigma_{a t m}}=k_{1} \cdot\left(\frac{\sigma_{o c t}}{\sigma_{a t m}}\right)^{k_{2}} \cdot\left(\frac{\tau_{o c t}}{\sigma_{a t m}}\right)^{k_{3}}
$$

onde: $\sigma_{\text {oct }}, \tau_{\text {oct }}:$ tensões normal e cisalhante octaédricas, respectivamente;

$\sigma_{\text {atm: }}$ pressão atmosférica;

$\mathrm{k}_{1}, \mathrm{k}_{2}$ e $\mathrm{k}_{3}$ : Constantes do modelo.

As constantes do modelo foram, a partir de regressões lineares múltiplas, correlacionadas com características do solo, tais como: massa específica, teor de umidade, grau de compactação, limites de consistência e outras propriedades do solo.

\subsubsection{Modelo Universal de Uzan-Witczak}

Neste modelo, o módulo de resiliência é função do primeiro invariante de tensão e da tensão cisalhante octaédrica. O modelo é dito universal, pois pode ser aplicado a todos os materiais não tratados, visto que incorpora os efeitos das tensões desvio e volumétricas. O modelo é representado pela equação (2.27):

$$
M_{R}=k_{1} \cdot \theta^{k_{2}} \cdot \tau_{\text {oct }}^{k 3}
$$

onde: $\mathrm{k}_{1}, \mathrm{k}_{2}$ e $\mathrm{k}_{3}$ : Constantes do modelo;

$\theta$ : Primeiro invariante de tensão $\left(\theta=\sigma_{1}+\sigma_{2}+\sigma_{3}=\sigma_{1}+2 \cdot \sigma_{3}\right)$; 
$\tau_{\text {oct }}$ : tensão cisalhante octaédrica, que é definida como:

$$
\tau_{\text {oct }}=\frac{1}{3} \cdot \sqrt{\left(\sigma_{1}-\sigma_{2}\right)^{2}+\left(\sigma_{2}-\sigma_{3}\right)^{2}+\left(\sigma_{1}-\sigma_{3}\right)^{2}}
$$

Sob condição de pressão de confinamento triaxial, ou seja,

$$
\sigma_{2}=\sigma_{3} \Rightarrow \tau_{\text {oct }}=\frac{1}{3} \cdot \sqrt{2 \cdot\left(\sigma_{1}-\sigma_{3}\right)^{2}}=\frac{\sqrt{2}}{3} \cdot \sigma_{d}
$$

Dessa forma o modelo universal pode se simplificado para a forma:

$$
M_{R}=k_{4} \cdot \theta^{k_{2}} \cdot \sigma_{d}^{k_{3}}
$$

Dai \& Zollars (2002) submeteram amostras indeformadas de solos de subleito, obtidas de seis seções diferentes de pavimentos do estado americano de Minnesota, a ensaios triaxiais de carga repetida para a determinação do módulo de resiliência. Os autores aplicaram dois modelos constitutivos, o modelo universal de Uzan-Witczak e o modelo $\left(k-\sigma_{d}\right)$, para descrever as relações entre o $M_{R}$ e o estado de tensão aplicado. Baseados nos dados experimentais dos materiais ensaiados, os resultados mostraram que o modelo universal descreve o comportamento do $M_{R}$ com o estado de tensão um pouco melhor do que o modelo $\left(\mathrm{k}-\sigma_{\mathrm{d}}\right)$. Verificou-se, também, que as constantes dos modelos são dependentes das propriedades dos materiais, tais como: massa específica seca máxima, teor de umidade, índice de plasticidade, limite de liquidez e porcentagem do material que passa na peneira \#200.

\subsubsection{Modelo Universal não-linear - AASHTO $\left(k-\theta-\tau_{\text {oct }}\right)$}

O protocolo para ensaios de módulo de resiliência desenvolvido no projeto NCHRP 1-28A considera este modelo para a caracterização resiliente de materiais de base não-tratados, sub-base e subleito. Trata-se de um modelo universal nãolinear, portanto, aplicável a todos os tipos de materiais de pavimentação nãotratados, variando de argilas muito plásticas até bases granulares. Este é o modelo adotado no novo guia de dimensionamento da AASHTO (NCHRP 1-37A, 2004) e é representado pela equação (2.29).

$$
M_{R}=k_{1} \cdot P_{a} \cdot\left[\frac{\theta-3 k_{6}}{P_{a}}\right]^{k_{2}} \cdot\left[\frac{\tau_{\text {oct }}}{P_{a}}+1\right]^{k_{3}}
$$


onde: $\mathrm{k}_{1}, \mathrm{k}_{2}, \mathrm{k}_{3}$ e $\mathrm{k}_{6}$ : Constantes de regressão;

$\mathrm{P}_{\mathrm{a}}$ : Pressão atmosférica (usada para normalizar as unidades do $\mathrm{M}_{\mathrm{R}}$ );

$\theta$ : Primeiro invariante de tensão $\left(\theta=\sigma_{1}+\sigma_{2}+\sigma_{3}=\sigma_{1}+2 \cdot \sigma_{3}\right)$;

$\sigma_{1}$ : Tensão principal maior;

$\sigma_{2}$ : Tensão principal intermediária $=\sigma_{3}$ para ensaios de $M_{R}$ em corpos-deprova cilíndricos;

$\sigma_{3}:$ Tensão principal menor = pressão de confinamento;

$\tau_{\text {oct: }}$ tensão cisalhante octaédrica;

Neste modelo, o coeficiente $\mathrm{k}_{1}$ é proporcional ao módulo de Young. Assim, os valores de $k_{1}$ devem ser positivos já que o $M_{R}$ não pode ser negativo. $O$ aumento da tensão volumétrica $(\theta)$ deveria produzir um enrijecimento ou endurecimento do material resultando valores maiores de $M_{R}$. Dessa forma, o expoente $\left(k_{2}\right)$ do termo do primeiro invariante de tensão do modelo deveria também ser positivo. $O$ coeficiente $k_{6}$ pretende levar em conta a poro-pressão ou coesão e é uma medida da habilidade do material resistir à tensão. Espera-se que seus valores sejam negativos ou, quando positivos, que sejam menores ou iguais a um terço da tensão volumétrica. $\mathrm{O}$ coeficiente $\mathrm{k}_{3}$, expoente do termo da tensão cisalhante octaédrica, deve ser negativo já que o aumento da tensão cisalhante produz um amolecimento do material, resultando em menores valores de $M_{R}$ (Yau \& Von Quintus, 2002).

O relatório FHWA-RD-02-051 (Yau \& Von Quintus, 2002) documenta a primeira revisão completa e avaliação dos ensaios de módulo de resiliência determinados para materiais de pavimentação e solos considerados no LTPP (Long Term Pavement Performance). Os resultados deste estudo indicaram que este modelo apresenta um excelente ajuste aos resultados de $M_{R}$ incluídos no banco de dados do LTPP (um total de 1920 ensaios). Especificamente, quase 92\% destes resultados têm características de resposta que podem ser simuladas com precisão pelo modelo, tendo sido, inclusive, selecionado para uso no novo guia de dimensionamento da AASHTO. Os autores destacam que todas as regressões realizadas consideraram $\circ \mathrm{M}_{R}$ em $\mathrm{MPa}$ e as tensões e pressões em $\mathrm{kPa}$. Ao analisarem os valores obtidos de $\mathrm{k}_{6}$, verificaram que mais da metade dos valores eram iguais a zero, enquanto os valores não nulos eram altamente variáveis com uma distribuição uniforme. Dessa forma, o valor de $k_{6}$ foi admitido como sendo igual a zero na equação anterior, resultando na equação (2.30). 


$$
M_{R}=k_{1} \cdot P_{a} \cdot\left[\frac{\theta}{P_{a}}\right]^{k_{2}} \cdot\left[\frac{\tau_{o c t}}{P_{a}}+1\right]^{k_{3}}
$$

Nesta nova condição, os valores de $\mathrm{k}_{1}$ variaram de 0 a 3 , considerando-se os valores de $M_{R}$ em MPa. O coeficiente $k_{2}$ variou de 0 a 1,5 e apresentou uma distribuição bi-normal, sugerindo a existência de dois grupos de solos. O coeficiente $\mathrm{k}_{3}$ variou de 0 a -7 e em $25 \%$ dos casos este valor foi igual a zero, e dentre estes a maioria estava relacionada a resultados de ensaios de materiais granulares não tratados ou solos granulares.

Os parâmetros do modelo constitutivo determinados para cada corpo-deprova devem ser tais que o coeficiente de determinação, $R^{2}$, exceda a 0,90 . Os parâmetros determinados para solos similares, ensaiados em condições também similares, podem ser combinados para a obtenção de $k_{1}, k_{2}$ e $k_{3}$ comuns. Se o valor de $R^{2}$ para um corpo-de-prova em particular é menor do que 0,90 , os resultados dos ensaios e os equipamentos devem ser verificados para a identificação de possíveis erros, que se não forem identificados levariam à consideração de uso de um modelo constitutivo diferente (NCHRP 1-37A, 2004).

A Tabela 2.3 apresenta uma comparação entre os valores das medianas e das médias destes coeficientes para cada grupo de solo. Observa-se que o valor médio do coeficiente $\mathrm{k}_{2}$ diminui à medida em que a granulometria do material/solo se torna mais fina. De forma semelhante, os valores médios de $k_{3}$ se tornam mais negativos quanto mais fina a granulometria do material/solo.

Tabela 2.3: Resumo dos valores das medianas e médias para cada coeficiente do modelo $k_{1}-k_{3}$, assumindo $k_{6}=0$, e para cada um dos materiais de base $e$ sub-base e solos de subleito (Yau \& Von Quintus, 2002)

\begin{tabular}{|c|c|c|c|c|}
\hline & \multirow[b]{2}{*}{ Coeficiente } & \multicolumn{3}{|c|}{ Material/Solo } \\
\hline & & $\begin{array}{c}\text { Materiais não-tratados } \\
\text { de base e sub-base }\end{array}$ & Solos granulares & Solos finos \\
\hline \multirow{3}{*}{$\mathrm{K}_{1}$} & Mediana & 0,853 & 0,764 & 0,804 \\
\hline & Média & 0,873 & 0,802 & 0,896 \\
\hline & Desvio-padrão & 0,2726 & 0,2661 & 0,3133 \\
\hline \multirow{3}{*}{$\mathrm{K}_{2}$} & Mediana & 0,628 & 0,446 & 0,243 \\
\hline & Média & 0,626 & 0,452 & 0,282 \\
\hline & Desvio-padrão & 0,1330 & 0,1927 & 0,1552 \\
\hline \multirow{3}{*}{$\mathrm{K}_{3}$} & Mediana & $-0,129$ & $-1,052$ & $-1,399$ \\
\hline & Média & $-0,170$ & $-1,140$ & $-1,576$ \\
\hline & Desvio-padrão & 0,2148 & 0,7365 & 1,1014 \\
\hline & mero de ensaios & 423 & 257 & 105 \\
\hline
\end{tabular}




\subsubsection{Relações com índices vinculados à natureza e estado do solo}

Um modelo que relaciona o valor do módulo de resiliência com a umidade e grau de saturação foi proposto por Jones \& Witczak (1977) ao analisarem solos finos de subleito provenientes de várias seções de uma rodovia experimental construída em San Diego, nos anos 60. A equação (2.31) caracteriza o modelo proposto.

$$
\log M_{R}=-0,111109 \cdot w+0,021699 \cdot S+1,17869
$$

onde: $\mathrm{M}_{\mathrm{R}}$ : módulo de resiliência em psi;

w: teor de umidade em \%;

S: grau de saturação em \%.

Rada \& Witczak (1981) propuseram um modelo, apresentado na equação (2.32), que relaciona o módulo de resiliência ao grau de saturação, grau de compactação e o primeiro invariante de tensão ao analisarem o comportamento resiliente de seis solos granulares.

$$
\log M_{R}=4,022-0,006832 \cdot S_{r}+0,007055 \cdot G C+0,005516 \cdot \log \theta
$$

onde: $M_{R}$ : módulo de resiliência ( $\left.p s i\right)$;

$S_{r}$ : grau de saturação (\%);

GC: grau de compactação em relação à massa específica aparente seca máxima para a energia modificada;

$\theta$ : primeiro invariante de tensão (psi).

Yau \& Von Quintus (2002) desenvolveram um amplo estudo com os resultados de ensaios de $M_{R}$ pertencentes ao banco de dados do LTPP, buscando correlacionar o módulo de resiliência com as propriedades físicas dos materiais. $\mathrm{Na}$ análise de correlação os materiais de base e sub-base foram analisados separadamente dos materiais de subleito. Estes últimos ainda foram agrupados por tipo material (argila, silte, areia e pedregulho). A Tabela 2.4 apresenta um resumo geral das propriedades físicas analisadas e indica aquelas consideradas importantes para cada um dos solos (estas informações dizem respeito apenas aos solos de subleito, sendo omitidas informações para materiais de base e sub-base). 
Tabela 2.4: Resumo das propriedades físicas consideradas importantes na previsão do $M_{R}$ para cada tipo de solo (Yau \& Von Quintus, 2002).

\begin{tabular}{|c|c|c|c|c|c|}
\hline \multirow{2}{*}{ Variável independente } & & \multicolumn{4}{|l|}{ Solos } \\
\hline & & pedregulho & Areia & silte & argila \\
\hline$\%$ que passa na peneira $3 / 8$ & $\mathrm{P}_{3 / 8}$ & $\sqrt{ }$ & $\sqrt{ }$ & & \\
\hline$\%$ que passa na peneira \#4 & $\mathrm{P}_{4}$ & & $\sqrt{ }$ & & \\
\hline$\%$ que passa na peneira $\# 40$ & $\mathrm{P}_{40}$ & & & & $\sqrt{ }$ \\
\hline$\%$ que passa na peneira $\# 200$ & $P_{200}$ & & $\sqrt{ }$ & & $\sqrt{ }$ \\
\hline Teor de argila & \%argila & $\sqrt{ }$ & $\sqrt{ }$ & $\sqrt{ }$ & $\sqrt{ }$ \\
\hline Teor de silte & $\%$ silte & & $\sqrt{ }$ & $\sqrt{ }$ & $\sqrt{ }$ \\
\hline Limite de liquidez & LL & $\sqrt{ }$ & $\sqrt{ }$ & & $\sqrt{ }$ \\
\hline Índice de plasticidade & IP & $\sqrt{ }$ & & $\sqrt{ }$ & \\
\hline Umidade de ensaio & $\mathrm{w}_{\mathrm{s}}$ & $\sqrt{ }$ & $\sqrt{ }$ & $\sqrt{ }$ & $\sqrt{ }$ \\
\hline Massa específica seca de ensaio & $\rho_{\mathrm{s}}$ & & $\sqrt{ }$ & & $\sqrt{ }$ \\
\hline Teor de umidade ótima & $w_{0}$ & & $\sqrt{ }$ & & $\sqrt{ }$ \\
\hline Massa específica seca máxima & $\rho_{d}$ & & $\sqrt{ }$ & & $\sqrt{ }$ \\
\hline Número de ensaios de $M_{R}$ & & 122 & 509 & 108 & 512 \\
\hline
\end{tabular}

Observa-se na Tabela 2.4 que a umidade de ensaio dos corpos-de-prova e o teor de argila são fatores importantes para todos os grupos de solos. O limite de liquidez foi considerado importante para todos os grupos de solo, exceto para o grupo silte, enquanto o teor de silte foi considerado importante para todos os solos exceto para o grupo pedregulho.

Os pesquisadores, então, realizaram uma análise de regressão não-linear para correlacionar os parâmetros de regressão $\left(k_{1}, k_{2}\right.$ e $\left.k_{3}\right)$ do modelo universal não-linear com as propriedades físicas consideradas importantes em cada caso. Ao se classificar os solos de subleito por tipos e separá-los nas análises, as estatísticas de regressão melhoraram quando comparado ao modelo que considera todos os solos em conjunto. Na seqüência são apresentadas as equações de regressão obtidas para cada um dos parâmetros de regressão separados por grupo de solo. Os símbolos usados na representação destes modelos foram descritos na Tabela 2.4.

Para pedregulhos os valores de $\mathrm{K}_{1}, \mathrm{k}_{2}$ e $\mathrm{k}_{3}$ são:

$$
\begin{aligned}
& k_{1}=1,3429-0,0051 P_{3 / 8}+0,0124(\% \text { argila })+0,0053 L L-0,0231 w_{s} \\
& k_{2}=0,3311+0,0010 P_{3 / 8}-0,0019(\% \text { argila })-0,0050 L L+0,0093 w_{s} \\
& k_{3}=1,5167-0,0302 P_{3 / 8}+0,0435(\% \text { argila })+0,0626 L L+0,0377 I P-0,2353 w_{s}
\end{aligned}
$$

Para os solos arenosos os valores de $\mathrm{K}_{1}, \mathrm{k}_{2}$ e $\mathrm{k}_{3}$ são: 


$$
\begin{aligned}
k_{1}= & 3,2868-0,0412 P_{3 / 8}+0,0267 P_{4}+0,0137(\% \text { argila })+0,0083 L L- \\
& -0,0379 w_{o}-0,0004 \rho_{s} \\
k_{2}= & 0,5670+0,0045 P_{3 / 8}-2,98 \cdot 10^{-5}\left(P_{4}\right)-0,0043(\% \text { silte })-0,0102(\% \text { argila })- \\
& -0,0041 L L+0,0014 w_{o}-3,41 \cdot 10^{-5} \rho_{s}-0,4582\left(\frac{\rho_{s}}{\rho_{d}}\right)+0,1779\left(\frac{w_{s}}{w_{o}}\right) \\
k_{3}= & -3,5677-0,1142 P_{3 / 8}-0,0839 P_{4}-0,1249 P_{200}+0,1030(\% \text { silte })+0,1191 . \\
& .(\% \text { argila })-0,0069 L L-0,0103 w_{o}-0,0017 \rho_{s}+4,3177\left(\frac{\rho_{s}}{\rho_{d}}\right)-1,1095\left(\frac{w_{s}}{w_{o}}\right)
\end{aligned}
$$

Para os solos siltosos os valores de $\mathrm{K}_{1}, \mathrm{k}_{2}$ e $\mathrm{k}_{3}$ são:

$k_{1}=1,0480+0,0177$ (\%argila) $+0,0279 / P-0,370 w_{s}$

$k_{2}=0,5097-0,0286 / P$

$k_{3}=-0,2218+0,0047(\%$ silte $)+0,0849 / P-0,1399 w_{s}$

Para os solos argilosos os valores de $\mathrm{K}_{1}, \mathrm{k}_{2}$ e $\mathrm{k}_{3}$ são:

$$
\begin{aligned}
k_{1}= & 1,3577+0,0106(\% \text { argila })-0,0437 w_{s} \\
k_{2}= & 0,5193-0,0073 P_{4}+0,0095 P_{40}-0,0027 P_{200}-0,0030 L L-0,0049 w_{o} \\
k_{3}= & 1,4258-0,0288 P_{4}+0,0303 P_{40}-0,0521 P_{200}+0,0251(\% \text { silte })+0,0535 L L- \\
& -0,0672 w_{o}-0,0026 \rho_{d}+0,0025 \rho_{s}-0,6055\left(\frac{w_{s}}{w_{o}}\right)
\end{aligned}
$$

Segundo Yau \& Von Quintus (2002), tanto para os materiais de base e subbase quanto para os solos de subleito, as correlações obtidas para todos os modelos foram de regulares a boas. Os resultados iniciais destas correlações indicam que o modelo universal não-linear pode prever razoavelmente o módulo de resiliência a partir das propriedades físicas dos materiais. Ressaltam também que, até que resultados adicionais de ensaios estejam disponíveis para melhorar ou confirmar estas relações, é recomendável que sejam realizados ensaios para a determinação do módulo de resiliência.

\subsubsection{Relações do $M_{R}$ com resultados de ensaios triaxiais convencionais}

Zaman et al. (1994) estudaram seis solos granulares a partir de ensaios triaxiais cíclicos e ensaios triaxiais convencionais e puderam estabelecer um modelo, descrito pela equação a seguir, que relaciona módulo de resiliência com o primeiro invariante de tensão, com a tensão principal maior, com a coesão e com o ângulo de atrito interno. 


$$
M_{R}=2860,94+275 \cdot c+128 \cdot \sigma_{1} \cdot \tan \phi+118 \cdot \theta
$$

onde: c: coesão (psi);

$\sigma_{1}$ : tensão principal maior (psi);

$\phi$ : ângulo de atrito interno

$\theta$ : primeiro invariante de tensão (psi).

\subsubsection{Relações com o valor do CBR}

O novo guia de dimensionamento da AASHTO permite, no Nível 2 de projeto, o uso de correlações para descrever o relacionamento entre índices do solo, propriedades de resistência e o módulo de resiliência, de forma direta (vide equação (2.46)) ou indireta (vide equação (2.47)). Neste último, as propriedades do material são inicialmente relacionadas com o CBR, e este posteriormente relacionado ao módulo de resiliência (NCHRP 1-37A, 2004).

$$
M_{R}=2555 \cdot C B R^{0,64}
$$

onde: $M_{R}$ : Módulo de resiliência em psi;

CBR: California Bearing Ratio em porcentagem.

$$
C B R=\frac{75}{1+0,728 \cdot(w P I)}
$$

onde: CBR: California Bearing Ratio;

wPI: $P_{200} \cdot P I$

$P_{200}$ : porcentagem que passa na peneira 200 , em decimais;

PI: índice de plasticidade, em porcentagem.

\subsubsection{Relações com resultados de ensaios de compressão simples}

O estudo de 11 solos finos, provenientes do estado americano do Tennessee, permitiu a Drumm et al. (1990) estabelecer uma relação entre o módulo de resiliência e resultados de ensaios de compressão, além de outros índices, tais como o índice de plasticidade, a massa específica aparente seca, o grau de saturação e a porcentagem de material que passa na peneira \#200. Os resultados 
de compressão simples considerados foram a tensão de ruptura e módulo tangente inicial $\left(E_{0}\right)$, determinados através do modelo proposto por Duncan \& Chang (1970), que considera a curva tensão-deformação uma hipérbole. A equação (2.48) descreve o modelo proposto pelos pesquisadores. É importante destacar que sua aplicação é válida para $\sigma_{d}=41,34 \mathrm{kPa}$. O coeficiente de determinação indicou que $83 \%$ dos valores experimentais podem ser representados pelo modelo.

$$
\begin{gathered}
M_{R i}=45,8+0,00052 \cdot\left(\frac{1}{a}\right)+0,188 \cdot q_{u}+0,45 \cdot I P- \\
-0,216 \cdot \rho-0,25 \cdot S-0,15 \cdot P_{200}
\end{gathered}
$$

onde: $M_{R I}$ : módulo de resiliência em psi para $\sigma_{d}=41,34 \mathrm{kPa}$;

1/a: módulo tangente inicial $\left(E_{0}\right)$ em psi;

$\mathrm{q}_{\mathrm{u}}$ : resistência à compressão simples;

IP: índice de plasticidade (\%);

$\rho:$ massa específica aparente seca $\left(\mathrm{lb} / \mathrm{ft}^{3}\right)$;

S: grau de saturação e;

$\mathrm{P}_{200}$ : percentual de material passando na peneira \#200.

Lee et al. (1995) pesquisaram relações entre o módulo de resiliência e resultados de ensaios de compressão simples para amostras indeformadas (Shelby) de solos coesivos extraídos do subleito de cinco seções de rodovias em uso em Indiana. Os ensaios de compressão foram executados até o corpo-de-prova apresentar deformação permanente de $1 \%$. Os autores consideraram possível relacionar o módulo de resiliência a parâmetros do ensaio de compressão simples para pequenas deformações devido às semelhanças nas deformações impostas aos corpos-de-prova nos dois ensaios. Determinaram a seguinte equação (2.49) para $\sigma_{\mathrm{d}}=41 \mathrm{kPa} \mathrm{e} \sigma_{3}=21 \mathrm{kPa}$ :

$$
M_{R}=1560+833,8 \cdot S_{u 1,0 \%}-6,97 \cdot S_{u 1,0 \%}^{2}
$$

onde: $M_{R}$ : módulo de resiliência (psi);

$\mathrm{S}_{\mathrm{u} 1,0 \%}$ : tensão correspondente à $1 \%$ de deformação axial no ensaio de compressão simples (psi). 
O coeficiente de determinação indicou que $85 \%$ dos resultados podem ser representados pelo modelo.

Cunto (1998) também desenvolveu uma pesquisa em que buscou relacionar o módulo de resiliência com o módulo tangente inicial $\left(E_{0}\right)$, determinado a partir de ensaios de compressão simples, e o estado tensão. Neste trabalho foram considerados um total de sete solos, sendo cinco LA' (A-2-4) e dois LG' (A-4 e A-7$5)$. Dentre estes materiais, três foram ensaiados exclusivamente na energia normal, outros dois apenas na energia intermediária, e os dois restantes nas duas energias. Nas análises de regressão múltiplas considerando-se todos os solos, independente da energia de compactação, o modelo que apresentou o melhor coeficiente de determinação $\left(R^{2}=0,67\right)$ é dado pela expressão:

$$
M_{R}=4,5231 \cdot E_{0}^{0,3158} \cdot \sigma_{d}^{-0,3436} \cdot \theta^{0,4393}
$$

onde: $\mathrm{M}_{\mathrm{R}}$ : módulo de resiliência (MPa);

$\mathrm{E}_{0}$ : módulo tangente inicial $(\mathrm{kPa})$;

$\sigma_{\mathrm{d}}$ : tensão desvio $(\mathrm{kPa})$;

$\theta$ : primeiro invariante de tensão.

De forma complementar, Cunto (1998) investigou as relações apenas para os solos arenosos, restringindo seu conjunto de dados. Verificou que de forma geral as correlações melhoraram e que dentre os modelos analisados aquele que apresentou o maior coeficiente de determinação $\left(R^{2}=0,82\right)$ é dado pela expressão:

$$
M_{R}=0,7170 \cdot E_{0}^{0,4668}+2,9016 \cdot \sigma_{1}^{0,7546}+0,3033 \cdot \sigma_{3}^{1,0721}
$$

onde: $M_{R}$ : módulo de resiliência ( $\left.M P a\right)$;

$\mathrm{E}_{0}$ : módulo tangente inicial $(\mathrm{kPa})$;

$\sigma_{1}$ : tensão principal maior $(\mathrm{kPa})$;

$\sigma_{3}:$ tensão confinante $(\mathrm{kPa})$. 


\section{Capítulo 3 - Materiais e Métodos}

\subsection{Introdução}

Neste capítulo são apresentados os procedimentos utilizados na investigação experimental para se alcançar os objetivos propostos nesta pesquisa, onde se estuda, em laboratório, a influência da variação de umidade no módulo de resiliência de solos tropicais finos (segundo a HRB) provenientes do subleito de rodovias do Estado de São Paulo.

\subsection{Coleta dos solos}

Para simplificar e agilizar o procedimento de amostragem, os solos estudados nesta pesquisa foram coletados em taludes de rodovias do interior do Estado de São Paulo ou potenciais jazidas localizadas nas proximidades das mesmas. Partiu-se da premissa de que estes materiais compõem o subleito das rodovias. Optou-se pela exclusão do litoral e da capital em face à dificuldade de se abranger todo o estado. Podem ser considerados como limite da área de coleta os eixos das rodovias SP-270 e BR-116.

A orientação inicial para a definição dos locais de coleta foi feita a partir da análise comparativa de categorias de solos determinadas em mapas pedológicos. 
Conforme já discutido por diversos pesquisadores (Oliveira, 1999; Godoy et al., 2000; Marangon \& Motta, 2001), os mapas pedológicos são documentos importantes por apresentarem uma visão geral da distribuição espacial dos solos, ressaltando contrastes entre regiões. Fornecem informações úteis na fase preliminar do estudo geotécnico para a implantação de obras viárias, contribuindo para a localização de jazidas e permitindo a avaliação da disponibilidade de materiais para a construção da estrutura do pavimento. Esta avaliação é facilitada pela possibilidade de se relacionarem as classes de solos consideradas na metodologia MCT e as classes pedológicas, com destaque para os materiais de comportamento laterítico (LG', LA' e LA).

Dessa forma, procurou-se selecionar materiais que representassem o maior número possível de classes pedológicas, dando-se ênfase aos solos classificados como PV, PVA, LV e LVA, respectivamente, argissolo vermelho, argissolo vermelho amarelo, latossolo vermelho e latossolo vermelho amarelo. No primeiro levantamento pedológico do estado realizado em 1960, segundo Oliveira (1999), os argissolos e os latossolos correspondiam a respectivamente $29 \%$ e $52 \%$ da área do estado. Levantamentos mais recentes (Oliveira et al., 1999) mostram que as classes anteriormente citadas correspondem, respectivamente, a $33 \%$ e $40 \%$ do total de unidades de mapeamento registradas. Ou seja, estas duas classes representam $73 \%$ das ocorrências no Estado de São Paulo.

Assim, a partir da análise dos mapas pedológicos, foram escolhidos 12 itinerários, ao longo dos quais foram coletadas 91 amostras de solos. Estes materiais receberam códigos de identificação de 1 até 91 , que correspondem à ordem cronológica de coleta. No Anexo A, a Tabela A.1 apresenta os locais de coleta com a indicação de coordenadas em termos de latitude e longitude. Não constam as coordenadas referentes às amostras de 1 a 20 , pois o uso do equipamento GPS foi incorporado apenas posteriormente à coleta destes materiais.

Outro critério considerado na escolha dos materiais coletados foi a busca de um equilíbrio entre as quantidades de amostras representativas de solos grossos e finos, entendendo-se por grossos ou finos, os solos que apresentam respectivamente, menos ou mais de $35 \%$ das partículas passando na peneira 200 , conforme descrito no item 3.7.1. Procurou-se também no mesmo perfil de solo, a 
coleta de amostras acima e abaixo da linha de seixos (LS). Entretanto, nem sempre foi possível identificar a presença da LS nos taludes em que se realizaram as coletas.

A Figura 3.1 indica a distribuição geográfica dos pontos de coleta no mapa do Estado de São Paulo. A escala do mapa não permite a identificação das amostras de 1 a 20 que concentram-se numa pequena região localizada nas proximidades de São Carlos.

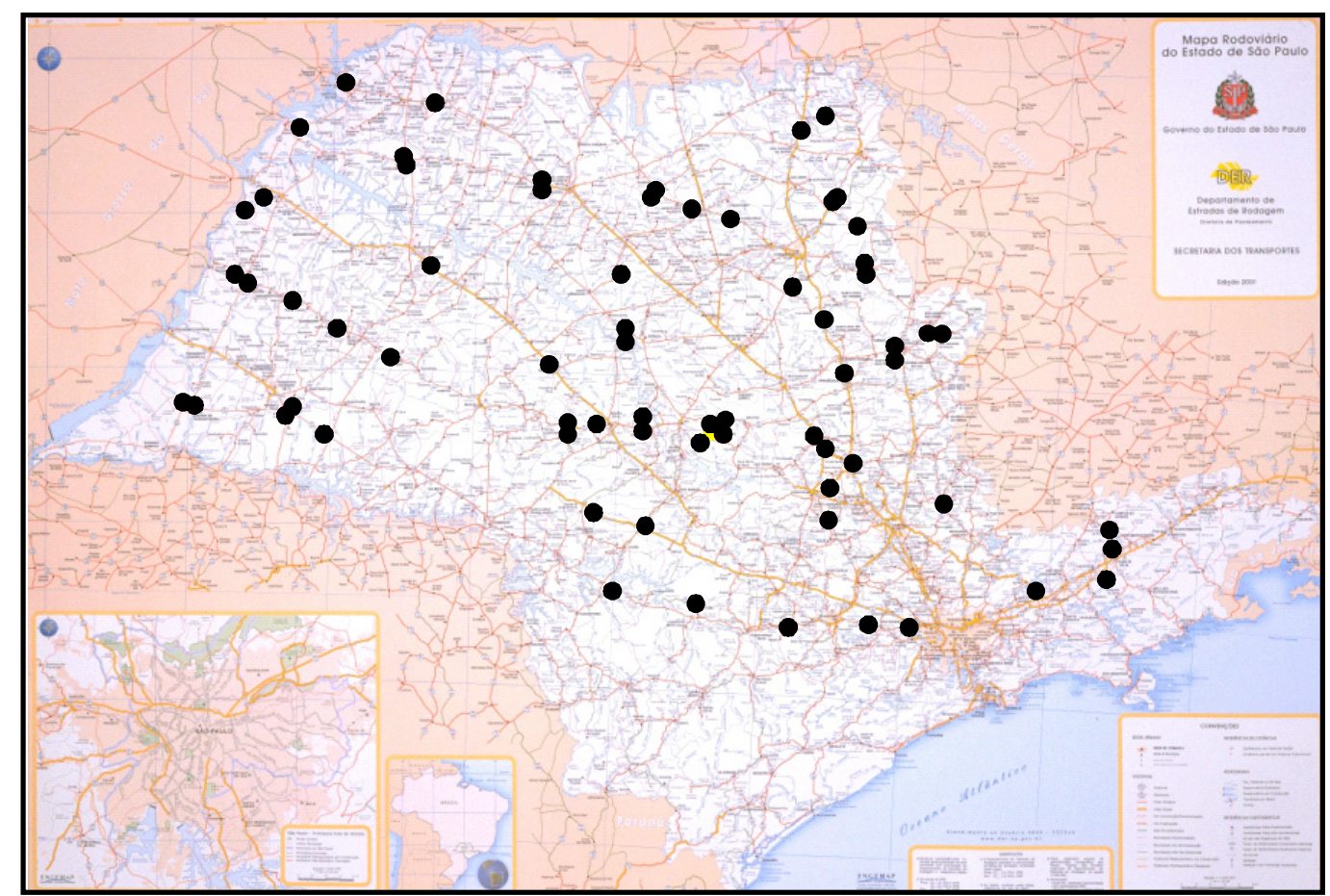

Figura 3.1: Mapa do Estado de São Paulo com indicação aproximada dos locais de coleta

Foram coletadas quantidades de cada amostra de solo suficientes para o desenvolvimento de toda a pesquisa, à exceção das amostras de 1 a 20 provenientes da região onde se desenvolveu a pesquisa, das quais coletou-se, inicialmente, material suficiente apenas para os ensaios de caracterização e classificação. Após a caracterização e classificação destes 20 solos (vide item 3.4), decidiu-se por selecionar apenas aqueles de maior interesse, amostras 11 e 17 , não incluindo os demais no prosseguimento dos estudos. Assim, a continuidade da pesquisa restringiu-se a um universo 72 solos. 


\subsection{Armazenagem e preparação dos materiais}

Após a coleta, os solos foram conduzidos ao Laboratório de Estradas da EESC-USP, onde foram secos ao ar até se atingir a umidade higroscópica. Após a secagem, os materiais foram passados na peneira de malha $4,8 \mathrm{~mm}\left(\mathrm{n}^{\circ} 4\right)$ e homogeneizados. Finalmente, foram quarteados e acondicionados em sacos plásticos devidamente identificados para uso posterior.

\subsection{Caracterização e classificação dos solos}

Considera-se como caracterização a determinação da massa específica dos sólidos, realizada segundo a norma NBR 6508 - "Grãos de solo que passam na peneira 4,8 mm - Determinação da Massa Específica", a análise granulométrica conjunta, realizada segundo a norma NBR 7181 - "Solos - Análise Granulométrica”, e a determinação dos limites de consistência, realizados segundo as normas NBR 6459 - "Solo - Determinação do Limite de Liquidez" e NBR 7180 "Solo - Determinação do Limite de Plasticidade". Os resultados destes ensaios permitiram a classificação dos solos segundo o Sistema Unificado e HRB (Highway Research Board). Os resultados dos ensaios de caracterização dos solos coletados e as respectivas classificações são apresentados na Tabela B.1 do Anexo B.

\subsection{Identificação do caráter laterítico dos solos}

A identificação do caráter laterítico dos materiais estudados foi de extrema importância visto que é objetivo da pesquisa estabelecer uma comparação entre o comportamento mecânico de solos lateríticos e não-lateríticos. Para esta identificação, as amostras foram analisadas segundo quatro diferentes metodologias descritas em seguida.

\subsubsection{Classificação MCT}


Em um primeiro momento, os 72 solos foram ensaiados e classificados segundo a metodologia MCT, cujo resultado indica o comportamento laterítico ou não-laterítico destes materiais.

Para a classificação dos solos segundo a metodologia MCT adotaram-se os procedimentos descritos nas normas DNER - M 256-94 - "Solos compactados com equipamento miniatura - Determinação da perda de massa por imersão" e DER - M 196-89 - "Classificação de solos tropicais segundo a metodologia MCT". Os resultados destes ensaios e da classificação podem ser encontrados no Anexo $\mathrm{C}$, onde são apresentados os valores dos índices $\mathrm{Pi}$, c' e e', além do gráfico de classificação MCT com a localização de cada um dos solos.

\subsubsection{Microscopia eletrônica de varredura (MEV)}

Posteriormente, os 72 solos foram submetidos ao ensaio de microscopia eletrônica de varredura com a finalidade de se observar a micro-estrutura dos argilominerais presentes na fração fina dos solos (porcentagem que passa na peneira 200 de abertura $0,074 \mathrm{~mm}$ ).

O aparelho usado na microscopia eletrônica foi o "Digital Scanning Microscope - DSM 960 - Zeiss" que pertence ao Instituto de Física de São Carlos/USP. Para a realização do ensaio de MEV, pequenas porções das frações finas de solo são fixadas com esmalte incolor sobre pequenos pinos de alumínio com dimensões padronizadas. Para garantir a perfeita secagem do esmalte, o conjunto amostra + pino deve ser mantido em estufa por vinte minutos.

A realização do ensaio de MEV depende da existência de um material condutor sobre as amostras se estas não apresentam tal característica. Então, as amostras de solo são submetidas a um banho metálico de ouro, que deposita sobre as mesmas uma camada do material, suficientemente fina para que não seja vista pelo microscópio e suficientemente espessa para que funcione como condutor (da ordem de $20 \eta \mathrm{m}$ ), condição para uma boa definição de imagem. 
Para cada uma das amostras, obtiveram-se duas imagens, correspondendo, respectivamente, a aumentos de 3.000 vezes e 10.000 vezes. As imagens resultantes destes ensaios são apresentadas no Anexo D.

\subsubsection{Difração de raios-x (DRX)}

Os ensaios de difração de raios-x têm por finalidade a identificação dos argilominerais presentes na fração fina dos solos (porcentagem que passa na peneira 200 de abertura $0,074 \mathrm{~mm}$ ). Apenas os solos selecionados para etapa de estudos envolvendo o comportamento mecânico dos materiais frente à variação da umidade, 30 amostras escolhidas conforme o critério descrito no item 3.7 , foram submetidos a este ensaio.

Os ensaios foram realizados no Laboratório de Difração de Raios-x do Instituto de Física de São Carlos/USP, utilizando-se o difratômetro automático (ânodo rotatório), RIGAKU ROTAFLEX, modelo RU-200B. O procedimento adotado observou varredura contínua de $5^{\circ}$ a $70^{\circ}$ e velocidade de $2 \%$ minuto em amostras secas em estufas e usadas na forma de pó. Para a execução dos ensaios, o pó é colocado no porta-amostra e ligeiramente pressionado, ou seja, as amostras não são orientadas.

Na seqüência faz-se uma descrição dos princípios físicos envolvidos nos ensaios, conforme adaptação realizada a partir de Santos (1992), Identificação de Argilas - Difração de Raios X, capítulo 12, bem como a descrição dos parâmetros usados na identificação dos minerais.

Conforme Santos (1992), vide Figura 3.2, um feixe de raios-x ao incidir em um cristal, o mesmo interage com os átomos presentes, originando o fenômeno de difração, ocorrendo segundo a Lei de Bragg (equação (3.1)), que estabelece a relação entre o ângulo de difração $(\theta)$ e a distância entre os planos (d) que a originaram (característicos para cada cristal).

$$
\mathrm{n} \lambda=2 \mathrm{~d} \operatorname{sen} \theta
$$


onde: $\quad \mathrm{n}$ : número inteiro;

$\lambda$ : comprimento de onda dos raios- $x$ incidentes $(\mathrm{Cu}-\lambda=1,542 \AA)$;

d: distância interplanar (medido em angstrom $\left[\AA=10^{-10} \mathrm{~m}\right]$ );

$\theta$ : ângulo de difração

Portanto, se o comprimento de onda dos raios-x é conhecido e o ângulo $\theta$ determinado experimentalmente, o valor de d pode ser determinado. O resultado do ensaio de difração fornecido para a análise é composto por um gráfico com a representação do espectro de difração (difratograma) e uma tabela com a indicação dos picos e os respectivos valores de $2 \theta$, d, intensidade do pico e intensidade relativa.

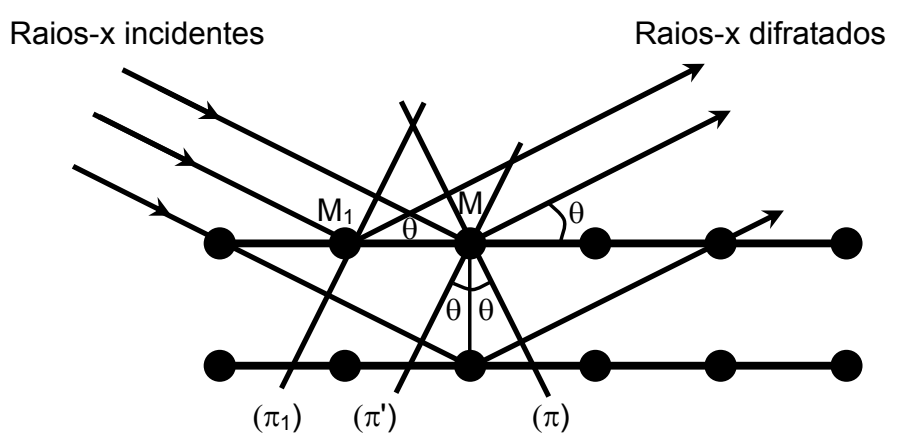

Figura 3.2: Difração de raios-x por um reticulado cristalino (lei de Bragg) (adaptado de Santos, 1992)

É importante salientar que não foram realizados procedimentos complementares em amostras tratadas com etileno-glicol, e nem amostras com tratamento térmico, que permitiriam a diferenciação e identificação dos filossilicatos presentes nos solos. O primeiro procedimento baseia-se na capacidade de alguns argilominerais admitirem em sua estrutura ligações com álcoois, e estes por sua vez, com a água, o que aumenta a distância interplanar (d). O segundo procedimento busca eliminar as moléculas de água adsorvidas nos argilominerais, resultando na redução da distância interplanar (d). Como exemplo prático, a glicolação não causa efeito sobre o pico principal da caulinita, entretanto, o tratamento térmico entre $550^{\circ}$ e $650^{\circ}$ o amortiza. No caso da montmorilonita, o pico principal expande de $15,4 \AA$ para $17 \AA$ com a glicolação, com o tratamento térmico a $300^{\circ} \mathrm{C}$ colapsa para $9 \AA$. 
Dessa forma, o procedimento adotado permite apenas a realização de uma classificação preliminar dos filossilicatos em grupos, o que atende aos objetivos estabelecidos neste trabalho. Seria possível, portanto, definir se os argilominerais presentes nas amostras de solos pertencem ao grupo da caulinita, das esmectitas ou das ilitas, sendo mais difícil, por exemplo, diferenciar um argilomineral entre uma ilita ou uma muscovita.

O procedimento para identificação dos minerais presentes em uma amostra de solo a partir do espectro de raios-x é extremamente trabalhoso e demorado, sendo necessária a comparação entre os valores calculados de d e $2 \theta$ com os valores característicos de cada mineral que se supõe compor a amostra. Neste sentido, para restringir o universo de minerais a ser pesquisado e reduzir o tempo para análise de cada espectro, realizou-se um levantamento bibliográfico com o intuito de identificar os minerais passíveis de serem encontrados nos diversos solos estudados. Foram consultados os trabalhos de Nogami \& Vilibor (1995), Brinatti (2001) e Alves (2002) para este fim. Diante das informações obtidas nas referências anteriores, foram providenciados os cartões de identificação da maioria dos minerais citados nos estudos para a identificação dos componentes dos solos estudados. No Anexo E pode ser encontrada a Tabela E.1, que apresenta os minerais considerados na identificação dos padrões de difração, separados segundo o grupo da caulinita, grupo das esmectitas grupo das ilitas, quartzo e óxidos e hidróxidos de ferro, alumínio e titânio, bem como os respectivos valores de espaçamento interplanar (d) e $2 \theta$.

O uso da Tabela E.1 para identificação dos minerais deve ser realizada por linha, ou seja, mineral por mineral, buscando compatibilizar os valores de $d$ do espectro desconhecido com os valores de d conhecidos para cada mineral. Havendo a coincidência entre estes valores é possível dizer que determinado mineral está presente na amostra analisada.

No estudo em questão, o espectro de difração de cada amostra ao ser analisado é comparado com o cartão de cada um dos minerais selecionados, ou seja, o procedimento de análise adotado se resume em encontrar indícios da presença destes minerais nas amostras dos solos coletados. Portanto, a existência 
na amostra de um mineral que não os selecionados conduziriam a não caracterização de alguns picos característicos.

No total, para identificação dos minerais cada espectro desconhecido é comparado com trinta e nove cartões de identificação, sendo oito do grupo da caulinita, seis do grupo das esmectitas, onze do grupo das ilitas, doze óxidos e hidróxidos de ferro, alumínio ou titânio e dois do quartzo.

Os resultados de identificação dos minerais para as trinta amostras selecionadas nesta etapa do estudo são apresentados no Capítulo 4 (vide Tabela 4.8).

\subsubsection{Adsorção de azul de metileno pelo método da mancha}

De forma complementar aos ensaios realizados para a identificação do caráter laterítico dos solos selecionados, realizou-se também o ensaio de adsorção de azul de metileno segundo método proposto por Fabbri (1994), que permite a caracterização da fração fina de solos tropicais. Assim como os ensaios de difração de raios- $x$, apenas os solos selecionados para etapa de estudos envolvendo o comportamento mecânico dos materiais frente à variação da umidade, trinta amostras escolhidas conforme o critério descrito no item 3.7 , foram submetidos a este ensaio.

Para a caracterização da fração fina dos solos por este método são necessários três parâmetros: a) a porcentagem que passa na peneira $0,074 \mathrm{~mm}$, denominada fração fina; b) a porcentagem que passa na peneira $0,005 \mathrm{~mm}$, denominada teor de argila, e; c) o volume de solução padrão de azul de metileno consumido pela fração fina do solo.

Com os três valores descritos anteriormente é possível determinar o Valor de Azul (Va) pela equação 3.2.

$$
V a=V \cdot \frac{P_{200}}{100} \cdot\left(1+\frac{w}{100}\right)
$$


onde: $\quad$ Va $=$ valor de azul para a amostra integral;

$\mathrm{V}=$ volume de solução padrão de azul de metileno adicionada à suspensão;

w = teor de umidade da fração do solo ensaiada;

$\mathrm{P}_{200}=$ porcentagem passada na peneira $200(0,074 \mathrm{~mm})$.

O Va e o teor de argila são utilizados para a identificação da atividade dos argilominerais presentes na fração fina do solo a partir de um ábaco construído para esta finalidade, conforme apresentado na Figura 3.3. Para a classificação, localiza-se no gráfico o par ordenado (teor de argila, Va) verificando-se a região em que este se encontra.

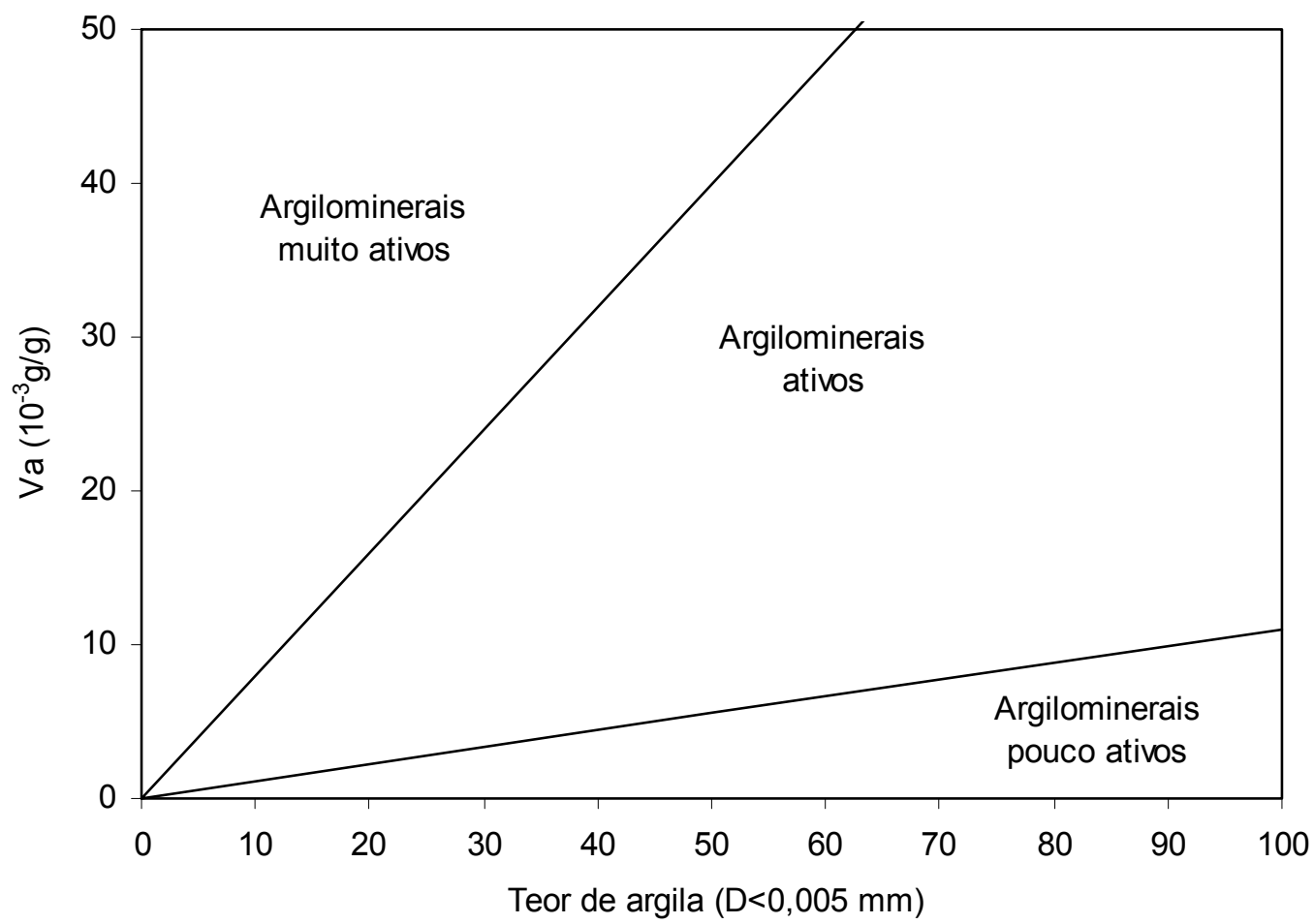

Figura 3.3: Gráfico para identificação da atividade dos argilominerais presentes na fração fina de um solo tropical

Alternativamente, pode ser calculado o valor do coeficiente de atividade da fração argila do solo (CA) através da equação 3.3 , e compará-lo com os valores pré-determinados apresentados na Tabela 3.1.

$$
C A=100 \cdot \frac{V a}{P_{F}}
$$


onde: $\quad \mathrm{CA}=$ coeficiente de atividade;

$\mathrm{Va}=$ volume de azul de metileno para amostra total;

$\mathrm{P}_{\mathrm{F}}=$ porcentagem que o solo contém da fração argila.

Tabela 3.1: Valores pré-determinados do coeficiente de atividade (CA) da fração fina do solo para caracterização do grau de atividade dos argilominerais

\begin{tabular}{cc}
\hline Valor de CA & Grau de atividade dos argilominerais \\
\hline $\mathrm{CA}<11$ & Pouco ativos \\
$11<\mathrm{CA}<80$ & Ativos \\
$\mathrm{CA}>80$ & Muito ativos \\
\hline
\end{tabular}

Segundo Fabbri (1994), os três graus de atividade citados caracterizam a presença dos seguintes argilominerais:

a) Muito ativos - montmorilonita, vermiculita, etc. (grupo das esmectitas);

b) Ativos - caulinitas, e/ou ilitas, combinações destes com os de grupos mais ativos e de grupos menos ativos;

c) Pouco ativos - materiais inertes até argilominerais laterizados ou ainda combinações entre estes e os de outros grupos mais ativos.

Assim, segundo os princípios descritos anteriormente, espera-se que dentre os solos estudados aqueles classificados como de comportamento laterítico apresentem valores de CA menores do que 11, ou que se encontrem na região definida para argilominerais pouco ativos dentro do ábaco de identificação. Ao contrário, espera-se que os solos classificados como não-lateríticos apresentem valores de CA maiores do que 11 , ou que se encontrem na região definida para argilominerais ativos ou muito ativos no gráfico de identificação.

\subsection{Ensaios de compactação}

Os setenta e três solos foram submetidos aos ensaios de compactação, realizados segundo a norma DER M 13-71, para determinação do par ordenado umidade ótima e massa específica seca máxima $\left(w_{\mathrm{o}} \times \rho_{\mathrm{dmax}}\right)$ na energia normal do Ensaio de Proctor. Estes resultados são apresentados no Anexo F. 


\subsection{Comportamento mecânico frente à variação da umidade}

Para a realização desta etapa do estudo foram selecionadas, conforme descrito na seqüência, trinta amostras dentre as setenta e três disponíveis.

\subsubsection{Seleção dos solos para o estudo do comportamento mecânico}

$\mathrm{Na}$ seleção dos materiais para o estudo do comportamento mecânico frente à variação de umidade foram considerados parâmetros relacionados à granulometria, classificação e gênese dos solos.

Inicialmente, os materiais foram divididos em função de faixas granulométricas definidas pela porcentagem que passa na peneira $n^{\circ} 200(0,074$ $\mathrm{mm}$ ). Foram adotados intervalos granulométricos para separar os solos em três grupos: finos, intermediários e grossos. Os valores limites destes intervalos são apresentados na Tabela 3.2.

Tabela 3.2: Valores limites adotados nas faixas granulométricas

\begin{tabular}{cc}
\hline Faixa granulométrica & Intervalo adotado \\
\hline Finos & $\mathrm{P}_{200}>50 \%$ \\
Intermediários & $35 \%<\mathrm{P}_{200} \leq 50 \%$ \\
Grossos & $\mathrm{P}_{200} \leq 35 \%$
\end{tabular}

Obs.: $\mathrm{P}_{200}=$ porcentagem que passa na peneira 200

Apesar de a pesquisa tratar principalmente do estudo de solos que apresentam mais de $35 \%$ das partículas passando na peneira 200 (solos finos, segundo a HRB), incorporou-se ao conjunto de amostras estudadas também uma parcela de solos classificados como grossos. Este procedimento tem por objetivo criar um grupo de controle para a análise comparativa de resultados. Entretanto, a maioria dos solos ensaiados nesta etapa do estudo é classificada como finos e intermediários segundo os critérios apresentados na Tabela 3.2.

Procurou-se também incluir no estudo "pares granulométricos", ou seja, materiais com curvas granulométricas muito semelhantes, a mesma classificação HRB e, quando possível, a mesma classificação unificada, mas com comportamentos distintos quanto à laterização, ou seja, um com comportamento laterítico e o outro, com comportamento não-laterítico. Para complementar o 
universo de amostras estudadas, selecionou-se também, pelo menos um solo de cada classe MCT, independentemente dos critérios destacados anteriormente.

Dentre todas as 72 amostras disponíveis, foram selecionados trinta solos para esta etapa do estudo. Estas amostras foram separadas por grupos granulométricos conforme apresentado na Tabela 3.3.

Tabela 3.3: Distribuição das amostras selecionadas por faixas granulométricas.

\begin{tabular}{cccc}
\hline Faixa granulométrica & Amostras & Total \\
\hline Grossos & $11,17,50,76,81,85,89$ & 7 solos & $23 \%$ \\
Intermediários & $27,30,46,55,57,60,88$ & 7 solos & $23 \%$ \\
Finos & $21,22,25,34,38,39,48,53,64$, & 16 solos & $54 \%$ \\
\hline
\end{tabular}

Conforme se verifica na Tabela 3.3, a maioria dos solos selecionados, vinte e três solos ou aproximadamente $77 \%$ do total, enquadram-se nas faixas finas e intermediárias, que correspondem aos solos classificados como finos segundo a HRB. Dentre estes trinta solos, aproximadamente a metade apresenta comportamento laterítico e o restante comportamento não-laterítico.

A fim de facilitar a interpretação e análise dos resultados no Capítulo 5, promoveu-se a renomeação dos solos, conforme apresentado na Tabela 3.4, onde são indicados os solos e a nova designação usada.

Tabela 3.4: Indicação da nomenclatura dos trinta solos selecionados

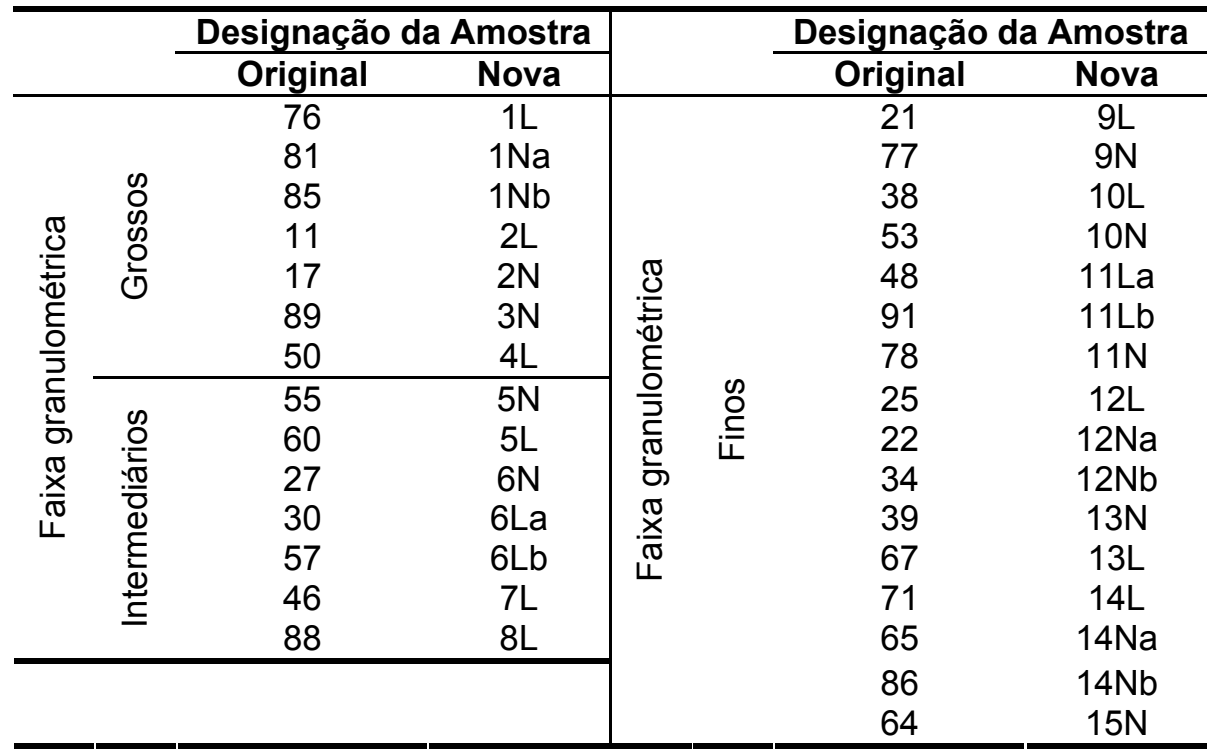


Conforme a Tabela 3.4 , os solos que formam "pares granulométricos" receberam o mesmo número acrescido da indicação do comportamento laterítico (L) ou não-laterítico $(\mathrm{N})$. O conjunto de solos considerados como grossos é formado pelos grupos $1(1 \mathrm{~L}, 1 \mathrm{Na}$ e $1 \mathrm{Nb})$ e 2 ( $2 \mathrm{~L}$ e $2 \mathrm{~N}$ ) e pelas amostras individuais, $3 \mathrm{~N}$ e $4 \mathrm{~L}$. Já o conjunto de solos intermediários é formado pelos grupos $5(5 \mathrm{~L}$ e $5 \mathrm{~N})$ e $6(6 \mathrm{~N}$, $6 \mathrm{La}$ e $6 \mathrm{Lb}$ ) e pelas amostras $7 \mathrm{~L}$ e $8 \mathrm{~L}$. $\mathrm{O}$ conjunto de solos finos é formado pelos grupos 9 (9L e $9 \mathrm{~N}), 10$ (10L e $10 \mathrm{~N}), 11$ (11La, 11Lb e $11 \mathrm{~N}), 12(12 \mathrm{~L}, 12 \mathrm{Na}$ e $12 \mathrm{Nb})$, $13(13 \mathrm{~L}$ e $13 \mathrm{~N})$ e $14(14 \mathrm{~L}, 14 \mathrm{Na}$ e $14 \mathrm{Nb})$ e pela amostra $15 \mathrm{~N}$.

No Anexo G, são apresentadas as curvas granulométricas destes solos, indicando os respectivos grupos de amostras, e a nova e a antiga nomenclatura dos solos e as respectivas classificações MCT, HRB e USCS.

\subsubsection{Ensaios triaxiais cíclicos, compressão simples e de medida de sucção}

Os solos apresentados na Tabela 3.3 foram submetidos aos seguintes ensaios: triaxiais cíclicos para determinação do módulo de resiliência, resistência à compressão simples para determinação do valor de resistência à compressão e módulo tangente inicial; e ensaios de medida de sucção. Para estes ensaios, os corpos-de-prova foram compactados na umidade ótima e massa específica seca máxima. O procedimento de moldagem é apresentado no item 3.7.2.1.

Nos ensaios triaxiais cíclicos, optou-se por ensaiar apenas um corpo-deprova para cada condição estudada em função da dificuldade na execução dos mesmos. Acredita-se que este procedimento não leve a problemas de confiabilidade, visto que estes ensaios apresentam boa repetibilidade tanto para ensaios realizados no mesmo corpo-de-prova quanto para ensaios realizados em corpos-de-prova diferentes (Parreira et al., 1998). No caso dos ensaios de compressão simples, por sua facilidade de execução, optou-se por ensaiar três corpos-de-prova para cada condição estudada. Dessa forma, os resultados de módulo tangente inicial e resistência à compressão simples são compostos pela média de três valores. Os critérios utilizados na aceitação dos resultados destes ensaios são apresentados na descrição do procedimento experimental de cada um destes. 
Os ensaios triaxiais cíclicos e alguns ensaios de compressão simples foram realizados em diferentes teores de umidade. Estas condições são discutidas caso a caso para cada uma das condições consideradas.

\subsubsection{Moldagem dos corpos-de-prova}

Todos os corpos-de-prova foram moldados seguindo os princípios aqui descritos. Ao solo previamente seco ao ar é adicionada água suficiente para se atingir a umidade desejada, sendo então o material homogeneizado e embalado em saco plástico. Após a homogeneização, duas cápsulas do solo são retiradas para a verificação do teor de umidade atingido. Portanto, nenhum corpo-de-prova é moldado antes de vinte quatro horas, período este usado para a determinação da umidade e também para a equalização da umidade na amostra. Realizava-se a moldagem apenas se umidade atingida pela amostra estivesse dentro de um intervalo de $\pm 0,25 \%$ da umidade alvo.

O processo de moldagem é realizado estaticamente em três camadas, para corpos-de-prova de $100 \mathrm{~mm}$ de altura e $50 \mathrm{~mm}$ de diâmetro, usando uma prensa Versatester 30M (vide Figura 3.4).

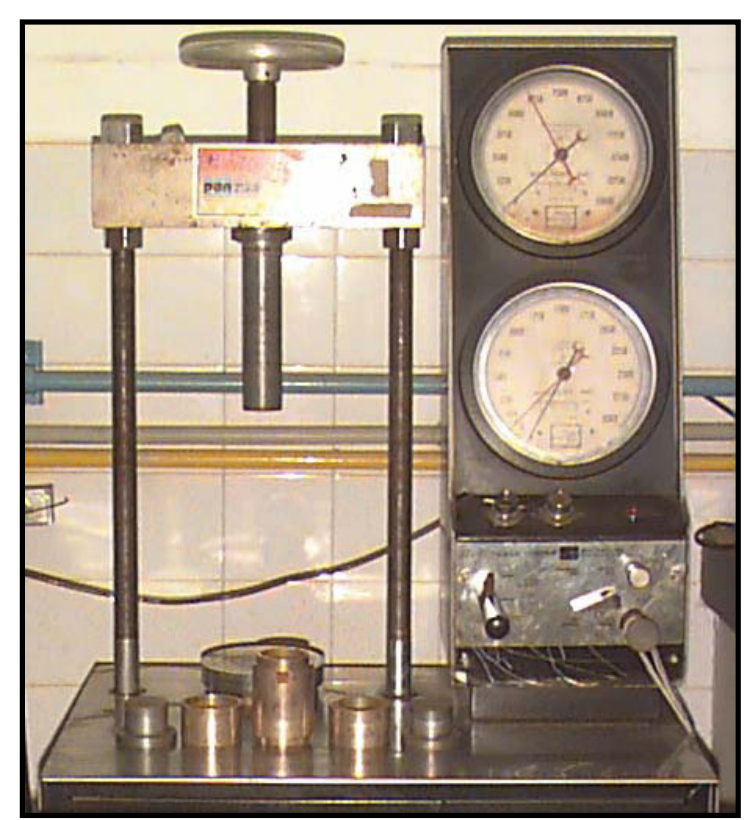

Figura 3.4: Prensa Versatester para compactação estática de corpos-de-prova e cilindro de compactação 
Após a moldagem de cada corpo-de-prova procedia-se á determinação de sua massa e geometria (altura e diâmetro), sendo possível assim a estimativa da massa específica úmida do corpo-de-prova e, conseqüentemente, a determinação do grau de compactação. Dessa forma, em função de critérios de aceitação, é possível decidir sobre o descarte ou não de corpos-de-prova. Descarta-se o corpode-prova cujo grau de compactação não esteja no intervalo de 99\% a 101\%.

\subsubsection{Condições de umidade dos corpos-de-prova}

Sabe-se que a variação das condições ambientais, ou seja, seu caráter sazonal pode alterar o estado físico do solo (e.g. umidade e massa específica seca) influenciando diretamente o valor do módulo de resiliência. Observa-se que, após a construção do pavimento, podem ocorrer variações positivas ou negativas do teor de umidade, tomando-se como referência a umidade ótima de compactação. Com o objetivo de simular tal fenômeno, realizaram-se, em corpos-de-prova compactados, ensaios triaxiais cíclicos após umedecimento, e após secagem.

Além de ensaios realizados na umidade ótima, foram ainda consideradas outras três condições de umidade, ou seja: $w_{0}-2 \%, w_{0}-1 \%$ e $w_{0}+1 \%$. É importante destacar que são variações absolutas de umidade, e não relativas, e que as variações ocorreram a partir de corpos-de-prova compactados na umidade ótima. Por exemplo, se um solo apresenta umidade ótima de $20 \%$, ele será compactado e ensaiado nesta umidade e nas umidades de $18 \%, 19 \%$ e $21 \%$. Os procedimentos de secagem e umedecimento dos corpos-de-prova usados na pesquisa são apresentados na seqüência.

A secagem dos corpos-de-prova é realizada em uma câmara construída para esta finalidade (vide Figura 3.5), de forma que as condições de temperatura variem pouco ao longo do tempo. A câmara é uma caixa de madeira que conta com um dispositivo para controle da temperatura interna mantida no intervalo de variação de $30^{\circ} \mathrm{C} \pm 2^{\circ} \mathrm{C}$. O aquecimento é gerado por um conjunto de lâmpadas localizado na parte inferior da caixa. Além do controle de temperatura, a câmara também conta com um ventilador na sua parte superior, que funciona como um exaustor, gerando um fluxo ascendente e constante de ar. O ar entra na caixa por orifícios laterais localizados na sua parte inferior, passando através do conjunto de 
lâmpadas para ser aquecido. A câmara é dotada de grelhas onde os corpos-deprova são depositados horizontalmente para a secagem.

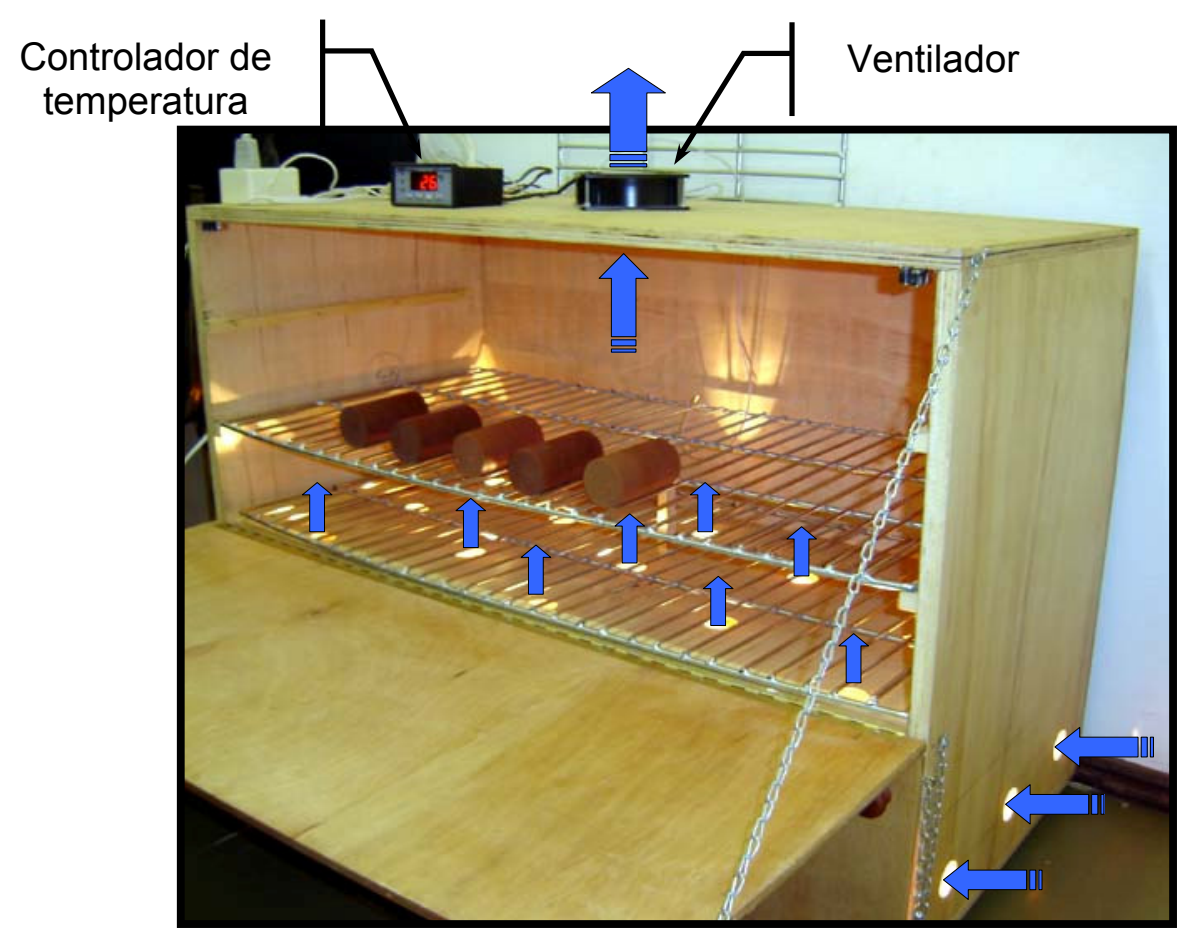

Figura 3.5: Câmara para secagem dos corpos-de-prova

O umedecimento dos corpos-de-prova foi realizado pelo posicionamento da face inferior dos mesmos sobre uma pedra porosa saturada, enquanto na face superior era colocado um papel filtro mantido permanentemente umedecido (vide Figura 3.6).

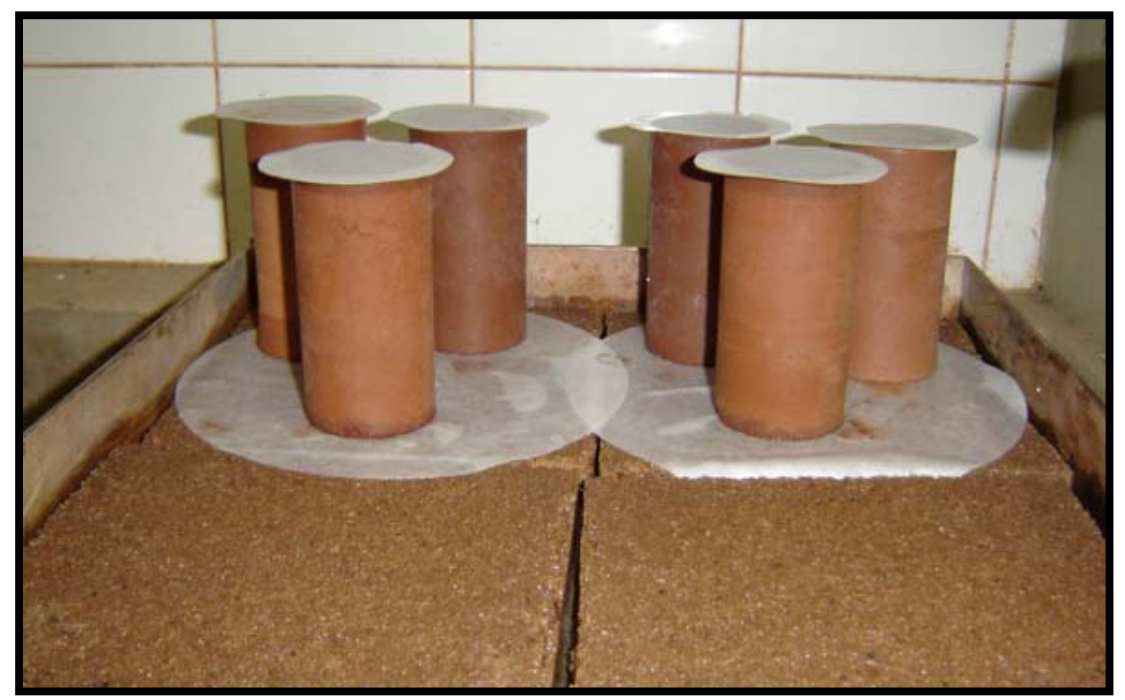

Figura 3.6: Conjunto de pedras porosas utilizadas no processo de umedecimento dos corpos-de-prova 
Tanto no processo de secagem quanto de umedecimento, o controle da perda ou ganho de umidade é realizado com o acompanhamento da variação da massa do corpo-de-prova. Ao se atingir a massa desejada, os corpos-de-prova preparados segundo as condições descritas anteriormente são envolvidos com várias camadas de filme plástico, identificados, embalados em sacos plásticos e mantidos em câmara úmida, por um período mínimo de 10 dias antes da realização dos ensaios, para a homogeneização da umidade. Verificou-se que este período permite uma boa homogeneização, evitando-se tempos maiores que poderiam ocasionar perdas de umidade indesejadas.

Destaca-se que no processo de umedecimento, durante os intervalos entre as pesagens sucessivas, os corpos-de-prova permaneciam protegidos por uma caixa de isopor adaptada sobre o conjunto de pedras porosas.

\subsubsection{Ensaios triaxiais cíclicos}

$\mathrm{Na}$ seqüência, são apresentados os equipamentos e procedimento experimental utilizado para a realização destes ensaios.

\subsection{Equipamento}

Para a realização dos ensaios triaxiais cíclicos foi usada uma prensa da marca MTS (Material Testing System), modelo 815 (vide Figura 3.7), pertencente ao Laboratório de Geotecnia da EESC - USP.

A prensa MTS possui um sistema de carregamento hidráulico que permite, através de um gerador de funções, que se selecione previamente a forma, duração e freqüência de aplicação das cargas. A célula de carga usada nos ensaios é da marca WYKEHAM FARRANCE, com capacidade máxima de carga de $3 \mathrm{kN}$, e posicionada internamente à câmara triaxial. $O$ equipamento permite manter-se uma tensão de contato mínima no corpo-de-prova, estabelecida em $10 \%$ da tensão máxima. O fluido usado para confinamento dos corpos-de-prova no interior da câmara triaxial é o ar, sendo o controle de aplicação realizado de forma manual. A medida dos deslocamentos é feita com o auxílio de dois LVDTs, instalados nos terços médios dos corpos-de-prova (vide Figura 3.8). 


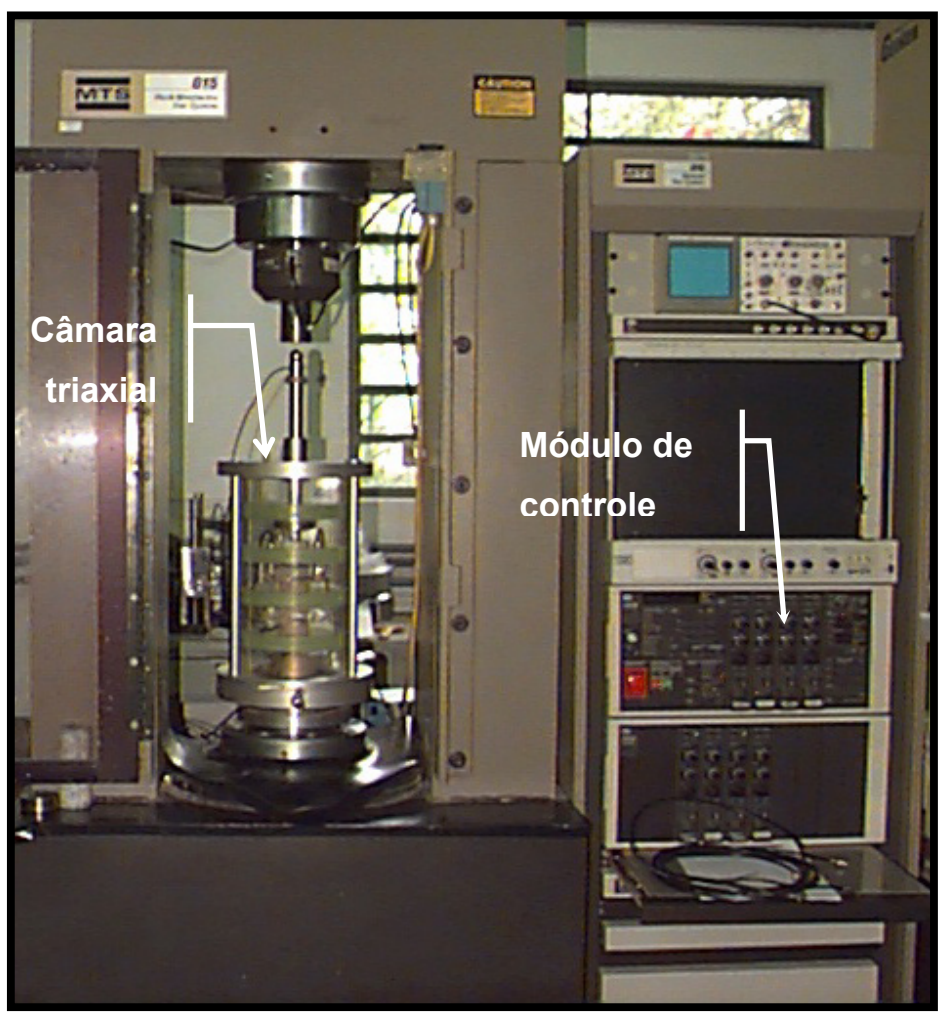

Figura 3.7: Prensa MTS modelo 815

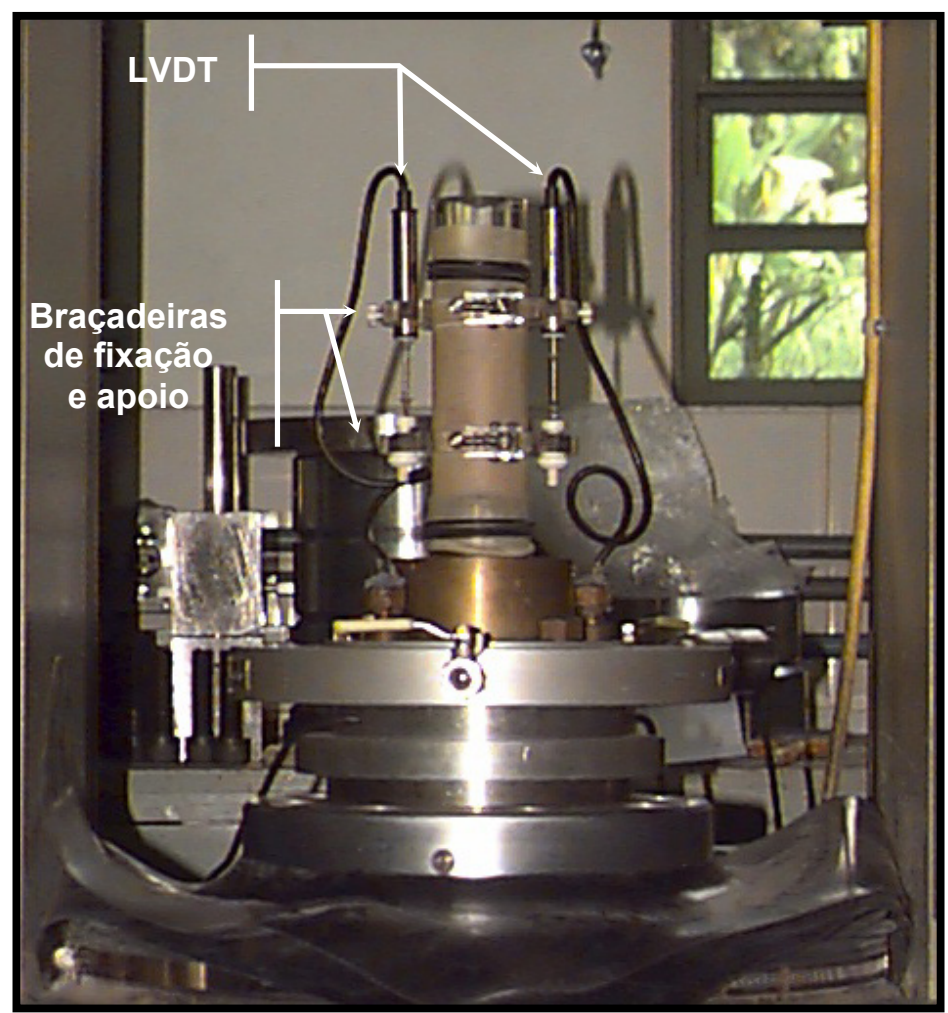

Figura 3.8: LVDT's instalados nos terços médios do corpo-de-prova 


\subsection{Procedimentos de ensaio}

Os ensaios foram realizados conforme os níveis de tensões preconizados na norma "Standard Method of Test for Determining the Resilient Modulus of Soils and Aggregate Materials" (AASHTO Designation: T 307-99). Este método descreve procedimentos de preparação e ensaio de solos de subleito, e materiais de base e sub-base não tratados, para a determinação do módulo de resiliência $\left(M_{R}\right)$ sob condições que simulam o estado físico e o estado de tensões dos materiais sob pavimentos flexíveis sujeitos a cargas de roda. Os níveis de tensões a que são submetidos os corpos-de-prova para determinação do $M_{R}$ são determinados por sua localização na estrutura do pavimento. Amostras de base e sub-base estão sujeitas a diferentes níveis de tensões quando comparado a amostras do subleito.

A Tabela 3.5 apresenta a seqüência de tensões usada para ensaio de materiais de subleito e a Tabela 3.6 apresenta a seqüência de tensões usada para ensaio de materiais de base e sub-base, ambas as seqüências definidas pela AASHTO Designation: T 307-99

A forma de carregamento usada é triangular, com período de carga de 0,1 $\mathrm{s}$, e $0,9 \mathrm{~s}$ de repouso, ou seja, uma freqüência de $1 \mathrm{~Hz}$.

Tabela 3.5: Seqüência de ensaio para subleito segundo a AASHTO T 307-99

\begin{tabular}{cccccc}
\hline Seqüência & $\begin{array}{c}\text { Tensão } \\
\text { confinante } \\
\sigma_{3}(\mathbf{k P a})\end{array}$ & $\begin{array}{c}\text { Tensão } \\
\text { máxima } \\
\mathbf{n}^{\mathbf{0}} \mathbf{( k P a )}\end{array}$ & $\begin{array}{c}\text { Tensão } \\
\text { de contato } \\
\sigma_{\mathbf{c}}(\mathbf{k P a})\end{array}$ & $\begin{array}{c}\text { Tensão } \\
\text { desvio } \\
\sigma_{\mathbf{d}} \mathbf{( k P a )}\end{array}$ & $\begin{array}{c}\text { Número de } \\
\text { aplicações } \\
\text { de carga }\end{array}$ \\
\hline 0 & 41,4 & 27,6 & 2,8 & 24,8 & $500-1000$ \\
\hline 1 & 41,4 & 13,8 & 1,4 & 12,4 & 100 \\
2 & 41,4 & 27,6 & 2,8 & 24,8 & 100 \\
3 & 41,4 & 41,4 & 4,1 & 37,3 & 100 \\
4 & 41,4 & 55,2 & 5,5 & 49,7 & 100 \\
5 & 41,4 & 68,9 & 6,9 & 62,0 & 100 \\
\hline 6 & 27,6 & 13,8 & 1,4 & 12,4 & 100 \\
7 & 27,6 & 27,6 & 2,8 & 24,8 & 100 \\
8 & 27,6 & 41,4 & 4,1 & 37,3 & 100 \\
9 & 27,6 & 55,2 & 5,5 & 49,7 & 100 \\
10 & 27,6 & 68,9 & 6,9 & 62,0 & 100 \\
\hline 11 & 13,8 & 13,8 & 1,4 & 12,4 & 100 \\
12 & 13,8 & 27,6 & 2,8 & 24,8 & 100 \\
13 & 13,8 & 41,4 & 4,1 & 37,3 & 100 \\
14 & 13,8 & 55,2 & 5,5 & 49,7 & 100 \\
15 & 13,8 & 68,9 & 6,9 & 62,0 & 100 \\
\hline
\end{tabular}


Tabela 3.6: Seqüência de ensaio para base/sub-base segundo a AASHTO T 307-99

\begin{tabular}{|c|c|c|c|c|c|}
\hline $\begin{array}{c}\text { Seqüência } \\
n^{\circ}\end{array}$ & $\begin{array}{c}\text { Tensão } \\
\text { confinante } \\
\sigma_{3}(\mathrm{kPa}) \\
\end{array}$ & $\begin{array}{c}\text { Tensão } \\
\text { máxima } \\
\sigma_{\mathrm{a}}(\mathrm{kPa}) \\
\end{array}$ & $\begin{array}{c}\text { Tensão } \\
\text { de contato } \\
\sigma_{c}(\mathrm{kPa}) \\
\end{array}$ & $\begin{array}{c}\text { Tensão } \\
\text { desvio } \\
\sigma_{d}(\mathrm{kPa}) \\
\end{array}$ & $\begin{array}{c}\text { Número de } \\
\text { aplicações } \\
\text { de carga }\end{array}$ \\
\hline 0 & 103,4 & 103,4 & 10,3 & 93,1 & $500-1000$ \\
\hline 1 & 20,7 & 20,7 & 2,1 & 18,6 & 100 \\
\hline 2 & 20,7 & 41,4 & 4,1 & 37,3 & 100 \\
\hline 3 & 20,7 & 62,1 & 6,2 & 55,9 & 100 \\
\hline 4 & 34,5 & 34,5 & 3,5 & 31,0 & 100 \\
\hline 5 & 34,5 & 68,9 & 6,9 & 62,0 & 100 \\
\hline 6 & 34,5 & 103,4 & 10,3 & 93,1 & 100 \\
\hline 7 & 68,9 & 68,9 & 6,9 & 62,2 & 100 \\
\hline 8 & 68,9 & 137,9 & 13,8 & 124,1 & 100 \\
\hline 9 & 68,9 & 206,8 & 20,7 & 186,1 & 100 \\
\hline 10 & 103,4 & 68,9 & 6,9 & 62,0 & 100 \\
\hline 11 & 103,4 & 103,4 & 10,3 & 93,1 & 100 \\
\hline 12 & 103,4 & 206,8 & 20,7 & 196,1 & 100 \\
\hline 13 & 137,9 & 103,4 & 10,3 & 93,1 & 100 \\
\hline 14 & 137,9 & 137,9 & 13,8 & 124,1 & 100 \\
\hline 15 & 137,9 & 275,8 & 27,6 & 248,2 & 100 \\
\hline
\end{tabular}

Conforme citado anteriormente, nesta pesquisa estuda-se a influência da variação de umidade no módulo de resiliência de solos de subleito de rodovias. Assim, cada corpo-de-prova ensaiado foi submetido à seqüência de ensaio descrita na Tabela 3.5, originalmente definida pela norma AASHTO T307-99 para solos de subleito.

Para cada um dos níveis de tensão da seqüência de ensaio considerada são armazenadas as informações de todos os ciclos de carregamento, entretanto, apenas os últimos cinco ciclos são considerados nos cálculos. A aquisição de dados é feita por meio de um programa desenvolvido no Departamento de Transportes, pelo Prof. Dr. Glauco Túlio Pessa Fabbri, em plataforma LabView. A Figura 3.9 apresenta a tela fornecida pelo programa.

Este programa permite a leitura de quatro canais individualmente onde são adquiridas informações sobre o deslocamento (canais 3 e 2), carga cíclica (canal 1) e pressão de confinamento (canal 0 ). 


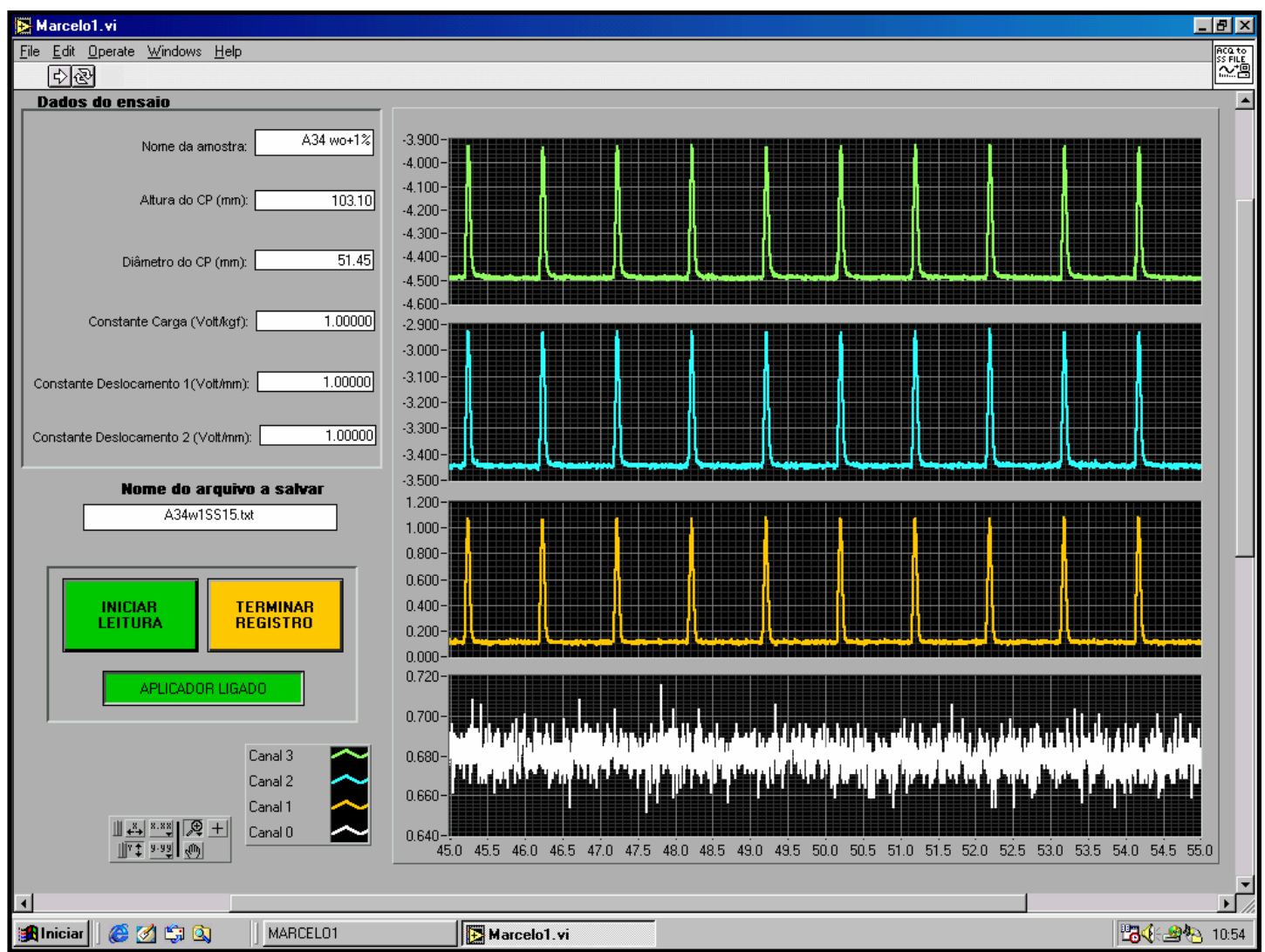

Figura 3.9: Tela principal do programa de aquisição de dados do ensaio triaxial cíclico

Dessa forma é possível determinar a carga cíclica e a pressão confinante efetivamente aplicada em cada ciclo de carregamento e os deslocamentos resultantes. O deslocamento resiliente de cada ciclo é obtido pela média dos deslocamentos registrados nos dois LVDTs. A média dos deslocamentos resilientes dos últimos cinco ciclos define o valor adotado para o cálculo da deformação resiliente $\left(\varepsilon_{R}\right)$. Conforme definido na equação (3.4), o valor da deformação resiliente é dado por:

$$
\varepsilon_{\mathrm{R}}=\frac{\Delta \mathrm{h}}{\mathrm{H}}
$$

onde: $\quad \varepsilon_{\mathrm{R}}$ : deformação resiliente;

$\Delta \mathrm{h}$ : média dos deslocamentos resilientes dos últimos 5 ciclos;

$\mathrm{H}$ : altura inicial do trecho onde estão instalados os LVDTs.

O módulo de resiliência $\left(M_{R}\right)$ é então calculado para cada estado de tensão pela equação (3.5). 


$$
\mathrm{M}_{\mathrm{R}}=\frac{\sigma_{\mathrm{d}}}{\varepsilon_{\mathrm{R}}}
$$

onde: $\quad M_{R}$ : módulo de resiliência;

$\sigma_{\mathrm{d}}$ : tensão desvio aplicada;

$\varepsilon_{\mathrm{R}}$ : deformação resiliente.

Durante a realização dos ensaios verificou-se que em diversas condições de umidade e para grande parte dos solos ensaiados, o dispositivo de medida de deslocamentos usados nos ensaios não são capazes de registrar os deslocamentos produzidos pela aplicação dos níveis mais baixos de tensão desvio, como os níveis 1, 6 e 11 da Tabela 3.5. Assim, decidiu-se que estes níveis de tensão não seriam considerados para a determinação do módulo de resiliência, apesar de terem sido utilizados nos ensaios.

Para os trinta solos selecionados nesta etapa da pesquisa, após a realização dos ensaios triaxiais cíclicos os corpos-de-prova eram divididos em duas partes de tamanhos diferentes, sendo $2 / 3$ usados para determinação da sucção, conforme procedimento descrito no item 3.7.2.5, e 1/3 para medida do teor de umidade após o ensaio.

Os resultados dos ensaios triaxiais cíclicos são apresentados e discutidos no Capítulo 5.

\subsubsection{Ensaios de Compressão Simples}

Os trinta solos selecionados para esta etapa do estudo foram submetidos a ensaios de compressão simples para determinação do módulo tangente inicial $\left(E_{0}\right)$ e da resistência à compressão (RCS). Os corpos-de-prova foram compactados conforme descrito no item 3.7.2.1.

\subsection{Equipamento}

Para a realização destes ensaios foi usada uma prensa convencional de deformação controlada, utilizada para a execução de ensaios de CBR, dotada de 
um sistema automático de aquisição de dados (vide Figura 3.10). Adotou-se uma velocidade de deslocamento de $1,27 \mathrm{~mm} / \mathrm{min}$, idêntica à do ensaio CBR.

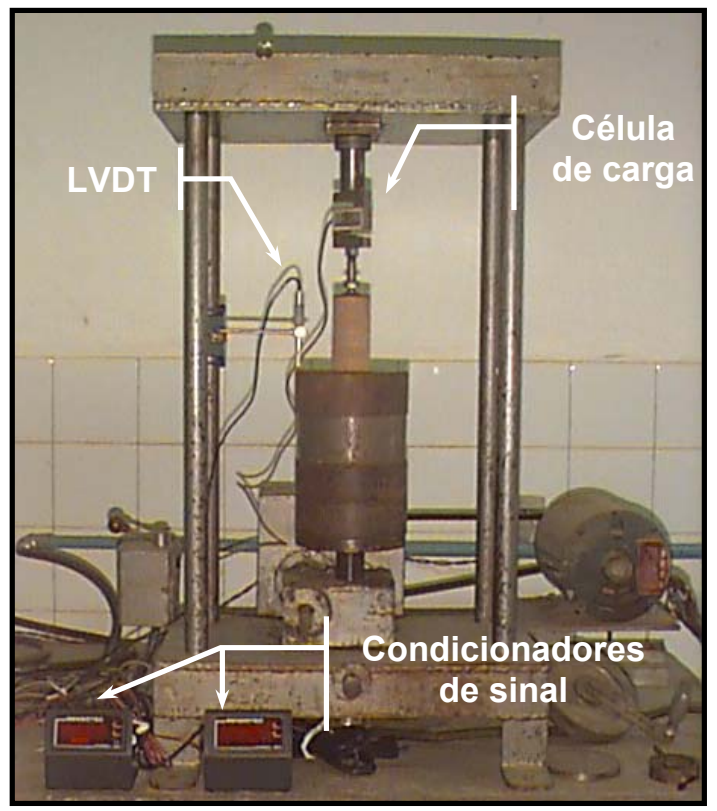

Figura 3.10: Prensa instrumentada para a realização do ensaio de compressão simples

A aquisição de dados é realizada através de um programa desenvolvido pelo Prof. Dr. Glauco Túlio Pessa Fabbri na plataforma LabView, e permite a leitura de dois canais individualmente que transmitem as informações de uma célula de carga e um LVDT (vide Figura 3.11).

A realização dos ensaios de compressão simples permite que sejam determinados o valor do módulo tangente inicial $\left(\mathrm{E}_{0}\right)$ de cada amostra nas diversas condições de umidade consideradas. Segundo Ruiz (1963) o $\mathrm{E}_{0}$, determinado a partir de curvas tensão $x$ deformação, apresenta uma relação próxima com 0 módulo dinâmico. Segundo Drumm et al. (1990), o módulo tangente inicial pode representar bem as condições de determinação do $M_{R}$ em um ensaio dinâmico, já que é determinado no trecho inicial da curva tensão $x$ deformação, que corresponde a pequenos níveis de tensão e deformação.

Para a obtenção do módulo tangente inicial optou-se pelo procedimento proposto por Duncan e Chang (1970) que supõe a curva tensão x deformação uma hipérbole, descrita conforme a equação (3.6). 


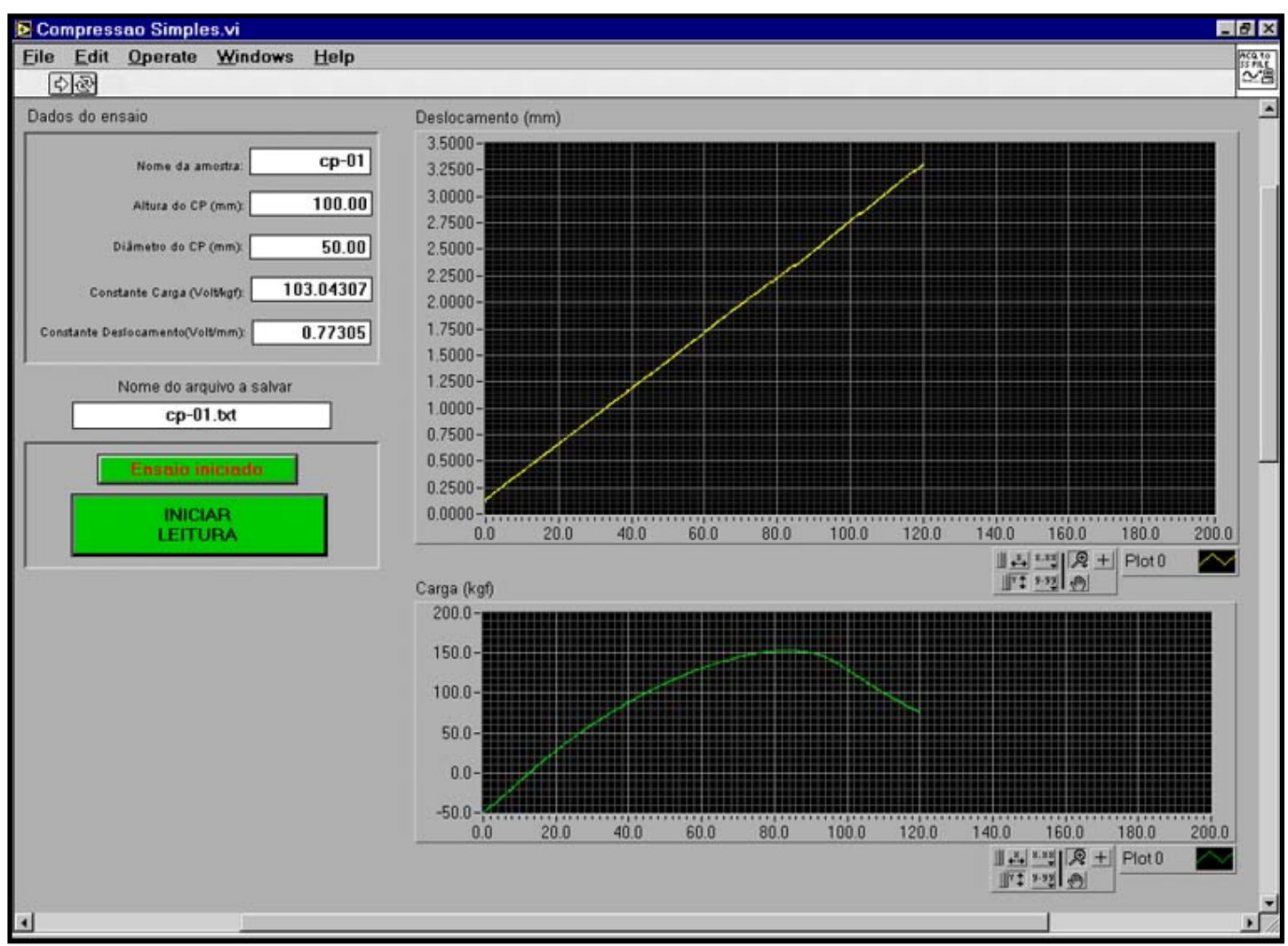

Figura 3.11: Tela principal do programa de aquisição de dados do ensaio de compressão simples

$$
\frac{\varepsilon_{\mathrm{a}}}{\sigma_{\mathrm{a}}}=\mathrm{a}+\mathrm{b} \cdot \varepsilon_{\mathrm{a}}
$$

onde: $\quad \varepsilon_{a}=$ deformação axial

$\sigma_{\mathrm{a}}=$ tensão axial.

Desta forma, os parâmetros a e b desta equação são obtidos a partir da reta que melhor se ajusta aos resultados experimentais e o módulo tangente inicial pode ser calculado pela equação (3.7).

$$
E_{0}=\frac{1}{a}
$$

Para o cálculo do parâmetro "a" adotou-se um intervalo relacionado ao valor máximo de resistência do solo, denominada de resistência à compressão simples (RCS). O intervalo adotado tem o seu limite inferior definido por $15 \%$ a $25 \%$ da RCS e o limite superior definido por $80 \%$ a $90 \%$ da RCS. A Figura 3.12 mostra um exemplo do procedimento utilizado na determinação do módulo tangente inicial. 


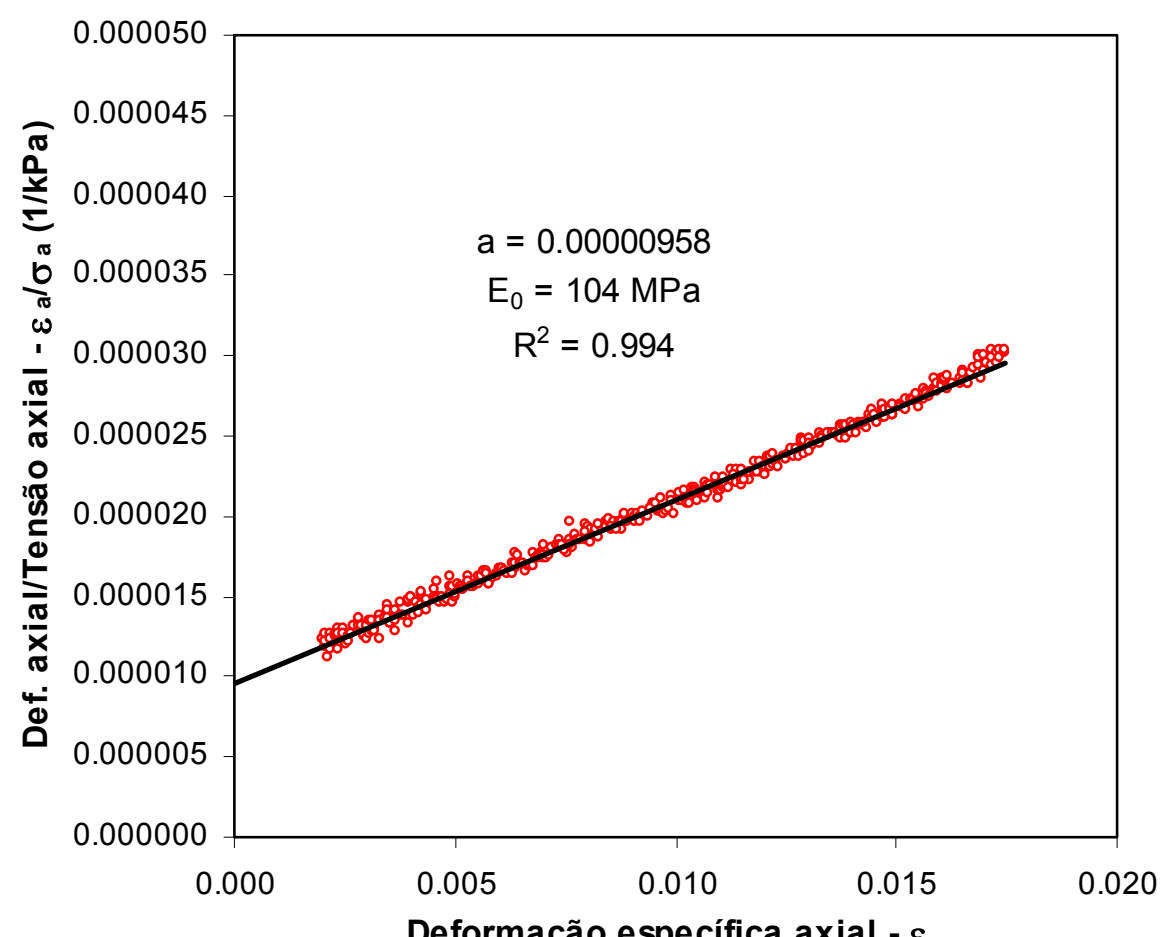

Figura 3.12: Exemplo de determinação do módulo tangente inicial.

Nesta pesquisa, pela simplicidade de cálculo, realizou-se a determinação do $E_{0}$ também manualmente, a partir da análise do trecho inicial da curva tensão versus deformação. Entretanto, pela subjetividade envolvida no processo, estes valores servem apenas para verificação dos resultados determinados pelo processo descrito anteriormente e não são apresentados. Os resultados de Módulo tangente inicial são apresentados e discutidos no Capítulo 5.

\subsubsection{Determinação da sucção no solo}

Segundo Marinho (1998), o método do papel filtro está baseado no princípio de que, um solo, quando colocado em contato com um material poroso que possua capacidade de absorver água, a mesma irá passar do solo para o material poroso até que o equilíbrio seja alcançado. Tendo-se a relação entre sucção e umidade do material poroso (calibração), a sucção do solo pode ser obtida referindo-se à curva de calibração. O estado de equilíbrio fornece a mesma sucção no solo e no material poroso, porém umidades diferentes.

Deve-se utilizar neste método papel filtro "quantitativo" tipo 2, sendo os mais usados Whatman 42 ou Schleicher \& Schuell 589. No caso específico deste 
projeto, adotou-se o papel filtro da marca Whatman 42. A consulta à literatura mostrou que equação de calibração mais utilizada para papéis filtro desta marca, dentre diversas propostas, é a de Chandler et al. (1992). Ressalta-se, porém, a possibilidade de uso das equações recomendadas pela ASTM D5298-92 para o mesmo papel filtro. As equações propostas por Chandler et al. (1992) também podem ser encontradas em Camacho e Bernucci (2000) e Botelho et al. (2000), que as utilizaram para determinação dos valores de sucção matricial. A Tabela 3.7 apresenta estas equações, bem como a calibração propostas pela ASTM, para o papel filtro Whatman 42.

Tabela 3.7: Equações de calibração entre sucção e umidade para o papel filtro Whatman 42

\begin{tabular}{ccc}
\hline Referência & Equação de calibração & Umidade do papel filtro \\
\hline \multirow{2}{*}{ Chandler et al. (1992) } & Sucção $(\mathrm{kPa})=10^{(6,05-2,48 \cdot \log \mathrm{w})}$ & $\mathrm{w}>47 \%$ \\
& Sucção $(\mathrm{kPa})=10^{(4,84-0,0622 \cdot \mathrm{w})}$ & $\mathrm{w} \leq 47 \%$ \\
\hline \multirow{2}{*}{ ASTM D5298-92 (1992) } & Sucção $(\mathrm{kPa})=10^{(2,412-0,0135 \cdot \mathrm{w})}$ & $\mathrm{w}>54 \%$ \\
& Sucção $(\mathrm{kPa})=10^{(5,327-0,0779 \cdot w)}$ & $\mathrm{w} \leq 54 \%$ \\
\hline
\end{tabular}

São descritos, na seqüência, procedimentos seguidos na determinação da sucção em corpos-de-prova compactados.

O papel filtro usado tem diâmetro de $125 \mathrm{~mm}$, o que impossibilita o seu uso diretamente nos corpos-de-prova e dificulta o processo de secagem em cápsulas de alumínio. Optou-se por dividir o papel filtro em quatro partes, o que permitia a sua colocação sobre os corpos-de-prova sem a sobreposição das extremidades e o uso de cápsulas de alumínio de $6 \mathrm{~cm}$ de diâmetro para conter o papel filtro durante os processos de pesagem e secagem em estufa. Destaca-se que a manipulação do papel filtro é realizada com o auxílio de pinças metálicas e com as mãos protegidas por luvas de látex.

A partir do momento em que um corpo-de-prova se encontrava preparado para a realização do ensaio, sobre este era colocado o papel filtro em contato íntimo. O conjunto era então envolvido com três ou mais camadas de filme plástico, colocado em um saco plástico selado e armazenado em uma caixa de isopor por no mínimo 10 dias, período este adotado na pesquisa para o equilíbrio hidráulico entre os elementos. 
Adotou-se como padrão o uso de dois papéis filtro sobrepostos tendo em vista que em algumas situações, após os dez dias, as folhas aderiam aos corposde-prova, inviabilizando a sua retirada para a determinação da sucção. Com os dois papeis filtro, o mais externo era usado na realização das medidas, e se possível, o mais interno para verificação do resultado.

Decorrido o prazo de dez dias, os papéis filtro são retirados do contato com o corpo-de-prova com o uso de pinça e colocados imediatamente (em até no máximo 5 segundos para evitar a evaporação) em cápsulas de alumínio previamente pesadas (tara fria).

O conjunto cápsula + papel filtro úmido é pesado e colocado em estufa para secagem do papel filtro. Após um prazo mínimo de 12 horas, o conjunto cápsula + papel filtro seco é pesado. Pesa-se novamente a cápsula para determinação da tara chamada de quente. Com estas informações é possível calcular a umidade do papel filtro e, conseqüentemente, a determinação da sucção com o uso das equações de calibração.

É importante destacar que todas as pesagens durante o procedimento de determinação da sucção pelo método do papel filtro foram realizadas em balança com capacidade de leitura de 0,0001 g (Balança Gehaka AG-200 - vide Figura 3.13).

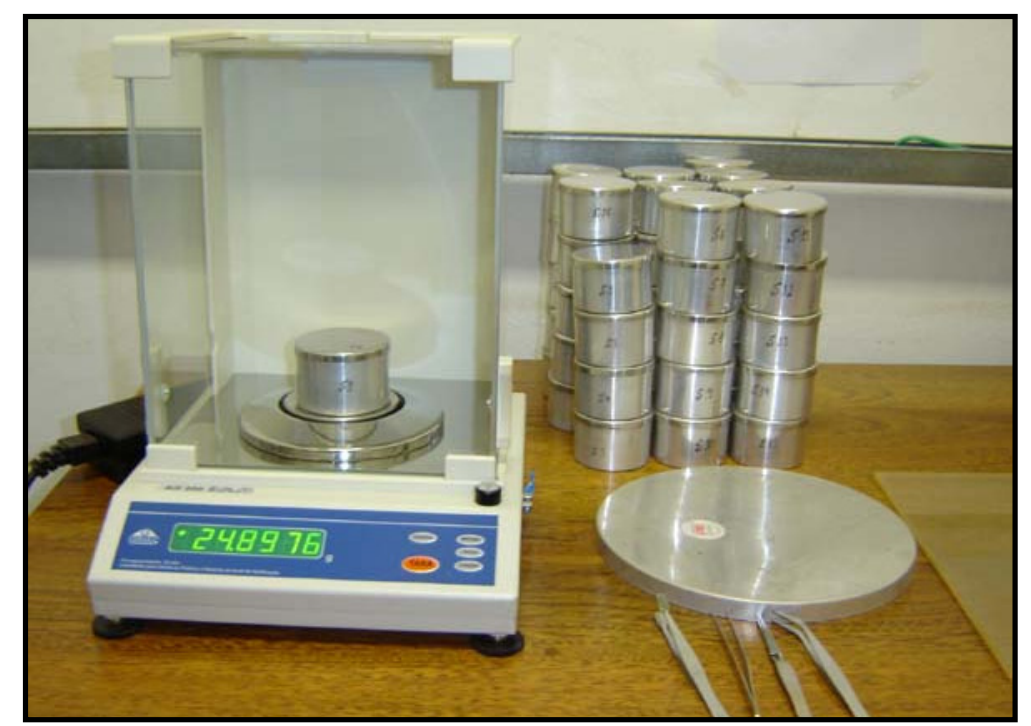

Figura 3.13: Balança com capacidade de leitura de $0,0001 \mathrm{~g}$ usada na determinação da umidade do papel filtro. 


\subsubsection{Análise dos resultados}

Finalmente, apresenta-se, na seqüência, um resumo das análises realizadas a partir dos resultados obtidos nesta pesquisa.

\subsubsection{Identificação do caráter laterítico dos solos}

As primeiras análises estão relacionadas à identificação do caráter lateríticos dos solos coletados. A realização dos ensaios de classificação MCT, microscopia eletrônica de varredura, difração de raios-x e azul de metileno permitiram a determinação do comportamento desses solos com maior confiabilidade. Também, com a determinação em mapa pedológico das classes pedológicas dos solos coletados, foi possível avaliar a existência ou não de uma relação entre esta e os resultados da classificação MCT. Estes análises são apresentadas no Capítulo 4.

\subsubsection{Modelagem dos resultados dos ensaios triaxiais cíclicos em função do estado de tensão}

O valor do módulo de resiliência é muito variável, podendo ser influenciado, entre outros fatores, pelo estado de tensão. Conforme apresentado no Capítulo 2, existem diversos modelos matemáticos propostos que permitem representar o módulo de resiliência em função deste fator. Estes modelos geralmente não são lineares. Dentre os vários modelos conhecidos, foram selecionados cinco que tiveram seu desempenho avaliado a partir do coeficiente de determinação $\left(\mathrm{R}^{2}\right)$. Estes modelos são apresentados na Tabela 3.8

Tabela 3.8: Modelos avaliados na representação do $M_{R}$ em função do estado de tensão

\begin{tabular}{lcc}
\hline & Modelo & Equação \\
\hline$\left(\mathrm{k}-\sigma_{\mathrm{d}}\right)$ & $M_{R}=k_{1} \sigma_{d}^{k_{2}}$ & $(3.8)$ \\
$\left(\mathrm{k}-\sigma_{3}\right)$ & $M_{R}=k_{1} \sigma_{3}^{k_{3}}$ & $(3.9)$ \\
$(\mathrm{k}-\theta)$ & $M_{R}=k_{1} \theta^{k_{3}}$ & $(3.10)$ \\
Composto $\left(\mathrm{k}-\sigma_{\mathrm{d}}-\sigma_{3}\right)$ & $M_{R}=k_{1} \sigma_{d}^{k_{2}} \sigma_{3}^{k_{3}}$ & $(3.11)$ \\
Universal - AASHTO $\left(\mathrm{k}_{1}-\tau_{\text {oct }}-\theta\right)$ & $M_{R}=k_{1} p_{a}\left(\frac{\tau_{\text {oct }}}{p_{a}}+1\right)^{k_{2}}\left(\frac{\theta}{p_{a}}\right)^{k_{3}}$ & $(3.12)$ \\
\hline
\end{tabular}


O modelo denominado $\left(\mathrm{k}-\sigma_{\mathrm{d}}\right)$, que representa a variação do módulo de resiliência com a tensão desvio, é usado, em geral, para solos coesivos. Já os modelos $\left(\mathrm{k}-\sigma_{3}\right)$ e $(\mathrm{k}-\theta)$, que representam a variação do módulo de resiliência, respectivamente, com a tensão confinante e o primeiro invariante de tensão, são, geralmente, usados para solos arenosos, ou granulares. Os demais modelos apresentados $\left(\left(k-\sigma_{d}-\sigma_{3}\right)\right.$ e $\left.\left(k-\tau_{\text {oct }}-\theta\right)\right)$ são ditos universais, pois podem ser aplicados a quaisquer tipos de solos ou materiais não tratados.

Inicialmente, os modelos foram utilizados para descrever a variação do módulo de resiliência com o estado de tensão para os trinta solos selecionados na etapa de estudo do comportamento mecânico frente à variação da umidade. É importante ressaltar que a modelagem foi realizada utilizando-se um programa estatístico, onde foram lançados os valores de módulo de resiliência em MPa e os demais valores (estado tensão considerado em cada modelo) em kPa.

Esta análise permitiu que se escolhesse um modelo único de representação do módulo de resiliência entre aqueles com os maiores valores de $\mathrm{R}^{2}$ para as análises subseqüentes.

Nestas análises avaliou-se a existência de relações entre parâmetros determinados para cada solo e condições de ensaio e suas características físicas, com destaque para gênese, granulometria, limites plásticos e índices físicos.

\subsubsection{Análise da influência da granulometria, da gênese e da variação da umidade no valor do $M_{R}$}

Investigou-se a influência tanto da granulometria quanto da gênese sobre o valor do $M_{R}$ a partir de valores de módulo determinados para duas condições, a saber: o módulo de resiliência típico, que corresponde a uma situação considerada crítica para o subleito; o módulo de resiliência médio, que representa o estado médio de tensão no subleito.

A existência de relações entre o módulo de resiliência e a variação de umidade, analisando-se os solos em conjunto ou em grupos, também foram investigadas. 
3.7.3.4 Relação do módulo de resiliência com os resultados dos ensaios de compressão simples e propriedades físicas dos solos

Verificaram-se a existência de relações matemáticas que permitam relacionar o módulo de resiliência, a partir dos parâmetros $k_{1}, k_{2}$ e $k_{3}$ do modelo composto, com o módulo tangente inicial, determinado a partir dos resultados dos ensaios de compressão simples, para as condições descritas no item 3.7.2.4, as propriedades físicas dos solos. 


\section{Capítulo 4 - Estudo da gênese dos materiais - Identificação do caráter laterítico dos solos}

\subsection{Introdução}

Apresenta-se neste Capítulo um estudo sobre a gênese dos solos objetos da pesquisa, buscando-se, com o auxílio de resultados de ensaios de microscopia eletrônica de varredura (MEV) e difração de raios-x (DRX), a confirmação do caráter laterítico ou não-laterítico de cada material previsto a partir da classificação MCT. De forma complementar, são também analisados resultados de ensaios de azul de metileno. Conforme já destacado, a identificação da gênese dos materiais é de extrema importância para a pesquisa, que tem por objetivo comparar o comportamento mecânico de solos lateríticos e não-lateríticos.

Inicialmente, para o universo preliminar de setenta e duas amostras, analisam-se os resultados da classificação MCT, mostra-se o posicionamento geográfico dos diversos tipos de solos na região de coleta, comparam-se os resultados da classificação MCT e a proposta por Vertamatti (1988), e buscam-se relações entre o comportamento previsto pela MCT e a pedologia dos materiais. Em seguida, para estes mesmos solos, são analisados os resultados dos ensaios de microscopia eletrônica de varredura (MEV) e a compatibilidade dos mesmos com o comportamento dos solos previsto pela classificação MCT. Finalmente, para o conjunto de trinta amostras selecionadas para o estudo do comportamento mecânico dos materiais, são analisados comparativamente os resultados dos ensaios de difração de raios-x e adsorção de azul de metileno com os resultados 
obtidos na etapa anterior do estudo. Os procedimentos adotados para a realização dos ensaios aqui discutidos são apresentados no Capítulo 3. É importante destacar que as observações apresentadas neste capítulo dizem respeito apenas aos solos coletados para a realização desta pesquisa, não podendo ser generalizada para a ocorrência de solos no estado de São Paulo.

\subsection{Resultados da classificação MCT}

A Figura 4.1 mostra o gráfico de classificação MCT com a indicação da posição dos setenta e dois solos do universo preliminar de amostras coletadas. No gráfico, cada solo é identificado e nomeado em função da sua classe MCT e sua classificação granulométrica, conforme discutido no Capítulo 3 , a saber: solos grossos $\left(P_{200} \leq 35 \%\right)$; solos intermediários $\left(35 \%<P_{200} \leq 50 \%\right)$ e, solos finos $\left(P_{200}>\right.$ $50 \%)$.

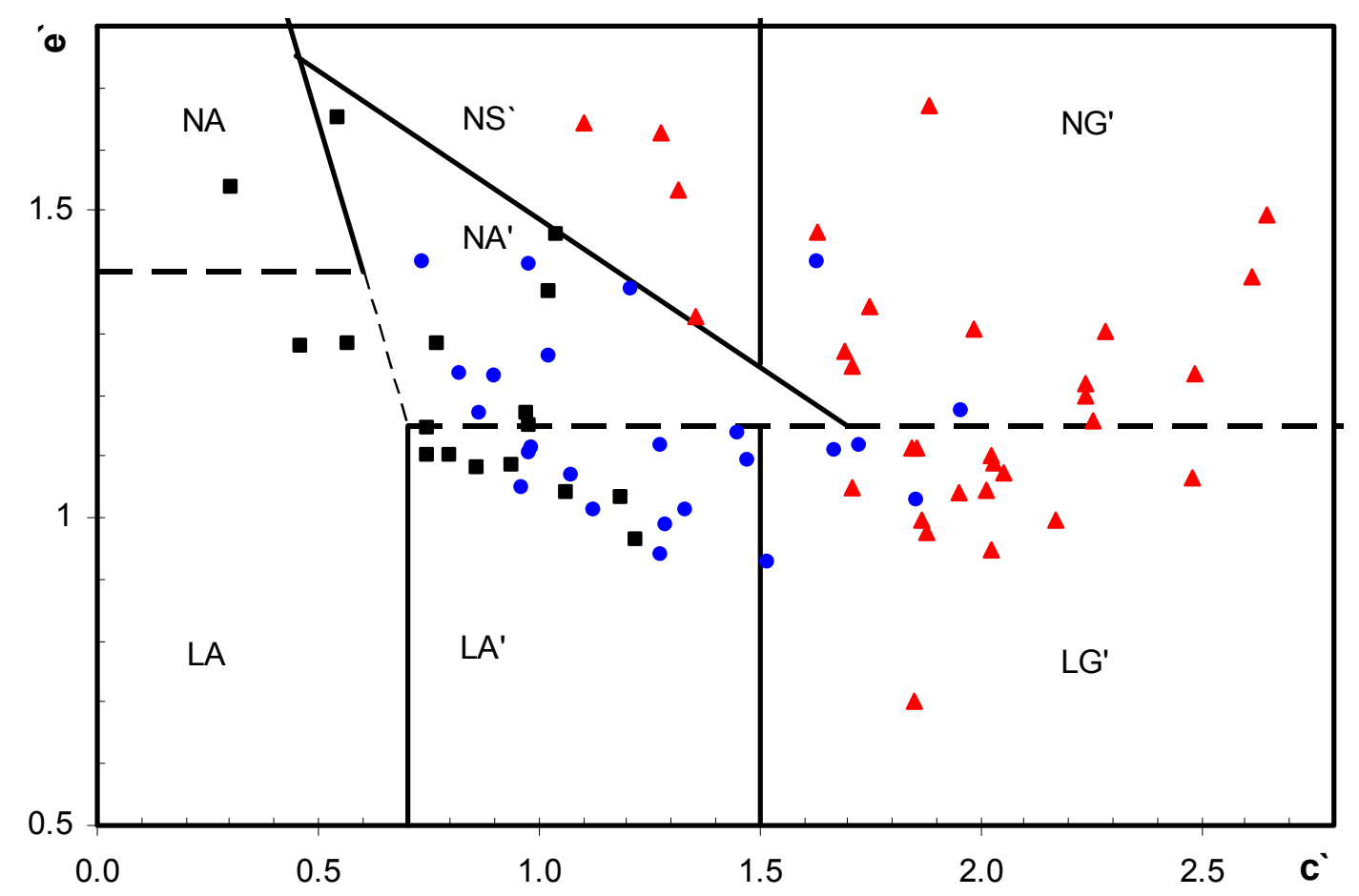

- Solos grossos (\% que passa \#200<35)

- Solos intermediários (35\% < \% que passa \#200<50\%)

• Solos finos (\% que passa \# $200>50 \%$ )

Figura 4.1: Gráfico de classificação MCT com a indicação dos setenta e dois solos coletados. 
A Tabela 4.1 apresenta a quantidade de solos encontrados em cada classe MCT, separados segundo o comportamento laterítico ou não-laterítico. Já a Tabela 4.2 apresenta o mesmo conteúdo, mas separando os solos em função dos limites granulométricos adotados e da respectiva classe MCT.

Tabela 4.1: Distribuição dos solos nas classes MCT.

\begin{tabular}{ccc|ccc}
\hline & Lateríticos & & \multicolumn{3}{c}{ Não-lateríticos } \\
\hline Classe MCT & Quantidade & $\%$ & Classe MCT & Quantidade & $\%$ \\
\hline LA & 2 & 3 & NA & 1 & 1 \\
LA' & 19 & 26 & NA' & 13 & 18 \\
LG' & 18 & 25 & NG' & 15 & 21 \\
& & & NS' & 4 & 6 \\
\hline Total & $\mathbf{3 9}$ & $\mathbf{5 4}$ & Total & $\mathbf{3 3}$ & $\mathbf{4 6}$ \\
\hline
\end{tabular}

Tabela 4.2: Distribuição dos solos em função da faixa granulométrica e classe MCT.

\begin{tabular}{cccc}
\hline Faixa granulométrica & Classe MCT & Quantidade & \% \\
\hline \multirow{3}{*}{ Grossos } & LA & 2 & 3 \\
& NA & 1 & 1 \\
& LA' $^{\prime}$ & 8 & 11 \\
& NA' $^{\prime}$ & 6 & 8 \\
\hline Total do grupo & & $\mathbf{1 7}$ & $\mathbf{2 3}$ \\
\hline \multirow{3}{*}{ Intermediários } & LA' $^{\prime}$ & 11 & 15 \\
& NA' & 7 & 10 \\
& LG' & 4 & 6 \\
& NG' & 2 & 3 \\
\hline Total do grupo & & $\mathbf{2 4}$ & $\mathbf{3 4}$ \\
\hline \multirow{2}{*}{ Finos } & LG' & 14 & 19 \\
& NG' & 13 & 18 \\
\hline Total do grupo & NS' & 4 & 6 \\
\hline Total geral & & $\mathbf{3 1}$ & $\mathbf{4 3}$ \\
\hline
\end{tabular}

Analisando-se a Figura 4.1 e a Tabela 4.1, observa-se que, das setenta e duas amostras coletadas, trinta e nove, ou $54 \%$ do total, são identificados como solos de comportamento laterítico, sendo que, dois ( $3 \%$ do total) são classificados como areias lateríticas (LA), dezenove ( $26 \%$ do total) são classificados como lateríticos arenosos (LA') e dezoito ( $25 \%$ do total) são classificados como lateríticos argilosos (LG'). Os outros 46\% das amostras, ou seja, trinta e três, são identificados como não-lateríticos. Dentre estes, um (1\% do total) é classificado como areia nãolaterítica (NA), treze (18\% do total) são classificados como não-lateríticos arenosos (NA'), quinze ( $21 \%$ do total) são classificados como não-lateríticos argilosos (NG') e quatro (6\% do total) são classificados como não-lateríticos siltosos (NS'). 
Analisando-se em conjunto a Figura 4.1 e a Tabela 4.2, observa-se que todos os solos finos (31 amostras) são classificados nos grupos LG' (14 amostras), NG' (13 amostras) e NS' (4 amostras). Quanto aos solos grossos (17 amostras), estes são classificados nos grupos LA (2 amostras), NA (1 amostra), LA' (8 amostras) e NA' (6 amostras), destacando-se que a maioria (82\%) situa-se nas duas últimas classes enumeradas. Já os solos intermediários (24 amostras) são classificados LG' (4 amostras), NG' (2 amostras), NA' (7 amostras) e LA' (11 amostras), portanto com a maioria $(75 \%)$ situando-se nas duas últimas classes citadas.

A Figura 4.2 mostra o mapa do Estado de São Paulo com a indicação dos locais de coleta, com os solos identificados em função do comportamento laterítico ou não-laterítico previsto pela MCT.

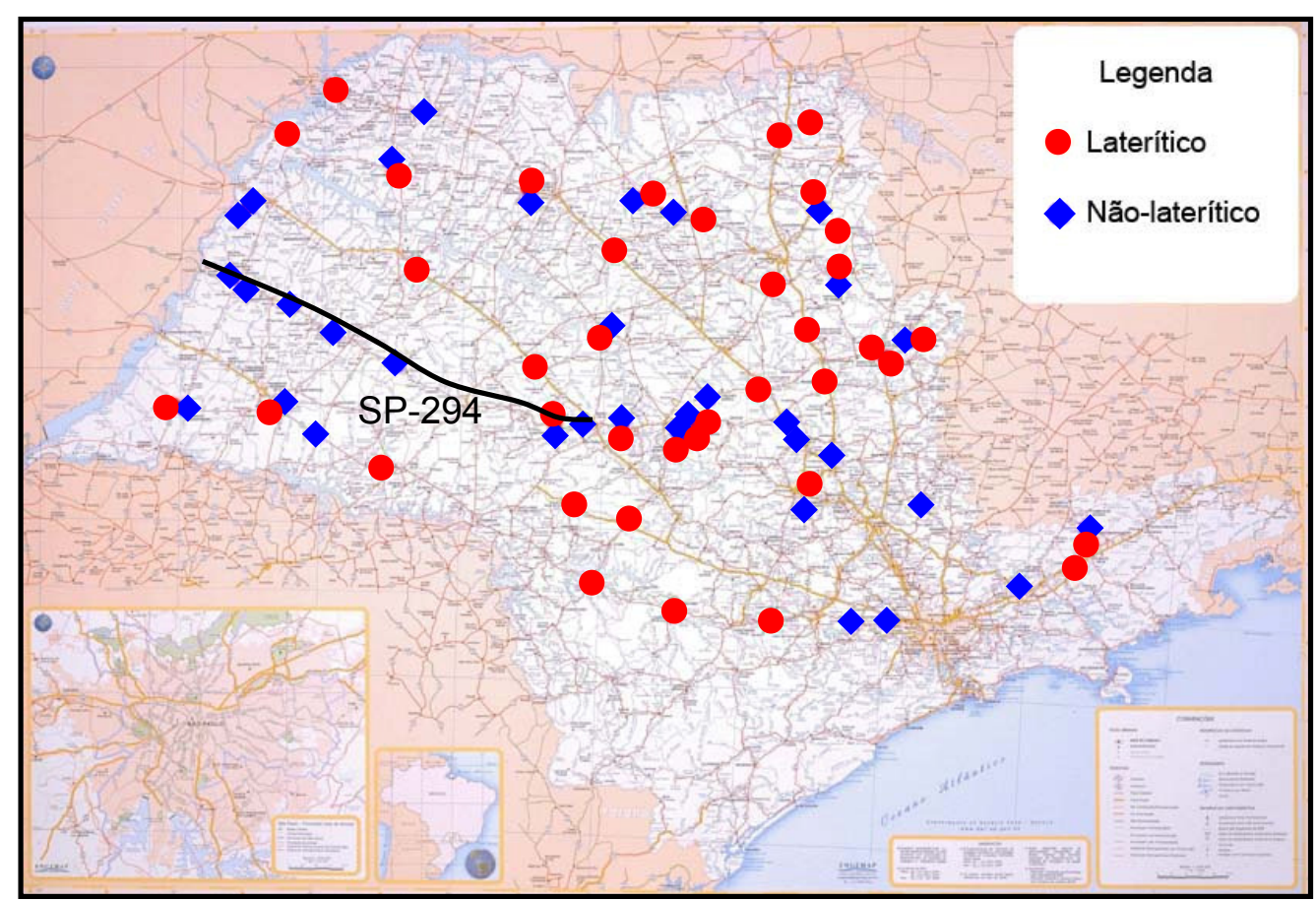

Figura 4.2: Mapa do Estado de São Paulo com indicação dos locais de coleta e a identificação do comportamento laterítico ou não-lateríticos dos solos.

Analisando-se a Figura 4.2, observa-se que os solos encontram-se distribuídos de maneira aproximadamente uniforme na área selecionada para a coleta, independentemente do comportamento laterítico ou não-laterítico determinado pela MCT. Portanto, não se verifica uma predominância de qualquer um dos tipos de solos em qualquer região específica. Uma ressalva deve ser feita para as coletas realizadas ao longo da rodovia SP-294 (Comandante João Ribeiro 
de Barros), região noroeste do estado, onde a grande maioria das amostras obtidas é classificada como sendo de comportamento não-laterítico pela MCT.

A Figura 4.3 mostra o mapa do Estado de São Paulo com a indicação dos locais de coleta dos solos separados em função das faixas granulométricas adotadas nesta pesquisa. De modo a facilitar as análises, este mapa é dividido em quatro regiões, a saber: (I), (II), (III) e (IV). O principal parâmetro considerado na divisão destas regiões é a predominância ou ausência de solos intermediários nas mesmas.

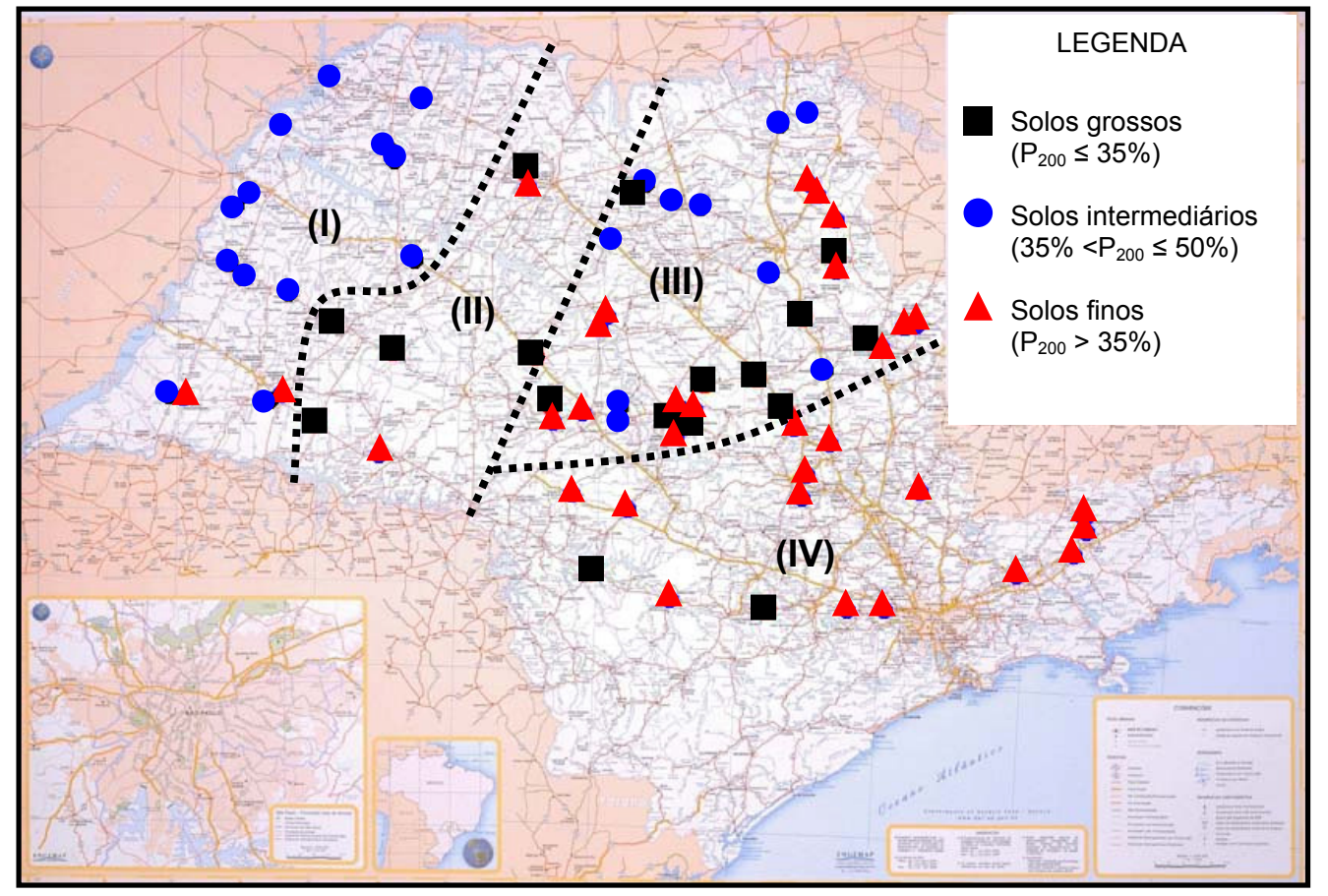

Figura 4.3: Mapa do Estado de São Paulo com indicação dos locais de coleta de solos separados em função das faixas granulométricas adotadas nesta pesquisa.

Analisando-se a Figura 4.3, observa-se que na região (I) existe predominância de solos intermediários. Já nas regiões (II) e (IV), os solos desta faixa granulométrica não são encontrados dentro do universo de amostras coletadas, havendo prevalência de solos grossos e finos, respectivamente. No caso da região (III), observa-se a ocorrência de solos de todas as faixas granulométricas, sem indicativos de predominância de uma ou outra classe.

A Figura 4.4 mostra o mapa do estado de São Paulo com a indicação dos locais de coleta dos solos associados aos grupos da classificação MCT. Conservam-se nesta figura as mesmas regiões consideradas na Figura 4.3. 


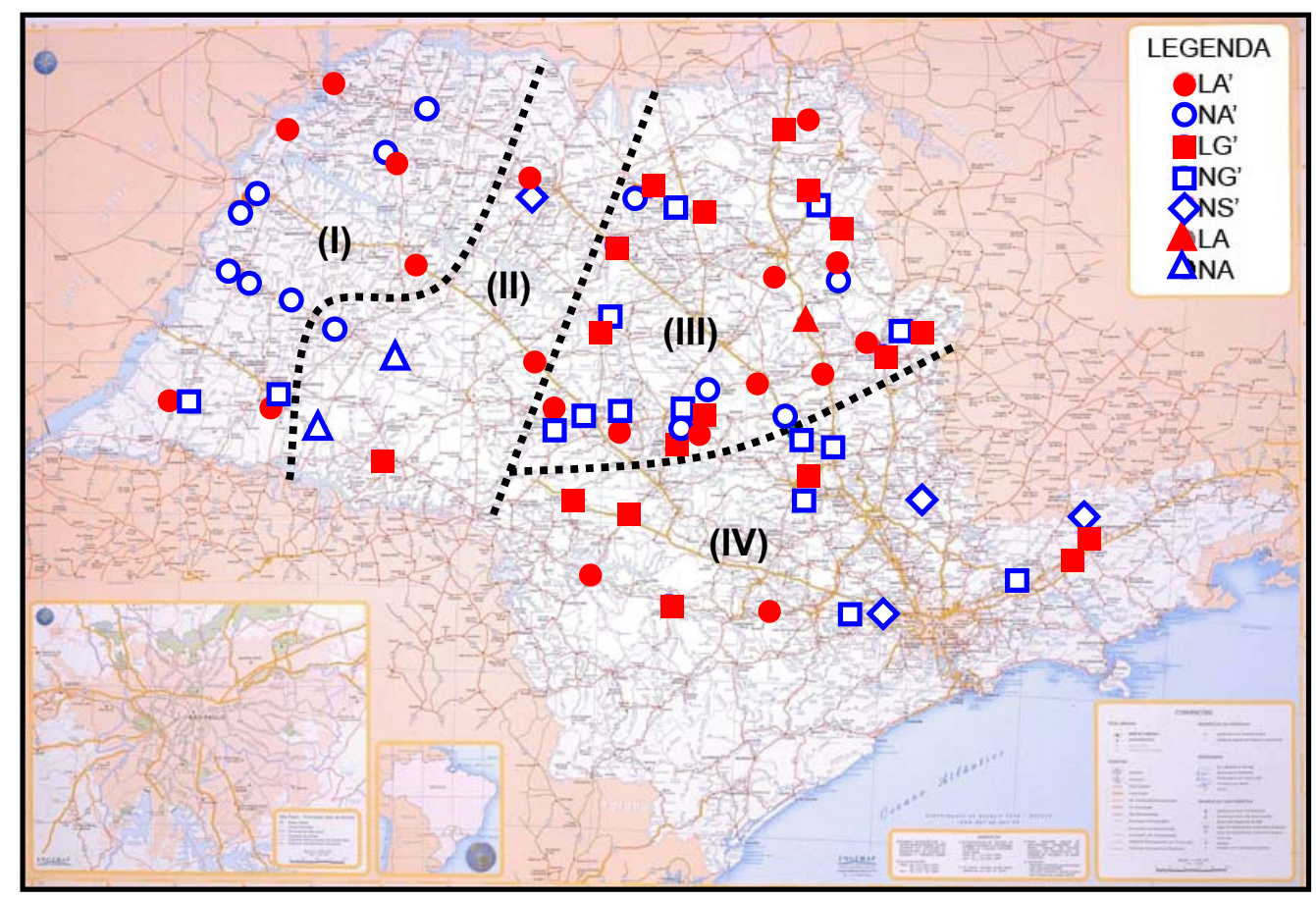

Figura 4.4: Mapa do Estado de São Paulo com os locais de coleta associados aos grupos da classificação MCT.

Analisando-se a Figura 4.4, observa-se na região (I) a predominância de solos classificados como LA' ou NA', correspondendo esta à região de maior ocorrência de solos intermediários, conforme mostrado na Figura 4.3. Este resultado é coerente com as observações anteriores, que mostram a concentração destas classes dentre os solos intermediários (vide Tabela 4.2). Nesta região observam-se aproximadamente $54 \%$ das ocorrências dos solos da classe NA' estudados na pesquisa. As demais amostras desta classe encontram-se nas regiões (II) e (III), não tendo sido coletada esta classe na região (IV). Já os solos da classe LA' foram coletados em todas as regiões, apresentando uma melhor distribuição se comparados aos solos NA'.

Quanto às amostras classificadas como LG' e NG', estas são encontradas principalmente nas regiões (III) e (IV), com raras ocorrências nas regiões (I) e (II). Outro destaque pode ser feito com relação aos solos NS', que se encontram na sua maioria (3/4) na região (IV), região esta de predominância de solos finos (vide Figura 4.3). Dentre os NS', a única amostra fora da referida região encontra-se na região (II), próxima à cidade de São José do Rio Preto. Entretanto, esta amostra posiciona-se, no gráfico de classificação MCT, próximo à linha de transição entre as classes NS' e NA', conforme ilustra a Figura 4.1. 
Ainda na Figura 4.1, pode-se observar uma quantidade grande de solos na mesma situação, ou seja, existe uma concentração de amostras na região próxima aos limites da transição entre os comportamentos laterítico e não-laterítico. Destaca-se ainda que existência de duas únicas amostras NA, coletadas na região (II), e de uma única LA, coletada na região (III), evidenciando que são classes de ocorrência rara no conjunto de solos estudados.

A Figura 4.5 apresenta os solos posicionados no gráfico de classificação MCT-M proposto por Vertamatti (1988). Segundo Vertamatti \& Araújo (2002), os solos lateríticos seriam solos tropicais muito bem desenvolvidos e com alta concentração de ferro e alumínio, enquanto os solos não-lateríticos seriam solos pouco desenvolvidos, mantendo ainda, algumas características da rocha original. Os solos transicionais estariam em um estágio intermediário de evolução entre os lateríticos e os não-lateríticos. A Tabela 4.3 indica a distribuição dos solos em cada uma das classes MCT-M e a porcentagem correspondente em relação ao total coletado.

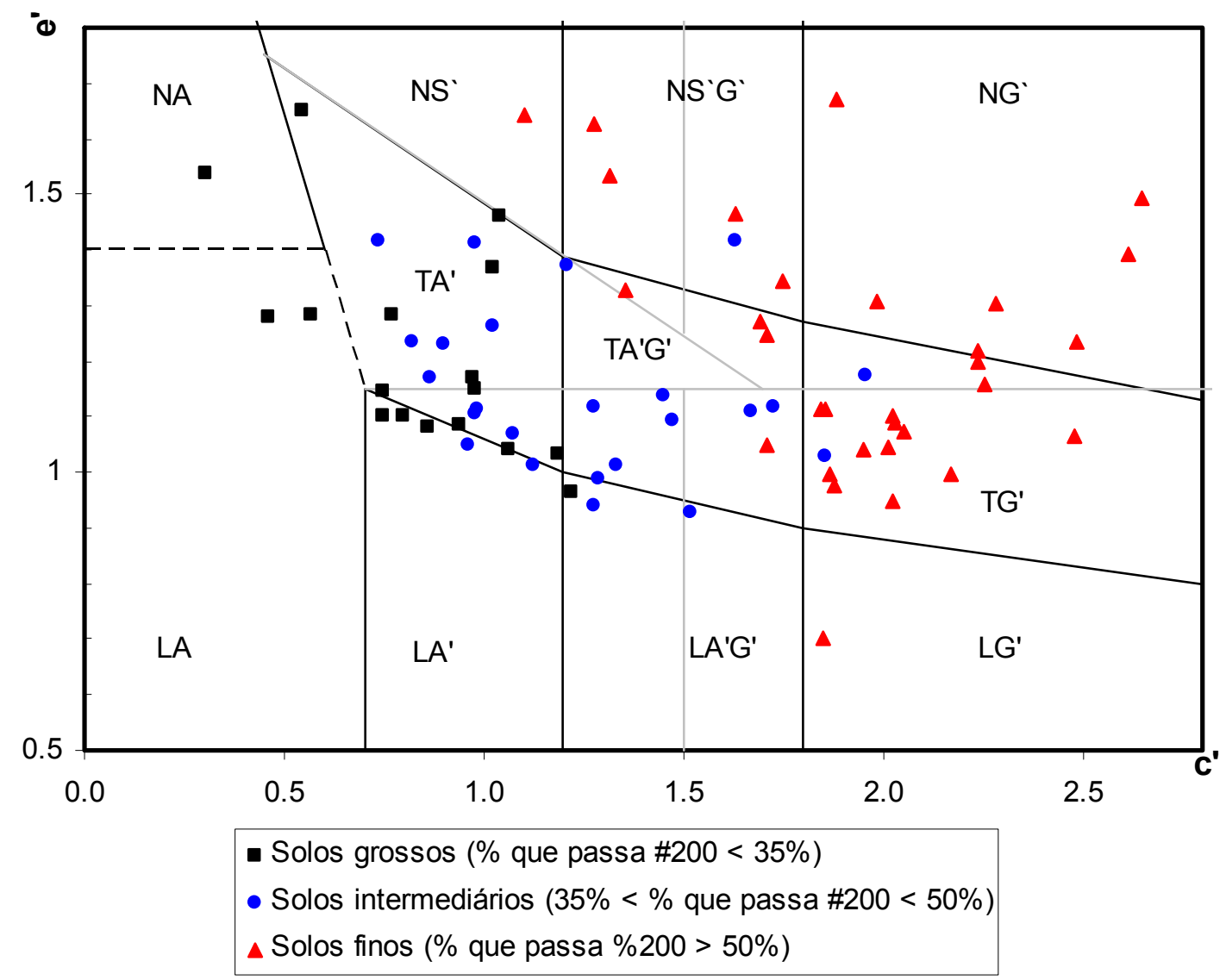

Figura 4.5: Gráfico de classificação MCT-M (Vertamatti, 1988) com a indicação dos setenta e dois solos classificados. 
Tabela 4.3: Distribuição de solos em função do comportamento e da classe MCT-M (Vertamatti, 1988).

\begin{tabular}{ccc|ccc|ccc}
\hline \multicolumn{2}{c|}{ Lateríticos } & \multicolumn{2}{c|}{ Transicionais } & \multicolumn{3}{c}{ Não-lateríticos } \\
\hline Classe MCT-M & $\mathbf{n}^{\circ}$ & $\%$ & Classe MCT-M & $\mathbf{n}^{\circ}$ & $\%$ & Classe MCT-M & $\mathbf{n}^{\circ}$ & $\%$ \\
\hline LA & 2 & 3 & TA' $^{\prime}$ & 18 & 25 & NA & 1 & 1 \\
LA' & 6 & 9 & TA $^{\prime} \mathbf{G}^{\prime}$ & 12 & 17 & NS' & 1 & 1 \\
LA'G' & 3 & 4 & TG' $^{\prime}$ & 16 & 22 & NS'G' & 5 & 7 \\
LG' & 1 & 1 & & & & NG' & 7 & 10 \\
\hline Total & $\mathbf{1 2}$ & $\mathbf{1 7}$ & Total & $\mathbf{4 6}$ & $\mathbf{6 4}$ & Total & $\mathbf{1 4}$ & $\mathbf{1 9}$ \\
\hline
\end{tabular}

Analisando-se a Figura 4.5 e a Tabela 4.3, observa-se que, segundo a proposta de Vertamatti (1988), a maioria das amostras, 46 solos ou $64 \%$ do total, são classificadas como solos transicionais. Quanto aos solos classificados como lateríticos, estes compõem um total de 12 amostras, ou $17 \%$ do total. Já os solos classificados como não-lateríticos são 14 , ou $19 \%$ do total.

Ainda analisando-se a Figura 4.5 e a Tabela 4.3, observa-se que dentre os trinta e nove solos classificados como lateríticos (LA, LA' e LG'), e trinta e três nãolateríticos (NA, NA', NS' e NG') pela MCT, apenas doze entre os primeiros, e quatorze entre os segundos, manteriam o respectivo caráter segundo a MCT-M. Os demais solos que completam os dois grupos, respectivamente vinte e sete e dezenove, seriam classificados como transicionais por esta última classificação.

\subsubsection{Relação entre as classes MCT e a pedologia}

Conforme discutido no Capítulo 3, o planejamento das coletas foi realizado tomando-se como partida o mapa pedológico na escala 1:500.000 apresentado por Oliveira (1999) e publicado pelo Instituto Agronômico de Campinas (IAC) e pela Embrapa, que cobre todo o Estado de São Paulo. Este mapa, segundo Oliveira et al. (1999), foi produzido por compilação, ou seja, a partir de uma base cartográfica já existente. Segundo estes autores, nos mapas compilados, em geral, não há controle de campo, ou se este existe, é reduzido, pressupondo generalizações e conseqüentes perdas de informações contidas nos mapas-base.

Sabe-se que o ideal seria o uso de mapas mais avançados, como os das quadriculas semi-detalhadas com escala 1:100.000 publicados pelo IAC (folhas de Campinas, São Carlos, Araras, Descalvado, Brotas, Jaú, Ribeirão Preto, Piracicaba, Guairá, Assis, Moji - Mirim, respectivamente por Oliveira et al. (1979), Prado et al. 
(1981), Oliveira et al. (1982a), Oliveira et al. (1982b), Almeida et al. (1982a), Almeida et al. (1982b), Oliveira \& Prado (1983), Oliveira et al. (1989), Oliveira et al. (1991), Bognola et al. (1996), Oliveira (1992)). Entretanto, as cartas disponíveis nesta condição contemplam apenas uma pequena parcela do estado, existindo somente onze destes mapas publicados.

As tabelas apresentadas na seqüência mostram para o conjunto preliminar de setenta e duas amostras, a classe MCT e a classe pedológica de cada um dos solos. As Tabelas 4.4 e 4.5 apresentam estes mesmos resultados para os solos agrupados, respectivamente, como lateríticos e não-lateríticos segundo a MCT.

É importante destacar que 19 amostras coletadas abaixo da linha de seixos (vide Anexo A) não foram consideradas análises entre a relação das classes MCT e pedologia. Portanto, excluindo-se estes solos do total de 72 inicialmente considerados, restam 53 para este estudo, dentre os quais 35 de comportamento laterítico e 18 de comportamento não-laterítico.

Tabela 4.4: Classificação pedológica dos solos classificados como de comportamento laterítico pela MCT.

\begin{tabular}{ccc|ccc}
\hline \multirow{2}{*}{ Amostra } & \multicolumn{2}{c|}{ Classe } & \multirow{2}{*}{ Amostra } & \multicolumn{2}{c}{ Classe } \\
\cline { 2 - 3 } \cline { 5 - 6 } & pedológica & MCT & & pedológica & MCT \\
\hline 30 & LV & LG' & 40 & LR & LA' $^{\prime}$ \\
41 & LV & LG' & 11 & LV & LA' $^{\prime}$ \\
48 & LV & LG' & 26 & LV & LA' $^{\prime}$ \\
67 & LV & LG' & 52 & LV & LA' $^{\prime}$ \\
69 & LV & LG' & 63 & LV & LA' \\
71 & LV & LG' & 66 & LV & LA' \\
21 & LVA & LG' & 88 & LV & LA' \\
37 & LVA & LG' & 68 & LVA & LA' \\
73 & LVA & LG' & 76 & LVA & LA' \\
91 & LVA & LG' & 72 & LVA & LA' \\
25 & NV & LG' & 23 & PVA & LA' \\
35 & NV & LG' & 28 & PVA & LA' \\
49 & NV & LG' & 46 & PVA & LA' \\
70 & NV & LG' & 54 & PVA & LA' \\
31 & PVA & LG' & 60 & PVA & LA' \\
44 & PVA & LG' & 79 & PVA & LA' \\
\cline { 2 - 2 } 57 & PVA & LG' & 50 & LV & LA \\
& & & & PVA & LA \\
\hline
\end{tabular}


Tabela 4.5: Classificação pedológica dos solos classificados como de comportamento não-laterítico pela MCT.

\begin{tabular}{|c|c|c|c|c|c|}
\hline \multirow{2}{*}{ Amostra } & \multicolumn{2}{|l|}{ Classe } & \multirow{2}{*}{ Amostra } & \multicolumn{2}{|l|}{ Classe } \\
\hline & pedológica & MCT & & pedológica & MCT \\
\hline 42 & LV & NG' & 55 & GX & $\mathrm{NA}^{\prime}$ \\
\hline 87 & LV & NG' & 84 & LV & $N^{\prime}$ \\
\hline 39 & PVA & NG' & 56 & PVA & $\mathrm{NA}^{\prime}$ \\
\hline 65 & PVA & NG' & 58 & PVA & NA' \\
\hline 86 & PVA & NG' & 62 & PVA & $\mathrm{NA}^{\prime}$ \\
\hline 34 & $\mathrm{RL}$ & NG' & 81 & PVA & NA' \\
\hline 36 & $C X$ & NS' & 82 & PVA & $N^{\prime}$ \\
\hline 64 & PVA & NS' & 83 & PVA & $\mathrm{NA}^{\prime}$ \\
\hline 89 & $\mathrm{RQ}$ & NA & 85 & PVA & NA' \\
\hline
\end{tabular}

Analisando-se a Tabela 4.4, observa-se que as amostras da classe LG' são classificadas como latossolos vermelhos (LV), latossolos vermelho-amarelos (LVA), nitossolos vermelhos (NV) e argissolos vermelho-amarelos (PVA), contando estas classes com, respectivamente, seis, quatro, quatro e três solos. A mesma tabela mostra que as amostras LA' são classificadas como latossolos roxos (LR), vermelhos (LV), vermelho-amarelos (LVA) e argissolos vermelho-amarelos (PVA), contado as citadas classes com, respectivamente, um, seis, três e seis solos. No caso das duas amostras LA, estas são classificadas como latossolo vermelho (LV) e argissolo vermelho-amarelo (PVA).

Analisando-se a Tabela 4.5, observa-se que as amostras NG' são classificadas como latossolos vermelhos (LV), argissolos vermelho-amarelos (PVA) e neossolos litólicos (RL), contando cada uma das referidas classes com, respectivamente, dois, três e um solo. A mesma tabela mostra que as amostras NA' são classificadas como gleissolos háplicos (GX), latossolos vermelhos (LV) e argissolos vermelho-amarelos (PVA), contando cada uma das classes citadas com, respectivamente, um, um e sete solos. No caso das amostras NS', a tabela também mostra que estes são classificados como cambissolos háplicos (CX) e argissolos vermelho-amarelos (PVA), contando cada uma destas classes com um solo. A única amostra NA coletada é classificada como neossolo quartzarênico (RQ).

Para a conclusão desta análise, foi elaborada a Tabela 4.6 onde se apresentam a quantidade de solos em cada classe pedológica e a respectiva 
porcentagem com relação ao comportamento laterítico ou não-laterítico previsto pela classificação MCT.

Tabela 4.6: Número de solos por classe pedológica em função do comportamento laterítico ou não-laterítico

\begin{tabular}{lcc|lcc}
\hline \multicolumn{1}{c|}{ Lateríticos (MCT) } & & \multicolumn{3}{c}{ Não-lateríticos (MCT) } \\
\hline \multicolumn{1}{c}{ Classe pedológica } & $\mathrm{n}^{\circ}$ & $\%$ & \multicolumn{1}{|c}{ Classe pedológica } & $\mathrm{n}^{\circ}$ & $\%$ \\
\hline Latossolos vermelhos (LV) & 13 & 37 & Latossolos vermelhos (LV) & 3 & 16 \\
Latossolos vermelho-amarelos (LVA) & 7 & 20 & Argissolos vermelho-amarelos (PVA) & 11 & 60 \\
Latossolos roxos (LR) & 1 & 3 & Cambissolos háplicos (CX) & 1 & 6 \\
Nitossolos vermelhos (NV) & 4 & 11 & lleissolos háplicos (GX) & 1 & 6 \\
Argissolos vermelho-amarelos (PVA) & 10 & 29 & Neossolos litólicos (RL) & 1 & 6 \\
& & & Neossolos quartzarênicos (RQ) & 1 & 6 \\
\hline \multicolumn{1}{c|}{ Total } & 35 & 100 & & 18 & 100 \\
\hline
\end{tabular}

Analisando-se a Tabela 4.6, observa-se que os solos de comportamento laterítico pertencem a cinco classes, ou subordens, sendo que $60 \%$ são latossolos, sejam eles vermelhos (LV), vermelho-amarelos (LVA) ou roxos (LR). Dentre estes, $37 \%$ são LV, $20 \%$ são LVA e $3 \%$ são LR. Outra grande classe são os argissolos vermelho-amarelos com $29 \%$ das ocorrências. A última subordem identificada para os solos lateríticos é a NV, com $11 \%$ das ocorrências. Estas relações são coerentes com o exposto por Nogami \& Villibor (1995). Os autores descrevem que os solos de comportamento laterítico são constituídos, do ponto de vista pedológico, pelo horizonte $\mathrm{B}$ dos grandes grupos pedológicos conhecidos como latossolos, argissolos e terras roxas estruturadas.

Ainda na Tabela 4.6, observa-se que para os solos não-lateríticos, a classe PVA é a de maior ocorrência, com $60 \%$ das observações. Os latossolos vermelhos representam 16\% das ocorrências. As demais classes, CX, GX, RL e RQ, dividemse igualmente, em termos de ocorrência, dentre os solos não-lateríticos, com $6 \%$ cada. Segundo Godoy et al. (2000), os latossolos roxos e vermelhos apresentam o comportamento laterítico e os latossolos vermelho-amarelos e argissolos podendo ou não apresentar este mesmo comportamento.

Nogami \& Villibor (2003) também destacam que os argissolos são predominantemente pertencentes à classe laterítica, mas exibindo, freqüentemente, um menor grau de laterização dado pelo coeficiente e', podendo, portanto, às vezes pertencer à classe não-laterítica. Pelo exposto anteriormente, não se esperava que 
os solos não-lateríticos fossem classificados como latossolos vermelhos (LV), as demais classes podem apresentar a ocorrência de solos deste tipo. É importante destacar que as classes pedológicas foram determinadas com o auxílio de um mapa pedológico de escala 1:500.000, conforme citado anteriormente, e que poderia conduzir a erros na classificação pela escala inadequada do mapa. Associado a este fato, a não homogeneidade entre as profundidades de coleta também poderiam conduzir a interpretações equivocadas, já que estas foram realizadas em taludes de corte em diversas profundidades.

\subsection{Ensaio de microscopia eletrônica de varredura (MEV)}

As setenta e duas amostras coletadas foram submetidas a ensaios de microscopia eletrônica de varredura com o intuito de identificar padrões de imagem que pudessem distinguir os solos segundo a sua gênese laterítica ou não-laterítica. Conforme discutido no Capítulo 3, para cada uma destas amostras obtiveram-se duas imagens, com aumentos de 3.000 vezes e 10.000 vezes, conforme apresentado no Anexo D.

Segundo Nogami \& Villibor (1995), os solos lateríticos caracterizam-se por possuírem a sua fração argila constituída pelo argilomineral caulinita. Estes ainda contêm elevada porcentagem de óxidos e hidróxidos de ferro e de alumínio que recobrem a caulinita conferindo ao conjunto um aspecto "cimentado". No caso dos solos não-lateríticos, os argilominerais e, eventualmente, outros minerais presentes não se apresentam recobertos por óxidos e hidróxidos de $\mathrm{Fe}$ e $\mathrm{Al}$, como no caso dos solos lateríticos. Os contornos dos argilominerais que os constituem podem ser distinguidos com nitidez nas imagens obtidas na microscopia eletrônica por varredura.

Seguindo estas premissas, as imagens obtidas foram analisadas buscandose identificar padrões condizentes com os apresentados por Nogami \& Villibor (1995), e que permitiriam caracterizar a gênese laterítica e não-laterítica dos solos. Ou seja, para os solos lateríticos espera-se encontrar imagens com um aspecto cimentado, e, para os solos não-lateríticos, imagens em que seja possível a identificação do contorno dos argilominerais constituintes da fração fina, ou ainda, 
uma imagem distinta do aspecto cimentado dos solos lateríticos. Identificados os aspectos destacados anteriormente, o resultado obtido é comparado com a indicação fornecida pela classificação MCT, podendo ou não confirmá-la. As Figuras 4.6 e 4.7 mostram respectivamente, exemplos de solos que apresentam padrões típicos de materiais que passaram, ou não, pelo processo de laterização. Estas imagens foram destacadas do Anexo D.

A Tabela 4.7 mostra um resumo das relações entre as indicações fornecidas a partir dos ensaios MEV e a classificação MCT para os solos coletados, apresentando o número de concordâncias e de discordâncias observadas na comparação entre as indicações dos ensaios, separadas em função da classe MCT. Os resultados para cada um dos solos são apresentados no Anexo H.

Tabela 4.7: Número de concordâncias e discordâncias observadas na comparação ente os resultados dos ensaios de MEV e classificação MCT.

\begin{tabular}{cccc|cccc}
\hline \multicolumn{3}{c|}{ Laterítico (MCT) $^{-}$} & \multicolumn{4}{c}{ Não-laterítico (MCT) } \\
\hline Classe MCT & Total & Concorda & Discorda & Classe MCT & Total & Concorda & Discorda \\
\hline LA & 2 & 2 & 0 & NA & 1 & 0 & 1 \\
LA' & 19 & 19 & 0 & NA' & 13 & 6 & 7 \\
LG' & 18 & 18 & 0 & NG' & 15 & 11 & 4 \\
& & & 0 & NS' & 4 & 2 & 2 \\
\hline Total & $\mathbf{3 9}$ & $\mathbf{3 9}$ & $\mathbf{0}$ & Total & $\mathbf{3 3}$ & $\mathbf{1 9}$ & $\mathbf{1 4}$ \\
\hline
\end{tabular}

Analisando-se a Tabela 4.7, observa-se que, para todas as amostras classificadas como lateríticas pela MCT, foram encontrados padrões de imagem que indicam a presença de cimentação entre suas partículas constituintes, característica esta marcante dos solos lateríticos.

Ainda na Tabela 4.7, observa-se, para os solos não-lateríticos, a existência de discordâncias entre o comportamento indicado pela classificação MCT e os padrões de imagens obtidos. Do total de solos assim classificados, em aproximadamente $42 \%$ dos casos, ou 14 amostras, foram verificadas divergências entre os resultados. Neste caso, os padrões encontrados nas imagens são bastante variáveis, tendo sido observado desde o contorno dos argilominerais até a presença de cimentação em alguns solos. Destaca-se que a maior parte destes casos está relacionada a solos classificados como NA', dentre os quais aproximadamente $50 \%$ (ou sete amostras) apresentaram esta inconsistência. 

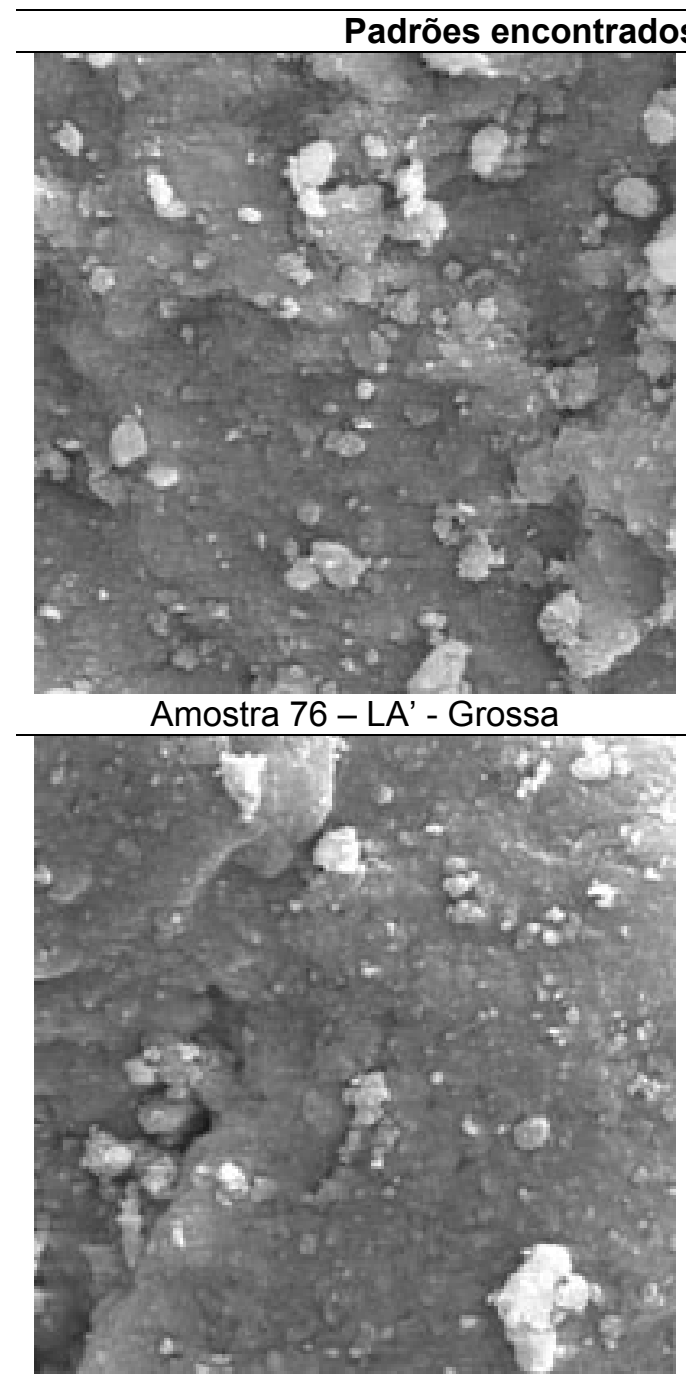

Amostra 26 - LA' - Intermediária
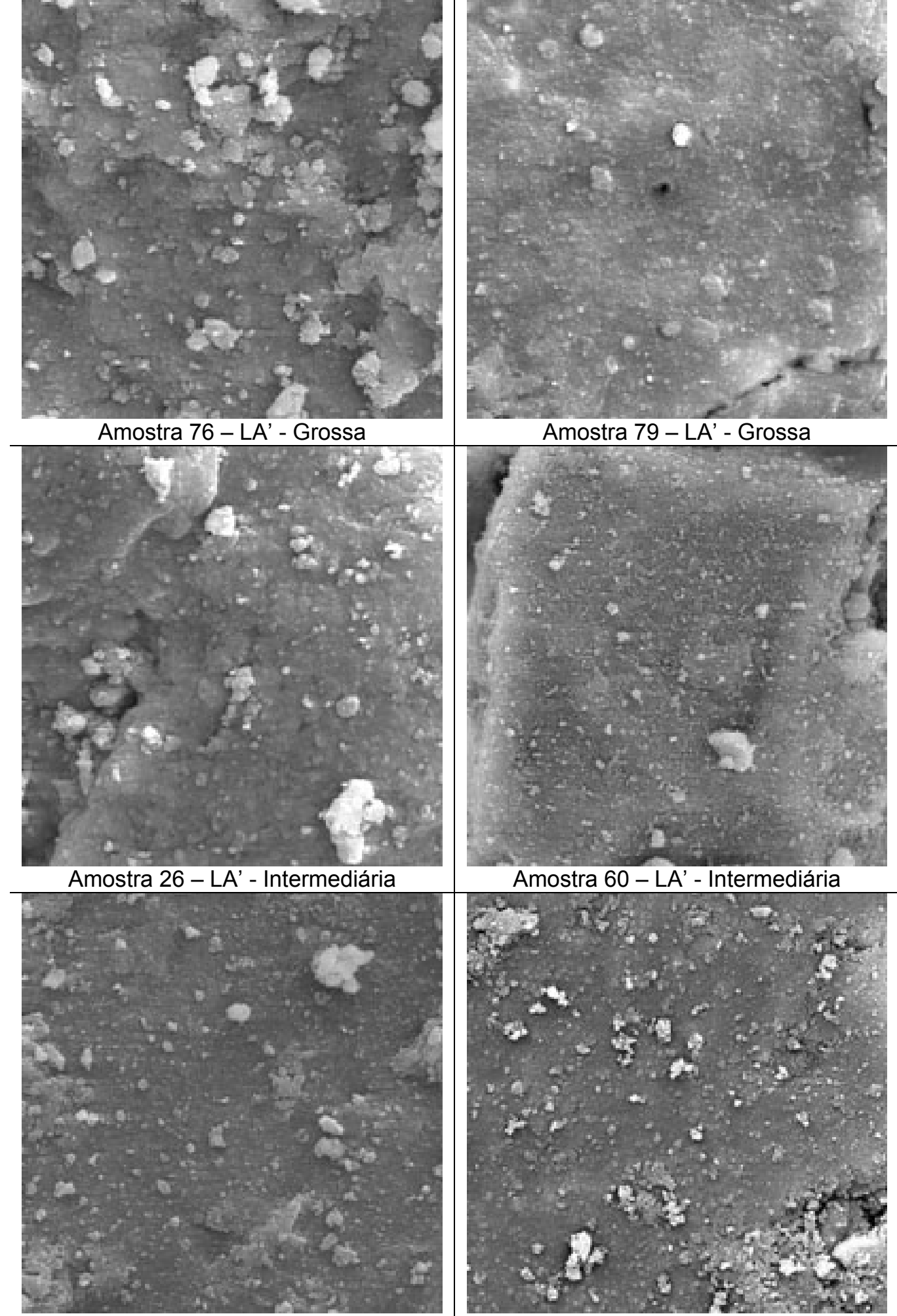

Amostra 60 - LA' - Intermediária

Amostra 70 - LG' - Fina

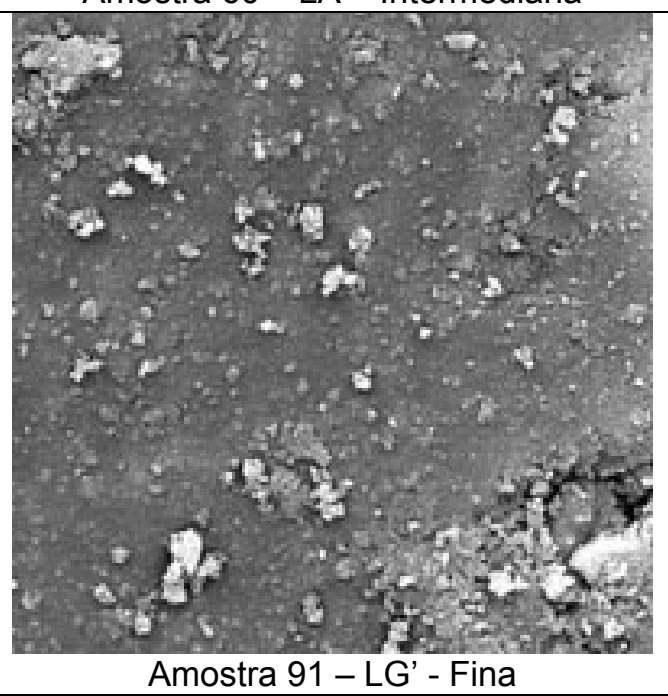

Figura 4.6: Padrões de imagens indicativos de solos de lateríticos (aumento 3.000x) 

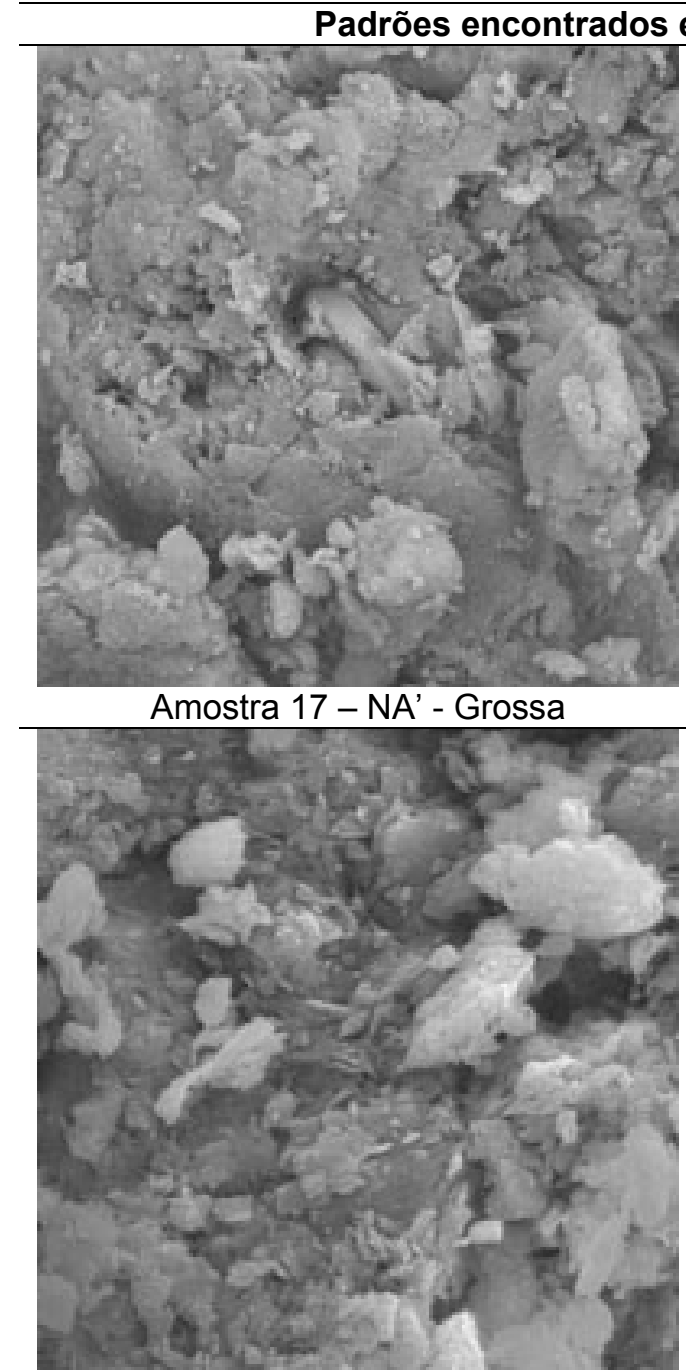

Amostra 27 - NG' - Intermediária

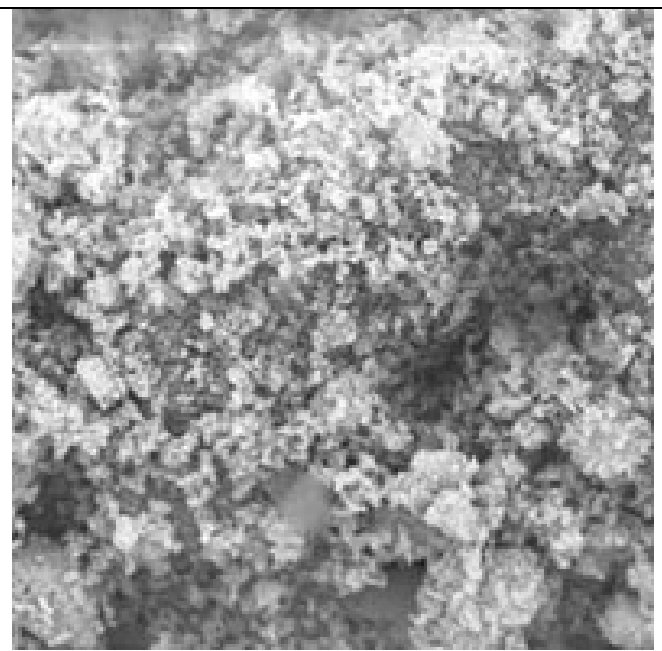

Amostra 39 - NG' - Fina

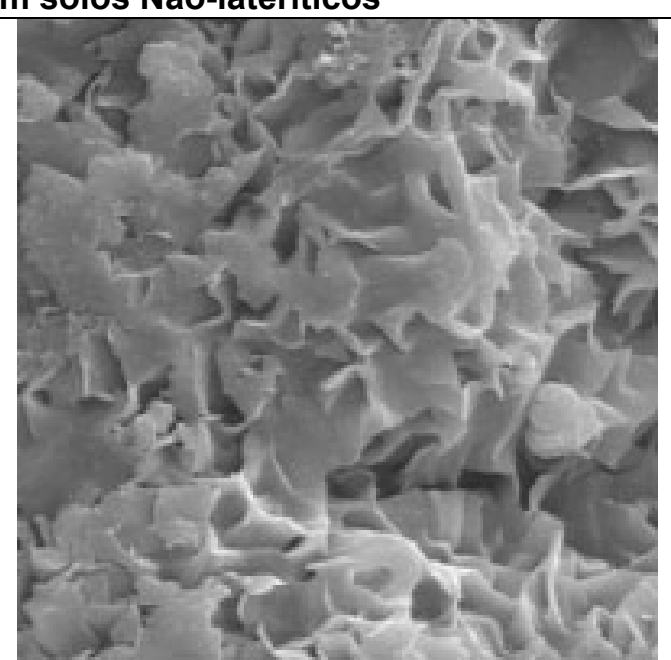

Amostra 85 - NA' - Grossa

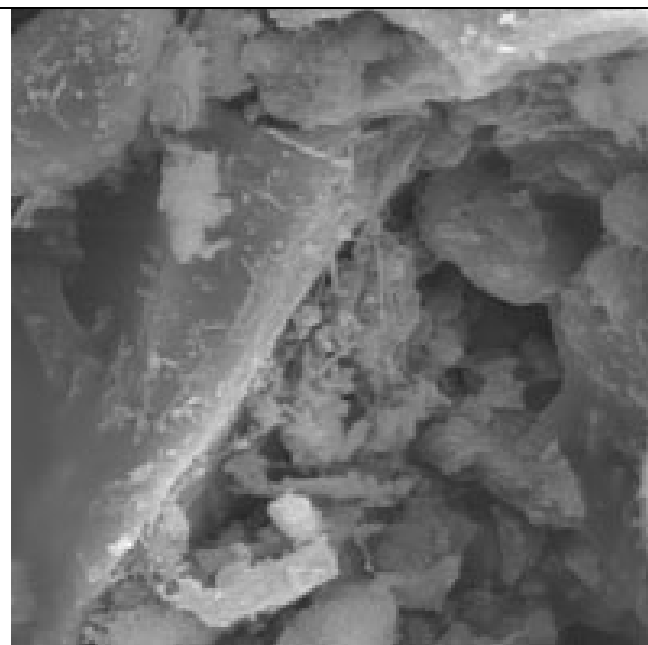

Amostra 36 - NS' - Fina

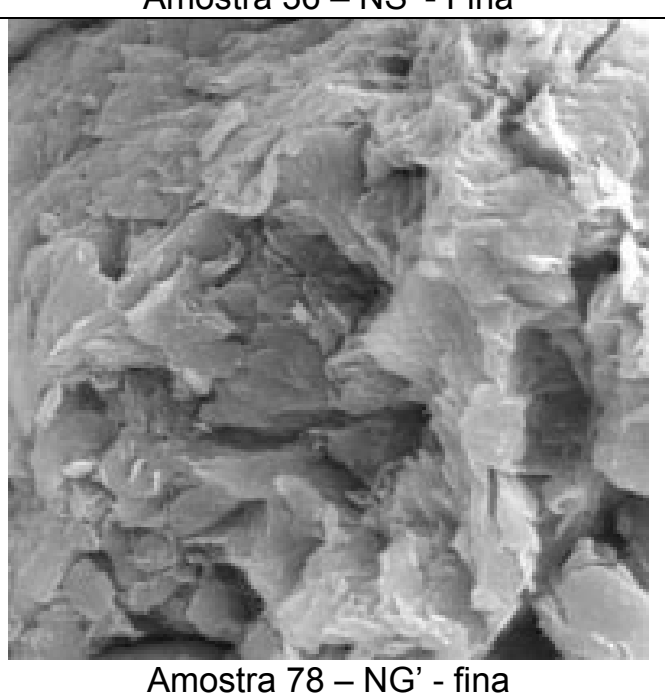

Amostra 78 - NG' - fina

Figura 4.7: Padrões de imagens indicativos de solos não-lateríticos (aumento 3000x). 
A Figura 4.8 apresenta uma sobreposição dos gráficos das classificações MCT e MCT-M, destacando a posição de cada um dos solos para os quais se verificaram divergências entre a análise dos resultados do ensaio de MEV e classificação MCT.

Analisando-se Figura 4.8, observa-se que, exceto pelas amostras 33 (NS') e 89 (NA), todos os solos com indicações "divergentes" situam na região de solos transicionais da classificação MCT-M. Dentre os solos classificados como NG' pela MCT, as amostras $42\left(e^{\prime}=1,17\right), 87\left(e^{\prime}=1,20\right)$ e $90\left(e^{\prime}=1,16\right)$ encontram-se em região muito próxima à linha de transição de comportamento da classificação $\mathrm{MCT}$, bem como a amostra $58\left(e^{\prime}=1,17\right)$, classificada como NA'.

É importante ressaltar que, mesmo quando possível, as imagens obtidas no ensaio de MEV não foram utilizadas na identificação dos tipos de argilominerais presentes nas amostras.

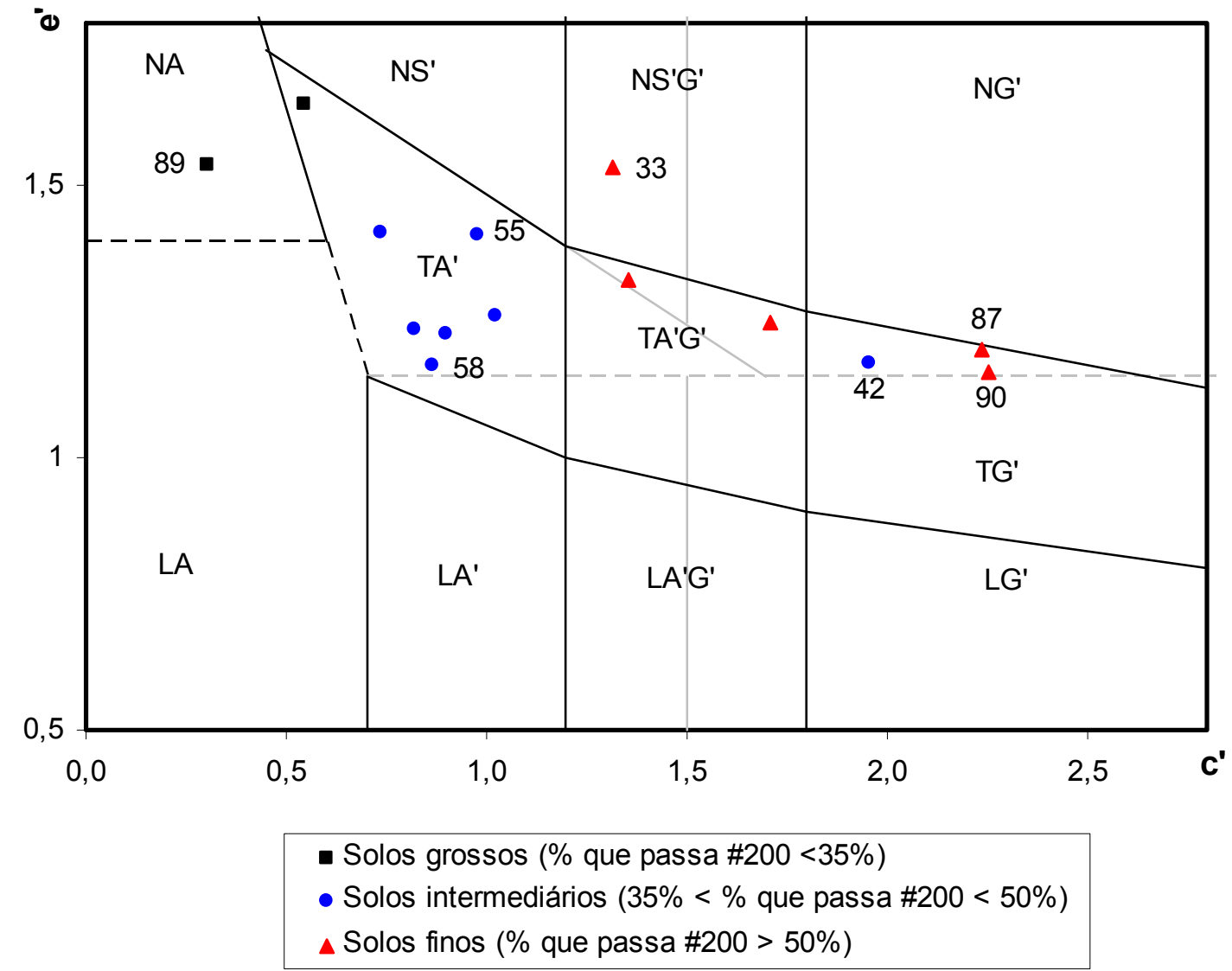

Figura 4.8: Gráfico de classificação MCT-M e MCT com a indicação dos solos em que foram observadas divergências entre as indicações da MEV e da classificação MCT. 


\subsection{Ensaio de difração de raios-x (DRX)}

Quando da seleção dos solos para o estudo do comportamento mecânico dos materiais com a variação da umidade, evitou-se a escolha de amostras entre aquelas que apresentaram divergências entre os resultados do ensaio de MEV e classificação MCT, à exceção das amostras 55 e 89. A primeira por compor um par granulométrico com a amostra 60 , e a segunda, por ser a única da classe LA entre as amostras coletadas.

A Figura 4.9 mostra o gráfico da classificação MCT com a indicação da posição de cada um dos trinta solos selecionados para esta etapa da pesquisa. Destaca-se que apenas este conjunto de amostras foi submetido ao ensaio de difração de raios-x para a identificação da constituição mineralógica.

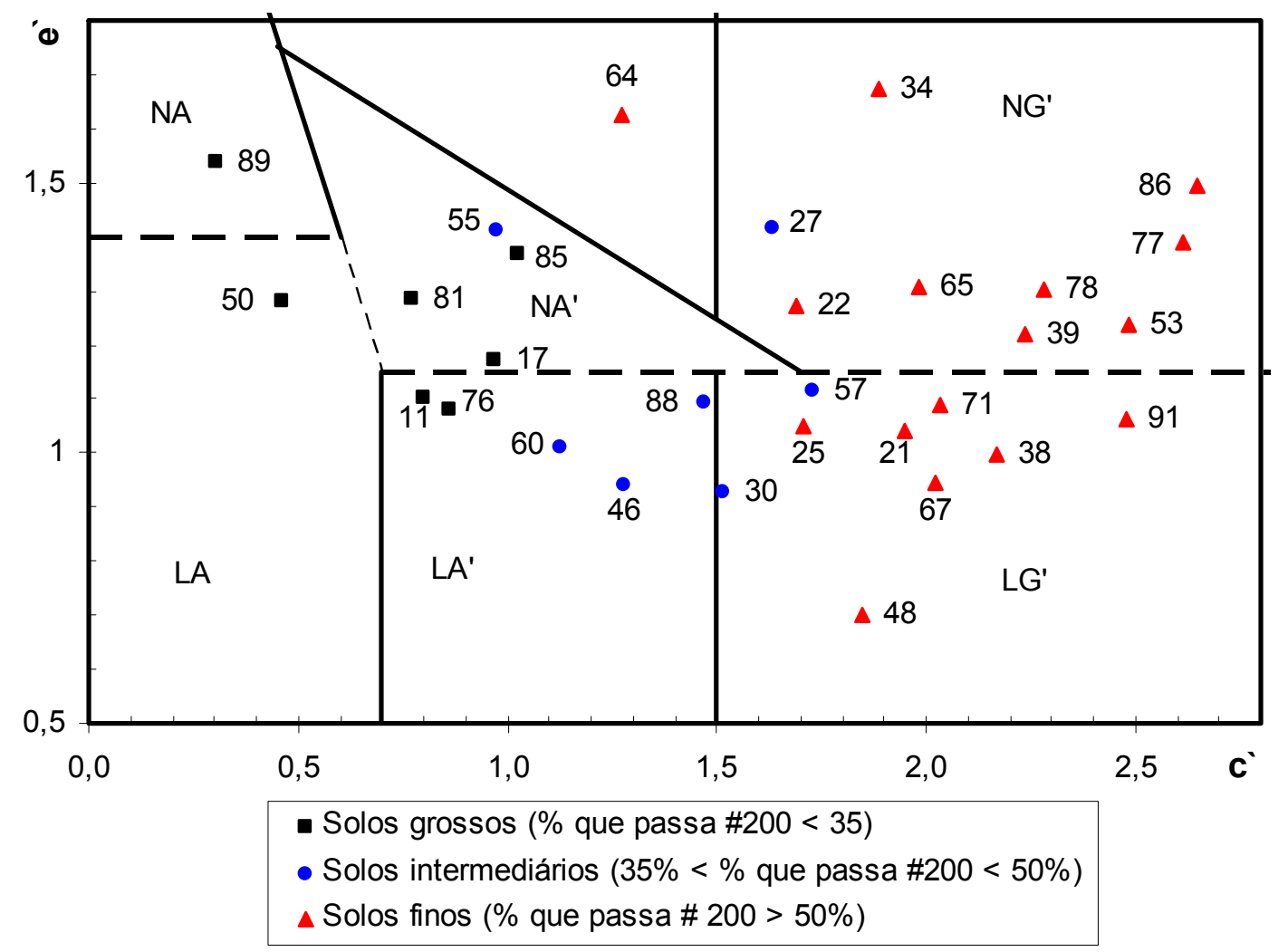

Figura 4.9: Gráfico da classificação MCT com a indicação da posição de cada um dos solos selecionados para a para o estudo do comportamento mecânico dos materiais com a variação da umidade.

A Figura 4.10 e a Figura 4.11 mostram o mapa do Estado de São Paulo com a indicação dos locais de coleta de cada uma das trinta amostras selecionadas, evidenciando, respectivamente, o grupo granulométrico e a classe 
MCT a que pertencem. Analisando-se estas figuras, observa-se que as amostras contemplam toda a área objeto do estudo.

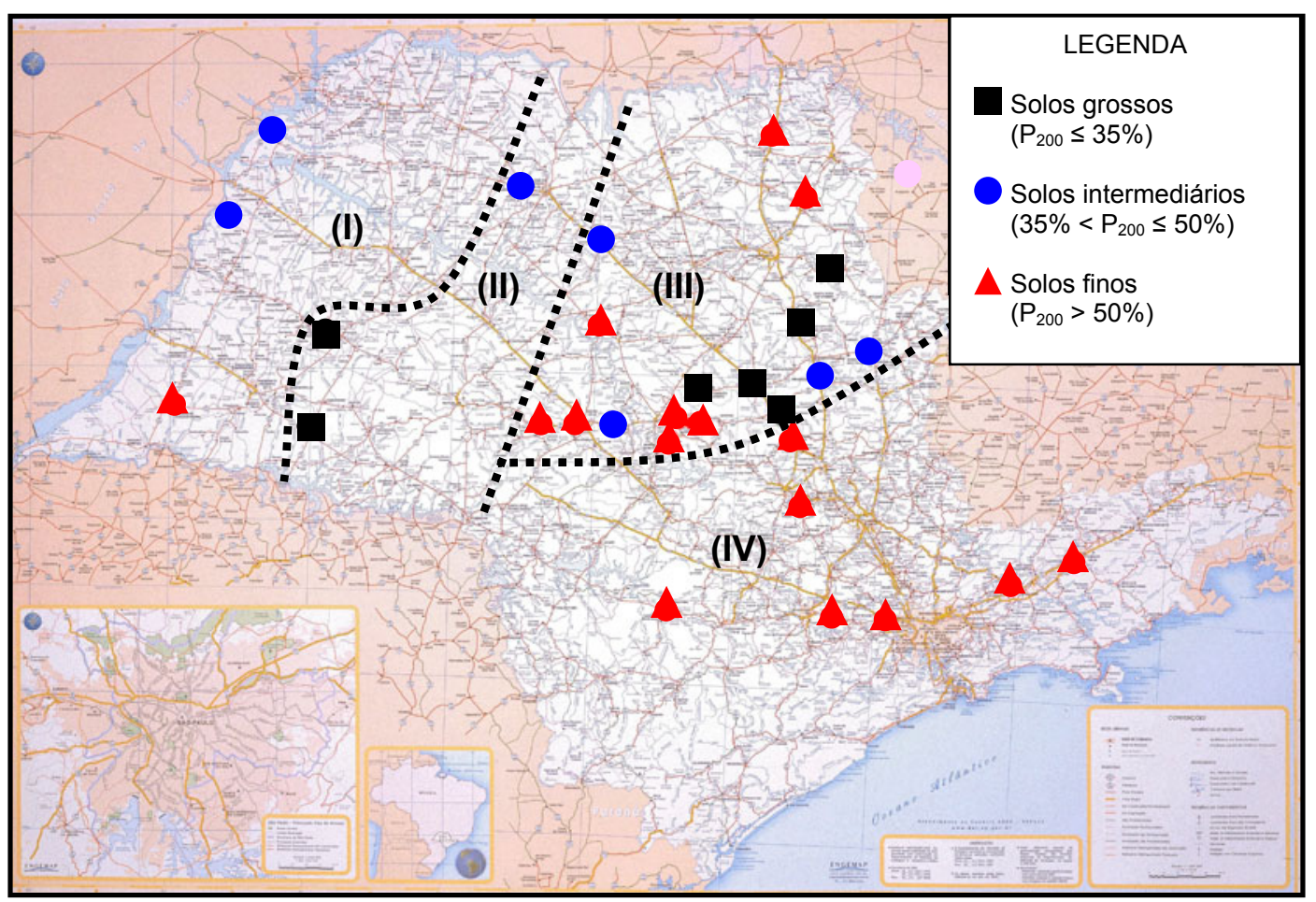

Figura 4.10: Mapa do Estado de São Paulo com a indicação dos locais de coleta associado à granulometria

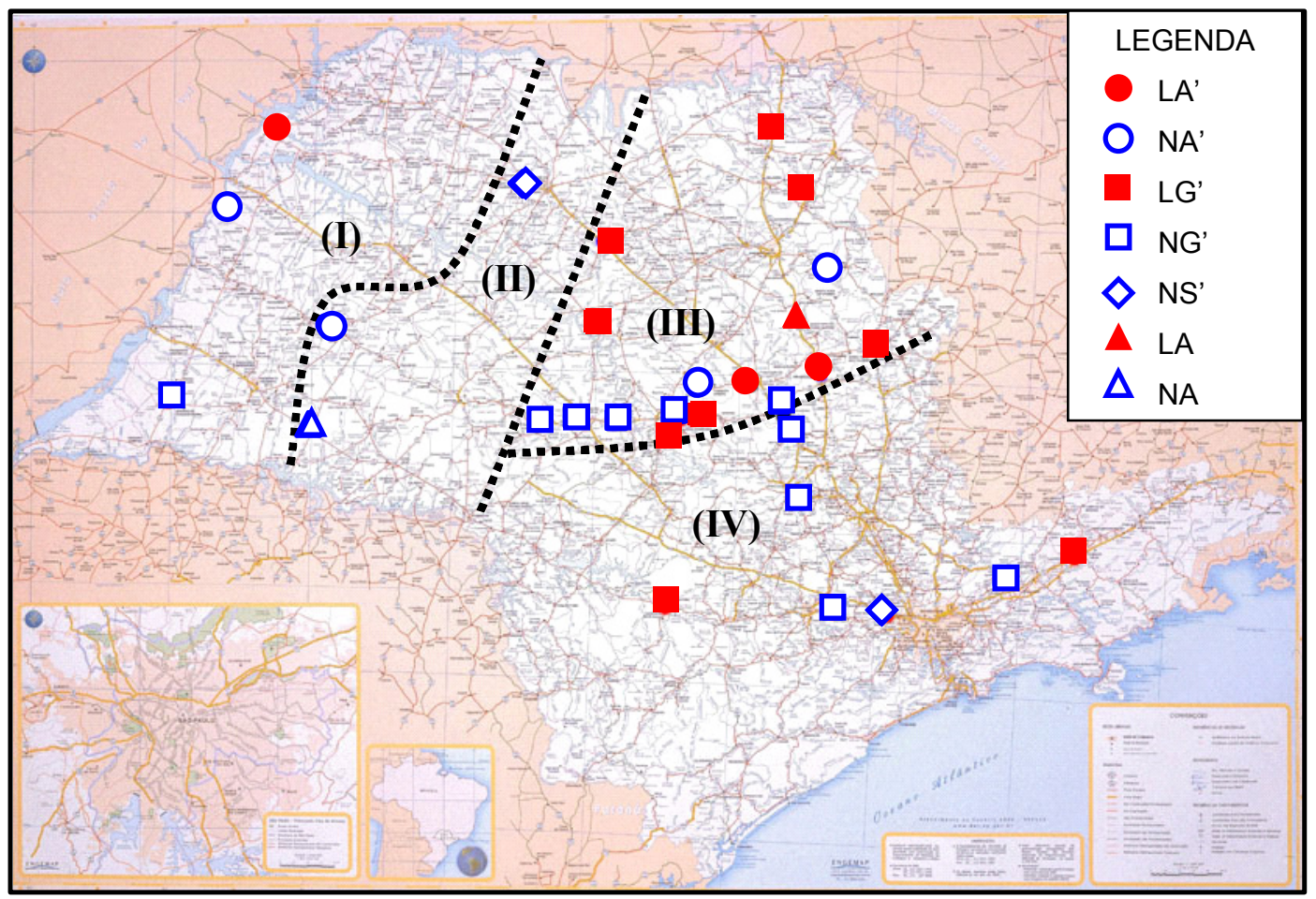

Figura 4.11: Mapa do Estado de São Paulo com a indicação dos locais de coleta associada à classificação MCT 
No tocante à granulometria, observa-se na Figura 4.10, que existe uma prevalência de solos grossos e intermediários nas regiões I e II, enquanto na região IV, os solos finos predominam. Já na região III, coexistem solos pertencentes aos três grupos granulométricos. Quanto ao comportamento previsto pela MCT, observa-se na Figura 4.11, que os solos lateríticos concentram-se na região III e os não-lateríticos concentram-se nas demais regiões.

Conforme apresentado no Capítulo 3, a análise dos resultados dos ensaios de difração de raios-x permite identificar os argilominerais que constituem a fração fina da amostra, separando-os segundo grupos: caulinitas, ilitas ou esmectitas. Entretanto, não permite a diferenciação dos componentes de cada um destes grupos.

Para os trinta solos selecionados, a Tabela 4.8 apresenta os grupos a que pertencem os argilominerais identificados, a presença ou não de óxidos e hidróxidos, a gênese do material inferida a partir da análise destes resultados, o comportamento segundo a MCT e finalmente, se existe concordância entre o comportamento e a gênese determinada através dos raios-x. Na tabela não é apresentada a ocorrência de quartzo e de goetita, já que estes minerais foram encontrados na maioria dos solos, com exceção das amostras 71, 86 e 91, onde não se observou a presença de quartzo, e das amostras 34, 64 e 78, onde não se observou a presença da goetita. Sobre este último mineral, os resultados estão de acordo com Alves (2002), que afirma que a goetita está presente em praticamente todos os solos.

Analisando-se a Tabela 4.8, observa-se que para os solos considerados de comportamento laterítico segundo a MCT, identificou-se, através da DRX, a presença de argilominerais menos ativos, como os do grupo das caulinitas. Destaca-se que a caulinita pode ser o argilomineral exclusivo ou ocorrer em conjunto com a gibbsita, sendo este último de ocorrência restrita aos solos lateríticos. As amostras 11, 21, 25, 48 e 71 são aquelas em que se observou a presença da caulinita e da gibsita, e nos demais solos que compõem o conjunto dos lateríticos, apenas o grupo da caulinita foi encontrado. Para todas estas amostras, identificou-se a presença de óxidos e/ou hidróxidos. Estas constatações corroboram Nogami e Villibor (1995), que afirmam que os solos lateríticos caracterizam-se por 
conter óxidos e hidróxidos de ferro e alumínio, e o argilomineral geralmente presente é a caulinita, podendo ainda ser encontrado outros membros do grupo da caulinita, como a haloisita e a nacrita.

Tabela 4.8: Minerais encontrados nas amostras de solo selecionadas e a característica determinada pela constituição dos solos.

\begin{tabular}{|c|c|c|c|c|c|}
\hline \multirow[b]{2}{*}{ Amostra } & \multicolumn{2}{|c|}{ Minerais encontrados com a DRX } & \multirow{2}{*}{$\begin{array}{c}\text { Característica } \\
\text { inferida a } \\
\text { partir da DRX } \\
\end{array}$} & \multirow[b]{2}{*}{ МСT } & \multirow{2}{*}{$\begin{array}{c}\text { Concordância } \\
\text { entre os } \\
\text { resultados }\end{array}$} \\
\hline & $\begin{array}{c}\text { Argilominerais } \\
\text { (grupos) }\end{array}$ & $\begin{array}{l}\text { Óxidos e/ou } \\
\text { hidróxidos }\end{array}$ & & & \\
\hline 11 & Caulinita e gibsita & $\operatorname{Sim}$ & $\mathrm{L}$ & $\mathrm{LA}^{\prime}$ & Sim \\
\hline 21 & Caulinita e gibsita & Sim & $\mathrm{L}$ & LG' & Sim \\
\hline 25 & Caulinita e gibsita & Sim & $\mathrm{L}$ & LG' & Sim \\
\hline 30 & Caulinita & Sim & $\mathrm{L}$ & LG' & Sim \\
\hline 38 & Caulinita & Sim & $\mathrm{L}$ & LG' & Sim \\
\hline 46 & Caulinita & Sim & $\mathrm{L}$ & $\mathrm{LA}^{\prime}$ & Sim \\
\hline 48 & Caulina e gibsita & Sim & $\mathrm{L}$ & LG' & Sim \\
\hline 50 & Caulinita & Sim & $\mathrm{L}$ & LA & Sim \\
\hline 57 & Caulinita & Sim & $\mathrm{L}$ & LG' & Sim \\
\hline 60 & Caulinita & Sim & $\mathrm{L}$ & $\mathrm{LA}^{\prime}$ & Sim \\
\hline 67 & Caulinita & Sim & $\mathrm{L}$ & LG' & Sim \\
\hline 71 & Caulinita e gibsita & Sim & $\mathrm{L}$ & LG' & Sim \\
\hline 76 & Caulinita & Sim & $\mathrm{L}$ & LA' & Sim \\
\hline 88 & Caulinita & Sim & $\mathrm{L}$ & $\mathrm{LA}^{\prime}$ & Sim \\
\hline 91 & Caulinita & Sim & $\mathrm{L}$ & LG' & Sim \\
\hline 27 & Caulinita & Não & L/NL & NG' & Sim \\
\hline 39 & Caulinita & Não & $\mathrm{L} / \mathrm{NL}$ & NG' & Sim \\
\hline 17 & Ilita e caulinita & Não & $\mathrm{NL}$ & NA' & Sim \\
\hline 22 & Caulinita e llita & Não & NL & NG' & Sim \\
\hline 34 & Ilita & Não & NL & NG' & Sim \\
\hline 53 & llita & Não & NL & NG' & Sim \\
\hline 55 & Ilita e caulinita & Não & NL & NA' & Sim \\
\hline 64 & Ilita e caulinita & Não & NL & NS' & Sim \\
\hline 65 & Ilita e caulinita & Não & $\mathrm{NL}$ & NG' & Sim \\
\hline 77 & Ilita & Não & NL & NG' & Sim \\
\hline 78 & Ilita & Não & $\mathrm{NL}$ & NG' & Sim \\
\hline 81 & Caulinita, ilita & Não & $\mathrm{NL}$ & NA' & Sim \\
\hline 85 & Ilita & Não & NL & NA' & Sim \\
\hline 86 & Ilita & Não & NL & NG' & Sim \\
\hline 89 & Caulinita e ilita & Não & $\mathrm{NL}$ & NA & Sim \\
\hline
\end{tabular}

( $\mathrm{L}$ - Laterítico; $\mathrm{NL}$ - Não-laterítico)

Ainda analisando-se a Tabela 4.8, observa-se que para os solos considerados como não-lateríticos segundo a MCT identificou-se, através da DRX, a presença de argilominerais mais ativos, como os do grupo das ilitas, isoladamente ou em conjunto com argilominerais menos ativos, como os do grupo das caulinitas. Para estes solos, não foi constatada a presença de óxidos e/ou hidróxidos. Neste caso, os resultados também corroboram Nogami e Villibor (1995), segundo os quais os solos não-lateríticos caracterizam-se pela possibilidade de ocorrerem argilominerais mais ativos do que os do grupo da caulinita, tais como os do grupo 
da smectita e da ilita. Entretanto, estes solos também podem conter exclusivamente argilominerais do grupo da caulinita, ou predominância destes na constituição. Os argilominerais e, eventualmente, outros minerais presentes nestes solos, não se apresentam recobertos por óxidos e hidróxidos de ferro e alumínio, como ocorre nos solos lateríticos.

Destaca-se que na análise da gênese do material, no caso da presença apenas de argilominerais do grupo das caulinita, sem a identificação da presença de óxidos e/ou hidróxidos, assumiu-se que os solos poderiam ser tanto lateríticos quanto não-lateríticos.

A comparação entre a gênese obtida a partir da análise dos resultados dos ensaios de raios-X e o comportamento previsto pela classificação MCT mostra concordância entre os mesmos para todos os trinta solos, inclusive para as amostras 55 e 89, que apresentaram discordância entre as indicações fornecidas pela MCT e a microscopia eletrônica de varredura (MEV). Entretanto, é importante destacar que a não existência de divergências pode ser decorrente da eliminação dos solos que apresentaram discordância entre a MCT e a indicação da gênese obtida a partir do MEV, à exceção das amostras 55 e 89, durante a seleção do conjunto de trinta amostras a serem analisadas.

\subsection{Ensaio de adsorção de azul de metileno}

De forma complementar aos ensaios utilizados para a identificação do caráter laterítico dos solos selecionados, realizou-se também o ensaio de adsorção de azul de metileno segundo o método proposto por Fabbri (1994), que permite a caracterização da fração fina de solos tropicais. Conforme detalhado no Capítulo 3 , são necessários três parâmetros para a caracterização da fração fina de solos por este método, a saber: o valor de azul (Va), o coeficiente de atividade (CA) e a porcentagem de argila, definida na peneira de $0,005 \mathrm{~mm}$.

A Figura 4.12 apresenta o ábaco para caracterização da atividade da fração argila dos solos com a indicação da localização de cada uma das amostras 
selecionadas. A Tabela 4.9 apresenta os valores calculados de Va e CA e a caracterização da atividade dos argilominerais.

Analisando-se a Figura 4.12 e a Tabela 4.9, observa-se a concordância entre as indicações obtidas a partir dos resultados do azul de metileno e o comportamento previsto pela classificação MCT para a maioria dos solos, à exceção das amostras 39, 57 e 65.

Dentre as três discordâncias observadas, a referente à amostra 57 corresponde a um solo classificado como laterítico pela MCT e caracterizado como ativo pelo ensaio de azul. Neste caso, o valor de e' $=1,12$ coloca a amostra muito próxima da transição entre os solos de comportamento laterítico e não-laterítico segundo a MCT, o que poderia levar à incongruência entre as indicações obtidas.

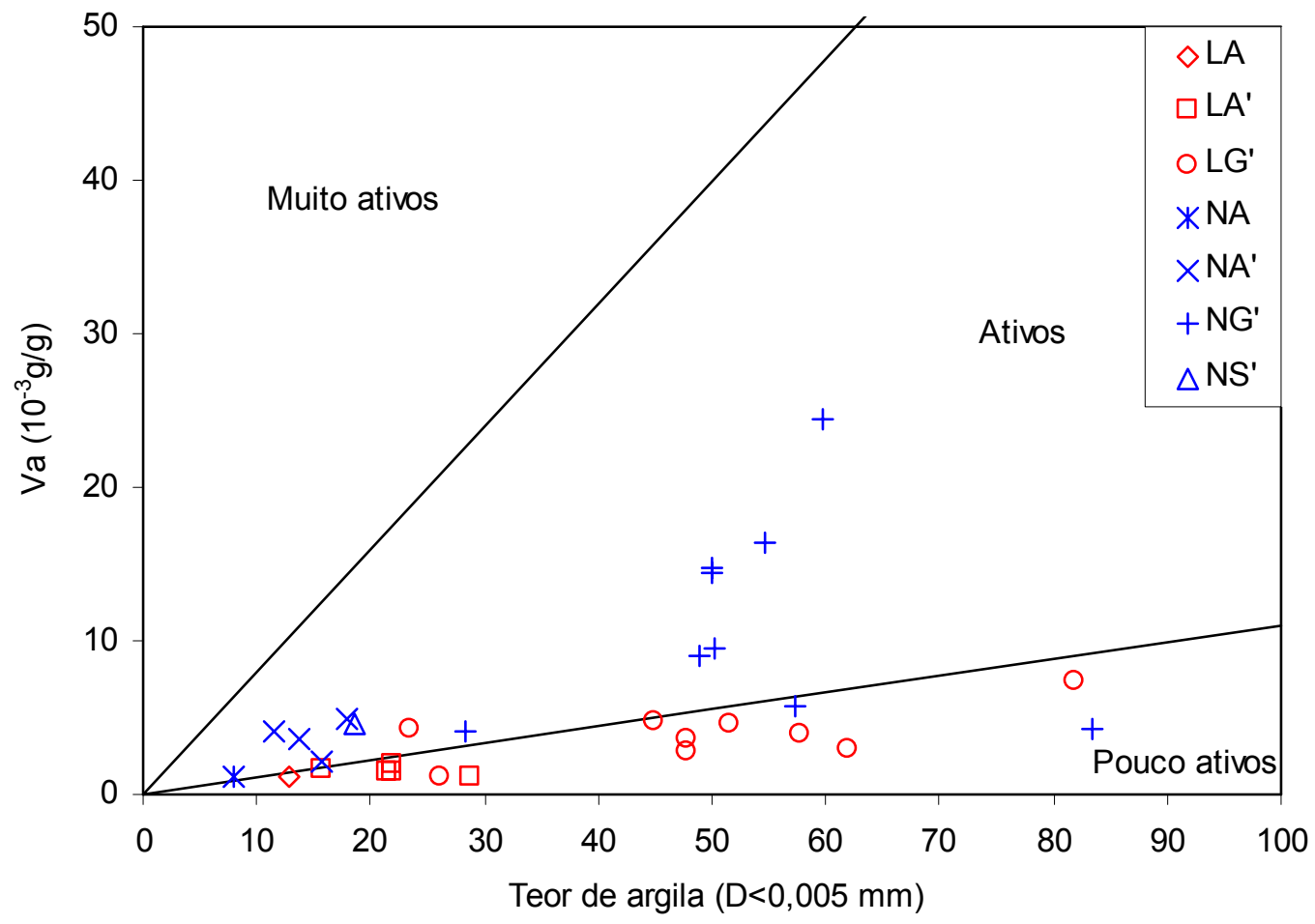

Figura 4.12: Ábaco para caracterização da atividade da fração argila dos solos com a indicação da posição dos solos selecionados. 
Tabela 4.9: Resultados dos ensaios de azul de metileno com a indicação da atividade dos argilominerais em comparação com a classificação MCT.

\begin{tabular}{|c|c|c|c|c|c|}
\hline Amostra & $\begin{array}{c}\mathrm{Va} \\
(10-3 \mathrm{~g} / \mathrm{g})\end{array}$ & $\begin{array}{c}\text { CA } \\
\text { (CA }<11-\text { pouco ativo) } \\
(11<\text { CA }<80-\text { ativo }) \\
\text { (CA }>80-\text { muito ativo })\end{array}$ & $\begin{array}{c}\text { Atividade } \\
\text { dos } \\
\text { argilominerais }\end{array}$ & MCT & $\begin{array}{l}\text { Existe } \\
\text { concordância } \\
\text { entre os } \\
\text { resultados }\end{array}$ \\
\hline 50 & 1,1 & 8,8 & $\mathrm{~L}$ & LA & Sim \\
\hline 11 & 1,4 & 6,4 & $L$ & $\mathrm{LA}^{\prime}$ & Sim \\
\hline 46 & 1,5 & 7,2 & L & LA' $^{\prime}$ & Sim \\
\hline 60 & 2,0 & 9,3 & L & LA' $^{\prime}$ & Sim \\
\hline 76 & 1,7 & 10,6 & L & LA' $^{\prime}$ & Sim \\
\hline 88 & 1,2 & 4,2 & $\mathrm{~L}$ & $\mathrm{LA}^{\prime}$ & Sim \\
\hline 21 & 2,8 & 6,0 & $\mathrm{~L}$ & $\mathrm{LG}^{\prime}$ & Sim \\
\hline 25 & 3,6 & 7,6 & L & LG' & Sim \\
\hline 30 & 1,2 & 4,7 & L & LG' & Sim \\
\hline 38 & 4,7 & 10,5 & L & LG' & Sim \\
\hline 48 & 4,0 & 6,9 & L & LG' & Sim \\
\hline 67 & 7,4 & 9,1 & L & LG' & Sim \\
\hline 71 & 2,9 & 4,7 & L & LG' & Sim \\
\hline 91 & 4,5 & 8,8 & $\mathrm{~L}$ & LG' & Sim \\
\hline 57 & 4,2 & 17,9 & NL & LG' & Não \\
\hline 89 & 1,2 & 15,2 & $\mathrm{NL}$ & NA & Sim \\
\hline 17 & 3,6 & 26,1 & $\overline{N L}$ & $\mathrm{NA}^{\prime}$ & Sim \\
\hline 55 & 4,9 & 27,5 & $\mathrm{NL}$ & NA' & Sim \\
\hline 81 & 2,1 & 13,2 & $\mathrm{NL}$ & $N^{\prime}$ & Sim \\
\hline 85 & 4,1 & 36,0 & $\mathrm{NL}$ & $\mathrm{NA}^{\prime}$ & Sim \\
\hline 39 & 5,5 & 6,6 & $\mathrm{~L}$ & NG' & Não \\
\hline 65 & 5,7 & 10,0 & $\mathbf{L}$ & NG' & Não \\
\hline 22 & 9,0 & 18,4 & NL & NG' & Sim \\
\hline 27 & 4,1 & 14,3 & NL & NG' & Sim \\
\hline 34 & 9,5 & 18,9 & NL & NG' & Sim \\
\hline 53 & 14,7 & 29,4 & NL & NG' & Sim \\
\hline 77 & 14,4 & 28,8 & NL & NG' & Sim \\
\hline 78 & 16,4 & 30,1 & NL & NG' & Sim \\
\hline 86 & 24,4 & 40,8 & $\mathrm{NL}$ & NG' & Sim \\
\hline 64 & 4,5 & 24,1 & $\mathrm{NL}$ & $N^{\prime}$ & Sim \\
\hline
\end{tabular}

(L - Laterítico (Pouco ativo); NL - Não-laterítico (Ativo))

Quanto às outras duas discordâncias, amostras 39 e 65, estas correspondem a solos classificados como não-lateríticos pela MCT e que apresentam na sua constituição, segundo o ensaio de azul, argilominerais pouco ativos. No caso da amostra 65 , o CA é igual a 10, valor este muito próximo do limite (11) que separa os argilominerais ativos dos pouco ativos. Para a amostra 39, o valor de CA é igual a 5,2, posicionando a amostra na região de solos pouco ativos e distante do limite destacado anteriormente. Entretanto, analisando-se os resultados de difração de raios-x (vide Tabela 4.8), observa-se que esta amostra apresenta 
apenas argilominerais do grupo das caulinitas, apesar de ser classificado como não-laterítico pela MCT, estes minerais poderiam se encontrar na sua forma menos ativa, justificando a característica indicada pelo método do azul de metileno.

Finalmente, o ensaio de azul não indicou a presença de argilominerais muito ativos, como os do grupo das esmectitas, para nenhum dos solos analisados, resultado compatível com as indicações obtidas a partir dos ensaios de raios-X.

\subsection{Análise conjunta dos ensaios MCT, MEV, DRX e adsorção de azul de metileno para as amostra selecionadas}

A Tabela 4.10 apresenta a gênese dos solos selecionados, laterítico $(L)$ e não-laterítico (NL), conforme obtido nos ensaios de microscopia eletrônica de varredura (MEV), difração de raios-X (DRX), adsorção de azul de metileno e classificação MCT. Analisando-se estes resultados, observa-se que para vinte e cinco amostras, ou $83 \%$ dos casos, houve concordância entre as indicações da totalidade dos ensaios utilizados.

Observa-se ainda, que dentre as amostras em que a concordância entre as indicações dos ensaios é parcial, sempre três entre quatro ensaios produziram resultados congruentes. As divergências encontradas seriam devidas ou aos ensaios de MEV ou aos ensaios de adsorção de azul de metileno. 
Tabela 4.10: Comparação entre os resultados dos ensaios de MEV, DRX, azul de metileno e classificação MCT.

\begin{tabular}{|c|c|c|c|c|c|}
\hline \multirow{2}{*}{ Amostra } & \multicolumn{3}{|c|}{ Característica determinada pelo ensaio } & \multirow{2}{*}{ МCT } & \multirow{2}{*}{$\begin{array}{l}\text { Existe concordância } \\
\text { entre os ensaios }\end{array}$} \\
\hline & MEV & DRX & $\begin{array}{l}\text { Azul de } \\
\text { metileno }\end{array}$ & & \\
\hline 50 & $\mathrm{~L}$ & $\mathrm{~L}$ & $\mathrm{~L}$ & LA & Total \\
\hline 46 & $\mathrm{~L}$ & $\mathrm{~L}$ & $\mathrm{~L}$ & $\mathrm{LA}^{\prime}$ & Total \\
\hline 11 & L & L & L & LA' & Total \\
\hline 60 & L & L & L & $\mathrm{LA}^{\prime}$ & Total \\
\hline 76 & L & L & L & LA' & Total \\
\hline 88 & L & L & L & $\mathrm{LA}^{\prime}$ & Total \\
\hline 21 & $\mathrm{~L}$ & $\mathrm{~L}$ & $\mathrm{~L}$ & LG' & Total \\
\hline 25 & L & L & L & LG' & Total \\
\hline 30 & L & L & L & LG' & Total \\
\hline 38 & L & L & L & LG' & Total \\
\hline 48 & L & L & $\mathrm{L}$ & LG' & Total \\
\hline 57 & $\mathbf{L}$ & $\mathbf{L}$ & NL & LG' & Parcial \\
\hline 67 & L & L & $\mathrm{L}$ & LG' & Total \\
\hline 71 & L & L & L & LG' & Total \\
\hline 91 & L & L & L & LG' & Total \\
\hline 89 & $\bar{L}$ & $\overline{N L}$ & $\mathrm{NL}$ & NA & Parcial \\
\hline 17 & $\mathrm{NL}$ & $\mathrm{NL}$ & $\mathrm{NL}$ & $\mathrm{NA}^{\prime}$ & Total \\
\hline 55 & $\mathbf{L}$ & NL & NL & NA' & Parcial \\
\hline 81 & $\mathrm{NL}$ & NL & NL & $\mathrm{NA}^{\prime}$ & Total \\
\hline 85 & $\mathrm{NL}$ & $\mathrm{NL}$ & NL & NA' & Total \\
\hline 22 & $\mathrm{NL}$ & $\mathrm{NL}$ & $\mathrm{NL}$ & NG' & Total \\
\hline 27 & $\mathrm{NL}$ & L/NL & NL & NG' & Total \\
\hline 34 & NL & $\mathrm{NL}$ & NL & NG' & Total \\
\hline 39 & NL & L/NL & $\mathrm{L}$ & NG' & Parcial \\
\hline 53 & NL & $\mathrm{NL}$ & NL & NG' & Total \\
\hline 65 & NL & NL & $\mathrm{L}$ & NG' & Parcial \\
\hline 77 & $\mathrm{NL}$ & NL & NL & NG' & Total \\
\hline 78 & $\mathrm{NL}$ & NL & NL & NG' & Total \\
\hline 86 & $\mathrm{NL}$ & NL & NL & NG' & Total \\
\hline 64 & $\mathrm{NL}$ & $\mathrm{NL}$ & $\mathrm{NL}$ & NS' & Total \\
\hline
\end{tabular}




\section{Capítulo 5 - Apresentação e discussão dos} resultados

\subsection{Introdução}

Neste capítulo são analisados os resultados dos ensaios realizados para se alcançar os objetivos desta tese no tocante ao comportamento mecânico de solos do interior paulista.

\subsection{Ensaios de compactação}

Os ensaios de compactação foram realizados na energia normal do ensaio de Proctor para determinação da umidade ótima e massa específica seca máxima (wo; $\rho_{\text {dmax }}$ ) de cada um dos solos. São analisados os resultados dos ensaios realizados para os setenta e dois solos coletados preliminarmente, conforme apresentado no Capítulo 3.

As curvas de compactação não são apresentadas neste texto, sendo que os valores de umidade ótima e massa específica obtidos para cada um dos solos encontram-se no Anexo F.

A Figura 5.1 mostra o gráfico que ilustra a relação da massa específica seca máxima e a umidade ótima correspondente, destacando os solos segundo o 
comportamento laterítico ou não-laterítico dos mesmos conforme previsto pela classificação MCT.

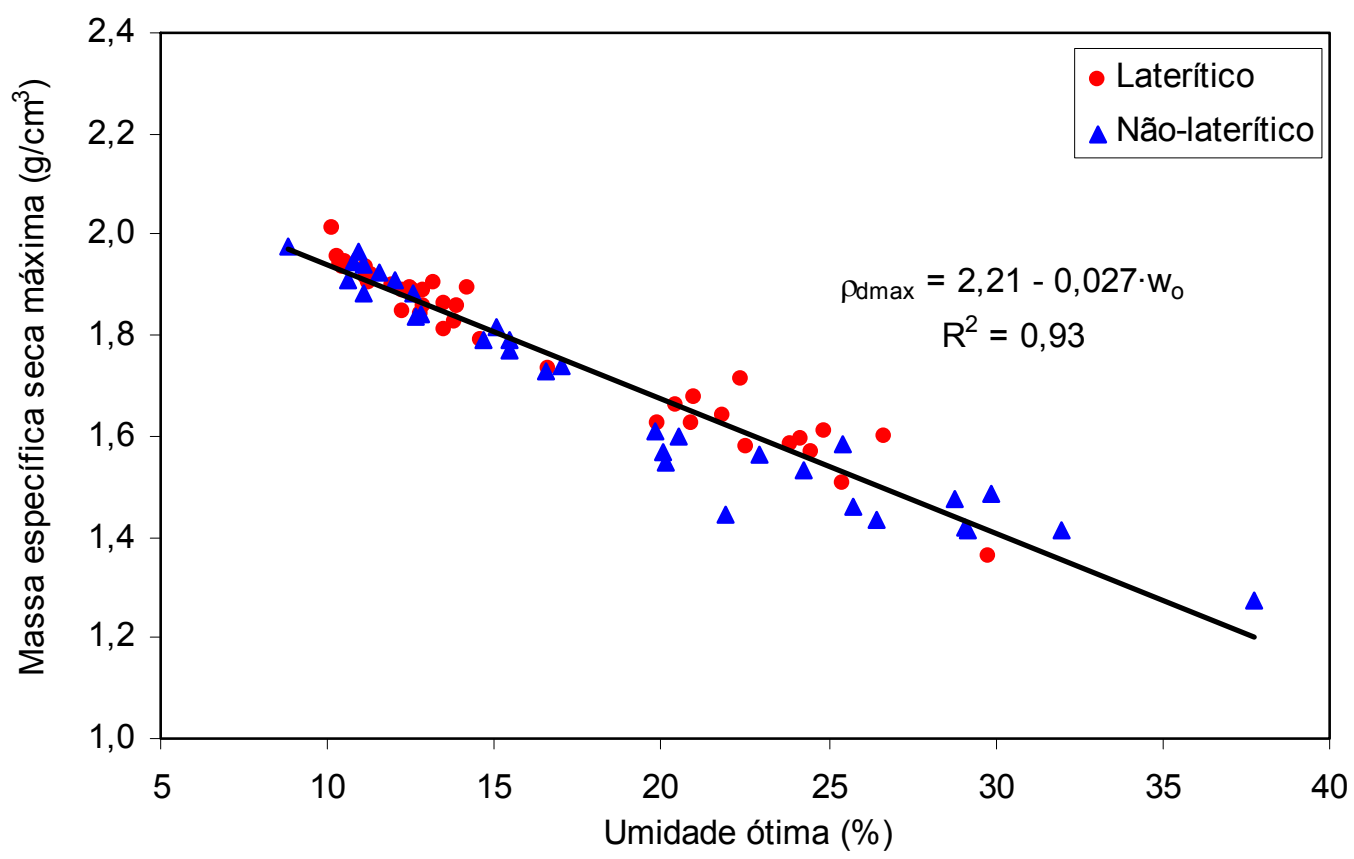

Figura 5.1: Umidade ótima versus massa específica seca máxima para os solos coletados e separados segundo o comportamento laterítico ou nãolaterítico previsto pela classificação MCT

Analisando-se a Figura 5.1, observa-se que os solos lateríticos e nãolateríticos alinham-se segundo uma mesma curva de tendência, cujo coeficiente de determinação $R^{2}$ é igual a 0,93 . Portanto, existe uma ótima correlação entre as variáveis consideradas. Do ponto de vista da gênese, não se pode distinguir comportamentos diversos para solos lateríticos ou não-lateríticos.

A Figura 5.2 mostra as mesmas variáveis da Figura 5.1, entretanto, destacando os solos segundo os critérios granulométricos adotados neste trabalho, conforme apresentados no Capítulo 3.

Analisando-se a Figura 5.2, observa-se a existência de um agrupamento de solos segundo os critérios granulométricos adotados. Verifica-se que todas as amostras grossas e intermediárias apresentaram um teor de umidade ótima variando entre $8,0 \%$ e $17,0 \%$, valores estes menores do que os observados para os solos finos, que apresentaram teores superiores a 19,5\%. A única exceção é a amostra 45 , que apresenta $52 \%$ das partículas passando na peneira \#200, ou seja, 
um solo situado muito próximo ao limite granulométrico de $50 \%$, adotado como critério para separar solos finos e intermediários.

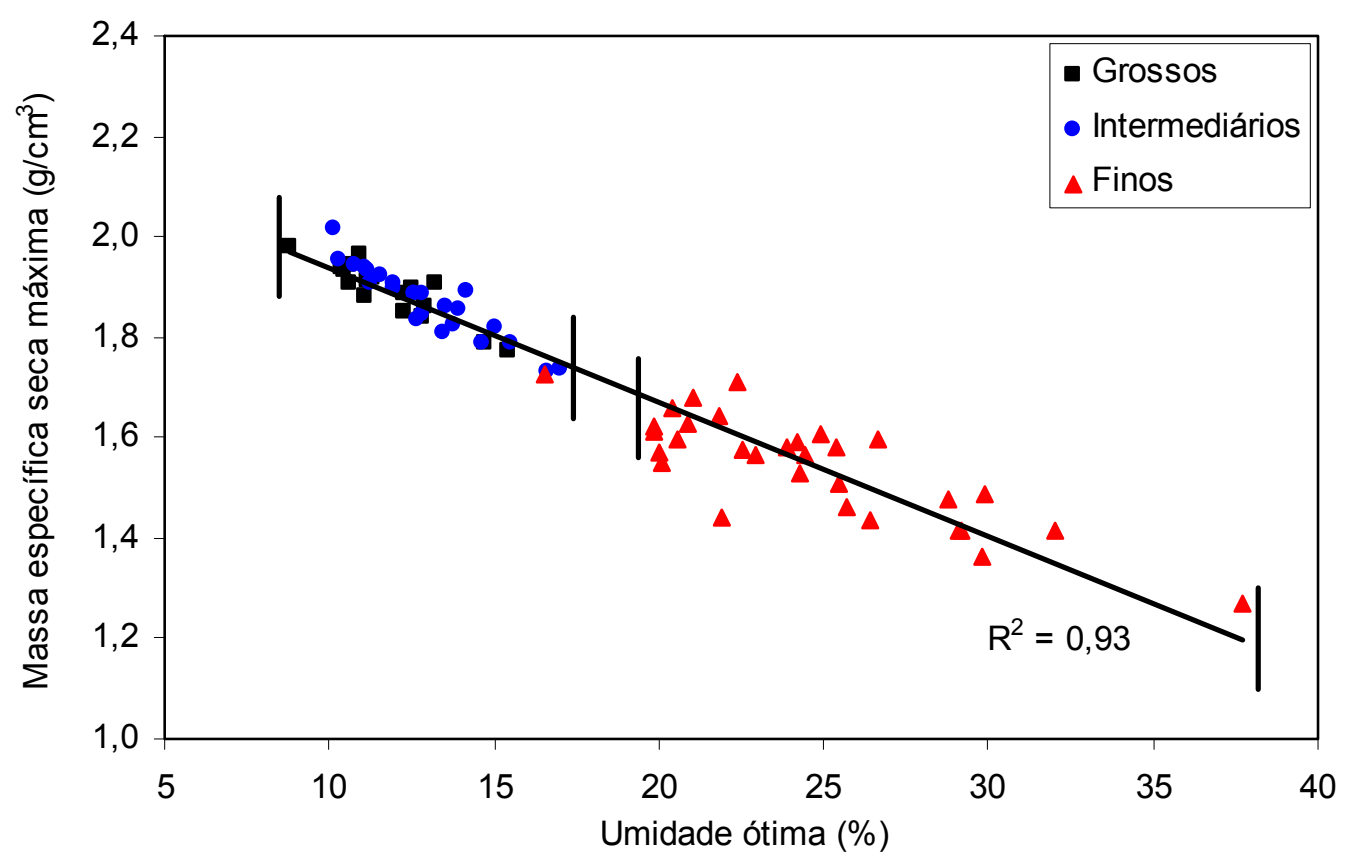

Figura 5.2: Umidade ótima versus massa específica seca máxima para os solos coletados e separados segundo a granulometria

Procurou-se analisar as relações entre a umidade ótima e massa específica seca máxima e características físicas dos solos, selecionadas dentre aquelas que apresentaram melhores correlações com os resultados dos ensaios de compactação, com destaque para o limite de liquidez (LL), o índice de plasticidade $(I P)$, o teor de finos $\left(P_{200}\right)$ e o teor de argila $\left(P_{\text {Argila }}\right)$. As Figuras 5.3 e 5.4 ilustram as relações consideradas para a $\mathrm{w}_{\mathrm{o}}$ e a $\rho_{\mathrm{dmax}}$, respectivamente, destacando os valores correspondentes de $\mathrm{R}^{2}$.

Analisando-se as Figuras 5.3 e 5.4, observa-se que das quatro relações consideradas, três apresentam coeficientes de determinação satisfatórios, ou sejam, em ordem decrescente, as que relacionam os resultados dos ensaios de compactação com o limite de liquidez, o teor de finos e o teor de argila, com valores de $R^{2}$ de $0,85,0,85$ e 0,69 e $0,84,0,80$ e 0,62, respectivamente para a $w_{o}$ e a $\rho_{\text {dmax }}$. 

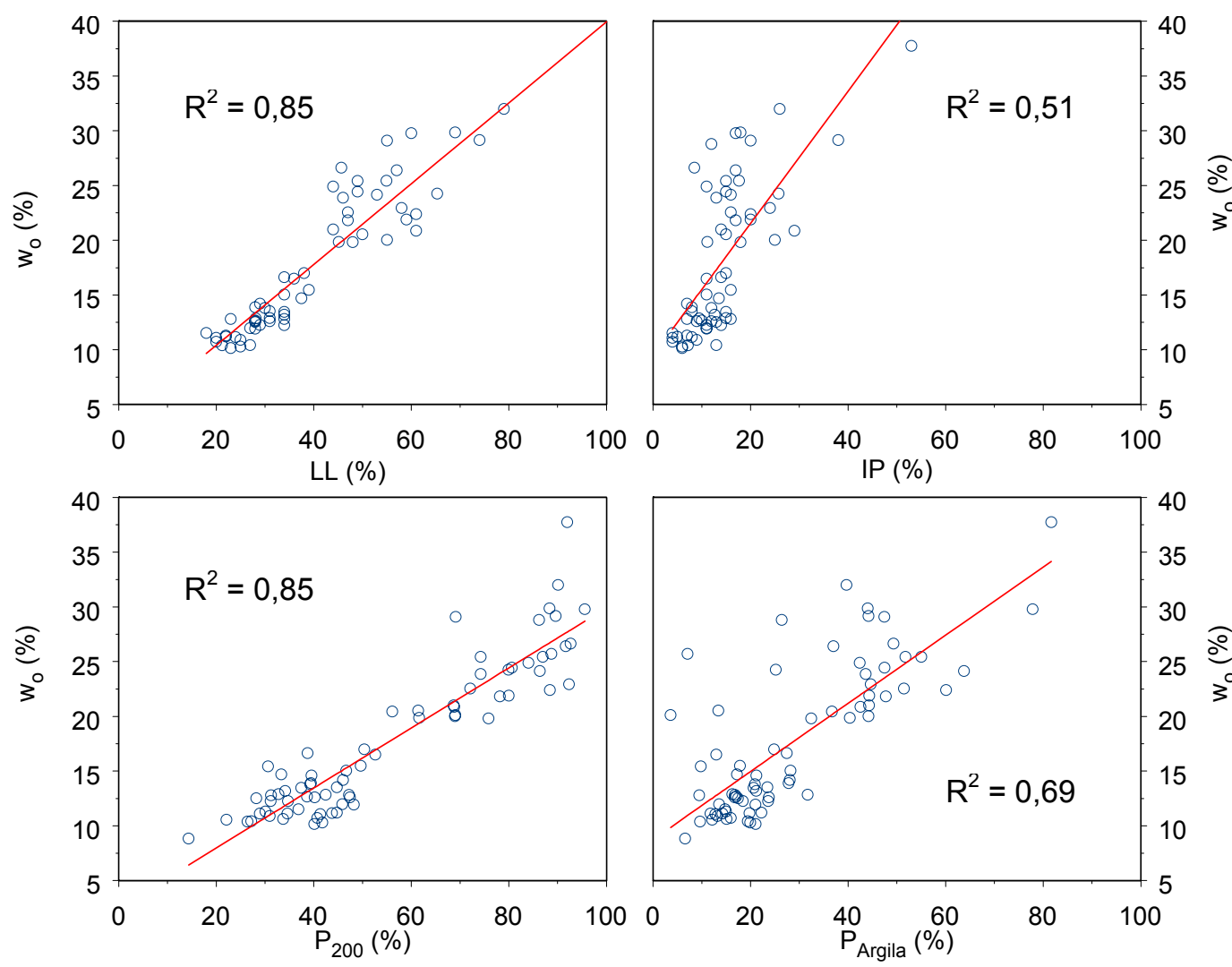

Figura 5.3: Relações entre a umidade ótima $\left(w_{0}\right)$ e características físicas dos solos
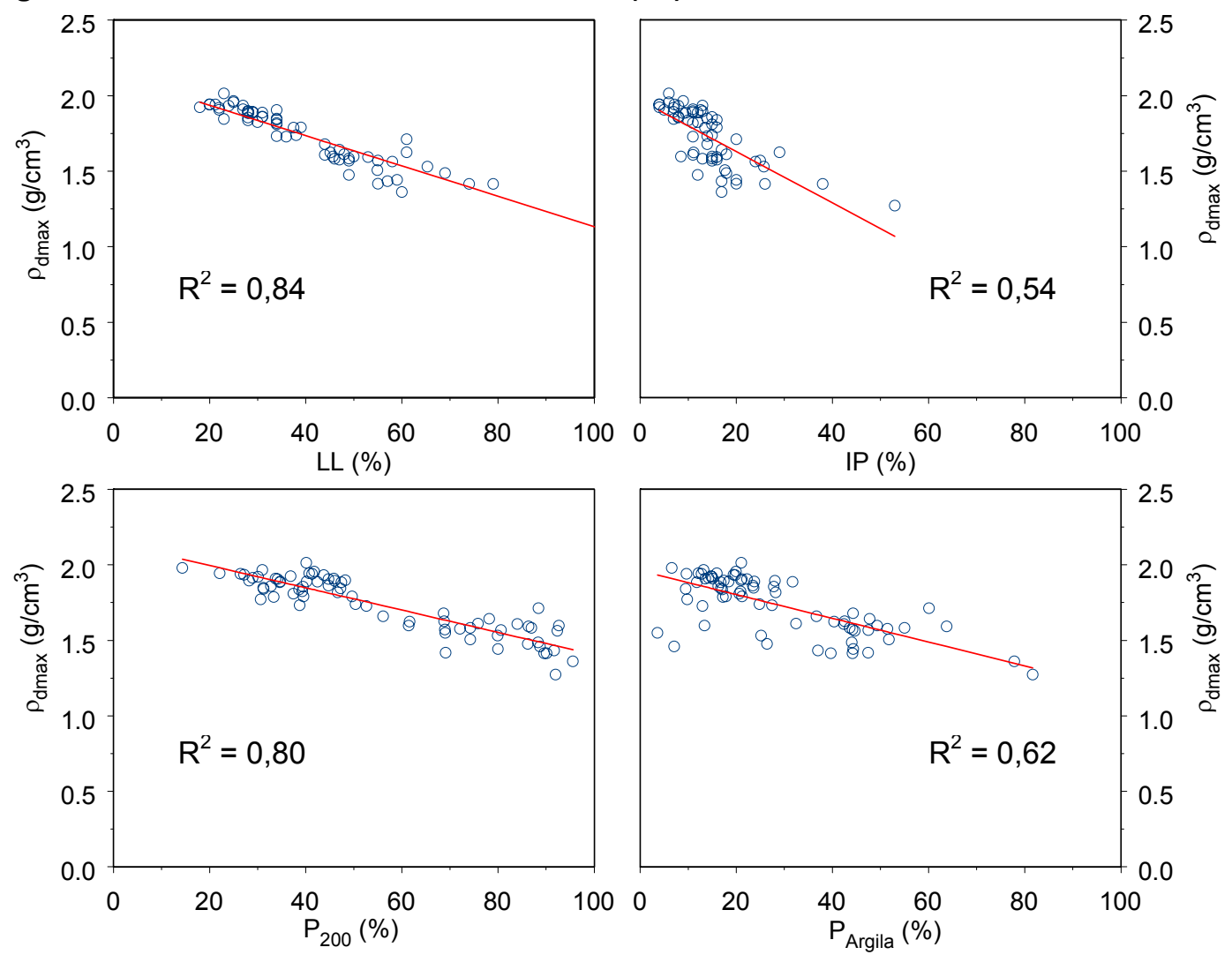

Figura 5.4: Relação entre a massa específica seca máxima ( $\left.\rho_{\mathrm{dmax}}\right)$ e características físicas dos solos 
Com o objetivo de identificar padrões de comportamento relacionados à influência da gênese dos solos na compactação, construíram-se as Figuras 5.5, 5.6 e 5.7, e as Figuras 5.8, 5.9 e 5.10, que apresentam, respectivamente, para a umidade ótima e massa específica seca máxima, as suas variações com as três características físicas melhor correlacionadas com estes parâmetros, mas destacando os solos conforme o comportamento laterítico ou não-laterítico dos materiais.

Analisando-se estas figuras, observa-se que as relações da umidade ótima e massa específica seca máxima com o limite de liquidez e o teor de finos (Figuras 5.5, 5.6, 5.8 e 5.9) não apresentam padrões de variação que evidenciem uma diversidade entre o comportamento de solos lateríticos e não-lateríticos. Entretanto, quando se analisam as variações de $w_{0}$ e $\rho_{d m a x}$ com o $P_{\text {Argila, }}$ conforme ilustram as Figuras 5.7 e 5.10, respectivamente, observa-se que solos lateríticos e nãolateríticos alinham-se segundo diferentes curvas de tendência, conforme já havia sido observado por Luz (2003). A razão para que a diferença de comportamento entre solos lateríticos e não-lateríticos seja melhor evidenciada a partir do teor de argila reside no fato de que esta é a fração granulométrica mais sujeita à ação dos agentes de laterização, conforme destacam Nogami \& Villibor (1995).

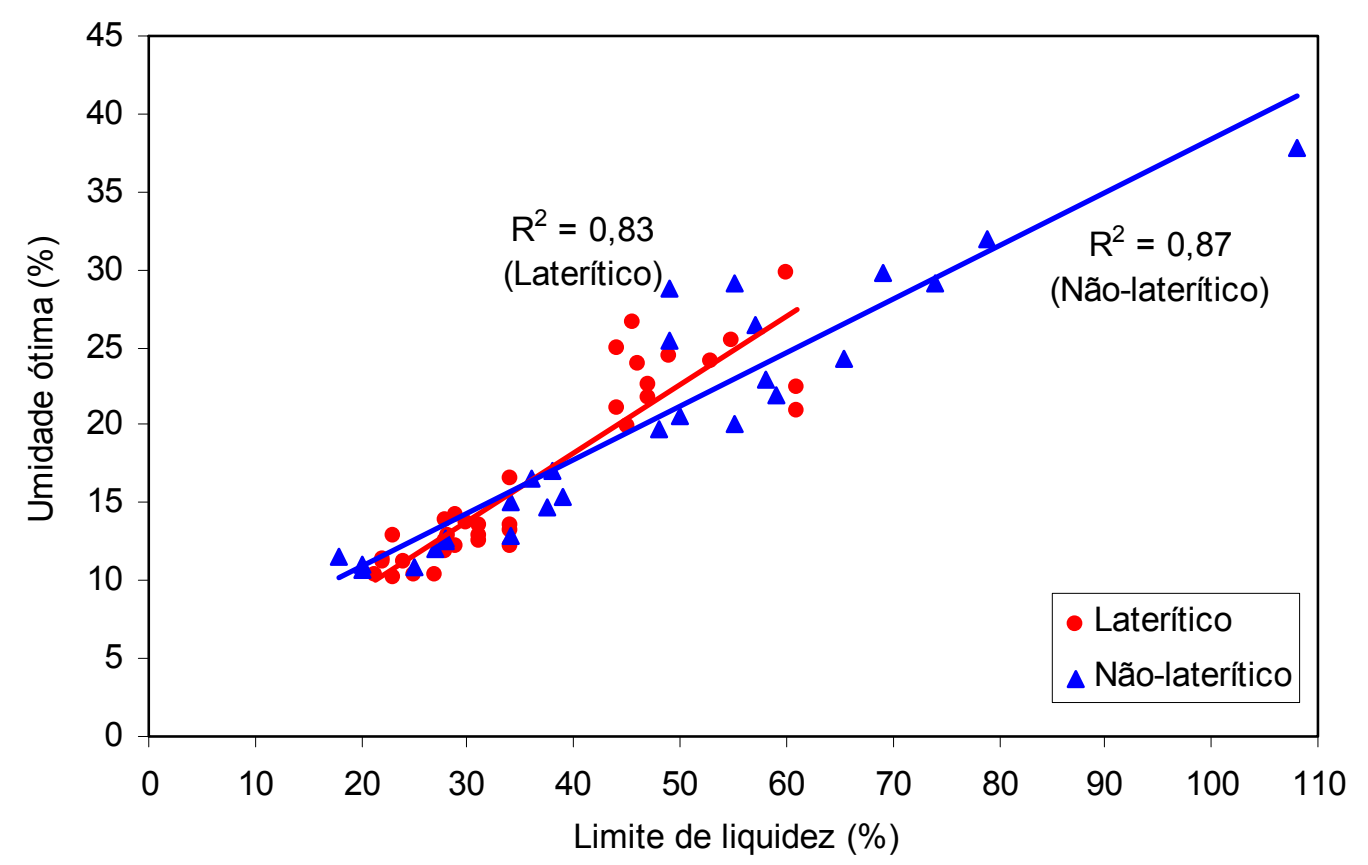

Figura 5.5: Limite de liquidez versus umidade ótima 


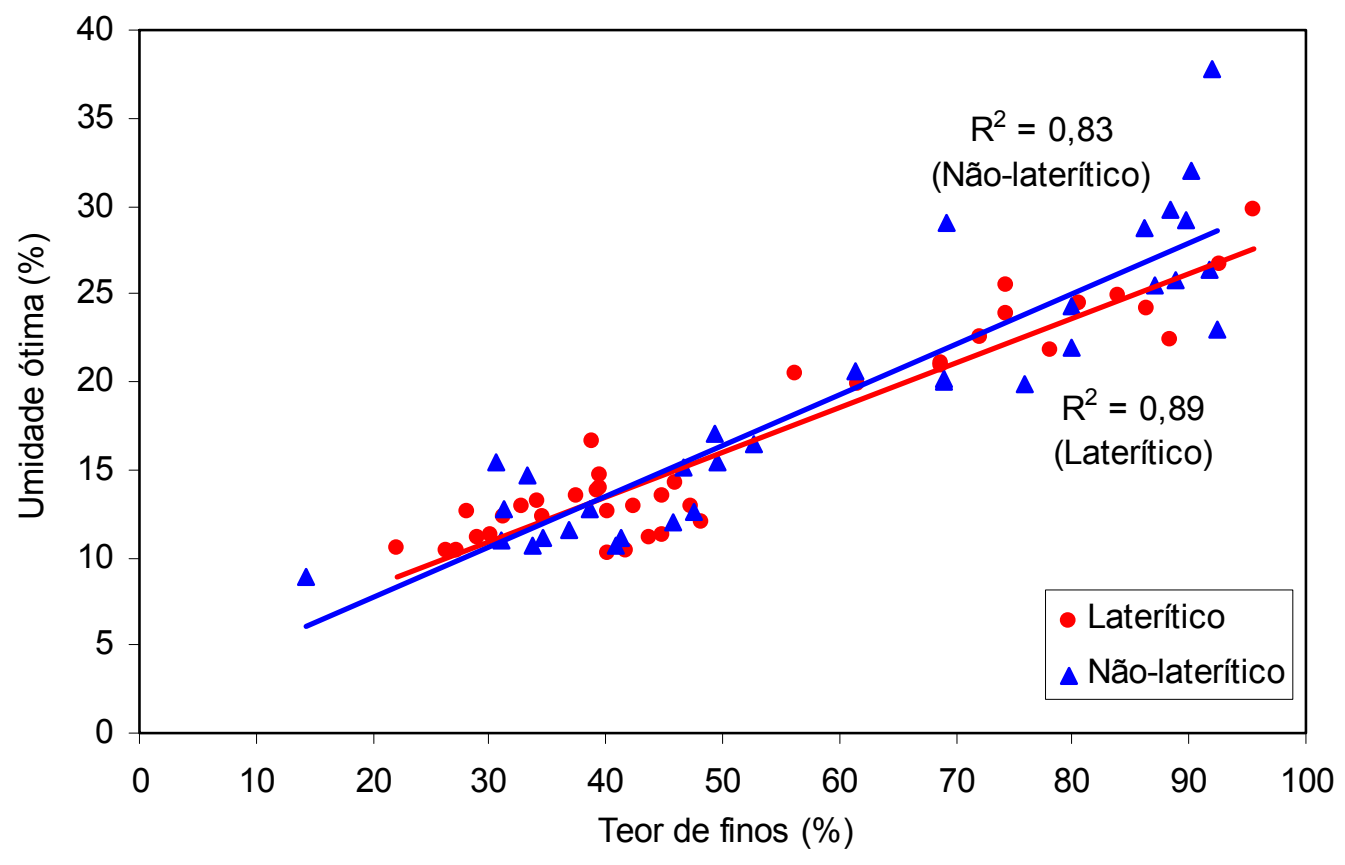

Figura 5.6: Teor de finos $\left(P_{200}\right)$ versus umidade ótima

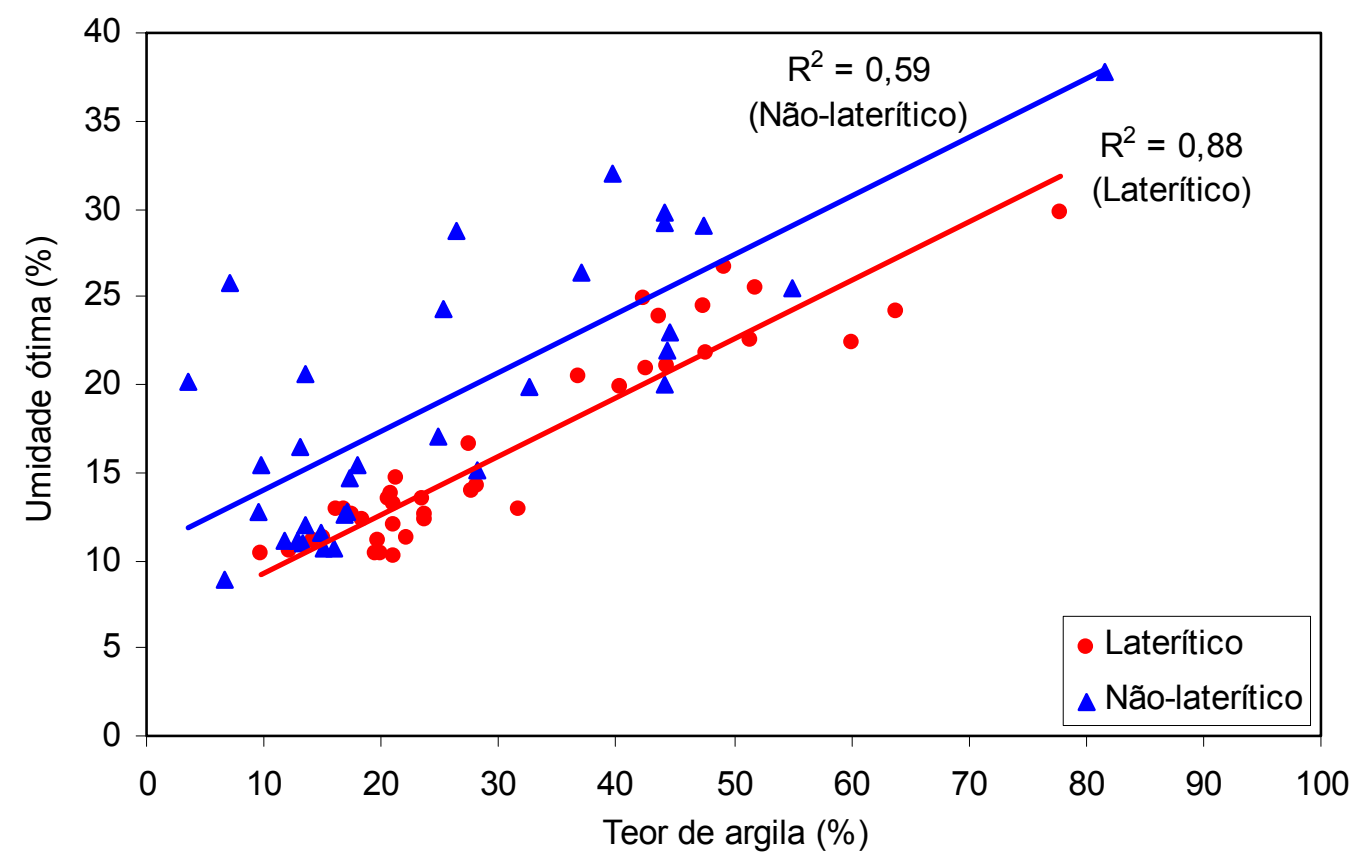

Figura 5.7: Teor de argila versus umidade ótima 


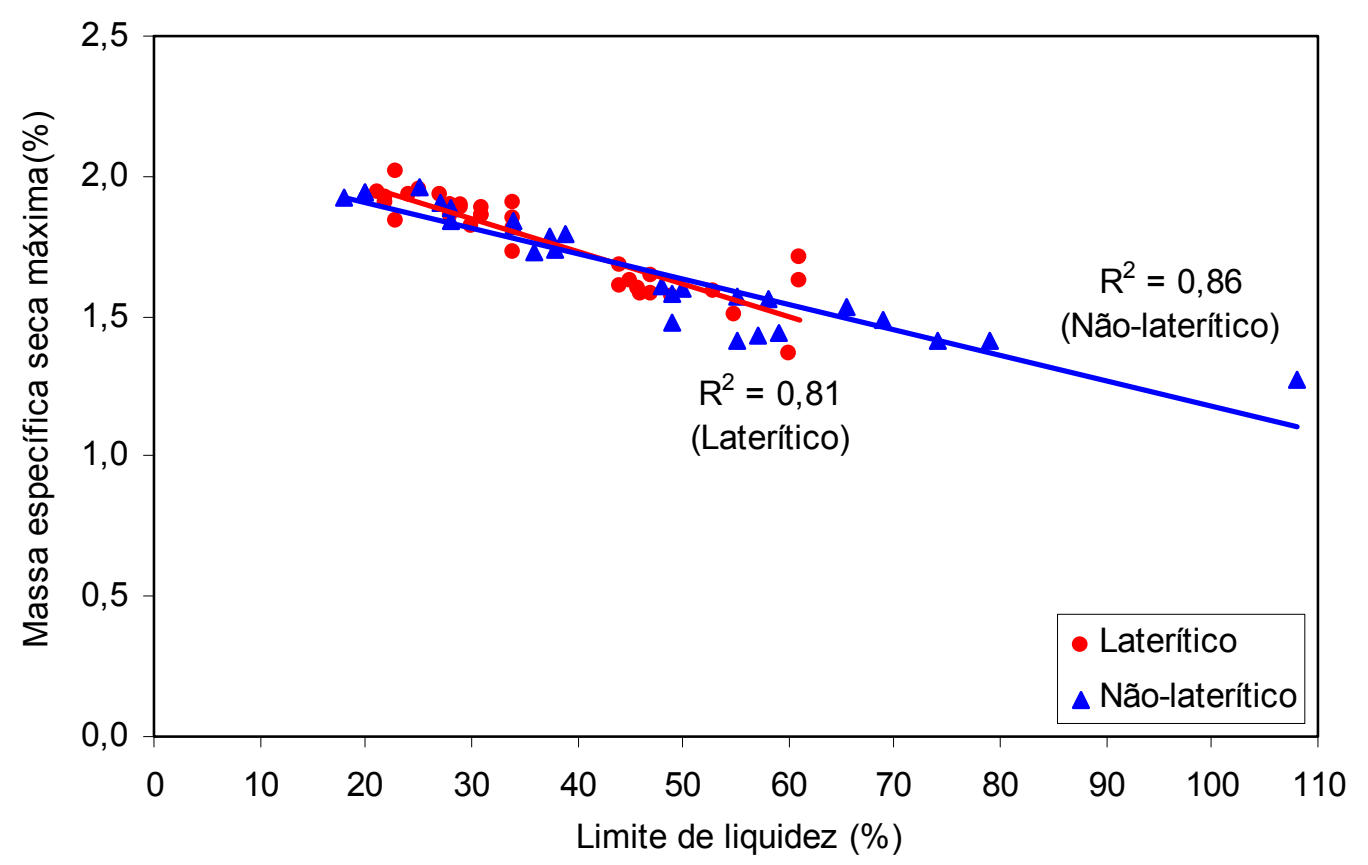

Figura 5.8: Limite de liquidez versus massa específica seca máxima

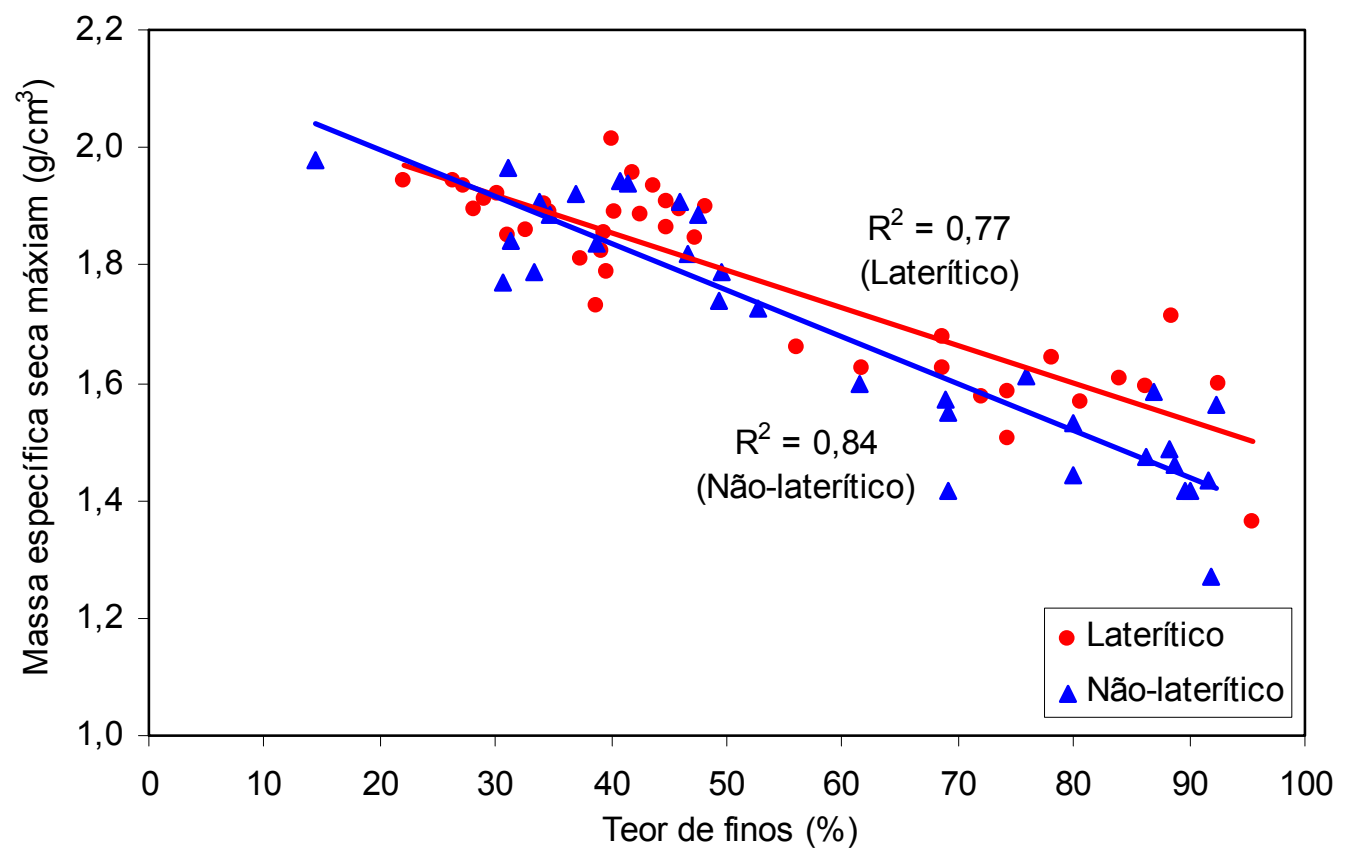

Figura 5.9: Teor de finos $\left(P_{200}\right)$ versus massa específica seca máxima 


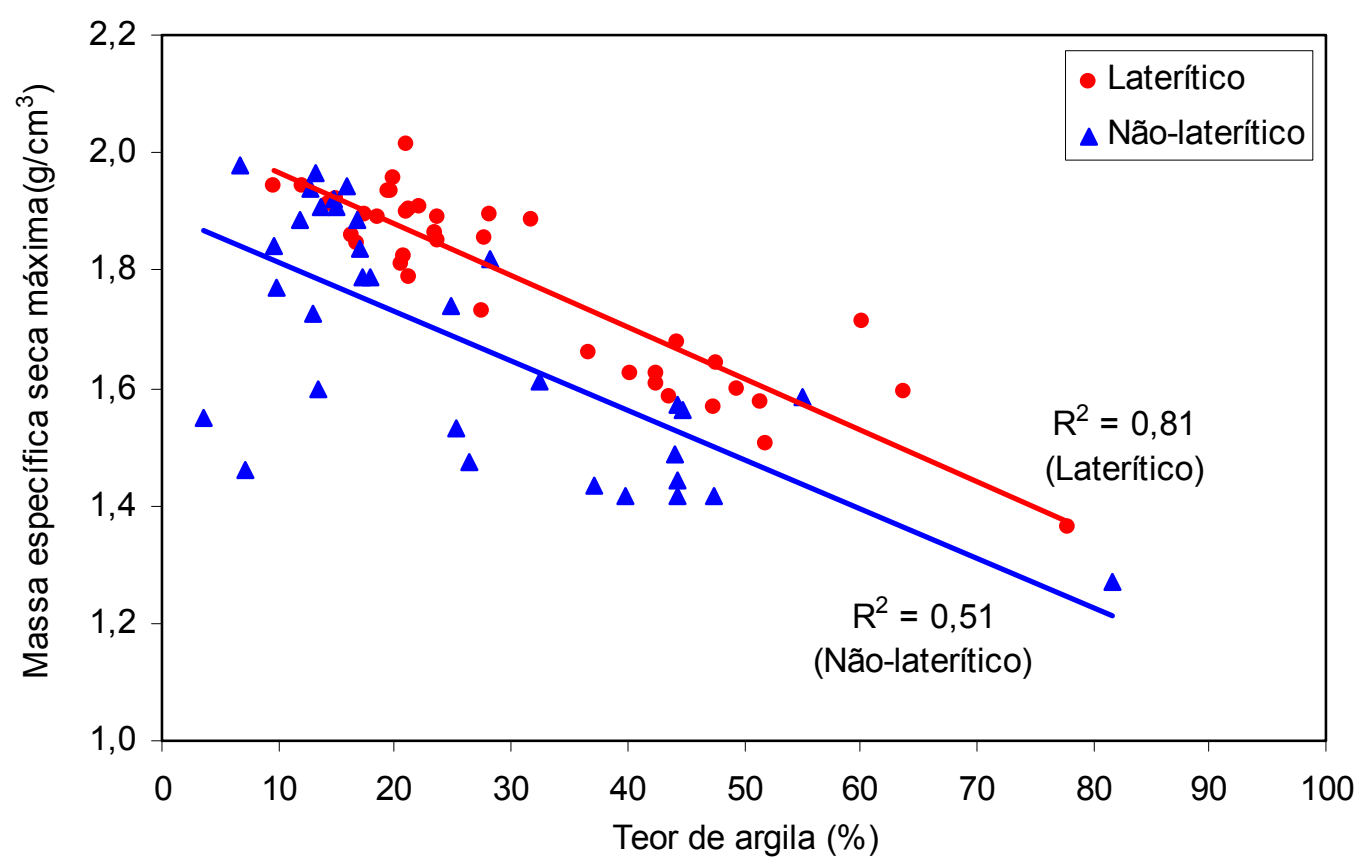

Figura 5.10: Teor de argila versus massa específica seca máxima

Ainda analisando-se as Figuras 5.7 e 5.10, observa-se que, para iguais teores de argila, a umidade ótima e a massa específica seca máxima de solos lateríticos, são respectivamente, na média e em valores absolutos, 4,63\% e 0,14 $\mathrm{g} / \mathrm{cm}^{3}$, menores e maiores que para os solos não-lateríticos.

Considerando-se a massa específica seca máxima, a diferença poderia ser explicada pela presença de minerais pesados na composição dos solos lateríticos, tais como a magnetita, ilmenita, entre outros óxidos e hidróxidos de ferro e alumínio, que contribuiriam para os valores mais elevados deste parâmetro. $\mathrm{E}$ ainda neste sentido, os solos lateríticos, no geral, apresentam índices de vazios inferiores aos dos solos não-lateríticos. Quanto à umidade ótima, a cimentação de partículas nos solos lateríticos induzida pela presença dos minerais já destacados contribuiria para a redução do valor do parâmetro em questão, pois causaria a diminuição da superfície específica das partículas da fração argilosa destes materiais.

O novo guia de dimensionamento da AASHTO - Guide for MechanisticEmpirical Design of New and Rehabilitated Pavement Structures - (NCHRP 1-37A, 2004) permite no nível hierárquico 2 de dimensionamento, conforme apresentado no Capítulo 2, o uso de correlações em detrimento da realização de ensaios para a determinação da umidade ótima $\left(w_{o}\right)$, massa específica seca máxima $\left(\rho_{\mathrm{dmax}}\right)$ e grau 
de saturação (S). No caso destas variáveis, as relações matemáticas indicadas são funções de propriedades físicas dos solos, tais como $P_{200}, \mathbb{P}, D_{60}$ e $\rho_{s}$, respectivamente teor de finos, índice de plasticidade, diâmetro com $60 \%$ das partículas passando e a massa específica dos sólidos. As relações preconizadas são apresentadas na Tabela 5.1.

Tabela 5.1: Relações matemáticas para determinação de parâmetros físicos dos solos no nível 2 do novo guia da AASHTO (NCHRP 1-37A)

$$
\begin{array}{lcc}
\text { Grau de saturação }-\mathrm{S}_{\mathrm{o}}(\%) & S_{0}=6,752 \cdot\left(P_{200} \cdot I P\right)^{0,147}+78 \\
\text { Umidade ótima }-\mathrm{w}_{\mathrm{o}}(\%) & \mathrm{Se}\left(\mathrm{P}_{200} \cdot \mathrm{IP}\right)>0 & w_{0}=1,3 \cdot\left(P_{200} \cdot I P\right)^{0,73}+11 \\
& \operatorname{Se}\left(\mathrm{P}_{200} \cdot \mathrm{IP}\right)=0 & w_{o}=8,6425 \cdot\left(D_{60}\right)^{-0,1038} \\
\begin{array}{l}
\text { Massa específica seca máxima } \\
-\rho_{\mathrm{dmax}}\left(\mathrm{g} / \mathrm{cm}^{3}\right)
\end{array} & \rho_{d \max }=\frac{\rho_{s}}{1+\frac{w_{o} \cdot \rho_{s}}{S_{o}}} \\
\hline
\end{array}
$$$$
w_{o}=8,6425 \cdot\left(D_{60}\right)^{-0,1038}
$$

Os modelos propostos pela AASHTO foram utilizados para os solos desta pesquisa para se testar a aplicabilidade dos mesmos aos nossos materiais. As Figuras 5.11, 5.12 e 5.13 apresentam, respectivamente, valores de umidade, massa específica e grau de saturação, calculados a partir das equações (5.1), (5.2), (5.3) e, (5.4) e os valores correspondentes destes mesmos parâmetros obtidos nos ensaios. Com o objetivo de facilitar a análise da existência de influência da gênese nos resultados, as figuras permitem distinguir solos lateríticos e não-lateríticos. Analisando-se as figuras em questão, poder-se-ia considerar como razoáveis as previsões obtidas para a umidade ótima e a massa específica seca máxima. 0 mesmo não se pode afirmar com relação ao grau de saturação, que mostrou uma grande discrepância entre os valores de laboratório e os previstos pelo modelo. No tocante à influência da gênese, não é possível identificar qualquer padrão que evidencie a diferença entre o comportamento de solos lateríticos ou não-lateríticos.

As Figuras 5.14 e 5.15 mostram as mesmas variáveis das Figuras 5.11 e 5.12, entretanto, destacando os solos segundo os critérios granulométricos adotados na pesquisa. 


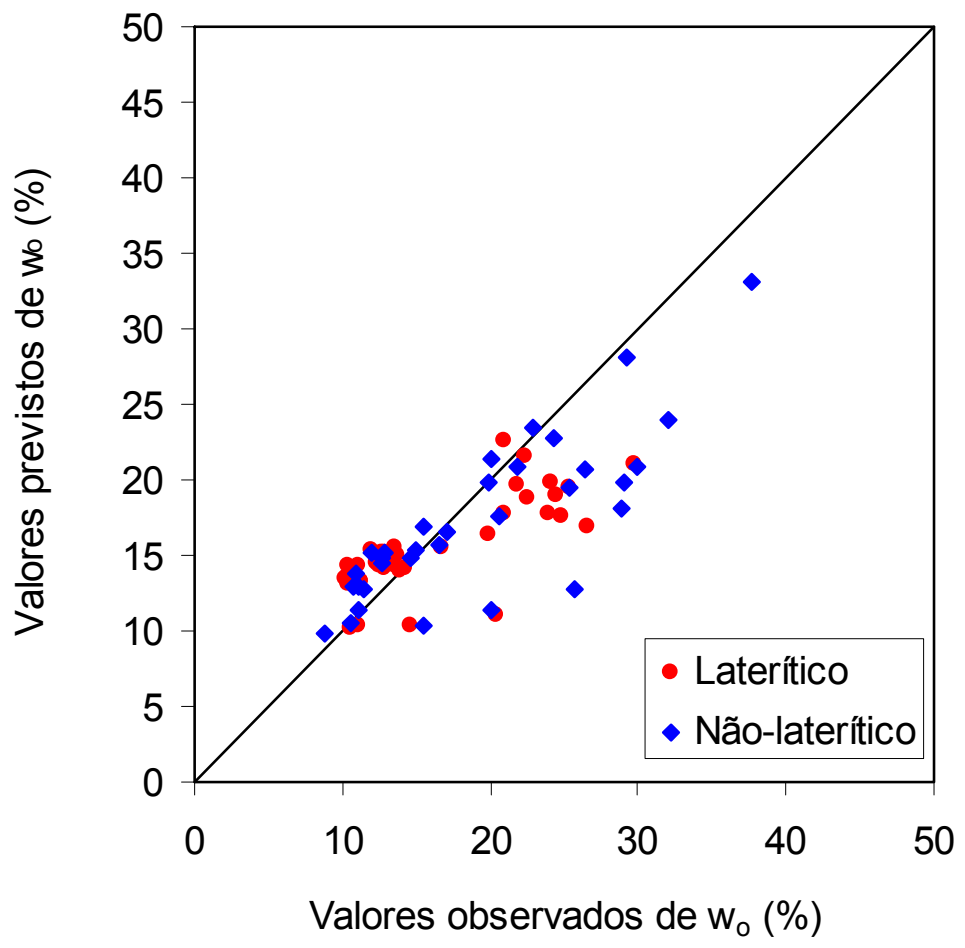

Figura 5.11: Valores observados de $w_{0}$ versus valores de $w_{0}$ previstos pelo modelo da AASHTO (equação (5.2) e (5.3)) (NCHRP 1-37A, 2004) - solos separados segundo o comportamento laterítico ou não-laterítico

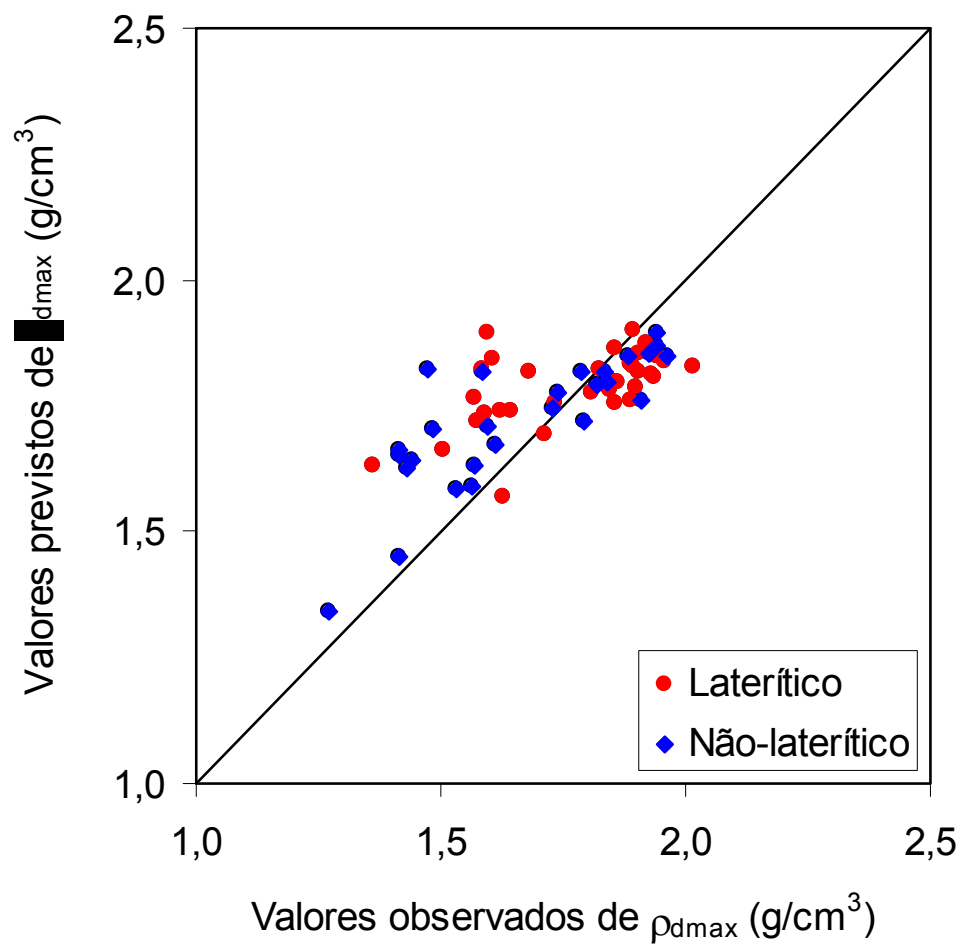

Figura 5.12: Valores observados de $\rho_{\mathrm{dmax}}$ versus valores de $\rho_{\mathrm{dmax}}$ previstos pelo modelo da AASHTO (equação (5.4)) (NCHRP 1-37A, 2004) - solos separados segundo o comportamento laterítico ou não-laterítico 


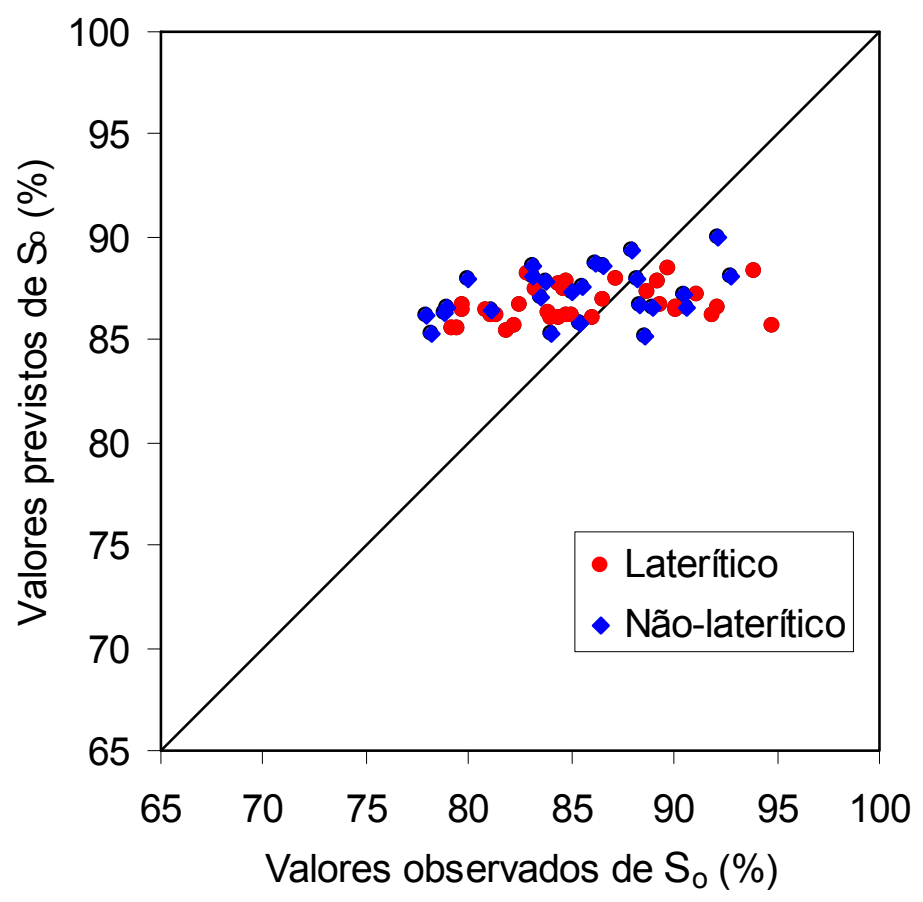

Figura 5.13: Valores observados de $S_{\circ}$ versus valores de $S_{\circ}$ previstos pelo modelo da AASHTO (equação (5.1)) (NCHRP 1-37A, 2004) - solos separados segundo o comportamento laterítico ou não-laterítico

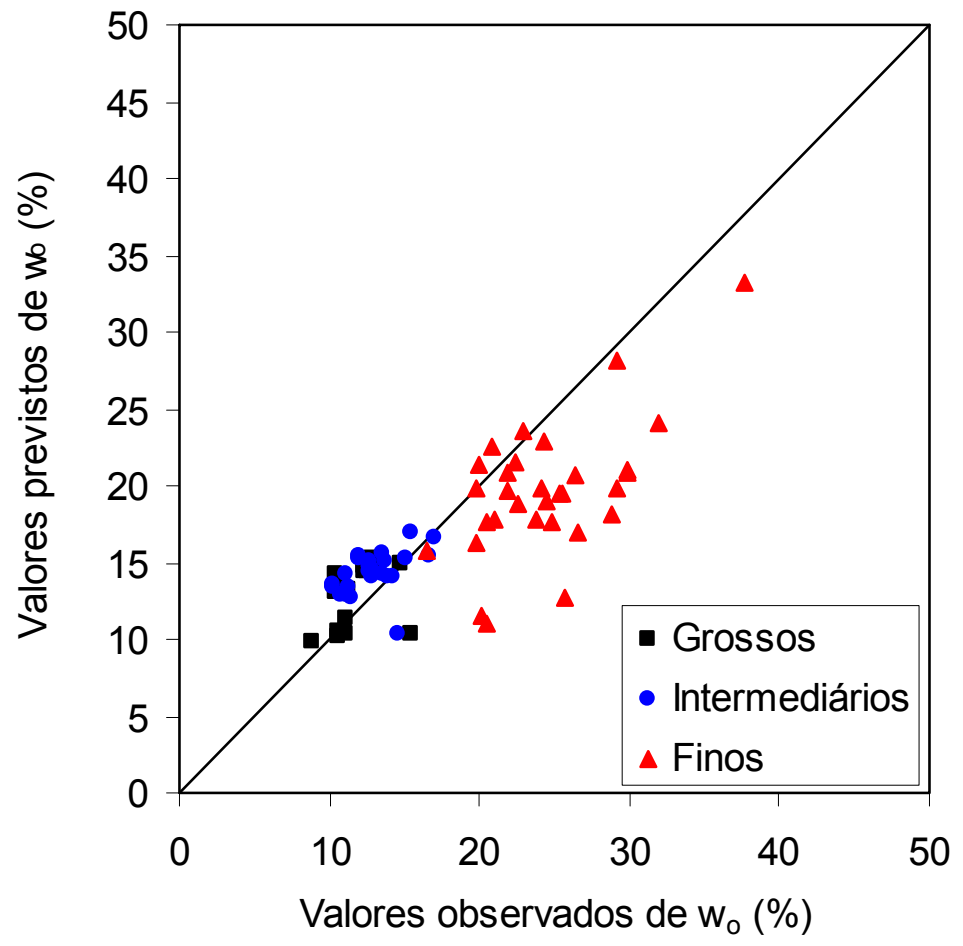

Figura 5.14: Valores observados de $w_{\mathrm{o}}$ versus valores de $w_{\mathrm{o}}$ previstos pelo modelo da AASHTO (equações (5.2) e (5.3)) (NCHRP 1-37A, 2004) - solos separados segundo a granulometria 


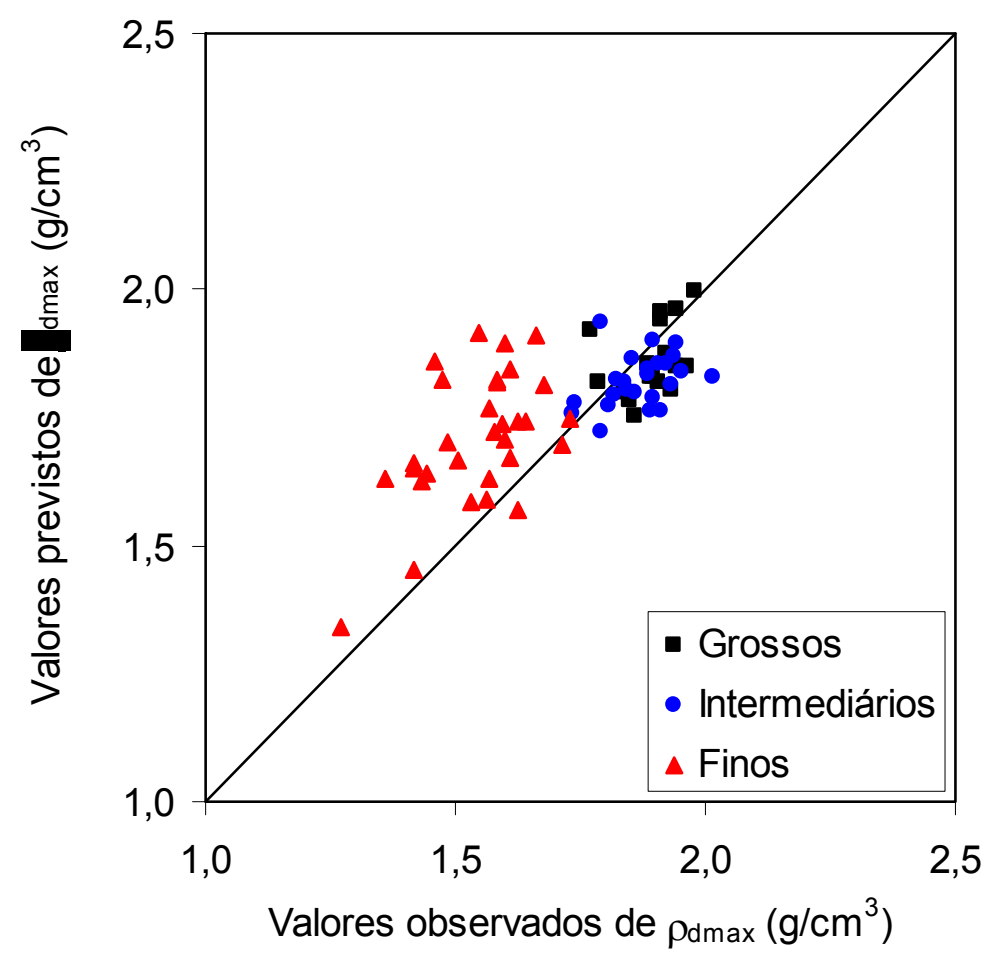

Figura 5.15: Valores observados de $\rho_{\mathrm{dmax}}$ versus valores de $\rho_{\mathrm{dmax}}$ previstos pelo modelo da AASHTO (equação (5.4)) (NCHRP 1-37A, 2004) - solos separados segundo a granulometria

Analisando-se as Figuras 5.14 e 5.15, observa-se, para a umidade ótima e massa específica seca máxima, respectivamente, que os solos agrupam-se em regiões distintas conforme suas granulometrias. Tem destaque o fato dos valores previstos para os solos grossos e intermediários apresentarem-se mais próximos dos reais quando comparados aos previstos para os solos finos. Isto indicaria que dentre os solos analisados, o comportamento dos materiais mais finos divergiriam, em maior grau, do comportamento dos solos americanos utilizados no desenvolvimento dos citados modelos que os solos mais grossos, possivelmente em razão dos solos finos, durante a sua formação, estarem mais sujeitos às condições do nosso clima tropical.

Considerando-se a grande discrepância entre os valores de grau de saturação previstos pela equação (5.1) e os determinados em laboratório, foram investigadas as relações entre este parâmetro e os valores de índice de plasticidade e teor de finos, parâmetros usados no modelo, e também, as relações com os valores de limite de liquidez e teor de argila, conforme ilustrado na Figura 5.16. Analisando-se esta figura, observa-se que não existem relações entre o grau 
de saturação e as variáveis consideradas para os solos estudados nesta pesquisa, explicando, neste caso, o desempenho ruim do modelo.
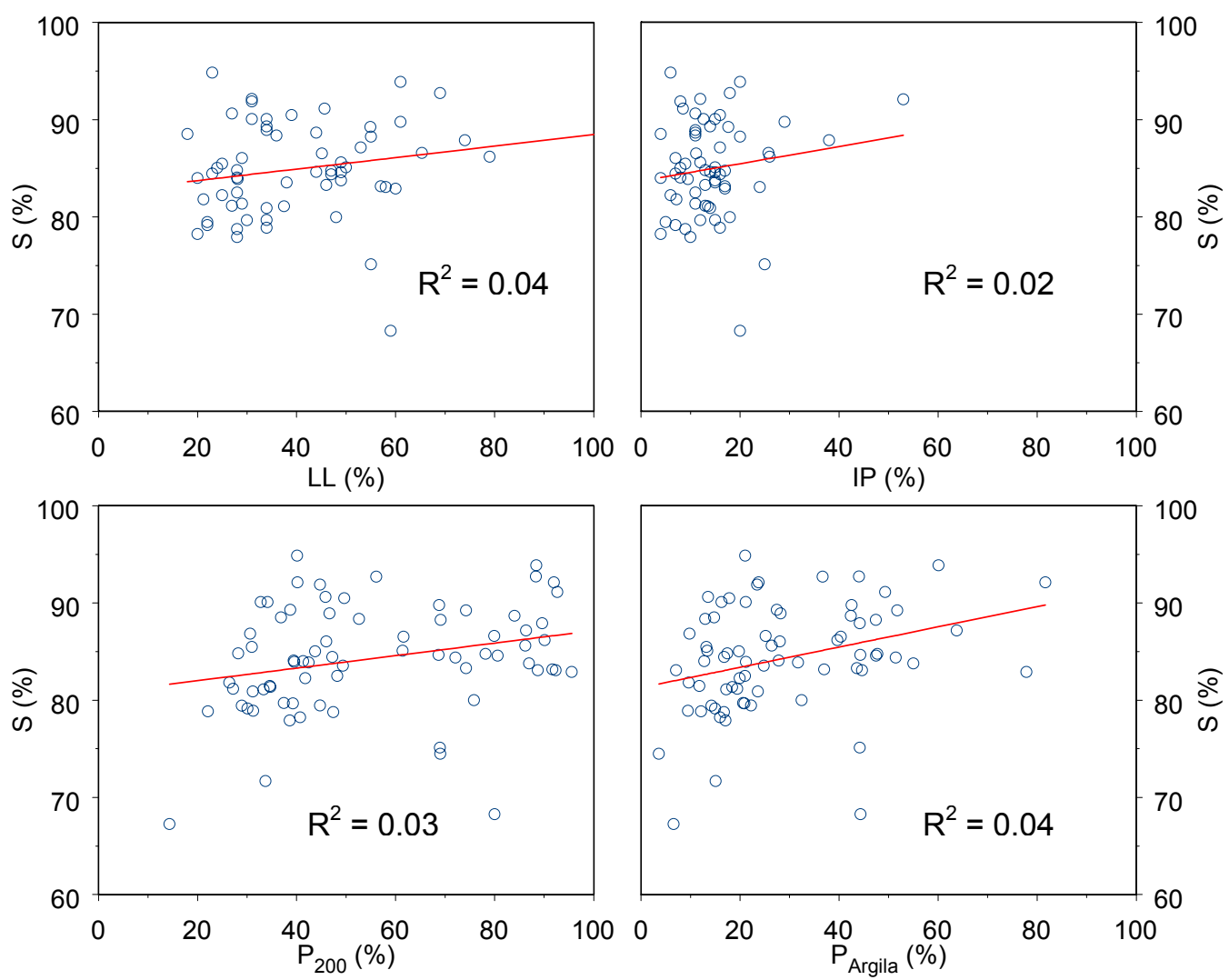

Figura 5.16: Relação entre o grau de saturação (S) e parâmetros físicos dos solos

$\mathrm{Na}$ continuidade dos estudos, optou-se por calibrar os modelos propostos pelo NCHRP 1-37A (2004) com os resultados dos ensaios obtidos nesta pesquisa. As relações matemáticas utilizadas são semelhantes às do novo guia da AASHTO, exceto para a massa específica seca máxima, para a qual se desenvolveu um modelo em função dos parâmetros físicos do solo, a exemplo do realizado para a umidade ótima e grau de saturação.

A primeira tentativa realizada foi para a umidade ótima, que da mesma forma que proposto no novo guia da AASHTO, separa os solos plásticos e nãoplásticos, respectivamente, equações (5.2) e (5.3). Conforme as observações anteriores, a umidade ótima apresenta uma relação melhor com o limite de liquidez do que com o índice de plasticidade. Assim, decidiu-se testar dois modelos para os solos plásticos, um considerando-se o LL e o $\mathrm{P}_{200}$ e outro, considerando-se o IP e o $\mathrm{P}_{200}$. As Tabelas 5.2 e 5.3 apresentam, respectivamente, as expressões analisadas 
em função do índice de plasticidade, limite de liquidez, teor de finos e diâmetro que passam $60 \%$ das partículas, e os correspondentes valores de regressão determinados.

Tabela 5.2: Modelos genéricos de regressão para a umidade ótima

\begin{tabular}{|c|c|c|c|c|c|c|}
\hline \multicolumn{7}{|c|}{ Umidade ótima (\%) } \\
\hline \multirow{2}{*}{\multicolumn{3}{|c|}{$\mathrm{Se}\left(\mathrm{P}_{200} \cdot \mathrm{IP}\right)>0$}} & \multicolumn{3}{|c|}{$w_{o}=a \cdot\left(P_{200} \cdot I P\right)^{b}+c$} & (5.5) \\
\hline & & & \multicolumn{3}{|c|}{$w_{o}=a \cdot\left(P_{200} \cdot L L\right)^{b}+c$} & (5.6) \\
\hline \multicolumn{3}{|c|}{$\mathrm{Se}\left(\mathrm{P}_{200} \cdot \mathrm{IP}\right)=0$} & \multicolumn{3}{|r|}{$w_{o}=a \cdot\left(D_{60}\right)^{b}$} & (5.7) \\
\hline \multicolumn{7}{|c|}{$\begin{array}{l}\text { Tabela 5.3: Resultados da regressão para modelagem da umidade ótima em função } \\
\text { dos parâmetros físicos dos solos }\end{array}$} \\
\hline \multicolumn{7}{|c|}{ Umidade ótima } \\
\hline Condição & a & $\mathrm{b}$ & c & $\mathrm{R}^{2}$ & Modelo & \\
\hline \multirow{2}{*}{$\left(\mathrm{P}_{200} \cdot \mathrm{IP}\right)>0$} & 6,048 & 0,2458 & $-12,422$ & 0,81 & $w_{o}=6,048 \cdot\left(P_{200} \cdot I P\right)^{0,2458}-12,4216$ & $(5.5)$ \\
\hline & 0,262 & 0,5311 & 1,984 & 0,93 & $w_{o}=0,262 \cdot\left(P_{200} \cdot L L\right)^{0,5311}+1,984$ & $(5.6)$ \\
\hline$\left(P_{200} \cdot I P\right)=0$ & 6,456 & $-0,374$ & --- & 0,67 & $w_{o}=6,456 \cdot\left(D_{60}\right)^{-0,374}$ & $(5.7)$ \\
\hline
\end{tabular}

Analisando-se a Tabela 5.3, observa-se que a expressão (5.6), em função do $P_{200}$ e LL, apresentou um valor de $R^{2}$ superior à expressão (5.5), em função do $\mathrm{P}_{200}$ e IP. Esta condição já era esperada pela melhor relação entre a umidade ótima e o limite de liquidez, conforme citado anteriormente. No caso dos solos nãoplásticos, a regressão conduziu a um valor de $R^{2}(0,67)$, apenas razoável, que pode ser explicado pelo pequeno número de amostras nesta condição, apenas dez, estudadas nesta pesquisa.

De modo geral, os valores previstos pelas equações (5.5), (5.6) e (5.7) produziram menores resíduos quando comparados aos resultantes do modelo da AASHTO (equações (5.2) e (5.3)). Esta situação pode ser vista ao se comparar os valores da soma dos quadrados dos resíduos (SQe), que no caso da previsão dos modelos da AASHTO resultou em um valor de 1380,6, para os modelos envolvendo as equações (5.5) e (5.7) resultou em 642,29 , e para os modelos com as equações (5.6) e (5.7) resultou em 305,62. Deste modo, pode-se de dizer que a última condição produziu os menores resíduos entre as analisadas, constituindo-se em 
modelos que explicam melhor as variações ocorridas na umidade ótima para os solos desta pesquisa.

A Figura 5.17 mostra os valores previstos pelas equações (5.6) e (5.7) contra os valores observados de $w_{0}$, separando os solos segundo os critérios granulométricos adotados na pesquisa. Esta figura ilustra a boa concordância entre os valores observados e previstos, e destaca, conforme já observado na Figura 5.14, que os solos grossos e intermediários, e os solos finos, agrupam-se em duas regiões distintas. No caso dos solos finos, a expressão conduz a resultados mais próximos à realidade que as previstas pela AASHTO, conforme as equações (5.2) e (5.3).

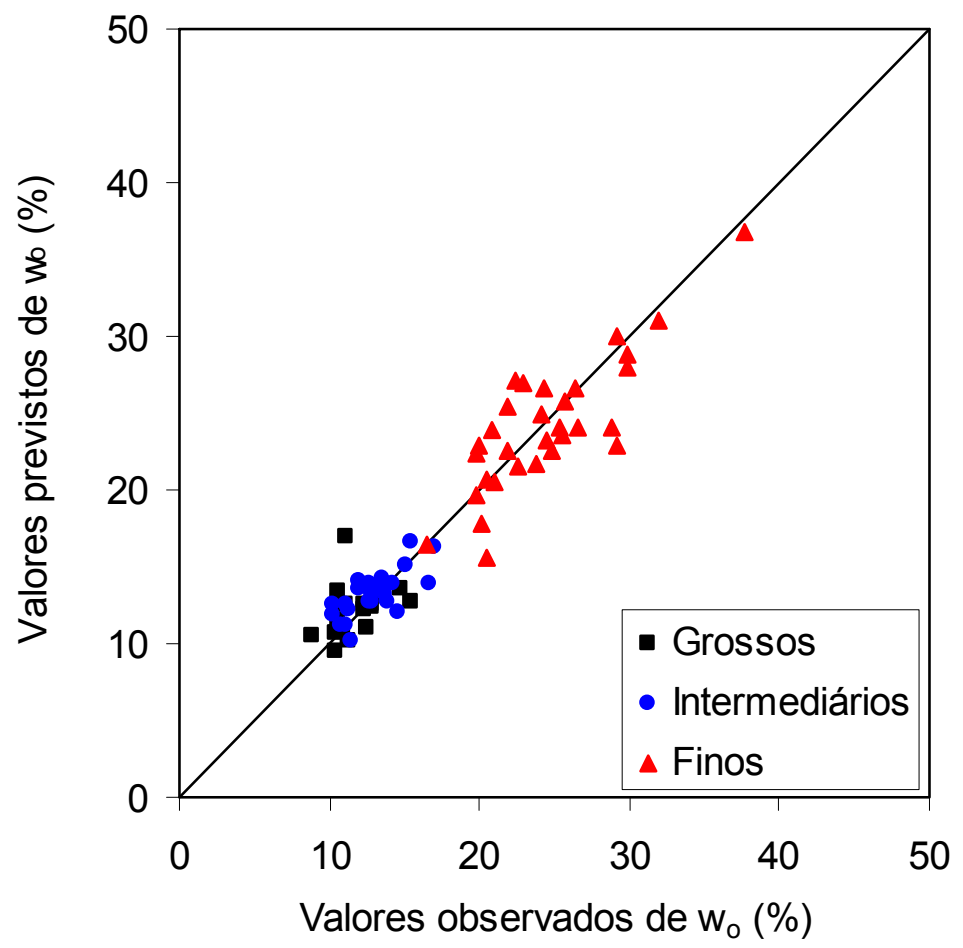

Figura 5.17: Valores observados de $w_{0}$ versus valores previstos pelas equações (5.6) e (5.7)

Com relação à massa específica seca máxima, procedeu-se uma análise semelhante à realizada com a umidade ótima, já que estas duas variáveis apresentaram uma excelente correlação entre si, conforme discutido anteriormente. As Tabelas 5.4 e 5.5 apresentam, respectivamente, as expressões analisadas em função do índice de plasticidade, limite de liquidez e teor de finos, e os correspondentes valores de regressão determinados. Não foi investigada uma relação que permitisse estimar-se o grau de saturação nos moldes do proposto pela 
AASHTO, equação (5.1), tendo em vista a dificuldade de relacionar-se o $S$ e as características dos solos, conforme já destacado anteriormente.

Tabela 5.4: Modelos genéricos de regressão para a massa específica seca máxima Massa específica seca máxima $\left(\mathrm{g} / \mathrm{cm}^{3}\right)$

\begin{tabular}{ccc}
\hline $\mathrm{Se}\left(\mathrm{P}_{200} \cdot \mathrm{IP}\right)>0$ & $\rho_{d \max }=a \cdot\left(P_{200} \cdot L L\right)^{b}+c$ & $(5.8)$ \\
\hline $\mathrm{Se}\left(\mathrm{P}_{200} \cdot \mathrm{IP}\right)=0$ & $\rho_{d \max }=a \cdot\left(D_{60}\right)^{b}$ & $(5.9)$ \\
\hline
\end{tabular}

Tabela 5.5: Resultados da regressão para modelagem da massa específica seca máxima em função dos parâmetros físicos dos solos

Umidade ótima

\begin{tabular}{ccccccc}
\hline Condição & $\mathrm{a}$ & $\mathrm{b}$ & $\mathrm{c}$ & $\mathrm{R}^{2}$ & Modelo & \\
\hline$\left(\mathrm{P}_{200} \cdot \mathrm{IP}\right)>0$ & 36,98 & $-0,007$ & $-33,415$ & 0,89 & $\rho_{d \max }=36,977 \cdot\left(P_{200} \cdot L L\right)^{-0,0067}-33,415$ & $(5.8)$ \\
\hline$\left(\mathrm{P}_{200} \cdot \mathrm{IP}\right)=0$ & 2,30 & 0,121 & -- & 0,70 & $\rho_{d \max }=2,303 \cdot\left(D_{60}\right)^{0,121}$ & $(5.9)$ \\
\hline
\end{tabular}

A Figura 5.18 mostra os valores previstos pelas equações (5.8) e (5.9) contra os valores observados de $\rho_{\mathrm{dmax}}$, separando os solos segundo os critérios granulométricos adotados na pesquisa.

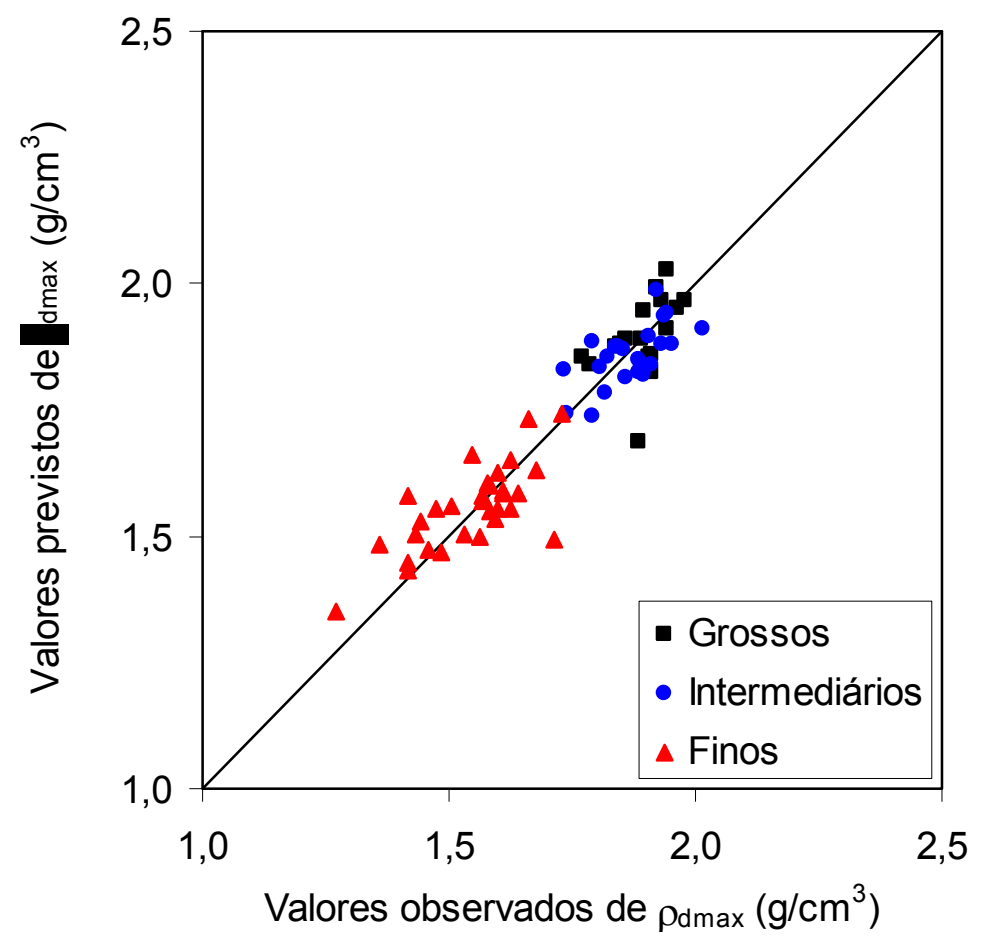

Figura 5.18: Valores observados de $\rho_{\mathrm{dmax}}$ versus valores previstos pelas equações (5.8) e (5.9) 
Os valores previstos pelas equações (5.8) e (5.9) produziram menores resíduos (SQe igual 0,317) quando comparados aos resultantes do modelo da AASHTO (equação 5.4) (SQe igual 1,498). Assim, pode-se dizer que as calibrações desenvolvidas explicam melhor as variações ocorridas na massa específica seca máxima para os solos desta pesquisa.

A Figura 5.18 ilustra a boa concordância entre os valores observados e previstos, e destaca, conforme já observado na Figura 5.14, que os solos grossos e intermediários, e os solos finos, agrupam-se em duas regiões distintas. Nos casos dos solos finos, a expressão conduz a resultados mais próximos à realidade que as previstas pela AASHTO, conforme a equação (5.4).

\subsection{Ensaios triaxiais cíclicos}

Inicialmente, compararam-se os desempenhos de cinco modelos matemáticos, selecionados dentre aqueles citados no Capítulo 2, na representação da variação do módulo de resiliência em função do estado de tensão. Em seguida, foram analisados os valores deste parâmetro considerando-se a gênese e a granulometria dos solos estudados. E finalmente, investigou-se o efeito da variação da umidade na rigidez dos materiais, ainda sob o aspecto das variáveis destacadas anteriormente.

Ressalta-se que as análises que se seguem baseiam-se nos resultados obtidos para a seqüência de ensaio correspondente ao subleito, visto que o objetivo principal da pesquisa é analisar o comportamento dos materiais constituintes desta camada do pavimento.

\subsubsection{Variação do módulo de resiliência com o estado de tensão}

\subsubsection{Calibração e desempenho dos modelos na representação do módulo de resiliência com o estado de tensão}

O valor do módulo de resiliência é muito variável, podendo ser influenciado, entre outros fatores, pelo estado de tensão. Conforme apresentado no Capítulo 2, 
existem diversos modelos matemáticos que permitem representar o módulo de resiliência em função desta variável. Dentre eles, foram selecionados cinco modelos que tiveram seus desempenhos avaliados a partir do coeficiente de determinação $\left(R^{2}\right)$ de cada um deles. As expressões analisadas são funções da tensão desvio $\left(\sigma_{d}\right)$, tensão confinante $\left(\sigma_{3}\right)$, primeiro invariante de tensão $(\theta)$ e tensão cisalhante octaédrica $\left(\tau_{\text {oct }}\right)$. A Tabela 5.6 apresenta os modelos escolhidos para o estudo.

Tabela 5.6 - Modelos avaliados na representação do $M_{R}$ em função do estado de tensão

\begin{tabular}{llc}
\hline & Modelo & Equação \\
\hline$\left(\mathrm{k}-\sigma_{\mathrm{d}}\right)$ & $M_{R}=k_{1} \sigma_{d}^{k_{2}}$ & $(5.10)$ \\
$\left(\mathrm{k}-\sigma_{3}\right)$ & $M_{R}=k_{1} \sigma_{3}^{k_{3}}$ & $(5.11)$ \\
$(\mathrm{k}-\theta)$ & $M_{R}=k_{1} \theta^{k_{3}}$ & $(5.12)$ \\
Composto $\left(\mathrm{k}-\sigma_{\mathrm{d}}-\sigma_{3}\right)$ & $M_{R}=k_{1} \sigma_{d}^{k_{2}} \sigma_{3}^{k_{3}}$ & $(5.13)$ \\
Universal da AASHTO $\left(\mathrm{k}-\theta-\tau_{\text {oct }}\right)$ & $M_{R}=k_{1} p_{a}\left(\frac{\theta}{p_{a}}\right)^{k_{2}}\left(\frac{\tau_{\text {oct }}}{p_{a}}+1\right)^{k_{3}}$ & \\
\hline
\end{tabular}

É importante ressaltar que a modelagem foi realizada utilizando-se um programa estatístico, onde foram lançados os valores de módulo de resiliência em MPa e os valores das tensões em $\mathrm{kPa}$. As unidades adotadas não se refletem nos valores $k_{2}$ e $k_{3}$, fazendo diferença apenas nos valores de $k_{1}$, que serão 1.000 vezes maiores do que os aqui apresentados, quando $\circ M_{R}$ e as tensões forem consideradas em $\mathrm{kPa}$.

A Tabela 5.7 apresenta os coeficientes de determinação $\left(R^{2}\right)$ para as regressões determinadas a partir de corpos-de-prova compactados na umidade ótima e massa específica seca máxima do Proctor Normal e ensaiados nesta condição. $\mathrm{Na}$ tabela, os solos foram agrupados segundo os critérios granulométricos adotados na pesquisa, e calcularam-se, apenas para efeito de comparação, os valores médios de $\mathrm{R}^{2}$ para cada um dos modelos estudados. 
Tabela 5.7: Coeficientes de determinação $\left(R^{2}\right)$ dos modelos (5.10), (5.11), (5.12), (5.13) e (5.14) para os solos ensaiados na umidade ótima

\begin{tabular}{|c|c|c|c|c|c|c|}
\hline & $\begin{array}{c}\text { Modelo } \\
\text { Equação }\end{array}$ & $\begin{array}{l}\left(k-\sigma_{d}\right) \\
(5.10) \\
\end{array}$ & $\begin{array}{l}\left(\mathbf{k}-\sigma_{3}\right) \\
(5.11) \\
\end{array}$ & $\begin{array}{r}(k-\theta) \\
(5.12) \\
\end{array}$ & $\begin{array}{c}\left(\mathbf{k}-\sigma_{\mathrm{d}}-\sigma_{3}\right) \\
(5.13) \\
\end{array}$ & $\begin{array}{c}\left(k-\theta-\tau_{\text {oct }}\right) \\
(5.14)\end{array}$ \\
\hline & upo/Amostra & $\mathbf{R}^{2}$ & $\mathbf{R}^{2}$ & $\mathbf{R}^{2}$ & $\mathbf{R}^{2}$ & $\mathbf{R}^{2}$ \\
\hline \multirow{7}{*}{ 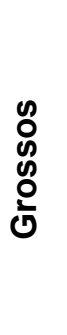 } & 1L (76) & 0,92 & 0,05 & 0,04 & 0,98 & 0.94 \\
\hline & $1 \mathrm{Na}(81)$ & 0,22 & 0,69 & 0,36 & 0,98 & 0.99 \\
\hline & $1 \mathrm{Nb}(85)$ & 0,93 & 0,05 & 0,03 & 1,00 & 0.95 \\
\hline & $2 L(17)$ & 0,81 & 0,16 & 0,00 & 0,98 & 0.94 \\
\hline & $2 \mathrm{~N}(11)$ & 0,88 & 0,02 & 0,07 & 0,92 & 0.95 \\
\hline & $3 N(89)$ & --- & --- & --- & --- & --- \\
\hline & 4L (50) & 0,27 & 0,66 & 0,26 & 0,99 & 0.97 \\
\hline \multirow{7}{*}{ 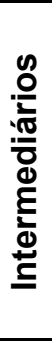 } & $5 \mathrm{~N}(55)$ & 0,72 & 0,24 & 0,01 & 0,98 & 0.94 \\
\hline & $5 \mathrm{~L}(60)$ & 0,66 & 0,26 & 0,03 & 0,96 & 0.97 \\
\hline & $6 N(27)$ & 0,88 & 0,09 & 0,01 & 0,97 & 0.98 \\
\hline & $6 \mathrm{La}(30)$ & 0,76 & 0,19 & 0,00 & 0,95 & 0.99 \\
\hline & 6Lb (57) & 0,91 & 0,07 & 0,03 & 0,99 & 0.96 \\
\hline & 7L (46) & 0,83 & 0,13 & 0,01 & 0,97 & 0.98 \\
\hline & $8 \mathrm{~L}(88)$ & 0,61 & 0,29 & 0,05 & 0,99 & 0.98 \\
\hline \multirow{16}{*}{$\stackrel{\mathscr{0}}{\stackrel{0}{=}}$} & $9 \mathrm{~L}(21)$ & 0,90 & 0,07 & 0,03 & 0,99 & 0.97 \\
\hline & $9 \mathrm{~N}(77)$ & 0,86 & 0,09 & 0,02 & 0,96 & 0.97 \\
\hline & $10 \mathrm{~L}(38)$ & 0,91 & 0,06 & 0,04 & 0,99 & 0.94 \\
\hline & $10 N(53)$ & 0,88 & 0,00 & 0,15 & 0,92 & 0.96 \\
\hline & 11La (48) & 0,86 & 0,07 & 0,03 & 0,94 & 0.91 \\
\hline & 11Lb (91) & 0,92 & 0,05 & 0,02 & 0,98 & 0.98 \\
\hline & $11 N(78)$ & 0,95 & 0,00 & 0,21 & 0,95 & 0.92 \\
\hline & $12 L(25)$ & 0,97 & 0,02 & 0,10 & 0,99 & 0.91 \\
\hline & $12 \mathrm{Na}(22)$ & 0,93 & 0,00 & 0,26 & 0,95 & 0.91 \\
\hline & $12 \mathrm{Nb}(34)$ & 0,99 & 0,00 & 0,18 & 0,99 & 0.92 \\
\hline & $13 L(67)$ & 0,93 & 0,04 & 0,06 & 0,97 & 0.94 \\
\hline & $13 N(39)$ & 0,97 & 0,00 & 0,25 & 0,97 & 0.96 \\
\hline & 14L (71) & 0,95 & 0,03 & 0,07 & 0,99 & 0.97 \\
\hline & $14 \mathrm{Na}(65)$ & 0,86 & 0,08 & 0,45 & 0,94 & 0.90 \\
\hline & $14 \mathrm{Nb}(86)$ & 0,97 & 0,01 & 0,11 & 0,99 & 0.98 \\
\hline & $15 \mathrm{~N}(64)$ & 0,93 & 0,05 & 0,02 & 0,99 & 0.94 \\
\hline \multicolumn{2}{|r|}{$\mathbf{R}^{2}$ médio } & 0.83 & 0,12 & 0,10 & 0,97 & 0,95 \\
\hline
\end{tabular}

Salienta-se que as regressões foram realizadas apenas a partir de ensaios onde se obteve um número mínimo de doze pontos, correspondentes a doze diferentes estágios de tensão. Caso contrário desconsideravam-se os resultados e um novo corpo-de-prova era ensaiado.

$\mathrm{Na}$ Tabela 5.7, não são apresentados os resultados correspondentes à amostra $3 N$ (89). Para este solo, analisando-se os resultados de $M_{R}$ obtidos numa 
etapa posterior do estudo, verificou-se que os corpos-de-prova ensaiados em condições variadas de umidades apresentaram valores muito próximos de módulo de resiliência. Na investigação deste fato, observou-se que o grau de saturação (S) correspondente à umidade ótima era um valor muito abaixo do esperado nesta condição, aproximadamente $67 \%$, indicando que, provavelmente, ocorrera erro na determinação da mesma. Dessa forma, para não comprometer o estudo, optou-se por não considerar os resultados correspondentes a esta amostra nas análises que se seguem.

Analisando-se a Tabela 5.7, observa-se que os modelos $\left(k-\sigma_{3}\right)$ e $(k-\theta)$, respectivamente equações (5.11) e (5.12), não mostraram um bom desempenho na representação do $M_{R}$ em função do estado de tensão para o conjunto de solos estudados, conduzindo a valores de $R^{2}$ baixos se comparados aos demais modelos. Contrapondo-se a estes modelos, observa-se o bom desempenho dos modelos $\left(\mathrm{k}-\sigma_{\mathrm{d}}\right)$, composto $\left(\mathrm{k}-\sigma_{\mathrm{d}}-\sigma_{3}\right)$ e universal da AASHTO (k- $\left.\theta-\tau_{\text {oct }}\right)$, respectivamente, equações (5.10), (5.13) e (5.14). Neste caso, os desempenhos dos dois últimos destacam-se quando comparados com o do primeiro. Esta constatação é confirmada quando são comparados os valores médios de $\mathrm{R}^{2}$, onde se observa que os modelos $\left(k-\sigma_{d}-\sigma_{3}\right)$ e $\left(k-\theta-\tau_{\text {oct }}\right)$ apresentaram valores de $R^{2}$ iguais a 0,97 e 0,95 , respectivamente, enquanto os modelos $\left(k-\sigma_{d}\right),\left(k-\sigma_{3}\right)$ e $(k-\theta)$, apresentaram valores iguais a $0,83,0,12$ e 0,10 , respectivamente.

Portanto, considerando-se o valor de $\mathrm{R}^{2}$ como parâmetro comparativo para se avaliar o desempenho dos modelos na representação do $M_{R}$ em função do estado de tensão, conclui-se que os melhores resultados correspondem aos modelos composto e universal da AASHTO. Estes modelos apresentam coeficientes de determinação equivalentes entre si, visto que as diferenças observadas são pouco significativas, e na grande maioria dos casos, iguais ou superiores aos demais modelos analisados.

Considerando-se o desempenho equivalente dos modelos composto e universal, e a tendência observada em nosso país de se privilegiar a utilização do primeiro deles, as análises que se seguem serão realizadas com base neste modelo. Para ilustrar o bom desempenho do modelo composto, a Figura 5.19 mostra o gráfico em que são apresentados os valores observados nos ensaios e os 
valores previstos pelo modelo composto (equação (5.13)), para os solos ensaiados na umidade ótima.

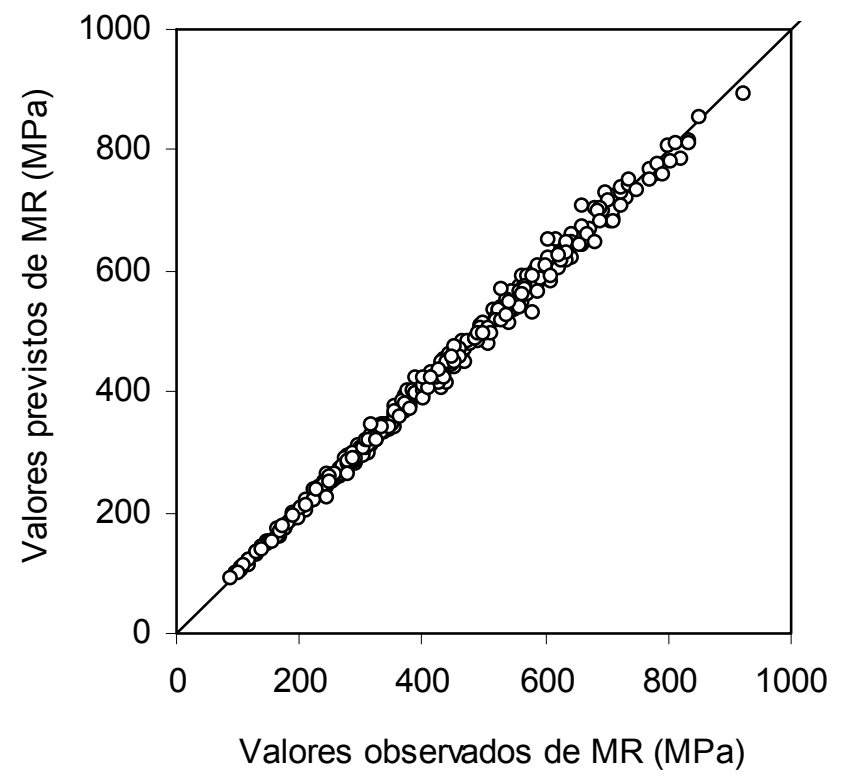

Figura 5.19: Valores observados de $M_{R}$ versus valores previstos de $M_{R}$ pelo modelo composto para corpos-de-prova ensaiados na umidade ótima

Complementando a análise comparativa do desempenho dos diversos modelos estudados, e considerando-se os resultados de $\mathrm{R}^{2}$ obtidos em ensaios realizados após a variação de umidade pós-compactação, conforme apresentado no Anexo I, observa-se a repetição do mesmo padrão já destacado para corpos-deprova ensaiados na umidade ótima. Deve-se salientar ainda, que o desempenho do modelo composto para todos os níveis de umidade é excelente, apresentando sempre valores de $R^{2}$ superiores a 0,90 , limite inferior estabelecido pelo NCHRP 137A (2004), a partir do qual se aconselha a repetição do ensaio ou a avaliação de um outro modelo.

\subsubsection{Análise da influência do estado de tensão no módulo de resiliência}

Para um solo, quando se analisam comparativamente os valores de $k_{2}$ e $k_{3}$ do modelo composto, expoentes, respectivamente, das tensões desvio e confinante, é possível associar ao valor mais elevado de um deles, a maior influência no módulo resiliência da tensão que lhe é relacionada, visto que as variações destas tensões durante os ensaios são de mesma ordem. Por outro lado, expoentes positivos ou negativos indicam que variações positivas da tensão 
contribuem, respectivamente, para o aumento ou diminuição do módulo de resiliência.

A Tabela 5.8 apresenta os valores de $k_{1}, k_{2}$ e $k_{3}$ do modelo composto e os respectivos coeficientes de determinação para as regressões realizadas a partir de corpos-de-prova ensaiados na umidade ótima. Os resultados foram agrupados segundo os critérios granulométricos adotados na pesquisa.

Tabela 5.8: Parâmetros de regressão $k_{1}, k_{2}$ e $k_{3}$ do modelo 5.13, e coeficientes de determinação $\left(R^{2}\right)$ para os solos ensaiados na umidade ótima

\begin{tabular}{|c|c|c|c|c|c|}
\hline & \multirow{2}{*}{ Amostra } & \multicolumn{4}{|c|}{ Modelo $\left(k-\sigma_{d}-\sigma_{3}\right)-(5.13)$} \\
\hline & & $k_{1}$ & $k_{2}$ & $k_{3}$ & $\mathbf{R}^{2}$ \\
\hline \multirow{7}{*}{ 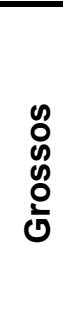 } & $1 \mathrm{~L}(76)$ & 519 & $-0,24$ & 0,08 & 0,98 \\
\hline & $1 \mathrm{Na}(81)$ & 214 & $-0,29$ & 0,38 & 0,98 \\
\hline & $1 \mathrm{Nb}(85)$ & 607 & $-0,48$ & 0,16 & 1,00 \\
\hline & $2 \mathrm{~N}(17)$ & 430 & $-0,28$ & 0,16 & 0,98 \\
\hline & $2 L(11)$ & 850 & $-0,31$ & 0,08 & 0,92 \\
\hline & $3 N(89)$ & --- & -- & --- & --- \\
\hline & 4L (50) & 117 & $-0,21$ & 0,43 & 0,99 \\
\hline \multirow{7}{*}{ 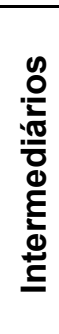 } & $5 \mathrm{~N} \mathrm{(55)}$ & 230 & $-0,34$ & 0,26 & 0,98 \\
\hline & $5 \mathrm{~L}(60)$ & 805 & $-0,38$ & 0,20 & 0,96 \\
\hline & $6 N(27)$ & 1076 & $-0,24$ & 0,06 & 0,97 \\
\hline & $6 \mathrm{La}(30)$ & 838 & $-0,23$ & 0,15 & 0,95 \\
\hline & $6 \mathrm{Lb}(57)$ & 674 & $-0,28$ & 0,11 & 0,99 \\
\hline & $7 \mathrm{~L}(46)$ & 864 & $-0,46$ & 0,26 & 0,97 \\
\hline & $8 \mathrm{~L}(88)$ & 1070 & $-0,67$ & 0,42 & 0,99 \\
\hline \multirow{16}{*}{ 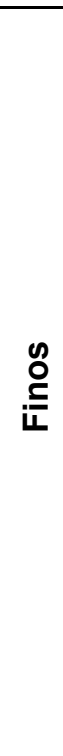 } & 9L (21) & 653 & $-0,33$ & 0,14 & 0,99 \\
\hline & $9 \mathrm{~N}(77)$ & 554 & $-0,17$ & 0,08 & 0,96 \\
\hline & $10 \mathrm{~L}(38)$ & 853 & $-0,33$ & 0,13 & 0,99 \\
\hline & $10 N(53)$ & 378 & $-0,13$ & 0,01 & 0,92 \\
\hline & 11La (48) & 867 & $-0,23$ & 0,09 & 0,94 \\
\hline & 91Lb (91) & 1308 & $-0,34$ & 0,07 & 0,98 \\
\hline & $11 \mathrm{~N}(78)$ & 963 & $-0,21$ & 0,00 & 0,95 \\
\hline & $12 L(25)$ & 1275 & $-0,42$ & 0,08 & 0,99 \\
\hline & $12 \mathrm{Na}(22)$ & 974 & $-0,12$ & $-0,05$ & 0,95 \\
\hline & $12 \mathrm{Nb}(34)$ & 822 & $-0,29$ & 0,01 & 0,99 \\
\hline & $13 L(67)$ & 746 & $-0,17$ & 0,05 & 0,97 \\
\hline & $13 N(39)$ & 1240 & $-0,19$ & $-0,01$ & 0,97 \\
\hline & 14L (71) & 1938 & $-0,34$ & 0,08 & 0,99 \\
\hline & $14 \mathrm{Na}(65)$ & 1195 & $-0,19$ & $-0,07$ & 0,94 \\
\hline & $14 \mathrm{Nb}(86)$ & 1997 & $-0,45$ & 0,07 & 0,99 \\
\hline & $15 N(64)$ & 329 & $-0,42$ & 0,13 & 0,99 \\
\hline
\end{tabular}


Analisando-se a Tabela 5.8, observa-se, como padrão, a tendência de diminuição do $M_{R}$ com o aumento da tensão desvio $\left(\sigma_{d}\right)$, visto que o parâmetro de regressão $k_{2}$ da variável independente $\sigma_{d}$ no modelo assume valores negativos para todos os solos estudados. Em contraposição, observa-se a tendência de aumento do $M_{R}$ com o aumento da tensão confinante, indicado pelos valores positivos de $k_{3}$ verificados na maior parte dos casos. As exceções correspondem a valores negativos de $k_{3}$ muito pequenos, que indicariam que a tensão confinante tem uma influência pouco significativa na variação da rigidez destes materiais.

Ainda analisando-se a Tabela 5.7, observa-se que, exceto pelas amostras $1 \mathrm{Na}(81)$ e $4 \mathrm{~L}$ (50), que seriam mais influenciadas pela tensão confinante, portanto apresentando um comportamento típico de solos granulares, as demais tiveram o $M_{R}$ mais influenciado pela variação da tensão desvio, comportamento típico dos solos coesivos.

A explicação para o fato da influência da tensão desvio ter maior destaque mesmo para os solos denominados grossos na pesquisa, é que a divisão granulométrica adotada inclui nesta categoria amostras com teores de finos (\% passante na peneira \#200) próximos a $35 \%$, definido pela HRB como limite entre solos grossos e finos. Neste caso, a única exceção de destaque é a amostra $4 \mathrm{~L}$ (50) com teor de finos de $14 \%$, o que explicaria a influência marcante de $\sigma_{3}$ no comportamento deste material. No caso da amostra $1 \mathrm{Na}(81)$, com um teor de finos de aproximadamente $34 \%$ e granulometria praticamente idêntica à da amostra $1 \mathrm{~L}$ (76), a maior influência de $\sigma_{3}$ não pode ser explicada a partir de considerações a respeito de sua granulometria, restando especular se algum aspecto relacionado à composição mineralógica do material poderia induzir à reversão observada.

A Tabela 5.9 apresenta os valores da média, mediana, desvio-padrão e coeficiente de variação (razão percentual entre o desvio-padrão e a média) para os parâmetros de regressão $k_{1}, k_{2}$ e $k_{3}$ do modelo composto. Os resultados foram agrupados segundo os critérios granulométricos adotados na pesquisa e também se considerando a gênese dos materiais, separando-os em solos lateríticos e nãolateríticos. É importante salientar que análises realizadas a partir destes resultados devem ser encaradas com ressalvas, visto o pequeno número de amostras 
consideradas. Em especial, destaca-se o caso dos solos intermediários nãolateríticos, que compreende apenas dois solos, amostras $6 \mathrm{~N}(27)$ e $5 \mathrm{~N}(55)$.

Tabela 5.9: Resumo dos valores da média, mediana e desvio-padrão para cada um dos coeficientes do modelo composto (Equação (5.13)) e solos separados segundo o comportamento laterítico (L) e não-laterítico (NL)

\begin{tabular}{|c|c|c|c|c|c|c|c|}
\hline & \multirow{3}{*}{ Parâmetros } & \multicolumn{6}{|c|}{ Grupos de solos } \\
\hline & & \multicolumn{2}{|c|}{ Grossos } & \multicolumn{2}{|c|}{ Intermediários } & \multicolumn{2}{|c|}{ Finos } \\
\hline & & $\mathbf{L}$ & NL & $\mathbf{L}$ & NL & $\mathbf{L}$ & NL \\
\hline \multirow{4}{*}{$\mathbf{k}_{1}$} & Média & 495 & 417 & 850 & 653 & 1091 & 939 \\
\hline & Mediana & 519 & 430 & 838 & 653 & 867 & 963 \\
\hline & Desvio padrão & 367 & 197 & 143 & 598 & 450 & 516 \\
\hline & Coeficiente de variação & 74 & 47 & 17 & 92 & 41 & 55 \\
\hline \multirow{4}{*}{$\mathbf{k}_{2}$} & Média & -0.24 & -0.36 & -0.40 & -0.29 & -0.31 & -0.24 \\
\hline & Mediana & -0.24 & -0.31 & -0.38 & -0.29 & -0.33 & -0.19 \\
\hline & Desvio padrão & 0.03 & 0.11 & 0.17 & 0.07 & 0.08 & 0.12 \\
\hline & Coeficiente de variação & 13 & 29 & 43 & 23 & 27 & 49 \\
\hline \multirow{4}{*}{$\mathbf{k}_{3}$} & Média & 0.22 & 0.21 & 0.23 & 0.16 & 0.09 & 0.02 \\
\hline & Mediana & 0.16 & 0.16 & 0.20 & 0.16 & 0.08 & 0.01 \\
\hline & Desvio padrão & 0.18 & 0.16 & 0.12 & 0.14 & 0.03 & 0.07 \\
\hline & Coeficiente de variação & 81 & 77 & 53 & 88 & 35 & 363 \\
\hline
\end{tabular}

Analisando-se a Tabela 5.9, observa-se que o valor médio do coeficiente $\mathrm{k}_{1}$ tende a aumentar com o aumento do teor de finos nos solos, independentemente da gênese do material. Ao contrário, o valor médio do coeficiente $k_{3}$, que representa a influência da tensão confinante no módulo de resiliência, tende a diminuir com o aumento do teor de finos. Tanto com relação à granulometria tanto quanto à gênese, não foi possível identificar um padrão de comportamento para o coeficiente $k_{2}$, que representa a influência da tensão desvio no módulo de resiliência. Analisando-se a mesma tabela, observa-se que o valor médio do coeficiente $\mathrm{k}_{1}$ para os solos lateríticos é maior do que o valor médio para os solos não-lateríticos. Já o valor médio do coeficiente $k_{3}$ para os solos finos é significativamente menor se comparado ao valor médio dos solos grossos e intermediários. O pequeno valor médio determinado tanto para os solos lateríticos quanto para os não-lateríticos é resultado da pouca influência da tensão confinante sobre os solos finos. Para os solos finos, poder-se-ia questionar sobre a influência da gênese no valor de $k_{3}$, entretanto, estas comparações podem não ser adequadas tendo em vista que a influência de $\sigma_{3}$ é muito pequena para estes solos. Quanto ao coeficiente $k_{2}$, verifica-se a existência de uma tendência dos valores médios dos solos lateríticos serem maiores em módulo do que os não-lateríticos. 
Estas comparações também ficam prejudicadas pela grande variabilidade dos resultados, como indicado por coeficientes de variação tão grandes quanto $70 \%$ (vide Tabela 5.9).

Quando se discutem os valores médios dos coeficientes $k_{1}, k_{2}$ e $k_{3}$ determinados a partir de um grande número de ensaios é possível que se obtenham resultados que possam caracterizar o conjunto de solos estudados. Entretanto, no caso desta pesquisa, a opção de ensaiar apenas um corpo-de-prova em cada condição também pode prejudicar estas análises, na medida em que o mesmo material ensaiado com réplicas pode produzir distintos conjuntos de coeficientes $k_{1}$, $k_{2}$ e $k_{3}$, mas que conduzam à determinação de valores de módulo de resiliência muito próximos entre si. Assim, diante das dificuldades enfrentadas na análise dos parâmetros $k_{1}, k_{2}$ e $k_{3}$, optou-se por avaliar a influência da granulometria e da gênese sobre valores específicos de módulo de resiliência (vide item 5.3.2), e não sobre os coeficientes de regressão.

As Tabelas 5.10, 5.11 e 5.12 apresentam os parâmetros de regressão $k_{1}, k_{2}$ e $k_{3}$ do modelo composto (equação (5.13)), além do coeficiente de determinação $\mathrm{R}^{2}$, respectivamente para os solos grossos, intermediários e finos, em todos os teores de umidade considerados no estudo, a saber: $\mathrm{w}_{\mathrm{o}}-2 \%, \mathrm{w}_{\mathrm{o}}-1 \%, \mathrm{w}_{\mathrm{o}}$ e $\mathrm{w}_{\mathrm{o}}+1 \%$.

Conforme discutido anteriormente para todos os modelos avaliados, analisando-se as Tabelas 5.10, 5.11 e 5.12, observa-se que o desempenho do modelo composto, medido pelo coeficiente de determinação, é excelente para todos os teores de umidade, apresentando valores de $\mathrm{R}^{2}$ acima de 0,90 .

Ainda analisando-se as Tabelas 5.10, 5.11 e 5.12, observa-se que, tomando-se como referência a umidade ótima $\left(w_{o}\right)$ e na medida em que se promoveu a secagem dos corpos-de-prova (de $w_{0}$ para $w_{0}-1 \%$ e $w_{0}-2 \%$ ), há uma tendência de aumento da influência da tensão desvio sobre o módulo de resiliência, indicado pelo aumento de $\mathrm{k}_{2}$. Fato este que pode ser justificado pelo aumento da sucção com a diminuição da umidade pós-compactação. 
Tabela 5.10: Parâmetros de regressão $k_{1}, k_{2}$ e $k_{3}$ do modelo composto (equação (5.13)) e coeficiente de determinação $R^{2}$ para os solos grossos

\begin{tabular}{|c|c|c|c|c|c|c|c|c|c|c|c|c|}
\hline \multicolumn{13}{|c|}{ Solos Grossos } \\
\hline Parâmetros & $\mathbf{k}_{1}$ & $\mathbf{k}_{2}$ & $\mathbf{k}_{3}$ & $\mathbf{R}^{2}$ & $\mathbf{k}_{1}$ & $\mathbf{k}_{2}$ & $\mathbf{k}_{3}$ & $\mathbf{R}^{2}$ & $\mathbf{k}_{1}$ & $\mathbf{k}_{2}$ & $\mathbf{k}_{3}$ & $\mathbf{R}^{2}$ \\
\hline $\begin{array}{l}\text { Umidade/ } \\
\text { Amostra }\end{array}$ & \multicolumn{4}{|c|}{$1 \mathrm{~L}(76)$} & \multicolumn{4}{|c|}{$1 \mathrm{Na}(85)$} & \multicolumn{4}{|c|}{$1 \mathrm{Nb}(81)$} \\
\hline$w_{0}-2 \%$ & 1534 & $-0,27$ & 0,04 & 0,98 & 1905 & $-0,47$ & 0,06 & 0,99 & 950 & $-0,15$ & 0,01 & 0,94 \\
\hline$w_{0}-1 \%$ & 784 & $-0,23$ & 0,08 & 0,99 & 1705 & $-0,53$ & 0,03 & 0,99 & 695 & $-0,32$ & 0,18 & 0,99 \\
\hline$w_{o}$ & 519 & $-0,24$ & 0,08 & 0,98 & 607 & $-0,48$ & 0,16 & 1,00 & 214 & $-0,29$ & 0,38 & 0,98 \\
\hline$w_{0}+1 \%$ & 146 & $-0,22$ & 0,37 & 0,97 & 168 & $-0,43$ & 0,33 & 0,99 & 124 & $-0,21$ & 0,41 & 0,98 \\
\hline $\begin{array}{l}\text { Umidade/ } \\
\text { Amostra }\end{array}$ & \multicolumn{4}{|c|}{$2 \mathrm{~L}(11)$} & \multicolumn{4}{|c|}{$2 \mathrm{~N}(17)$} & \multicolumn{4}{|c|}{$4 \mathrm{~L}(50)$} \\
\hline$w_{0}-2 \%$ & 3948 & $-0,27$ & 0,10 & 0,98 & 5904 & $-0,37$ & 0,06 & 0,99 & 663 & $-0,25$ & 0,15 & 0,99 \\
\hline$w_{0}-1 \%$ & 2022 & $-0,29$ & 0,10 & 0,90 & 2176 & $-0,31$ & 0,08 & 1,00 & 509 & $-0,37$ & 0,23 & 0,99 \\
\hline$w_{0}$ & 430 & $-0,28$ & 0,16 & 0,98 & 850 & $-0,31$ & 0,08 & 0,92 & 117 & $-0,21$ & 0,43 & 0,99 \\
\hline$w_{0}+1 \%$ & 117 & $-0,24$ & 0,39 & 0,99 & 262 & $-0,29$ & 0,20 & 0,99 & 58 & $-0,17$ & 0,55 & 0,98 \\
\hline
\end{tabular}

Tabela 5.11: Parâmetros de regressão $k_{1}, k_{2}$ e $k_{3}$ do modelo composto (equação (5.13)) e coeficiente de determinação $R^{2}$ para os solos intermediários

\begin{tabular}{|c|c|c|c|c|c|c|c|c|c|c|c|c|}
\hline \multicolumn{13}{|c|}{ Solos Intermediários } \\
\hline Parâmetros & $\mathbf{k}_{1}$ & $\mathbf{k}_{2}$ & $\mathbf{k}_{3}$ & $\mathbf{R}^{2}$ & $\mathbf{k}_{1}$ & $\mathbf{k}_{\mathbf{2}}$ & $\mathbf{k}_{3}$ & $\mathbf{R}^{2}$ & $\mathbf{k}_{1}$ & $\mathbf{k}_{\mathbf{2}}$ & $\mathbf{k}_{3}$ & $\mathbf{R}^{2}$ \\
\hline $\begin{array}{l}\text { Umidade/ } \\
\text { Amostra }\end{array}$ & \multicolumn{4}{|c|}{$5 \mathrm{~N}(55)$} & \multicolumn{4}{|c|}{$5 \mathrm{~L}(60)$} & \multicolumn{4}{|c|}{$6 \mathrm{~N}(27)$} \\
\hline$w_{0}-2 \%$ & 3538 & $-0,37$ & 0,05 & 0,99 & 3710 & $-0,36$ & 0,04 & 0,99 & 2285 & $-0,18$ & 0,03 & 0,96 \\
\hline$w_{0}-1 \%$ & 655 & $-0,26$ & 0,08 & 0,99 & 2299 & $-0,42$ & 0,07 & 0,98 & 1319 & $-0,12$ & 0,02 & 0,96 \\
\hline$w_{0}$ & 230 & $-0,34$ & 0,26 & 0,98 & 805 & $-0,38$ & 0,20 & 0,96 & 1076 & $-0,24$ & 0,06 & 0,97 \\
\hline$w_{o}+1 \%$ & 33 & $-0,27$ & 0,69 & 0,98 & 192 & $-0,25$ & 0,40 & 0,98 & 1069 & $-0,30$ & $-0,03$ & 0,97 \\
\hline $\begin{array}{l}\text { Umidade/ } \\
\text { Amostra }\end{array}$ & \multicolumn{4}{|c|}{$6 \mathrm{La}(30)$} & \multicolumn{4}{|c|}{$6 \mathrm{Lb}(57)$} & \multicolumn{4}{|c|}{ 7L (46) } \\
\hline$w_{0}-2 \%$ & 7145 & $-0,40$ & 0,12 & 0,99 & 8860 & $-0,45$ & 0,03 & 0,99 & 3234 & $-0,39$ & 0,07 & 0,96 \\
\hline$w_{0}-1 \%$ & 3198 & $-0,31$ & 0,12 & 0,99 & 1612 & $-0,18$ & 0,01 & 0,98 & 2548 & $-0,52$ & 0,16 & 0,98 \\
\hline$w_{0}$ & 838 & $-0,23$ & 0,15 & 0,95 & 674 & $-0,28$ & 0,11 & 0,99 & 864 & $-0,46$ & 0,26 & 0,97 \\
\hline$w_{o}+1 \%$ & 148 & $-0,23$ & 0,45 & 0,97 & 134 & $-0,33$ & 0,42 & 0,98 & 224 & $-0,28$ & 0,34 & 0,99 \\
\hline $\begin{array}{c}\text { Umidade/ } \\
\text { Amostra }\end{array}$ & \multicolumn{4}{|c|}{ 8L (88) } & & & & & & & & \\
\hline$w_{0}-2 \%$ & & & & & & & & & & & & \\
\hline$w_{0}-1 \%$ & 1672 & $-0,55$ & 0,39 & 1,00 & & & & & & & & \\
\hline$w_{o}$ & 1070 & $-0,67$ & 0,42 & 0,99 & & & & & & & & \\
\hline$w_{0}+1 \%$ & 229 & $-0,48$ & 0,45 & 0,99 & & & & & & & & \\
\hline
\end{tabular}


Tabela 5.12: Parâmetros de regressão $k_{1}, k_{2}$ e $k_{3}$ do modelo composto (equação (5.13)) e coeficiente de determinação $R^{2}$ para os solos finos

\begin{tabular}{|c|c|c|c|c|c|c|c|c|c|c|c|c|}
\hline \multicolumn{13}{|c|}{ Solos Finos } \\
\hline Parâmetros & $\mathbf{k}_{1}$ & $k_{2}$ & $\mathbf{k}_{3}$ & $\mathbf{R}^{2}$ & $\mathbf{k}_{1}$ & $\mathbf{k}_{2}$ & $\mathbf{k}_{3}$ & $\mathbf{R}^{2}$ & $\mathbf{k}_{1}$ & $\mathbf{k}_{2}$ & $k_{3}$ & $\mathbf{R}^{2}$ \\
\hline $\begin{array}{l}\text { Umidade/ } \\
\text { Amostra }\end{array}$ & \multicolumn{4}{|c|}{ 9L (21) } & \multicolumn{4}{|c|}{$9 \mathrm{~N}(77)$} & \multicolumn{4}{|c|}{$10 \mathrm{~L}(38)$} \\
\hline$w_{0}-2 \%$ & 2989 & -0.27 & 0.02 & 0.97 & 3281 & -0.29 & 0.06 & 0.98 & 4793 & -0.39 & 0.02 & 0.96 \\
\hline$w_{0}-1 \%$ & 2221 & -0.41 & 0.03 & 0.97 & 2521 & -0.31 & 0.03 & 0.99 & 1336 & -0.30 & 0.14 & 0.98 \\
\hline$w_{0}$ & 653 & -0.33 & 0.14 & 0.99 & 554 & -0.17 & 0.08 & 0.96 & 853 & -0.33 & 0.13 & 0.99 \\
\hline$w_{o}+1 \%$ & 176 & -0.11 & 0.19 & 0.93 & 429 & -0.18 & 0.07 & 0.96 & 205 & -0.21 & 0.30 & 0.98 \\
\hline $\begin{array}{l}\text { Umidade/ } \\
\text { Amostra }\end{array}$ & \multicolumn{4}{|c|}{$10 \mathrm{~N}(53)$} & \multicolumn{4}{|c|}{ 11La (48) } & \multicolumn{4}{|c|}{ 11Lb (91) } \\
\hline$w_{0}-2 \%$ & 635 & -0.15 & 0.03 & 0.98 & 1790 & -0.19 & 0.05 & 0.92 & & & & \\
\hline$w_{0}-1 \%$ & 485 & -0.13 & 0.01 & 0.97 & 1151 & -0.15 & 0.05 & 0.97 & 3938 & -0.43 & 0.04 & 0.96 \\
\hline$w_{0}$ & 378 & -0.13 & 0.01 & 0.92 & 867 & -0.23 & 0.09 & 0.94 & 1308 & -0.34 & 0.07 & 0.98 \\
\hline$w_{0}+1 \%$ & 228 & -0.19 & 0.06 & 0.94 & 597 & -0.22 & 0.10 & 0.98 & 469 & -0.38 & 0.31 & 0.98 \\
\hline $\begin{array}{l}\text { Umidade/ } \\
\text { Amostra }\end{array}$ & \multicolumn{4}{|c|}{$11 \mathrm{~N}(78)$} & \multicolumn{4}{|c|}{$12 \mathrm{~L}(25)$} & \multicolumn{4}{|c|}{$12 \mathrm{Na}(22)$} \\
\hline$w_{0}-2 \%$ & 3341 & -0.33 & 0.08 & 0.96 & 2327 & -0.28 & 0.04 & 0.99 & 3517 & -0.21 & 0.01 & 0.92 \\
\hline$w_{0}-1 \%$ & 1577 & -0.24 & 0.03 & 0.99 & 2042 & -0.33 & 0.01 & 0.98 & 2111 & -0.22 & 0.03 & 0.99 \\
\hline$w_{o}$ & 963 & -0.21 & 0.00 & 0.95 & 1275 & -0.42 & 0.08 & 0.99 & 974 & -0.12 & -0.05 & 0.95 \\
\hline$w_{o}+1 \%$ & 667 & -0.31 & 0.01 & 0.98 & 385 & -0.29 & 0.22 & 0.99 & & & & \\
\hline $\begin{array}{l}\text { Umidade/ } \\
\text { Amostra }\end{array}$ & \multicolumn{4}{|c|}{$12 \mathrm{Nb}(34)$} & \multicolumn{4}{|c|}{ 13L (67) } & \multicolumn{4}{|c|}{$13 N(39)$} \\
\hline$w_{0}-2 \%$ & 1491 & -0.34 & 0.02 & 0.99 & 3816 & -0.36 & 0.03 & 0.99 & & & & \\
\hline$w_{0}-1 \%$ & 1170 & -0.36 & 0.05 & 0.98 & 1587 & -0.21 & 0.00 & 0.96 & 2529 & -0.17 & 0.02 & 0.97 \\
\hline$w_{0}$ & 822 & -0.29 & 0.01 & 0.99 & 746 & -0.17 & 0.05 & 0.97 & 1240 & -0.19 & -0.01 & 0.97 \\
\hline$w_{0}+1 \%$ & 640 & -0.31 & 0.01 & 0.99 & 552 & -0.22 & 0.10 & 0.98 & 381 & -0.24 & 0.07 & 0.99 \\
\hline $\begin{array}{l}\text { Umidade/ } \\
\text { Amostra }\end{array}$ & \multicolumn{4}{|c|}{ 14L (71) } & \multicolumn{4}{|c|}{$14 \mathrm{Na}(65)$} & \multicolumn{4}{|c|}{$14 \mathrm{Nb}(86)$} \\
\hline$w_{0}-2 \%$ & 11321 & -0.49 & 0.04 & 0.98 & 3651 & -0.20 & -0.08 & 0.91 & 4225 & -0.42 & 0.06 & 1.00 \\
\hline$w_{0}-1 \%$ & 5590 & -0.43 & 0.01 & 0.99 & 2385 & -0.36 & 0.05 & 0.97 & 2144 & -0.36 & 0.07 & 0.99 \\
\hline$w_{o}$ & 1938 & -0.34 & 0.08 & 0.99 & 1195 & -0.19 & -0.07 & 0.94 & 1997 & -0.45 & 0.07 & 0.99 \\
\hline$w_{0}+1 \%$ & 868 & -0.34 & 0.22 & 0.98 & 715 & -0.19 & -0.03 & 0.92 & 987 & -0.37 & 0.12 & 0.94 \\
\hline $\begin{array}{l}\text { Umidade/ } \\
\text { Amostra }\end{array}$ & \multicolumn{4}{|c|}{$15 \mathrm{~N}(64)$} & & & & & & & & \\
\hline$w_{0}-2 \%$ & 537 & -0.43 & 0.09 & 1.00 & & & & & & & & \\
\hline$w_{0}-1 \%$ & 461 & -0.43 & 0.09 & 1.00 & & & & & & & & \\
\hline$w_{o}$ & 329 & -0.42 & 0.13 & 0.99 & & & & & & & & \\
\hline$w_{0}+1 \%$ & 182 & -0.39 & 0.20 & 0.98 & & & & & & & & \\
\hline
\end{tabular}

Da mesma forma, ao se analisar as Tabelas $5.10,5.11$ e 5.12 , e considerando-se a $\mathrm{w}_{\mathrm{o}}$ como referência, o umedecimento dos corpos de prova até a $\mathrm{w}_{\mathrm{o}}+1 \%$ reduz a influência da tensão desvio e aumenta a influência da tensão confinante, fatos indicados, respectivamente, pela tendência de diminuição de $\mathrm{k}_{2} \mathrm{e}$ aumento de $k_{3}$. Em especial nos solos lateríticos, esta tendência pode conduzir, 
para os corpos-de-prova na $w_{0}+1 \%$, à inversão da tensão mais influente, gerando valores de $k_{3}$ maiores do que $k_{2}$, enquanto no caso dos solos mais secos $\left(w_{0}, w_{0}\right.$ $1 \%$ e $w_{0}-2 \%$ ) a tendência é de valores maiores de $k_{2}$ quando comparados aos valores de $k_{3}$. Assim como a sucção influencia no caso da secagem dos corpos-deprova, a redução desta durante o processo de umedecimento pode justificar a redução da influência da tensão desvio e o aumento da influência da tensão confinante. Entretanto, em grande parte dos casos, as diferenças observadas nos parâmetros de regressão poderiam ser decorrentes da variabilidade inerente aos ensaios triaxiais cíclicos, que, conforme discutido anteriormente, conduziriam um mesmo material ensaiado várias vezes a produzir conjuntos de parâmetros $k_{1}, k_{2} e$ $\mathrm{k}_{3}$ que produziriam valores de módulo de resiliência semelhantes.

\subsubsection{Análise da influência da granulometria e da gênese no valor do módulo de resiliência}

Conforme já discutido, não é trivial a comparação dos parâmetros de regressão $k_{1}, k_{2}$ e $k_{3}$, tendo em vista que o valor do módulo de resiliência depende simultaneamente destes três coeficientes. Assim, com o intuito de simplificar as análises, optou-se por calcular o valor do módulo de resiliência para duas condições:

1) o módulo de resiliência típico $\left(M_{R-T i ́ p i c o ~}\right)$, em um estado de tensão correspondente à seqüência 15 (vide Tabela 3.5) utilizada no ensaio triaxial cíclico $\left(\sigma_{3}=13,8 \mathrm{kPa}\right.$ e $\left.\sigma_{\mathrm{d}}=62,0 \mathrm{kPa}\right)$;

2) o módulo de resiliência médio ( $\left.M_{R-M e ́ d i o}\right)$, que corresponde à média dos valores de $M_{R}$ para os diferentes estados de tensão da seqüência de ensaio de subleito.

É importante destacar que todos os valores de módulo de resiliência usados nas análises foram calculados a partir do modelo composto.

\subsubsection{O módulo de resiliência típico}

A Tabela 5.13 apresenta os valores típicos de $M_{R}$ obtidos a partir do modelo composto, considerando-se solos ensaiados na umidade ótima e massa específica seca máxima e separados segundo a granulometria e a gênese. 
Tabela 5.13: Valores típicos de módulo de resiliência determinados a partir do modelo composto para valores de $\sigma_{3}=13,8 \mathrm{kPa}$ e $\sigma_{\mathrm{d}}=62,0 \mathrm{kPa}$ - solos separados em função da granulometria e da gênese

\begin{tabular}{|c|c|c|c|c|c|c|c|}
\hline \multicolumn{2}{|c|}{$\begin{array}{c}\text { Grupos de } \\
\text { solos }\end{array}$} & \multirow{2}{*}{$\frac{\text { Amostra }}{1 \mathrm{~L}(76)}$} & \multirow{2}{*}{$\frac{\mathrm{M}_{\mathrm{R}}(\mathrm{MPa})}{237}$} & \multicolumn{2}{|c|}{ Grupos de solos } & \multirow{2}{*}{$\frac{\text { Amostra }}{9 \mathrm{~L}(21)}$} & \multirow{2}{*}{$\frac{\mathbf{M}_{\mathbf{R}}(\mathrm{MPa})}{235}$} \\
\hline \multirow{13}{*}{ 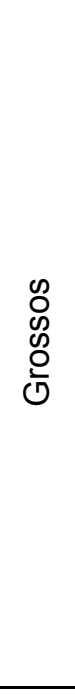 } & \multirow{5}{*}{\lrcorner} & & & \multirow{9}{*}{\multicolumn{2}{|c|}{\lrcorner}} & & \\
\hline & & $2 \mathrm{~L}(11)$ & 205 & & & $10 \mathrm{~L}(38)$ & 303 \\
\hline & & $4 \mathrm{~L}(50)$ & 146 & & & 11La (48) & 413 \\
\hline & & Média & 196 & & & 11Lb (91) & 373 \\
\hline & & Desvio-padrão & 46 & & & 12L (25) & 265 \\
\hline & \multirow{6}{*}{$\dot{z}$} & $1 \mathrm{Na}(81)$ & 175 & & & 13L (67) & 407 \\
\hline & & $1 \mathrm{Nb}(85)$ & 121 & & & 14L (71) & 564 \\
\hline & & $3 N(89)$ & --- & & & Média & 365 \\
\hline & & $2 \mathrm{~N}(17)$ & 281 & & & Desvio-padrão & 111 \\
\hline & & Média & 192 & \multirow{13}{*}{$\stackrel{\mathscr{0}}{\stackrel{2}{=}}$} & \multirow{11}{*}{$\bar{z}$} & $9 \mathrm{~N}(77)$ & 328 \\
\hline & & Desvio-padrão & 81 & & & $10 \mathrm{~N}(53)$ & 231 \\
\hline & & Média & 194 & & & $11 \mathrm{~N}(78)$ & 388 \\
\hline & & svio-padrão & 59 & & & $12 \mathrm{Na}(22)$ & 499 \\
\hline \multirow{13}{*}{ 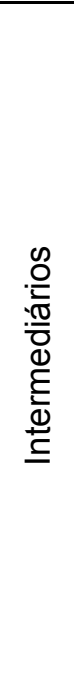 } & \multirow{7}{*}{\lrcorner} & $5 \mathrm{~L}(60)$ & 277 & & & $12 \mathrm{Nb}(34)$ & 248 \\
\hline & & $6 \mathrm{La}(30)$ & 474 & & & $13 N(39)$ & 530 \\
\hline & & $6 \mathrm{Lb}(57)$ & 273 & & & $14 \mathrm{Na}(65)$ & 438 \\
\hline & & $7 \mathrm{~L}(46)$ & 241 & & & $14 \mathrm{Nb}(86)$ & 366 \\
\hline & & 8L (88) & 190 & & & $16 \mathrm{~N}(64)$ & 79 \\
\hline & & Média & 291 & & & Média & 345 \\
\hline & & Desvio-padrão & 108 & & & Desvio-padrão & 143 \\
\hline & \multirow{4}{*}{$\vec{z}$} & $5 \mathrm{~N}(55)$ & 111 & & Média & & 354 \\
\hline & & $6 \mathrm{~N}(27)$ & 453 & & \multicolumn{2}{|c|}{ Desvio-padrão } & 126 \\
\hline & & Média & 282 & \multicolumn{3}{|c|}{ Média (lateríticos) } & 307 \\
\hline & & Desvio-padrão & 241 & \multicolumn{3}{|c|}{ Desvio-padrão (lateríticos) } & 116 \\
\hline & \multicolumn{2}{|l|}{ Média } & 288 & \multicolumn{3}{|c|}{ Média (não-lateríticos) } & 303 \\
\hline & \multicolumn{2}{|c|}{ Desvio-padrão } & 132 & \multicolumn{3}{|c|}{ Desvio-padrão (não-lateríticos) } & 149 \\
\hline
\end{tabular}

Analisando-se a Tabela 5.13, observa-se que os solos classificados como grossos apresentaram os menores valores de módulo de resiliência, com um valor médio de $194 \mathrm{MPa}$. Para os solos intermediários obteve-se uma média de $288 \mathrm{MPa}$ e para os solos finos a média resultante foi de $354 \mathrm{MPa}$. Verifica-se, portanto, a existência de indícios da influência da granulometria nos valores típicos, com o módulo aumentando com o aumento do teor de finos. Para se verificar realmente a existência desta influência realizou-se um teste de análise de variância (ANOVA) em que se avaliou a hipótese de igualdade entre as médias, para um nível de 
significância $(\alpha)$ de $5 \%$, sendo as hipóteses nula $\left(H_{0}\right)$ e alternativa $\left(H_{1}\right)$ formuladas como mostrado a seguir.

$$
\left\{\begin{array}{l}
H_{0}: \mu_{1}=\mu_{2}=\mu_{3} \\
H_{1}: \mu_{1} \neq \mu_{2} \neq \mu_{3}
\end{array}\right.
$$

No Apêndice 1 podem se vistas as tabelas resultantes desta análise estatística, e de todas as outras análises realizadas na seqüência.

Assim, ao nível de significância de 5\%, existem evidências estatísticas de que as médias populacionais para os solos grossos, intermediários e finos são diferentes, na medida em que o resultado do teste conduziu à rejeição da hipótese nula $\left(H_{0}\right)$. Dessa forma, é possível concluir que exista influência da granulometria no valor do módulo de resiliência. Contudo, a fim de avaliar a relação entre as classes granulométricas citadas, foram conduzidos testes-t considerando-se as classes duas a duas. No primeiro caso, o teste foi aplicado para comparação entre as médias dos solos grossos e intermediários, para o mesmo valor de $\alpha$ já citado, sendo as hipóteses nula e alternativa formuladas como mostrado a seguir.

$$
\left\{\begin{array}{l}
H_{0}: \mu_{1}=\mu_{2} \\
H_{1}: \mu_{1} \neq \mu_{2}
\end{array}\right.
$$

Ao nível de significância de $5 \%$, concluiu-se que existam evidências estatísticas de que as médias populacionais para os solos grossos e intermediários não são diferentes, na medida em que o resultado do teste conduziu a não rejeição de $H_{0}$. No segundo caso, o teste foi aplicado à semelhança do anterior, inclusive com as hipóteses sendo formuladas da mesma maneira, entretanto, considerandose as médias dos solos intermediários e finos. Assim, ao mesmo nível de significância, considera-se que existam evidências estatísticas de que as médias populacionais para os solos destas classes granulométricas não são diferentes, já que a hipótese nula não é rejeitada. No terceiro caso, compararam-se as médias para os solos grossos e finos segundo os mesmos princípios dos testes anteriores. Neste caso, considera-se que existam evidências estatísticas de que as médias populacionais para os solos destas classes granulométricas são diferentes, na medida em que o resultado do teste-t conduziu à rejeição de $H_{0}$. 
Analisando-se os resultados dos testes estatísticos (teste-t) de comparação de médias, descritos anteriormente, concluiu-se que a granulometria influencia no valor do módulo de resiliência, principalmente entre as classes de solos grossos e finos, que apresentaram médias diferentes entre si. Entretanto, a comparação de ambas as classes com os solos intermediários, indicam que esta classe pode se comportar, em termos do valor do módulo de resiliência, tanto como solos grossos como solos finos. A Figura 5.20 mostra o gráfico Box plot para estas classes granulométricas. Analisando-se esta figura, observa-se uma maior dispersão dos resultados dos solos intermediários, o que pode justificar este comportamento descrito anteriormente.

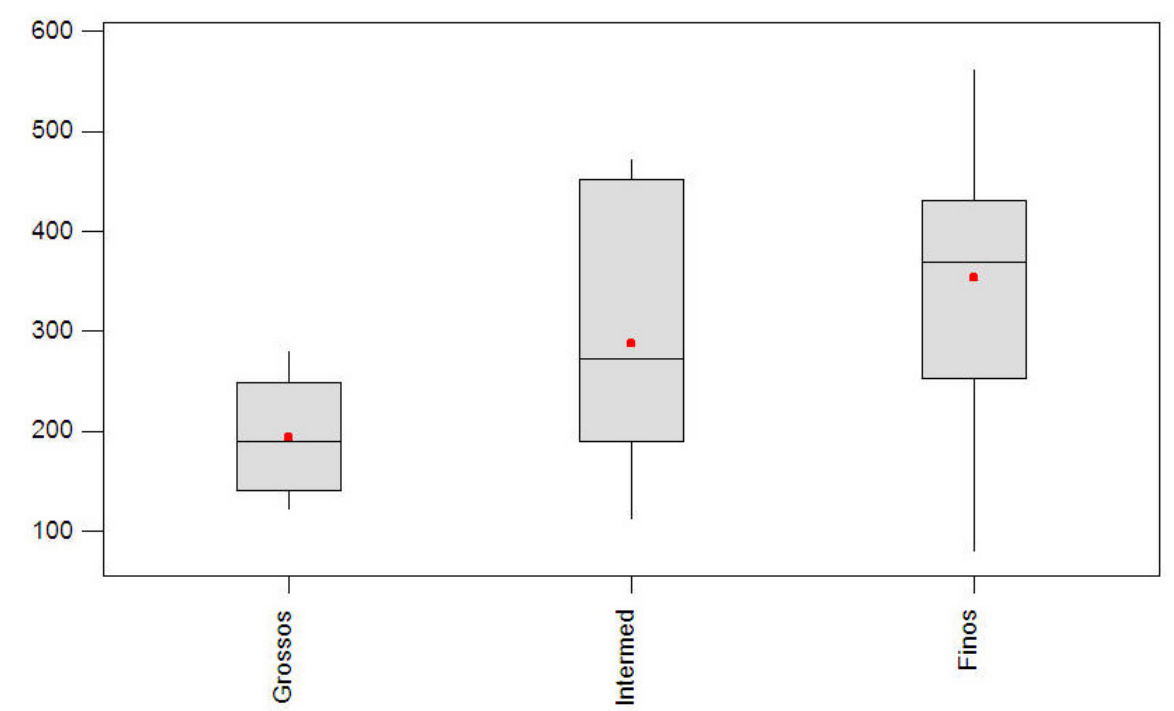

Figura 5.20: Box plots para os valores de módulo de resiliência típico dos solos grossos, intermediários e finos

Considerando-se apenas a separação do módulo de resiliência típico quanto à gênese (vide Tabela 5.13), observa-se que os valores calculados para os solos lateríticos e não-lateríticos, respectivamente 307 MPa e 303 MPa, são praticamente iguais, não indicando, neste caso um efeito da gênese sobre o valor do módulo. Esta condição também foi avaliada pela aplicação do teste-t de comparação entre médias, ao nível de significância de 5\%. As hipóteses nula e alternativa, apresentadas na seqüência, foram formuladas de maneira a se verificar a igualdade entre as médias das classes de solos lateríticos e não lateríticos.

$$
\left\{\begin{array}{l}
H_{0}: \mu_{1}=\mu_{2} \\
H_{1}: \mu_{1} \neq \mu_{2}
\end{array}\right.
$$


O resultado do teste indicou que existem evidências estatísticas de que as médias populacionais para os solos lateríticos e não-lateríticos não são diferentes, na medida em que a hipótese nula não é rejeitada. Portanto, acredita-se que não há influência da gênese no valor do módulo de resiliência, conforme apresentado anteriormente.

Analisando-se isoladamente cada grupo granulométrico e a influência da gênese (vide Tabela 5.13), ainda assim os valores típicos dos solos lateríticos, apesar de maiores, são próximos dos não-lateríticos (196 MPa e $192 \mathrm{MPa}$, para os solos grossos, $291 \mathrm{MPa}$ e $282 \mathrm{MPa}$ para os solos intermediários e, 365 MPa e 345 MPa para os solos finos). Novamente, não indicando uma predominância da gênese sobre o módulo de resiliência. Contudo, sabe-se que, em especial no caso dos solos intermediários e não-lateríticos, estas comparações ficam prejudicadas em função do pequeno número de amostras consideradas. Também em função do pequeno número de amostras, não foram realizados testes estatísticos para comparação entre estas médias.

Ainda analisando-se a Tabela 5.13, é possível a comparação dos valores de módulo de resiliência entre os diferentes solos que apresentam curvas granulométricas semelhantes e gênese distinta. Observa-se que dentre os 10 grupos de solos selecionados $(1,2,5,6,9,10,11,12,13$ e 14), exceto pelos grupos 1, 6, 9, 12 e 13, em todos os demais os solos lateríticos apresentaram valores de $M_{R}$ superiores aos não-lateríticos. Entretanto, sabe-se que em pelo menos dois casos de solos não-lateríticos, amostras $9 \mathrm{~N}(77)$ e $11 \mathrm{~N}(78)$, os altos valores de módulo encontrados podem ser justificados, em parte, por problemas relacionados à determinação da umidade ótima. Conforme se verifica no Anexo $F$, os graus de saturação (S) determinados para estes solos são, respectivamente, $75 \%$ e $68 \%$, que poderiam indicar um provável erro na determinação da umidade ótima e massa específica seca máxima, e conseqüentemente, conduzirem à compactação dos corpos-de-prova em condição diferente da especificada para o Proctor Normal.

Portanto, diante do exposto anteriormente, concluiu-se que a influência da granulometria é predominante sobre o módulo de resiliência se comparado à influência da gênese dos solos deste estudo. 


\subsubsection{O módulo de resiliência médio}

A Tabela 5.14 apresenta os valores médios de módulo de resiliência, separados segundo a granulometria e a gênese, para as amostra ensaiadas na condição ótima do Proctor Normal.

Tabela 5.14: Valores médios de módulo de resiliência - solos separados em função da granulometria e da gênese

\begin{tabular}{|c|c|c|c|c|c|c|c|}
\hline \multicolumn{2}{|c|}{$\begin{array}{c}\text { Grupos de } \\
\text { solos }\end{array}$} & \multirow{2}{*}{$\frac{\text { Amostra }}{1 \mathrm{~L}(76)}$} & \multirow{2}{*}{$\frac{\mathbf{M}_{\mathbf{R}}(\mathbf{M P a})}{306}$} & \multicolumn{2}{|c|}{$\begin{array}{c}\text { Grupos de } \\
\text { solos }\end{array}$} & \multirow{2}{*}{$\frac{\text { Amostra }}{9 L(21)}$} & \multirow{2}{*}{$\frac{\mathrm{M}_{\mathrm{R}}(\mathrm{MPa})}{343}$} \\
\hline \multirow{13}{*}{ 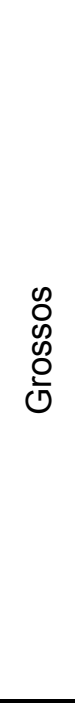 } & \multirow{5}{*}{-} & & & \multirow{9}{*}{\multicolumn{2}{|c|}{\lrcorner}} & & \\
\hline & & $2 \mathrm{~L}(11)$ & 289 & & & $10 \mathrm{~L}(38)$ & 435 \\
\hline & & $4 \mathrm{~L}(50)$ & 233 & & & 11La (48) & 529 \\
\hline & & Média & 276 & & & 11Lb (91) & 474 \\
\hline & & Desvio-padrão & 38 & & & $12 \mathrm{~L}(25)$ & 406 \\
\hline & \multirow{6}{*}{$\bar{z}$} & $1 \mathrm{Na}(81)$ & 271 & & & $13 L(67)$ & 482 \\
\hline & & $1 \mathrm{Nb}(85)$ & 212 & & & 14L (71) & 788 \\
\hline & & $3 N(89)$ & --- & & & Média & 494 \\
\hline & & $2 \mathrm{~N}(17)$ & 392 & & & Desvio-padrão & 143 \\
\hline & & Média & 291 & \multirow{13}{*}{ 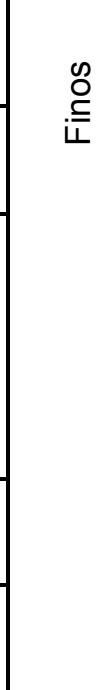 } & \multirow{11}{*}{$\bar{z}$} & $9 \mathrm{~N}(77)$ & 397 \\
\hline & & Desvio-padrão & 92 & & & $10 \mathrm{~N}(53)$ & 258 \\
\hline & & Média & 284 & & & $11 \mathrm{~N}(78)$ & 464 \\
\hline & & vio-padrão & 64 & & & $12 \mathrm{Na}(22)$ & 519 \\
\hline \multirow{13}{*}{ 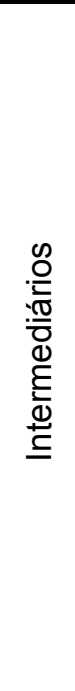 } & \multirow{7}{*}{-} & $5 \mathrm{~L}(60)$ & 396 & & & $12 \mathrm{Nb}(34)$ & 321 \\
\hline & & $6 \mathrm{La}(30)$ & 531 & & & $13 N(39)$ & 617 \\
\hline & & $6 \mathrm{Lb}(57)$ & 371 & & & $14 \mathrm{Na}(65)$ & 490 \\
\hline & & $7 \mathrm{~L}(46)$ & 429 & & & $14 \mathrm{Nb}(86)$ & 567 \\
\hline & & $8 \mathrm{~L}(88)$ & 394 & & & $15 \mathrm{~N}(64)$ & 131 \\
\hline & & Média & 424 & & & Média & 418 \\
\hline & & Desvio-padrão & 64 & & & Desvio-padrão & 157 \\
\hline & \multirow{4}{*}{$\bar{z}$} & $5 \mathrm{~N}(55)$ & 179 & & Média & & 451 \\
\hline & & $6 \mathrm{~N}(27)$ & 539 & & \multicolumn{2}{|c|}{ Desvio-padrão } & 151 \\
\hline & & Média & 359 & \multicolumn{3}{|c|}{ Média (lateríticos) } & 427 \\
\hline & & Desvio-padrão & 255 & \multicolumn{3}{|c|}{ Desvio-padrão (lateríticos) } & 131 \\
\hline & \multicolumn{2}{|c|}{ Média } & 370 & \multicolumn{3}{|c|}{ Média (não-lateríticos) } & 383 \\
\hline & \multicolumn{2}{|c|}{ Desvio-padrão } & 155 & Desvic & padrão & ão-lateríticos) & 156 \\
\hline
\end{tabular}

Analisando-se em conjunto as Tabelas 5.13 e 5.14 , observa-se que os valores médios de módulo resiliência são maiores do que os valores típicos, em todos os casos. Para os solos grossos, o primeiro é aproximadamente $46,0 \%$ maior do que o segundo, enquanto para os solos intermediários e finos o aumento é de 
aproximadamente $29,0 \%$. Com relação aos solos grossos, ocorreu uma inversão nos valores de módulo de resiliência, com os não-lateríticos apresentando valores médios maiores do que os lateríticos, respectivamente, $291 \mathrm{MPa}$ e $276 \mathrm{MPa}$.

A exemplo do realizado para os valores médios dos módulos de resiliência

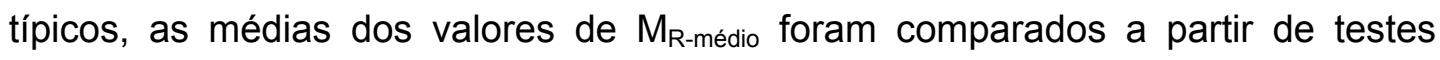
estatísticos de modo a identificar a influência da granulometria e da gênese sobre estes.

Com relação à granulometria, a única diferença encontrada entre os $\mathrm{M}_{\mathrm{R} \text {-tipico }}$

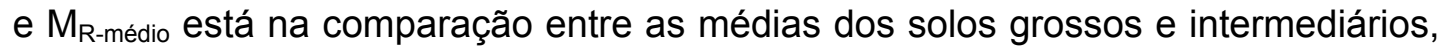
cujo resultado conduziu à rejeição da hipótese nula. Ou seja, concluiu-se que existem evidências estatísticas de que as médias destas duas classes granulométricas não são iguais. Portanto, ao se analisar o módulo de resiliência médio, observa-se que neste caso os solos intermediários comportam-se mais como os solos finos, considerando-se também que o teste de hipótese comparando as médias destas classes mostrou que $H_{0}$ não é rejeitada, ou seja, que estas são iguais. A Figura 5.21 mostra o gráfico Box plot considerando-se os valores de $M_{R-}$ médio e as diferentes classes granulométricas consideradas. Analisando-se esta figura, observa-se um comportamento dos solos intermediários mais próximo do comportamento dos solos finos, o que pode justificar os resultados dos testes.

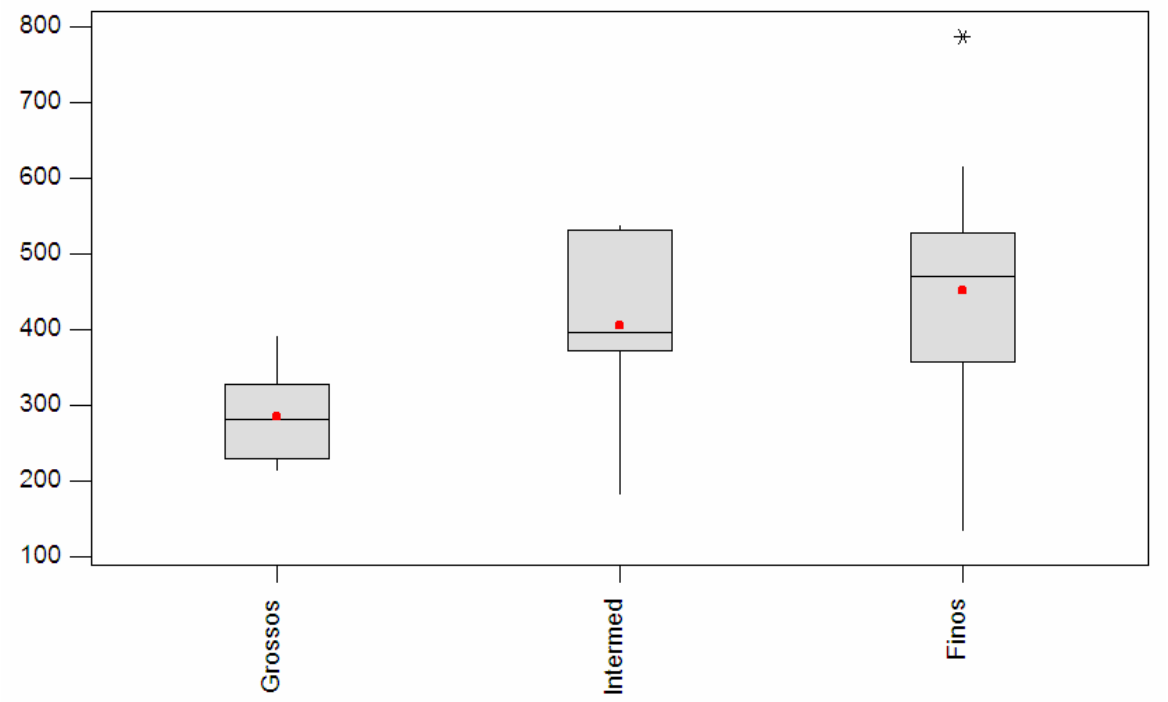

Figura 5.21: Box plots para os valores de módulo de resiliência médios dos solos grossos, intermediários e finos 
Os testes estatísticos realizados para a comparação das médias dos solos lateríticos e não-lateríticos também resultaram na não rejeição da hipótese nula, ou seja, que as médias não são diferentes. Assim, acredita-se que não exista influência da gênese nos valores de módulo de resiliência médios dos solos estudados.

Portanto, conforme verificado para os valores de $M_{R \text {-tipicos, }}$ para os valores

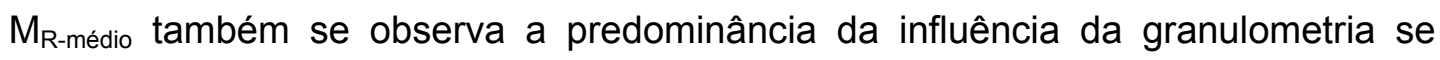
comparado à influência da gênese.

\subsubsection{A influência da variação da umidade pós-compactação no valor do módulo de resiliência}

Avaliou-se a influência da variação da umidade pós-compactação sobre o módulo de resiliência e a sua relação com a granulometria e a gênese. Optou-se por realizar esta etapa do estudo considerando-se apenas o módulo de resiliência típico, tendo em vista a análise anterior, que mostrou um comportamento semelhante entre este e o módulo de resiliência médio.

Segundo o NCHRP 1-37A (2004), permanecendo todas as outras condições iguais, quanto maior for o teor de umidade menor será o módulo de resiliência. Entretanto, a umidade apresenta dois efeitos separados:

- Primeiro, pode afetar o estado de tensão através da sucção. Tanto solos granulares quanto finos podem aumentar o módulo de resiliência em mais de cinco vezes devido à secagem;

- Segundo, pode afetar a estrutura do solo através da destruição da cimentação entre as partículas dos solos.

A Tabela 5.15 apresenta os valores de módulo de resiliência típicos e as correspondentes taxas de variação definidas como a razão entre a variação do módulo de resiliência em uma dada umidade $\left(\Delta M_{R}=M_{R w}-M_{R w o}\right)$ e o módulo de resiliência na umidade ótima $\left(M_{R w o}\right)$, para cada um dos materiais e umidades analisadas. 
Tabela 5.15: Valores de módulo de resiliência típicos em diferentes teores de umidade e taxa de variação do $M_{R}$

\begin{tabular}{|c|c|c|c|c|c|c|c|c|}
\hline \multirow{2}{*}{\multicolumn{2}{|c|}{ Amostra }} & \multicolumn{4}{|c|}{ Módulo de resiliência (MPa) } & \multicolumn{3}{|c|}{$\Delta M_{R} / M_{R w o}$} \\
\hline & & $w_{0}-2 \%$ & $w_{0}-1 \%$ & $\mathbf{w}_{\mathrm{o}}$ & $w_{0}+1 \%$ & $w_{0}-2 \%$ & $w_{0}-1 \%$ & $w_{0}+1 \%$ \\
\hline \multirow{6}{*}{ 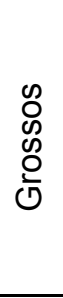 } & $1 \mathrm{~L}(76)$ & 535 & 359 & 237 & 149 & 1,26 & 0,51 & $-0,37$ \\
\hline & $1 \mathrm{Na}(81)$ & 525 & 288 & 175 & 147 & 2,00 & 0,64 & $-0,16$ \\
\hline & $1 \mathrm{Nb}(85)$ & 307 & 195 & 121 & 64 & 1,54 & 0,61 & $-0,47$ \\
\hline & $2 \mathrm{~L}(11)$ & 1633 & 769 & 205 & 120 & 6,97 & 2,75 & $-0,42$ \\
\hline & $2 \mathrm{~N}(17)$ & 1476 & 726 & 281 & 127 & 4,26 & 1,58 & $-0,55$ \\
\hline & $4 \mathrm{~L}(50)$ & 337 & 195 & 146 & 120 & 1,30 & 0,33 & $-0,18$ \\
\hline \multirow{7}{*}{ 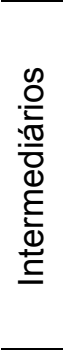 } & $5 \mathrm{~N}(55)$ & 828 & 263 & 111 & 66 & 6,45 & 1,37 & $-0,41$ \\
\hline & $5 \mathrm{~L}(60)$ & 895 & 471 & 277 & 187 & 2,23 & 0,70 & $-0,33$ \\
\hline & $6 \mathrm{~N}(27)$ & 1131 & 820 & 453 & 285 & 1,50 & 0,81 & $-0,37$ \\
\hline & $6 \mathrm{La}(30)$ & 1829 & 1156 & 474 & 179 & 2,86 & 1,44 & $-0,62$ \\
\hline & $6 \mathrm{Lb}(57)$ & 1455 & 773 & 273 & 100 & 4,34 & 1,84 & $-0,63$ \\
\hline & 7L (46) & 756 & 432 & 241 & 165 & 2,13 & 0,79 & $-0,32$ \\
\hline & $8 \mathrm{~L}(88)$ & & 440 & 190 & 97 & & 1,31 & $-0,49$ \\
\hline \multirow{22}{*}{$\begin{array}{l}\stackrel{0}{0} \\
\stackrel{0}{=}\end{array}$} & 9L (21) & 1009 & 420 & 235 & 183 & 3,30 & 0,79 & $-0,22$ \\
\hline & $9 \mathrm{~N}(77)$ & 1155 & 727 & 328 & 248 & 2,52 & 1,21 & $-0,25$ \\
\hline & $10 \mathrm{~L}(38)$ & 987 & 559 & 303 & 184 & 2,26 & 0,85 & $-0,39$ \\
\hline & $10 \mathrm{~N}(53)$ & 362 & 289 & 231 & 118 & 0,57 & 0,25 & $-0,49$ \\
\hline & 11La (48) & 923 & 684 & 413 & 301 & 1,24 & 0,66 & $-0,27$ \\
\hline & 11Lb (91) & & 716 & 373 & 211 & & 0,92 & $-0,43$ \\
\hline & $11 \mathrm{~N}(78)$ & 1029 & 639 & 388 & 182 & 1,66 & 0,65 & $-0,53$ \\
\hline & $12 L(25)$ & 802 & 510 & 265 & 205 & 2,03 & 0,93 & $-0,23$ \\
\hline & $12 \mathrm{Na}(22)$ & 1452 & 889 & 499 & & 1,91 & 0,78 & \\
\hline & $12 \mathrm{Nb}(34)$ & 376 & 289 & 248 & 173 & 0,52 & 0,17 & $-0,30$ \\
\hline & 13L (67) & 893 & 643 & 407 & 281 & 1,20 & 0,58 & $-0,31$ \\
\hline & $13 N(39)$ & 1319 & 530 & 169 & & 6,79 & 2,13 & \\
\hline & 14L (71) & 1552 & 957 & 564 & 368 & 1,75 & 0,70 & $-0,35$ \\
\hline & $14 \mathrm{Na}(65)$ & 1272 & 601 & 438 & 287 & 1,90 & 0,37 & $-0,34$ \\
\hline & $14 \mathrm{Nb}(86)$ & 836 & 564 & 366 & 284 & 1,28 & 0,54 & $-0,22$ \\
\hline & $15 \mathrm{~N}(64)$ & 109 & 95 & 79 & 58 & 0,39 & 0,21 & $-0,26$ \\
\hline & \multicolumn{5}{|c|}{ Média geral } & 2,45 & 0,91 & $-0,37$ \\
\hline & \multicolumn{5}{|c|}{ Desvio-padrão geral } & 1,82 & 0,59 & 0,13 \\
\hline & \multicolumn{5}{|c|}{ Média (lateríticos) } & 2,53 & 1,01 & $-0,37$ \\
\hline & & & \multicolumn{3}{|c|}{ Desvio-padrão (lateríticos) } & 1,62 & 0,62 & 0,13 \\
\hline & & & \multicolumn{3}{|c|}{ Média (Não-lateríticos) } & 2,04 & 0,71 & $-0,36$ \\
\hline & & & \multicolumn{3}{|c|}{ Desvio-padrão (Não-lateríticos) } & 1,66 & 0,45 & 0,13 \\
\hline
\end{tabular}

Analisando-se a Tabela 5.15, observa-se que, tomando-se como referência o valor do módulo de resiliência na $w_{0}$, a secagem produziu o aumento do valor do $M_{R}$, e quanto menor a umidade maior é o $M_{R}$. No caso da variação da umidade póscompactação até o nível $w_{0}-2 \%$, o aumento médio observado no valor do $M_{R}$ foi de 
$245 \%$, se comparado ao valor de referência na $w_{0}$. Entretanto, este aumento pode atingir níveis próximos a $700 \%$ em alguns materiais. Ao se secar estes solos até a $w_{0}-1 \%$, verificou-se um aumento médio de $91 \%$ no valor típico do $M_{R}$, também se comparado ao valor na $\mathrm{w}_{\mathrm{o}}$. Já o umedecimento dos solos até níveis próximos a $\mathrm{w}_{\mathrm{o}}+1 \%$, resultou em uma diminuição média de $37 \%$ no valor do módulo de resiliência típico.

Verificou-se a influência da gênese nos resultados obtidos de variação do módulo de resiliência. Os testes estatísticos (teste-t) formulados para comparação entre as médias obtidas para os solos lateríticos e não-lateríticos (vide Tabela 5.15), em todas as umidades, indicaram que existem evidências estatísticas de que as médias não são diferentes, em cada uma das respectivas umidades. Portanto, conclui-se que a gênese não interferiu nos resultados de perda ou ganho de $M_{R}$. Especialmente no caso do umedecimento, isto é contrário ao inicialmente suposto. Esperava-se nestes casos que o aumento da umidade pudesse evidenciar características distintas de comportamento entre os solos lateríticos e os nãolateríticos. Inclusive, ao se analisar os "pares" de solos selecionados na pesquisa, observa-se que em alguns casos os solos lateríticos apresentaram, após o umedecimento, uma redução maior no valor do módulo de resiliência do que os não-lateríticos.

Tendo em vista a análise realizada anteriormente não ter evidenciado diferença entre o comportamento laterítico e o não-laterítico, decidiu-se aplicar uma nova abordagem, tomando-se a razão entre a taxa de variação do módulo de resiliência e a taxa de variação da umidade $\left(\left(\Delta \mathrm{M}_{R} / \mathrm{M}_{\mathrm{R} w o}\right) /\left(\Delta \mathrm{w} / \mathrm{w}_{\mathrm{o}}\right)\right)$. A Tabela 5.16 apresenta os valores de umidade obtidos após a realização dos ensaios triaxiais cíclicos, assim como o desvio obtido com relação à umidade ótima $(\Delta \mathrm{w})$ do ensaio de compactação e a razão entre taxa de variação do módulo de resiliência e a taxa de variação da umidade. Analisando-se esta tabela, observa-se que os solos secos até $\mathrm{w}_{\mathrm{o}}-2 \%$ apresentaram um desvio médio de $-2,33 \%$ com relação à umidade ótima do ensaio de compactação. Um desvio médio de $-1,27 \%$ foi encontrado para os solos secos até a $\mathrm{w}_{\mathrm{o}}-1 \%$ e o processo de umedecimento dos solos produziu um desvio médio de $+0,95 \%$. Já os corpos de prova ensaiados tendo como referência a umidade ótima apresentaram um desvio médio de $-0,12 \%$. Verifica-se assim que, em média, a umidade de ensaio situa-se abaixo do valor de referência. Esta 
condição pode ter sido causada pela perda de umidade durante o processo de equalização da mesma, ou pela imprecisão no controle dos processos de secagem e umedecimento, que apesar de simples exige pesagens sucessivas dos corposde-prova para estimativa da perda ou ganho de umidade.

Tabela 5.16: Valores de umidade de ensaio e razão entre a taxa de variação do módulo de resiliência e a taxa de variação da umidade

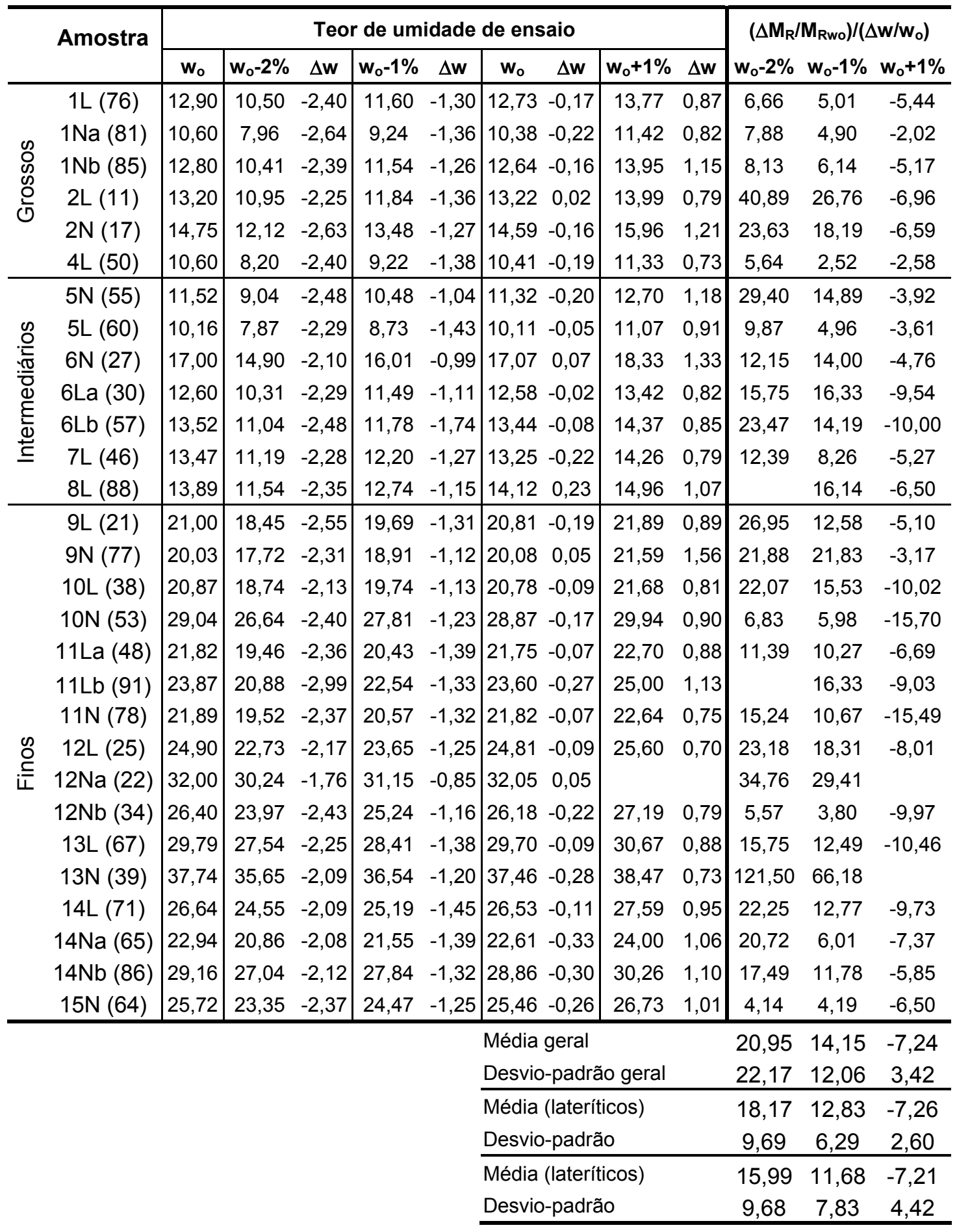


Ainda analisando-se a Tabela 5.16, observa-se que, apesar da consideração da variação da umidade nas análises, ainda assim não foi possível identificar diferenças marcantes entre os solos lateríticos e não-lateríticos que pudessem separar seus comportamentos frente à ação da água. À semelhança do verificado na Tabela 5.15, a análise dos "pares" de solos continua a indicar que em alguns casos os solos lateríticos apresentaram uma redução maior no valor do módulo de resiliência após o processo de umedecimento, quando comparado aos solos nãolateríticos.

Sabe-se que em campo, os solos lateríticos comportam-se melhor do que os solos não-lateríticos, situação não verificada em laboratório nesta pesquisa. Acredita-se que, ao contrário do que se esperava, o procedimento de ensaio escolhido inicialmente, principalmente para o umedecimento, pode não reproduzir de forma adequada o que ocorre em campo.

Uma das vantagens observadas dos solos lateríticos com relação aos nãolateríticos é que os primeiros estão menos sujeitos à ação da água, na medida em que esta encontra mais dificuldades para penetrar no solo compactado (Luz, 2003). Verificou-se assim, que ao se forçar a variação da umidade pós-compactação ao mesmo nível $\left(w_{0}+1 \%\right)$, os solos apresentam comportamento frente à ação da água que pode conduzir as amostras não-lateríticas apresentarem um comportamento melhor do que as lateríticas, ou vice-versa. Contudo, salienta-se que o processo de umedecimento para os solos lateríticos demanda um tempo superior àquele necessário para os solos não-lateríticos.

$\mathrm{Na}$ seqüência apresenta-se a análise dos tempos de preparação dos corpos-de-prova, entenda-se por processos de secagem e umedecimento. A Tabela 5.17 apresenta os tempos, em minutos, determinados para os processos de secagem e umedecimento dos corpos-de-prova submetidos aos ensaios triaxiais cíclicos.

Analisando-se a Tabela 5.17, observa-se que, em média, os solos lateríticos demandam um tempo maior tanto no processo de secagem quanto no processo de umedecimento se comparado aos tempos necessários para os solos não-lateríticos. A comparação entre as médias destas classes de solos em cada nível de umidade 
a partir de testes estatísticos (teste-t) mostra, ao nível de significância de $5 \%$, que existem evidências estatísticas de que as médias populacionais dos solos lateríticos e não-lateríticos não são iguais, na medida em que é rejeitada a hipótese nula $\left(H_{0}\right)$ que considera a igualdade entre as médias. Portanto, acredita-se que a gênese influencia nos tempos de preparação dos corpos-de-prova, tanto em trajetórias de secagem quanto de umedecimento.

Tabela 5.17: Tempos de secagem e umedecimento dos corpos-de-prova submetidos ao ensaio triaxial cíclico

\begin{tabular}{|c|c|c|c|c|}
\hline & \multirow{2}{*}{ Amostra } & \multicolumn{3}{|c|}{ Tempo de preparo dos corpos-de-prova (minutos) } \\
\hline & & $w_{0}-2 \% \leftarrow w_{0}$ & $w_{0}-1 \% \leftarrow w_{0}$ & $w_{o} \rightarrow w_{o}+1 \%$ \\
\hline \multirow{6}{*}{$\begin{array}{l}\text { o } \\
\text { D } \\
\text { Oे } \\
\text { o }\end{array}$} & $1 \mathrm{~L}(76)$ & 66 & 28 & 378 \\
\hline & $1 \mathrm{Na}(81)$ & 59 & 16 & 60 \\
\hline & $1 \mathrm{Nb}(85)$ & 76 & 40 & 132 \\
\hline & 2L (11) & 75 & 33 & 333 \\
\hline & $2 \mathrm{~N}(17)$ & 99 & 38 & 77 \\
\hline & $4 \mathrm{~L}(50)$ & 89 & 33 & 15 \\
\hline \multirow{7}{*}{ 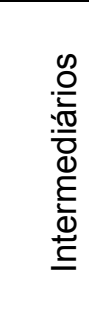 } & $5 \mathrm{~N}(55)$ & 62 & 18 & 116 \\
\hline & $5 \mathrm{~L}(60)$ & 83 & 38 & 551 \\
\hline & $6 \mathrm{~N}(27)$ & 74 & 36 & 57 \\
\hline & $6 \mathrm{La}(30)$ & 80 & 22 & 148 \\
\hline & $6 \mathrm{Lb}(57)$ & 85 & 52 & 239 \\
\hline & 7L (46) & 94 & 34 & \\
\hline & $8 \mathrm{~L}(88)$ & 80 & 29 & 92 \\
\hline \multirow{16}{*}{ 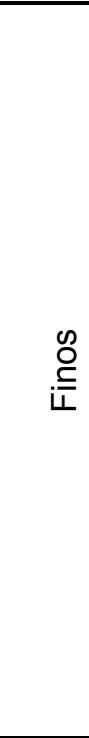 } & 9L (21) & 92 & 44 & 131 \\
\hline & $9 \mathrm{~N}(77)$ & 74 & 29 & 16 \\
\hline & $10 \mathrm{~L}(38)$ & 84 & 38 & 97 \\
\hline & $10 \mathrm{~N}(53)$ & 68 & 37 & 48 \\
\hline & 11La (48) & 76 & 36 & 124 \\
\hline & 11Lb (91) & 106 & 63 & 105 \\
\hline & $11 \mathrm{~N}(78)$ & 59 & 30 & 26 \\
\hline & $12 \mathrm{~L}(25)$ & 75 & 32 & 102 \\
\hline & $12 \mathrm{Na}(22)$ & 83 & 35 & 46 \\
\hline & $12 \mathrm{Nb}(34)$ & 49 & 19 & 33 \\
\hline & $13 \mathrm{~L}(67)$ & 64 & 30 & 48 \\
\hline & $13 \mathrm{~N}(39)$ & 73 & 30 & 81 \\
\hline & $14 \mathrm{~L}(71)$ & 70 & 33 & 156 \\
\hline & $14 \mathrm{Na}(65)$ & 64 & 27 & 30 \\
\hline & $14 \mathrm{Nb}(86)$ & 43 & 25 & 26 \\
\hline & $15 \mathrm{~N}(64)$ & 40 & 25 & 12 \\
\hline \multicolumn{2}{|c|}{ Média geral } & 74 & 33 & 117 \\
\hline \multicolumn{2}{|c|}{ Média (lateríticos) } & 81 & 36 & 180 \\
\hline \multicolumn{2}{|c|}{ Média (Não-lateríticos) } & 66 & 29 & 54 \\
\hline
\end{tabular}

Ainda analisando-se a Tabela 5.17, verifica-se que os tempos de secagem dos solos lateríticos são, aproximadamente, 1,24 vezes maiores do que os não- 
lateríticos, ou ainda $24 \%$ maiores. Já os tempos de umedecimento apresentam um razão de 3,31 entre os solos lateríticos e os não-lateríticos, ou seja, os primeiros têm um tempo médio de umedecimento $231 \%$ maior do que os segundos. Entretanto, analisando-se a mesma tabela, observa-se que os solos lateríticos podem apresentar tempos de umedecimento de 2 a 8 vezes maiores do que os seus semelhantes granulométricos.

As Figuras 5.22, 5.23 e 5.24 apresentam a taxa de variação da umidade $\left(\Delta \mathrm{w} / \mathrm{w}_{\mathrm{o}}\right)$ em função dos tempos de preparo dos corpos-de-prova, respectivamente para as trajetórias da $\mathrm{w}_{\mathrm{o}}$ até $\mathrm{w}_{\mathrm{o}}+1 \%, \mathrm{w}_{\mathrm{o}}-1 \%$ e $\mathrm{w}_{\mathrm{o}}-2 \%$.

Analisando-se as Figuras 5.22, 5.23 e 5.24, observa-se que, apesar de estatisticamente os tempos de secagem dos solos lateríticos e não-lateríticos serem diferentes, conforme discutido anteriormente, não é possível identificar uma relação entre a taxa de variação de umidade e o tempo de secagem. Ao contrário da relação com o tempo de umedecimento, onde se observa uma relação de regular a boa, medida pelos valores de $R^{2}$ iguais a 0,55 e 0,78 , respectivamente para os solos lateríticos e não-lateríticos.

Na construção dos gráficos supracitados optou-se por não se considerar os resultados obtidos pela amostra $4 \mathrm{~L}(50)$ em todas as umidades, que ao ser analisado sob o ponto de vista da taxa de variação da umidade mostrou um comportamento totalmente distinto dos demais solos lateríticos, que pode ter ser sido ocasionado por se tratar de um solo classificado como LA pela MCT. Ainda com relação aos solos lateríticos, o resultado da amostra $8 \mathrm{~L}$ (88) no umedecimento também não foi considerado por ter apresentado um comportamento distinto dos demais solos desta classe. $\mathrm{Na}$ análise dos solos não-lateríticos, não se considerou os resultados de umedecimento obtidos pela amostra $13 \mathrm{~N}$ (39), que também mostrou um comportamento diferente dos solos desta classe. Vale ressaltar que este material, quando submetido ao ensaio de adsorção de azul de metileno, indicou um comportamento semelhante aos dos solos lateríticos, situando-o na região de solos com argilominerais pouco ativos. 


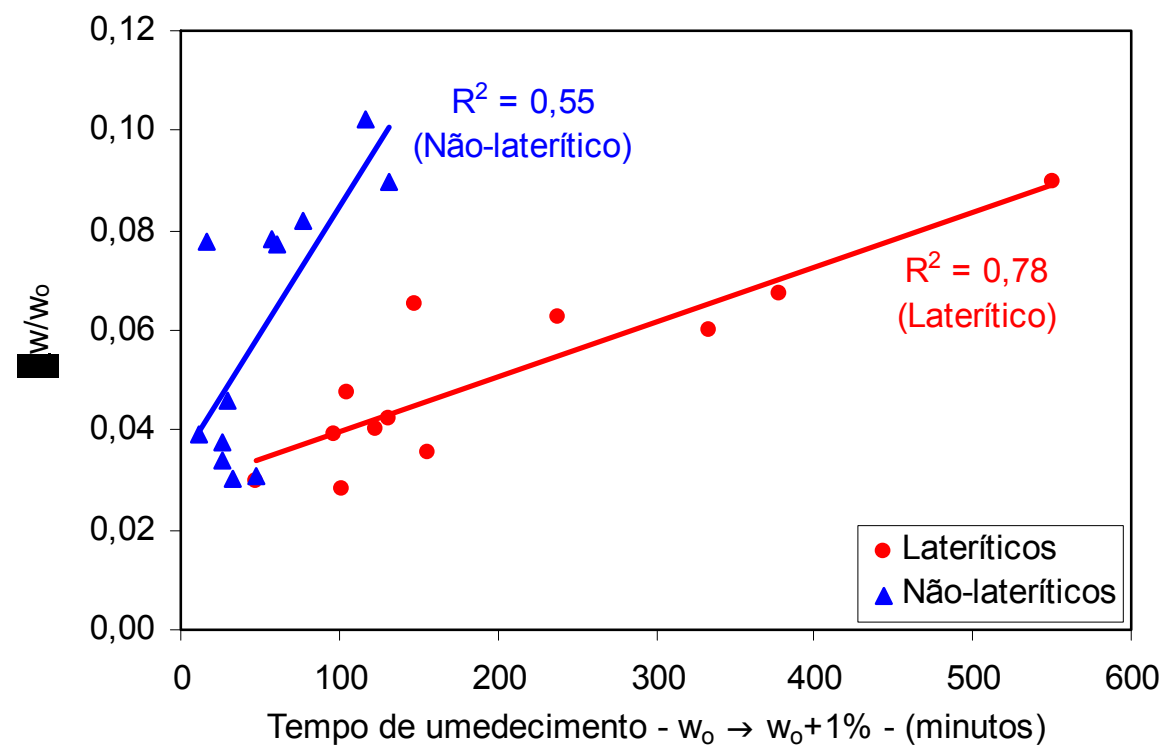

Figura 5.22: Taxa de variação da umidade $\left(\Delta \mathrm{w} / \mathrm{w}_{\mathrm{o}}\right)$ versus tempo de umedecimento segundo a trajetória $w_{0} \rightarrow w_{0}+1 \%$

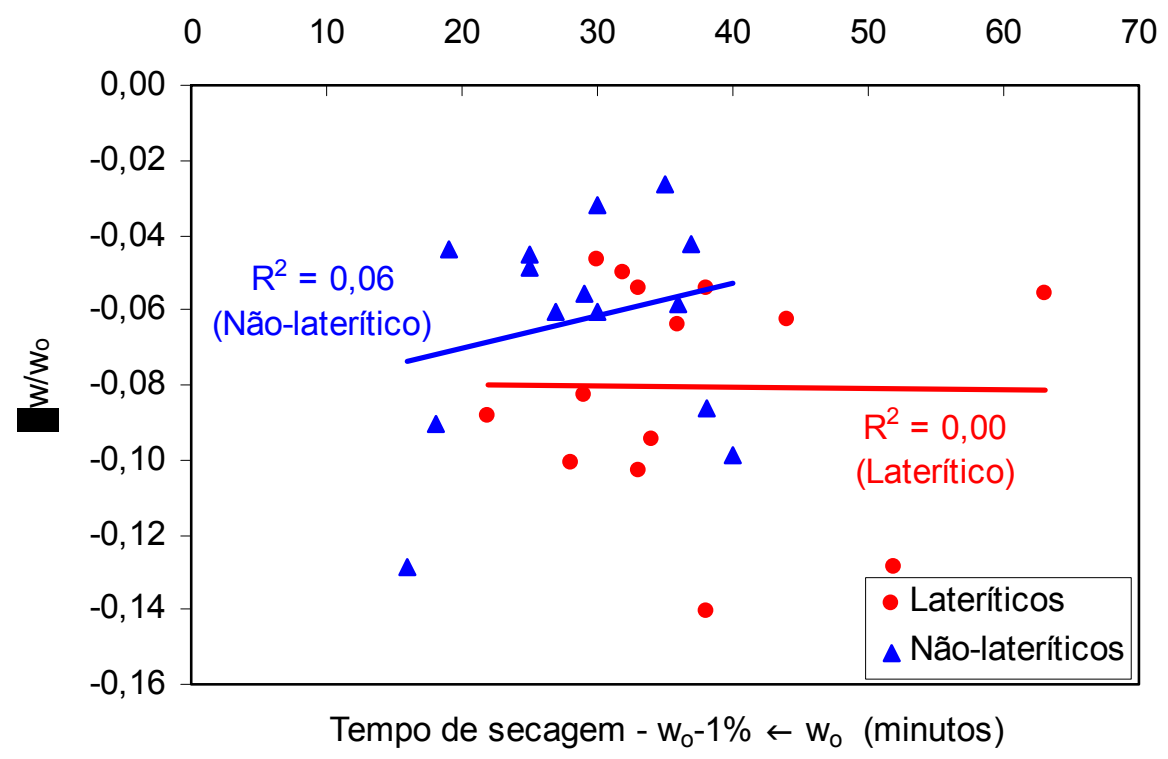

Figura 5.23: Taxa de variação da umidade $\left(\Delta \mathrm{w} / \mathrm{w}_{\mathrm{o}}\right)$ versus tempo de secagem segundo a trajetória $w_{0}-1 \% \leftarrow w_{0}$ 


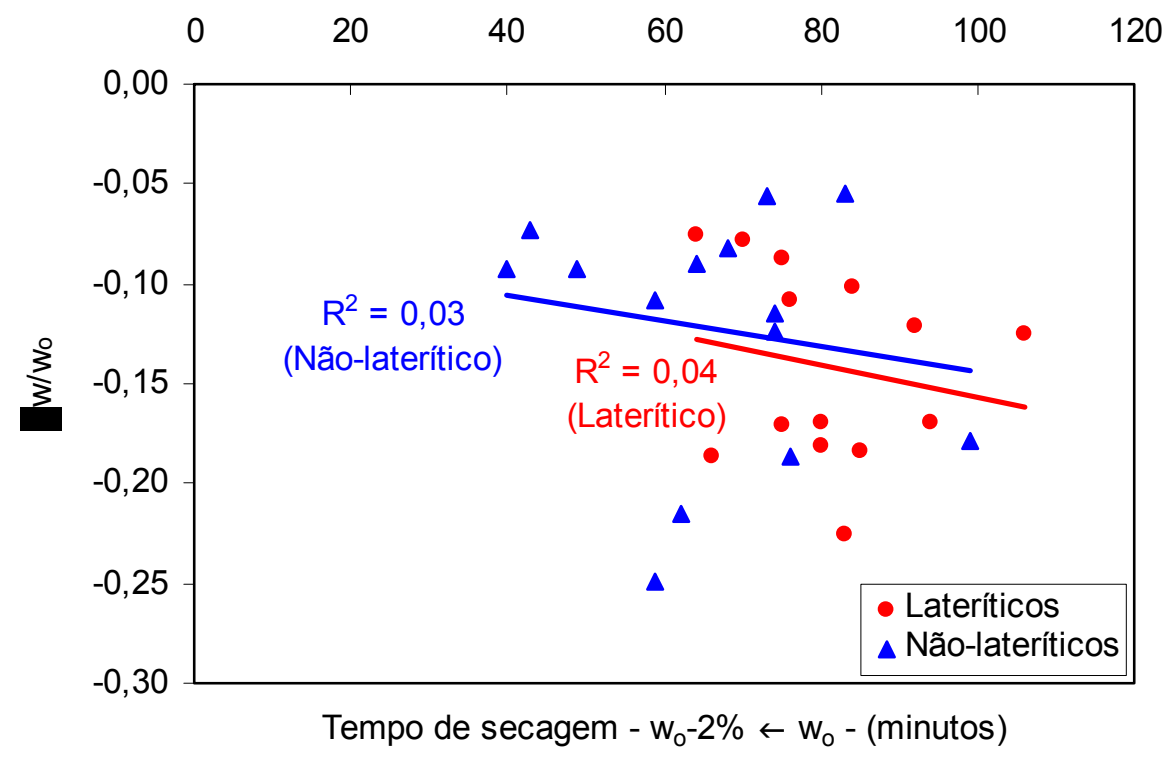

Figura 5.24: Taxa de variação da umidade $\left(\Delta w / w_{0}\right)$ versus tempo de secagem segundo a trajetória $w_{0}-2 \% \leftarrow w_{0}$

Analisando-se a Figura 5.22, observa-se que os solos não-lateríticos tendem a umedecer mais, e mais rapidamente do que os solos lateríticos. Em termos relativos e independentemente da gênese, verifica-se que os solos grossos e intermediários apresentaram um aumento médio de 7,5\%, com relação à umidade ótima, até atingir a umidade de referência $w_{0}+1 \%$. Para a mesma situação, os solos finos mostraram um aumento médio de $3,9 \%$. A secagem dos solos grossos e intermediários resultou em perda relativa média de umidade de $-19,0 \%$ e $-10,3 \%$, respectivamente para a $w_{0}-2 \%$ e $w_{0}-1 \%$. Para estas, os solos finos apresentaram perdas relativas aproximadamente iguais à metade das observadas pelas outras classes granulométricas. Os valores foram $-9,1 \%$ e $-5,0 \%$, respectivamente para a $\mathrm{w}_{\mathrm{o}}-2 \%$ e $\mathrm{w}_{\mathrm{o}}-1 \%$. Portanto, a perda ou ganho relativo de umidade é menor para os solos finos se comparado aos solos grossos e intermediários.

Ao se constatar a influência da gênese nos tempos de preparação dos corpos-de-prova a serem submetidos aos ensaios triaxiais cíclicos, em especial durante o processo de umedecimento, optou-se por analisar a taxa de variação do módulo de resiliência com relação ao tempo de preparação demandado durante a trajetória $w_{0} \rightarrow w_{0}+1 \%$. Assim, construiu-se a Tabela 5.18 com a indicação dos valores de $M_{R}$ na $w_{o}$ e $w_{o}+1 \%$, os tempos de umedecimento e a razão $\frac{\Delta M_{R}}{M_{R_{\text {wo }}} \cdot \text { tempo }}$, que foi multiplicado por um fator igual a 1000 para facilitar a interpretação. 
Tabela 5.18: Taxa de variação do módulo de resiliência com relação ao tempo de umedecimento dos corpos-de-prova

\begin{tabular}{|c|c|c|c|c|c|c|c|}
\hline & & & $\mathrm{Pa})$ & & & $\Delta M_{P}$ & \\
\hline & Amostra & $w_{0}$ & $w_{0}+1 \%$ & $\Delta \mathbf{M}_{\mathbf{R}} / \mathbf{M}_{\mathbf{R} w o}$ & (minutos) & $\overline{M_{R_{\text {wo }}} \cdot \text { tempo }}$ & .1000 \\
\hline & $1 \mathrm{~L}(76)$ & 237 & 149 & $-0,37$ & 378 & $-0,98$ & \\
\hline & $1 \mathrm{Na}(81)$ & 175 & 147 & $-0,16$ & 60 & $-2,66$ & \\
\hline Oొ & $1 \mathrm{Nb}(85)$ & 121 & 64 & $-0,47$ & 132 & $-3,56$ & \\
\hline 음 & 2L (11) & 205 & 120 & $-0,42$ & 333 & $-1,25$ & \\
\hline & $2 \mathrm{~N}(17)$ & 281 & 127 & $-0,55$ & 77 & $-7,10$ & \\
\hline & 4L (50) & 146 & 120 & $-0,18$ & 15 & $-12,04$ & \\
\hline & $5 \mathrm{~N}(55)$ & 111 & 66 & $-0,41$ & 116 & $-3,52$ & \\
\hline \& & $5 \mathrm{~L}(60)$ & 277 & 187 & $-0,33$ & 551 & $-0,59$ & \\
\hline : & $6 \mathrm{~N}(27)$ & 453 & 285 & $-0,37$ & 57 & $-6,49$ & \\
\hline ర్ల & 6La (30) & 474 & 179 & $-0,62$ & 148 & $-4,20$ & \\
\hline$\frac{5}{0}$ & 6Lb (57) & 273 & 100 & $-0,63$ & 239 & $-2,64$ & \\
\hline$\underline{\Xi}$ & 7L (46) & 241 & 165 & $-0,32$ & & & \\
\hline & 8L (88) & 190 & 97 & $-0,49$ & 92 & $-5,36$ & \\
\hline & 9L (21) & 235 & 183 & $-0,22$ & 131 & $-1,67$ & \\
\hline & 9N (77) & 328 & 248 & $-0,25$ & 16 & $-15,37$ & \\
\hline & 10L (38) & 303 & 184 & $-0,39$ & 97 & $-4,05$ & \\
\hline & $10 \mathrm{~N}(53)$ & 231 & 118 & $-0,49$ & 48 & $-10,20$ & \\
\hline & 11La (48) & 413 & 301 & $-0,27$ & 124 & $-2,18$ & \\
\hline & 11Lb (91) & 373 & 211 & $-0,43$ & 105 & $-4,13$ & \\
\hline & $11 \mathrm{~N}(78)$ & 388 & 182 & $-0,53$ & 26 & $-20,40$ & \\
\hline జ) & $12 \mathrm{~L}(25)$ & 265 & 205 & $-0,23$ & 102 & $-2,23$ & \\
\hline$i \frac{1}{2}$ & $12 \mathrm{Na}(22)$ & 499 & & & 46 & & \\
\hline & $12 \mathrm{Nb}(34)$ & 248 & 173 & $-0,30$ & 33 & $-9,16$ & \\
\hline & 13L (67) & 407 & 281 & $-0,31$ & 48 & $-6,45$ & \\
\hline & $13 \mathrm{~N}(39)$ & 169 & & & 81 & & \\
\hline & 14L (71) & 564 & 368 & $-0,35$ & 156 & $-2,23$ & \\
\hline & $14 \mathrm{Na}(65)$ & 438 & 287 & $-0,34$ & 30 & $-11,49$ & \\
\hline & 14Nb (86) & 366 & 284 & $-0,22$ & 26 & $-8,57$ & \\
\hline & $15 \mathrm{~N}(64)$ & 79 & 58 & $-0,26$ & 12 & $-21,48$ & \\
\hline & & & & Média geral & & $-6,54$ & \\
\hline & & & & Desvio-padrã & & 5,71 & \\
\hline & & & & Média (lateríti & & $-2,92$ & \\
\hline & & & & Desvio-padrã & & 1,78 & \\
\hline & & & & Média (não-la & (cos) & $-10,00$ & \\
\hline & & & & Desvio-padrã & & 6,26 & \\
\hline
\end{tabular}

Pelas mesmas razões expostas anteriormente, o resultado da amostra 4L (50) não foi considerado no cálculo da média e desvio-padrão dos solos lateríticos. Analisando-se a Tabela 5.18, observa-se que a redução relativa do módulo de resiliência é aproximadamente 3,4 vezes maior para os solos não-lateríticos quando 
comparado com os lateríticos. Isto significa que, ao se considerar tempos iguais durante o processo de umedecimento, é provável que os solos lateríticos apresentem um desempenho melhor do que os não-lateríticos frente à ação da água, conforme já havia sido discutido anteriormente.

Ainda considerando-se a Tabela 5.18, observa-se que, ao se analisar os "pares" de solos, em todos os casos os lateríticos apresentariam uma redução menor do que os seus semelhantes granulométricos não-lateríticos, com a ressalva de que os tempos de umedecimento devem ser iguais. Este é um resultado contrário ao encontrado anteriormente, entretanto, coerente com a suposição inicial.

Portanto, conforme apresentado anteriormente, é provável que o procedimento adotado para o umedecimento dos solos realmente não simule a ocorrência em campo, podendo conduzir a situações em que os solos nãolateríticos apresentem resultados que indiquem um comportamento melhor do que os lateríticos frente à ação da água. Assim, em estudos posteriores devem ser considerados procedimentos de preparação dos corpos-de-prova que contemplem a igualdade dos tempos, e não variações absolutas de umidade. Dessa forma, acredita-se serão destacadas as vantagens dos solos lateríticos sobre os nãolateríticos.

O maior tempo de umedecimento dos solos lateríticos com relação aos nãolateríticos pode ser justificado pela tendência dos primeiros de desenvolver valores de sucção inferiores, quando comparados aos valores de sucção dos segundos, conforme se observa na Tabela 5.19, que apresenta os valores de sucção determinados a partir de corpos-de-prova compactados na $\mathrm{w}_{0}$. A Figura 5.25 apresenta os valores de sucção em função da umidade ótima de ensaio separados em função do comportamento laterítico e não-laterítico.

Tabela 5.19: valores de sucção determinados a partir de corpos de prova compactados na umidade ótima

\begin{tabular}{c|ccc|cc|cc|ccc|c|cc}
\hline Amostra & $1 \mathrm{~L}$ & $1 \mathrm{Na}$ & $1 \mathrm{Nb}$ & $2 \mathrm{~L}$ & $2 \mathrm{~N}$ & $5 \mathrm{~L}$ & $5 \mathrm{~N}$ & $6 \mathrm{La}$ & $6 \mathrm{Lb}$ & $6 \mathrm{~N}$ & $7 \mathrm{~L}$ & $9 \mathrm{~L}$ & $9 \mathrm{~N}$ \\
\hline Sucção $(\mathrm{kPa})$ & 19 & 19 & 42 & 45 & 70 & 37 & 28 & 61 & 48 & 90 & 26 & 35 & 138 \\
Umidade $(\%)$ & 12,7 & 10,4 & 12,6 & 13,2 & 14,6 & 10,1 & 11,3 & 12,6 & 13,4 & 17,1 & 13,3 & 20,8 & 20,1 \\
\hline Amostra & $10 \mathrm{~L}$ & $10 \mathrm{~N}$ & $11 \mathrm{La}$ & $11 \mathrm{Lb}$ & $11 \mathrm{~N}$ & $12 \mathrm{Na}$ & $12 \mathrm{Nb}$ & $13 \mathrm{~L}$ & $13 \mathrm{~N}$ & $14 \mathrm{~L}$ & $14 \mathrm{Na}$ & $14 \mathrm{Nb}$ & \\
\hline Sucção $(\mathrm{kPa})$ & 67 & 50 & 28 & 46 & 97 & 109 & 59 & 69 & 148 & 50 & 120 & 100 & \\
Umidade (\%) & 20,8 & 28,9 & 21,8 & 23,6 & 21,8 & 32,0 & 26,2 & 29,7 & 37,5 & 26,5 & 22,6 & 28,9 \\
\hline
\end{tabular}




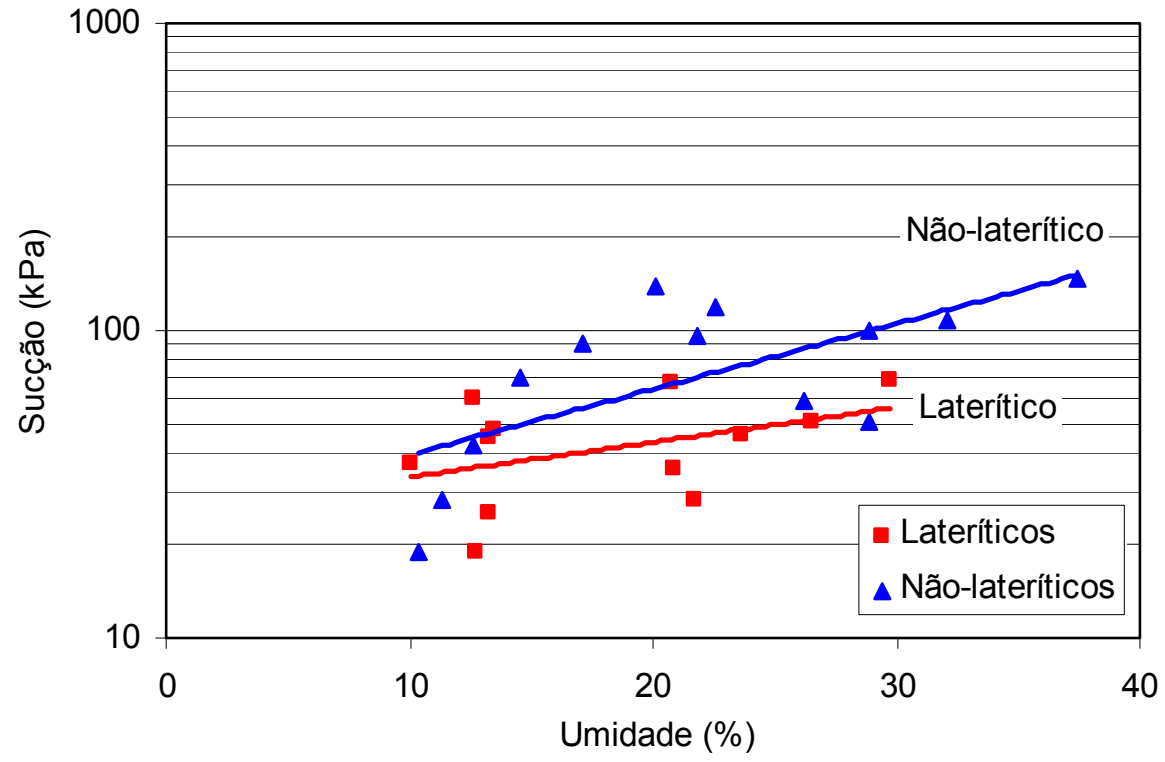

Figura 5.25: Sucção versus umidade ótima de ensaio

Analisando-se a Figura 5.25, observa-se, para o conjunto de solos estudados, que à medida que aumenta o teor de umidade ótima, ocorre o aumento da sucção.

\subsubsection{O módulo de resiliência como função da umidade dos solos}

No campo, os materiais não tratados quimicamente usados em pavimentação são inicialmente compactados próximos à condição ótima de umidade e massa específica determinadas no ensaio de Proctor. Com o tempo, o teor de umidade atingirá uma condição de equilíbrio que pode variar dependendo das propriedades de drenagem e condições ambientais. De forma a simular esta variação de campo em laboratório, recomenda-se a compactação dos corpos-deprova na umidade ótima e massa específica seca máxima, e então variar o teor de umidade, por umedecimento ou secagem, até se atingir o teor desejado. Após estes procedimentos de variação de umidade pós-compactação, os ensaios para determinação do módulo de resiliência devem ser realizados. Estas alterações de umidade produzem modificações no $M_{R}$, que para fins de projeto ou avaliação de pavimentos, devem ser transformadas em variações do módulo de resiliência com as condições ambientais. 
Assim, estudou-se a variação do módulo de resiliência típico com a variação da umidade, onde o $M_{R}$ em um determinado teor de umidade (w) é normalizado pelo módulo determinado na umidade ótima e massa específica seca máxima $\left(M_{R w o}\right)$. A Figura 5.26 apresenta o gráfico em que se relacionam $\left(M_{R} / M_{R w o}\right)$ e $\left(w-w_{o}\right)$ para o conjunto de solos da pesquisa, ressaltando-se que apenas para os valores típicos. Ou seja, os valores de módulo de resiliência são determinados a partir do modelo composto para cada um dos solos modelados para o estado de tensões $\sigma_{3}$ $=13,8 \mathrm{kPa}$ e $\sigma_{\mathrm{d}}=62,0 \mathrm{kPa}$.

Na construção da Figura 5.26 adotou-se como critério descartar os pontos que estivessem fora do intervalo da média \pm 2 -desvio-padrão. Analisando-se esta figura, observa-se a existência de uma relação exponencial (equação (5.15)) entre as variáveis estudadas, sendo considerada esta a melhor entre outras avaliadas por apresentar o maior coeficiente de determinação. Para se manter a igualdade entre os módulos no caso de $\left(w-w_{0}\right)=0$, a regressão foi realizada impondo-se a passagem pelo valor $\left(M_{R} / M_{R w o}\right)=1$. Dessa forma, o valor de $R^{2}$ encontrado foi igual a 0,86 , que pode ser considerado como bom. A análise em separado dos solos lateríticos $\mathrm{e}$ não-lateríticos não produziram melhorias significativas no modelo que justificasse esta consideração.

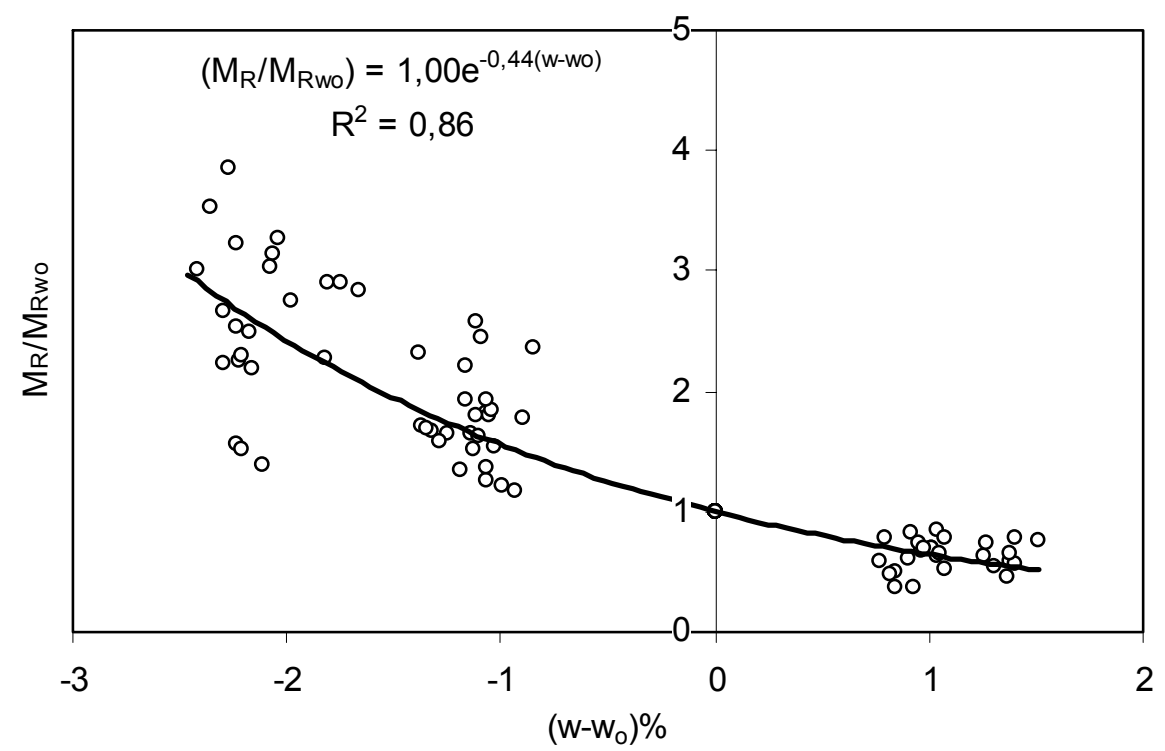

Figura 5.26: Variação do módulo de resiliência versus variação da umidade de ensaio 


$$
\left(\frac{M_{R_{w}}}{M_{R_{\text {wo }}}}\right)=e^{-0,44 \cdot\left(w-w_{o}\right)}
$$

onde: $M_{R w}$ : módulo de resiliência na umidade que se deseja avaliar;

$\mathrm{M}_{\mathrm{Rwo}}$ : módulo de resiliência na umidade ótima e massa específica seca máxima;

w: teor de umidade em que se deseja avaliar $M_{R}$;

$\mathrm{w}_{\mathrm{o}}$ : umidade ótima.

A abordagem adotada permitiria, portanto, a determinação da razão entre o módulo de resiliência típico para uma determinada variação de umidade e o $M_{R \text {-Típico }}$ na umidade ótima e massa específica seca máxima. Analisando-se a partir da equação (5.15), verifica-se que variações de umidade iguais a $-2 \%,-1 \%$ e $+1 \%$, resultariam, respectivamente, em aumentos de $142 \%$ e $56 \%$ e redução de $36 \%$ nos valores de módulo de resiliência típicos.

Contudo, esta mesma abordagem não considera a influência do estado de tensão na variação do módulo de resiliência com a variação da umidade, já que foi calculado para um par de tensão desvio e confinante, tendo recebido o nome de

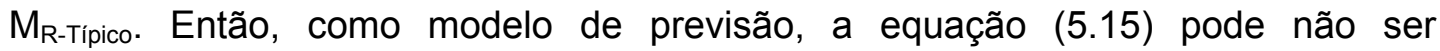
suficiente, havendo necessidade de se considerar outros estados de tensão. Neste sentido, foram determinados, a partir do modelo composto, os valores de módulo de resiliência para todos os estados de tensão utilizados nos ensaios triaxiais cíclicos para solos de subleito (vide Tabela 3.5) e realizada a mesma análise anterior. Também neste caso, para se manter a igualdade entre os módulos no caso de (w$\left.w_{o}\right)=0$, a regressão foi realizada impondo-se a passagem pelo valor $\left(M_{R w} / M_{R w o}\right)=1$ para todos os estados de tensão considerados.

A Figura 5.27 apresenta o gráfico com as relações obtidas de $\left(\mathrm{M}_{\mathrm{Rw}} / \mathrm{M}_{\mathrm{Rwo}}\right)$ em função da variação da umidade $\left(w-w_{0}\right)$ considerando-se os diferentes estados de tensão, e para os quais verificou-se o melhor ajuste matemático para o conjunto de pontos. Observou-se a existência de uma relação exponencial entre as variáveis, cuja expressão de melhor ajuste tem a forma geral apresentada na equação (5.16). A Tabela 5.20 apresenta os parâmetros $a$ e $b$ e os coeficientes de determinação para as regressões realizadas nos quinze estados de tensões considerados. 


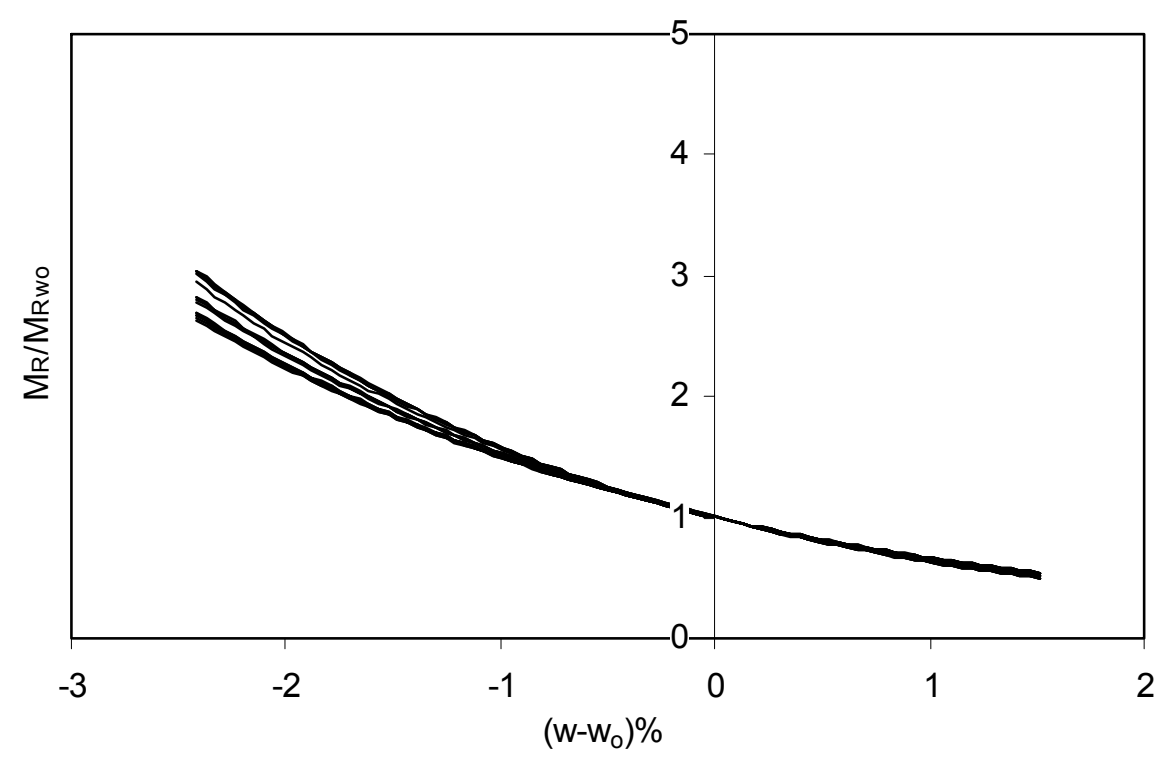

Figura 5.27: Variação do módulo de resiliência versus variação da umidade para diferentes estados de tensão

$$
\left(\frac{M_{R_{w}}}{M_{R_{w o}}}\right)=a \cdot e^{b \cdot\left(w-w_{o}\right)}
$$

onde: $M_{R w}$ : módulo de resiliência na umidade que se deseja avaliar;

$M_{R w o}$ : módulo de resiliência na umidade ótima e massa específica seca máxima;

w: teor de umidade em que se deseja avaliar $M_{R}$;

$\mathrm{w}_{\mathrm{o}}$ : umidade ótima;

$a$ e b: parâmetros de regressão.

Tabela 5.20: Parâmetros de regressão e coeficiente de determinação para o ajuste entre a taxa de variação do módulo de resiliência e a variação da umidade para diferentes estados de tensão

\begin{tabular}{|c|c|c|c|c|c|c|c|c|c|c|c|c|c|c|}
\hline \multicolumn{2}{|c|}{$\begin{array}{l}\text { Estado } \\
\text { de tensão }\end{array}$} & \multicolumn{2}{|c|}{$\begin{array}{c}\text { Parâmetros } \\
\text { de } \\
\text { regressão }\end{array}$} & & \multicolumn{2}{|c|}{$\begin{array}{l}\text { Estado } \\
\text { de tensão }\end{array}$} & \multicolumn{2}{|c|}{$\begin{array}{c}\text { Parâmetros } \\
\text { de } \\
\text { regressão }\end{array}$} & \multirow[t]{2}{*}{$\mathbf{R}^{2}$} & \multicolumn{2}{|c|}{$\begin{array}{c}\text { Estado } \\
\text { de tensão }\end{array}$} & \multicolumn{2}{|c|}{$\begin{array}{c}\text { Parâmetros } \\
\text { de } \\
\text { regressão }\end{array}$} & \multirow{2}{*}{$\mathbf{R}^{2}$} \\
\hline \multicolumn{4}{|c|}{$(\mathrm{kPa})(\mathrm{kPa})$} & & \multicolumn{4}{|c|}{$(\mathrm{kPa})(\mathrm{kPa})$} & & $\sigma_{3}$ & $\begin{array}{c}\sigma_{\mathrm{d}} \\
(\mathrm{kPa})\end{array}$ & a & b & \\
\hline \multirow{5}{*}{13,8} & 12,4 & 00 & & 0,86 & \multirow{5}{*}{27,0} & & 00 & & & \multirow{5}{*}{41,4} & & & & \\
\hline & & & & 0,86 & & & & & & & & & & \\
\hline & 36 & ט, & $-0,46$ & 0,86 & & & 1,00 & & 0,83 & & & 1,0 & -0 & \\
\hline & 49,7 & 1,00 & $-0,45$ & 0,85 & & 49,7 & 1,00 & $-0,42$ & 0,83 & & 49,7 & 1,00 & $-0,40$ & 0,8 \\
\hline & 62,0 & 1,00 & $-0,46$ & 0,84 & & 62,0 & 1,00 & $-0,41$ & 0,82 & & 62,0 & 1,00 & $-0,41$ & 0,80 \\
\hline
\end{tabular}


Analisando-se a Figura 5.27, observa-se a sobreposição das curvas que representam quinze diferentes estados de tensão analisados, com maior tendência de dispersão nos resultados para trajetórias de secagem, ensejando o questionamento sobre a independência da relação entre as variáveis e o estado de tensão. Em última análise, poder-se-ia considerar que conhecidos os coeficientes $\mathrm{k}_{2}$ e $k_{3}$ do modelo composto para um determinado material ensaiado na umidade ótima, estes valores manter-se-iam para os ensaios realizados com variação da umidade pós-compactação. Isto reforça a idéia de que as diferenças observadas entre estes parâmetros (vide Tabelas 5.10, 5.11 e 5.12) podem ser decorrentes da variabilidade inerente à realização dos ensaios triaxiais cíclicos, conforme discutido anteriormente.

Analisando-se a Tabela 5.20, observa-se que os coeficientes de determinação são considerados como bons, com valores entre 0,80 e 0,86. Verificase também a tendência de diminuição de $b$ com o aumento das tensões confinante e desvio. Tendência semelhante à dos valores de $R^{2}$, que diminuíram com o aumento daqueles. Os valores de a permanecem constantes, com valor igual a 1 , conforme discutido anteriormente para manter a igualdade entre os módulos no caso de $\left(\mathrm{w}-\mathrm{w}_{\mathrm{o}}\right)=0$.

$\mathrm{Na}$ medida em que se observou a tendência de sobreposição entre as curvas para os estados de tensão analisados, bem como a pequena diferença entre os valores de $b$, avaliou-se a possibilidade de existência de uma única expressão que pudesse estimar estas variações com um desempenho semelhante aos dos modelos obtidos individualmente. Assim, considerando-se todos os valores de $M_{R}$ calculados para os solos da pesquisa nos diferentes estados de tensão, obteve-se a equação (5.17) que permite a estimativa da taxa de variação do módulo de resiliência em função apenas da variação da umidade. A expressão apresenta um bom desempenho, medido pelo valor de $\mathrm{R}^{2}$ igual 0,83 .

$$
\left(\frac{M_{R_{w}}}{M_{R_{w o}}}\right)=e^{-0,43 \cdot\left(w-w_{o}\right)}
$$

A Figura 5.28 ilustra a equação (5.17), que representa a relação entre a taxa de variação de variação do módulo de resiliência com a variação da umidade. 


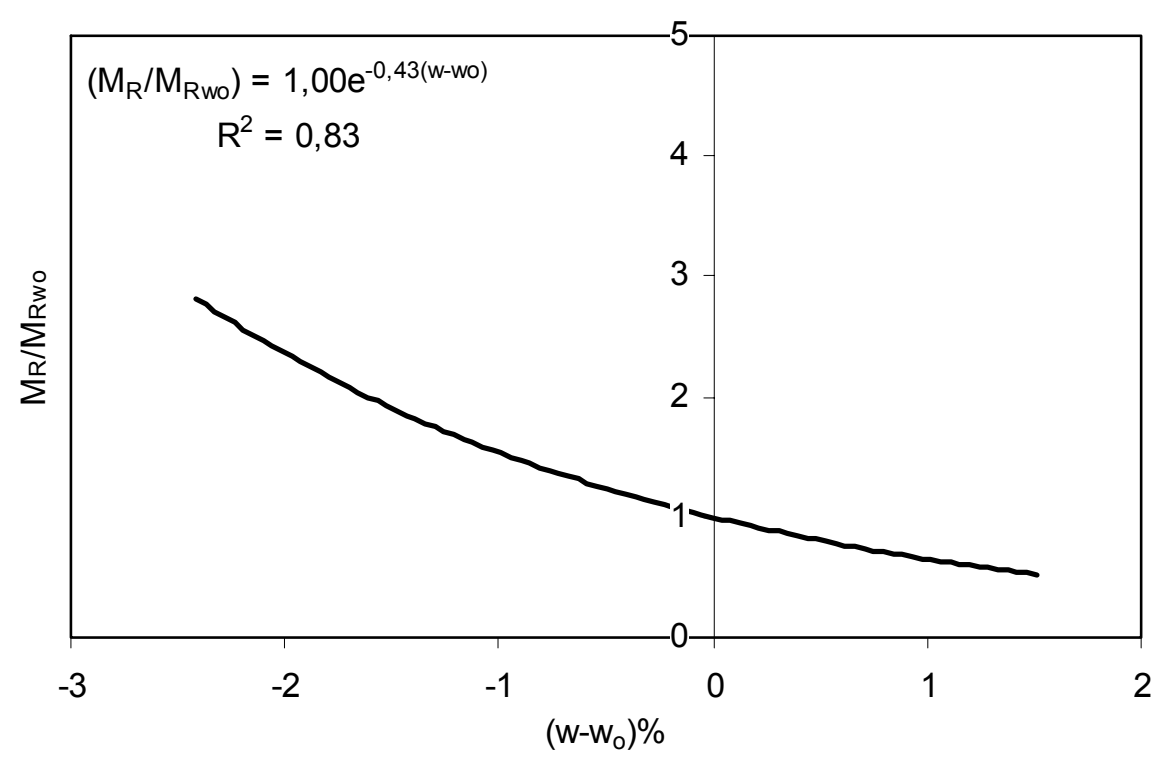

Figura 5.28: Variação do módulo de resiliência versus variação da umidade para todos os solos e todas as umidades

A partir da relação expressa pela equação (5.17), é possível estimar o efeito da variação da umidade pós-compactação sobre o módulo de resiliência, desde que sejam conhecidos o resultado do ensaio na condição ótima do Proctor Normal e a variação de umidade a ser avaliada. Partindo-se da premissa exposta anteriormente, de que as variações observadas nos coeficientes $k_{2}$ e $k_{3}$ para as diferentes umidades de ensaio poderiam ser resultado da variabilidade do ensaio, ou seja, que estes valores poderiam até ser considerados como iguais durante as variações das umidades, a expressão resultante poderia ser simplificada para uma variação no parâmetro $\mathrm{k}_{1}$, conforme se segue.

$$
\left(\frac{M_{R_{w}}}{M_{R_{w o}}}\right)=a \cdot e^{b \cdot(w-w o)} \Rightarrow M_{R_{w}}=M_{R_{w o}} \cdot a \cdot e^{b \cdot(w-w o)}
$$

Considerando-se o modelo composto, tem-se para uma umidade (w) de interesse e a umidade ótima $\left(\mathrm{w}_{\mathrm{o}}\right)$.

$$
\left(k_{1 w} \cdot \sigma_{d}{ }^{k_{2 w}} \cdot \sigma_{3}^{k_{3 w}}\right)=\left(k_{1 w 0} \cdot \sigma_{d}^{k_{2 w 0}} \cdot \sigma_{3}^{k_{3 w o}}\right) \cdot a \cdot e^{b \cdot(w-w o)}
$$

Admitindo-se que os valores de $k_{2 w}=k_{2 w o}$ e $k_{3 w}=k_{3 w o}$, tem-se a equação (5.18).

$$
k_{1_{w}}=k_{1_{w o}} \cdot\left(a \cdot e^{b \cdot(w-w o)}\right)
$$


Substituindo-se os valores de a e $b$, respectivamente 1,00 e $-0,43$, da equação (5.17) na expressão (5.18), ter-se-ia um modelo para a análise da variação do módulo de resiliência pela variação na magnitude do coeficiente $k_{1}$, considerando-se os solos desta pesquisa (equação (5.19)).

$$
k_{1_{w}}=k_{1_{w o}} \cdot e^{-0,43 \cdot\left(w-w_{o}\right)}
$$

onde: $k_{1 w}$ : valor do parâmetro $k_{1}$ do modelo composto na umidade que se deseja avaliar;

$\mathrm{k}_{1 \text { wo }}$ : valor do parâmetro $\mathrm{k}_{1}$ do modelo composto na umidade ótima e massa específica seca máxima;

w: teor de umidade em que se deseja avaliar $M_{R}$;

$\mathrm{w}_{\mathrm{o}}$ : umidade ótima;

\subsection{Ensaios de compressão simples}

Os ensaios de compressão simples foram realizados para determinação dos valores de módulo tangente inicial $\left(E_{0}\right)$. Os procedimentos adotados para ensaio e cálculo do valor de $\mathrm{E}_{0}$ são apresentados no Capítulo 3.

Os trinta solos selecionados na pesquisa foram submetidos aos ensaios na condição ótima do Proctor Normal, tendo sido compactados e ensaiados três corpos-de-prova para cada amostra na mesma condição, ou seja, na umidade ótima e massa específica seca máxima. Portanto, o módulo tangente inicial considerado para cada solo é resultado da média de até três valores de $E_{0}$. Para quatro destes solos também foram realizados ensaios considerando-se a variação da umidade pós-compactação.

\subsubsection{Resultados de módulo tangente inicial na condição ótima do Proctor Normal}

A Tabela 5.21 apresenta os valores médios de módulo tangente inicial $\left(E_{0}\right)$ e resistência à compressão simples (RCS) para os solos submetidos ao ensaio de compressão simples na condição ótima do Proctor Normal. Ressalta-se que os resultados apresentados correspondem à média de três ensaios. 
Tabela 5.21: Valores médios de $E_{0}$ e RCS para os solos submetidos ao ensaio de compressão simples na condição ótima do Proctor Normal

\begin{tabular}{|c|c|c|c|c|c|c|c|}
\hline \multicolumn{2}{|c|}{ Amostra } & $\begin{array}{c}\mathrm{E}_{0} \\
(\mathrm{MPa})\end{array}$ & $\begin{array}{l}\text { RCS } \\
\text { (kPa) }\end{array}$ & \multicolumn{2}{|c|}{ Amostra } & $\begin{array}{c}\mathrm{E}_{0} \\
(\mathrm{MPa})\end{array}$ & $\begin{array}{l}\text { RCS } \\
(\mathrm{kPa})\end{array}$ \\
\hline \multirow{7}{*}{ 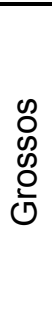 } & 1L (76) & 36 & 239 & \multirow{15}{*}{ 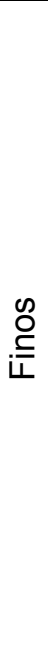 } & 9L (21) & 97 & 553 \\
\hline & $1 \mathrm{Na}(81)$ & 25 & 292 & & $9 \mathrm{~N}(77)$ & 92 & 709 \\
\hline & $1 \mathrm{Nb}(85)$ & 22 & 259 & & 10L (38) & 60 & 278 \\
\hline & $2 \mathrm{~L}(11)$ & 20 & 245 & & $10 \mathrm{~N}(53)$ & 51 & 185 \\
\hline & $2 \mathrm{~N}(17)$ & 67 & 438 & & 11La (48) & 115 & 595 \\
\hline & 3N (89) & 11 & 116 & & 11Lb (91) & 98 & 254 \\
\hline & 4L (50) & 16 & 205 & & $11 \mathrm{~N}(78)$ & 65 & 381 \\
\hline \multirow{8}{*}{ 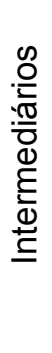 } & $5 \mathrm{~N}(55)$ & 34 & 331 & & 12L (25) & 84 & 457 \\
\hline & $5 \mathrm{~L}(60)$ & 52 & 437 & & $12 \mathrm{Na}(22)$ & 123 & 828 \\
\hline & $6 \mathrm{~N}(27)$ & 110 & 700 & & $12 \mathrm{Nb}(34)$ & 57 & 497 \\
\hline & 6La (30) & 103 & 728 & & 13L (67) & 176 & 719 \\
\hline & $6 \mathrm{Lb}(57)$ & 96 & 486 & & $13 N(39)$ & 153 & 906 \\
\hline & 7L (46) & 69 & 143 & & 14L (71) & 109 & 630 \\
\hline & 8L (88) & 42 & 181 & & $14 \mathrm{Na}(65)$ & 98 & 600 \\
\hline & & & & & $15 \mathrm{~N}(64)$ & 11 & 205 \\
\hline
\end{tabular}

Analisando-se em conjunto as Tabelas 5.13 e 5.21 , observa-se que os maiores valores de módulo tangente inicial correspondem aos maiores valores de módulo de resiliência típicos. Considerando-se separadamente cada grupo, ou "pares" de amostras, observa-se que, na maioria dos casos, os solos lateríticos apresentaram maiores valores de $\mathrm{E}_{0}$ do que os seus semelhantes granulométricos não-lateríticos. Esta tendência é exceção para as amostras 2N (17), 6N (27) e 12Na (22) que apresentaram valores de módulo tangente inicial maiores do que as amostras 2L (11), 6La (30), 6Lb (57) e 12L (25), seus "pares" respectivos. A Figura 5.29 ilustra a variação dos valores médios de módulo tangente inicial com o teor de argila para os solos separados segundo a gênese.

Analisando-se a Figura 5.29, observa-se a tendência de aumento do módulo tangente inicial com o aumento do teor de argila. Não se identificou características diversas entre os solos lateríticos e não-lateríticos, corroborado pela comparação entre as médias das duas classes. O resultado do teste-t indicou para a não rejeição da hipótese nula, que considera a igualdade entre as médias. Portanto, concluir-se-ia que a gênese não influencia o valor do módulo tangente inicial, da mesma forma que o verificado para os valores de módulo de resiliência médio e típico. 


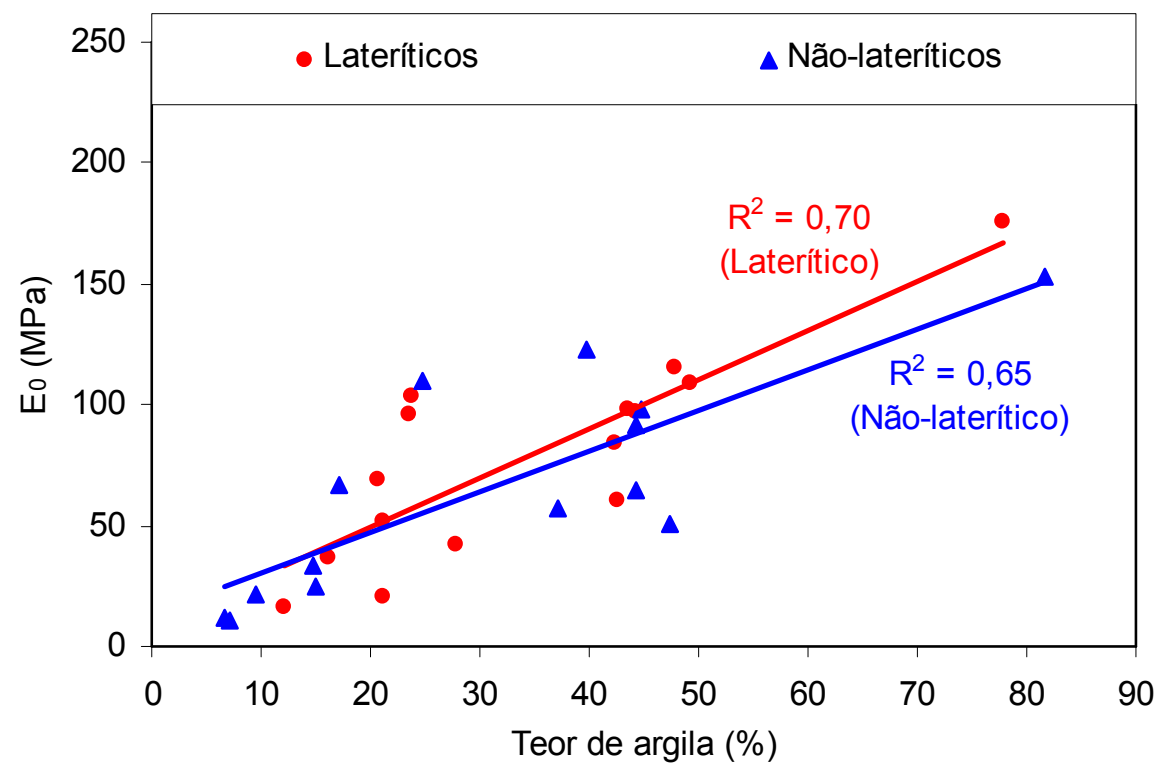

Figura 5.29: Valores médios de módulo tangente inicial versus teor de argila

As comparações entre as médias dos grupos granulométricos, a partir do teste-t, mostraram que existem evidências estatísticas de diferenças entre as médias dos solos grossos e as demais classes. Entretanto, a comparação entre os solos intermediários e finos indica a existência de evidências de igualdade entre as médias. Portanto, conclui-se que a granulometria influencia no valor do módulo tangente inicial, contudo, no que diz respeito ao $E_{0}$, o comportamento dos solos intermediários e finos é semelhante.

\subsubsection{Resultados de módulo tangente inicial com variação da umidade pós- compactação}

Foram escolhidos cinco solos, dentre os trinta selecionados, para realização de ensaios de compressão simples com variação da umidade pós-compactação. Seguiram-se os mesmos princípios na preparação dos corpos-de-prova descritos para os ensaios de módulo de resiliência, ou seja, partindo-se da umidade ótima $\left(w_{0}\right)$, seguindo-se trajetórias de secagem até $w_{0}-1 \%$ e $w_{0}-2 \%$, e trajetória de umedecimento até $w_{0}+1 \%$. Os solos selecionados são: $1 \mathrm{~L}$ (76), $1 \mathrm{Nb}(85), 5 \mathrm{~L}(60)$, $5 \mathrm{~N}(55)$ e 11La (48). A Tabela 5.22 apresenta os resultados de módulo tangente inicial com a variação de umidade pós-compactação. Salienta-se que nestes casos os valores de $E_{0}$ também correspondem à média de três ensaios realizados em cada condição de umidade. 
Tabela 5.22: Valores médios de módulo tangente inicial $\left(\mathrm{E}_{0}\right)$ para os solos submetidos ao ensaio de compressão simples com variação da umidade póscompactação

\begin{tabular}{ccccc}
\hline \multirow{2}{*}{ Amostra } & \multicolumn{4}{c}{$\mathbf{E}_{\mathbf{0}}$ (MPa) } \\
\cline { 2 - 5 } & $\mathbf{w}_{\mathbf{o}}-\mathbf{2} \%$ & $\mathbf{w}_{\mathbf{o}}-\mathbf{1 \%}$ & $\mathbf{w}_{\mathbf{o}}$ & $\mathbf{w}_{\mathbf{o}} \mathbf{+ 1} \%$ \\
\hline $1 \mathrm{~L}(76)$ & 79 & 55 & 36 & 23 \\
$1 \mathrm{Nb}(85)$ & 38 & 27 & 22 & 13 \\
$5 \mathrm{~L}(60)$ & 107 & 82 & 52 & 27 \\
$5 \mathrm{~N}(55)$ & 56 & 39 & 34 & 15 \\
11La (48) & 299 & 216 & 115 & 92 \\
\hline
\end{tabular}

Analisando-se a Tabela 5.22, observa-se que o processo de secagem conduziu ao aumento do módulo tangente inicial, sendo este maior quanto menor a umidade. Ao contrário, o umedecimento levou à redução do $\mathrm{E}_{0}$. Estas variações também podem ser justificadas pela variação do nível de sucção.

Avaliou-se a variação do módulo tangente inicial com a variação da umidade de ensaio, à semelhança do realizado para o módulo de resiliência. A Figura 5.30 ilustra esta relação para os cinco solos selecionados nesta etapa do estudo.

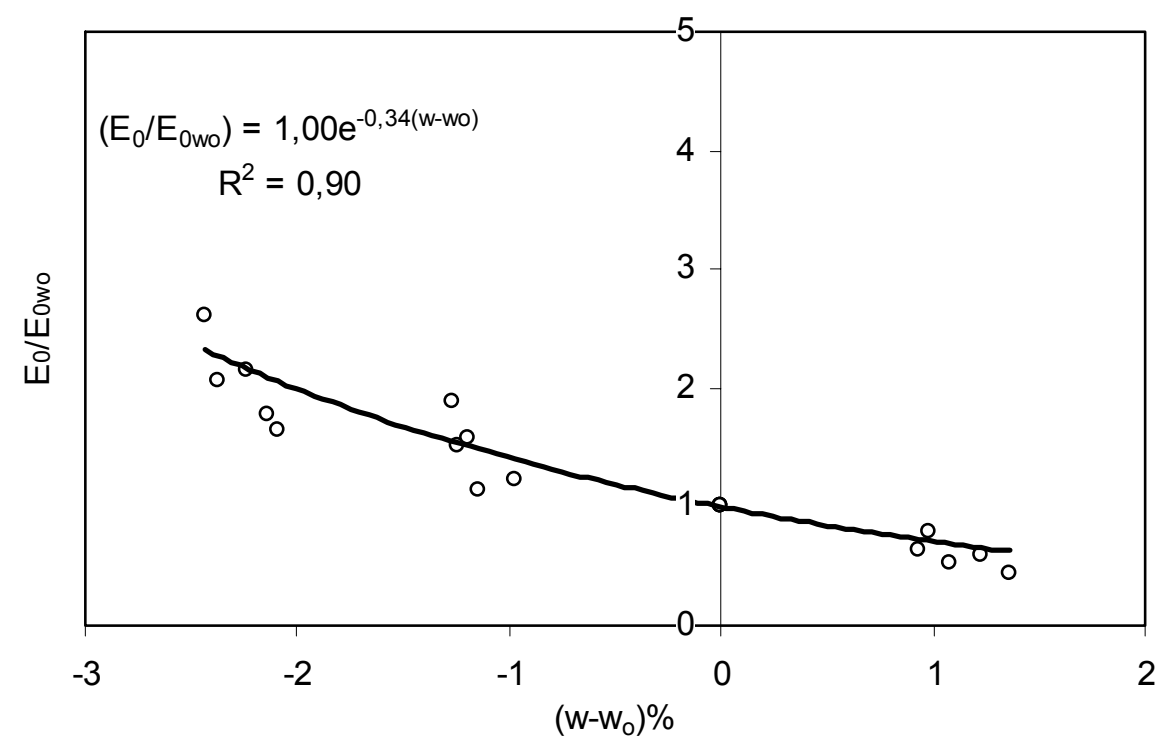

Figura 5.30: Variação do módulo tangente inicial versus variação da umidade de ensaio

A Figura 5.30 mostra o ajuste aos pontos por uma função exponencial, da mesma forma que o verificado para o caso do módulo de resiliência. A equação (5.16) mostra a forma geral desta expressão. O ajuste encontrado, com $a=1,00$ e $b$ 
$=-0,34$, pode ser considerado como excelente pelo valor de $R^{2}$ igual a 0,90 . Destaca-se que na regressão realizada foi imposta a passagem da curva pelo valor 1, que significa a igualdade entre os módulos tangentes iniciais para a situação em que $\left(w-w_{o}\right)=0$. A equação (5.20) mostra a expressão resultante.

$$
\left(\frac{E_{0_{w}}}{E_{0 w_{o}}}\right)=e^{-0,34 \cdot\left(w-w_{o}\right)}
$$

onde: $\mathrm{E}_{0 \mathrm{w}}$ : módulo tangente inicial na umidade que se deseja avaliar;

$\mathrm{E}_{\text {Owo }}$ : módulo tangente inicial na umidade ótima e massa específica seca máxima;

w: teor de umidade em que se deseja avaliar $E_{0}$;

$\mathrm{w}_{\mathrm{o}}$ : umidade ótima;

Entretanto, salienta-se que esta relação deve ser melhor avaliada com a consideração de um número maior de amostras. Ainda assim, pela semelhança entre os resultados deste estudo com o realizado para o $M_{R}$, optou-se por avaliar em conjunto as relações entre o $M_{R}$ e o $E_{0}$ e a variação da umidade.

A Figura 5.31 apresenta no mesmo gráfico as variações do módulo de resiliência e do módulo tangente inicial com a variação da umidade de ensaio.

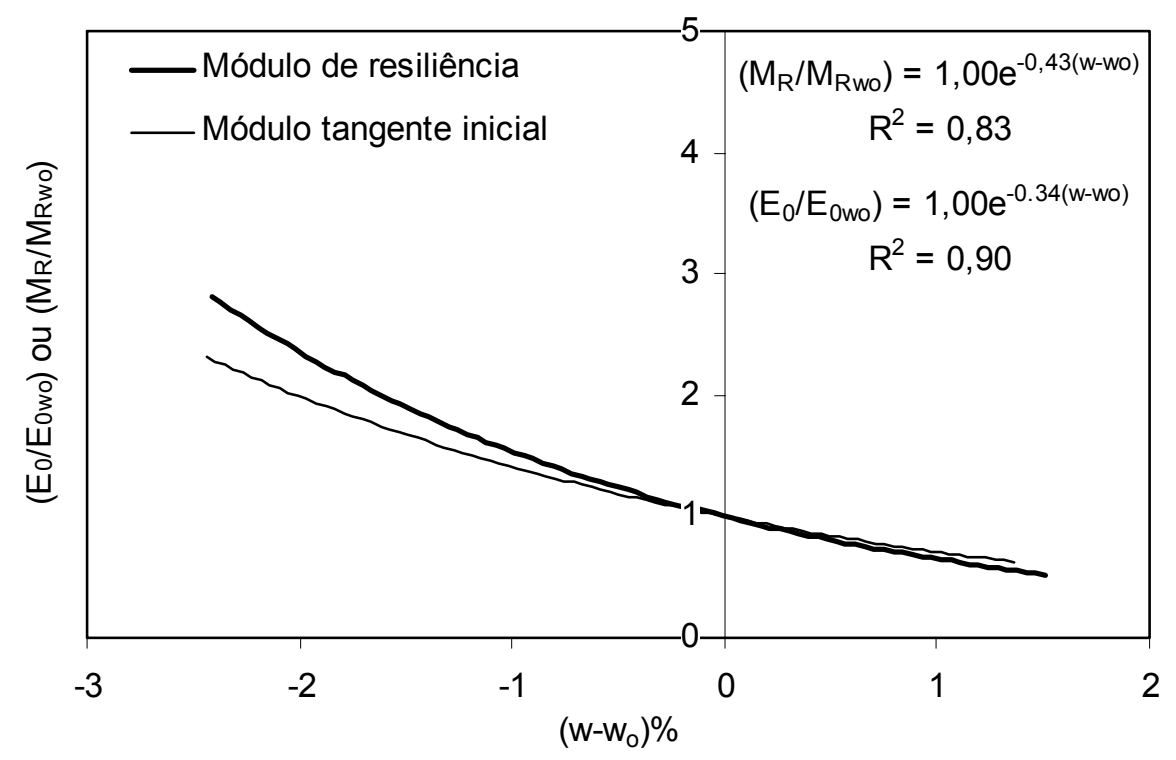

Figura 5.31: Variação do módulo de resiliência e do módulo tangente inicial versus variação da umidade de ensaio 
Analisando-se a Figura 5.31, observa-se uma semelhança entre as curvas de tendência, com estas divergindo quanto mais negativas ou positivas as diferenças de umidade, ou seja, quanto maior o desvio da umidade com relação à $\mathrm{w}_{\mathrm{o}}$. Durante a secagem é maior a distância entre as curvas, se comparado ao umedecimento.

Conforme discutido anteriormente, deve ser considerado um número maior de amostras na análise da variação do módulo tangente inicial. Como conseqüência, as curvas de tendência apresentadas na Figura 5.31 poderiam ser mais próximas, ensejando a utilização destas relações para estimar a variação do módulo de resiliência com a umidade a partir da realização de um ensaio mais simples do que o triaxial cíclico, que é o caso do ensaio de compressão simples.

\subsection{Relações do Módulo de resiliência com as propriedades físicas dos solos e os resultados dos ensaios de compressão simples}

Nesta etapa do estudo decidiu-se por avaliar a relação do módulo de resiliência com propriedades físicas dos solos a partir de possíveis correlações entre tais características e os parâmetros $\mathrm{k}_{1}, \mathrm{k}_{2}$ e $\mathrm{k}_{3}$ do modelo composto.

Conforme apresentado no Capítulo 2, Yau \& Von Quintus (2002) consideram como os índices mais importantes na previsão do módulo de resiliência de solos as porcentagens que passam nas peneiras $n^{\circ} 4\left(P_{4}\right), n^{\circ} 40\left(P_{40}\right)$ e $n^{\circ} 200\left(P_{200}\right)$, os teores de argila $\left(P_{\text {Argila }}\right)$ e silte $\left(P_{\text {Silte }}\right)$, o limite de liquidez $(L L)$ e o índice de plasticidade (IP), a umidade ( $w$ ) e a massa específica seca de ensaio $\left(\rho_{d}\right)$, e a umidade ótima $\left(w_{0}\right)$ e massa específica seca máxima $\left(\rho_{\mathrm{dmax}}\right)$.

Tomando-se como referência o estudo citado anteriormente, selecionaramse oito propriedades físicas, determinadas para os solos desta pesquisa, para avaliação das relações com k $k_{1}$, $k_{2}$ e $k_{3}$ que são: os teores de finos, de argila e silte, os limites de liquidez e plasticidade e índice de plasticidade, além da umidade ótima e massa específica seca máxima. A Figura 5.32 apresenta para $k_{1}, k_{2}$ e $k_{3}$ do modelo composto as suas relações individuais com os parâmetros físicos dos solos escolhidos para o estudo. 


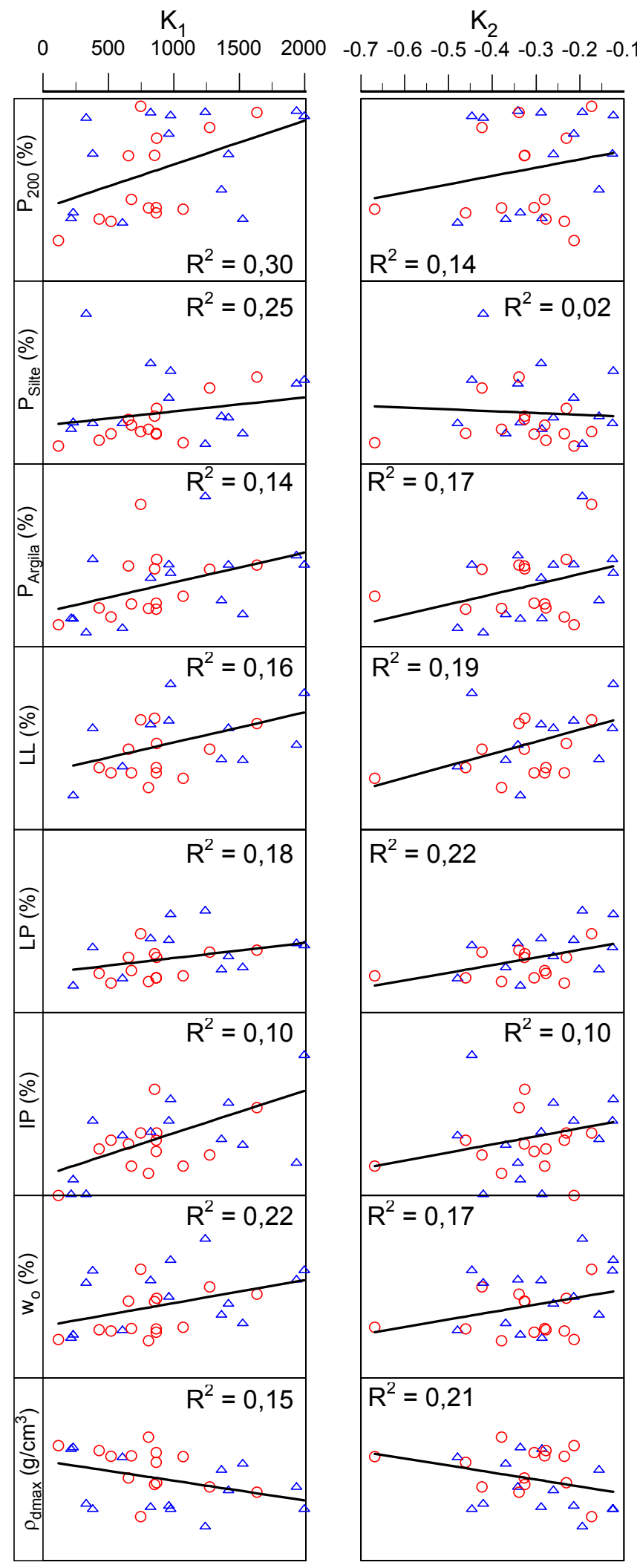

$\mathrm{K}_{3}$

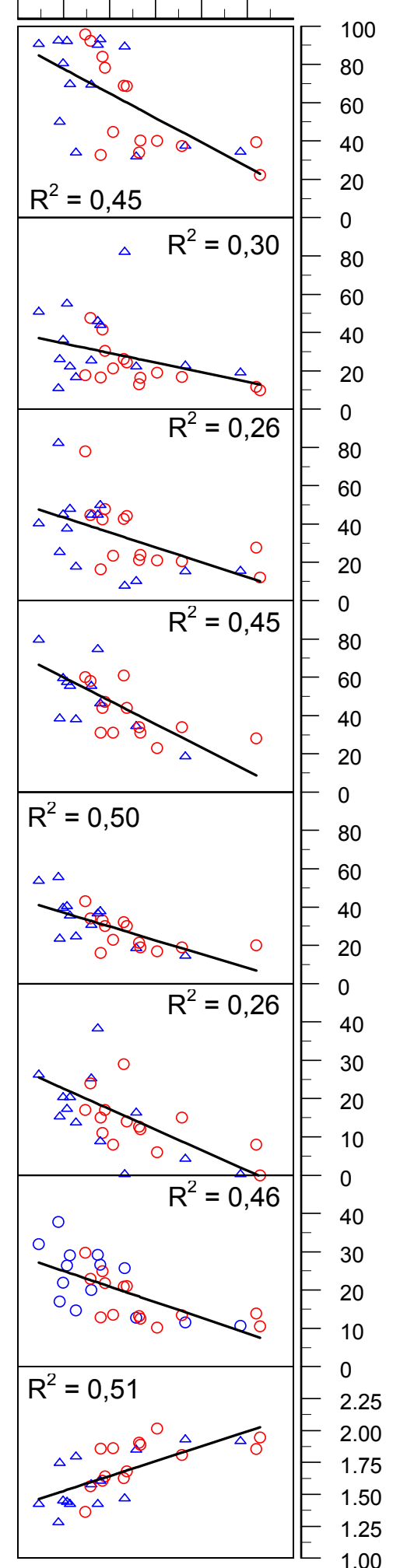

Figura 5.32: Relações entre os parâmetros $k_{1}, k_{2}$ e $k_{3}$ do modelo composto com propriedades físicas dos solos 
Analisando-se a Figura 5.32, observa-se que a melhor correlação de $\mathrm{k}_{1}$ se dá com o teor de finos $\left(P_{200}\right)$, com um $R^{2}$ igual a 0,30 , mas que pode ser considerado ruim. Todas as outras correlações produziram valores menores do que este. No caso de $k_{2}$, a melhor relação foi encontrada com o limite de plasticidade (LP). Entretanto, para este coeficiente, todos os valores de $R^{2}$ podem ser considerados ruins, já que os resultados são menores ou iguais a 0,22 . $O k_{3}$, se comparado aos outros coeficientes, apresenta as melhores correlações, com $\mathrm{R}^{2}$ variando entre 0,26 e 0,51 , ou seja, poderiam ser considerados no máximo regulares.

Identificadas as relações individuais entre os parâmetros de regressão do modelo composto e as propriedades físicas dos solos, foram realizadas regressões lineares múltiplas pelo método forward stepwise para verificar a existência de outras correlações mais complexas que pudessem descrever as variações dos coeficientes $k_{1}$, $k_{2}$ e $k_{3}$ com um desempenho melhor.

As regressões múltiplas realizadas produziram, para o coeficiente $k_{1}, a$ expressão descrita pela equação (5.21), que apresentou um valor de $R^{2}$ igual a 0,50 , e é função do limite de liquidez (LL), do teores de silte $\left(P_{\text {sitete }}\right)$, argila $\left(P_{\text {argila }}\right)$ e finos $\left(P_{200}\right)$, da massa específica seca máxima $\left(\rho_{\text {dmax }}\right)$ e do índice de plasticidade (IP). A Figura 5.33 apresenta os valores previstos de $k_{1}$ pela equação (5.21) contra os valores observados de $\mathrm{k}_{1}$.

$$
\begin{aligned}
k_{1}= & -3371+20,60 \cdot L P-371,79 * P_{200}+384,99 \cdot P_{\text {Argila }}+ \\
& +387,76 * P_{\text {Silte }}+1648,05 \cdot \rho_{d \max }
\end{aligned}
$$

onde: $\mathrm{k}_{1}$ : parâmetro de regressão do modelo composto;

LP e IP: respectivamente, limite de plasticidade e índice de plasticidade (\%);

$P_{\text {silte }}, P_{\text {argila }}, P_{200}$ : respectivamente, teores de silte, argila e finos (\%);

$\rho_{\mathrm{dmax}}$ : massa específica seca máxima, em $\mathrm{g} / \mathrm{cm}^{3}$; 


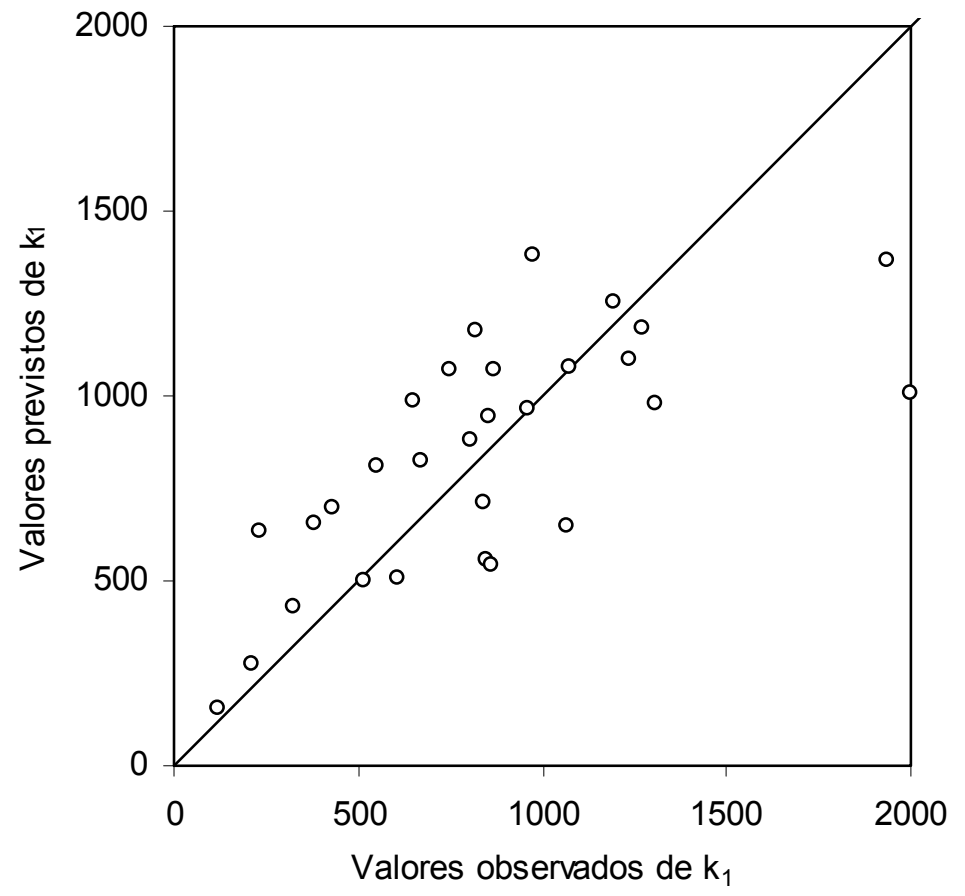

Figura 5.33: Valores previstos de $k_{1}$ versus valores observados de $k_{1}$

Análises semelhantes foram realizadas para o coeficiente $k_{2}$, entretanto, nenhuma relação melhor do que as individuais foi determinada entre este parâmetro e as propriedades físicas dos solos.

A equação (5.22) mostra a expressão obtida para a relação de $k_{3}$ com o limite de plasticidade (LP) e o teor de silte $\left(P_{\text {site }}\right)$, sendo esta o melhor resultado da regressão linear múltipla, e cujo coeficiente de determinação encontrado foi 0,69.

$$
k_{3}=0,37-0,0066 \cdot L P-0,0026 \cdot P_{\text {silte }}
$$

onde: $\mathrm{k}_{3}$ : parâmetro de regressão do modelo composto;

LP: limite de plasticidade (\%);

$P_{\text {silte: }}$ teor de silte (\%);

A Figura 5.34 apresenta os valores previstos de $k_{3}$ pela equação (5.22) contra os valores observados de $\mathrm{k}_{3}$. 


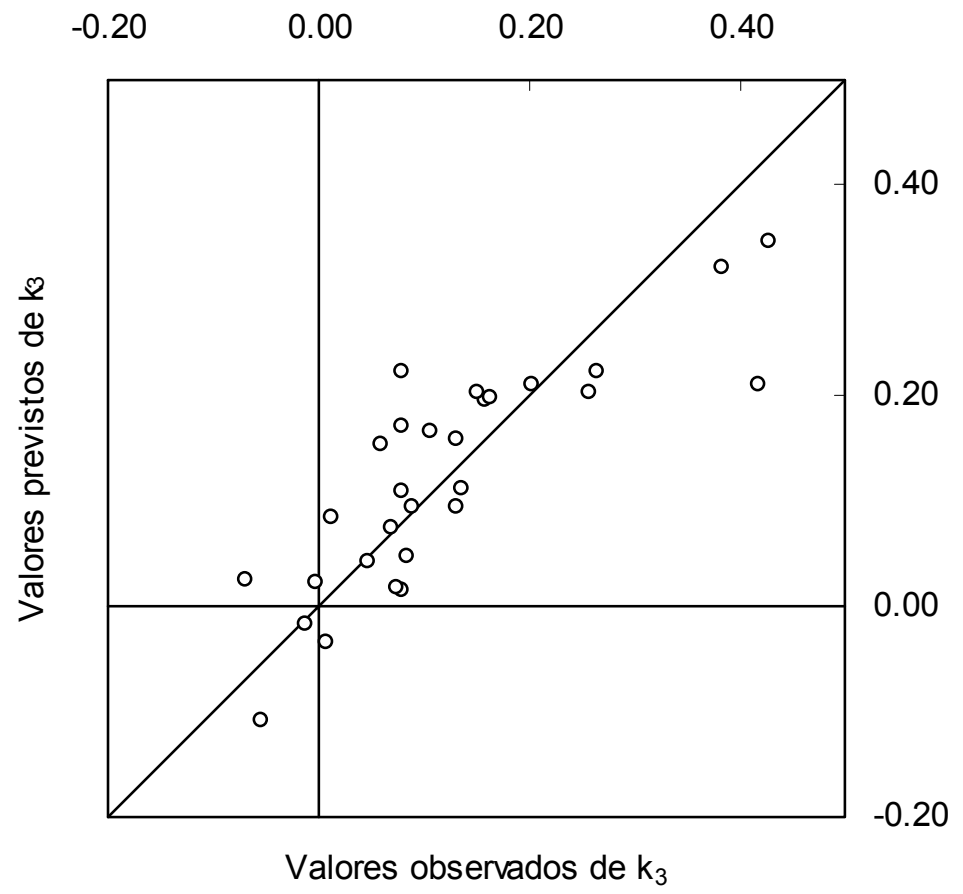

Figura 5.34: Valores previstos de $k_{3}$ versus valores observados de $k_{3}$

Analisando-se a Figura 5.34, observa-se a dispersão dos resultados em torno da reta de igualdade, indicando uma previsão razoável do modelo, e que é corroborado pelo valor também razoável de $\mathrm{R}^{2}(0,69)$.

De forma geral, poder-se-ia-se dizer que, para os solos considerados neste estudo, o parâmetro $k_{2}$ não se relaciona com as propriedades físicas selecionadas para o estudo, enquanto os coeficientes $k_{1}$ e $k_{3}$ apresentam correlação apenas razoável com algumas destas propriedades.

Com o intuito de avaliar a existência de correlações melhores do que as descritas pelas equações (5.21) e (5.22), optou-se por incluir nas regressões, como variáveis independentes, o módulo tangente inicial $\left(E_{0}\right)$ e a resistência à compressão simples (RCS). Partindo-se das expressões obtidas apenas com as propriedades físicas dos solos, adicionou-se separadamente às análises de regressão o $\mathrm{E}_{0}$ e a RCS, e posteriormente as duas variáveis em conjunto, avaliando as conseqüências pela alteração do valor de $\mathrm{R}^{2}$. 
No caso do coeficiente $k_{2}$, a inclusão de $E_{0}$ ou RCS, ou ainda as duas variáveis, não introduziu melhorias que pudessem gerar um modelo para previsão deste parâmetro com as variáveis em questão e as propriedades dos solos.

A inclusão das variáveis citadas produziu o melhor efeito para o parâmetro $\mathrm{k}_{1}$, que, ao se adicionar somente o $\mathrm{E}_{0}$ às variáveis da equação (5.21), aumentou o coeficiente de determinação de 0,50 para 0,60. A inclusão nas análises apenas da RCS levou ao aumento de $R^{2}$ até 0,63 , indicando um efeito maior desta variável sobre as variações de $k_{1}$, se comparado à influência de $E_{0}$. Como seria de se esperar neste caso, a consideração em conjunto das duas variáveis aumento o valor de $R^{2}$ para 0,67 . A equação (5.23) mostra a expressão que melhor explica as variações $k_{1}$, para o conjunto de solos estudados e para as variáveis selecionadas.

$$
\begin{aligned}
k_{1}= & -4396+4,24 \cdot E_{0}-840,56 \cdot R C S+21,26 \cdot L P+492,54 \cdot P_{\text {site }}+ \\
& +489,05 \cdot P_{\text {argila }}-474,03 \cdot P_{200}+2177,14 \cdot \rho_{d \max }
\end{aligned}
$$

onde: $\mathrm{k}_{1}$ : parâmetro de regressão do modelo composto;

$\mathrm{E}_{0}$ : módulo tangente inicial (MPa);

RCS: resistência à compressão simples (MPa);

LP e IP: respectivamente, limite de plasticidade e índice de plasticidade (\%);

$P_{\text {site, }}, P_{\text {argila, }}, P_{200}$ : respectivamente, teores de silte, argila e finos (\%);

$\rho_{\mathrm{dmax}}$ : massa específica seca máxima, em $\mathrm{g} / \mathrm{cm}^{3}$;

A Figura 5.35 apresenta os valores previstos de $k_{1}$ pelas equações (5.21) e (5.23) contra os valores observados de $k_{1}$.

Analisando-se a Figura 5.35, observa-se a menor dispersão dos valores gerados pela equação (5.23), se comparado à (5.21), mas ainda assim o ajuste poderia ser considerado no máximo como razoável, como indica o valor de $\mathrm{R}^{2}$ igual a 0,67 .

No caso do parâmetro $\mathrm{k}_{3}$, a inclusão de $\mathrm{E}_{0}$ e RCS, individualmente ou em conjunto, às variáveis definidas na equação (5.22) produziu efeitos pouco significativos ao ajuste, elevando o coeficiente de determinação de 0,69 a 0,70, em 
qualquer dos casos. Isto é indicativo da pequena influência destas variáveis sobre as variações de $k_{3}$ e não justificariam a inclusão das variáveis ao modelo.

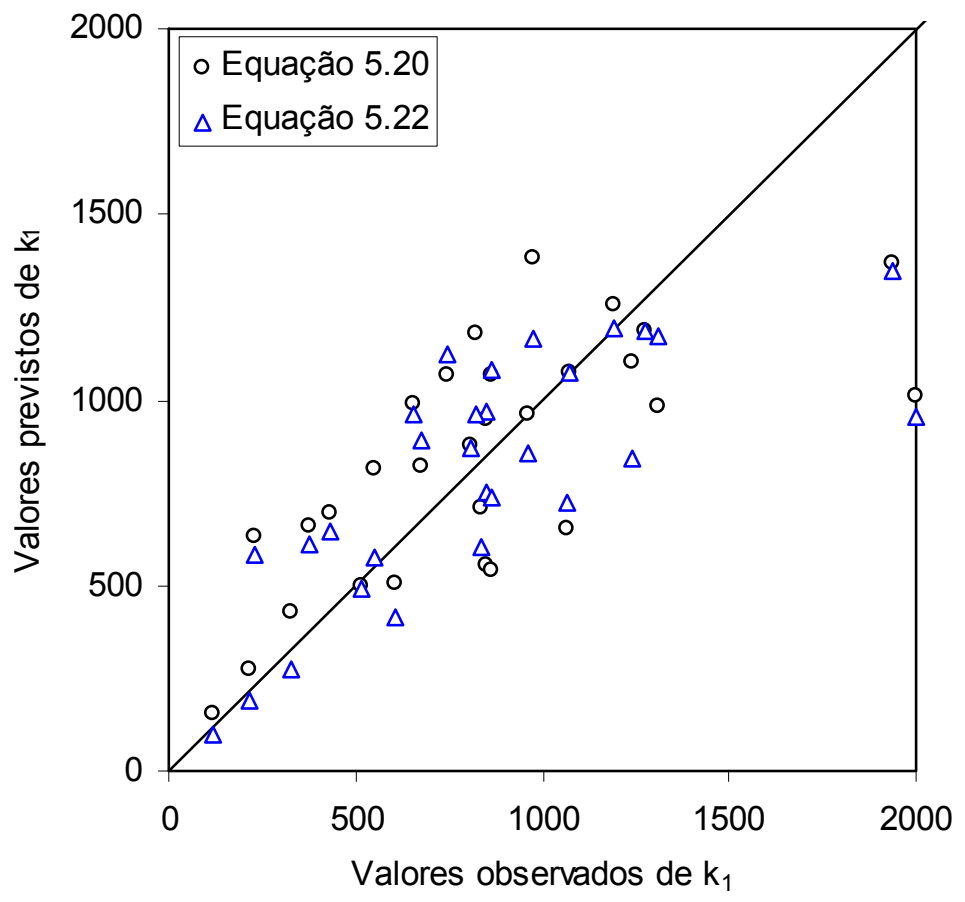

Figura 5.35: Valores previstos de $k_{1}$ pelas equações (5.21) e (5.23) versus valores observados de $\mathbf{k}_{1}$

Portanto, conclui-se que o parâmetro $k_{2}$ não apresenta correlação com as variáveis estudas. No caso de $k_{1}$, obteve-se um modelo de ajuste razoável das variações do coeficiente com propriedades físicas dos solos e os resultados dos ensaios de compressão simples. Da mesma forma, um ajuste razoável foi obtido para explicar as variações de $k_{3}$ em função de características dos solos. 


\section{Capítulo 6 - Conclusões e recomendações}

\subsection{Introdução}

Neste capítulo são apresentadas as conclusões desta pesquisa, que teve por objetivo principal estudar a influência da variação da umidade pós-compactação no comportamento mecânico de solos de subleito de rodovias do interior paulista. Ressalta-se que todas as conclusões apresentadas estão restritas ao universo de solos estudados.

\subsection{Conclusões}

Os solos lateríticos e não-lateríticos distribuem-se de forma aproximadamente uniforme dentro da região considerada na coleta, não tendo sido identificada a predominância de ocorrência destes em qualquer região específica.

A separação da área de coleta em quatro regiões evidenciou algumas características relacionadas à granulometria. Observou-se que na região (I) existe a predominância de solos intermediários, e que estes não foram encontrados nas regiões (II) e (IV), onde se observa a prevalência de amostras grossas e finas, respectivamente. Na região (III) encontram-se solos pertencentes a todas as faixas granulométricas. 
A consideração das regiões também evidenciou aspectos relacionados às classes MCT. Observou-se que os solos das classes LA' e NA' são predominantes na região (I). As classes LG' e NG' são encontradas principalmente nas regiões (III) e (IV), com raras ocorrências nas regiões (I) e (II). A maioria das amostras NS' encontra-se na região (IV). Os solos das classes LA e NA são ocorrência rara no conjunto de solos estudados.

Considerando-se a classificação MCT-M, a maioria das amostras, 64\% do total, seria classificada como solos transicionais.

A análise dos ensaios de difração de raios-x indicou a presença do quartzo e da goetita em praticamente todos os solos selecionados, independentemente da gênese. Porém, a gibbsita só foi encontrada em alguns solos lateríticos. A mesma análise mostrou que os solos lateríticos apresentam na sua constituição argilominerais menos ativos, do grupo da caulinita, enquanto nos solos nãolateríticos verificou-se a presença de argilominerais mais ativos, do grupo das ilitas, isoladamente ou em associação com argilominerais do grupo das caulinitas. E, apenas para as amostras lateríticas identificou-se a presença de óxidos e/ou hidróxidos de ferro e alumínio.

O ensaio de adsorção de azul de metileno se mostrou eficiente na caracterização dos argilominerais presentes na fração fina dos solos, possibilitando a associação do grau de atividade destes para a distinção dos solos lateríticos e não-lateríticos.

$\mathrm{Na}$ análise conjunta dos ensaios MCT, microscopia eletrônica de varredura, difração de raios-x e azul de metileno, observa-se que em $83 \%$ dos casos houve concordância entre as indicações da totalidade dos ensaios verificou-se ainda, que dentre as amostras em que a concordância entre as indicações dos ensaios é parcial, sempre três entre quatro ensaios produziram resultados congruentes. As divergências encontradas seriam devidas ou aos ensaios de MEV ou aos ensaios de adsorção de azul de metileno. Portanto, conclui-se que a classificação MCT conseguiu prever com eficiência o caráter laterítico ou não-laterítico dos solos selecionados na pesquisa. Grande parte de exceções são explicadas pelo posicionamento destes solos próximo aos limites entre as classes lateríticas e não- 
lateríticas, e que podem indicar uma característica intermediária, ou de transição para estas amostras.

Observou-se uma forte correlação entre a umidade ótima e massa específica seca máxima, indicado pelo alto valor de coeficiente de determinação $\left(R^{2}\right.$ $=0,93)$. Entretanto, não foi possível se distinguir características distintas entre os solos lateríticos e não-lateríticos. Quanto à granulometria, destacam-se diferenças de comportamento entre os solos grossos e intermediários e os solos finos. Os últimos apresentam teores de umidade ótima superiores a 19,5\%, enquanto as outras classes possuem valores de umidade ótima variando entre 8,0\% e 17,0\%.

A análise tanto da umidade ótima quanto da massa específica seca máxima com o limite de liquidez e o teor finos não evidenciou diferenças entre os solos lateríticos e os não-lateríticos. Ao contrário do estudo realizado entre estas variáveis e o teor de argila, que mostrou os solos lateríticos e não-lateríticos alinhando-se segundo distintas curvas de tendência.

Os modelos propostos pela AASHTO para estimativa da umidade ótima e massa específica seca máxima funcionam razoavelmente para os solos utilizados nesta pesquisa. As maiores diferenças foram encontradas para os solos finos, evidenciando as diferenças existentes na formação dos solos utilizados pela AASHTO e os deste trabalho.

Avaliou-se a existência de relações entre a umidade ótima e massa específica seca máxima com propriedades físicas dos solos, à semelhança do proposto pela AASHTO. Os resultados mostraram uma boa correlação entre estas variáveis e o limite de liquidez e o teor de finos, avaliados em conjunto, permitindo a estimativa a partir de propriedades físicas dos solos.

As condições ambientais, refletidas na umidade relativa do ar e temperatura ambiente, são fatores intervenientes nos processo de preparação das amostras e compactação dos corpos de prova. Também, interferem sobremaneira nos processos de secagem e umedecimento dos corpos de provas submetidos à variação de umidade pós-compactação. 
As perdas de umidade observadas durante o processo de compactação e armazenamento são variáveis, dependendo do tipo de solo e do tempo de armazenamento, tendo atingido até $0,5 \%$ de perda nesta pesquisa.

Um dos problemas enfrentados durante a análise dos resultados dos ensaios triaxiais cíclicos foi a determinação do módulo de resiliência para o nível de tensão desvio igual a $12,4 \mathrm{kPa}$, que, principalmente para os solos finos, não foi o suficiente para sensibilizar os equipamentos de medida de deslocamento e realizar efetivamente o registro das informações.

De forma geral, os modelos $\left(k-\sigma_{3}\right)$ e $(k-\theta)$ não mostraram um bom desempenho na representação do $M_{R}$ em função do estado de tensão para o conjunto de solos estudados, obtendo valores de $\mathrm{R}^{2}$ baixos se comparados aos demais modelos avaliados.

Os modelos ditos universais, composto e da AASHTO, apresentam excelente desempenho na descrição das variações do módulo de resiliência em função do estado de tensão, apresentando coeficientes de determinação sempre superiores 0,90. Na maior parte dos casos, as diferenças apresentadas nos valores de $\mathrm{R}^{2}$ são pouco significativas, portanto, o uso de qualquer um destes dois modelos na representação do $M_{R}$ destes solos parece ser razoável. E, como existe no Brasil a tendência de se utilizar o modelo composto, este foi o escolhido para a realização das análises.

Como tendência padrão, o $M_{R}$ diminui com o aumento da tensão desvio $\left(\sigma_{d}\right)$ e aumenta com o aumento da tensão confinante $\left(\sigma_{3}\right)$.

Analisando-se os parâmetros de regressão do modelo composto, observase que o valor médio do coeficiente $k_{1}$ tende a aumentar com o aumento do teor de finos nos solos, independentemente da gênese do material. Ao contrário, o valor médio do coeficiente $k_{3}$, que representa a influência da tensão confinante no módulo de resiliência, tende a diminuir com o aumento do teor de finos. Tanto com relação à granulometria tanto quanto à gênese, não foi possível identificar um padrão de comportamento para o coeficiente $k_{2}$, que representa a influência da tensão desvio no módulo de resiliência. 
Ainda com relação aos parâmetros do modelo composto, o valor médio do coeficiente $\mathrm{k}_{1}$ para os solos lateríticos é maior do que o valor médio para os solos não-lateríticos. Já $o$ valor médio do coeficiente $k_{3}$ para os solos finos é significativamente menor se comparado ao valor médio dos solos grossos e intermediários.

Verificou-se a influência da granulometria sobre o módulo de resiliência típico, com a tendência de aumento deste com o aumento do teor de finos. Esta influência destaca, principalmente, as diferenças entre os solos grossos e finos, com os intermediários podendo se comportar como um ou outro.

A análise dos valores de módulo de resiliência típico, determinado para um certo estado de tensões, não indicou haver influência da gênese sobre os resultados.

Para os grupos de solos, observou-se que na maior parte dos casos os solos lateríticos apresentaram valores de módulo de resiliência maiores do que os solos não-lateríticos.

A influência da granulometria é predominante sobre o módulo de resiliência se comparada à influência da gênese.

Como verificado para o módulo de resiliência típico, observa-se uma predominância da influência da granulometria sobre o módulo de resiliência médio se comparada à influência da gênese.

Sendo o valor do módulo de resiliência na $w_{0}$ a referência inicial, a trajetória de secagem produziu o aumento do valor do Módulo de resiliência típico, e quanto menor a umidade maior é o $\mathrm{M}_{\mathrm{R}}$. Em contraposição, a trajetória de umedecimento levou a uma redução do valor do $M_{R}$.

O processo de secagem dos corpos de prova até a $w_{0}-2 \%$, a partir de corpos de provas compactados na $w_{0}$, produziu um aumento médio nos valores do módulo de resiliência da ordem de $245 \%$ quando comparados aos resultados dos 
ensaios realizados na umidade ótima. Enquanto a secagem até $\mathrm{w}_{0}-1 \%$ produziu um aumento médio de 91\%.

O processo de umedecimento dos corpos de prova até a $w_{0}+1 \%$, a partir de corpos de prova compactados na $w_{0}$, produziu uma diminuição média de $37 \%$ nos valores do módulo de resiliência, quando comparados aos resultados dos ensaios realizados na umidade ótima.

Verificou-se que a gênese não influenciou nos resultados de aumento ou diminuição do módulo de resiliência, respectivamente durante os processos de secagem e umedecimento.

Verificou-se que ao se forçar a variação positiva da umidade póscompactação ao nível $\left(w_{0}+1 \%\right)$, os solos apresentam comportamento frente à ação da água que pode conduzir as amostras não-lateríticas apresentarem um comportamento melhor do que as lateríticas, ou vice-versa.

A gênese dos solos influencia nos tempos de preparação dos corpos-deprova, tanto em trajetórias de secagem quanto de umedecimento. Observou-se que os tempos de secagem e umedecimento dos solos lateríticos são, em média, 1,24 vezes e 3,31 vezes, respectivamente, maiores do que os não-lateríticos.

Ao se considerar o tempo de preparação nas análises, observou-se que a redução relativa do módulo de resiliência é aproximadamente 3,4 vezes maior para os solos não-lateríticos quando comparado com os lateríticos. Isto significa que, ao se considerar tempos iguais durante o processo de umedecimento, é provável que os solos lateríticos apresentem um desempenho melhor do que os não-lateríticos frente à ação da água.

Analisando-se a redução do módulo de resiliência entre os "pares" e considerando-se a condição de tempos iguais durante o umedecimento, em todos os casos os solos lateríticos apresentariam uma redução menor do que os seus semelhantes granulométricos não-lateríticos. 
O procedimento adotado em laboratório para simular os efeitos do umedecimento não representa a ocorrência em campo, conduzindo a situações em que os solos não-lateríticos apresentam resultados que indicam um comportamento melhor do que os lateríticos frente à ação da água.

Os solos não-lateríticos tendem a desenvolver níveis de sucção superiores quando comparados aos solos lateríticos.

Para o conjunto de solos estudados, a sucção medida em corpos-de-prova compactados e ensaiados na umidade ótima aumenta com o aumento do teor de finos.

Independentemente da gênese e do estado de tensão, existe uma relação exponencial entre a variação do módulo de resiliência e a variação da umidade, cujo coeficiente de determinação pode ser considerado como bom $\left(R^{2}=0,83\right)$, e que permite o estudo do efeito de trajetórias de secagem e umedecimento sobre o módulo de resiliência. Esta relação pode ser simplificada de forma a se estudar a influência das variações de umidade a partir do coeficiente $k_{1}$ do modelo composto e das diferenças de umidade.

Similarmente ao módulo de resiliência, o módulo tangente inicial tende a aumentar com o aumento do teor de argila. Entretanto, não é possível separar padrões distintos de comportamento entre os solos lateríticos e os não-lateríticos. Mas verifica-se a influência da granulometria, com o $E_{0}$ aumentando com o teor de finos.

A variação do módulo tangente inicial com a variação da umidade póscompactação apresenta comportamento semelhante ao módulo de resiliência. É possível ajustar uma equação exponencial aos resultados de ensaio, ensejando o uso desta expressão para estimar a variação do $M_{R}$ com a umidade a partir da realização de um ensaio mais simples do que o triaxial cíclico, que é o caso do ensaio de compressão simples. 
Não foi possível estabelecer expressões para estimativa do parâmetro $k_{2} a$ partir de propriedades físicas dos solos e dos resultados dos ensaios de compressão simples.

Observou-se a existência de relações matemáticas, com coeficientes de determinação regular, dos parâmetros $k_{1}$ e $k_{3}$ com os resultados dos ensaios de compressão simples e as propriedades físicas dos solos, permitindo a estimativa destes a partir de ensaios mais simples do que o triaxial cíclico.

\subsection{Recomendações e sugestões para trabalhos futuros}

Sugere-se que, em trabalhos futuros, sejam desenvolvidos os seguintes aspectos:

- Aumentar o número de amostras na pesquisa, considerando-se solos de diferentes granulometrias, classe MCT e gênese;

- Avaliar a eficiência de redes neurais artificiais nas análises desenvolvidas;

- Analisar a influência do grau de compactação no valor do $M_{R}$ de corpos-de-prova compactados na mesma umidade;

- Avaliar o efeito das dimensões dos corpos de prova e do método de compactação sobre o módulo de resiliência;

- Analisar o efeito de trajetórias de secagem e umedecimento sobre o valor do $M_{R}$ considerando-se tempos iguais na preparação dos corposde-prova;

- $\quad$ Ampliar o estudo da variação de umidade sobre o módulo de resiliência considerando-se a realização de ciclos de secagem e/ou umedecimento na preparação dos corpos-de-prova;

- Analisar a variação do módulo tangente inicial com a variação da umidade para um conjunto maior de solos. 
- Estudar uma metodologia que permita que se incorpore os resultados do estudo da variação do módulo de resiliência com as variações de umidade ao dimensionamento e análise do comportamento de pavimentos 


\section{Referências Bibliograficas}

ABO-HASHEMA, M. A.; BAYOMY, F. M.; SMITH, R.; SALEM, H. M. (2002). Environmental impacts on the subgrade resilient modulus for Idaho pavements. In: $81^{\text {th }}$ ANNUAL MEETING OF TRANSPORTATION RESEARCH BOARD. Washington, D.C., January 13-17, 2002. TRB 2002 Annual Meeting CD-ROM.

AGUILAR, S. A. S. (1990). Deformabilidade de uma argila colapsível não saturada sob compressão isotrópica com sucção controlada. Rio de Janeiro. Dissertação (mestrado) -Departamento de Engenharia Civil, Pontifícia Universidade Católica do Rio de Janeiro.

ALBERS, A. P. F.; MELCHIADES, F. G.; MACHADO, R.; BALDO, J. B.; BOSCHI, A. O. (2001). Um método simples de caracterização de argilominerais por difração de raios-x. IN: 45 CONGRESSO BRASILEIRO DE CERÂMICA, Florianópolis, SC, 2001. Anais. P 201-11.

ALMEIDA, C. L. F.; OLIVEIRA, J. B.; PRADO, H. (1982a).Levantamento pedológico semidetalhado do Estado de São Paulo: Quadricula de Brotas. Campinas, Convênio EMBRAPA/CPA/IA. Mapa, escala 1:100.000.

ALMEIDA, C. L. F.; OLIVEIRA, J. B.; PRADO, H. (1982b).Levantamento pedológico semidetalhado do Estado de São Paulo: Quadricula de Jaú. Campinas, Convênio EMBRAPA/CPA/IA. Mapa, escala 1:100.000.

ALVES, M. E. (2002). Atributos mineralógicos e eletroquímicos, absorção e dessorção de sulfato em solos paulistas. Piracicaba. 169p. Tese (doutorado) - Escola Superior de Agricultura Luiz de Queiroz, Universidade de São Paulo.

AMERICAN ASSOCIATION OF HIGHWAY AND TRANSPORTATION OFFICIALS (1999). AASHTO Designation T307-99 - Determining the resilient modulus of soils and aggregate materials. Washington, DC.

ANDREW, J. W.; JACKSON, N. M. DRUMM, E. C. (1998). Measurement of seasonal variations in subgrade properties. In: APPLICATIONS OF GEOTECHNICAL PRINCIPLES IN PAVEMENT ENGINEERING - PROCEEDINGS OF SESSIONS OF GEO-CONGRESS 98. Geotechnical Special Publications, n. 85, p.13-38. 
ASSOCIAÇÃO BRASILEIRA DE NORMAS TÉCNICAS (1984). NBR 6490 - Solo determinação do limite de liquidez. Rio de Janeiro.

ASSOCIAÇÃO BRASILEIRA DE NORMAS TÉCNICAS (1984). NBR 6508 - Grãos de solo que passam na peneira de $4,8 \mathrm{~mm}$ - determinação da massa específica. Rio de Janeiro.

ASSOCIAÇÃO BRASILEIRA DE NORMAS TÉCNICAS (1984). NBR 7180 - Solo determinação do limite de plasticidade. Rio de Janeiro.

ASSOCIAÇÃO BRASILEIRA DE NORMAS TÉCNICAS (1984). NBR 7181 - Solo análise granulométrica. Rio de Janeiro.

ASSOCIAÇÃO BRASILEIRA DE NORMAS TÉCNICAS (1992). NBR 12770 - Solos coesivos - determinação da resistência à compressão simples. Rio de Janeiro.

BERNUCCI, L. B. (1997). Módulo resiliente de solos lateríticos e sua aplicação ao dimensionamento de pavimentos de vias de baixo volume de tráfego. In: $1^{\circ}$ SIMPÓSIO INTERNACIONAL DE PAVIMENTAÇÃO DE RODOVIAS DE BAIXO VOLUME DE TRÁFEGO, 1., Rio de Janeiro, RJ, 1997. Anais. Rio de Janeiro, ABPV. v.2, p.490-508.

BERNUCCI, L. B. (1998). Conseqüências da perda de umidade em solos lateríticos compactados. In: CONGRESSO DE PESQUISA E ENSINO EM TRANSPORTES, 12., Fortaleza, CE, 1998. Anais. Fortaleza, ANPET. v.1, p.290-99.

BERNUCCI, L. B.; CAMACHO, J.; MARINHO, F. M.; NOGAMI, J. S. (2000). Efeitos da temperatura na movimentação d'água em pavimentos construídos com solos lateríticos. In: CONGRESSO DE PESQUISA E ENSINO EM TRANSPORTES, 14., Gramado, RS, 2000. Anais. Gramado, ANPET. v.1, p.539-550.

BERNUCCI, L. L. B. (1995). Considerações sobre o dimensionamento de pavimentos utilizando solos lateríticos para rodovias de baixo volume de tráfego. São Paulo. 237p. Tese (doutorado) - Escola Politécnica, Universidade de São Paulo.

BOGNOLA, I. A.; JOAQUIM, A. C.; PRADO, H.; LEPSCH, I. F.; MENK, J. R. F.; JAHNEL, T. C.; SOARES, M. R. C.; MENEZES, F. D.; NOGUEIRA, S. M. (1996). Carta pedológica semidetalhada do Estado de São Paulo: Quadrícula de Assis. Campinas, IAC/IBGE. Mapa, escala 1:100.000.

BOTELHO, F. V. C.; CARVALHO, J. C.; REZENDE, L. R. (2000). Influência da variação da umidade de compactação na curva característica de um solo fino laterítico. In: REUNIÃO ANUAL DE PAVIMENTAÇÃO, 32., Brasília, DF, 2000. Anais. Brasília, ABPV. v.1, p.86-95.

BRINATTI, A. M. (2001). Uso de espectroscopias e difração de Raios $X$ aplicadas à caracterização mineralógica de solos. São Carlos, 194p. Tese (doutorado) - Instituto de Física de São Carlos, Universidade de São Paulo.

BRINATTI, A. M. (2001). Uso de espectroscopias e difração de Raios $X$ aplicadas à caracterização mineralógica de solos (Apêndices A, B, C). São Carlos, 147p. Tese (doutorado) - Instituto de Física de São Carlos, Universidade de São Paulo.

CAMACHO, J.; BERNUCCI, L. B. (2000). Sucções matriciais e índices de suporte MiniCBR de um solo arenoso fino laterítico. In: REUNIÃO ANUAL DE PAVIMENTAÇÃO, 32., Brasília, DF, 2000. Anais. Brasília, ABPV. v.1, p.116-23.

CAMACHO, J.; BERNUCCI, L. B.; MARINHO, F. A. M. (2001). Considerações sobre as 
umidades de equilíbrio em camadas de base de um solo laterítico a partir do equilíbrio das sucções matriciais. In: CONGRESSO DE PESQUISA E ENSINO EM TRANSPORTES, 15., Campinas, SP, 2001. Anais. campinas, ANPET. v.1, p.357-361.

CAMAPUM DE CARVALHO, J..; LEROUEIL, S. (2000). Modelo de normalização da curva característica. In: REUNIÃ̃O ANUAL DE PAVIMENTAÇÃO, 32., Brasília, DF, 2000. Anais. Brasília, ABPV. v.1, p.96-106.

CHANDLER, R. J.; CRILLY, M. S.; MONTGOMERY-SMITH, G. (1992). A low-cost method of assessing clay desiccation for low-rise buildings. In: INSTITUTE OF CIVIL ENGINEERING. May 1992, Proceedings. p.82-89.

CHANDLER, R. J.; GUTIERREZ, C. I. (1986). The filter-paper method of suction measurement. Geotechnique, v.2, n.36, p.265-78.

CUNTO, F. J. C. (1998). Determinação do módulo de resiliência através de ensaios triaxiais dinâmicos e a sua estimativa a partir de ensaios de compressão simples: estudo de três solos do nordeste brasileiro. São Carlos. 133p Dissertação (mestrado) Escola de Engenharia de São Carlos, Universidade de São Paulo.

DAI, S.; ZOLLARS, J. (2002). Resilient modulus of Mn/Road subgrade soil. In: $81^{\text {th }}$ ANNUAL MEETING OF TRANSPORTATION RESEARCH BOARD. Washington, D.C., January 13-17, 2002. TRB 2002 Annual Meeting CD-ROM.

DELGADO, A. K. C. (2002). Influência da sucção no comportamento de um perfil de solo tropical compactado. Brasília. Dissertação (mestrado) - Faculdade de Tecnologia, Departamento de Engenharia Civil, Universidade de Brasília.

DEPARTAMENTO DE ESTRADAS DE RODAGEM DE SÃO PAULO (1971). DER M1371. Ensaio de compactação de solos. São Paulo.

DEPARTAMENTO DE ESTRADAS DE RODAGEM DE SÃO PAULO (1989). DER M196-89. Classificação de solos tropicais segundo a metodologia MCT. São Paulo.

DEPARTAMENTO NACIONAL DE ESTRADAS DE RODAGEM (1994). DNER-ME 131/94 - Solos - determinação do módulo de resiliência. Rio de Janeiro.

DEPARTAMENTO NACIONAL DE ESTRADAS DE RODAGEM (1994). DNER-ME 228/94 - Solos - compactação em equipamento miniatura. Rio de Janeiro.

DRUMM, E. C.; BOATENG-POKU, Y.; PIERCE, T. J. (1990). Estimation of subgrade resilient modulus from standard tests. Journal of Geotechnical and Geoenvironmental Engineering, v.116, n.5, p.774-89.

DRUMM, E. C.; REEVES, J. S.; MADGETT, M. R.; TROLINGER, W. D. (1997). Subgrade resilient modulus correction for saturation effects. Journal of Geotechnical and Geoenvironmental Engineering, v.123, n.7, p.663-71.

DUNCAN, J.M.; CHANG, C. Y. (1970). Nonlinear analysis of stress and strain in soils. Journal of the Soil Mechanics and Foundations Division, v.96, n.5, p.1629-53.

EDIL, T. B.; MOTAN, S. E. (1979). Soil-water potential and resilient behavior of subgrade soils. Transportation Research Record, n.705, p.54-63.

ELFINO, M. K.; DAVIDSON, J. L. (1989). Modeling field moisture in resilient moduli test. Resilient moduli of soils: laboratory conditions, ASCE, New York, N. Y., n.24, p.31-51. 
ELLIOT, R. P.; THORNTON, S. I. (1988a). Resilient modulus and AASHTO pavement design. Transportation Research Record, n.1196, p.116-24.

ELLIOT, R. P.; THORNTON, S. I. (1988b). Simplification of subgrade resilient modulus testing. Transportation Research Record, n.1192, p.1-7.

FABBRI, G. T. P. (1994). Caracterização da fração fina de solos tropicais através da adsorção de azul de metileno. São Carlos, 101p. Tese (Doutorado) - Escola de Engenharia de São Carlos, Universidade de São Paulo.

FERREIRA, J. G. H. M.; MOTTA, L. M. G. (2002). Análise comparativa de modelos de resiliência de solos e materiais não tratados quimicamente. In: CONGRESSO DE PESQUISA E ENSINO EM TRANSPORTES, 16., Natal, RN, 2002. Anais. Natal, ANPET. v.1, p.109-20.

FREDLUND, D. G.; BERGAN, A. T.; WONG, P. K. (1977). Relation between resilient modulus and stress conditions for cohesive subgrade solis. Transportation Research Record, n.642, p.73-81.

FREDLUND, D. G.; RAHARDJO, H. (1993). Soil mechanics for unsaturated soils. 517p. New York, Willey-Interscience Publications.

GODOY, H.; BERNUCCI, L. B. (2000). Caracterização de propriedades geotécnicas de solos realizada no próprio campo e de maneira expedita. In: REUNIÃO ANUAL DE PAVIMENTAÇÃO, 32., Brasília, DF, 2000. Anais. Brasília, ABPV. v.1, p.107-15.

GONÇALVES, R. F. (1999). Estudo de influência da variação do teor de umidade no valor do módulo de resiliência de um solo argiloso encontrado em subleito de rodovias no interior de paulista. São Carlos. 149p. Dissertação (mestrado) - Escola de Engenharia de São Carlos, Universidade de São Paulo.

GONÇALVES, R. F.; PARREIRA, A. B. (1999). Influência da variação do teor de umidade no valor do módulo de resiliência de um solo argiloso de subleito rodoviário. In: CONGRESSO DE PESQUISA E ENSINO EM TRANSPORTES, 13., São Carlos, SP, 1999. Anais. São Carlos, ANPET. v.1, p.395-405.

HALIBURTON, T. A. (1972). Highway designs to resist subgrade moisture variations. Highway Research Record, n.370, p.45-56.

HEYDINGER, A. G. (2003). Evaluation of seasonal effects on subgrade soils. In: $82^{\text {th }}$ ANNUAL MEETING OF TRANSPORTATION RESEARCH BOARD. Washington, D.C., January 12-16, 2003. TRB 2003 Annual Meeting CD-ROM.

HICKS, R. G.; MONISMITH, C. L. (1971). Factors influencing the resilient response of granular materials. Transportation Research Record, n.354, p.15-31.

HOLTZ, R. D.; KOVACS, W. D. (1981). An introduction to Geotechnical engineering. 733p. New Jersey, Prentice-Hall.

JONES, W. E. I.; WITCZAK, M. W. (1977). Subgrade modulus on the San Diego test road. Transportation Research Record, n.641, p.1-6.

KHOGALI, W. E. I.; ANDERSON, K. O. (1996). Evaluation of seasonal variability in cohesive subgrades using backcalculation. Transportation Research Record, n.1546, p.140-50.

KHOURY, N. N.; MUSHARAF, Z. M. NEVELS, J. B. MANN, J. (2003). Effect of soil 
suction on resilient modulus of subgrade soil using the filter paper technique. In: $82^{\text {th }}$ ANNUAL MEETING OF TRANSPORTATION RESEARCH BOARD. Washington, D.C., January 12-16, 2003. TRB 2003 Annual Meeting CD-ROM.

KSAIBATI, K.; ARMAGHANI, J.; FISHER, J. (2000).Effect of moisture on the modulus values of base and subgrade materials. In: $79^{\text {th }}$ ANNUAL MEETING OF TRANSPORTATION RESEARCH BOARD. Washington, D.C., January 9-13, 2000. TRB 2000 Annual Meeting CD-ROM.

LEE, W. BOHRA, N. C.; ALTSCHAEFFL, A. G.; WHITE, T. D. (1995). Resilient modulus of cohesive soils and the effects of freeze-thaw. Canadian Geotechnical Journal, v.32, n.4, p.559-68.

LI, D.; SELIG, E. T. (1994). Resilient modulus for fine-grained subgrade soils. Journal of Geotechnical Engineering, v.120, n.6, p.939-57.

LUZ, M. P. (2003). Análise dos resultados do ensaio CBR realizado em condições variadas de umidade pós-compactação. 108p. Dissertação (Mestrado). Escola de Engenharia de São Carlos, Universidade de São Paulo. São Carlos, 2003.

MACÊDO, J. A. G. (1996). Interpretação de ensaios deflectométricos para avaliação estrutural de pavimentos flexíveis - A experiência com o FWD no Brasil. 456p. Tese (Doutorado). PEC. COPPE, Universidade Federal do Rio de Janeiro. Rio de Janeiro, 1996.

MARAGON, M.; MOTTA, L. M. G. (2001). Considerações sobre a utilização da pedologia na engenharia Geotécnica a partir de um sistema de classificação dos solos. In: REUNIÃO ANUAL DE PAVIMENTAÇÃO, 33. Florianópolis, SC, 2001. Anais. Florianópolis, ABPV. CD-Rom, p.406-422.

MARINHO, F. A. M. (1994). Medição de sucção com o método do papel filtro. In: CONGRESSO BRASILEIRO DE MECÂNICA DOS SOLOS E ENGENHARIA DE FUNDAÇÕES, X.Foz de Iguaçu, PR Anais, v2, p.515-22.

MARINHO, F. A. M. (1998). Mecânica dos solos. Notas de aula para o curso de Mecânica dos Solos Não Saturados. São Paulo, Escola Politécnica da USP.

MEDINA, J. (1997). Mecânica dos pavimentos. 380p. Rio de Janeiro, Editora UFRJ.

MOHAMMAD, L. N.; HUANG, B.; PUPPALA, A. J.; ALLEN, A. (1999). Regression model for resilient modulus of subgrade soils. Transportation Research Record, n.1687, p.4754.

MOHAMMAD, L. N.; PUPPALA, A. J.; ALAVILLI, P. (1995). Resilient properties of laboratory compacted subgrade soils. Transportation Research Record, n.1504, p.87102.

MOTTA, L. M. G.; ARANOVICH, L. A. S.; CERATTI, J. A. P. (1985). Comportamento resiliente de solos utilizados em pavimentos de baixo custo. Solos e Rochas, v.8, n.3, p.15-42.

MOTTA, L. M. G.; CERATTI, J. A. P. (1986). Comportamento resiliente de solos arenosos finos. In: REUNIÃO ANUAL DE PAVIMENTAÇÃO, 21., Salvador, BA, 1986. Anais. Salvador, ABPV. v.1, p.51-68.

MOTTA, L. M. G.; MEDINA, J.; MATOS, M. V. M.; VIANNA, A. A. D. (1990). Resiliência de solos pedregulhosos lateríticos. In: REUNIÃO ANUAL DE PAVIMENTAÇÃO, 24., 
Belém, PA, 1990. Anais. Belém, ABPV. v.1, p.234-55.

MUHANNA, A. S.; RAHMAN, M. S.; LAMBE, P. C. (1999). Resilient modulus measurement of fine-grained subgrade soils. Transportation Research Record, n.1687, p.3-12.

NATAATMADJA, A.; PARKIN, A. K. (1989). Characterization of granular materials for pavements. Canadian Geotechnical Journal, v.26, p.725-30.

NATIONAL COOPERATIVE HIGHWAY RESEARCH PROGRAM (1997). NCHRP 1-28A - Laboratory determination of resilient modulus for flexible pavement design - Final Report (NCHRP Web Document 14). Transportation Research Board. 464p.

NATIONAL COOPERATIVE HIGHWAY RESEARCH PROGRAM (2004). NCHRP 1-37A - Guide for mechanistic-empirical design of new and rehabilitated pavement structures Final Report. Transportation Research Board.

NOGAMI, J. S.; VILLIBOR, D. F. (1995). Pavimentação de baixo custo com solos lateríticos. 213p. São Paulo, Villibor.

NOGAMI, J. S.; VILLIBOR, D. F. (2003). Modificações recentes na classifcação MCT. In: REUNIÃO ANUAL DE PAVIMENTAÇÃO, 34., Campinas, SP, 2003. Anais. São Paulo, ABPV. v.1, p.44-68.

OLIVEIRA, J. B. (1992). Carta pedológica do Estado de São Paulo: Moji-Mirim. Rio de Janeiro, Aerofoto Cruzeiro do Sul. Mapa, escala 1:100.000.

OLIVEIRA, J. B. (1999). Solos do Estado de São Paulo: descrição das classes registradas no mapa pedológico. Campinas, Instituto Agronômico. (Boletim Científico n.45).

OLIVEIRA, J. B. (1979). Levantamento pedológico semidetalhado do Estado de São Paulo: Quadricula de Campinas. Rio de Janeiro, IBGE. 169p

OLIVEIRA, J. B.; BARBIERI, J. L.; ROTTA, C. L.; TREMOCOLDI, W. (1982a). Levantamento pedológico semidetalhado do estado de São Paulo: Quadrícula de Araras. Campinas, Instituto Agronômico. 182p. Mapa, escala 1:100.000 (Boletim Técnico, 72).

OLIVEIRA, J. B.; CAMARGO, M. N.; ROSSI, M.; CALDERANO FILHO, B. (1999). Mapa pedológico do Estado de São Paulo: legenda expandida. Campinas, Empresa Brasileira de Pesquisa Agropecuária - Centro Nacional de Pesquisa de Solos/Instituto Agronômico, 64p. e mapa.

OLIVEIRA, J. B.; PRADO, H. (1983). Levantamento pedológico semidetalhado do estado de São Paulo: Quadrícula de Ribeirão Preto. Campinas, Convênio EMBRAPA/SAA/IA. Mapa, escala 1:100.000.

OLIVEIRA, J. B.; PRADO, H. (1991). Carta pedológica semidetalhada do Estado de São Paulo: Folha de Guaíra. Campinas, Plano Cartográfico do Estado de São Paulo. IAC/IGC. Mapa, escala 1:100.000.

OLIVEIRA, J. B.; PRADO, H.; ALMEIDA, C. L. F. (1982b). Levantamento pedológico semidetalhado do estado de São Paulo: Quadrícula de Descalvado. Rio de Janeiro, Aerofoto Cruzeiro do Sul. Mapa, escala 1:100.000.

OLIVEIRA, J. B.; PRADO, H.; BEJAR, O. I. G.; OLIVEIRA, E. R.; LONGOBARDI, R. C.; 
ASSIS, E. A.. (1989). Carta pedológica semidetalhada do Estado de São Paulo: Folha de Piracicaba. São Paulo, Secretaria da Agricultura/CPC/IA; Secretaria de Economia e Planejamento/CAR/IGC. Mapa, escala 1:100.000.

PARREIRA, A. B.; CARMO, C. A. T.; CUNTO, F. J. C. (1998). Estudo do módulo de resiliência de materiais usados em pavimentação. In: REUNIÃO ANUAL DE PAVIMENTAÇÃO, 31., São Paulo, SP, 1998. Anais. São Paulo, ABPV. v.1, p.233-247.

PEZO, R. F.; HUDSON, W. R. (1994). Prediction models of resilient modulus for nongranular materials. Geotchnical Testing Journal, 17 (3), p.349-55.

PHILLIP, A. W.; CAMERON, D. A. (1995). The influence of soil suction on the resilient modulus of expansive soil subgrades. In: INTERNATIONAL CONFERENCE ON UNSATURATED SOILS, 1., Paris, FR, 1995. Proceedings. Paris, v.1, p.171-6.

PRADO, H.; OLIVEIRA, J. B.; ALMEIDA, C. L. F. (1981). Levantamento pedológico semidetalhado do Estado de São Paulo: Quadricula de São Carlos. Campinas, EMBRAPA/CPA/IA. Mapa, escala 1:100.000.

RADA, G.; WITCZAK, M. W. (1981). Comprehensive evaluation of laboratory resilient moduli results for granular material. Transportation Research Record, n.810, p.23-33.

RODRIGUES, M. R (1997). Influência da sucção no módulo de resiliência de solos típicos de subleito de pavimentos do Rio Grande do Sul. Dissertação (Mestrado). Porto Alegre, UFRGS. 105p.

RODRIGUES, M. R.; GEHLING, W. Y. Y.; CERATTI, J. A.; BICA, A. V. D. (1997). Influência das trajetórias de secagem e umedecimento no módulo de resili6encia de um solo típico do subleito de pavimentos. In: SIMPÓSIO INTERNACIONAL DE PAVIMENTAÇÃO DE RODOVIAS DE BAIXO VOLUME DE TRÁFEGO, 1., Rio de Janeiro, RJ, 1997. Anais. Rio de Janeiro, ABPV. v.2, p.479-89.

RUIZ, C. L. (1963). Presentacíon y comentario sobre los diagramas Shell 1963 para el diseño de pavimentos flexibles. DVBA, Ministerio de Obras Publicas, La Plata, Argentina.

SALEM, H. M.; BAYOMY, F. M.; AL-TAHER, M. G. (2003). Prediction of seasonal variation of subgrade resilient modulus using LTPP data. In: $82^{\text {th }}$ ANNUAL MEETING OF TRANSPORTATION RESEARCH BOARD. Washington, D.C., January 12-16, 2003. TRB 2003 Annual Meeting CD-ROM.

SANTOS, P. S. (1992). Ciência e tecnologia das argilas, 2ed. V.3. 1089p. Editora Edgard Blucher Ltda.

SEED, H. B.; CHAN, C. K. \& LEE, C. E. (1962). Resilience characteristics of subgrade solis and their relation to fatigue failures in asphalt pavements. International Conference on the Structural Design of Asphalt Pavements Proceedings. University of Michigan, Ann Arbor, Michigan, p.611-36.

THADKAMALLA, G. B.; GEORGE, K. P. (1995). Characterization of subgrade soils at simulated field moisture. Transportation Research Record, n.1481, p.21-7.

VASWANI, N. K. (1975). Case studies of variations in subgrade moisture and temperature under road pavements. Transportation Research Record, n.532, p.30-42. 
VERTAMATTI, E. (1988). Contribuição ao conhecimento geotécnico de solos da Amazônia com base na investigação de aeroportos e metodologias MCT e resiliente. São José dos Campos. Tese (Doutorado) - Instituto Tecnológico da Aeronáutica.

VERTAMATTI, E.; ARAÚJO, F. A. R. (2002). Association of soil-water characteristic curves with genesis and grain size composition of tropical soils. In: THIRD INTERNACIONAL CONFERENCE ON UNSATURATED SOILS, Recife - Br, 2002. Proceedings. p.261-65.

VILLIBOR, D. F. (1981). Pavimentos econômicos. Novas considerações. São Carlos. Tese (Doutorado). Escola de Engenharia de São Carlos, Universidade de São Paulo.

YAU, A.; VON QUINTUS, H. L. (2002). Study of LTPP laboratory resilient modulus test data and response characteristics: final report. Publication n ${ }^{\circ}$ FHWA-RD-02-051.

ZAMAM, M.; CHEN, D.; LAGUROS, J. (1994). Resilient moduli of granular materials. Journal of Transportation Engineering, v.120, n.6, p.967-88 


\section{Anexo A - Informações sobre os locais de coleta}

\section{A.1 Introdução}

Apresenta-se neste anexo a Tabela A1 que contém informações necessárias para a correta localização dos pontos de amostragem, bem como, outras informações relevantes. Na primeira coluna encontra-se a identificação da amostra. As colunas de 2 a 6 apresentam informações para a identificação do local de coleta, contando com a identificação da rodovia, o sentido de percurso, o quilômetro da coleta, o lado da rodovia onde se realizou a coleta (relacionado ao sentido de percurso) e as coordenadas em termos de latitude e longitude. $\mathrm{Na}$ sétima coluna encontra-se a indicação da posição de coleta das amostras em relação à linha de seixos (LS), quando foi possível a sua identificação. 
Tabela A.1 - Informações sobre a localização do ponto de coleta de cada uma das amostras

\begin{tabular}{|c|c|c|c|c|c|c|}
\hline \multirow{2}{*}{ Amostra } & \multicolumn{5}{|c|}{ Local de coleta } & \multirow{2}{*}{$\begin{array}{c}\text { Posição em } \\
\text { Relação à } \\
\text { Linha de seixos }\end{array}$} \\
\hline & Rodovia & Sentido & $\mathrm{Km}$ & Lado & Coordenadas & \\
\hline \multirow[t]{2}{*}{1} & \multirow{2}{*}{ SP-215 } & Descalvado & \multirow{2}{*}{$145+500$} & \multirow{2}{*}{ Direito } & & \multirow{2}{*}{ Abaixo } \\
\hline & & São Carlos & & & & \\
\hline \multirow[t]{2}{*}{2} & \multirow{2}{*}{ SP-215 } & Descalvado & \multirow{2}{*}{$145+500$} & \multirow{2}{*}{ Direito } & & \multirow{2}{*}{ Acima } \\
\hline & & São Carlos & & & & \\
\hline \multirow{2}{*}{3} & \multirow{2}{*}{ SP-215 } & Descalvado & \multirow{2}{*}{$144+300$} & \multirow{2}{*}{ Direito } & & \multirow{2}{*}{ Acima } \\
\hline & & São Carlos & & & & \\
\hline \multirow{2}{*}{4} & \multirow{2}{*}{ SP-215 } & Descalvado & \multirow{2}{*}{$144+300$} & \multirow{2}{*}{ Direito } & & \multirow{2}{*}{ Abaixo } \\
\hline & & São Carlos & & & & \\
\hline \multirow{2}{*}{5} & SP-215 & Descalvado & $141+500$ & Fsquerdo & & Acima \\
\hline & $31-213$ & São Carlos & $141+500$ & Esquerdo & & Acinta \\
\hline 6 & SP-215 & Descalvado & $141+500$ & Esquerdo & & Abaixo \\
\hline & & São Carlos & 1417500 & & & AIUdixu \\
\hline 7 & SP-215 & Descalvado & $9+100$ & Direito & & Acima \\
\hline$r$ & $3 r-2<10$ & São Carlos & 䧄 & DIIETU & & मстाта \\
\hline 8 & SP-215 & Descalvado & $139+100$ & Fsquerdo & & Abaixo \\
\hline 0 & $3 r-215$ & São Carlos & $109+100$ & Esquerdo & & Audixu \\
\hline 9 & SP-215 & Descalvado & $130+200$ & Esquerdo & & Abaixo \\
\hline & & São Carlos & $100+200$ & Esquerao & & \\
\hline 10 & SP-215 & Descalvado & $0+200$ & Direito & & Acima \\
\hline 10 & $3 r-210$ & São Carlos & 0 & DIIETU & & Rermia \\
\hline 11 & SP-215 & São Carlos & $5+500$ & Fsquerdo & & Acima \\
\hline TI & $4=-210$ & Ribeirão Bonito & $0<-300$ & Loquetú & & Мсліпा \\
\hline 12 & SP_215 & São Carlos & $152+500$ & Direito & & Ahaixo \\
\hline 16 & $01-210$ & Ribeirão Bonito & $102-1000$ & 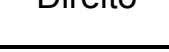 & & RINAIAU \\
\hline 13 & SP-215 & São Carlos & & Esquerdo & & Abaixo \\
\hline 10 & $3 r-210$ & Ribeirão Bonito & $11 / 2+300$ & Esqueruo & & ANdixu \\
\hline 14 & SP-215 & São Carlos & $172+500$ & Direito & & Acima \\
\hline & & Ribeirão Bonito & $16 \angle 2000$ & DIIETU & & Reimia \\
\hline 15 & SP-215 & Ribeirão Bonito & $183+500$ & Esquerdo & & Ahaixo \\
\hline & & Dourado & 1001000 & Loquetuo & & MUIIXU \\
\hline 16 & SP-215 & Ribeirão Bonito & $183+500$ & Esquerdo & & Acima \\
\hline & & Dourado & 1001000 & & & \\
\hline 17 & SP-215 & Ribeirão Bonito & & Esquerdo & & Abaixo \\
\hline & & Dourado & 904100 & Esqueruo & & \\
\hline 18 & SP-215 & Ribeirão Bonito & $193+100$ & Fsquerdo & & Acima \\
\hline 10 & $35-210$ & Dourado & 904 100 & Esqueruo & & ACinta \\
\hline 19 & SP-310 & Araraquara & 293 & Direito & & Abaixo \\
\hline & SP-326 & Matão & & & & \\
\hline 20 & SP-310 & Araraquara & 293 & Direito & & Acima \\
\hline 20 & SP-326 & Matão & 290 & Diretio & & Acimla \\
\hline 21 & Vicinal & SP-225 & 006 & Direito & S 22 $18^{\prime} 58^{\prime \prime}$ & Acima \\
\hline 21 & vicinaa & Dois Córregos & 000 & БाICU & W 48 $23^{\prime} 36,5^{\prime \prime}$ & лстіп \\
\hline
\end{tabular}




\begin{tabular}{|c|c|c|c|c|c|c|}
\hline \multirow{2}{*}{ Amostra } & \multicolumn{5}{|c|}{ Local de coleta } & \multirow{2}{*}{$\begin{array}{c}\text { Posição em } \\
\text { Relação à } \\
\text { Linha de seixos }\end{array}$} \\
\hline & Rodovia & Sentido & $\mathrm{Km}$ & Lado & Coordenadas & \\
\hline \multirow{2}{*}{22} & \multirow{2}{*}{ Vicinal } & SP-225 & \multirow{2}{*}{006} & \multirow{2}{*}{ Direito } & S 220 18' 58" & \multirow{2}{*}{ Abaixo } \\
\hline & & Dois Córregos & & & W 48 $23^{\prime} 36,5^{\prime \prime}$ & \\
\hline \multirow{2}{*}{23} & \multirow{2}{*}{ Vicinal } & SP-225 & \multirow{2}{*}{011} & \multirow{2}{*}{ Esquerdo } & S $22^{\circ} 21^{\prime} 30,9^{\prime \prime}$ & \multirow{2}{*}{ Acima } \\
\hline & & Dois Córregos & & & W 48 $23^{\prime} 28,5^{\prime \prime}$ & \\
\hline \multirow{2}{*}{24} & \multirow{2}{*}{ Vicinal } & SP-225 & \multirow{2}{*}{011} & \multirow{2}{*}{ Esquerdo } & S $22^{\circ} 21^{\prime} 30,9^{\prime \prime}$ & \multirow{2}{*}{ Abaixo } \\
\hline & & Dois Córregos & & & W 48 $23^{\prime} 28,5^{\prime \prime}$ & \\
\hline \multirow{2}{*}{25} & \multirow{2}{*}{ SP-304 } & Dois Córregos & \multirow{2}{*}{$277+50$} & \multirow{2}{*}{ Esquerdo } & S 22 $22^{\circ} 58,1^{\prime \prime}$ & \\
\hline & & Min. do Tiête & & & W 48 27'02,4" & \\
\hline \multirow{2}{*}{26} & \multirow{2}{*}{ SP-225 } & Pederneiras & $220+500$ & & S $22^{\circ} 19^{\prime} 44,9^{\prime \prime}$ & Acima \\
\hline & & Bauru & $220+500$ & Esquerdo & $\bar{W} 48^{\circ} 55^{\prime} 26,8^{\prime \prime}$ & Acima \\
\hline 27 & SP-225 & Pederneiras & & & S $22^{\circ} 19^{\prime} 44,9^{\prime \prime}$ & Abaixo \\
\hline 27 & $S P-2 \angle 5$ & Bauru & +500 & E & W 48 55' 26,8" & Adalxo \\
\hline 28 & $\mathrm{SP}_{3} 300$ & Pirajuí & 400 & Direito & $\mathrm{S} 21^{\circ} 57^{\prime} 51^{\prime \prime}$ & \\
\hline 28 & $2 P-300$ & Cafelândia & 400 & Direlto & W 492 $27^{\prime} 39,3^{\prime \prime}$ & \\
\hline 29 & $S P-215$ & $\begin{array}{l}\text { Sta Cruz das } \\
\text { Palmeiras }\end{array}$ & $54+400$ & Direito & S $21^{\circ} 47^{\prime} 53,6^{\prime \prime}$ & Abaixo \\
\hline & & Casa Branca & & Dileno & $\bar{W} 47^{\circ} 05^{\prime} 05,1^{\prime \prime}$ & Mudixu \\
\hline 30 & SP -215 & $\begin{array}{l}\text { Sta Cruz das } \\
\text { Palmeiras }\end{array}$ & $54+400$ & Direito & $S 21^{\circ} 47^{\prime} 53,6^{\prime \prime}$ & Acima \\
\hline ( & & Casa Branca & $24+400$ & Dineno & $\bar{W} 47^{\circ} 05^{\prime} 05,1^{\prime \prime}$ & Acinta \\
\hline 31 & SP - 207 & S. J. Rio Pardo & 008 & Direito & S 21영 $08,9^{\prime \prime}$ & Acima \\
\hline 31 & & S. S. da Grama & 008 & Direlto & W 460 52' 13,9" & Acinta \\
\hline & & S. J. Rio Pardo & & & S 21⒊ $39^{\prime} 08,9^{\prime \prime}$ & Abaixo \\
\hline 32 & SP - 207 & S. S. da Grama & 008 & Direlto & W 460 52' 13,9" & Adalxo \\
\hline & & Amparo & & & S 22 $42^{\circ} 45,1^{\prime \prime}$ & \\
\hline 33 & $S P-360$ & Morungaba & 124 & Direito & $\bar{W} 46^{\circ} 45^{\prime} 47,3^{\prime \prime}$ & Abaixo \\
\hline 34 & SP 308 & Capivari & 150 & Direito & S $22^{\circ} 49^{\prime} 23,2^{\prime \prime}$ & \\
\hline 34 & $5+-308$ & Rio das pedras & 100 & Dirento & W 470 34' 28,4" & \\
\hline & & Piracicaba & & & S 22 $42^{\circ} 44,6^{\prime \prime}$ & \\
\hline 35 & & Limeira & 133 & Direito & W 47033'56,5" & \\
\hline 36 & SP 123 & $\begin{array}{l}\text { Sto Antônio } \\
\text { do Pinhal }\end{array}$ & 029 & Esquerdo & S $22^{\circ} 51^{\prime} 10,7^{\prime \prime}$ & \\
\hline & & Via Dutra & & & W 45 $36^{\prime} 56,8^{\prime \prime}$ & \\
\hline 37 & SP 123 & Tremembé & $23+500$ & Direito & S 220 53' 19,6" & \\
\hline 31 & $5+120$ & Via Dutra & +500 & Direlto & W 45 $35^{\prime} 47,4^{\prime \prime}$ & \\
\hline & & Via Dutra & & & S 230 $06^{\prime} 01,6^{\prime \prime}$ & \\
\hline 38 & Vicinal & Caçapava Velha & 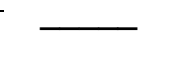 & Esquerd & W 45 $40^{\prime} 33,2^{\prime \prime}$ & Abaixo \\
\hline & & Via Dutra & & & S $23^{\circ} 14^{\prime} 58,2^{\prime \prime}$ & \\
\hline 39 & SP 65 & Igaratá & 700 & Direito & $\overline{\text { W 460 } 06^{\prime} 21,3^{\prime \prime}}$ & \\
\hline 40 & SP 255 & São Carlos & 600 & Ecourdo & S 210 $23^{\prime} 29,9^{\prime \prime}$ & \\
\hline 40 & $5 P<50$ & Rib. Preto & & Esquerao & W 470 $51^{\prime} 40,7^{\prime \prime}$ & \\
\hline 41 & & Pitangueiras & & & S 205 $57^{\prime} 53,6^{\prime \prime}$ & \\
\hline 41 & SP 322 & Bebedouro & +500 & Direito & W 48 19' 53,5" & \\
\hline & & Bebedouro & & & S $20^{\circ} 54^{\prime} 36,3^{\prime \prime}$ & \\
\hline 42 & SP 322 & Monte Azul & & & W $48^{\circ} 34^{\prime} 13,4^{\prime \prime}$ & \\
\hline
\end{tabular}




\begin{tabular}{|c|c|c|c|c|c|c|}
\hline \multirow[t]{2}{*}{ Amostra } & \multicolumn{5}{|c|}{ Local de coleta } & \multirow{2}{*}{$\begin{array}{c}\text { Posição em } \\
\text { Relação à } \\
\text { Linha de seixos }\end{array}$} \\
\hline & Rodovia & Sentido & $\mathrm{Km}$ & Lado & Coordenadas & \\
\hline \multirow{2}{*}{43} & \multirow{2}{*}{ SP 322} & Monte Azul & \multirow{2}{*}{$-429+100$} & \multirow{2}{*}{ Esquerdo } & S $20^{\circ} 49^{\prime} 20,8^{\prime \prime}$ & \multirow{2}{*}{ abaixo } \\
\hline & & Severinea & & & W 48 47' 12,8" & \\
\hline \multirow{2}{*}{44} & \multirow{2}{*}{ SP 322} & Monte Azul & \multirow{2}{*}{$-429+100$} & \multirow{2}{*}{ Esquerdo } & S $20^{\circ} 49^{\prime} 20,8^{\prime \prime}$ & \multirow{2}{*}{ acima } \\
\hline & & Severinea & & & W 48 $47^{\circ} 12,8^{\prime \prime}$ & \\
\hline \multirow{2}{*}{45} & \multirow{2}{*}{ SP 310} & Mirassol & \multirow{2}{*}{458} & \multirow{2}{*}{ Esquerdo } & S $20^{\circ} 47^{\prime} 41,0^{\prime \prime}$ & \multirow{2}{*}{ abaixo } \\
\hline & & Monte Aprazível & & & $\bar{W} 49^{\circ} 34^{\prime} 35,0^{\prime \prime}$ & \\
\hline \multirow{2}{*}{46} & \multirow{2}{*}{ SP 310} & Mirassol & \multirow{2}{*}{458} & \multirow{2}{*}{ Direito } & S $20^{\circ} 47^{\prime} 41,0^{\prime \prime}$ & \multirow{2}{*}{ acima } \\
\hline & & Monte Aprazível & & & W 493' 35,0" & \\
\hline \multirow{2}{*}{47} & & Borborema & & & $S 21^{\circ} 41^{\prime} 35,9^{\prime \prime}$ & \\
\hline & SP 304 & Ibitinga & & squerde & $\bar{W} 49^{\circ} 00^{\prime} 31,9^{\prime \prime}$ & abaixo \\
\hline 48 & SP 304 & Borborema & & & S $21^{\circ} 41^{\prime} 35,9^{\prime \prime}$ & acima \\
\hline 48 & $5 \times 304$ & Ibitinga & & & W 49 $09^{\circ} 31,9^{\prime \prime}$ & acıma \\
\hline 49 & SP 270 & Assis & 460 & Direito & S 22 $37^{\prime} 39,5^{\prime \prime}$ & \\
\hline 49 & $5+210$ & Maracaí & 460 & Direlto & $\bar{W} 50^{\circ} 33^{\prime} 52,2^{\prime \prime}$ & \\
\hline 50 & SP 270 & Maracaí & & Fsquerdo & $S 22^{\circ} 25^{\prime} 05,5^{\prime \prime}$ & \\
\hline 30 & $0 r 260$ & Regente Feijó & & Esquerdo & $\bar{W} 51^{\circ} 02^{\prime} 12,5^{\prime \prime}$ & \\
\hline 51 & SP 270 & SP 487 & & Direito & S 22 $2^{\circ} 15^{\prime} 10,9^{\prime \prime}$ & abaixo \\
\hline 51 & $5 P 210$ & Regente Feijó & & Direito & 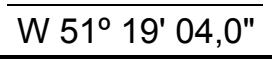 & abaixo \\
\hline & & SP 487 & & & S 22 $15^{\circ} 10,9^{\prime \prime}$ & \\
\hline 52 & SP 270 & Regente Feijó & +500 & Direito & $\bar{W} 51^{\circ} 19^{\prime} 04,0^{\prime \prime}$ & acıma \\
\hline 53 & SP 563. & Teodoro Sampaio & 33 & Direito & S 22 $2^{\circ} 15^{\prime} 13,2^{\prime \prime}$ & ahaivo \\
\hline (30 & - & Marabá P. & 3 & Dilentu & W 5201' 03,9" & andixu \\
\hline 54 & SP 563 & Teodoro Sampaio & 33 & Direito & $S 22^{\circ} 15^{\prime} 13,2^{\prime \prime}$ & acima \\
\hline & & Marabá P. & & & $\bar{W} 52^{\circ} 01^{\prime} 03,9^{\prime \prime}$ & \\
\hline 55 & SPV 9 & $\begin{array}{c}\text { Nova } \\
\text { Independência }\end{array}$ & - & _- & S $20^{\circ} 57^{\prime} 26,9^{\prime \prime}$ & \\
\hline & & Pontal & & & $\bar{W} 51^{\circ} 37^{\prime} 26,9^{\prime \prime}$ & \\
\hline 56 & SPV 8 & $\begin{array}{c}\text { Nova } \\
\text { Independência }\end{array}$ & - & Direito & S $20^{\circ} 56^{\prime} 05,1^{\prime \prime}$ & \\
\hline & & Castilho & & & $\overline{\text { W 51ㅇ } 32^{\prime} 36,4^{\prime \prime}}$ & \\
\hline 57 & & São Carlos & & Diroito & $S 21^{\circ} 10^{\prime} 14,2^{\prime \prime}$ & \\
\hline 57 & SP 310 & Catanduva & +800 & Direlto & W 48 $58^{\circ} 17,2^{\prime \prime}$ & \\
\hline 58 & SP 320 & Fernandópolis & & Diroito & S $20^{\circ} 16^{\prime} 13,6^{\prime \prime}$ & \\
\hline 58 & $S P 320$ & Estrela d'Oeste & +500 & Direlto & $\overline{\text { W 50 } 10^{\prime} 50,8^{\prime \prime}}$ & \\
\hline & & Santa Fé (SP) & & & S $20^{\circ} 08^{\prime} 09,6^{\prime \prime}$ & \\
\hline 59 & SP 597 & $\begin{array}{l}\text { Aparecida do } \\
\text { Taboado (MS) }\end{array}$ & 634 & Esquerdo & $\bar{W} 50^{\circ} 58^{\prime} 11,6^{\prime \prime}$ & abaixo \\
\hline 60 & SP 595 & Nova Canaã & & Direito & S $20^{\circ} 26^{\prime} 15,8^{\prime \prime}$ & acima \\
\hline 60 & SP 595 & SP 310 & & Direıto & $\overline{\text { W 510 16' 26,4" }}$ & acıma \\
\hline 61 & SP 310 & Auriflama & 563 & & 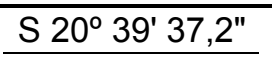 & abaixo \\
\hline 61 & SP 310 & SP 463 & 563 & & $\overline{\text { W 50 } 31^{\prime} 59,9^{\prime \prime}}$ & abaixo \\
\hline 62 & & Auriflama & 563 & & S 20⒊ $39^{\prime} 37,2^{\prime \prime}$ & acima \\
\hline & & SP 463 & 503 & Esque & W 50 $31^{\prime} 59,9^{\prime \prime}$ & acima \\
\hline 63 & SP 300 & Birigui & & Direito & $\mathrm{S} \mathrm{21^{ \circ } 2 0 ^ { \prime } 1 2 , 0 ^ { \prime \prime }}$ & \\
\hline 00 & & Penápolis & & & W 50 19' 38,8" & \\
\hline
\end{tabular}




\begin{tabular}{|c|c|c|c|c|c|c|}
\hline \multirow[t]{2}{*}{ Amostra } & \multicolumn{5}{|c|}{ Local de coleta } & \multirow{2}{*}{$\begin{array}{c}\text { Posição em } \\
\text { Relação à } \\
\text { Linha de seixos }\end{array}$} \\
\hline & Rodovia & Sentido & $\mathrm{Km}$ & Lado & Coordenadas & \\
\hline \multirow{2}{*}{64} & \multirow{2}{*}{ SP-280 } & Interior-capital & \multirow{2}{*}{34} & \multirow{2}{*}{ Esquerdo } & $\mathrm{S} 23^{\circ} 31^{\prime} 8,3^{\prime \prime}$ & \\
\hline & & Barueri & & & W 46 $56^{\circ} 52,8^{\prime \prime}$ & \\
\hline \multirow{2}{*}{65} & \multirow{2}{*}{ SP-270 } & Mairinque & \multirow{2}{*}{72} & \multirow{2}{*}{ Esquerdo } & $\mathrm{S} 23^{\circ} 31^{\prime} 49,7^{\prime \prime}$ & \\
\hline & & Alumínio & & & W $47^{\circ} 13^{\prime} 38,4^{\prime \prime}$ & \\
\hline \multirow{2}{*}{66} & \multirow{2}{*}{ SP-270 } & Sorocaba & \multirow{2}{*}{$140+400$} & \multirow{2}{*}{ Direito } & $S 23^{\circ} 33^{\prime} 20,9^{\prime \prime}$ & \\
\hline & & Itapetininga & & & 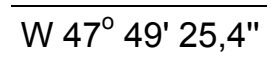 & \\
\hline \multirow{2}{*}{67} & \multirow{2}{*}{ SP-270 } & Itapetininga & \multirow{2}{*}{$213+300$} & \multirow{2}{*}{ Direito } & $\mathrm{S} 23^{\circ} 31^{\prime} 28,8^{\prime \prime}$ & \\
\hline & & Piraju & & & W 48 $28^{\circ} 39,2^{\prime \prime}$ & \\
\hline \multirow{2}{*}{68} & \multirow{2}{*}{ SP-270 } & Itapetininga & \multirow{2}{*}{\multicolumn{2}{|c|}{$273+500$ Esquerdo }} & S $23^{\circ} 21^{\prime} 53,6^{\prime \prime}$ & \\
\hline & & Piraju & & & $\bar{W} 49^{\circ} 00^{\prime} 38,7^{\prime \prime}$ & \\
\hline \multirow{2}{*}{69} & \multirow{2}{*}{ SP-255 } & Avaré & \multirow{2}{*}{\multicolumn{2}{|c|}{ Direito }} & S $22^{\circ} 57^{\prime} 38,8^{\prime \prime}$ & \\
\hline & & Barra Bonita & & & W 48 48' $26,0^{\prime \prime}$ & \\
\hline 70 & SP_280 & SP-255 & $282+600$ & Diroito & 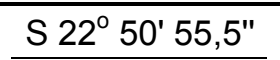 & \\
\hline 10 & $S P-200$ & laras & $282+600$ & Dirento & W 49 $10^{\circ} 51,6^{\prime \prime}$ & \\
\hline 71 & SP 330 & Guará & $100+500$ & Diroito & $S 20^{\circ} 25^{\prime} 03,3^{\prime \prime}$ & \\
\hline 11 & $5 P-330$ & Ituverava & $400+500$ & Dirento & 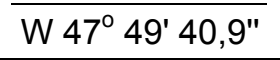 & \\
\hline 72 & Vicinal & Ituverava & & Direito & $S 20^{\circ} 20^{\prime} 04,6^{\prime \prime}$ & \\
\hline 12 & VICIIIdi & Jeriquara & & Dineno & W $47^{\circ} 36^{\prime} 58,3^{\prime \prime}$ & \\
\hline 73 & SP_351 & Batatais & & Direito & S $21^{\circ} 00^{\prime} 28,4^{\prime \prime}$ & \\
\hline 10 & $2 t-321$ & Altinópolis & & Direno & W $47^{\circ} 24^{\prime} 20,1^{\prime \prime}$ & \\
\hline 74 & SP_338 & Altinópolis & 333 & Direito & $S 21^{\circ} 03^{\prime} 12,3^{\prime \prime}$ & \\
\hline 14 & $5 P-338$ & Cajuru & 333 & Dirento & W $47^{\circ} 18^{\prime} 50,1^{\prime \prime}$ & \\
\hline & & Cajuru & & & $\mathrm{S} 21^{\circ} 17^{\prime} 28,5^{\prime \prime}$ & \\
\hline 75 & SP-333 & $\begin{array}{c}\text { Santa Cruz da } \\
\text { Esperança }\end{array}$ & $13+400$ & Direito & $\bar{W} 47^{\circ} 24^{\prime} 46,6^{\prime \prime}$ & Abaixo \\
\hline & & Cajuru & & & $\mathrm{S} 21^{\circ} 17^{\prime} 28,5^{\prime \prime}$ & \\
\hline 76 & SP-333 & $\begin{array}{c}\text { Santa Cruz da } \\
\text { Esperança }\end{array}$ & $13+400$ & Direito & $\overline{W 47^{\circ} 24^{\prime} 46,6^{\prime \prime}}$ & Acima \\
\hline 77 & SP-294 & Bauru & & Direito & $\mathrm{S} \mathrm{22}^{\circ} 20^{\prime} 28,5^{\prime \prime}$ & abaixo \\
\hline 11 & $5 P-294$ & Piratininga & & Direno & W 49 $12^{\prime} 24,8^{\prime \prime}$ & dodixu \\
\hline 78 & SP_294 & Piratininga & 375 & Direito & S 22 $12^{\circ} 38,5^{\prime \prime}$ & ahaixo \\
\hline 10 & $5 r-294$ & Duartina & 310 & Direno & W 49 19' 31,6" & addixu \\
\hline 79 & & Piratininga & 375 & & S 22 $19^{\circ} 38,5^{\prime \prime}$ & \\
\hline 19 & SP-294 & Duartina & $3 / 5$ & Direito & W 490 19' 31,6" & acıma \\
\hline 80 & SP_294 & Tupã & $7+700$ & Fsquerdo & S 2 210 $57^{\prime} 53,7^{\prime \prime}$ & \\
\hline 80 & $\mathrm{SP}-294$ & Osvaldo Cruz & $1+100$ & Esquerdo & W 50 25' 56,4" & \\
\hline 81 & SP_294 & Osvaldo Cruz & 575 & Eayerds & S $21^{\circ} 45^{\prime} 43,7^{\prime \prime}$ & \\
\hline 01 & $5 P-\angle 94$ & Lucélia & 510 & squerdac & W 50 55' 29,6" & \\
\hline 82 & SP-20 & Pacaembu & +500 & Escumerds & S 210 33' 11,4" & \\
\hline 82 & $S P-29$ & Tupi Paulista & & Esquerdo & W 510 $17^{\prime} 18,3^{\prime \prime}$ & \\
\hline 83 & SP_294 & Dracena & & Direito & $\mathrm{S} \mathrm{21^{ \circ } 2 5 ^ { \prime } 5 1 , 1 ^ { \prime \prime }}$ & \\
\hline & & SP-563 & & & W 51 $31^{\circ} 36^{\prime} 07,0^{\prime \prime}$ & \\
\hline
\end{tabular}




\begin{tabular}{|c|c|c|c|c|c|c|}
\hline \multirow{2}{*}{ Amostra } & \multicolumn{5}{|c|}{ Local de coleta } & \multirow{2}{*}{$\begin{array}{c}\text { Posição em } \\
\text { Relação à } \\
\text { Linha de seixos }\end{array}$} \\
\hline & Rodovia & Sentido & $\mathrm{Km}$ & Lado & Coordenadas & \\
\hline \multirow[b]{2}{*}{84} & \multirow[b]{2}{*}{ SP-294 } & SP-563 & \multirow[b]{2}{*}{$665+500$} & \multirow[b]{2}{*}{ Esquerdo } & S 21을 $53,3^{\prime \prime}$ & \\
\hline & & $\begin{array}{c}\text { Nova } \\
\text { Guataporanga }\end{array}$ & & & $\bar{W} 51^{\circ} 40^{\prime} 31,6^{\prime \prime}$ & \\
\hline \multirow{2}{*}{85} & \multirow{2}{*}{ SP-310 } & São Carlos & \multirow{2}{*}{191} & \multirow{2}{*}{ Esquerdo } & S $22^{\circ} 18^{\prime} 17,0^{\prime \prime}$ & \\
\hline & & Rio Claro & & & 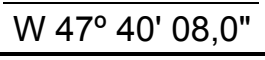 & \\
\hline \multirow{2}{*}{86} & \multirow{2}{*}{ SP-310 } & São Carlos & \multirow{2}{*}{187} & \multirow{2}{*}{ Esquerdo } & S $22^{\circ} 19^{\prime} 50,3^{\prime \prime}$ & \\
\hline & & Rio Claro & & & W 470 39' 14,4" & \\
\hline \multirow{2}{*}{87} & \multirow{2}{*}{ SP-330 } & Limeira & \multirow{2}{*}{$154+300$} & \multirow{2}{*}{ Direito } & S 22 $22^{\circ} 36,5^{\prime \prime}$ & \\
\hline & & Araras & & & $\overline{\text { W 470 } 23^{\prime} 55,5^{\prime \prime}}$ & \\
\hline \multirow{2}{*}{88} & \multirow{2}{*}{ SP-330 } & Pirassununga & & \multirow{2}{*}{ Direito } & S 21ㄷ6' 31,0" & \\
\hline & & Porto Ferreira & & & W 470 $27^{\prime} 51,5^{\prime \prime}$ & \\
\hline \multirow{2}{*}{89} & \multirow{2}{*}{ SP-330 } & $\begin{array}{c}\mathrm{S}^{\text {ta }} \text { Rita Passa } \\
\text { Quatro }\end{array}$ & \multirow{2}{*}{255} & \multirow{2}{*}{ Direito } & $S 21^{\circ} 38^{\prime} 20,2^{\prime \prime}$ & \\
\hline & & Luís Antônio & & & W 470 36' 41,5" & \\
\hline \multirow{2}{*}{90} & \multirow{2}{*}{ SP-334 } & Batatais & \multirow{2}{*}{$356+800$} & \multirow{2}{*}{ Direito } & S $20^{\circ} 50^{\prime} 22,9^{\prime \prime}$ & \multirow{2}{*}{ abaixo } \\
\hline & & Franca & & & $\bar{W} 47^{\circ} 36^{\prime} 03,8^{\prime \prime}$ & \\
\hline \multirow{2}{*}{91} & \multirow{2}{*}{ SP-334 } & Batatais & \multirow{2}{*}{$356+800$} & \multirow{2}{*}{ Direito } & S 20 50' 22,9" & \multirow{2}{*}{ acima } \\
\hline & & Franca & & & $\bar{W} 47^{\circ} 36^{\prime} 03,8^{\prime \prime}$ & \\
\hline
\end{tabular}




\title{
Anexo B - Resultados dos ensaios de caracterização e classificação dos materiais
}

\begin{abstract}
Apresentam-se, neste anexo, os resultados de caracterização e classificação de todo conjunto de amostras coletadas neste estudo. Como se observa na Tabela B.1, podem ser encontradas a indicação do número designado à amostra, a classe pedológica obtida no mapa pedológico, a massa específica dos sólidos, o teor de finos (\% que passa na peneira $200-0,074 \mathrm{~mm}$ ), as porcentagens de areia, silte e argila, os limites de consistência (LL, LP e IP), bem como a classificação dos solos segundo a HRB e USCS, conseqüência da caracterização dos materiais.
\end{abstract}


Tabela B.1: Resultados dos ensaios de caracterização e classificação dos solos

\begin{tabular}{|c|c|c|c|c|c|c|c|c|c|c|c|}
\hline \multirow{2}{*}{ 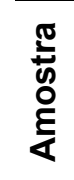 } & \multirow[b]{2}{*}{$\begin{array}{c}\text { Classe } \\
\text { pedológica }\end{array}$} & \multicolumn{8}{|c|}{ Caracterização } & \multicolumn{2}{|c|}{ Classificação } \\
\hline & & $\begin{array}{c}\rho_{\mathrm{s}} \\
\left(\mathrm{g} / \mathrm{cm}^{3}\right)\end{array}$ & $\begin{array}{c}\% \text { passa } \\
\# 200\end{array}$ & $\begin{array}{c}\text { Areia } \\
(\%)\end{array}$ & $\begin{array}{l}\text { Silte } \\
(\%)\end{array}$ & $\begin{array}{c}\text { Argila } \\
(\%)\end{array}$ & LL & LP & IP & HRB & USCS \\
\hline 11 & LV 9 & 2.633 & 34 & 66 & 13 & 22 & 34 & 21 & 13 & A-2-6 & $\mathrm{SC}$ \\
\hline 17 & LV 68 & 2.638 & 33 & 67 & 14 & 20 & 38 & 24 & 14 & A-2-6 & SC \\
\hline 21 & LVA 9 & 2.878 & 69 & 31 & 24 & 44 & 44 & 30 & 14 & A-7-5 & ML \\
\hline 22 & LVA 9 & 2.980 & 90 & 10 & 50 & 40 & 79 & 532 & 26 & A-7-5 & $\mathrm{MH}$ \\
\hline 23 & PVA 109 & 2.645 & 30 & 70 & 15 & 15 & 22 & 15 & 7 & $A-2-4$ & SM-SC \\
\hline 24 & PVA 109 & 2.622 & 31 & 69 & 18 & 13 & 25 & 16 & 9 & A-2-4 & SC \\
\hline 25 & NV 7 & 2.932 & 84 & 16 & 42 & 42 & 46 & 33 & 13 & $A-7-5$ & ML \\
\hline 26 & LV 1 & 2.668 & 39 & 61 & 18 & 21 & 30 & 18 & 12 & A-6 & SC \\
\hline 27 & LV 1 & 2.691 & 49 & 50 & 26 & 25 & 38 & 23 & 15 & $A-6$ & SC \\
\hline 28 & PVA 10 & 2.642 & 35 & 65 & 16 & 18 & 29 & 18 & 11 & A-2-6 & SC \\
\hline 29 & LV 49 & 2.577 & 26 & 74 & 17 & 10 & 21 & 14 & 7 & A-2-4 & SM-SC \\
\hline 30 & LV 49 & 2.546 & 40 & 60 & 16 & 24 & 31 & 19 & 12 & A-6 & SC \\
\hline 31 & PVA 8 & 2.639 & 74 & 26 & 22 & 52 & 55 & 37 & 18 & A-7-5 & $\mathrm{MH}$ \\
\hline 32 & PVA 8 & 2.680 & 80 & 20 & 55 & 25 & 65 & 40 & 26 & A-7-5 & $\mathrm{MH}$ \\
\hline 33 & PVA 8 & 2.600 & 61 & 39 & 48 & 13 & 50 & & 15 & A-7-5 & ML \\
\hline 34 & RL 22 & 2.629 & 92 & 8 & 55 & 37 & 57 & 40 & 17 & A-7-5 & $\mathrm{MH}$ \\
\hline 35 & NV 4 & 2.852 & 86 & 14 & 23 & 64 & 53 & 37 & 16 & $A-7-5$ & $\mathrm{MH}$ \\
\hline 36 & CX 19 & 2.664 & 69 & 31 & 65 & 4 & & $N P$ & & $A-4$ & $\mathrm{CL}$ \\
\hline 37 & LVA 23 & 2.587 & 62 & 38 & 21 & 40 & 45 & 34 & 11 & A-7-5 & ML \\
\hline 38 & LVA 40 & 2.613 & 69 & 31 & 26 & 43 & 61 & 32 & 29 & $A-7-5$ & $\mathrm{MH}$ \\
\hline 39 & PVA 55 & 2.657 & 92 & 8 & 10 & 82 & 108 & 55 & 53 & $A-7-5$ & $\mathrm{MH}$ \\
\hline 40 & LR & 2.755 & 46 & 54 & 18 & 28 & 29 & 22 & 7 & A-4 & SM-SC \\
\hline 41 & LV 15 & 2.654 & 42 & 58 & 11 & 32 & 28 & 19 & 9 & A-4 & SC \\
\hline 42 & LV 45 & 2.624 & 47 & 53 & 18 & 28 & 34 & 23 & 11 & A-6 & SC \\
\hline 43 & PVA 10 & 2.582 & 31 & 69 & 21 & 10 & & $N P$ & & A-2-4 & SM \\
\hline 44 & PVA 10 & 2.558 & 39 & 61 & 11 & 27 & 34 & 20 & 14 & A-6 & SC \\
\hline 45 & PVA 1 & 2.551 & 53 & 47 & 40 & 13 & 36 & 25 & 11 & A-6 & $M L$ \\
\hline 46 & PVA 1 & 2.606 & 37 & 63 & 17 & 21 & 34 & 19 & 15 & A-6 & SC \\
\hline 47 & LV 6 & 2.932 & 86 & 14 & 60 & 26 & 49 & 37 & 12 & $A-7-5$ & $M L$ \\
\hline 48 & LV 6 & 2.844 & 78 & 22 & 30 & 48 & 47 & 30 & 17 & $A-7-5$ & $\mathrm{ML}$ \\
\hline 49 & NV & 2.723 & 72 & 28 & 21 & 51 & 47 & 31 & 16 & $A-7-5$ & $\mathrm{ML}$ \\
\hline 50 & LV 78 & 2.629 & 22 & 78 & 10 & 12 & & $N P$ & & $A-2-4$ & SM \\
\hline 51 & LV 78 & 2.681 & 76 & 24 & 43 & 32 & 48 & 30 & 18 & $A-7-5$ & $\mathrm{ML}$ \\
\hline 52 & LV 78 & 2.561 & 47 & 53 & 30 & 17 & 23 & 16 & 7 & A-4 & SM-SC \\
\hline 53 & PVA 10 & 2.660 & 69 & 31 & 22 & 47 & 55 & 35 & 20 & $A-7-5$ & $\mathrm{MH}$ \\
\hline 54 & PVA 10 & 2.590 & 42 & 58 & 22 & 20 & 25 & 19 & 6 & A-4 & SM-SC \\
\hline 55 & GX 10 & 2.565 & 37 & 63 & 22 & 15 & 18 & 14 & 4 & A-4 & SM-SC \\
\hline 56 & PVA 10 & 2.535 & 35 & 65 & 23 & 12 & & $N P$ & & A-2-4 & SM \\
\hline 57 & PVA 2 & 2.564 & 45 & 55 & 21 & 23 & 31 & 23 & 8 & A-4 & SM \\
\hline 58 & PVA 1 & 2.554 & 46 & 54 & 32 & 14 & 27 & 16 & 11 & A-6 & SC \\
\hline 59 & PV 1 & 2.590 & 44 & 56 & 24 & 20 & 24 & 16 & 8 & $A-6$ & SC \\
\hline 60 & PVA 10 & 2.568 & 40 & 60 & 19 & 21 & 23 & 17 & 6 & $A-4$ & SM-SC \\
\hline 61 & PVA 10 & 2.616 & 48 & 52 & 27 & 21 & 27 & 17 & 10 & $A-4$ & SC \\
\hline 62 & PVA 10 & 2.607 & 41 & 59 & 29 & 13 & 20 & 16 & 4 & A-4 & SM-SC \\
\hline 63 & LV 45 & 2.607 & 45 & 55 & 23 & 22 & 22 & 17 & 5 & $A-4$ & SM-SC \\
\hline 64 & PVA & 2.661 & 89 & 11 & 82 & 7 & & $N P$ & & A-4 & $\mathrm{CL}$ \\
\hline 65 & PVA & 2.749 & 92 & 8 & 48 & 45 & 58 & 34 & 24 & $A-7-5$ & $\mathrm{MH}$ \\
\hline 66 & LV60 & 2.566 & 31 & 69 & 8 & 24 & 34 & 20 & 14 & A-2-6 & SC \\
\hline
\end{tabular}




\begin{tabular}{|c|c|c|c|c|c|c|c|c|c|c|}
\hline \multirow{2}{*}{ 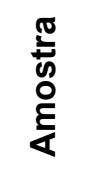 } & \multirow[b]{2}{*}{$\begin{array}{c}\text { Classe } \\
\text { pedológica }\end{array}$} & \multicolumn{7}{|c|}{ Caracterização } & \multicolumn{2}{|c|}{ Classificação } \\
\hline & & $\begin{array}{c}\rho_{\mathrm{s}} \\
\left(\mathrm{g} / \mathrm{cm}^{3}\right)\end{array}$ & $\begin{array}{c}\text { \% passa } \\
\text { \# } 200\end{array}$ & $\begin{array}{c}\text { Areia } \\
(\%)\end{array}$ & $\begin{array}{l}\text { Silte } \\
(\%)\end{array}$ & $\begin{array}{c}\text { Argila } \\
(\%)\end{array}$ & LL & LP IF & HRB & USCS \\
\hline 67 & LV41 & 2.666 & 96 & 4 & 18 & 78 & 60 & 431 & 7 A-7-5 & $\mathrm{MH}$ \\
\hline 68 & LVA13 & 2.574 & 27 & 73 & 8 & 19 & 27 & 141 & 3 A-2-6 & SC \\
\hline 69 & LV6 & 2.867 & 81 & 19 & 33 & 48 & 49 & 341 & 5 A-7-5 & ML \\
\hline 70 & NV1 & 2.894 & 88 & 12 & 28 & 60 & 61 & 412 & A-7-5 & $\mathrm{MH}$ \\
\hline 71 & LV15 & 2.996 & 93 & 7 & 43 & 49 & 47 & 379 & A-7-5 & ML \\
\hline 72 & LVA31 & 2.600 & 40 & 60 & 18 & 21 & & $N P$ & $\mathrm{~A}-4$ & SM \\
\hline 73 & LVA31 & 2.617 & 56 & 44 & 19 & 37 & & $N P$ & $A-4$ & $C L$ \\
\hline 74 & RQ4 & 2.559 & 9 & & & & & $N P$ & A-3 & GC-SM \\
\hline 75 & LVA24 & 2.580 & 50 & 50 & 32 & 18 & 39 & 231 & A-6 & SC \\
\hline 76 & LVA24 & 2.532 & 33 & 67 & 16 & 16 & 31 & 161 & 5 A-2-6 & SC \\
\hline 77 & PVA2 & 2.701 & 69 & 31 & 25 & 44 & 55 & 302 & 5 A-7-5 & $\mathrm{MH}$ \\
\hline 78 & PVA2 & 2.684 & 80 & 20 & 36 & 44 & 59 & 392 & A-7-5 & $\mathrm{MH}$ \\
\hline 79 & PVA2 & 2.633 & 28 & 72 & 11 & 17 & 28 & 151 & 3 A-2-6 & SC \\
\hline 80 & PVA10 & 2.614 & 29 & 71 & 15 & 14 & & $N P$ & A-2-4 & SM \\
\hline 81 & PVA5 & 2.663 & 34 & 66 & 19 & 15 & & $N P$ & A-2-4 & SM \\
\hline 82 & PVA5 & 2.619 & 39 & 61 & 22 & 17 & 28 & 181 & A-4 & SC \\
\hline 83 & PVA10 & 2.697 & 47 & 53 & 31 & 17 & 28 & 199 & A-4 & SC \\
\hline 84 & LV45 & 2.650 & 41 & 59 & 25 & 16 & 20 & 164 & A-4 & SM-SC \\
\hline 85 & PVA27 & 2.624 & 31 & 69 & 22 & 10 & 34 & 181 & A-2-6 & SC \\
\hline 86 & PVA27 & 2.665 & 90 & 10 & 45 & 44 & 74 & 363 & 3 A-7-5 & $\mathrm{MH}$ \\
\hline 87 & LV4 & 3.047 & 87 & 13 & 32 & 55 & 49 & 341 & 5 A-7-5 & ML \\
\hline 88 & LV51 & 2.675 & 39 & 61 & 12 & 28 & 28 & 208 & A-4 & SC \\
\hline 89 & RQ8 & 2.673 & 14 & 86 & 8 & 7 & & $N P$ & A-2-4 & SM \\
\hline 90 & LVA31 & 2.849 & 88 & 12 & 44 & 44 & 69 & 511 & 3 A-7-5 & $\mathrm{MH}$ \\
\hline 91 & LVA31 & 2.896 & 74 & 26 & 31 & 44 & 46 & 331 & 3 A-7-5 & ML \\
\hline
\end{tabular}




\section{Anexo C - Resultados da classificação MCT}

Apresentam-se neste anexo os resultados da classificação MCT realizada em todo conjunto de amostras consideradas neste estudo. Como se observa na Tabela C.1, podem ser encontradas a indicação do número designado à amostra, os valores da perda por imersão $(\mathrm{Pi})$, bem como os coeficientes c' e e'. 
Tabela C.1: Resultados dos ensaios da classificação MCT (Pi, c' e e')

\begin{tabular}{|c|c|c|c|c|c|c|c|c|c|}
\hline Amostra & $\mathbf{P i}$ & $c^{\prime}$ & $e^{\prime}$ & Classe & Amostra & $\mathbf{P i}$ & $\mathbf{c}^{\prime}$ & $e^{\prime}$ & Classe \\
\hline 11 & 122 & 0,80 & 1,10 & $\mathrm{LA}^{\prime}$ & 55 & 234 & 0,98 & 1,41 & $\mathrm{NA}^{\prime}$ \\
\hline 17 & 147 & 1,00 & 1,17 & $\mathrm{NA}^{\prime}$ & 56 & 289 & 0,54 & 1,65 & $\mathrm{NA}^{\prime}$ \\
\hline 21 & 81 & 1,95 & 1,04 & LG' & 57 & 114 & 1,73 & 1,12 & LG' \\
\hline 22 & 84 & 1,69 & 1,27 & NG' & 58 & 128 & 0,87 & 1,17 & $\mathrm{NA}^{\prime}$ \\
\hline 23 & 109 & 0,75 & 1,15 & LA' $^{\prime}$ & 59 & 91 & 0,98 & 1,11 & LA' $^{\prime}$ \\
\hline 24 & 99 & 0,98 & 1,15 & $\mathrm{NA}^{\prime}$ & 60 & 83 & 1,13 & 1,01 & LA' $^{\prime}$ \\
\hline 25 & 90 & 1,71 & 1,05 & LG' & 61 & 90 & 1,07 & 1,07 & LA' $^{\prime}$ \\
\hline 26 & 65 & 1,29 & 0,99 & LA' $^{\prime}$ & 62 & 210 & 0,74 & 1,42 & $\mathrm{NA}^{\prime}$ \\
\hline 27 & 235 & 1,63 & 1,42 & NG' & 63 & 100 & 0,98 & 1,12 & LA' \\
\hline 28 & 76 & 1,19 & 1,03 & LA' $^{\prime}$ & 64 & 315 & 1,28 & 1,63 & NS' \\
\hline 29 & 98 & 0,75 & 1,10 & LA' $^{\prime}$ & 65 & 90 & 1,98 & 1,31 & NG' \\
\hline 30 & 66 & 1,52 & 0,93 & LG' & 66 & 69 & 1,22 & 0,96 & LA' $^{\prime}$ \\
\hline 31 & 72 & 1,87 & 1,00 & LG' & 67 & 40 & 2,02 & 0,95 & LG' \\
\hline 32 & 172 & 1,63 & 1,47 & NG' & 68 & 71 & 0,94 & 1,09 & LA' $^{\prime}$ \\
\hline 33 & 212 & 1,32 & 1,54 & NS' & 69 & 100 & 1,86 & 1,11 & LG' \\
\hline 34 & 330 & 1,89 & 1,67 & NG' & 70 & 94 & 2,02 & 1,10 & LG' \\
\hline 35 & 99 & 2,05 & 1,07 & LG' & 71 & 93 & 2,03 & 1,09 & LG' \\
\hline 36 & 328 & 1,10 & 1,64 & NS' & 72 & 89 & 1,45 & 1,14 & LA' \\
\hline 37 & 53 & 1,88 & 0,98 & LG' & 73 & 102 & 1,84 & 1,11 & LG' \\
\hline 38 & 78 & 2,17 & 1,00 & LG' & 75 & 135 & 1,36 & 1,37 & NS' \\
\hline 39 & 75 & 2,24 & 1,22 & NG' & 76 & 79 & 0,86 & 1,08 & $\mathrm{LA}^{\prime}$ \\
\hline 40 & 83 & 1,33 & 1,01 & $\mathrm{LA}^{\prime}$ & 77 & 192 & 2,62 & 1,39 & NG' \\
\hline 41 & 97 & 1,86 & 1,03 & LG' & 78 & 131 & 2,28 & 1,30 & NG' \\
\hline 42 & 135 & 1,96 & 1,17 & NG' & 79 & 70 & 1,07 & 1,04 & $\mathrm{LA}^{\prime}$ \\
\hline 43 & 240 & 1,24 & 1,63 & NS' & 80 & 107 & 0,57 & 1,28 & LA \\
\hline 44 & 110 & 1,67 & 1,11 & LG' & 81 & 171 & 0,8 & 1,28 & NA' \\
\hline 45 & 123 & 1,27 & 1,33 & NA' & 82 & 119 & 0,9 & 1,23 & $\mathrm{NA}^{\prime}$ \\
\hline 46 & 42 & 1,28 & 0,94 & $\mathrm{LA}^{\prime}$ & 83 & 78 & 1 & 1,26 & $\mathrm{NA}^{\prime}$ \\
\hline 47 & 102 & 1,71 & 1,25 & NG' & 84 & 119 & 0,8 & 1,24 & $\mathrm{NA}^{\prime}$ \\
\hline 48 & 6 & 1,85 & 0,70 & LG' & 85 & 121 & 1 & 1,37 & NA' \\
\hline 49 & 88 & 2,01 & 1,04 & LG' & 86 & 253 & 2,6 & 1,49 & NG' \\
\hline 50 & 130 & 0,46 & 1,28 & LA & 87 & 135 & 2,2 & 1,20 & NG' \\
\hline 51 & 213 & 1,75 & 1,34 & NG' & 88 & 107 & 1,5 & 1,09 & LA' $^{\prime}$ \\
\hline 52 & 96 & 1,28 & 1,12 & $\mathrm{LA}^{\prime}$ & 89 & 281 & 0,3 & 1,54 & NA \\
\hline 53 & 128 & 2,48 & 1,24 & NG' & 90 & 93 & 2,3 & 1,16 & NG' \\
\hline 54 & 87 & 0,96 & 1,05 & $\mathrm{LA}^{\prime}$ & 91 & 103 & 2,5 & 1,06 & LG' \\
\hline
\end{tabular}




\section{Anexo D - Microscopia Eletrônica de Varredura (MEV)}

Apresentam-se neste anexo as imagens obtidas nos ensaios de microscopia eletrônica de varredura. Cada amostra foi caracterizada por duas imagens com diferentes aumentos. Conforme se observa a seguir, a primeira foto tem aumento de 3.000 vezes e a segunda aumento de 10.000 vezes. 

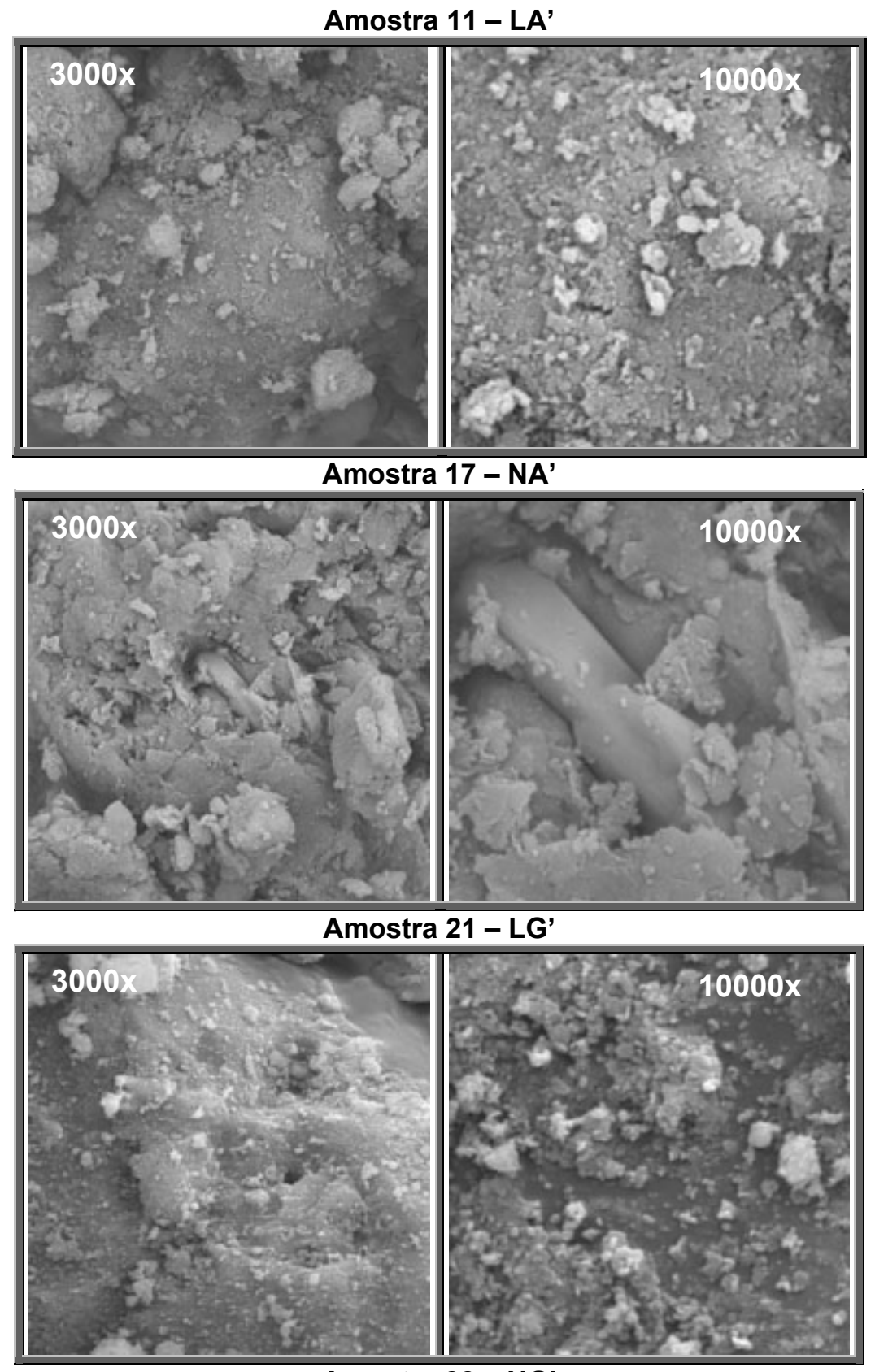

Amostra 22 - NG'

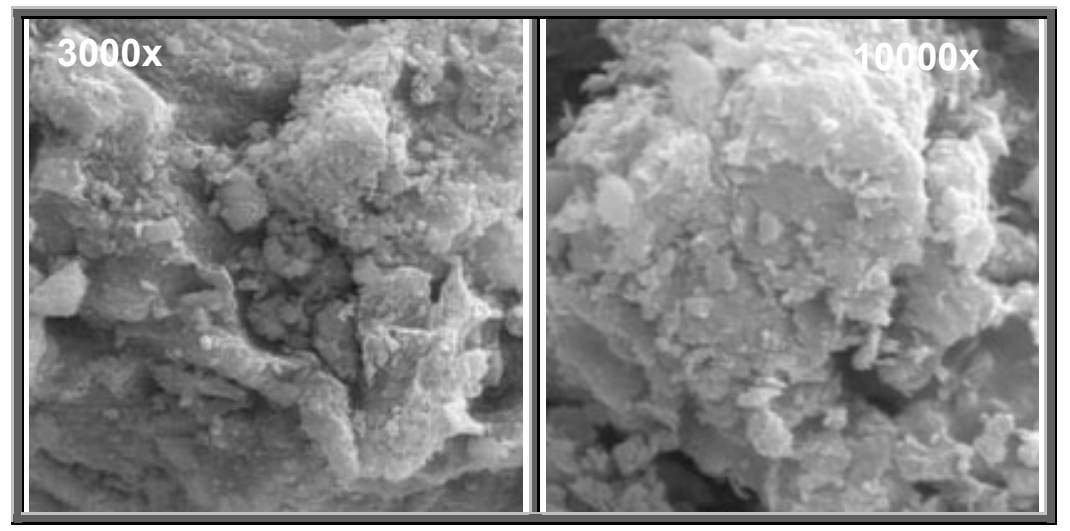




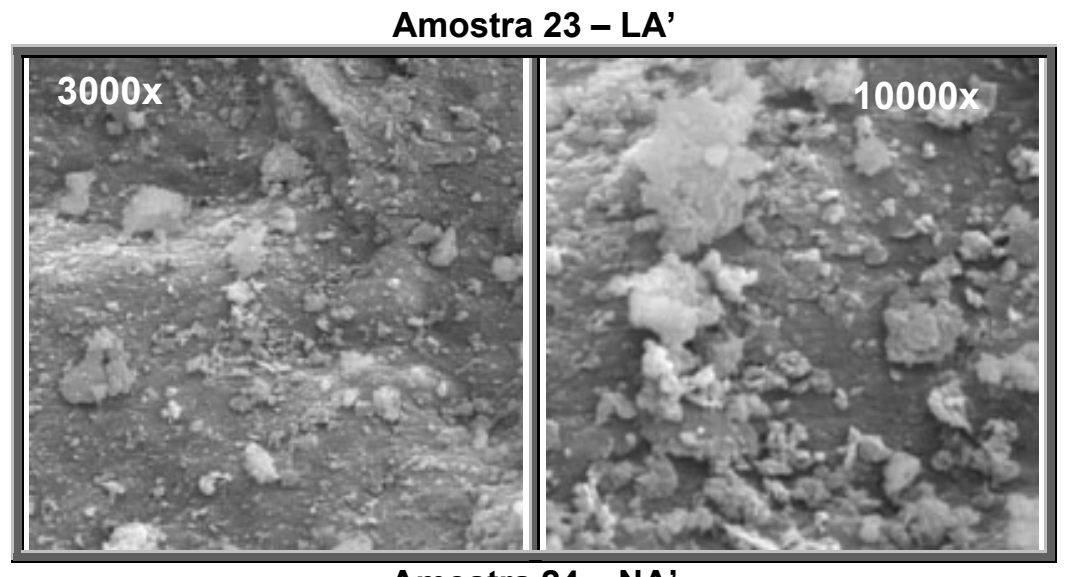

Amostra 24 - NA'

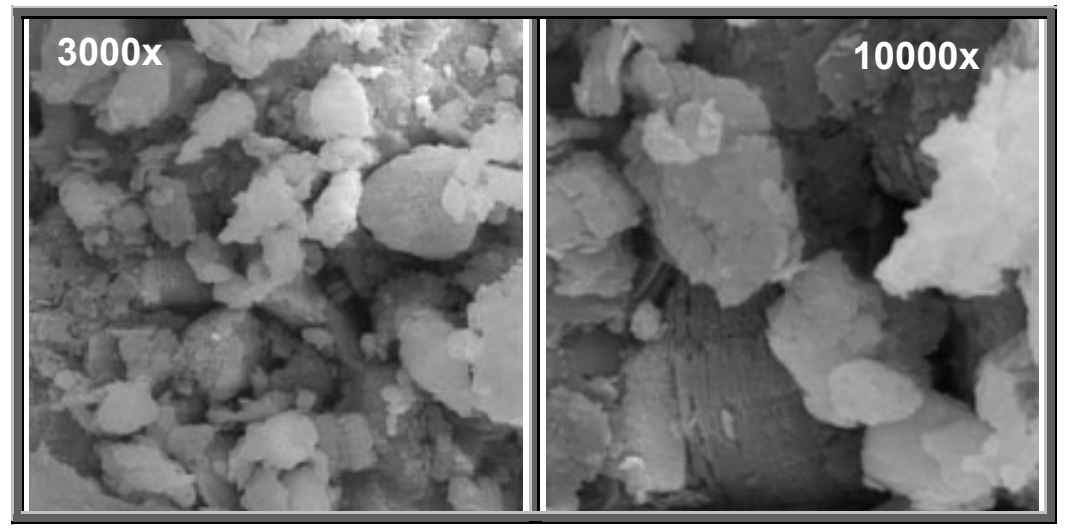

Amostra 25 - LG'

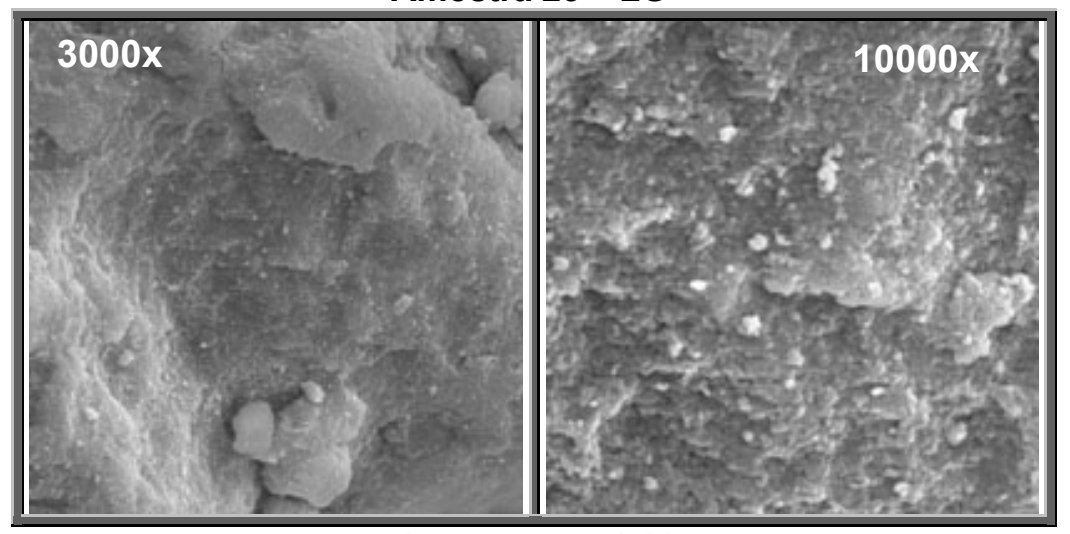

Amostra 26 - LA'

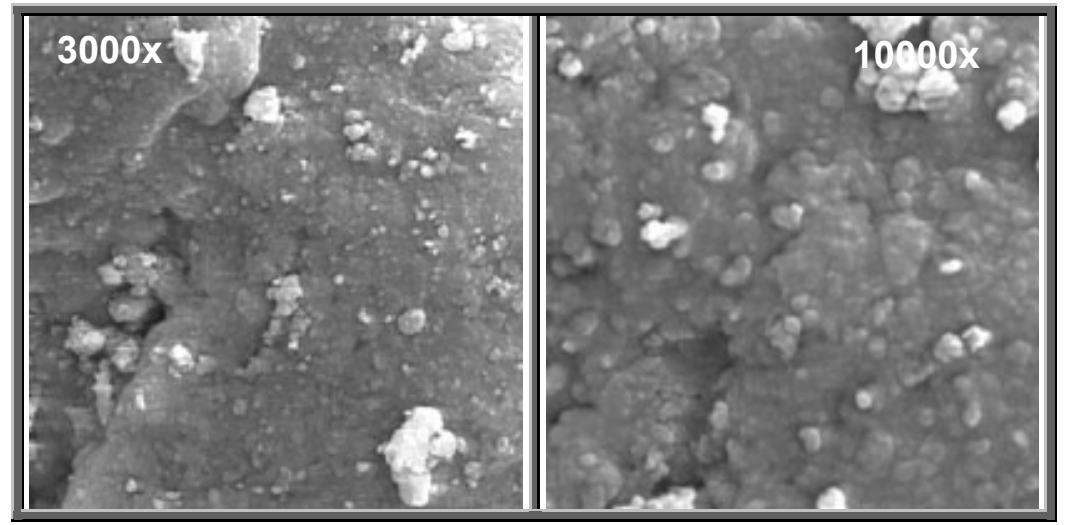



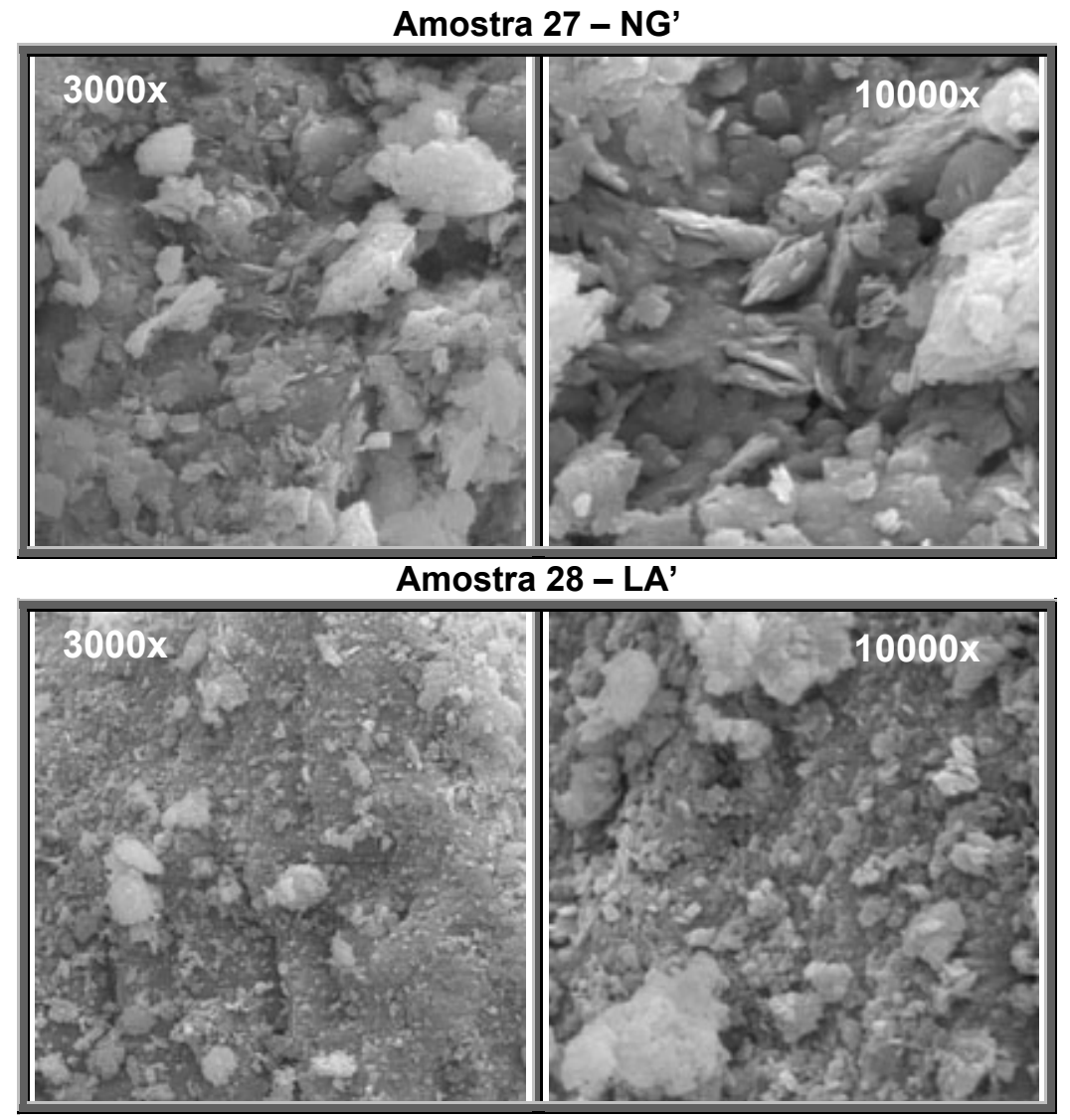

Amostra 29 - LA'

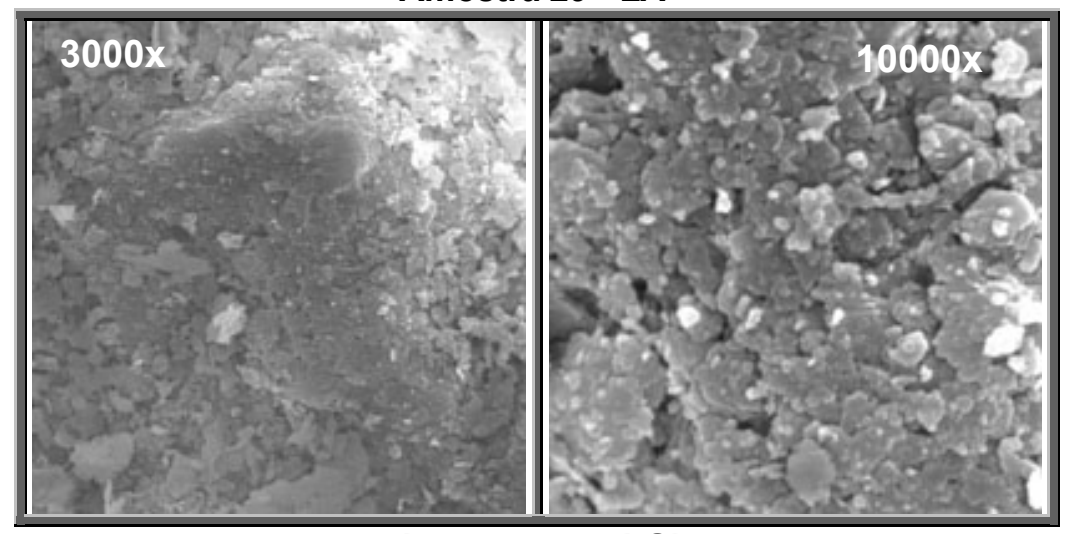

Amostra 30 - LG'

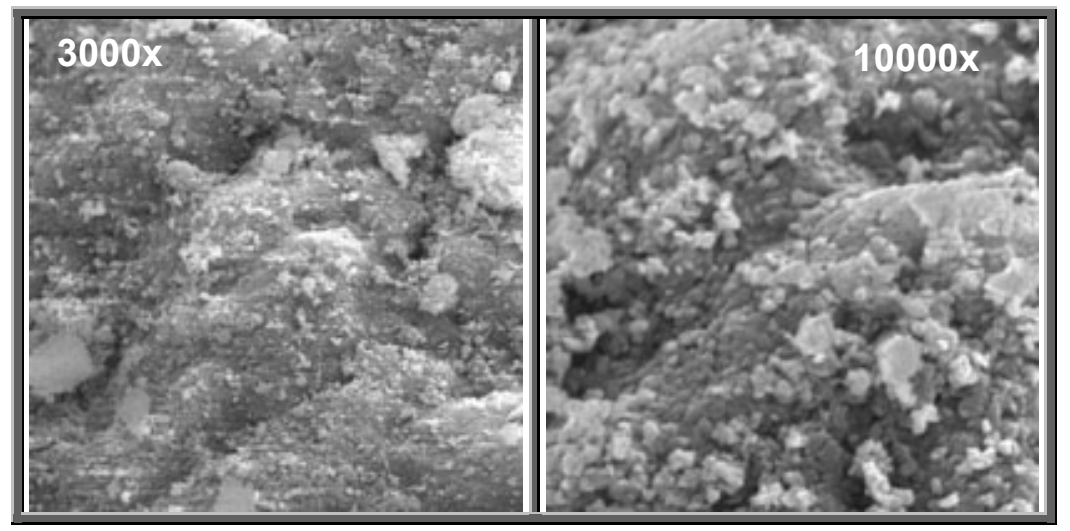



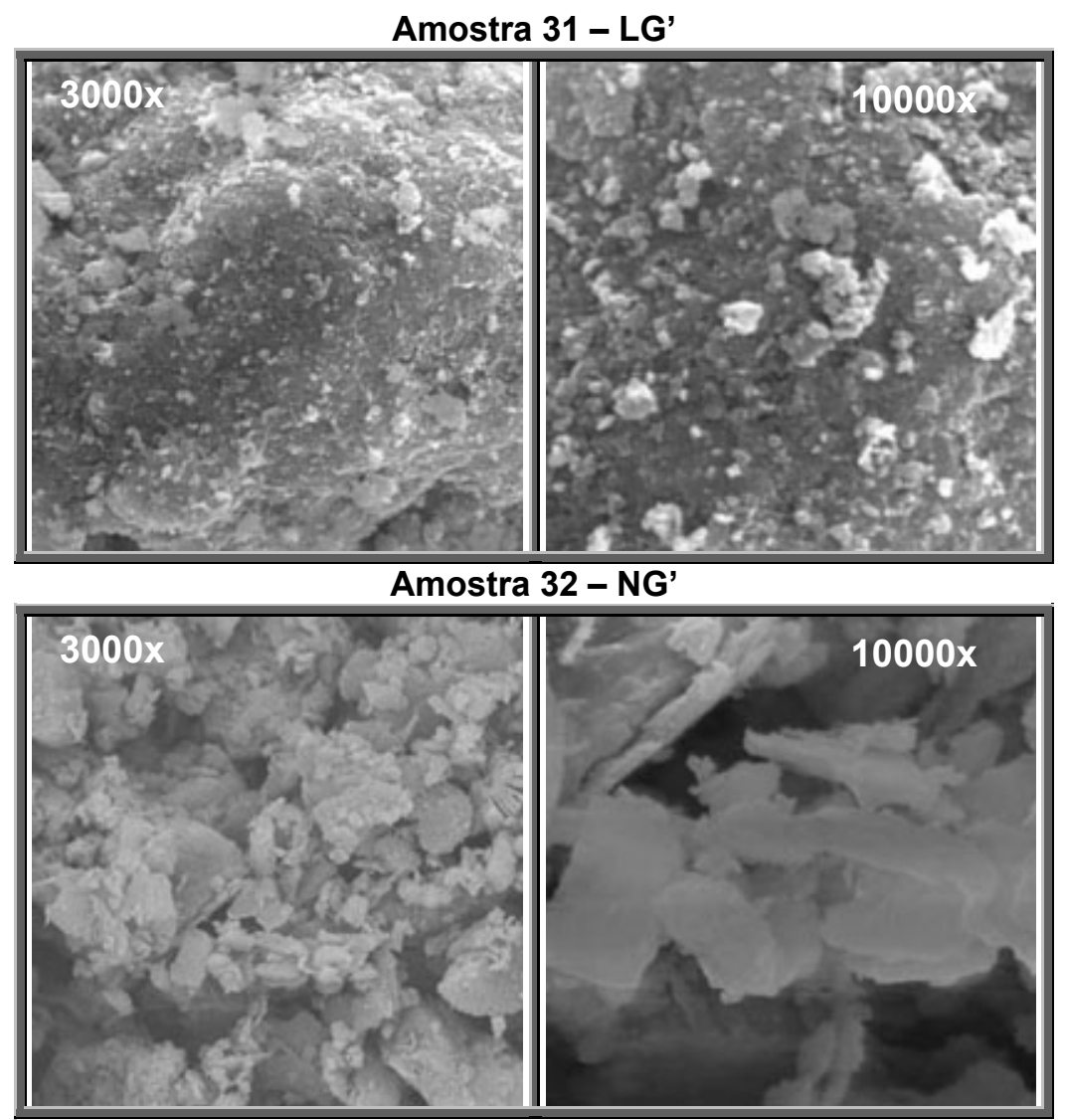

Amostra 33- NS'

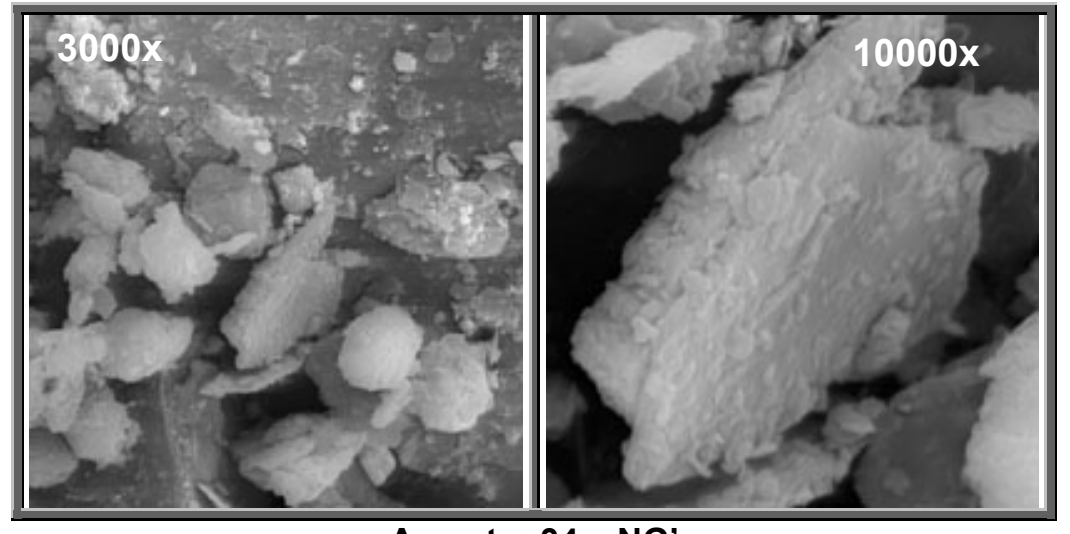

Amostra 34 - NG'

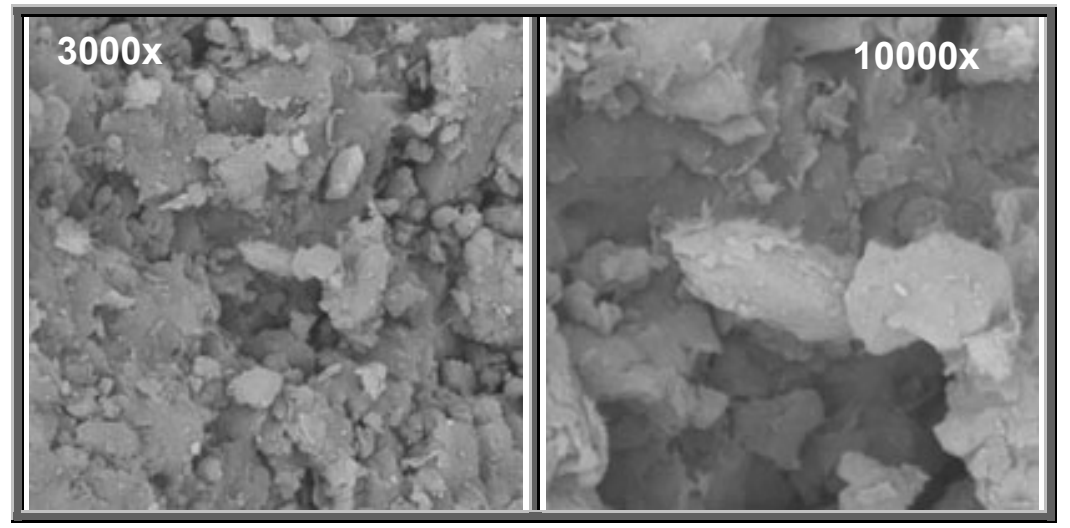




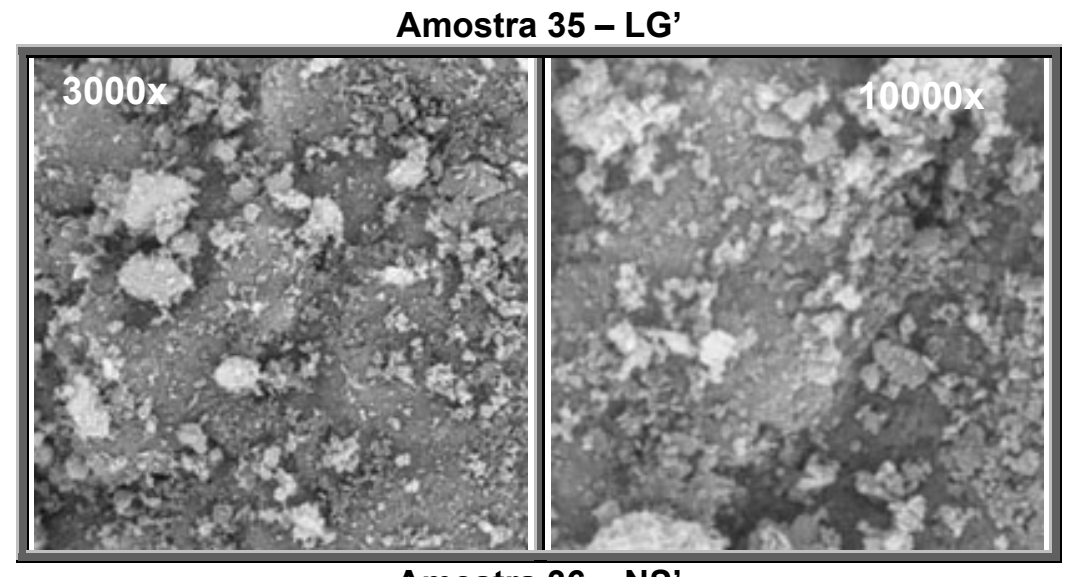

\section{Amostra 36 - NS'}

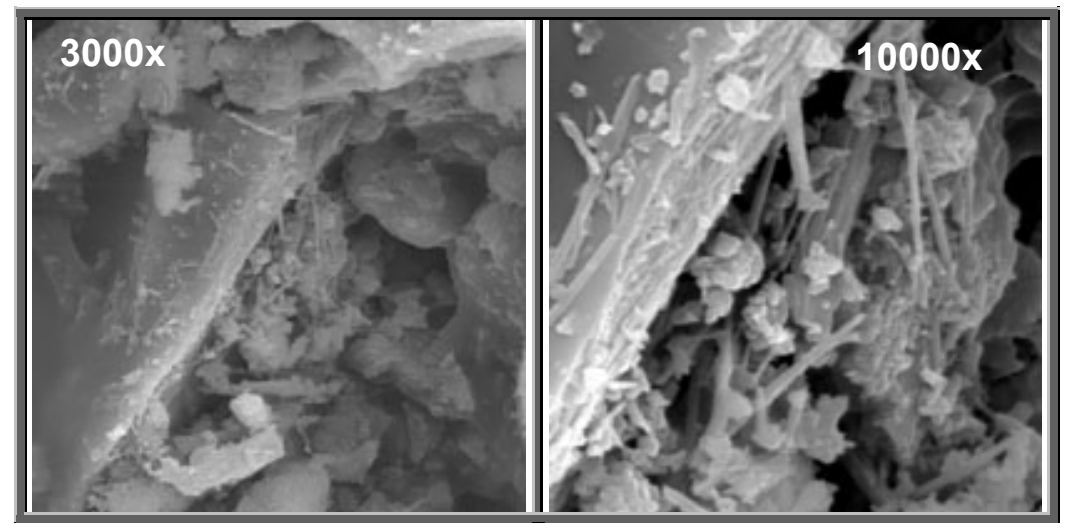

Amostra 37 - LG'

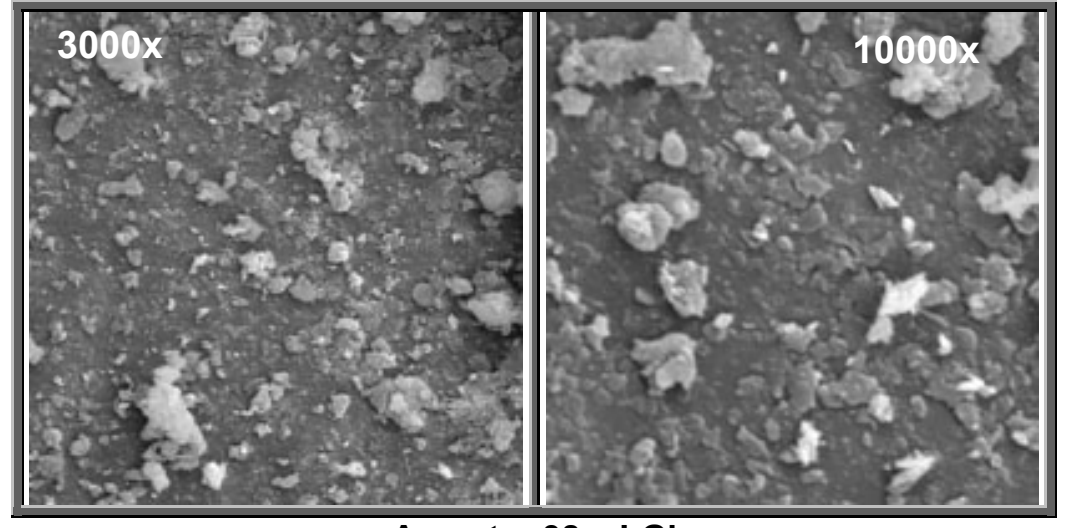

Amostra 38 - LG'

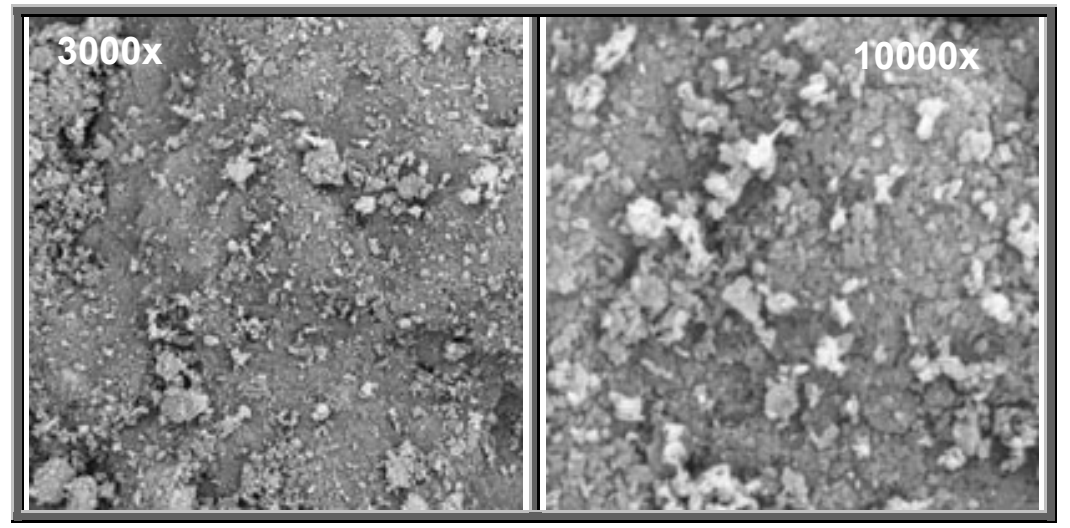




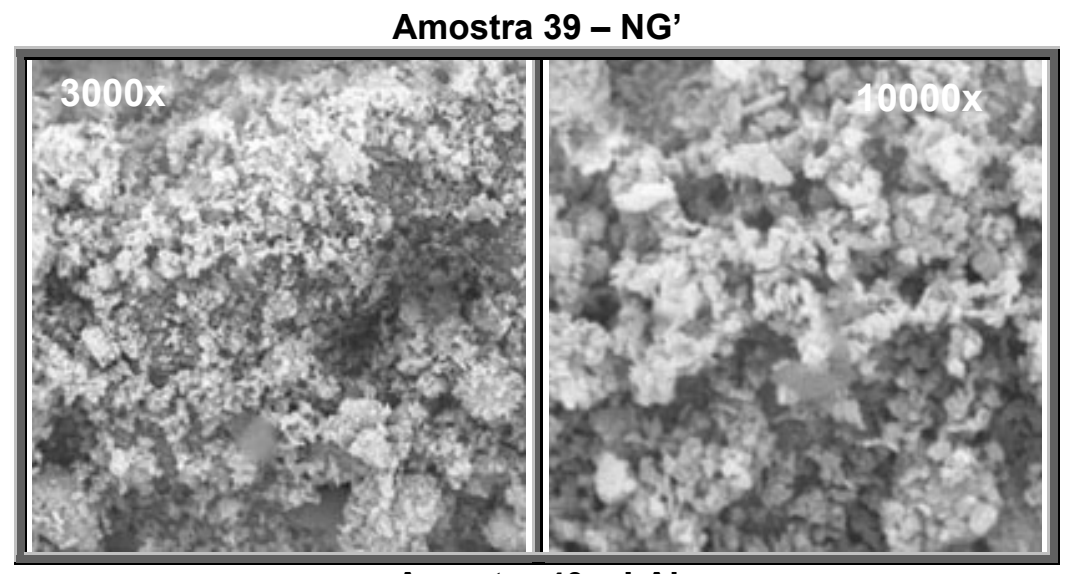

Amostra 40 - LA'

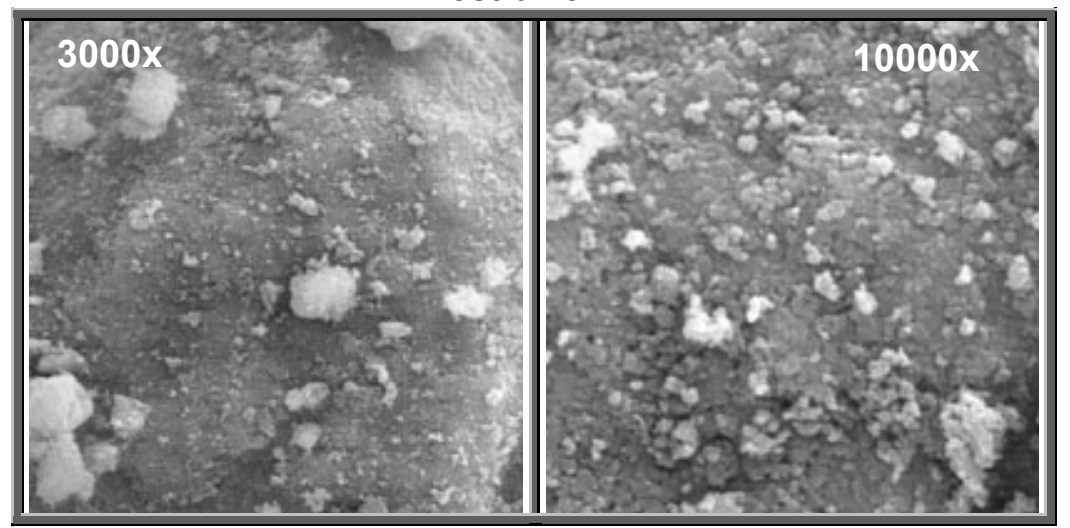

Amostra 41 - LG'

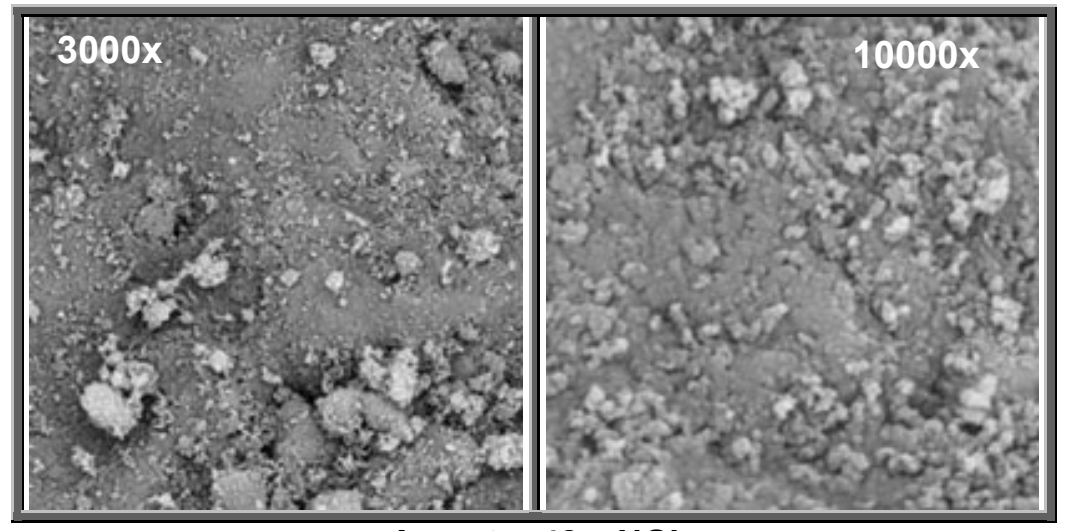

Amostra 42 - NG'

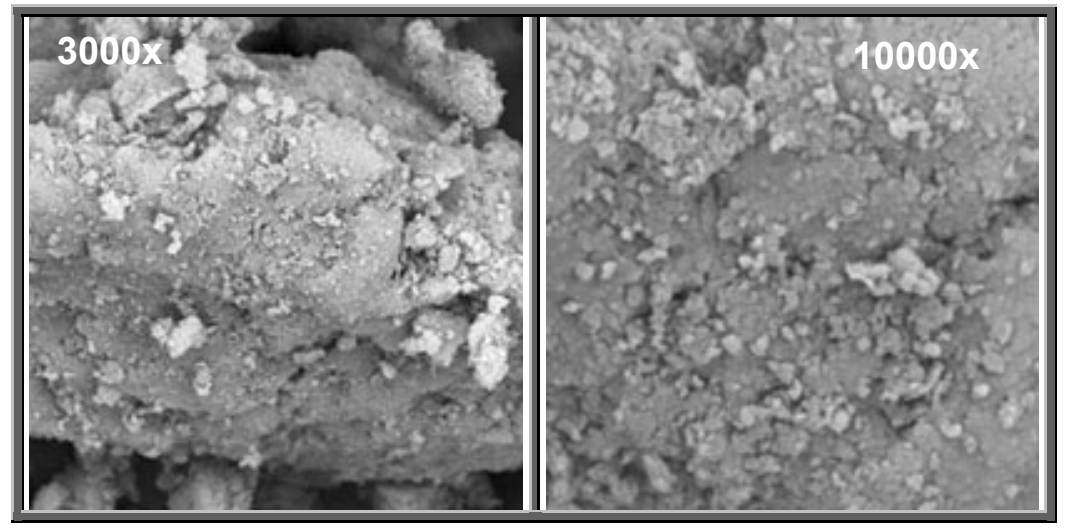




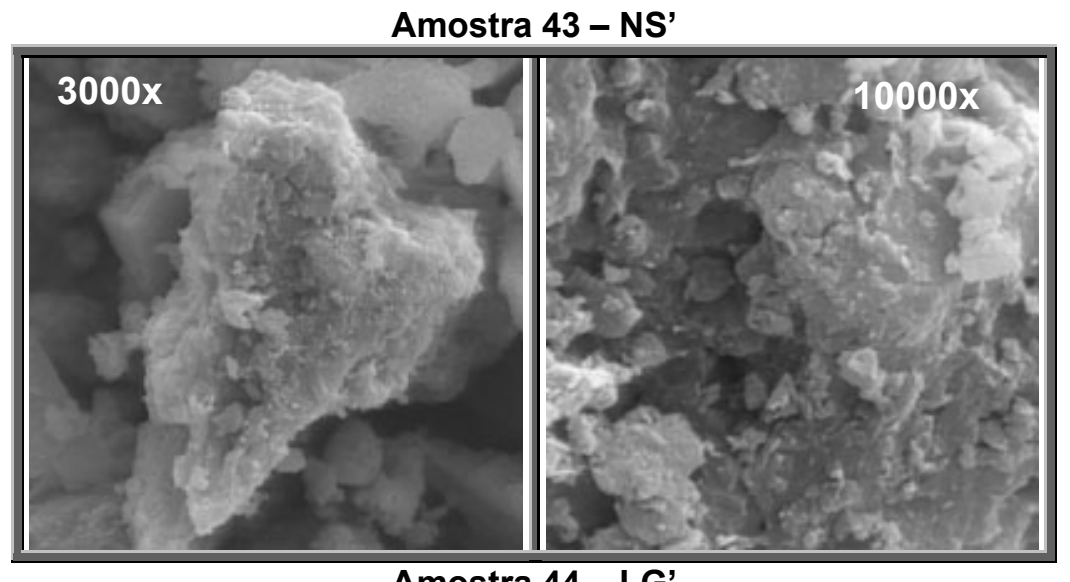

Amostra 44 - LG'

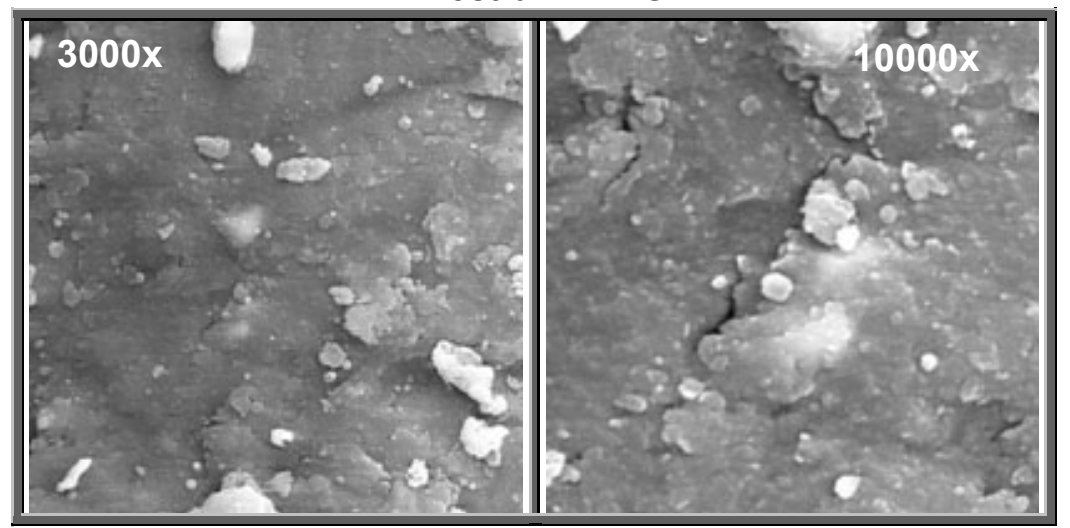

\section{Amostra 45 - NA'}

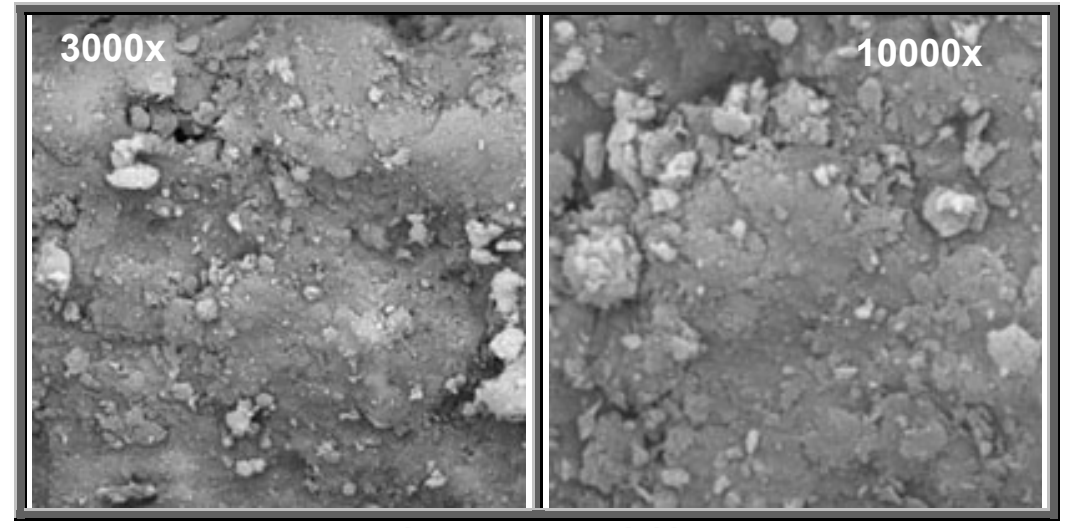

Amostra 46 - LA'

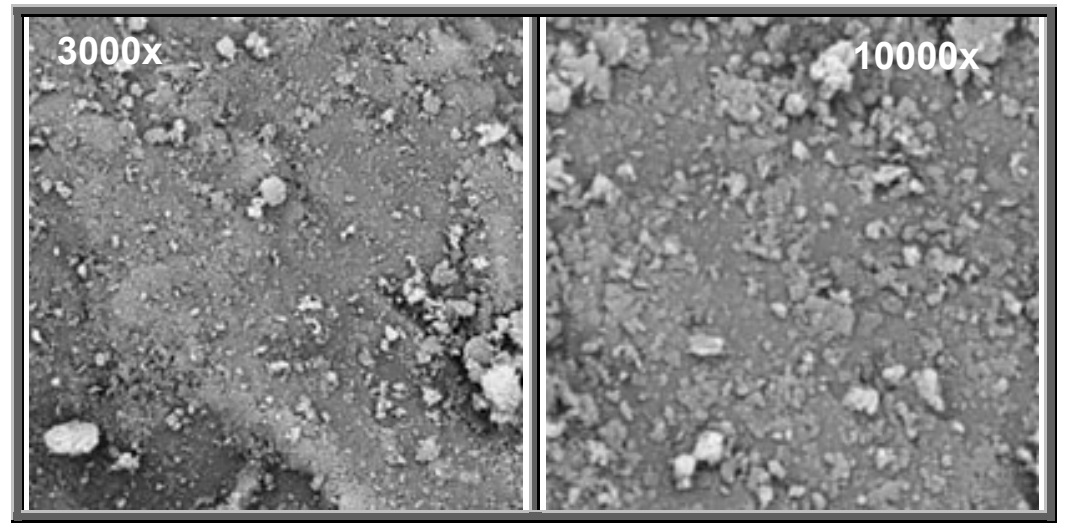



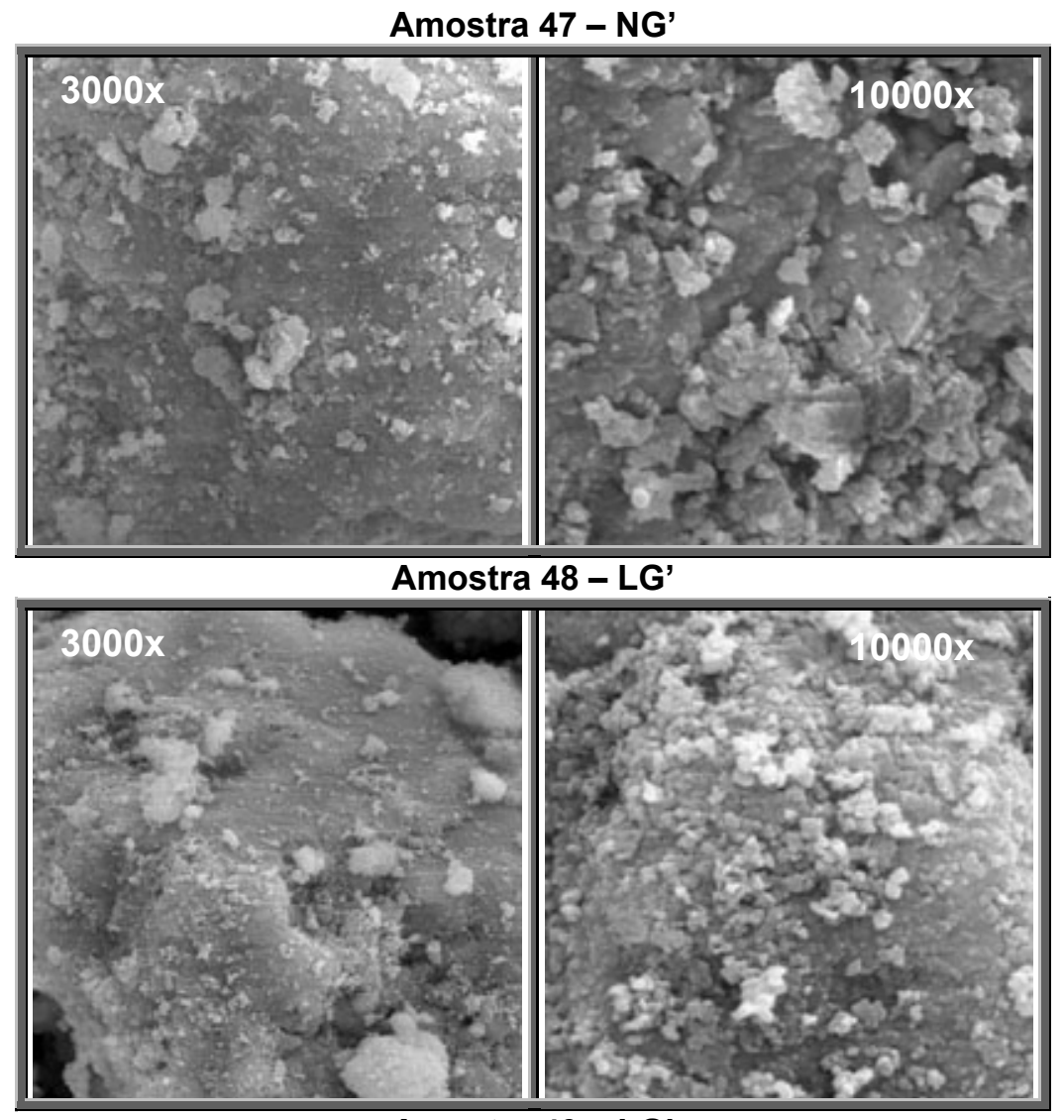

\section{Amostra 49 - LG'}

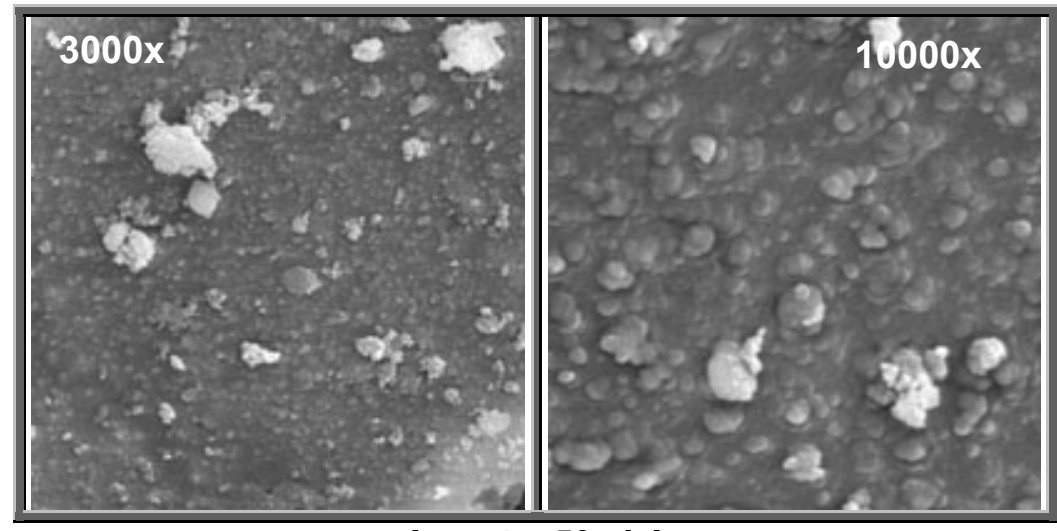

Amostra 50 - LA

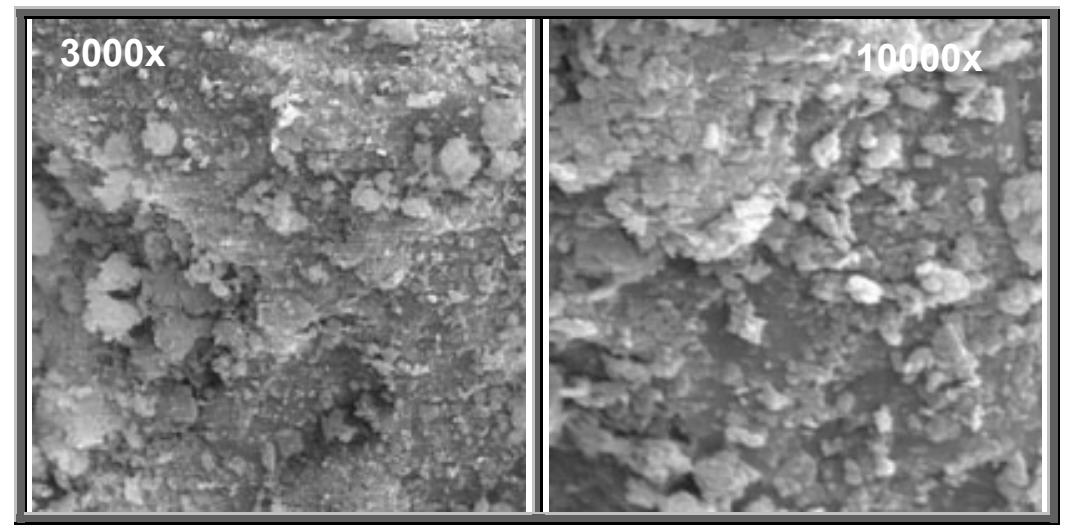



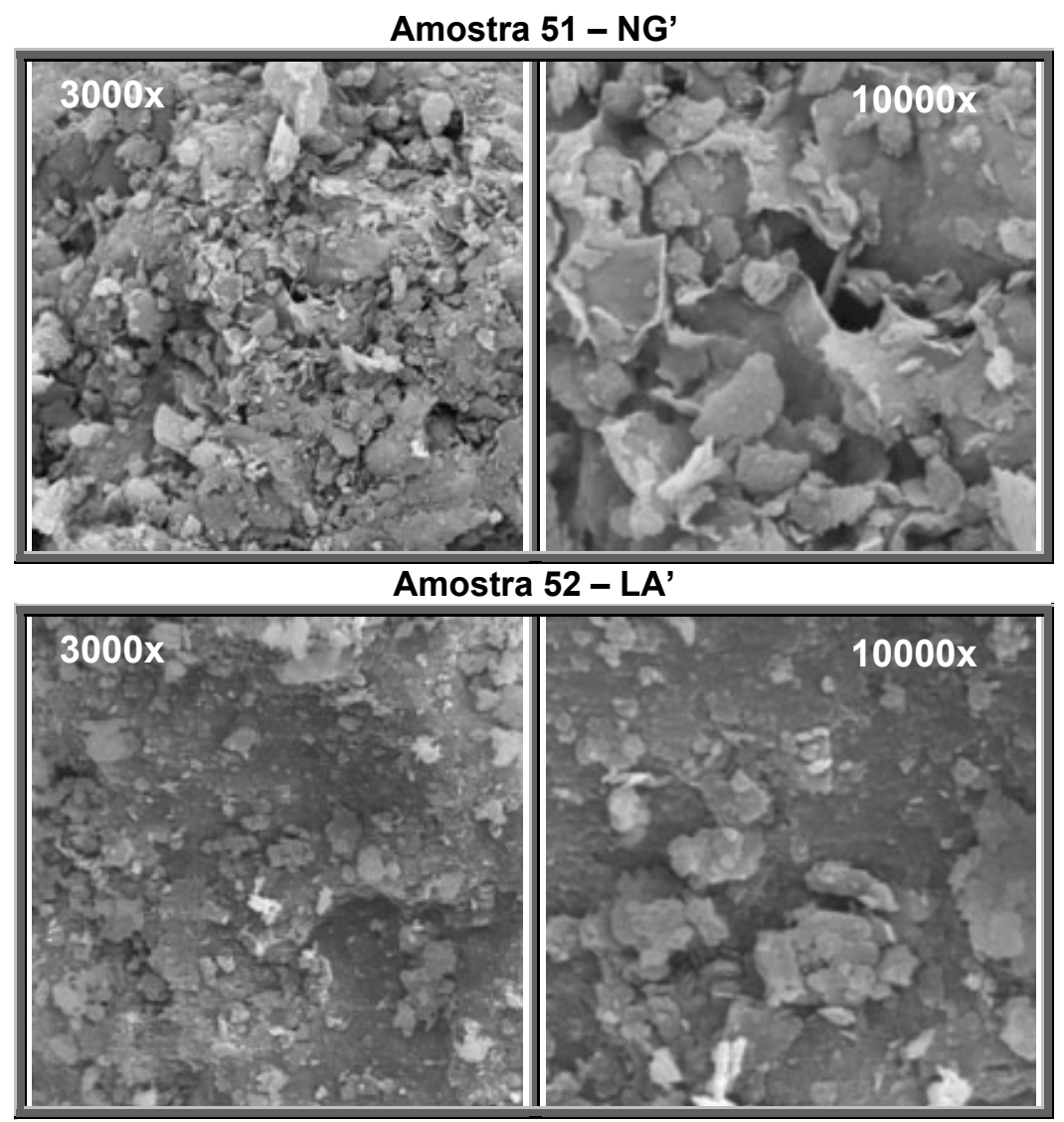

Amostra 53 - NG'

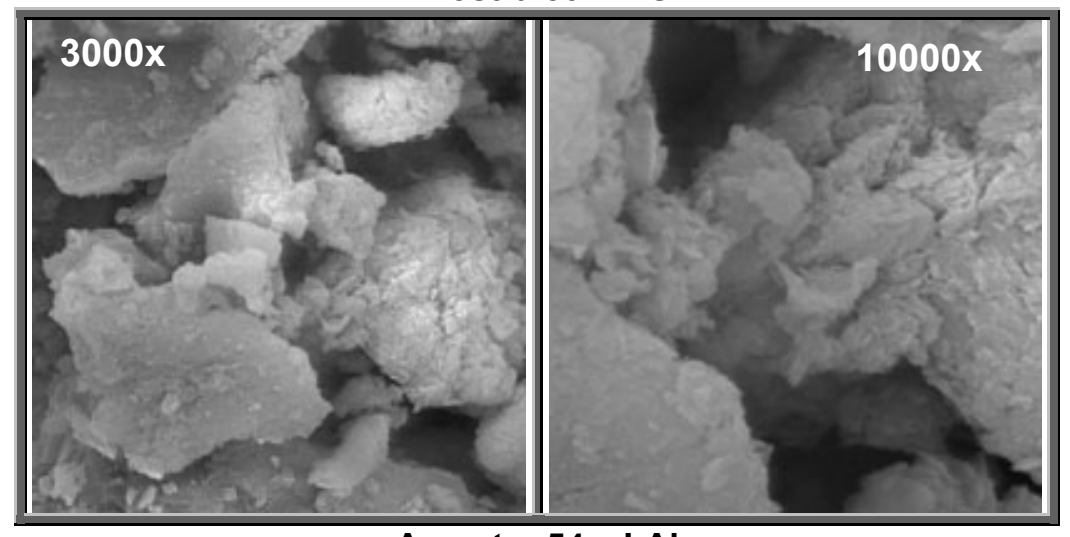

Amostra 54 - LA'

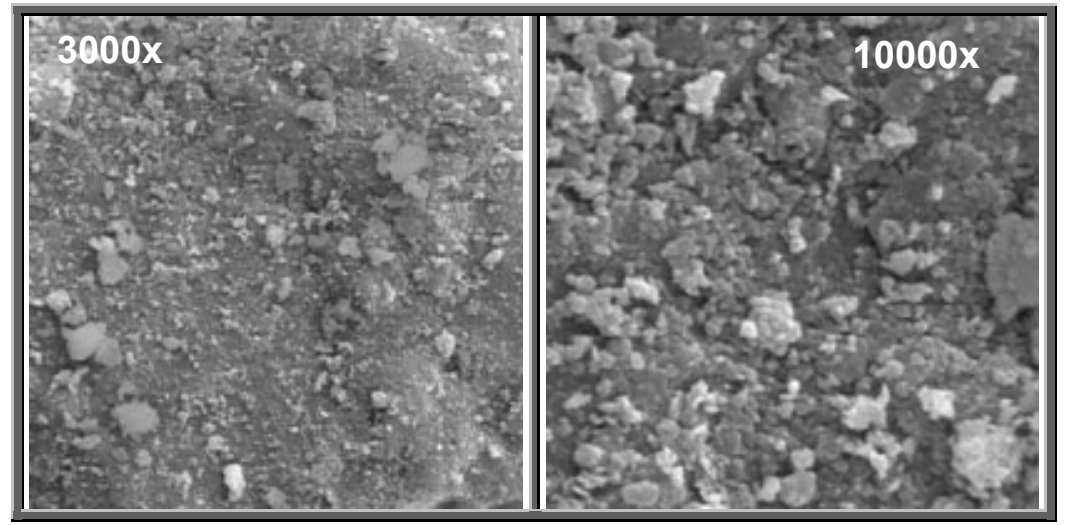



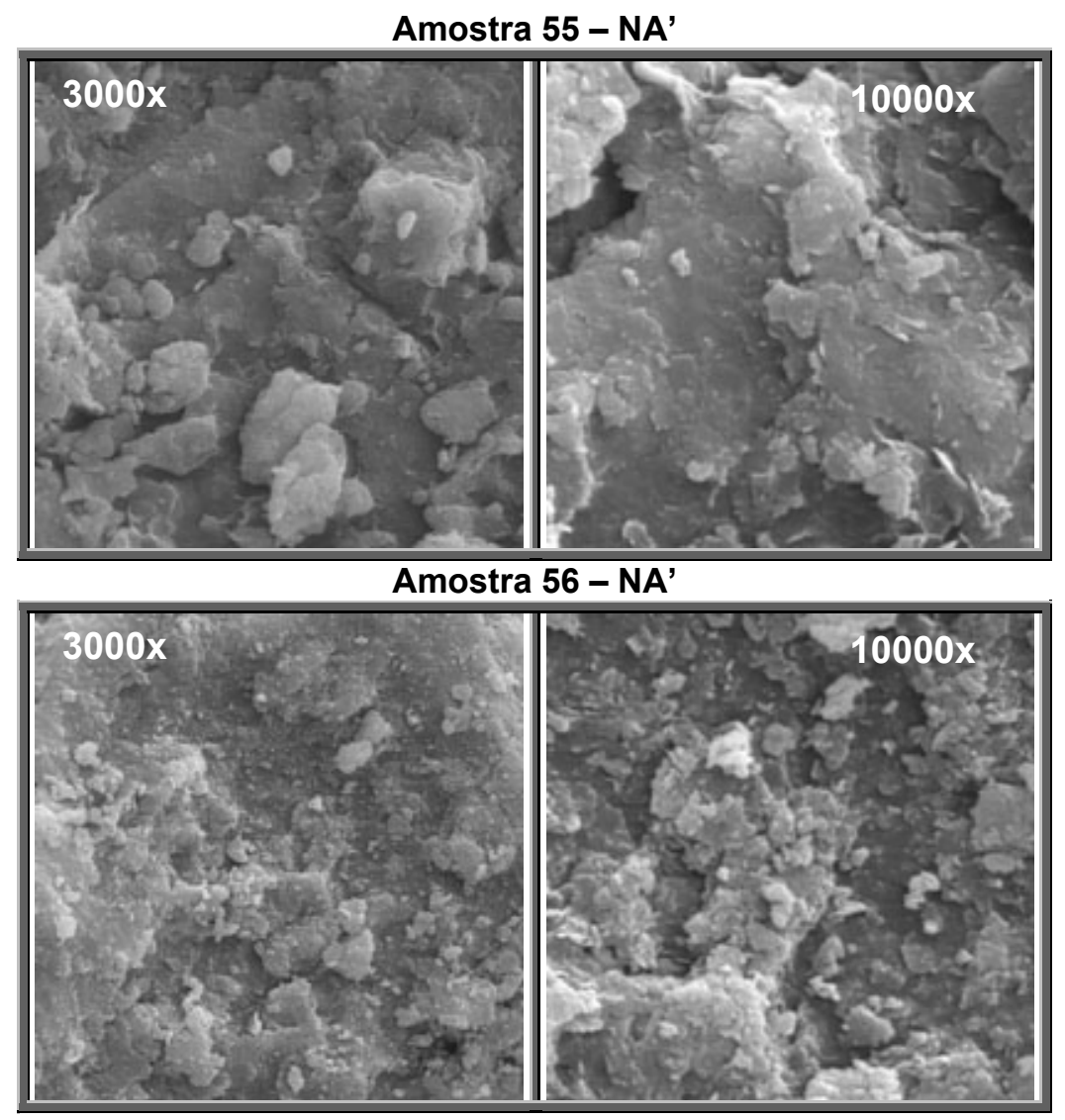

Amostra 57 - LG'

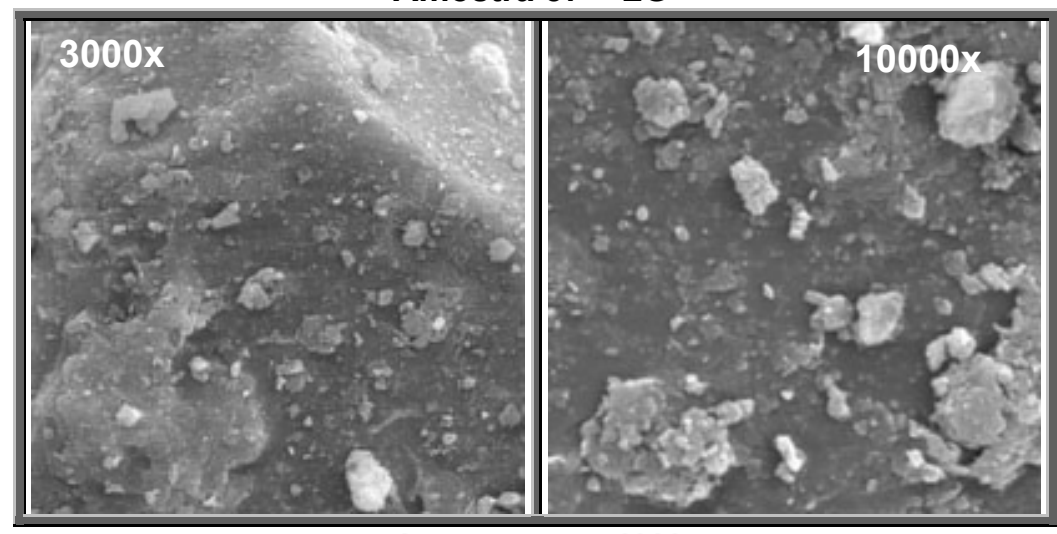

Amostra 58 - NA'

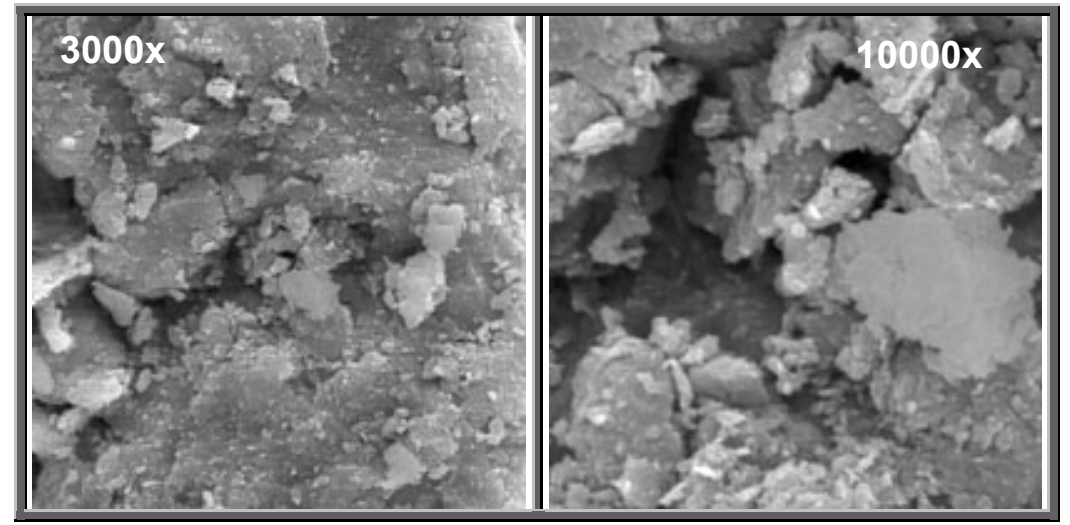




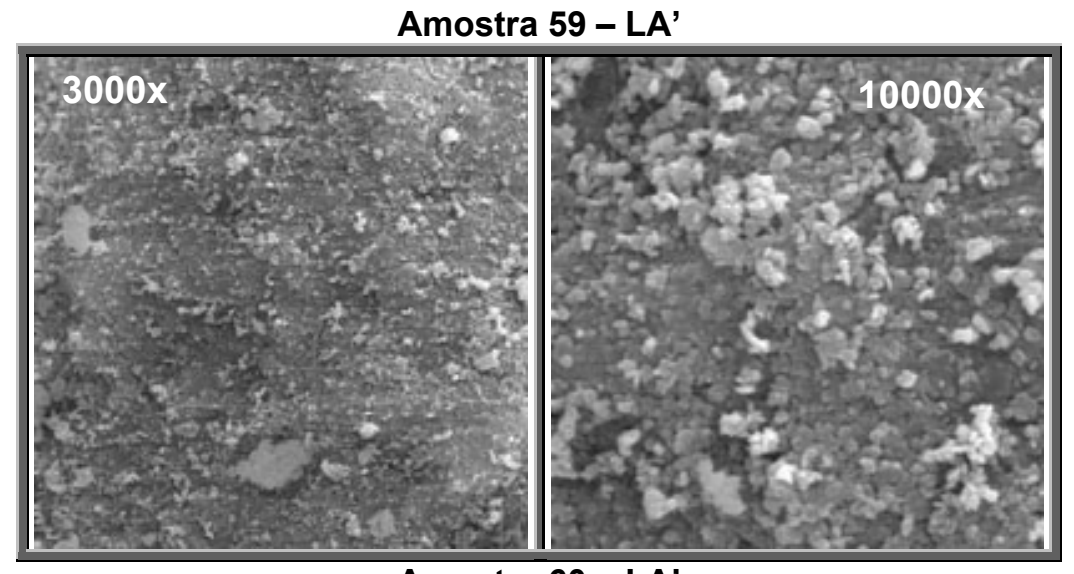

Amostra 60 - LA'

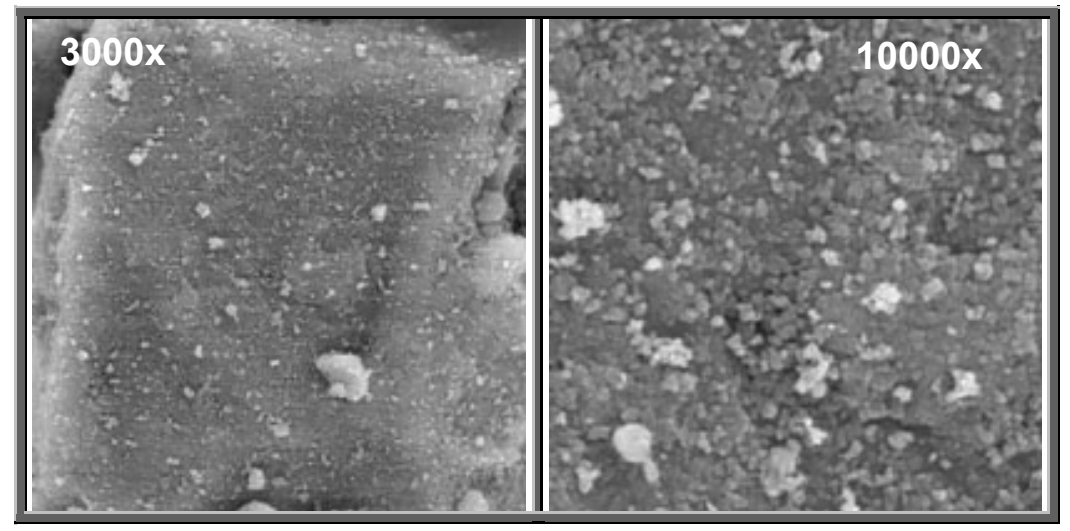

Amostra 61 - LA'

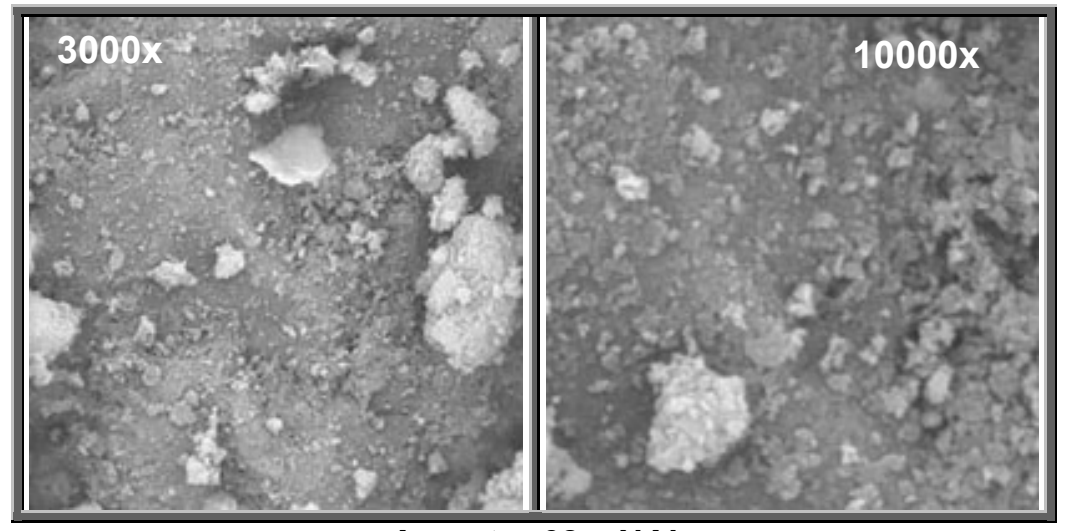

Amostra 62 - NA'

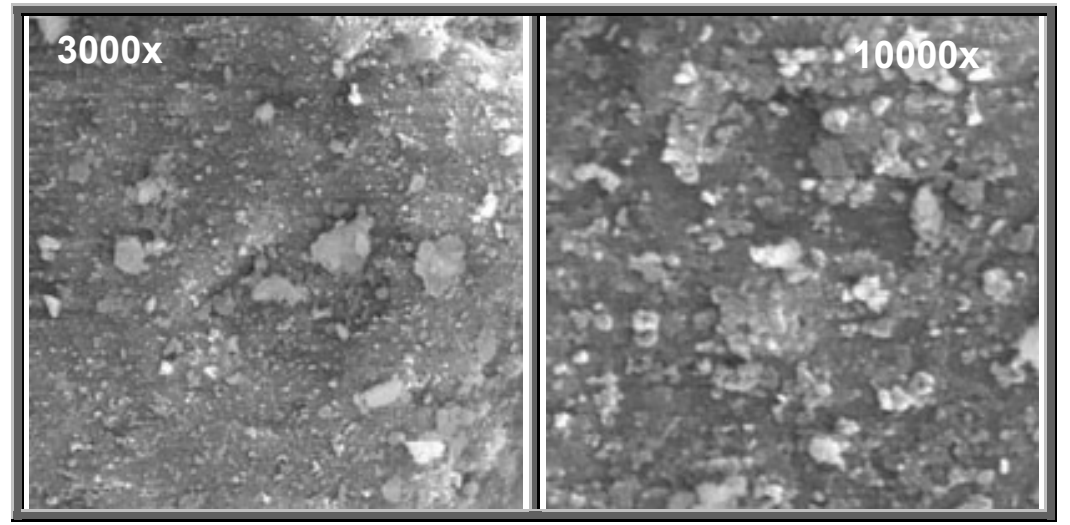




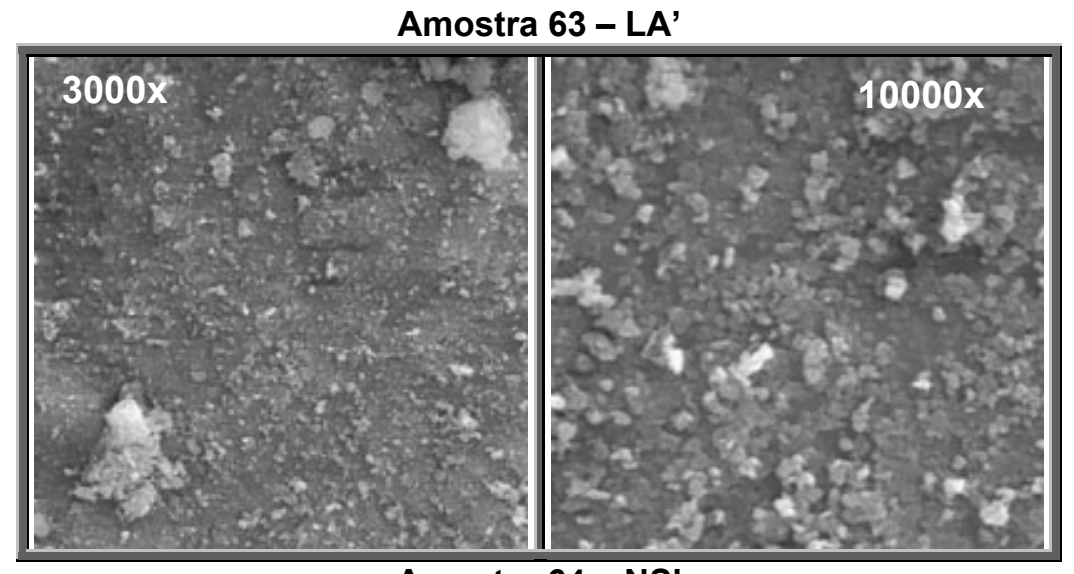

Amostra 64 - NS

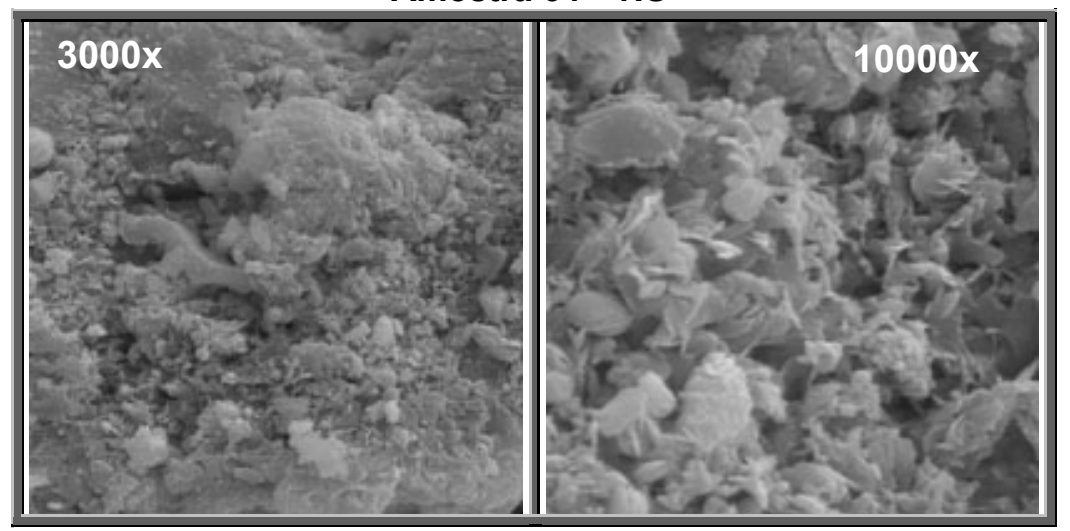

Amostra 65 - NG'

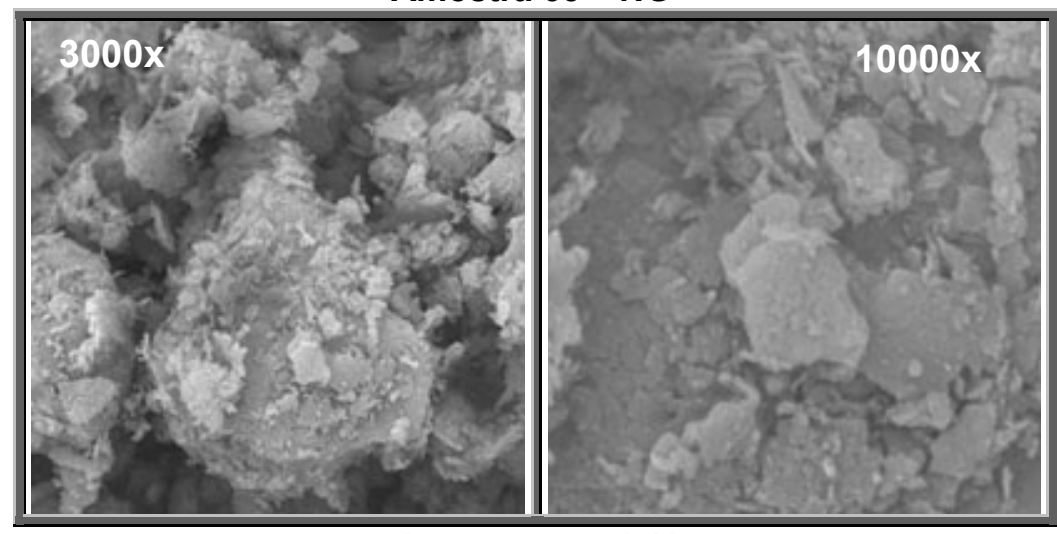

Amostra 66 - LA'

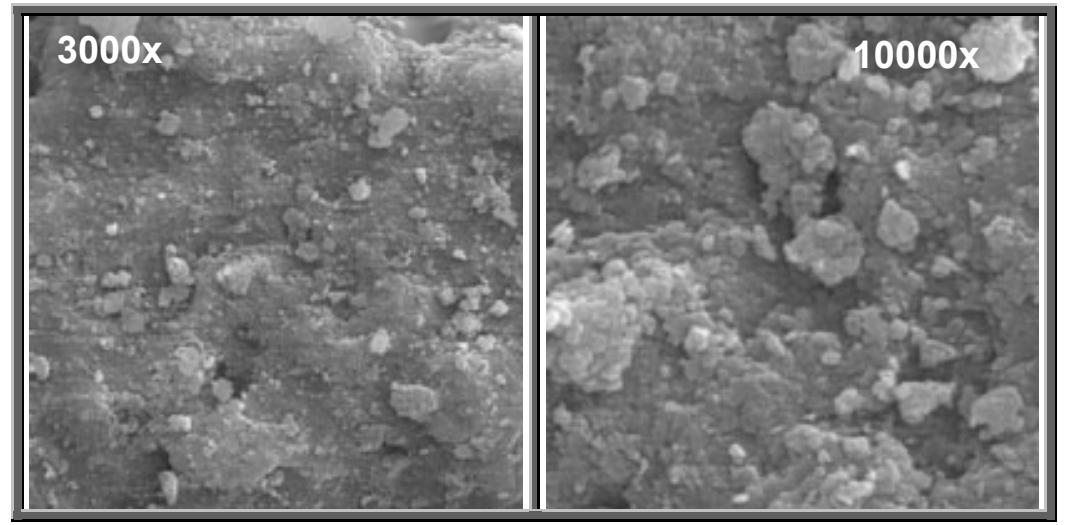




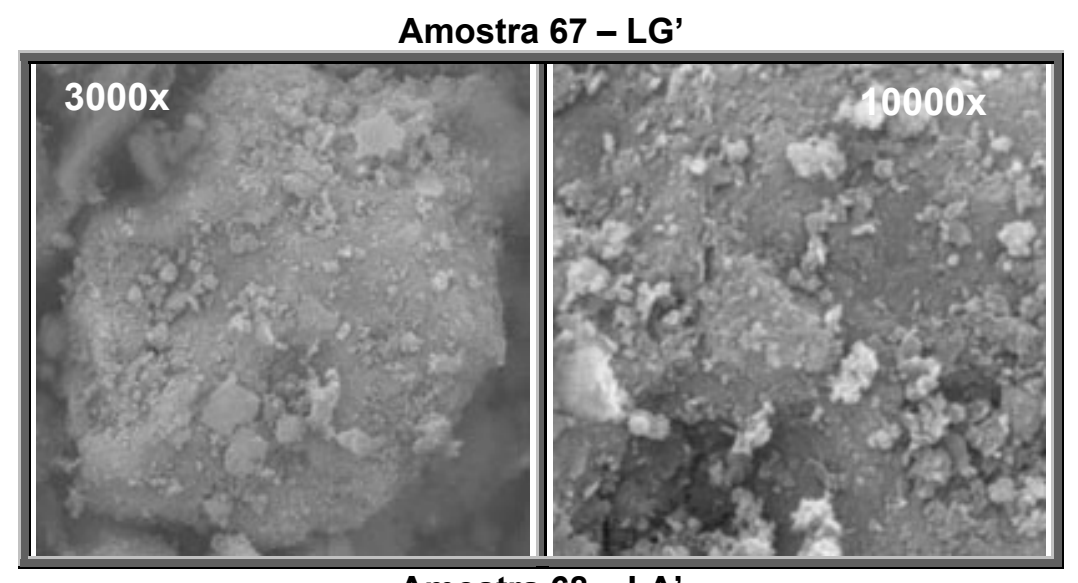

Amostra 68 - LA'

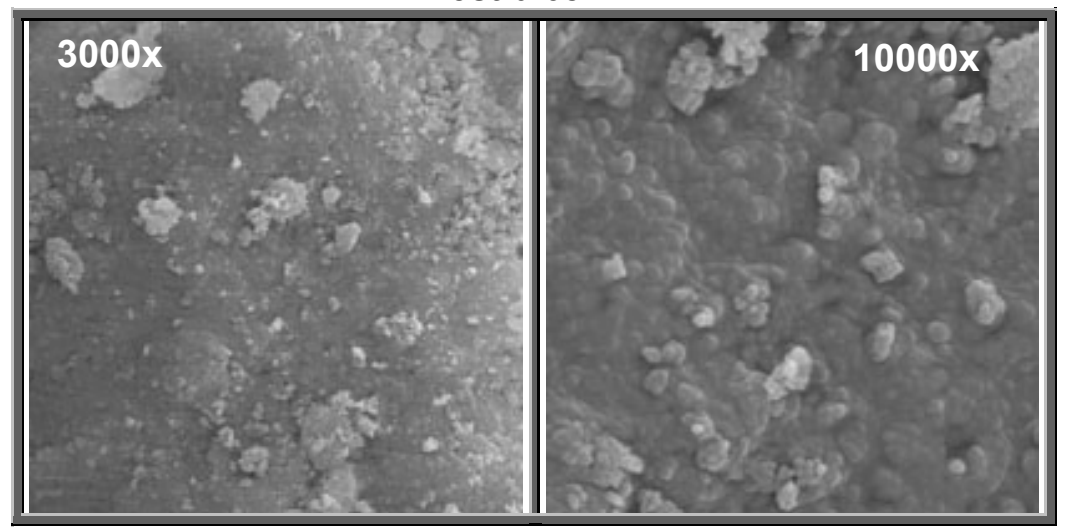

Amostra 69 - LG'

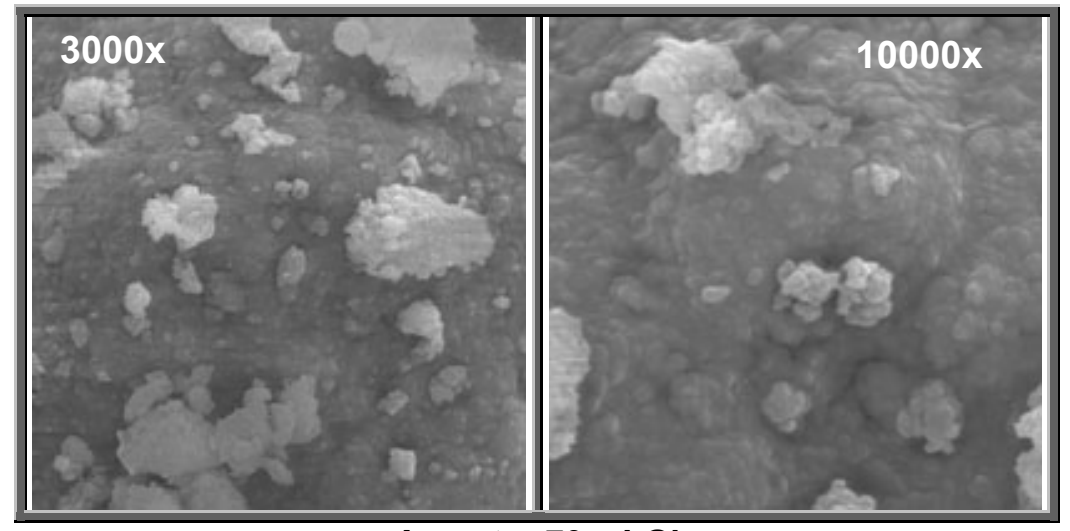

Amostra 70 - LG'

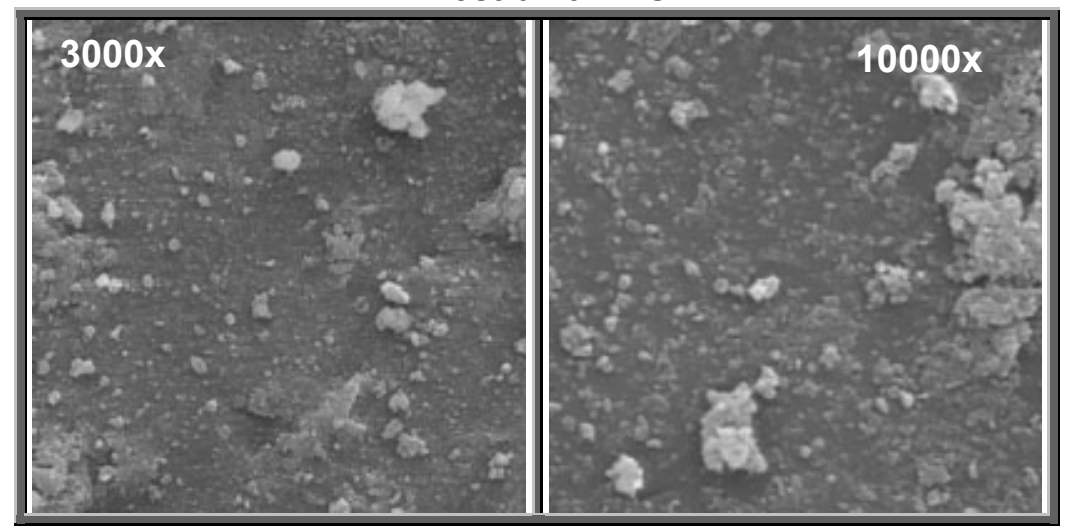



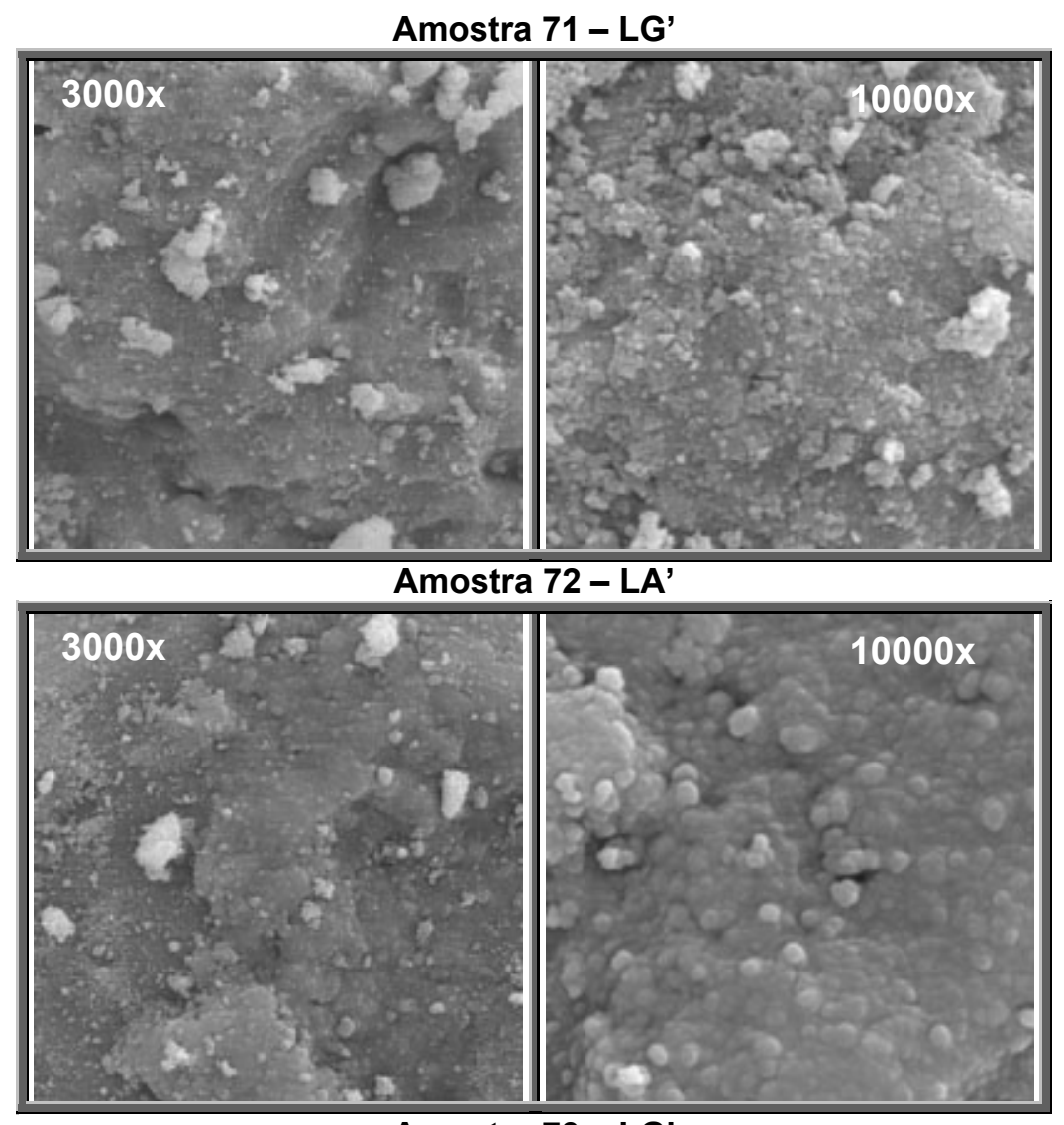

Amostra 73 - LG'

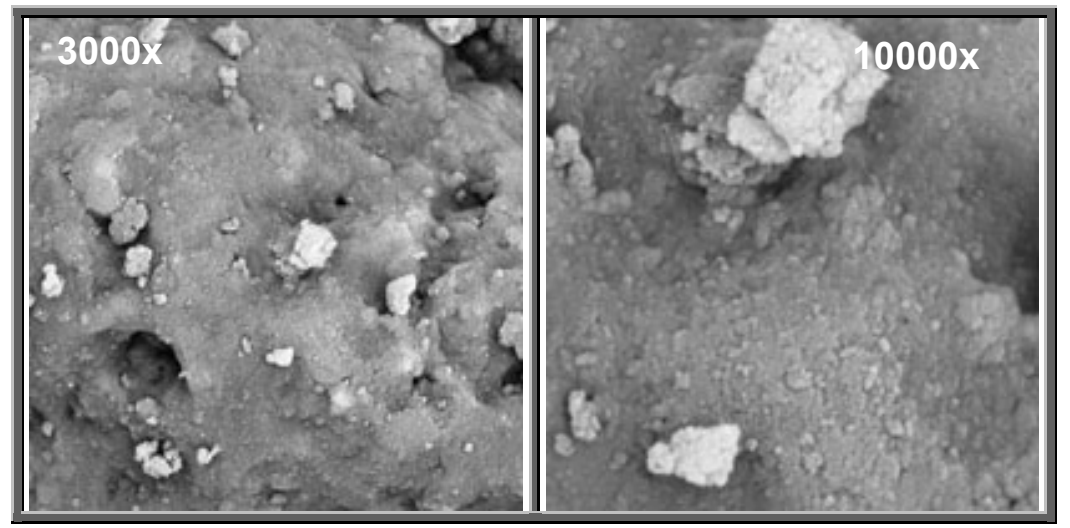

Amostra 75 - NS'

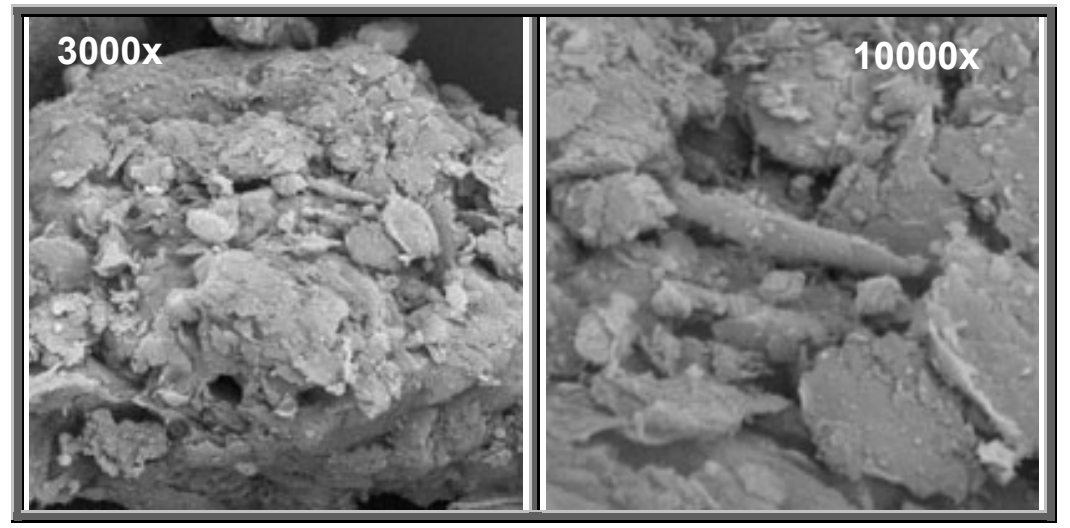



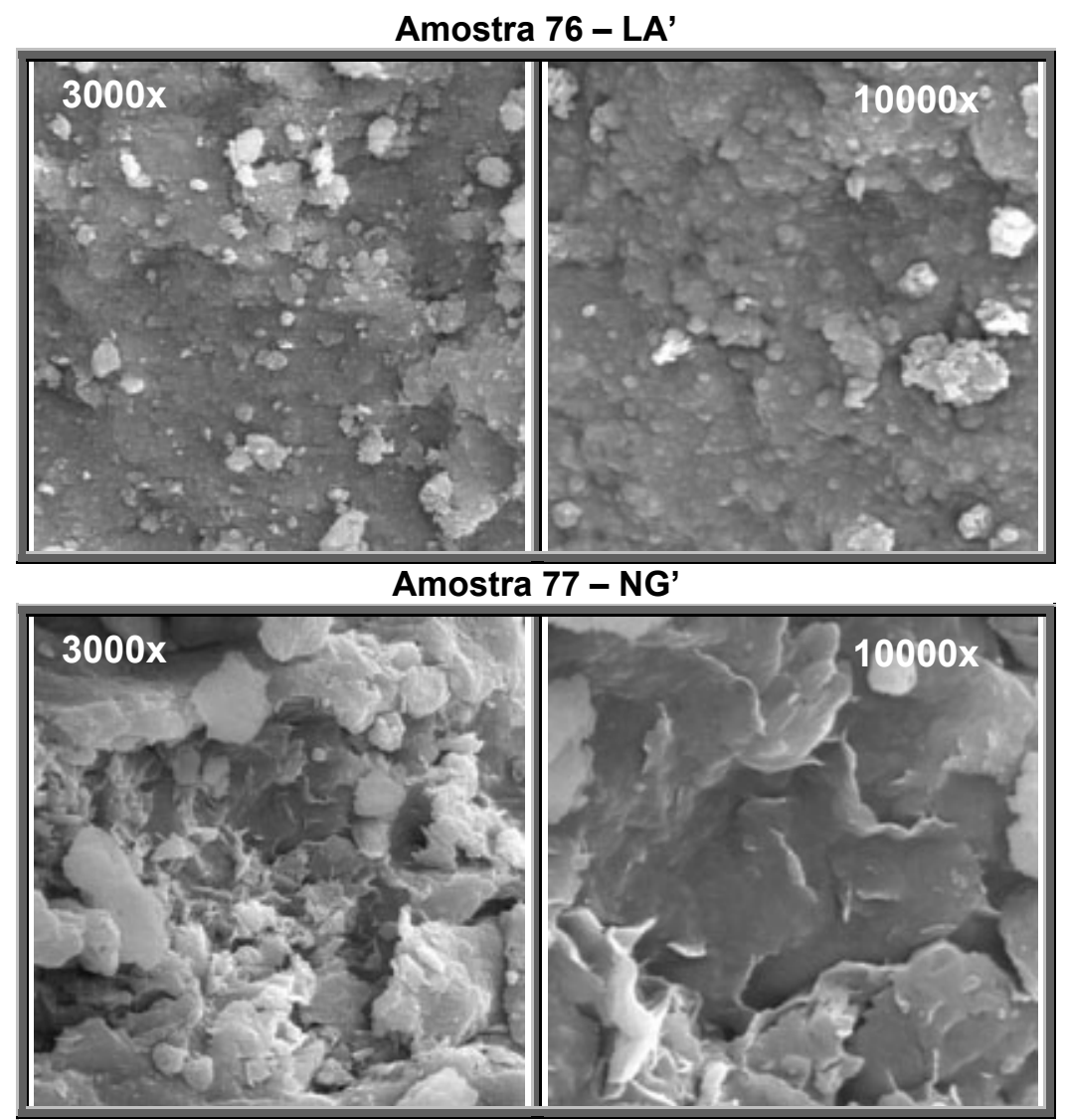

Amostra 78 - NG'

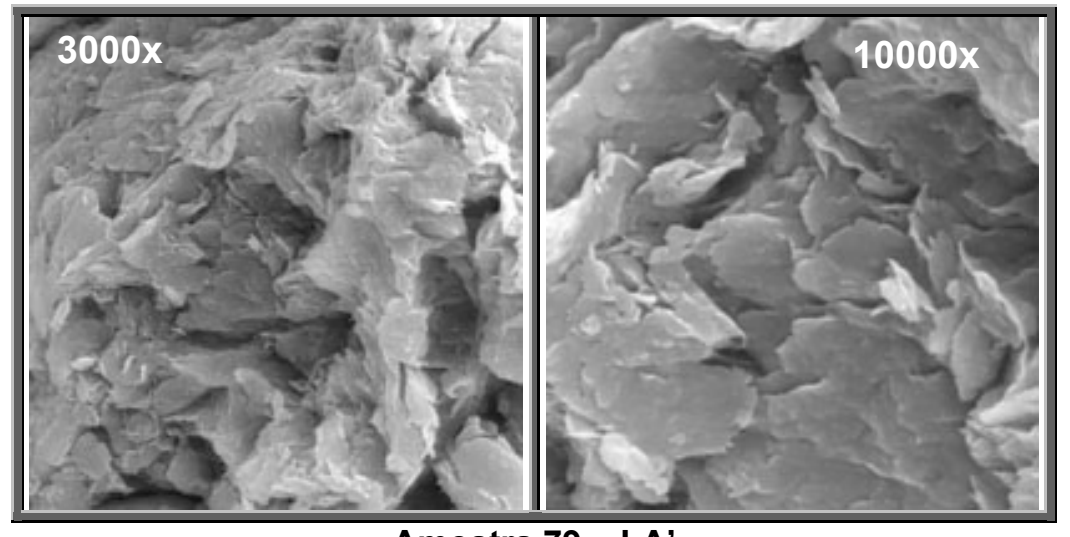

Amostra 79 - LA'

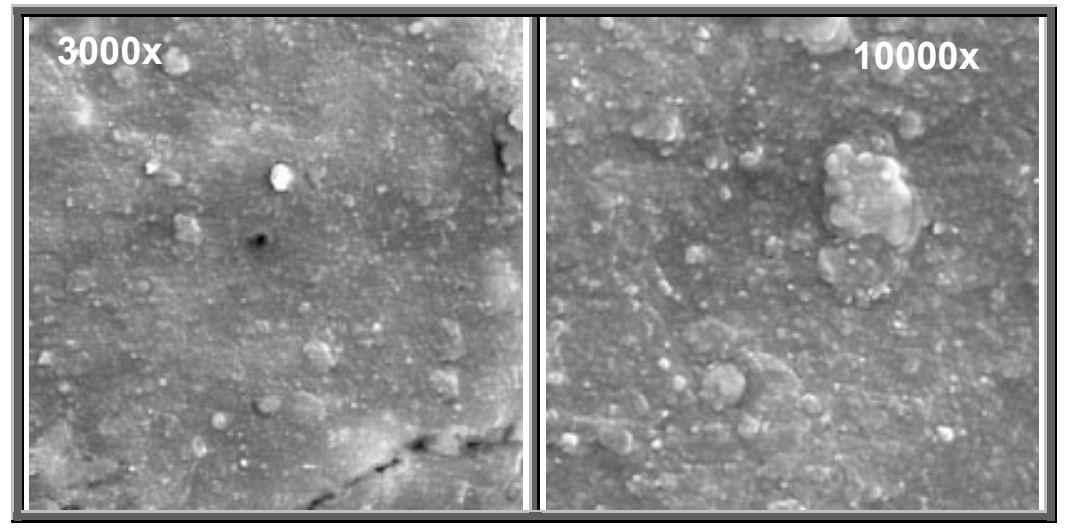




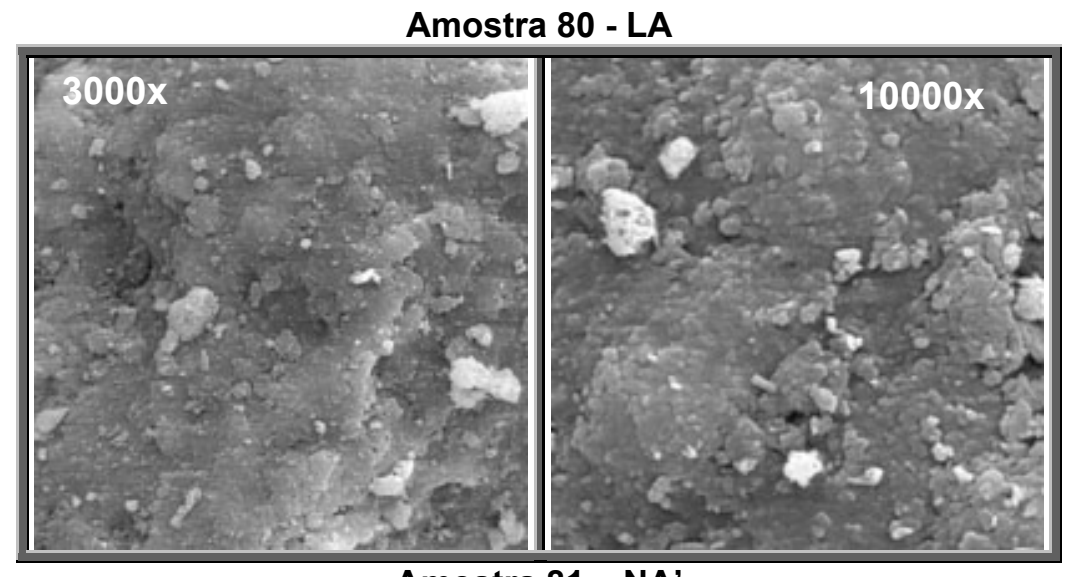

Amostra 81 - NA

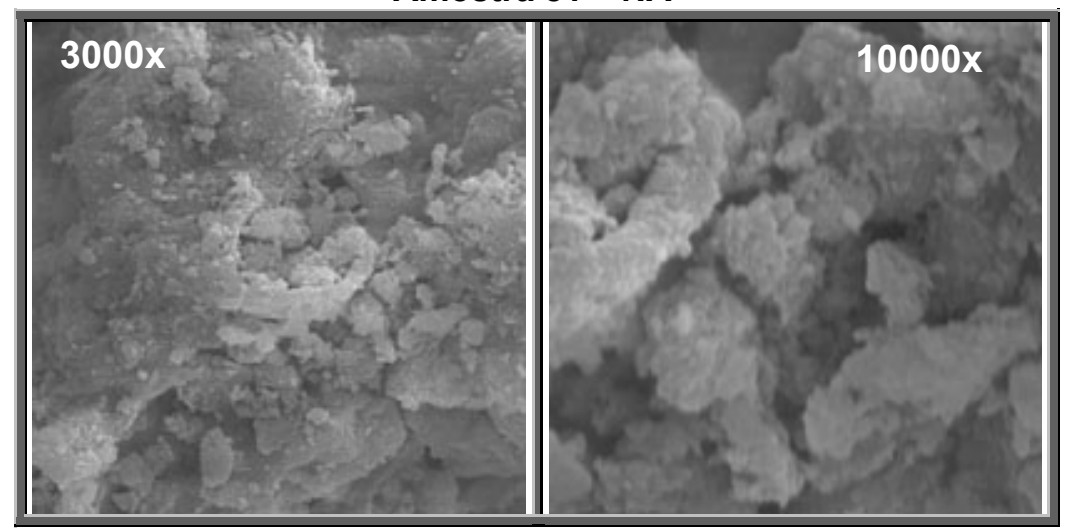

Amostra 82 - NA'

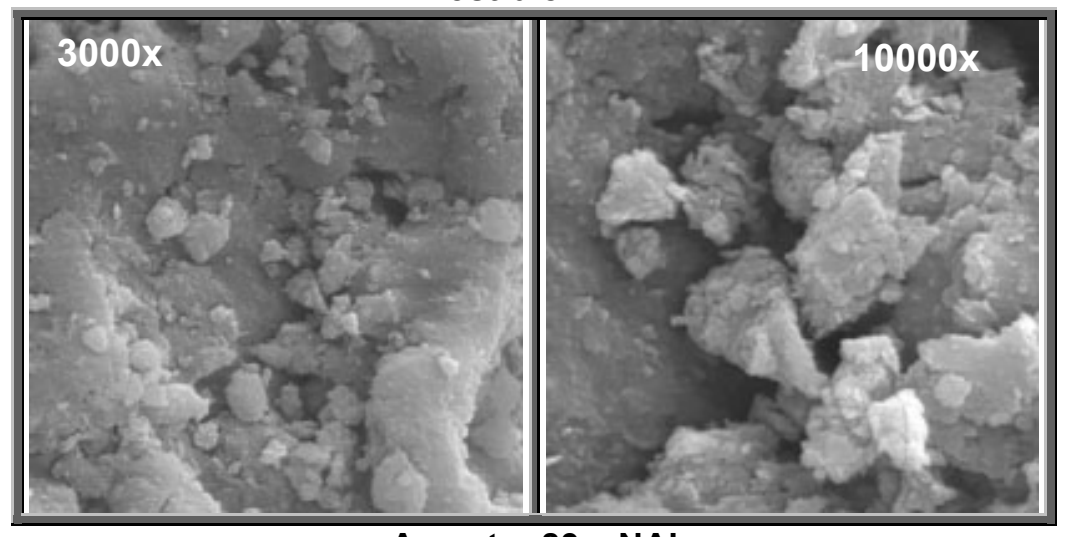

Amostra 83 - NA'

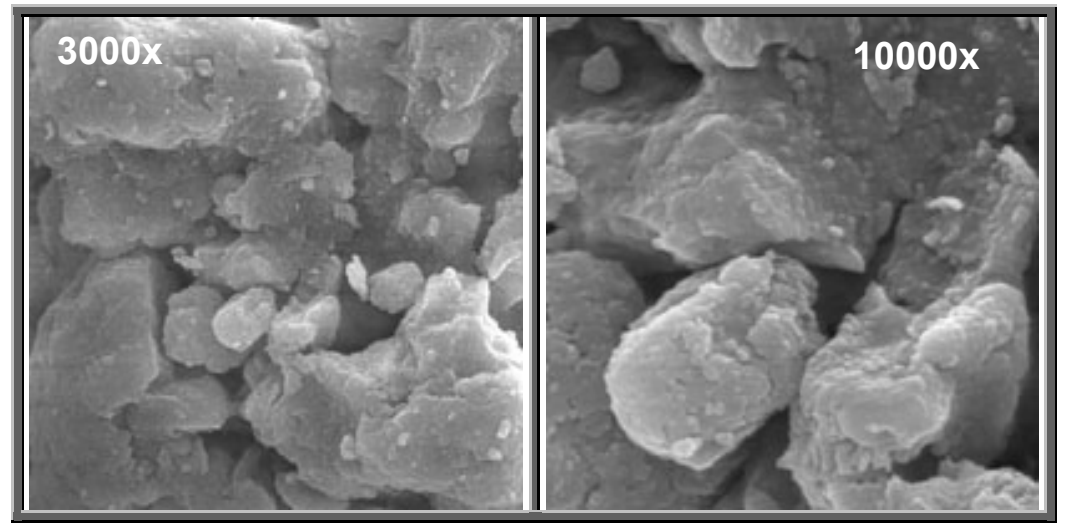



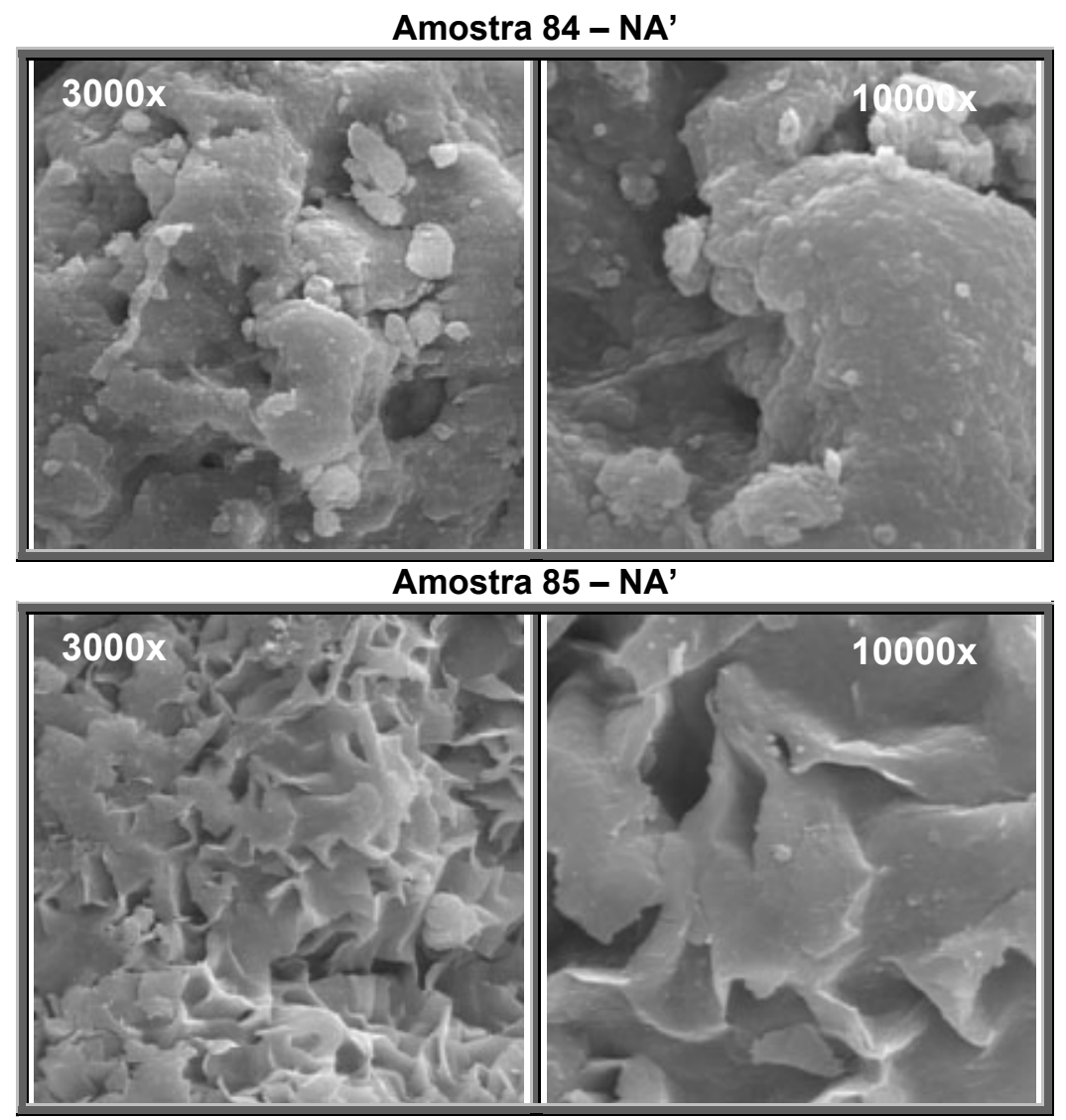

\section{Amostra 86 - NG'}

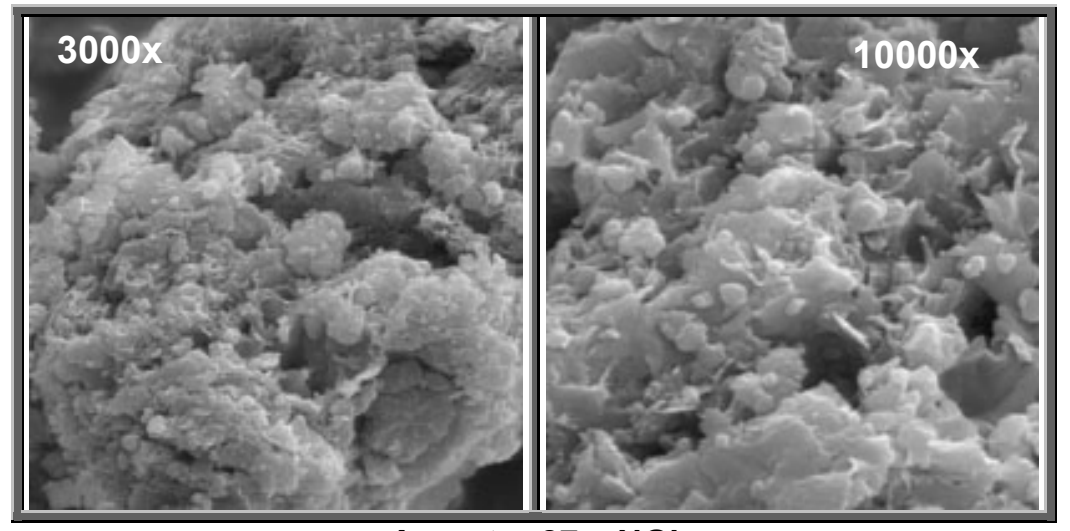

Amostra 87 - NG'

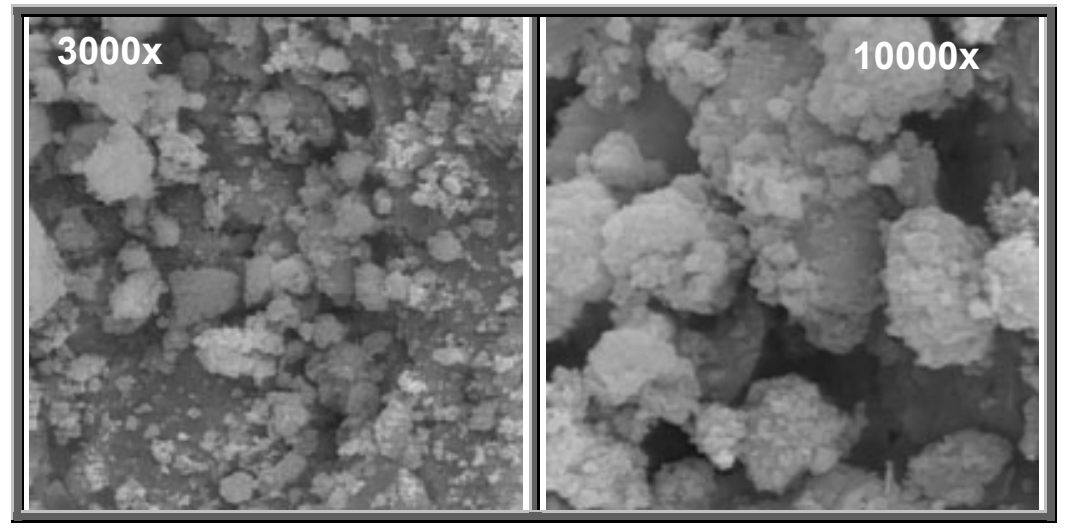




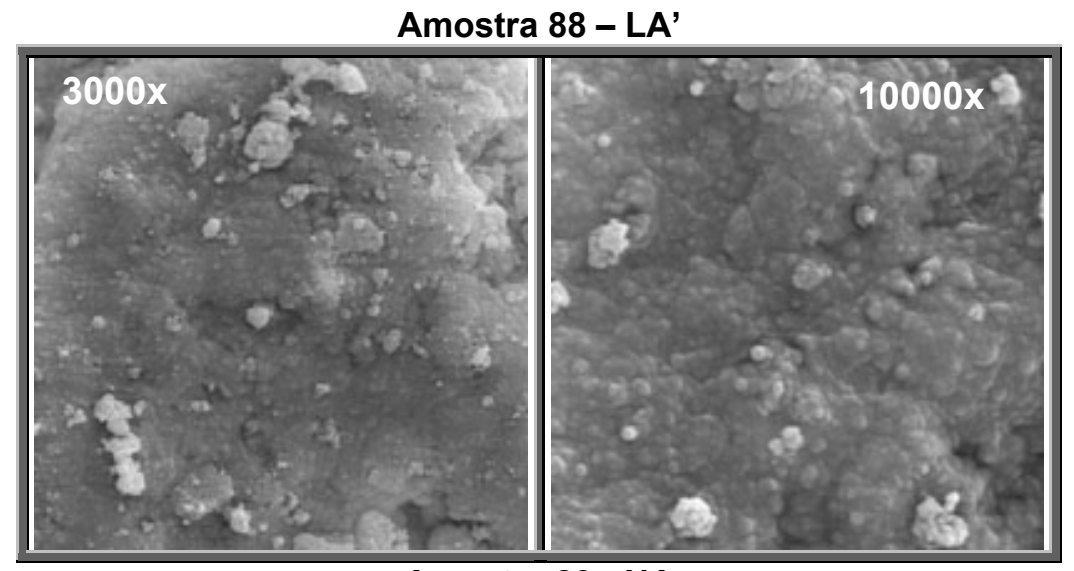

Amostra 89 - NA

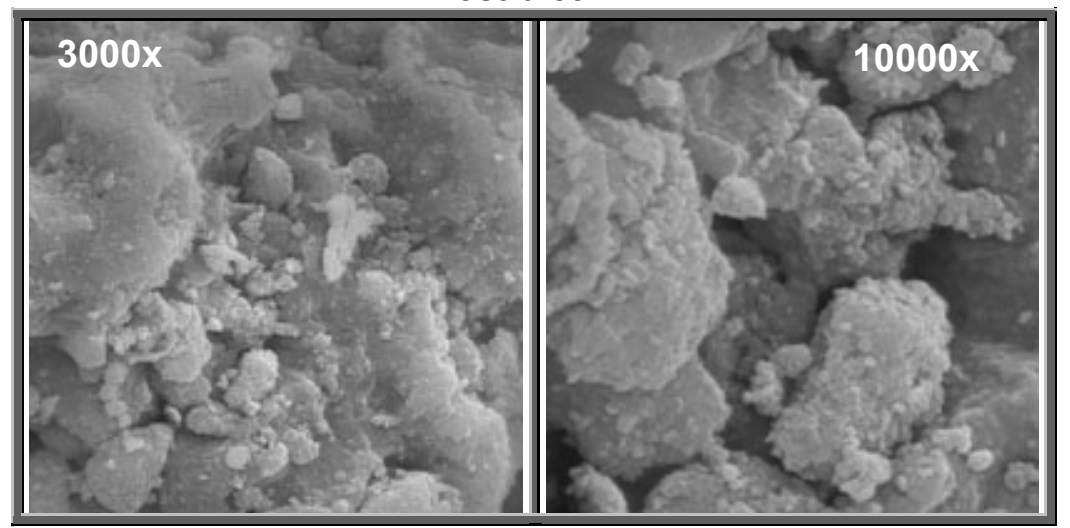

Amostra 90 - NG'

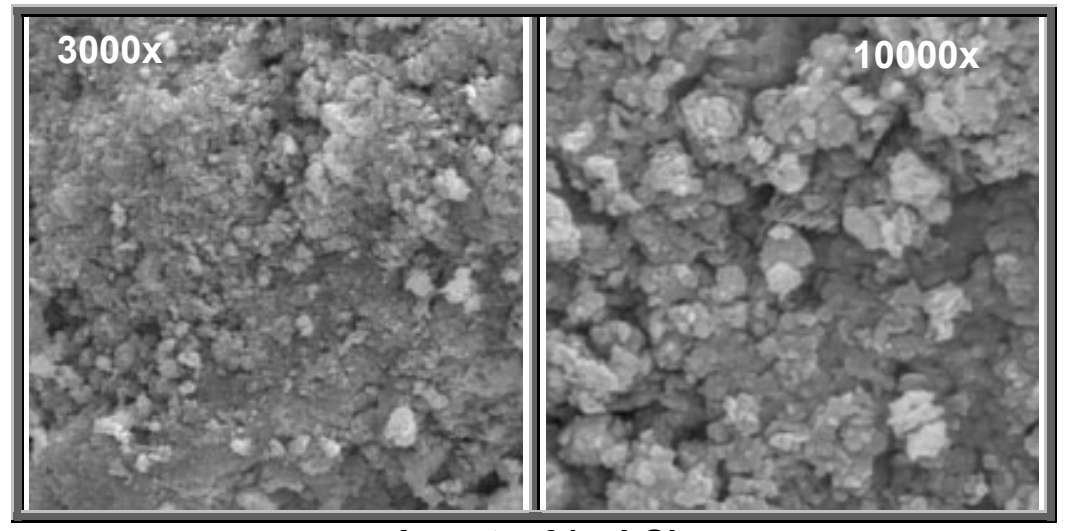

Amostra 91 - LG'

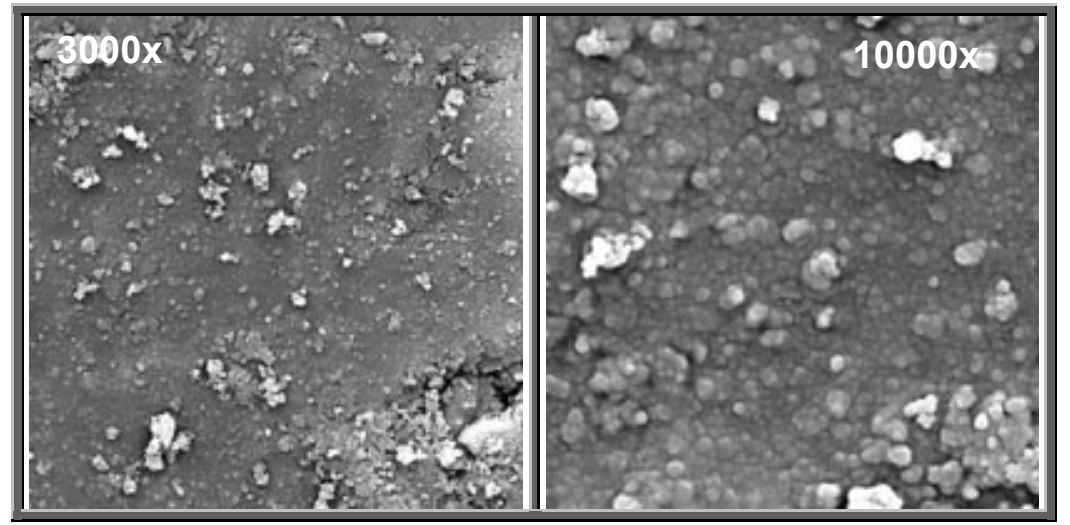




\section{Anexo E - Espaçamento interplanar (d) e $2 \theta$}

Apresentam-se, neste anexo, os valores de espaçamento interplanar (d) e $2 \theta$ para os minerais considerados na identificação dos padrões de difração. Os valores de d são apresentados em ordem decrescente de intensidade, ou seja, o primeiro valor de d corresponde ao pico mais intenso do mineral (intensidade relativa igual a 100\%), o segundo valor corresponde ao segundo pico mais intenso, e assim por diante. A Tabela E.1, que mostra estes valores, foi compilada a partir de arquivos PDF (Powder Diffraction Files), obtidos junto ao laboratório de Raios-X do IFSC-USP, para facilitar o procedimento de identificação dos minerais. 
Tabela E.1: Espaçamento interplanar (d) e $2 \theta$ dos minerais considerados na identificação das amostras estudadas.

\begin{tabular}{|c|c|c|c|c|c|c|c|c|c|}
\hline \multicolumn{10}{|c|}{ Grupo da Caulinita } \\
\hline \multirow{2}{*}{ Caulinita -1A } & $d(\AA)$ & $7.17 / X$ & $1.49 / 9$ & $3.58 / 8$ & $1.62 / 7$ & $4.37 / 6$ & $1.59 / 6$ & $4.19 / 5$ & $2.49 / 5$ \\
\hline & $2 \theta$ & 12.33 & 62.34 & 24.86 & 56.78 & 20.32 & 58.11 & 21.21 & 35.97 \\
\hline \multirow{2}{*}{ Caulinita-1Md } & $d(\AA)$ & $3.56 / X$ & $7.10 / X$ & $4.41 / 6$ & $2.33 / 4$ & $1.49 / 3$ & $2.49 / 3$ & $2.55 / 3$ & $2.38 / 2$ \\
\hline & $2 \theta$ & 24.99 & 12.46 & 20.12 & 37.85 & 62.35 & 36.03 & 35.15 & 37.85 \\
\hline \multirow{2}{*}{ Haloisita -10A } & $d(\AA)$ & $10.00 / X$ & $4.36 / 7$ & $3.35 / 4$ & $2.54 / 4$ & $1.48 / 3$ & $1.67 / 1$ & $1.28 / 1$ & \\
\hline & $2 \theta$ & 8.84 & 20.35 & 26.59 & 35.31 & 62.73 & 54.86 & 73.93 & \\
\hline \multirow{2}{*}{ Haloisita -10A } & $d(\AA)$ & $4.42 / X$ & $1.48 / 9$ & $3.34 / 9$ & $10.10 / 9$ & $2.56 / 8$ & $1.68 / 8$ & $1.28 / 7$ & $1.23 / 7$ \\
\hline & $2 \theta$ & 20.07 & 73.79 & 26.67 & 8.75 & 35.02 & 54.65 & 73.79 & 77.40 \\
\hline \multirow{2}{*}{ Haloisita -7A } & $d(\AA)$ & $4.42 / X$ & $1.48 / 9$ & $3.63 / 9$ & $7.50 / 9$ & $2.56 / 8$ & $1.68 / 8$ & $1.28 / 7$ & $1.23 / 7$ \\
\hline & $2 \theta$ & 20.07 & 62.68 & 24.50 & 11.79 & 35.02 & 54.65 & 73.79 & 77.40 \\
\hline \multirow{2}{*}{ Haloisita-7A } & $d(\AA)$ & $4.42 / X$ & $7.30 / 7$ & $3.62 / 6$ & $1.48 / 3$ & $2.56 / 3$ & $1.68 / 2$ & & \\
\hline & $2 \theta$ & 20.07 & 12.11 & 24.57 & 62.59 & 35.02 & 54.55 & & \\
\hline \multirow{2}{*}{ Dickita-2M1 } & $d(\AA)$ & $7.15 / X$ & $3.58 / X$ & $2.33 / 9$ & $4.12 / 7$ & $3.80 / 6$ & $1.65 / 5$ & $2.51 / 5$ & $1.98 / 5$ \\
\hline & $2 \theta$ & 12.37 & 24.85 & 38.68 & 21.53 & 23.40 & 55.59 & 35.74 & 45.91 \\
\hline \multirow{2}{*}{ Nacrita-2M2 } & $d(\AA)$ & $7.18 / X$ & $1.49 / 8$ & $4.36 / 8$ & $3.59 / 8$ & $4.13 / 7$ & $2.43 / 6$ & $1.26 / 4$ & $1.27 / 4$ \\
\hline & $2 \theta$ & 12.32 & 62.44 & 20.35 & 24.79 & 21.50 & 36.93 & 75.16 & 74.68 \\
\hline \multicolumn{10}{|c|}{ Grupo das Smectitas } \\
\hline \multirow{2}{*}{$\begin{array}{c}\text { Caulinita- } \\
\text { Montmorilonita }\end{array}$} & $d(\AA)$ & $7.24 / X$ & $4.31 / 7$ & $3.55 / 7$ & $2.32 / 5$ & $2.50 / 4$ & $2.55 / 4$ & $1.49 / 3$ & $1.66 / 2$ \\
\hline & $2 \theta$ & 12.22 & 20.59 & 25.06 & 38.80 & 35.92 & 35.12 & 62.35 & 55.11 \\
\hline \multirow{2}{*}{ Montmorilonita-14A } & $d(\AA)$ & $13.60 / X$ & $4.47 / 2$ & $3.23 / 1$ & $3.34 / 1$ & $2.92 / 1$ & $2.49 / 1$ & $2.59 / 1$ & \\
\hline & $2 \theta$ & 6.49 & 19.85 & 27.59 & 26.67 & 30.59 & 36.04 & 34.60 & \\
\hline \multirow{2}{*}{ Montmorilonita-15A } & $d(\AA)$ & $15.00 / X$ & $4.50 / 8$ & $5.01 / 6$ & $3.02 / 6$ & $1.50 / 5$ & $1.49 / 5$ & $2.50 / 4$ & $2.58 / 4$ \\
\hline & $2 \theta$ & 5.89 & 19.71 & 17.69 & 29.55 & 61.80 & 62.12 & 35.89 & 34.74 \\
\hline \multirow{2}{*}{ Montmorilonita-15A } & $d(\AA)$ & $13.60 / X$ & $4.46 / 7$ & $2.56 / 2$ & $1.50 / 1$ & $5.16 / 1$ & $1.69 / 1$ & & \\
\hline & $2 \theta$ & 6.49 & 19.89 & 35.02 & 62.03 & 17.17 & 54.23 & & \\
\hline \multirow{2}{*}{ Montmorilonita-21A } & $d(\AA)$ & $21.50 / X$ & $4.45 / 6$ & $2.56 / 4$ & $1.50 / 3$ & $10.60 / 2$ & $1.33 / 1$ & $1.69 / 1$ & \\
\hline & $2 \theta$ & 4.11 & 19.94 & 35.02 & 62.03 & 8.33 & 71.09 & 54.23 & \\
\hline \multirow{2}{*}{ Montmorilonita-18A } & $d(\AA)$ & $17.60 / X$ & $4.49 / 8$ & $1.50 / 6$ & $9.00 / 5$ & $3.58 / 4$ & $2.57 / 4$ & $2.99 / 3$ & $1.70 / 2$ \\
\hline & $2 \theta$ & 5.02 & 19.76 & 61.62 & 9.82 & 24.85 & 34.88 & 29.86 & 53.92 \\
\hline \multicolumn{10}{|c|}{ Grupo das Ilitas (designação geral para os minerais argilosos do grupo das micas) } \\
\hline \multirow{2}{*}{ Ilita- Montmorilonita } & $d(\AA)$ & $3.33 / \mathrm{X}$ & $9.50 / 9$ & $5.17 / 4$ & $12.60 / 4$ & $4.46 / 3$ & & & \\
\hline & $2 \theta$ & 26.75 & 9.30 & 17.14 & 7.01 & 19.89 & & & \\
\hline & $\mathbf{d}(\AA)$ & $4.43 / X$ & $2.56 / 9$ & $3.06 / 4$ & $3.66 / 4$ & $1.50 / 4$ & $3.31 / 4$ & $10.70 / 4$ & $4.33 / 3$ \\
\hline IIta-1IV & $2 \theta$ & 20.03 & 35.02 & 29.16 & 24.30 & 61.98 & 26.91 & 8.26 & 20.49 \\
\hline & $d(\AA)$ & $3.34 / \mathrm{X}$ & $10.00 / 9$ & $2.01 / 5$ & $5.02 / 5$ & $2.99 / 2$ & $3.20 / 2$ & $4.48 / 2$ & $1.50 / 1$ \\
\hline Ilita-2M1 & $2 \theta$ & 26.67 & 8.84 & 45.19 & 17.65 & 29.88 & 27.86 & 19.80 & 61.84 \\
\hline & $d(\AA)$ & $4.49 / X$ & $2.58 / 7$ & $1.50 / 5$ & $3.35 / 5$ & $10.25 / 5$ & $3.68 / 4$ & $5.06 / 4$ & $3.07 / 3$ \\
\hline Ilita-2IM2 & $2 \theta$ & 19.76 & 34.70 & 61.80 & 26.60 & 8.62 & 24.16 & 17.51 & 29.10 \\
\hline & $d(\AA)$ & $4.50 / X$ & $9.91 / 9$ & $2.56 / 8$ & $3.06 / 7$ & $3.62 / 7$ & $3.29 / 6$ & $3.33 / 6$ & $2.59 / 5$ \\
\hline IMUSCOVIta-1IVI, IVIg & $2 \theta$ & 19.71 & 8.92 & 34.97 & 29.16 & 24.57 & 27.08 & 26.75 & 34.65 \\
\hline & $d(\AA)$ & $10.10 / X$ & $3.36 / X$ & $2.57 / 9$ & $4.49 / 9$ & $3.66 / 6$ & $2.58 / 5$ & $3.07 / 5$ & $1.50 / 4$ \\
\hline Muscovita-1M & $2 \theta$ & 8.75 & 26.51 & 34.95 & 19.76 & 24.30 & 34.71 & 29.06 & 61.84 \\
\hline & $d(\AA)$ & $3.20 / X$ & $3.11 / 8$ & $3.33 / 8$ & $3.63 / 6$ & $3.87 / 6$ & $2.92 / 6$ & $9.91 / 6$ & $4.49 / 6$ \\
\hline IVIuscovita-2IVI2, Ca & $2 \theta$ & 27.86 & 28.68 & 26.75 & 24.50 & 22.96 & 30.59 & 8.92 & 19.76 \\
\hline & $d(\AA)$ & $2.55 / X$ & $4.44 / 8$ & $9.98 / 6$ & $2.57 / 5$ & $3.49 / 5$ & $3.18 / 4$ & $3.65 / 4$ & $2.08 / 4$ \\
\hline IVIUScoVIta-2IVIZ & $2 \theta$ & 35.11 & 19.96 & 8.85 & 34.94 & 25.48 & 28.03 & 24.33 & 43.56 \\
\hline & $d(\AA)$ & $3.33 / \mathrm{X}$ & $9.97 / X$ & $4.99 / 6$ & $2.00 / 5$ & $2.56 / 3$ & $4.46 / 2$ & $4.49 / 2$ & $2.59 / 2$ \\
\hline Muscovita-3I & $2 \theta$ & 26.74 & 8.86 & 17.76 & 45.33 & 34.97 & 19.89 & 19.76 & 34.62 \\
\hline & $d(\AA)$ & $2.97 / X$ & $3.08 / X$ & $4.62 / X$ & $3.33 / \mathrm{X}$ & $3.20 / X$ & $3.46 / X$ & $3.59 / 6$ & $3.73 / 6$ \\
\hline Biotita-4IM3, II & $2 \theta$ & 30.07 & 28.93 & 19.21 & 26.75 & 27.81 & 25.73 & 24.75 & 23.84 \\
\hline & $d(\AA)$ & $14.20 / X$ & $1.53 / 7$ & $4.57 / 6$ & $2.57 / 5$ & $2.62 / 5$ & $2.53 / 5$ & $2.38 / 4$ & $2.37 / 4$ \\
\hline & $2 \theta$ & 6.22 & 60.55 & 19.41 & 34.88 & 34.26 & 35.52 & 37.77 & 38.02 \\
\hline
\end{tabular}




\begin{tabular}{|c|c|c|c|c|c|c|c|c|c|}
\hline \multicolumn{10}{|c|}{ Quartzo } \\
\hline \multirow{2}{*}{ Quartzo } & $d(\AA)$ & $3.34 / X$ & $4.26 / 2$ & $1.82 / 1$ & $1.54 / 1$ & $2.46 / 1$ & $2.28 / 1$ & $1.37 / 1$ & $1.38 / 1$ \\
\hline & $2 \theta$ & 26.65 & 20.85 & 50.14 & 59.95 & 36.54 & 39.46 & 68.32 & 67.75 \\
\hline \multirow{2}{*}{ Quartzo } & $d(\AA)$ & $3.34 / X$ & $4.25 / 2$ & $1.82 / 1$ & $1.54 / 1$ & $2.46 / 1$ & $2.28 / 1$ & $1.37 / 1$ & $2.13 / 1$ \\
\hline & $2 \theta$ & 26.64 & 20.86 & 50.14 & 59.96 & 36.54 & 39.46 & 68.32 & 42.45 \\
\hline \multicolumn{10}{|c|}{ Óxidos e hidróxidos de ferro, alumínio e titânio } \\
\hline \multirow{2}{*}{ Goetita } & $d(A)$ & $4.18 / X$ & $2.45 / 5$ & $2.69 / 4$ & $1.72 / 2$ & $2.19 / 2$ & $2.25 / 1$ & $4.98 / 1$ & $2.58 / 1$ \\
\hline & $2 \theta$ & 21.22 & 36.65 & 33.24 & 53.24 & 41.19 & 39.98 & 17.80 & 34.70 \\
\hline \multirow{2}{*}{ Lepidocrocita } & $d(\AA)$ & $6.26 / X$ & $3.29 / 9$ & $2.47 / 8$ & $1.94 / 7$ & $1.52 / 4$ & $1.08 / 4$ & $1.73 / 4$ & $1.37 / 3$ \\
\hline & $2 \theta$ & 14.14 & 27.08 & 36.34 & 46.87 & 60.72 & 91.54 & 52.81 & 68.59 \\
\hline \multirow{2}{*}{ Lepidocrocita } & $d(\AA)$ & $3.29 / X$ & $2.47 / 8$ & $1.94 / 7$ & $6.27 / 6$ & $1.94 / 5$ & $2.36 / 4$ & $2.43 / 3$ & $1.53 / 3$ \\
\hline & $2 \theta$ & 27.05 & 36.30 & 46.78 & 14.11 & 46.91 & 38.07 & 36.90 & 60.27 \\
\hline \multirow{2}{*}{ Magnetita } & $d(\AA)$ & $2.53 / X$ & $1.48 / 4$ & $2.97 / 3$ & $1.62 / 3$ & $2.10 / 2$ & $1.09 / 1$ & $1.28 / 1$ & $1.71 / 1$ \\
\hline & $2 \theta$ & 35.42 & 62.52 & 30.10 & 56.94 & 43.05 & 89.62 & 73.95 & 53.39 \\
\hline \multirow{2}{*}{ Hematita } & $d(\AA)$ & $2.70 / X$ & $2.52 / 7$ & $1.69 / 5$ & $1.84 / 4$ & $3.68 / 3$ & $1.49 / 3$ & $1.45 / 3$ & $2.21 / 2$ \\
\hline & $2 \theta$ & 33.15 & 35.61 & 54.09 & 49.48 & 24.14 & 62.45 & 63.99 & 40.85 \\
\hline \multirow{2}{*}{ Maghemita-Q } & $d(\AA)$ & $2.51 / X$ & $1.47 / 4$ & $2.95 / 3$ & $1.60 / 2$ & $2.09 / 2$ & $1.09 / 1$ & $1.70 / 1$ & $1.27 / 1$ \\
\hline & $2 \theta$ & 35.68 & 63.01 & 30.27 & 57.40 & 43.34 & 90.35 & 53.85 & 74.54 \\
\hline \multirow{2}{*}{ Ferrihidrita } & $d(\AA)$ & $2.50 / X$ & $1.96 / 8$ & $1.48 / 8$ & $2.21 / 8$ & $1.51 / 7$ & $1.72 / 5$ & & \\
\hline & $2 \theta$ & 35.89 & 46.28 & 62.73 & 40.80 & 61.34 & 53.21 & & \\
\hline \multirow{2}{*}{ Gibbsita } & $d(\AA)$ & $4.85 / X$ & $4.37 / 7$ & $1.46 / 6$ & $2.39 / 6$ & $4.32 / 5$ & $2.05 / 4$ & $2.45 / 4$ & $1.75 / 3$ \\
\hline & $2 \theta$ & 18.28 & 20.30 & 63.80 & 37.68 & 20.55 & 44.17 & 36.62 & 52.17 \\
\hline \multirow{2}{*}{ Diásporo } & $d(\AA)$ & $3.99 / X$ & $2.32 / 6$ & $2.13 / 5$ & $2.08 / 5$ & $1.63 / 4$ & $2.56 / 3$ & $1.48 / 2$ & $1.38 / 2$ \\
\hline & $2 \theta$ & 22.26 & 38.84 & 42.38 & 43.54 & 56.29 & 35.05 & 62.73 & 68.08 \\
\hline \multirow{2}{*}{ Ilmenita } & $d(\AA)$ & $2.75 / X$ & $2.54 / 7$ & $1.73 / 6$ & $1.87 / 4$ & $1.47 / 4$ & $3.74 / 3$ & $2.24 / 3$ & $1.51 / 3$ \\
\hline & $2 \theta$ & 32.48 & 35.25 & 53.01 & 48.70 & 63.27 & 23.79 & 40.28 & 61.54 \\
\hline \multirow{2}{*}{ Anatásio } & $d(\AA)$ & $3.52 / \mathrm{X}$ & $1.89 / 4$ & $2.38 / 2$ & $1.67 / 2$ & $1.70 / 2$ & $1.48 / 1$ & $2.43 / 1$ & $1.26 / 1$ \\
\hline & $2 \theta$ & 25.28 & 48.05 & 37.80 & 55.06 & 53.89 & 62.69 & 36.95 & 75.03 \\
\hline \multirow{2}{*}{ Rutílio } & $d(\AA)$ & $3.25 / X$ & $1.69 / 6$ & $2.49 / 5$ & $2.19 / 3$ & $1.62 / 2$ & $1.36 / 2$ & $0.82 / 1$ & $1.35 / 1$ \\
\hline & $2 \theta$ & 27.45 & 54.32 & 36.09 & 41.23 & 56.64 & 69.01 & 140.04 & 69.79 \\
\hline
\end{tabular}




\section{Anexo F - Resultados dos ensaios de compactação}

Apresentam-se, para a energia do Proctor Normal, os resultados de umidade ótima $\left(w_{0}\right)$ e massa específica seca máxima $\left(\rho_{\mathrm{dmax}}\right)$, obtidos dos ensaios de compactação. Os valores do grau de saturação $\left(S_{r}\right)$ calculados para cada um dos solos também são apresentados. 
Tabela F.1: Resultados de umidade ótima $\left(w_{0}\right)$, massa específica seca máxima $\left(\rho_{\mathrm{dmax}}\right)$ e grau de saturação $\left(S_{r}\right)$ para os solos coletados.

\begin{tabular}{|c|c|c|c|c|c|c|c|c|c|}
\hline \multicolumn{2}{|c|}{ Amostra } & \multirow{2}{*}{$\begin{array}{c}\begin{array}{c}\mathbf{w}_{\mathrm{o}} \\
\mathbf{( \% )}\end{array} \\
13,2\end{array}$} & \multirow{2}{*}{$\frac{\begin{array}{c}\rho_{\mathrm{dmax}} \\
\left(\mathbf{g} / \mathbf{c m}^{3}\right)\end{array}}{1,905}$} & \multirow{2}{*}{$\begin{array}{c}\mathbf{S}_{\mathbf{r}} \\
\mathbf{( \% )} \\
90,1 \%\end{array}$} & \multicolumn{2}{|c|}{ Amostra } & \multirow{2}{*}{$\begin{array}{l}\begin{array}{c}\mathbf{w}_{\mathrm{o}} \\
\mathbf{( \% )}\end{array} \\
11,5\end{array}$} & \multirow{2}{*}{$\frac{\begin{array}{c}\rho_{\mathrm{dmax}} \\
\left(\mathbf{g} / \mathbf{c m}^{3}\right)\end{array}}{1,923}$} & \multirow{2}{*}{$\begin{array}{c}\begin{array}{c}\mathbf{S}_{\mathbf{r}} \\
(\%)\end{array} \\
88,5 \%\end{array}$} \\
\hline 11 & $2 \mathrm{~L}(11)$ & & & & 55 & $5 \mathrm{~N}(55)$ & & & \\
\hline 17 & $2 \mathrm{~N}(17)$ & 14,7 & 1,788 & $81,1 \%$ & 56 & --- & 11,1 & 1,884 & $81,5 \%$ \\
\hline 21 & 9L (21) & 21,0 & 1,679 & $84,6 \%$ & 57 & --- & 13,5 & 1,862 & $91,9 \%$ \\
\hline 22 & $12 \mathrm{Na}(22)$ & 32,0 & 1,415 & $86,2 \%$ & 58 & $6 \operatorname{Lb}(57)$ & 12,0 & 1,909 & $90,6 \%$ \\
\hline 23 & --- & 11,3 & 1,920 & $79,2 \%$ & 59 & --- & 11,2 & 1,933 & $85,0 \%$ \\
\hline 24 & & 10,9 & 1,965 & $85,5 \%$ & 60 & $5 \mathrm{~L}(60)$ & 10,2 & 2,014 & $94,9 \%$ \\
\hline 25 & $12 \mathrm{~L}(25)$ & 24,9 & 1,608 & $88,7 \%$ & 61 & --- & 11,9 & 1,898 & $82,5 \%$ \\
\hline 26 & --- & 13,8 & 1,825 & $79,7 \%$ & 62 & --- & 11,1 & 1,940 & $84,0 \%$ \\
\hline 27 & $6 \mathrm{~N}(27)$ & 17,0 & 1,739 & $83,5 \%$ & 63 & --- & 11,2 & 1,906 & $79,5 \%$ \\
\hline 28 & --- & 12,3 & 1,889 & $81,4 \%$ & 64 & $15 \mathrm{~N}(64)$ & 25,7 & 1,459 & $83,1 \%$ \\
\hline 29 & --- & 10,4 & 1,941 & $81,8 \%$ & 65 & $14 \mathrm{Na}(65)$ & 22,9 & 1,563 & $83,1 \%$ \\
\hline 30 & $6 \mathrm{La}(30)$ & 12,6 & 1,888 & $92,1 \%$ & 66 & --- & 12,3 & 1,848 & $80,9 \%$ \\
\hline 31 & --- & 25,4 & 1,506 & $89,2 \%$ & 67 & 13L (67) & 29,8 & 1,362 & $82,9 \%$ \\
\hline 32 & --- & 24,3 & 1,531 & $86,6 \%$ & 68 & --- & 10,4 & 1,934 & $81,2 \%$ \\
\hline 33 & --- & 20,5 & 1,597 & $85,1 \%$ & 69 & --- & 24,5 & 1,568 & $84,6 \%$ \\
\hline 34 & $12 \mathrm{Nb}(34)$ & 26,4 & 1,433 & $83,2 \%$ & 70 & --- & 22,4 & 1,712 & $93,9 \%$ \\
\hline 35 & --- & 24,2 & 1,593 & $87,1 \%$ & 71 & 14L (71) & 26,6 & 1,597 & $91,1 \%$ \\
\hline 36 & --- & 20,1 & 1,549 & $74,5 \%$ & 72 & --- & 14,6 & 1,790 & $83,9 \%$ \\
\hline 37 & --- & 19,9 & 1,624 & $86,5 \%$ & 73 & --- & 20,4 & 1,659 & $92,7 \%$ \\
\hline 38 & $10 \mathrm{~L}(38)$ & 20,9 & 1,626 & $89,8 \%$ & 75 & --- & 15,5 & 1,790 & $90,5 \%$ \\
\hline 39 & $13 N(39)$ & 37,7 & 1,272 & $92,1 \%$ & 76 & 1L (76) & 12,9 & 1,858 & $90,1 \%$ \\
\hline 40 & --- & 14,2 & 1,894 & $86,0 \%$ & 77 & $9 \mathrm{~N}(77)$ & 20,0 & 1,570 & $75,1 \%$ \\
\hline 41 & --- & 12,9 & 1,887 & $83,9 \%$ & 78 & $11 \mathrm{~N}(78)$ & 21,9 & 1,443 & $68,3 \%$ \\
\hline 42 & --- & 15,0 & 1,817 & $88,9 \%$ & 79 & --- & 12,5 & 1,896 & $84,8 \%$ \\
\hline 43 & --- & 15,4 & 1,770 & $86,9 \%$ & 80 & --- & 11,1 & 1,913 & $79,4 \%$ \\
\hline 44 & --- & 16,6 & 1,732 & $89,3 \%$ & 81 & $1 \mathrm{Na}(81)$ & 10,6 & 1,909 & $71,7 \%$ \\
\hline 45 & --- & 16,5 & 1,728 & $88,4 \%$ & 82 & --- & 12,7 & 1,837 & $77,9 \%$ \\
\hline 46 & $7 \mathrm{~L}(46)$ & 13,5 & 1,809 & $79,7 \%$ & 83 & --- & 12,6 & 1,884 & $78,8 \%$ \\
\hline 47 & --- & 28,8 & 1,476 & $85,6 \%$ & 84 & --- & 10,7 & 1,944 & $78,2 \%$ \\
\hline 48 & 11La (48) & 21,8 & 1,642 & $84,8 \%$ & 85 & $1 \mathrm{Nb}(85)$ & 12,8 & 1,841 & $78,9 \%$ \\
\hline 49 & --- & 22,6 & 1,576 & $84,4 \%$ & 86 & $14 \mathrm{Nb}(86)$ & 29,2 & 1,415 & $87,9 \%$ \\
\hline 50 & $4 \mathrm{~L}(50)$ & 10,6 & 1,944 & $78,8 \%$ & 87 & --- & 25,4 & 1,583 & $83,8 \%$ \\
\hline 51 & --- & 19,8 & 1,611 & $80,0 \%$ & 88 & 8L (88) & 13,9 & 1,855 & $84,1 \%$ \\
\hline 52 & --- & 12,8 & 1,844 & $84,5 \%$ & 89 & $3 \mathrm{~N}(89)$ & 8,8 & 1,979 & $67,3 \%$ \\
\hline 53 & $10 \mathrm{~N}(53)$ & 29,1 & 1,417 & $88,3 \%$ & 90 & --- & 29,9 & 1,486 & $92,7 \%$ \\
\hline 54 & --- & 10,3 & 1,956 & $82,3 \%$ & 91 & 11Lb (91) & 23,9 & 1,583 & $83,3 \%$ \\
\hline
\end{tabular}




\section{Anexo G - curvas granulométricas dos trinta solos selecionados para a análise do comportamento frente a variação da umidade}

Apresentam-se as curvas granulométricas dos trinta solos selecionados para a análise do comportamento frente a da variação da umidade póscompactação. Estas curvas estão agrupadas segundo a semelhança entre as granulometrias, conforme discutido no Capítulo 3. As amostras que não compõem "pares" de solos formaram dois gráficos, sendo o primeiro constituído pelos solos grossos (3N (89) e 4L (50)) e o segundo pelos intermediários e finos (7L (46), 8L (88) e $15 \mathrm{~N}(64))$. 

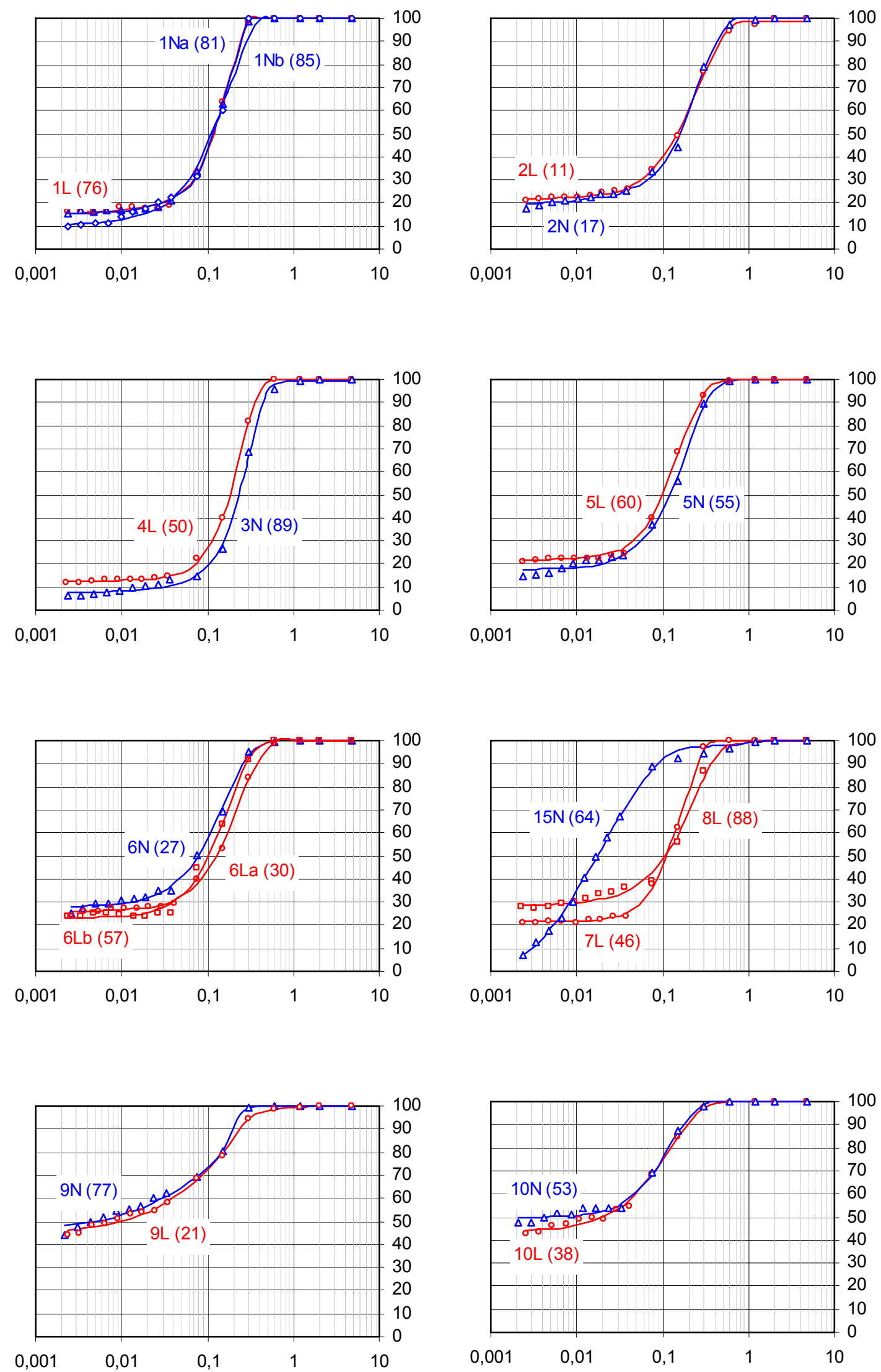

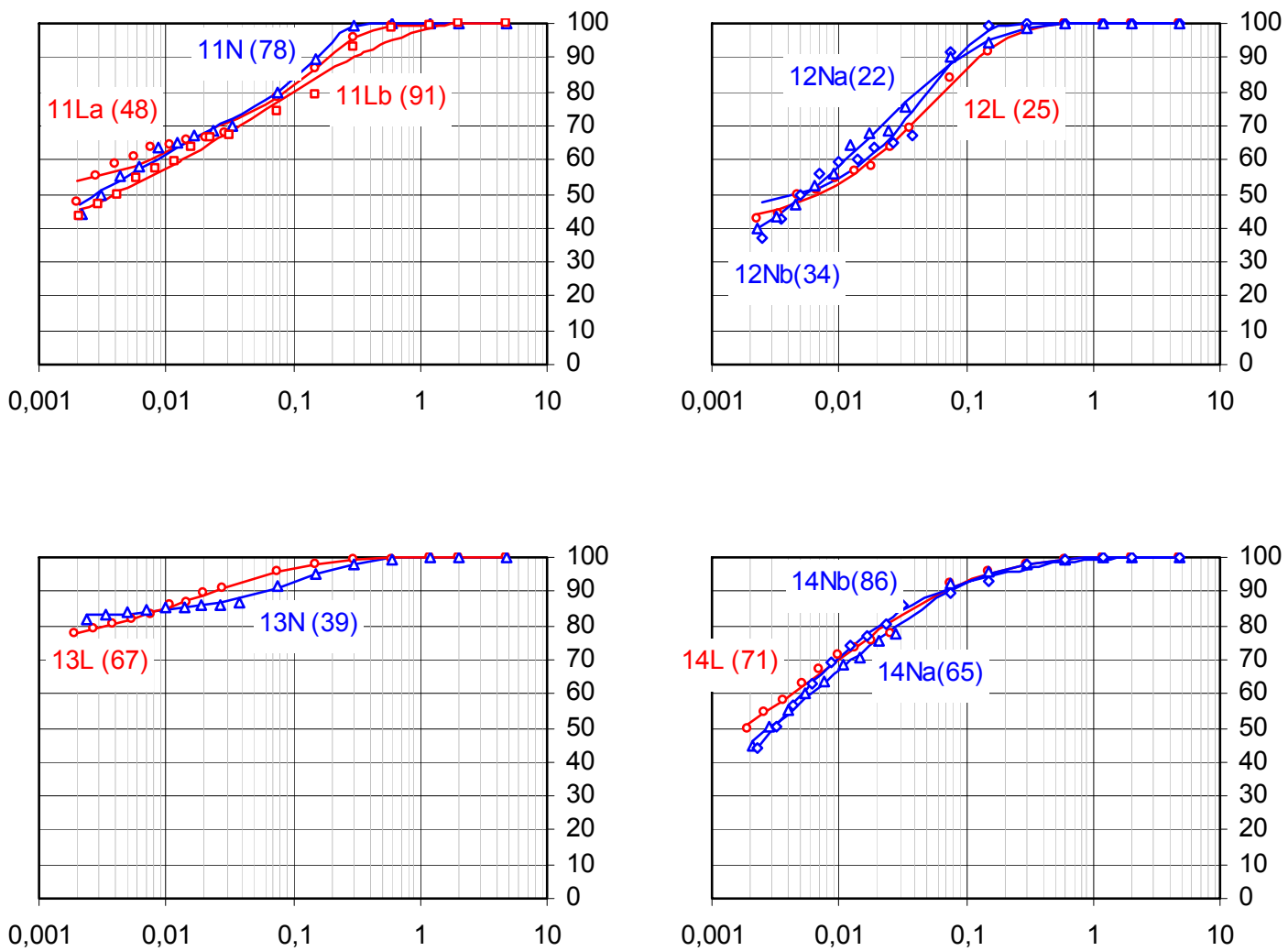


\section{Anexo H - Relação entre as indicações fornecidas a partir dos ensaios MEV e a classificação MCT}

Tabela H.1: Determinação da gênese dos solos lateríticos (LA e LA'), segundo a MCT, a partir dos ensaios de MEV.

\begin{tabular}{|c|c|c|c|c|c|}
\hline \multirow[b]{2}{*}{ Amostra } & \multicolumn{2}{|c|}{ Características observadas } & \multirow{2}{*}{$\begin{array}{c}\text { Gênese } \\
\text { determinada } \\
\text { pela MEV }\end{array}$} & \multirow[b]{2}{*}{ MCT } & \multirow[b]{2}{*}{ Concorda } \\
\hline & Cimentação & $\begin{array}{l}\text { Contorno dos } \\
\text { argilominerais }\end{array}$ & & & \\
\hline 50 & $\operatorname{Sim}$ & Não & $\mathrm{L}$ & LA & $\operatorname{Sim}$ \\
\hline 80 & Sim & Não & $\mathrm{L}$ & LA & Sim \\
\hline 11 & Sim & Não & $\mathrm{L}$ & $\mathrm{LA}^{\prime}$ & Sim \\
\hline 23 & $\operatorname{Sim}$ & Não & $\mathrm{L}$ & LA' & Sim \\
\hline 26 & Sim & Não & L & LA' & Sim \\
\hline 28 & Sim & Não & L & LA' & Sim \\
\hline 29 & $\operatorname{Sim}$ & Não & $\mathrm{L}$ & LA' & $\operatorname{Sim}$ \\
\hline 40 & Sim & Não & $\mathrm{L}$ & $\mathrm{LA}^{\prime}$ & Sim \\
\hline 46 & $\operatorname{Sim}$ & Não & L & LA' & $\operatorname{Sim}$ \\
\hline 52 & Sim & Não & $\mathrm{L}$ & LA' & Sim \\
\hline 54 & $\operatorname{Sim}$ & Não & $\mathrm{L}$ & LA' & Sim \\
\hline 59 & Sim & Não & L & LA' & Sim \\
\hline 60 & Sim & Não & $\mathrm{L}$ & LA' & Sim \\
\hline 61 & Sim & Não & $\mathrm{L}$ & LA' & Sim \\
\hline 63 & Sim & Não & L & LA' & Sim \\
\hline 66 & Sim & Não & L & LA' & Sim \\
\hline 68 & Sim & Não & L & LA' & Sim \\
\hline 72 & Sim & Não & L & LA' & Sim \\
\hline 76 & Sim & Não & L & LA' & Sim \\
\hline 79 & Sim & Não & L & LA' & Sim \\
\hline 88 & Sim & Não & L & LA' & Sim \\
\hline
\end{tabular}

(L - Laterítico; NL - Não-laterítico) 
Tabela H.2: Determinação da gênese dos solos lateríticos (LG'), segundo a MCT, a partir dos ensaios de MEV.

\begin{tabular}{|c|c|c|c|c|c|}
\hline \multirow[b]{2}{*}{ Amostra } & \multicolumn{2}{|c|}{ Características observadas } & \multirow{2}{*}{$\begin{array}{c}\text { Característica } \\
\text { determinada } \\
\text { pela MEV }\end{array}$} & \multirow[b]{2}{*}{ MCT } & \multirow[b]{2}{*}{ Concorda } \\
\hline & Cimentação & $\begin{array}{l}\text { Contorno dos } \\
\text { argilominerais }\end{array}$ & & & \\
\hline 21 & Sim & Não & $L$ & LG' $^{\prime}$ & Sim \\
\hline 25 & Sim & Não & L & LG' & Sim \\
\hline 30 & Sim & Não & L & LG' & Sim \\
\hline 31 & Sim & Não & L & LG' & Sim \\
\hline 35 & Sim & Não & $\mathrm{L}$ & LG' & Sim \\
\hline 37 & Sim & Não & L & LG' & Sim \\
\hline 38 & Sim & Não & $\mathrm{L}$ & LG' & Sim \\
\hline 41 & Sim & Não & L & LG' & Sim \\
\hline 44 & Sim & Não & L & LG' & Sim \\
\hline 48 & Sim & Não & $\mathrm{L}$ & LG' & Sim \\
\hline 49 & Sim & Não & L & LG' & Sim \\
\hline 57 & Sim & Não & L & LG' & Sim \\
\hline 67 & Sim & Não & L & LG' & Sim \\
\hline 69 & Sim & Não & $\mathrm{L}$ & LG' & Sim \\
\hline 70 & Sim & Não & $\mathrm{L}$ & LG' & Sim \\
\hline 71 & Sim & Não & L & LG' & Sim \\
\hline 73 & Sim & Não & L & LG' & Sim \\
\hline 91 & Sim & Não & $\mathrm{L}$ & LG' & Sim \\
\hline
\end{tabular}

( $\mathrm{L}$ - Laterítico; NL - Não-laterítico)

Tabela H.3: Determinação da gênese dos solos não-lateríticos (NS'), segundo a MCT, a partir dos ensaios de MEV.

\begin{tabular}{|c|c|c|c|c|c|}
\hline \multirow[b]{2}{*}{ Amostra } & \multicolumn{2}{|c|}{ Características observadas } & \multirow{2}{*}{$\begin{array}{c}\text { Característica } \\
\text { determinada } \\
\text { pela MEV }\end{array}$} & \multirow[b]{2}{*}{ MCT } & \multirow[b]{2}{*}{ Concorda } \\
\hline & Cimentação & $\begin{array}{l}\text { Contorno dos } \\
\text { argilominerais }\end{array}$ & & & \\
\hline 33 & Sim & Não & $\mathrm{L}$ & $\mathrm{NS}^{\prime}$ & Não \\
\hline 45 & Sim & Não & $\bar{L}$ & NS' & Não \\
\hline 36 & Não & Sim & $\mathrm{NL}$ & NS' & Sim \\
\hline 64 & Não & Sim & $\mathrm{NL}$ & NS' & Sim \\
\hline
\end{tabular}

( $\mathrm{L}$ - Laterítico; NL - Não-laterítico)

Tabela H.4: Determinação da gênese dos solos não-lateríticos (NA e NA'), segundo a MCT, a partir dos ensaios de MEV.

\begin{tabular}{|c|c|c|c|c|c|}
\hline \multirow[b]{2}{*}{ Amostra } & \multicolumn{2}{|c|}{ Características observadas } & \multirow{2}{*}{$\begin{array}{c}\text { Característica } \\
\text { determinada } \\
\text { pela MEV }\end{array}$} & \multirow[b]{2}{*}{ MCT } & \multirow[b]{2}{*}{ Concorda } \\
\hline & Cimentação & $\begin{array}{l}\text { Contorno dos } \\
\text { argilominerais }\end{array}$ & & & \\
\hline 89 & Sim & Não & $\mathrm{L}$ & NA & Não \\
\hline 55 & Sim & Não & L & NA' $^{\prime}$ & Não \\
\hline 56 & Sim & Não & $\mathbf{L}$ & NA' & Não \\
\hline 58 & Sim & Não & L & NA' & Não \\
\hline 62 & Sim & Não & L & NA' & Não \\
\hline 82 & Sim & Não & L & NA' & Não \\
\hline 83 & Sim & Não & $\mathbf{L}$ & NA' & Não \\
\hline 84 & Sim & Não & L & NA' & Não \\
\hline 17 & Não & Não & NL & NA' & Sim \\
\hline 24 & Não & Sim & NL & NA' & Sim \\
\hline 43 & & Não & $\mathrm{NL}$ & NA' & Sim \\
\hline 75 & Não & Não & $\mathrm{NL}$ & NA' & Sim \\
\hline 81 & Não & Não & $\mathrm{NL}$ & NA' & $\operatorname{Sim}$ \\
\hline 85 & Não & Sim & $\mathrm{NL}$ & NA' & Sim \\
\hline
\end{tabular}

( $\mathrm{L}$ - Laterítico; NL - Não-laterítico) 
Tabela H.5: Determinação da gênese dos solos NG' a partir dos ensaios de MEV.

\begin{tabular}{|c|c|c|c|c|c|}
\hline \multirow[b]{2}{*}{ Amostra } & \multicolumn{2}{|c|}{ Características observadas } & \multirow{2}{*}{$\begin{array}{c}\text { Característica } \\
\text { determinada } \\
\text { pela MEV }\end{array}$} & \multirow[b]{2}{*}{ МСT } & \multirow[b]{2}{*}{ Concorda } \\
\hline & Cimentação & $\begin{array}{l}\text { Contorno dos } \\
\text { argilominerais }\end{array}$ & & & \\
\hline 42 & Sim & Não & $\mathrm{L}$ & NG' & Não \\
\hline 47 & Sim & Não & L & NG' & Não \\
\hline 87 & Sim & Não & $\mathbf{L}$ & NG' & Não \\
\hline 90 & Sim & Não & $\mathbf{L}$ & NG' & Não \\
\hline 22 & Não & Não & NL & NG' & Sim \\
\hline 27 & Não & Não & NL & NG' & Sim \\
\hline 32 & Não & Não & NL & NG' & Sim \\
\hline 34 & Não & Não & NL & NG' & Sim \\
\hline 39 & Não & Não & NL & NG' & Sim \\
\hline 51 & Não & Sim & NL & NG' & Sim \\
\hline 53 & Não & Não & NL & NG' & Sim \\
\hline 65 & Não & Não & NL & NG' & Sim \\
\hline 77 & Não & Sim & NL & NG' & Sim \\
\hline 78 & Não & Sim & NL & NG' & Sim \\
\hline 86 & Não & Sim & NL & NG' & Sim \\
\hline
\end{tabular}

(L - Laterítico; NL - Não-laterítico) 


\section{Anexo I - Parâmetros de regressão $k_{1}, k_{2}$ e $k_{3}$ dos modelos analisados para representação do módulo de resiliência com o estado de tensão}

Apresentam-se neste anexo os valores dos parâmetros de regressão $k_{1}, k_{2}$ e $k_{3}$ dos modelos listados a seguir, e que foram utilizados na descrição da variação do módulo de resiliência com o estado de tensão.

\begin{tabular}{llc}
\hline & Modelo & Equação \\
\hline$\left(\mathrm{k}-\sigma_{\mathrm{d}}\right)$ & $M_{R}=k_{1} \sigma_{d}^{k_{2}}$ & $(5.1)$ \\
$\left(\mathrm{k}-\sigma_{3}\right)$ & $M_{R}=k_{1} \sigma_{3}^{k_{3}}$ & $(5.2)$ \\
$(\mathrm{k}-\theta)$ & $M_{R}=k_{1} \theta^{k_{3}}$ & $(5.3)$ \\
Composto $\left(\mathrm{k}-\sigma_{\mathrm{d}}-\sigma_{3}\right)$ & $M_{R}=k_{1} \sigma_{d}^{k_{2}} \sigma_{3}^{k_{3}}$ & $(5.4)$ \\
Universal da AASHTO (k- $\left.\theta-\tau_{\text {oct }}\right)$ & $M_{R}=k_{1} p_{a}\left(\frac{\theta}{p_{a}}\right)^{k_{2}}\left(\frac{\tau_{\text {oct }}}{p_{a}}+1\right)^{k_{3}}$ & $(5.5)$ \\
\hline
\end{tabular}




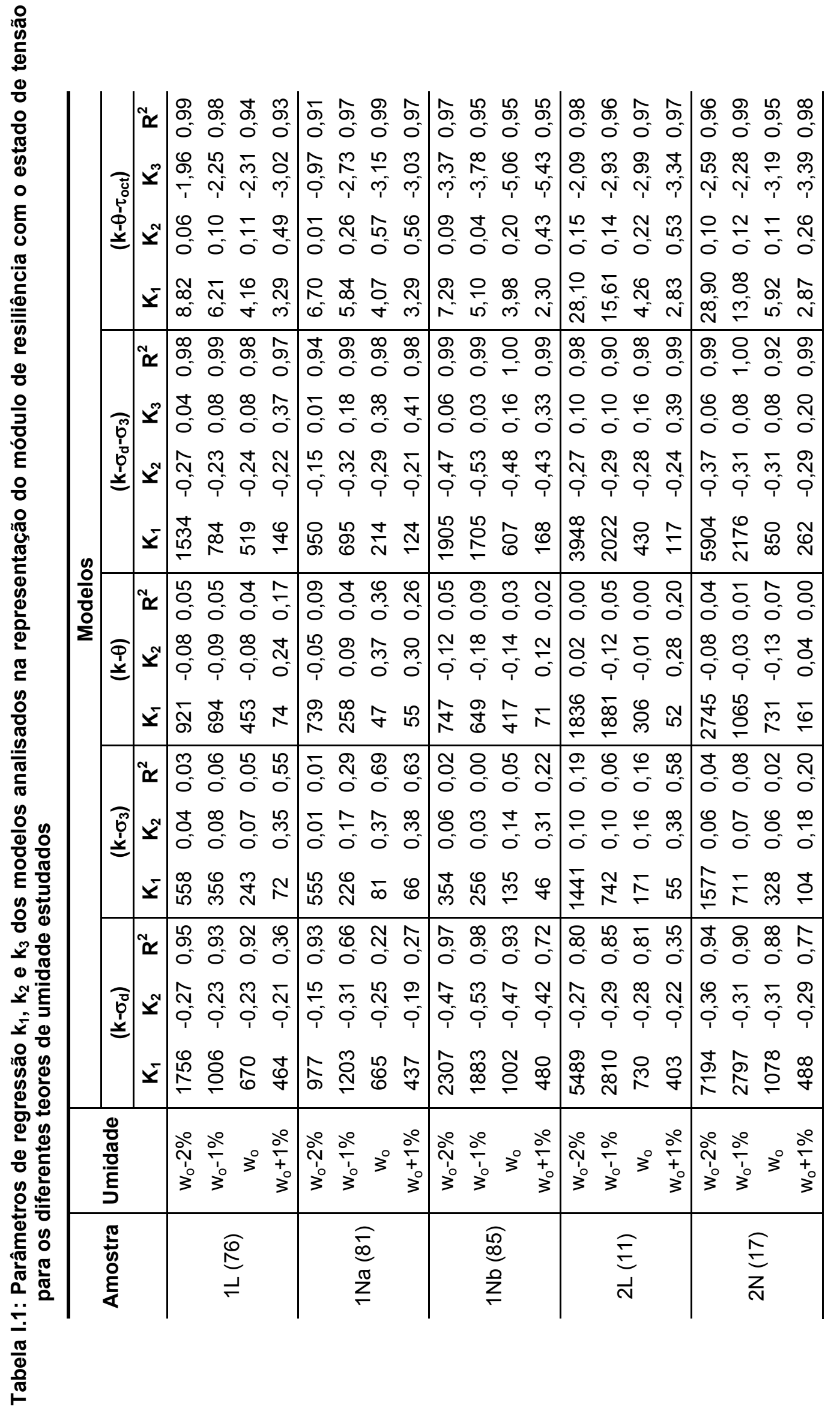




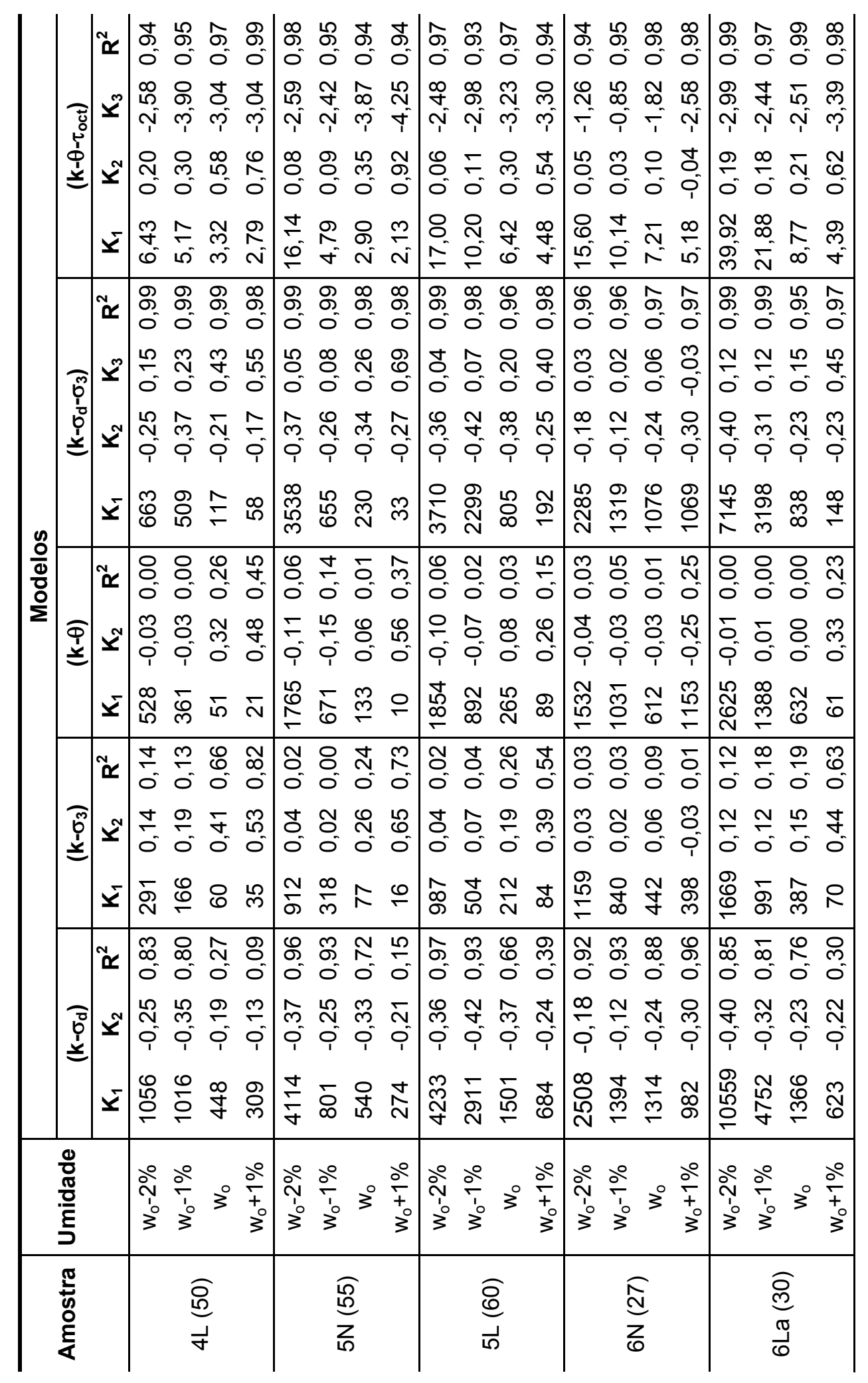




\begin{tabular}{|c|c|c|c|c|c|}
\hline 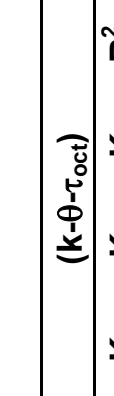 & 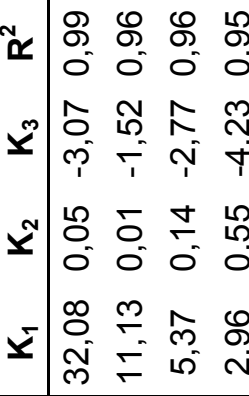 & 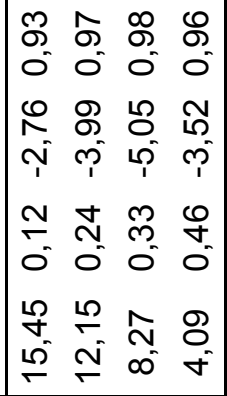 & 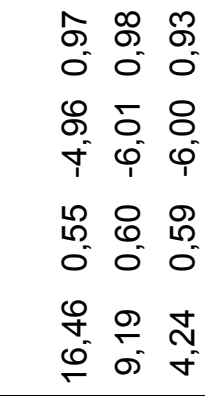 & 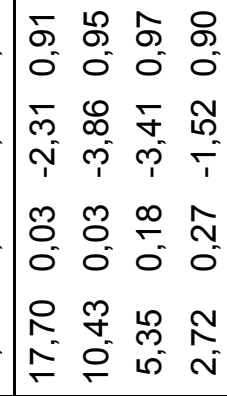 & 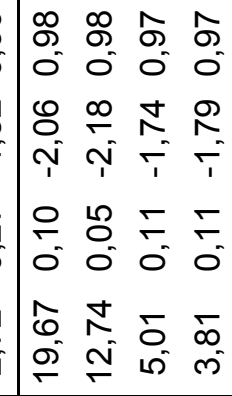 \\
\hline : & 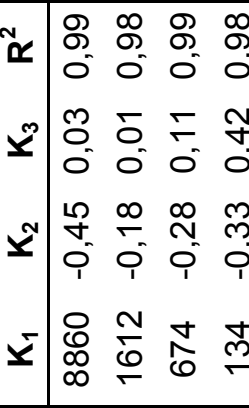 & 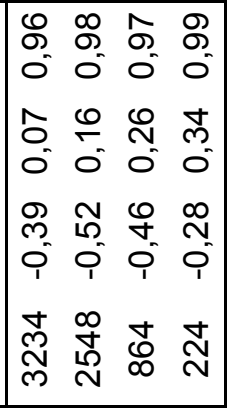 & 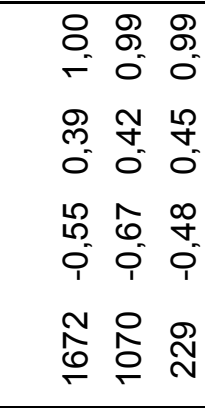 & 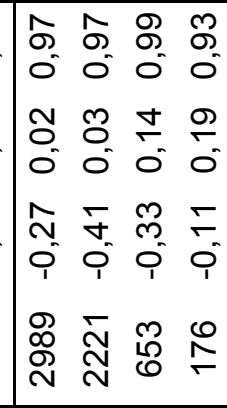 & 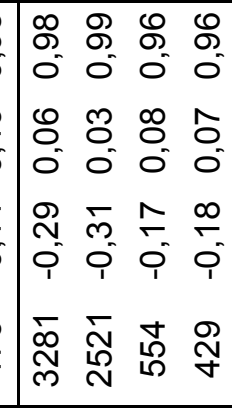 \\
\hline 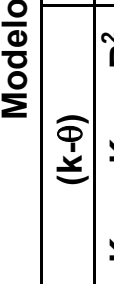 & 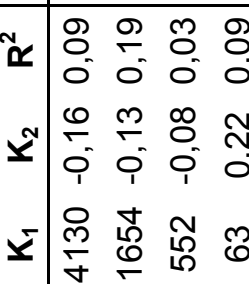 & 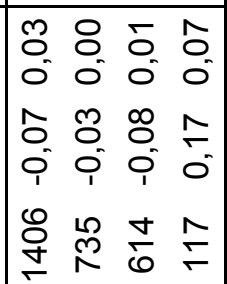 & 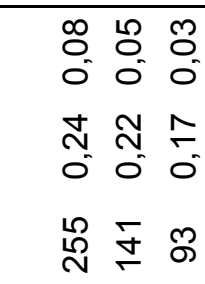 & 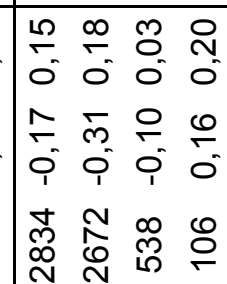 & 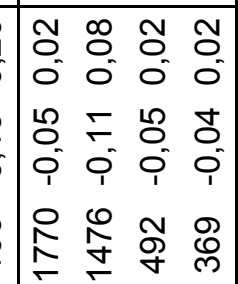 \\
\hline : & 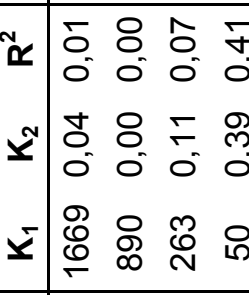 & 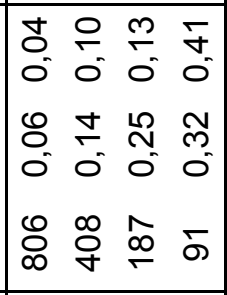 & 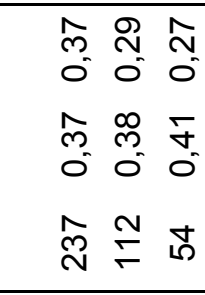 & 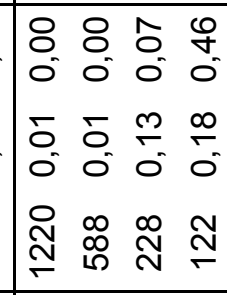 & 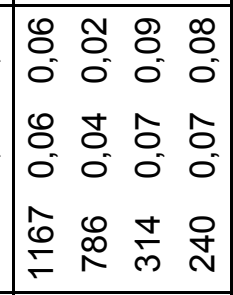 \\
\hline : & 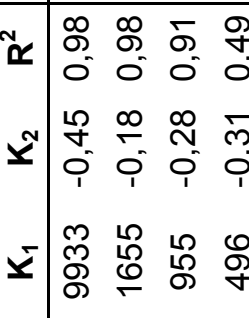 & 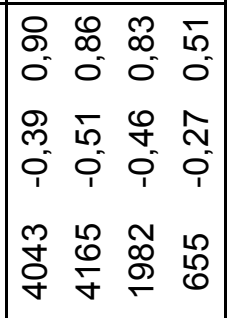 & 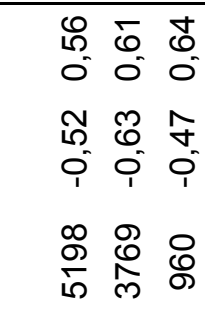 & 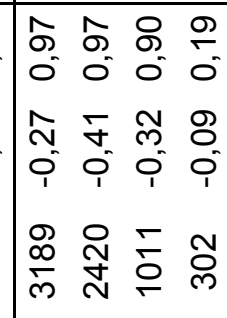 & 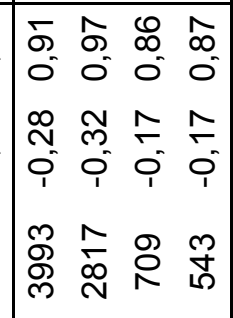 \\
\hline $\begin{array}{l}\frac{0}{0} \\
\frac{0}{0} \\
\text { हू } \\
\end{array}$ & 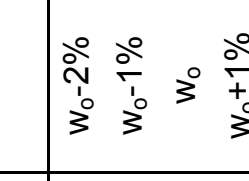 & ○० & 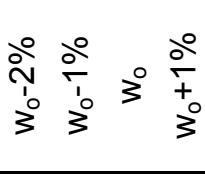 & & خิن \\
\hline 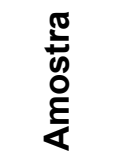 & $\begin{array}{l}\frac{\pi}{60} \\
0 \\
0 \\
0\end{array}$ & 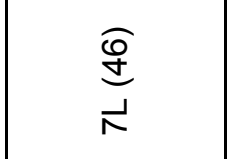 & 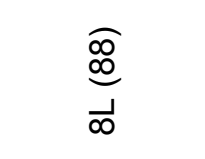 & & \\
\hline
\end{tabular}




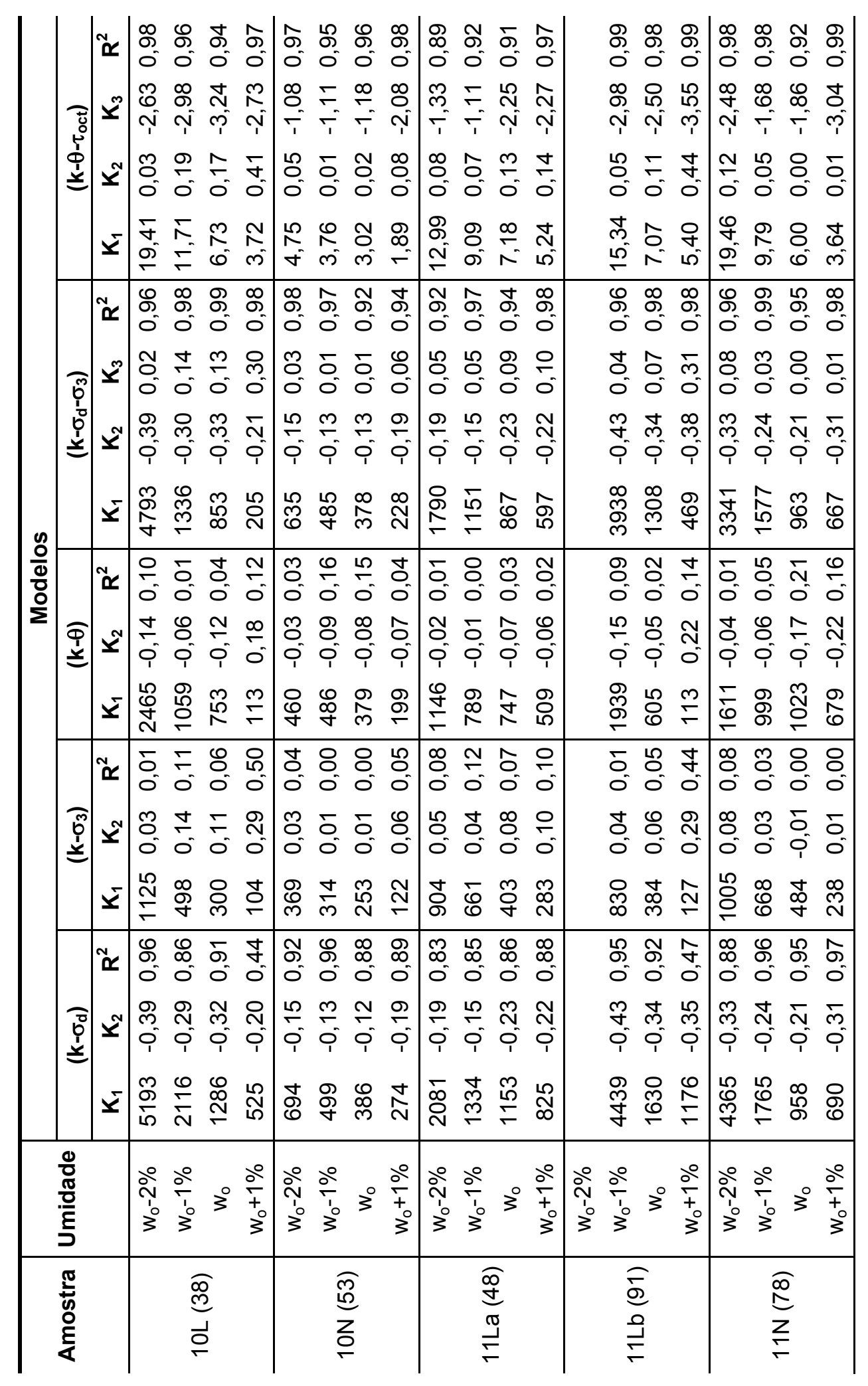




\begin{tabular}{|c|c|c|c|c|c|}
\hline . & 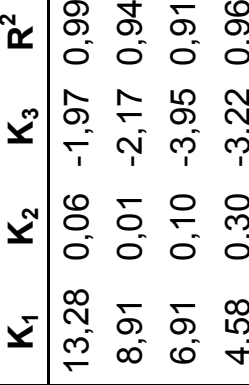 & 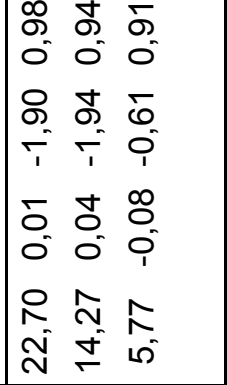 & 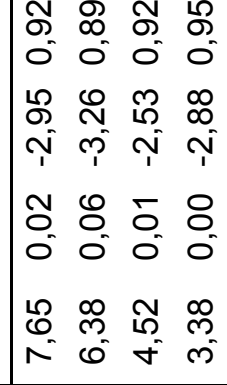 & 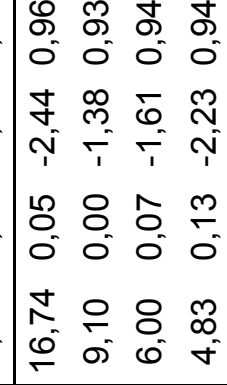 & 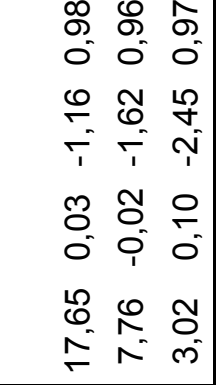 \\
\hline 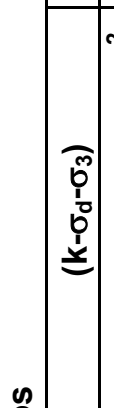 & 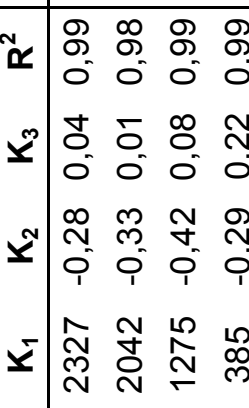 & $\begin{array}{lll}\tilde{N} & 0 & 0 \\
0 & 0 & 0 \\
0 & 0 & 0 \\
0 & 0 & 0 \\
0 & 0 & 0 \\
0 & 0 & 0 \\
0\end{array}$ & 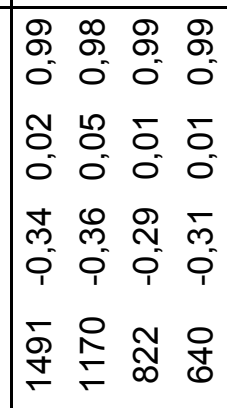 & 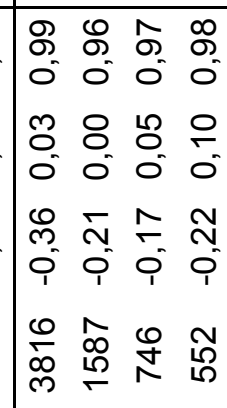 & 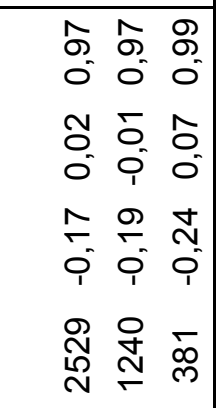 \\
\hline 竞 & 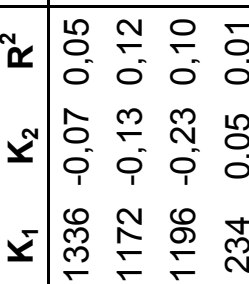 & 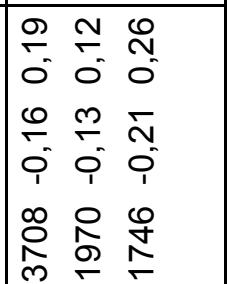 & 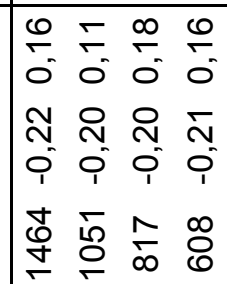 & 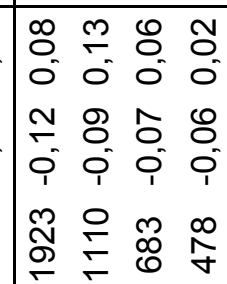 & 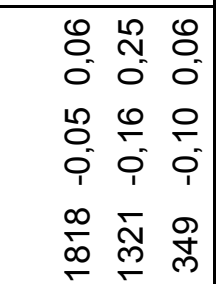 \\
\hline 常 & 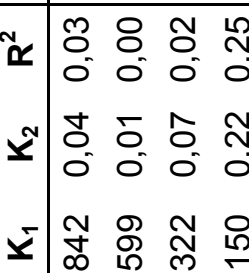 & $\begin{array}{lll}0 & 0 & 0 \\
0 & 0 & 0 \\
0 & 0 & 0 \\
0 & 0 & 0 \\
0 & 0 & 0 \\
0\end{array}$ & 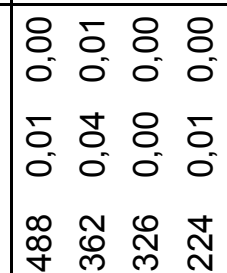 & 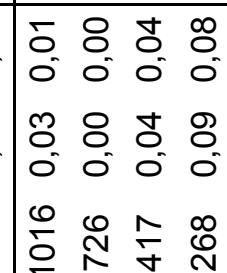 & 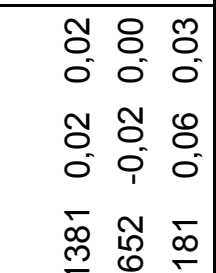 \\
\hline 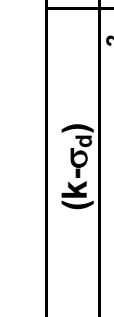 & 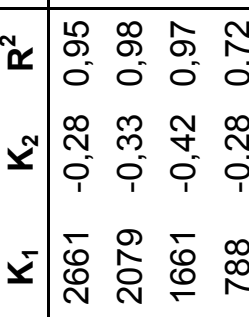 & 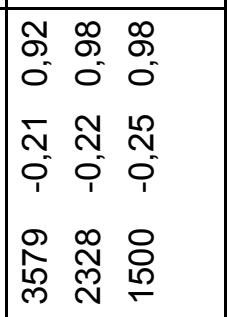 & 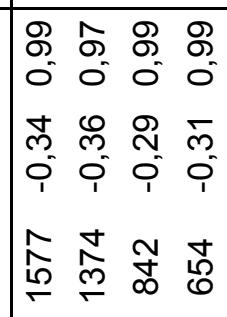 & 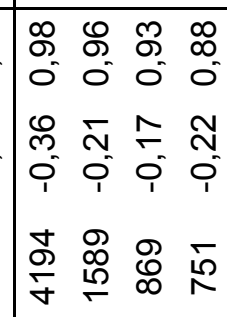 & 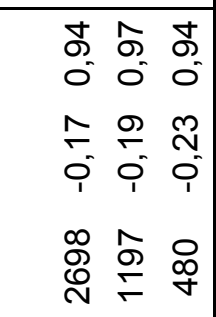 \\
\hline 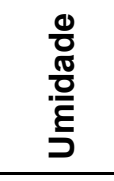 & خें & 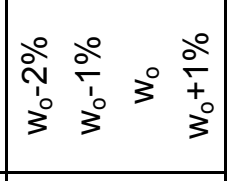 & & & 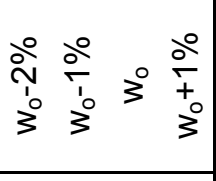 \\
\hline 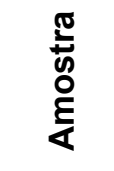 & $\frac{\sqrt[\widehat{d}]{\mathscr{N}}}{\stackrel{N}{N}}$ & $\begin{array}{l}\underset{\mathbb{N}}{\mathbb{N}} \\
\underset{N}{N}\end{array}$ & 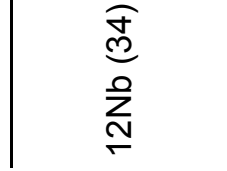 & $\frac{\widehat{\widehat{c}}}{\underline{\underline{m}}}$ & 吕 \\
\hline
\end{tabular}




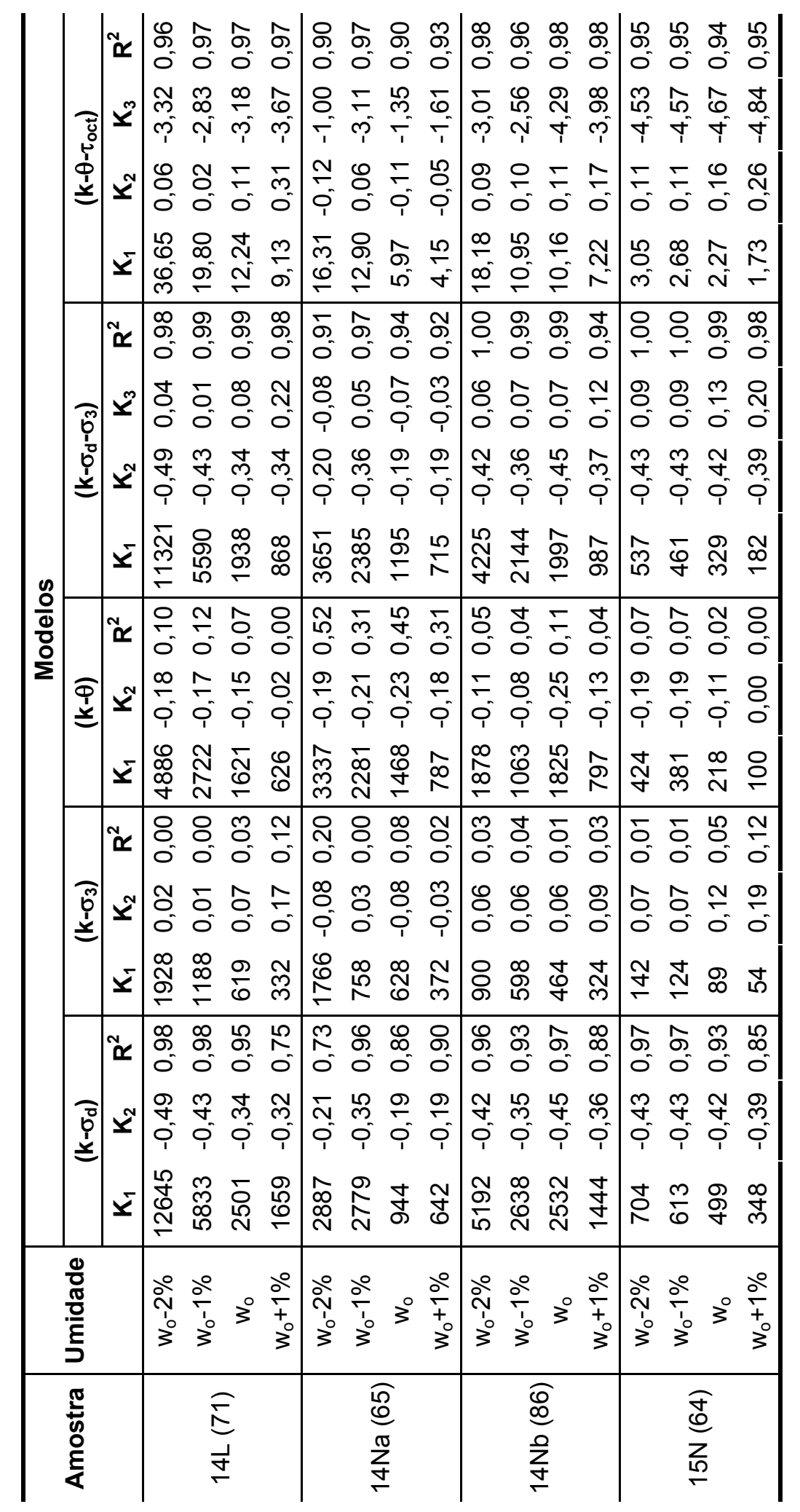




\section{Apêndice 1 - Análise estatística}

\subsection{Análise da influência da granulometria e da gênese no valor do Módulo de resiliência típico}

RESUMO

\begin{tabular}{lcccc}
\hline \multicolumn{1}{c}{ Grupo } & Contagem & Soma & Média & Variância \\
\hline Grossos & 6 & 1165 & 194 & 3498 \\
Intermediários & 7 & 2018 & 288 & 17487 \\
Finos & 16 & 5664 & 354 & 15914 \\
\hline
\end{tabular}

ANOVA

\begin{tabular}{lcccccc}
\hline Fonte da variação & $S Q$ & gl & $M Q$ & $F$ & valor-P & F crítico \\
\hline Entre grupos & 114070 & 2 & 57035 & 4,106 & 0,028 & 3,369 \\
Dentro dos grupos & 361128 & 26 & 13890 & & & \\
Total & 475198 & 28 & & & & \\
\hline
\end{tabular}

Hipóteses: $\left\{\begin{array}{l}\mathrm{H}_{0}: \mu_{1}=\mu_{2}=\mu_{3} \\ \mathrm{H}_{1}: \mu_{1} \neq \mu_{2} \neq \mu_{3}\end{array}, \alpha=0,05 \Rightarrow \mathrm{F}>\mathrm{F}_{\text {critico, }}\right.$, portanto rejeita $\mathrm{H}_{0}$.

\begin{tabular}{|c|c|c|}
\hline Teste-t (bi-caudal) & Grossos & Intermediários \\
\hline Média & 194 & 288 \\
\hline Variância & 3498 & 17487 \\
\hline Observações & 6 & 7 \\
\hline gl & 9 & \\
\hline Stat $t$ & $-1,696$ & \\
\hline$P(T<=t)$ bi-caudal & 0,124 & \\
\hline $\mathrm{t}$ crítico bi-caudal & 2,262 & \\
\hline
\end{tabular}

Hipóteses: $\left\{\begin{array}{l}\mathrm{H}_{0}: \mu_{1}=\mu_{2} \\ \mathrm{H}_{1}: \mu_{1} \neq \mu_{2}\end{array}, \alpha=0,05 \Rightarrow|\mathrm{t}|<\mathrm{t}_{\text {critico, }}\right.$, portanto não rejeita $\mathrm{H}_{0}$. 


\begin{tabular}{|c|c|c|}
\hline Teste-t (bi-caudal) & Intermediários & Finos \\
\hline Média & 288 & 354 \\
\hline Variância & 17487 & 15914 \\
\hline Observações & 7 & 16 \\
\hline $\mathrm{gl}$ & 11 & \\
\hline Stat $\mathrm{t}$ & $-1,112$ & \\
\hline $\mathrm{P}(\mathrm{T}<=\mathrm{t})$ bi-caudal & 0,290 & \\
\hline t crítico bi-caudal & 2,201 & \\
\hline
\end{tabular}

Hipóteses: $\left\{\begin{array}{l}\mathrm{H}_{0}: \mu_{1}=\mu_{2} \\ \mathrm{H}_{1}: \mu_{1} \neq \mu_{2}\end{array}, \alpha=0,05 \Rightarrow|\mathrm{t}|<\mathrm{t}_{\text {crítico, }}\right.$, portanto não rejeita $\mathrm{H}_{0}$.

\begin{tabular}{|c|c|c|}
\hline Teste-t (bi-caudal) & Grossos & Finos \\
\hline Média & 194 & 354 \\
\hline Variância & 3498 & 15914 \\
\hline Observações & 6 & 16 \\
\hline gl & 19 & \\
\hline Stat t & $-4,024$ & \\
\hline $\mathrm{P}(\mathrm{T}<=\mathrm{t})$ bi-caudal & 0,001 & \\
\hline t crítico bi-caudal & 2,093 & \\
\hline
\end{tabular}

Hipóteses: $\left\{\begin{array}{l}\mathrm{H}_{0}: \mu_{1}=\mu_{2} \\ \mathrm{H}_{1}: \mu_{1} \neq \mu_{2}\end{array}, \alpha=0,05 \Rightarrow|\mathrm{t}|>\mathrm{t}_{\text {critico, }}\right.$, portanto rejeita $\mathrm{H}_{0}$.

\begin{tabular}{|c|c|c|}
\hline Teste-t (bi-caudal) & Lateríticos & Não-lateríticos \\
\hline Média & 307 & 303 \\
\hline Variância & 13379 & 22139 \\
\hline Observações & 15 & 14 \\
\hline $\mathrm{gl}$ & 25 & \\
\hline Stat $t$ & 0,069 & \\
\hline $\mathrm{P}(\mathrm{T}<=\mathrm{t})$ bi-caudal & 0,946 & \\
\hline t crítico bi-caudal & 2,060 & \\
\hline
\end{tabular}

Hipóteses: $\left\{\begin{array}{l}\mathrm{H}_{0}: \mu_{1}=\mu_{2} \\ \mathrm{H}_{1}: \mu_{1} \neq \mu_{2}\end{array}, \alpha=0,05 \Rightarrow|\mathrm{t}|<\mathrm{t}_{\text {crítico, }}\right.$, portanto não rejeita $\mathrm{H}_{0}$. 


\subsection{Análise da influência da granulometria e da gênese no valor do Módulo de resiliência médio}

RESUMO

\begin{tabular}{lcccc}
\hline \multicolumn{1}{c}{ Grupo } & Contagem & Soma & Média & Variância \\
\hline Grossos & 6 & 1702 & 284 & 4057 \\
Intermediários & 7 & 2839 & 406 & 14504 \\
Finos & 16 & 7220 & 451 & 22777 \\
\hline
\end{tabular}

ANOVA

\begin{tabular}{lcccccc}
\hline Fonte da variação & $S Q$ & gl & $M Q$ & $F$ & valor-P & F crítico \\
\hline Entre grupos & 122542 & 2 & 61271 & 3,55 & 0,043 & 3,37 \\
Dentro dos grupos & 448959 & 26 & 17268 & & & \\
Total & 571502 & 28 & & & & \\
\hline
\end{tabular}

Hipóteses: $\left\{\begin{array}{l}\mathrm{H}_{0}: \mu_{1}=\mu_{2}=\mu_{3} \\ \mathrm{H}_{1}: \mu_{1} \neq \mu_{2} \neq \mu_{3}\end{array}, \alpha=0,05 \Rightarrow \mathrm{F}>\mathrm{F}_{\text {critico, }}\right.$, portanto rejeita $\mathrm{H}_{0}$.

\begin{tabular}{lccc}
\hline & Teste-t (bi-caudal) & Grossos & Intermediários \\
\hline Média & 284 & 406 \\
Variância & 4057 & 14504 \\
Observações & 6 & 7 \\
gl & 9 & \\
Stat t & $-2,32$ & \\
$\mathrm{P}(\mathrm{T}<=\mathrm{t})$ bi-caudal & 0,05 & \\
$\mathrm{t}$ crítico bi-caudal & 2,26 & \\
\hline
\end{tabular}

Hipóteses: $\left\{\begin{array}{l}\mathrm{H}_{0}: \mu_{1}=\mu_{2} \\ \mathrm{H}_{1}: \mu_{1} \neq \mu_{2}\end{array}, \alpha=0,05 \Rightarrow|\mathrm{t}|>\mathrm{t}_{\text {critico, }}\right.$, portanto rejeita $\mathrm{H}_{0}$. 


\begin{tabular}{|c|c|c|}
\hline Teste-t (bi-caudal) & Intermediários & Finos \\
\hline Média & 406 & 451 \\
\hline Variância & 14504 & 22777 \\
\hline Observações & 7 & 16 \\
\hline $\mathrm{gl}$ & 14 & \\
\hline Stat $\mathrm{t}$ & $-0,773$ & \\
\hline $\mathrm{P}(\mathrm{T}<=\mathrm{t})$ bi-caudal & 0,452 & \\
\hline t crítico bi-caudal & 2,145 & \\
\hline
\end{tabular}

Hipóteses: $\left\{\begin{array}{l}\mathrm{H}_{0}: \mu_{1}=\mu_{2} \\ \mathrm{H}_{1}: \mu_{1} \neq \mu_{2}\end{array}, \alpha=0,05 \Rightarrow|\mathrm{t}|<\mathrm{t}_{\text {crítico, }}\right.$, portanto não rejeita $\mathrm{H}_{0}$.

\begin{tabular}{|c|c|c|}
\hline Teste-t (bi-caudal) & Grossos & Finos \\
\hline Média & 284 & 451 \\
\hline Variância & 4057 & 22777 \\
\hline Observações & 6 & 16 \\
\hline gl & 19 & \\
\hline Stat $\mathrm{t}$ & $-3,657$ & \\
\hline $\mathrm{P}(\mathrm{T}<=\mathrm{t})$ bi-caudal & 0,002 & \\
\hline $\mathrm{t}$ crítico bi-caudal & 2,093 & \\
\hline
\end{tabular}

Hipóteses: $\left\{\begin{array}{l}\mathrm{H}_{0}: \mu_{1}=\mu_{2} \\ \mathrm{H}_{1}: \mu_{1} \neq \mu_{2}\end{array}, \alpha=0,05 \Rightarrow|\mathrm{t}|>\mathrm{t}_{\text {critico, }}\right.$, portanto rejeita $\mathrm{H}_{0}$.

\begin{tabular}{|c|c|c|}
\hline Teste-t (bi-caudal) & Lateríticos & Não-lateríticos \\
\hline Média & 427 & 383 \\
\hline Variância & 17196 & 24347 \\
\hline Observações & 15 & 14 \\
\hline $\mathrm{gl}$ & 25 & \\
\hline Stat t & 0,826 & \\
\hline$P(T<=t)$ bi-caudal & 0,417 & \\
\hline t crítico bi-caudal & 2,060 & \\
\hline
\end{tabular}

Hipóteses: $\left\{\begin{array}{l}\mathrm{H}_{0}: \mu_{1}=\mu_{2} \\ \mathrm{H}_{1}: \mu_{1} \neq \mu_{2}\end{array}, \alpha=0,05 \Rightarrow|\mathrm{t}|<\mathrm{t}_{\text {crítico, }}\right.$, portanto não rejeita $\mathrm{H}_{0}$. 


\subsection{Influência da gênese na taxa de variação do módulo de resiliência típico}

\begin{tabular}{|c|c|c|}
\hline Teste-t (bi-caudal) - $\mathrm{w}_{0}-2 \%$ & Lateríticos & Não-lateríticos \\
\hline Média & 2,83 & 2,04 \\
\hline Variância & 3,72 & 2,76 \\
\hline Observações & 14 & 13 \\
\hline gl & 25 & \\
\hline Stat t & 1,151 & \\
\hline$P(T<=t)$ bi-caudal & 0,261 & \\
\hline t crítico bi-caudal & 2,060 & \\
\hline
\end{tabular}

Hipóteses: $\left\{\begin{array}{l}\mathrm{H}_{0}: \mu_{1}=\mu_{2} \\ \mathrm{H}_{1}: \mu_{1} \neq \mu_{2}\end{array}, \alpha=0,05 \Rightarrow|\mathrm{t}|<\mathrm{t}_{\text {critico, }}\right.$, portanto não rejeita $\mathrm{H}_{0}$.

\begin{tabular}{|c|c|c|}
\hline Teste-t (bi-caudal) - $\mathrm{w}_{0}-1 \%$ & Lateríticos & Não-lateríticos \\
\hline Média & 1,01 & 0,81 \\
\hline Variância & 0,38 & 0,33 \\
\hline Observações & 15 & 14 \\
\hline gl & 27 & \\
\hline Stat t & 0,895 & \\
\hline $\mathrm{P}(\mathrm{T}<=\mathrm{t})$ bi-caudal & 0,379 & \\
\hline t crítico bi-caudal & 2,052 & \\
\hline
\end{tabular}

Hipóteses: $\left\{\begin{array}{l}\mathrm{H}_{0}: \mu_{1}=\mu_{2} \\ \mathrm{H}_{1}: \mu_{1} \neq \mu_{2}\end{array}, \alpha=0,05 \Rightarrow|\mathrm{t}|<\mathrm{t}_{\text {crítico, }}\right.$, portanto não rejeita $\mathrm{H}_{0}$.

\begin{tabular}{|c|c|c|}
\hline Teste-t (bi-caudal) $-\mathrm{w}_{\mathrm{o}}+1 \%$ & Lateríticos & Não-lateríticos \\
\hline Média & $-0,370$ & $-0,362$ \\
\hline Variância & 0,018 & 0,016 \\
\hline Observações & 15 & 12 \\
\hline gl & 24 & \\
\hline Stat $t$ & $-0,160$ & \\
\hline$P(T<=t)$ bi-caudal & 0,874 & \\
\hline t crítico bi-caudal & 2,064 & \\
\hline
\end{tabular}

Hipóteses: $\left\{\begin{array}{l}\mathrm{H}_{0}: \mu_{1}=\mu_{2} \\ \mathrm{H}_{1}: \mu_{1} \neq \mu_{2}\end{array}, \alpha=0,05 \Rightarrow|\mathrm{t}|<\mathrm{t}_{\text {crítico, }}\right.$, portanto não rejeita $\mathrm{H}_{0}$. 


\subsection{A influência da gênese nos tempos de preparação dos corpos-de- prova}

\begin{tabular}{|c|c|c|}
\hline Teste-t (bi-caudal) - $w_{0}-2 \%$ & Lateríticos & Não-lateríticos \\
\hline Média & 81 & 66 \\
\hline Variância & 124 & 252 \\
\hline Observações & 15 & 14 \\
\hline gl & 23 & \\
\hline Stat $t$ & 2,993 & \\
\hline$P(T<=t)$ bi-caudal & 0,006 & \\
\hline $\mathrm{t}$ crítico bi-caudal & 2,069 & \\
\hline
\end{tabular}

Hipóteses: $\left\{\begin{array}{l}\mathrm{H}_{0}: \mu_{1}=\mu_{2} \\ \mathrm{H}_{1}: \mu_{1} \neq \mu_{2}\end{array}, \alpha=0,05 \Rightarrow|\mathrm{t}|>\mathrm{t}_{\text {critico, }}\right.$, portanto rejeita $\mathrm{H}_{0}$.

\begin{tabular}{|c|c|c|}
\hline Teste-t (bi-caudal) $-\mathrm{w}_{0}-1 \%$ & Lateríticos & Não-lateríticos \\
\hline Média & 36 & 29 \\
\hline Variância & 103 & 60 \\
\hline Observações & 15 & 14 \\
\hline gl & 26 & \\
\hline Stat t & 2,215 & \\
\hline$P(T<=t)$ bi-caudal & 0,036 & \\
\hline $\mathrm{t}$ crítico bi-caudal & 2,056 & \\
\hline
\end{tabular}

Hipóteses: $\left\{\begin{array}{l}\mathrm{H}_{0}: \mu_{1}=\mu_{2} \\ \mathrm{H}_{1}: \mu_{1} \neq \mu_{2}\end{array}, \alpha=0,05 \Rightarrow|\mathrm{t}|>\mathrm{t}_{\text {crítico, }}\right.$, portanto rejeita $\mathrm{H}_{0}$.

\begin{tabular}{|c|c|c|}
\hline Teste-t (bi-caudal) $-w_{o}+1 \%$ & Lateríticos & Não-lateríticos \\
\hline Média & 180 & 54 \\
\hline Variância & 21682 & 1317 \\
\hline Observações & 14 & 14 \\
\hline gl & 15 & \\
\hline Stat t & 3,100 & \\
\hline$P(T<=t)$ bi-caudal & 0,007 & \\
\hline t crítico bi-caudal & 2,131 & \\
\hline
\end{tabular}


Hipóteses: $\left\{\begin{array}{l}\mathrm{H}_{0}: \mu_{1}=\mu_{2} \\ \mathrm{H}_{1}: \mu_{1} \neq \mu_{2}\end{array}, \alpha=0,05 \Rightarrow|\mathrm{t}|>\mathrm{t}_{\text {crítico, }}\right.$, portanto rejeita $\mathrm{H}_{0}$.

\subsection{Influência da granulometria e da gênese no valor do Módulo tangente inicial}

\begin{tabular}{lccc}
\hline & Teste-t & Grossos & Intermediários \\
\hline Média & 28 & 73 \\
Variância & 351 & 879 \\
Observações & 7 & 7 \\
gl & 10 & \\
Stat $\mathrm{t}$ & $-3,413$ & \\
$\mathrm{P}(\mathrm{T}<=\mathrm{t})$ bi-caudal & 0,007 & \\
$\mathrm{t}$ crítico bi-caudal & 2,228 & \\
\hline
\end{tabular}

Hipóteses: $\left\{\begin{array}{l}\mathrm{H}_{0}: \mu_{1}=\mu_{2} \\ \mathrm{H}_{1}: \mu_{1} \neq \mu_{2}\end{array}, \alpha=0,05 \Rightarrow|\mathrm{t}|>\mathrm{t}_{\text {crítico, }}\right.$, portanto rejeita $\mathrm{H}_{0}$.

\begin{tabular}{|c|c|c|}
\hline Teste-t & Intermediários & Finos \\
\hline Média & 73 & 97 \\
\hline Variância & 879 & 1661 \\
\hline Observações & 7 & 15 \\
\hline $\mathrm{gl}$ & 16 & \\
\hline Stat $\mathrm{t}$ & $-1,524$ & \\
\hline $\mathrm{P}(\mathrm{T}<=\mathrm{t})$ bi-caudal & 0,147 & \\
\hline $\mathrm{t}$ crítico bi-caudal & 2,120 & \\
\hline
\end{tabular}

Hipóteses: $\left\{\begin{array}{l}\mathrm{H}_{0}: \mu_{1}=\mu_{2} \\ \mathrm{H}_{1}: \mu_{1} \neq \mu_{2}\end{array}, \alpha=0,05 \Rightarrow|\mathrm{t}|<\mathrm{t}_{\text {critico, }}\right.$, portanto não rejeita $\mathrm{H}_{0}$. 


\begin{tabular}{|c|c|c|}
\hline Teste-t & Grossos & Finos \\
\hline Média & 28 & 97 \\
\hline Variância & 351 & 1661 \\
\hline Observações & 7 & 15 \\
\hline gl & 20 & \\
\hline Stat t & $-5,415$ & \\
\hline $\mathrm{P}(\mathrm{T}<=\mathrm{t})$ bi-caudal & 0,000 & \\
\hline t crítico bi-caudal & 2,086 & \\
\hline
\end{tabular}

Hipóteses: $\left\{\begin{array}{l}\mathrm{H}_{0}: \mu_{1}=\mu_{2} \\ \mathrm{H}_{1}: \mu_{1} \neq \mu_{2}\end{array}, \alpha=0,05 \Rightarrow|\mathrm{t}|>\mathrm{t}_{\text {crítico, }}\right.$, portanto rejeita $\mathrm{H}_{0}$.

\begin{tabular}{|c|c|c|}
\hline Teste-t & Lateríticos & Não-lateríticos \\
\hline Média & 78 & 66 \\
\hline Variância & 1781 & 1953 \\
\hline Observações & 15 & 14 \\
\hline $\mathrm{gl}$ & 27 & \\
\hline Stat $t$ & 0,787 & \\
\hline $\mathrm{P}(\mathrm{T}<=\mathrm{t})$ bi-caudal & 0,438 & \\
\hline t crítico bi-caudal & 2,052 & \\
\hline
\end{tabular}

Hipóteses: $\left\{\begin{array}{l}\mathrm{H}_{0}: \mu_{1}=\mu_{2} \\ \mathrm{H}_{1}: \mu_{1} \neq \mu_{2}\end{array}, \alpha=0,05 \Rightarrow|\mathrm{t}|<\mathrm{t}_{\text {crítico, }}\right.$ portanto não rejeita $\mathrm{H}_{0}$. 